US Army Corps

of Engineers ${ }_{\circledast}$

Engineer Research and

Development Center

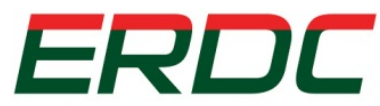

INNOVATIVE SOLUTIONS

for a safer, better world

\title{
Historic Landscape Survey, Randolph AFB, Texas
}

Megan W. Tooker, Ellen R. Hartman, and Adam D. Smith

September 2013

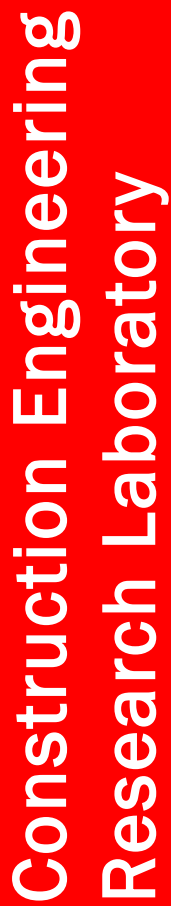

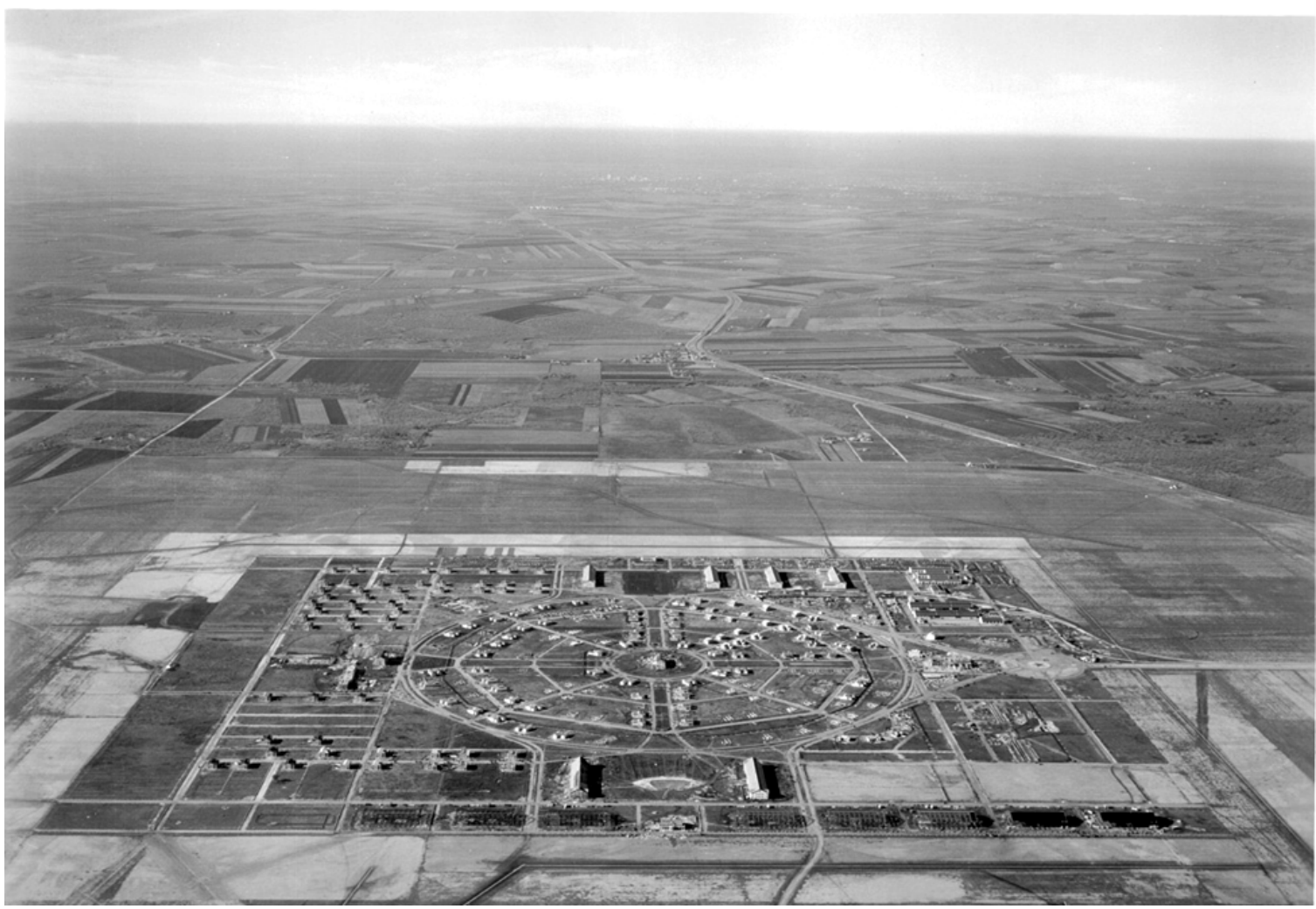


The US Army Engineer Research and Development Center (ERDC) solves the nation's toughest engineering and environmental challenges. ERDC develops innovative solutions in civil and military engineering, geospatial sciences, water resources, and environmental sciences for the Army, the Department of Defense, civilian agencies, and our nation's public good. Find out more at www.erdc.usace.army.mil.

To search for other technical reports published by ERDC, visit the ERDC online library at http://acwc.sdp.sirsi.net/client/default. 


\section{Historic Landscape Survey, Randolph AFB, Texas}

Megan W. Tooker, Ellen R. Hartman, and Adam D. Smith

Construction Engineering Research Laboratory

U.S. Army Engineer Research and Development Center

2902 Newmark Drive

PO Box 9005

Champaign, IL 61826-9005

Final report

Approved for public release; distribution is unlimited.

Prepared for HQ AETC/A7CAN

266 F Street West

Bldg 901

Randolph AFB, TX 78150

Under Project No. 370647, "Historic Landscape Contexts, Inventories, and Management Plans for Randolph AFB \& Maxwell AFB." 


\section{Abstract}

As an inventory and evaluation of the historic landscape and landscape features of Randolph Air Force Base (AFB), Texas, this document meets the requirement for federal agencies to address their cultural resources, defined as any prehistoric or historic district, site, building, structure, or object.

Randolph AFB's historic landscape is unique in its design and implementation. The base was planned and designed as an ideal "Air City" to meet flying training requirements while providing a pleasant place for airmen and their families to live. The landscape reflects early twentiethcentury planning ideas that grouped functional uses together in geometrically distinct patterns. Implementing these design principles at Randolph Field resulted in a main circle surrounded by a grid of streets, with two flight lines on the east and west sides.

This report identifies several historic component landscapes within Randolph AFB and makes recommendations on their maintenance and preservation. The component landscapes are the administration area; the warehouse and shop area; the base support areas such as the Chapel, hospital, former Post School, and former Post Exchange; the residential areas of the officers' housing, NCO quarters, and former barracks; the former Cadet Complex; and the flight lines.

DISCLAIMER: The contents of this report are not to be used for advertising, publication, or promotional purposes. Citation of trade names does not constitute an official endorsement or approval of the use of such commercial products. All product names and trademarks cited are the property of their respective owners. The findings of this report are not to be construed as an official Department of the Army position unless so designated by other authorized documents. 


\section{Table of Contents}

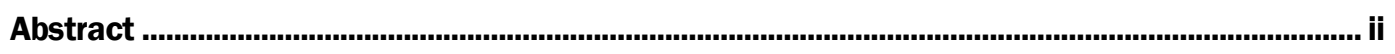

List of Figures and Tables........................................................................................................

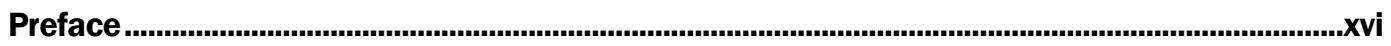

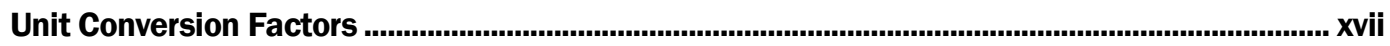

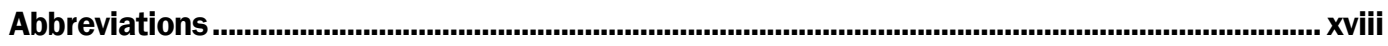

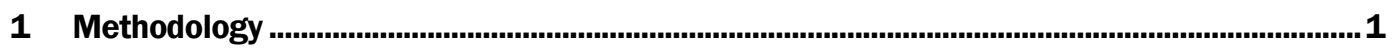

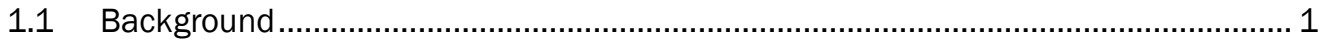

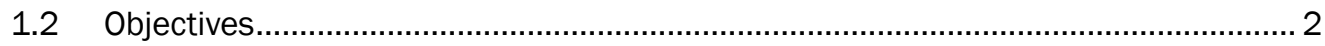

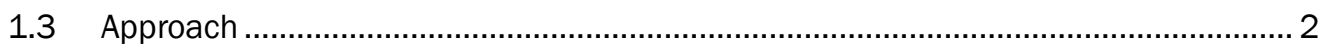

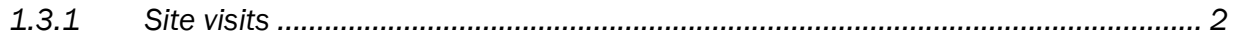

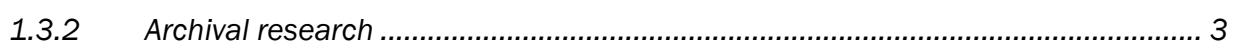

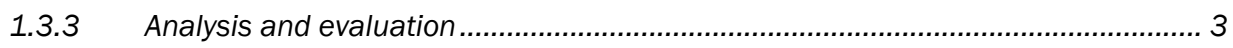

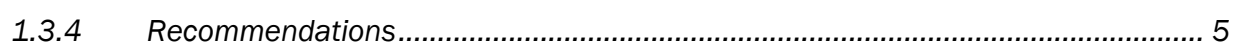

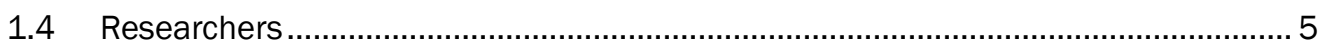

2 Historic Context...............................................................................................................

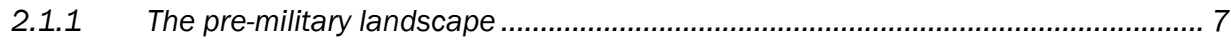

2.1.2 Initial construction at Randolph AFB .................................................................. 8

2.1.3 Randolph Air Force Base since World War II .................................................... 17

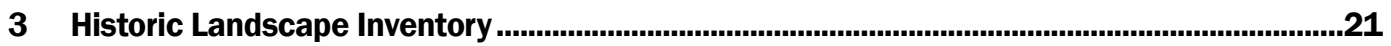

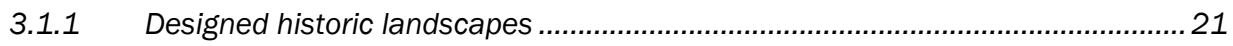

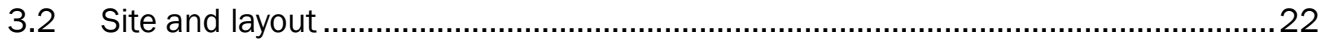

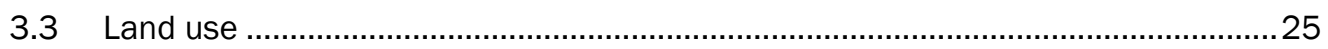

3.3.1 Overall layout of the "Airfield Plan" .................................................................... 31

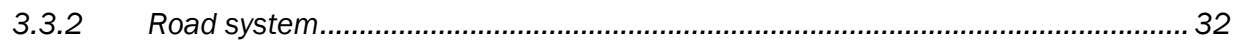

3.3.3 Harmon Drive and Washington Circle area ....................................................... 33

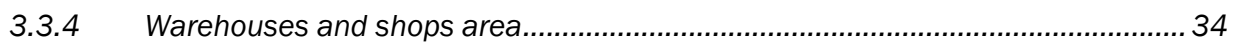

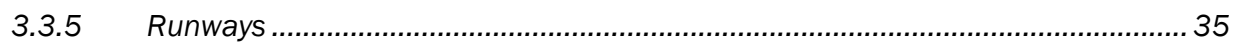

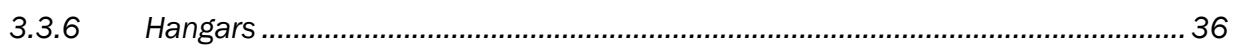

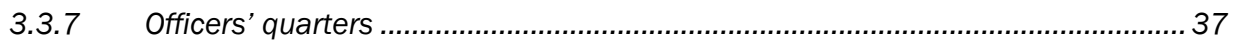

3.3.8 Noncommissioned officers' quarters................................................................... 38

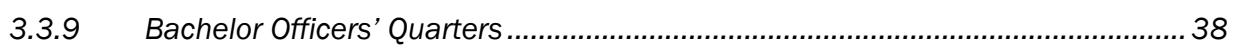

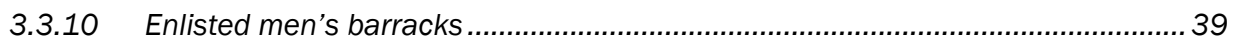

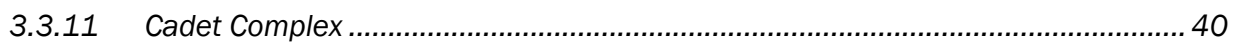

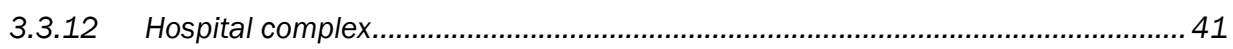

3.4 Expression of military cultural traditions........................................................... 42

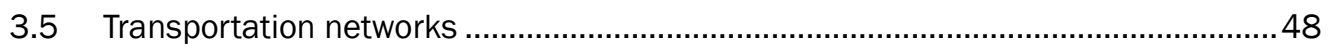


3.6 Clusters of buildings and structures............................................................ 53

3.6.1 Administrative, service, and operations facilities................................................54

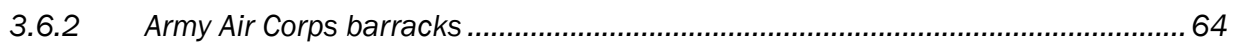

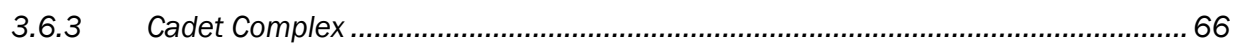

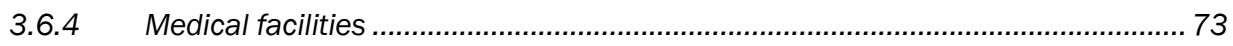

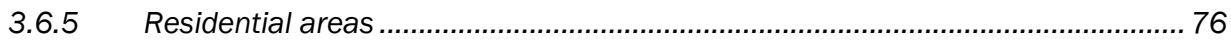

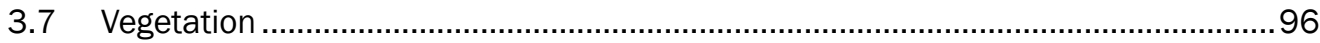

3.7.1 Boulevards and medians in the road system ..................................................104

3.7.2 Entrance boulevard and Washington Circle ...................................................109

3.7.3 Aviation areas-hangars and flight lines......................................................111

3.7.4 Administration area ................................................................................. 113

3.7.5 Warehouse and shops area ..................................................................... 120

3.7.6 Officers' residential area ............................................................................... 123

3.7.7 NCO residential area................................................................................. 128

3.7.8 Bachelor Officers' Quarters ......................................................................... 129

3.7.9 Enlisted men's barracks ............................................................................ 131

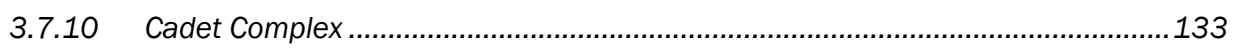

3.7.11 Hospital complex............................................................................................. 135

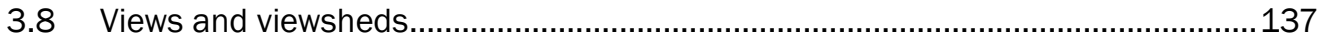

S.9 Small-scale features........................................................................................ 144

3.9.1 Landscape objects ...................................................................................... 144

3.9.2 Monuments and ceremonial features ............................................................. 158

4 Criteria for Evaluating Historic Landscapes ................................................................... 167

4.1 Criteria for evaluation ........................................................................... 167

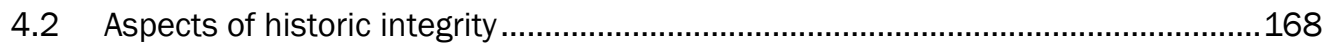

4.3 Categories of historic properties.................................................................. 169

4.4 Previous studies and nominations ................................................................ 170

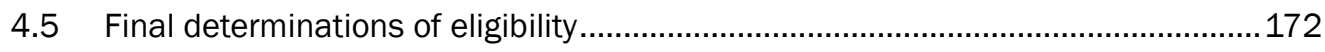

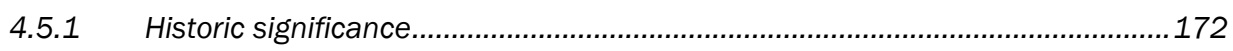

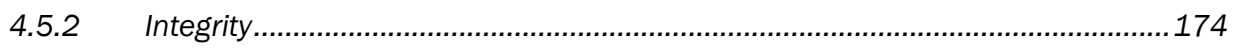

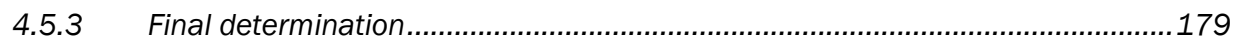

4.5.4 Character-defining features .................................................................... 182

5 Recommendations for Historic Landscape Preservation ...................................................187

5.1 Overall district management guidelines............................................................ 187

5.2 Base-wide design recommendations ................................................................189

5.3 Component landscape design recommendations ................................................190

\begin{tabular}{|c|c|}
\hline 3.1 & oad system.... \\
\hline 5.3 .2 & Entrance Boulevard and Washington Circle ...................... \\
\hline 3.3 & Warehouse and shops area ....... \\
\hline 3.4 & Flight lines/hangars......... \\
\hline .3 .5 & Residential areas ..... \\
\hline & Cadet Complex..... \\
\hline & Views and viewsheds. \\
\hline
\end{tabular}




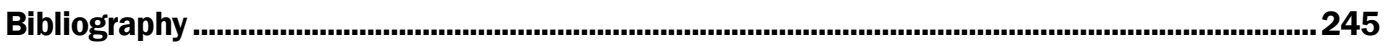

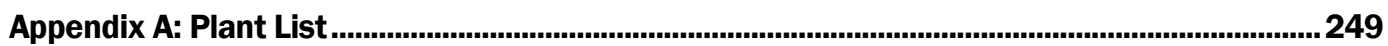

Report Documentation Page 


\section{List of Figures and Tables}

\section{Figures}

Figure 1. The 1929 plan of Randolph Field showing that changes occurred between the finalization of this plan and the field's construction. The changes included the organization of buildings in what was to be the Bachelor Officers' Quarters area, the Cadet Complex area, and a reduction in the officers' and NCO housing (NARA RG 342-FM Box 1071).

Figure 2. The plan for Randolph Field published in the San Antonio Express in 1929 (Norfleet Giddings Bone Papers, University of Texas at San Antonio Libraries Special Collections).

Figure 3. The road system was laid out and constructed by 1929 , before building construction started, 1930 (University of Texas San Antonio, Norfleet Glddings Bone Papers)...

Figure 4. Aerial view of the hangars and aprons on the west flight line, undated but soon after construction, undated (NARA RG 342 Box 1071 B20672).

Figure 5. Cadets arrive at Randolph for training, 1932 (NARA B12335 Box 1042)

Figure 6. Randolph Air Force Base historic district is outlined with a dark blue line. Historical buildings are colored red, and eligible historical buildings are striped in red and yellow, 2011 (Randolph AFB Cultural Resources).

Figure 7. The strong geometrical organization of Randolph Field was centered on two dominant axes; the primary axis extended northwest to-southeast and the secondary axis extended northeast to southwest (ERDC-CERL).

Figure 8. Aerial view of the Randolph street network before the major building construction phase began (Bone Collection 123535, Randolph AFB Cultural Resources). 24

Figure 9. Land use designations of the 1930s base plan, 2012 (ERDC-CERL).

Figure 10. The medians created by the road system provided Randolph Field with distinct open areas that are diagrammed here, 2012 (ERDC-CERL).

Figure 11. The base nursery was located east of the cantonment (as shown in the center foreground), undated (NARA RG 342, Box 1071 B20671).

Figure 12. As Randolph Field expanded during WWII, land uses were still grouped together. Much of the Field's growth was along the northern and southern edges and included a nine-hole golf course (outlined here with a green line toward bottom of figure), 2012 (ERDC-CERL).

Figure 13. Component landscapes within Randolph AFB historic district. Red is the entrance sequence and administration areas. Orange is the shops and warehouse area. Dark purple marks the flight lines. Light purple marks the Cadet Complex. Yellow highlights the hospital complex. Shades of green delineate the residential areas: dark green marks the original barracks, medium green is the BOQ area, light green marks the SOQ area, and yellow-green marks the NCO areas. , 2012 (ERDC-CERL).

Figure 14. The overall layout of Randolph AFB has remained consistent with the original design concept of the ideal Air City. Although the base has grown since initial construction, the basic form of the airfield remains shown here (from left) in the 1930s, 1946, and 2012 (ERDC-CERL). 
Figure 15. Changes in road system layouts of Randolph AFB (from left): initial construction in the 1930s, the build-up for WWII, and growth in the later part of the twentieth century (ERDC-CERL, 2012).

Figure 16. The entrance boulevard (from left) in the 1930s, 1946, and 2012. Harmon Drive and Washington Circle comprise the entrance sequence to Randolph AFB. While some changes have been made, the overall land use has remained consistent since the base's initial construction. North is to the top of the diagram (ERDC-CERL, 2012).

Figure 17. From left, the red outline depicts the warehouses and shops area in the 1930s, 1946, and 2012 located west of Washington Circle. North is to the top of the drawing (ERDC-CERL, 2012).

Figure 18. Comparison of the runways in 1946 (left) and 2012 (right). Prior to the construction of formal runways, grassed fields on the east and west flight lines accommodated takeoffs and landings. As a result, the only infrastructure needed for these grassed fields were the aprons extending out from the lines of hangars, which can be seen in the hangar line component landscape (ERDC-CERL).

Figure 19. From left, the hangar sequence in the 1930s, 1946, and 2012 is outlined in red, 2012 (ERDC-CERL).

Figure 20. From left, the land use outlined in red of officers' housing in the Main Circle has remained the same from the 1930s, the 1946 installation plan, and the 2012 plan. The only major change has been the appropriation of land in the northern triangles for other uses by 2012 (ERDC-CERL).

Figure 21. The NCO housing areas have mostly retained their original usage boundaries from the initial construction of the base in the 1930s (left) through the 2000 s (right). Only a portion of the eastern section of NCO housing has been appropriated for other uses (ERDC-CERL).

Figure 22. Land use changes in the BOQ area in the 1930s, 1946, and 2012 (ERDCCERL). 39

Figure 23. From left, enlisted men's barracks in the 1930s, 1946, 2012 (ERDC-CERL)

Figure 24. From left, the Cadet Complex development through the 1930s, 1946, and 2012 (ERDC-CERL).

Figure 25. From left, the Post Hospital and the School of Aviation Medicine in the 1930s, 1946, and 2012 (ERDC-CERL).

Figure 26. Aligned on the primary north-south axis through the base were the prominent areas and buildings, such as the Administration Building, Commanding General's quarters, Officers' Club, and Cadet Education Building in the Cadet Complex. On the secondary east-west axis were the stage houses for the east and west flight lines, as well as the barracks complexes. Axial lines drawn on an undated, but pre-WWII plan of the base (ERDC-CERL)

Figure 27. View south from the Taj Mahal along the primary north-south axis, emphasizing the alignment of the Main Circle officers' housing, 2012 (ERDC-CERL).

Figure 28. The warehouse and shop area, on the right, conveys the same uniform visual aesthetics as the officers' housing area, on the left, 2012 (ERDC-CERL).

Figure 29. Although the chapel is highly ornamented, it blends into the overall aesthetic of the base through the use of similar construction materials and vegetation, 2012 (ERDCCERL).

Figure 30. The highly ornamented and visually distinct Administration Building, also known as the Taj Mahal (Bone Collection Randolph AFB Cultural Resources). 
Figure 31. View from the Taj Mahal toward the main entrance. The base flagpole is located north of the Administration Building, on axis with the main entrance, 2012 (ERDCCERL)..

Figure 32. View of the Taj Mahal from the chapel, 2012 (ERDC-CERL).

Figure 33. Main entrance to Randolph Field during the 1930s showing the Old Seguin Road and the Southern Pacific Railroad (Norfleet Giddings Bone Papers, University of Texas at San Antonio Libraries Special Collections).

Figure 34. County roads and the rail spur leading into Randolph Field, 1930s (ERDCCERL).

Figure 35. Plan of Randolph Field's road network in the 1930s (Norfleet Giddings Bone Papers, University of Texas at San Antonio Libraries Special Collections) .

Figure 36. In 1946 county roads still bounded Randolph Field on the east, west, and south sides while Seguin Road to the north was widened and State Highway 218 now connected to the base's main entrance (Randolph AFB Cultural Resources).

Figure 37. By 1946 the rail spur into Randolph Field had been expanded, but still directly served the warehouse and shop area in the northwestern corner of the base (Randolph AFB Cultural Resources)

Figure 38. Randolph's buildings were clustered according to functional use and aesthetically unified through shared architectural styles and construction materials, undated (NARA RG 342, Box 1071 B20624).

Figure 39. The Administration Building, known as the Taj Mahal because of its distinct design and architectural treatments, 2012 (ERDC-CERL). 55

Figure 40. The Post Chapel in the early 1940s (NARA RG342 Box 1072 B20767) .........................56

Figure 41. Post Chapel, 2012 (ERDC-CERL) ..................................................................................56

Figure 42. Post Exchange in the 1930s (NARA RG342 Box 1072 B20769)..................................57

Figure 43. Interior courtyard of the Post Exchange in the 1930s (NARA RG342 Box 1072 B20770). .58

Figure 44. Courtyard of the former Post Exchange, 2012 (ERDC-CERL)..........................................58

Figure 45. Fire station building in the 1930s (NARA RG342 Box 1072 B2077). .............................59

Figure 46. Post garage in the warehouse and shop area in the 1930s (NARA RG342 Box 1072 B20773). 60

Figure 47. Engineering shops in the 1930s (NARA RG342 Box 1072 B20800). 60

Figure 48. The warehouse and shop area conveys the same visual aesthetics as the rest of the base, 2012 (ERDC-CERL). 61

Figure 49. Hangar “D” in the 1930s (NARA RG 342 Box 1072 B20803). .........................................62

Figure 50. Row of hangars, 2012 (ERDC-CERL). . .63

Figure 51. Stage house and operations office on one of the flight lines, 1935 (NARA RG342 Box 1072 B20809).

Figure 52. Former stage house with hangars in the background, 2012 (ERDC-CERL).

Figure 53. Enlisted men's barracks complex in the 1930s (NARA RG342 Box 1072 B20807).

Figure 54. Former enlisted men's barracks altered to serve as administrative spaces, 2012 (ERDC-CERL). 66

Figure 55. Cadet Complex during construction in the 1930s, before the additional barracks were added (NARA RG342 Box 1071 B20695). 
Figure 56. Aerial view of the Cadet Complex looking toward the west flight line. By 1939, when the photograph was taken, two additional barracks had been added at right angles to the original barracks buildings, 1939 (NARA Box 1042 B12329).

Figure 57. Aerial view of the former Cadet Complex, 2012 (bing.com/maps)...................................68

Figure 58. Cadet Academic Building in the 1930s (NARA RG342 Box 1072 B20837).....................68

Figure 59. Cadet Administration Building, undated (NARA RG342 Box 1072 B20835)..................69

Figure 60. Swimming pool south of the Cadet Administration Building, 1932 (NARA

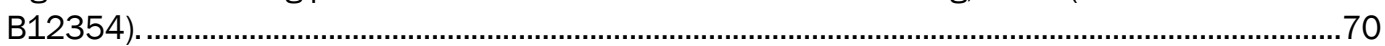

Figure 61. The former Cadet Administration Building, 2012 (ERDC-CERL). .......................................70

Figure 62. Cadet Barracks in the 1930s (NARA RG342 Box 1072 B20848)................................... 71

Figure 63. Cadet Complex Barracks, now converted to offices, 2012 (ERDC-CERL). …………….....72

Figure 64. Circular courtyard of the Cadet Complex, 2012 (ERDC-CERL)..........................................73

Figure 65. Post hospital in the 1930s (NARA RG 342 Box 1072 B20832)....................................... 74

Figure 66. The former Post Hospital, 2012 (ERDC-CERL). ................................................................ 74

Figure 67. School of Aviation Medicine, 1948 (NARA RG342 Box 1072 B20820)............................75

Figure 68. The former School of Aviation Medicine building, 2012 (ERDC-CERL)............................75

Figure 69. Commanding General's house main façade, undated (NARA RG342 Box 1072

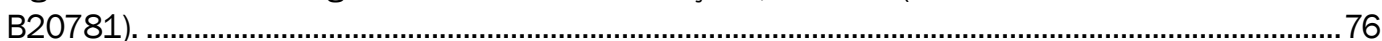

Figure 70. Main Circle officers' housing, 2012 (ERDC-CERL)...........................................................77

Figure 71. Quarters No. 11 on South Park, late 1930s (RG342 Box 1072 B20758).......................78

Figure 72. Example of the single-story type of officers' quarters, 2012 (ERDC-CERL). ....................78

Figure 73. One of Marriot's variations of the two-story officers' quarters had an arched door surround, 1930s (NARA RG342 Box 1072 B20784).

Figure 74. One of Marriot's variations of the two-story officers' houses, featuring a squared-entrance surround , with balconet and tile-decorated window above, 2012 (ERDC-CERL).

Figure 75. Another of Marriot's two variations on two-story officers' quarters, showing the squared-door surround, with tile-decorated window above, 1930s (NARA RG342 Box 1072 B20755).

Figure 76. Another current example of Marriott's variation of two-story officers' quarters, with squared-door surround and tile-decorated window above, 2012 (ERDCCERL).

Figure 77. Example of one variation on the two-story officers' quarters in the 1930s (NARA RG342 Box 1072 B20785)

Figure 78. Two-story officers' quarters, 2012 (ERDC-CERL).

Figure 79. An example of one of the variations on the two-story officers' quarters in the 1930s (NARA RG342 Box 1072 B20783).

Figure 80. Current view of Green's variation on two-story officers' quarters, 2012 (ERDCCERL).

Figure 81. An example of one of Green's variations on the two-story officers' quarters in the 1930s (NARA RG342 Box 1072 B20787).

Figure 82. Open area behind the officers' housing showing the regular spacing of the quarters, 2012 (ERDC-CERL).

Figure 83. Main entrance of the Officers' Club, undated (Norfleet Giddings Bone Papers, University of Texas at San Antonio Libraries Special Collections). 
Figure 84. Officers' Club, 2012 (ERDC-CERL)

Figure 85. Officers' club, undated (Norfleet Giddings Bone Papers, University of Texas at San Antonio Libraries Special Collections).

Figure 86. New patio behind the Officers' Club in the 1930s (NARA RG342 Box 1072 B20847). 87

Figure 87. Back of the Officers' Club, 2012 (ERDC-CERL).

Figure 88. Officers' Club swimming pool with elaborate diving stand in the 1930s (NARA RG342 Box 1072 B20799). .88

Figure 89. Officers' Club pool and pool house, 2012 (ERDC-CERL). .89

Figure 90. Western section of the noncommissioned officers' quarters in December 1930, looking northeast (Bone Collection Randolph AFB Cultural Resources).

Figure 91. Two-story duplex NCO quarters, 2012 (ERDC-CERL). .90

Figure 92. Two-story duplex NCO quarters, 2012 (ERDC-CERL). 91

Figure 93. Exterior of the western enlisted men's club in 1931 (then designated as Building \#253), (Norfleet Giddings Bone Papers, University of Texas at San Antonio Libraries Special Collections).

Figure 94. Former NCO club near the west flight line. Additions to the original structure have been made on the north side of the building, 2012 (ERDC-CERL)...

Figure 95. NCO club on the east side of the base in the 1930s (then designated as Building \#254), (NARA RG342 Box 1072 B20806).

Figure 96 . South façade of the former NCO club near the east flight line, now converted to office space. An addition has been added to the north (ERDC-CERL, 2012).

Figure 97. Bachelor Officers' Quarters (center) in the 1930s. Mess hall is to the left, garage buildings are to the right, and hangars are in the background of this photo (NARA RG342 Box 1072 B20792).

Figure 98. Bachelor Officers' Mess Hall in the 1930s (NARA RG342 Box 1072 B20793)...............95

Figure 99. Former BOQ Mess Hall, now Randolph Inn, 2012 (ERDC-CERL)......................................95

Figure 100. South elevation of the BOQ, 2012 (ERDC-CERL)........................................................96

Figure 101. Aerial view of Randolph Field's nursery and greenhouse, 1930 (Bone Collection Randolph AFB Cultural Resources).

Figure 102. View of the extensive plantings around the main gate, 1930s (Norfleet Giddings Bone Papers, University of Texas at San Antonio Libraries Special Collections).

Figure 103. The Randolph Field nursery, undated (University of Texas at San Antonio, Norfleet Bone Collection). 101

Figure 104. In this aerial view of the Taj Mahal the landscaping around the administration building is illustrated as well as the tree and shrub patterns in the areas around Washington Circle and down the median of North Park, 1939 (NARA B12364).

Figure 105. Arboreal layout that shows most of Randolph's streets lined with trees, May 1946 (Randolph AFB Cultural Resources).

Figure 106. Looking south along the planting designs of North Park in the 1930s. This view also shows trees lining the streets (NARA RG342 Box 1072 B20828).

Figure 107. View south along North Park, 2012 (ERDC-CERL). 105

Figure 108. The extensively planted medians on North Park, looking toward the Officers' Club, undated (Norfleet Giddings Bone Papers, University of Texas at San Antonio Libraries Special Collections). 
Figure 109. North Park median looking toward the Officers' Club. A sidewalk has been added down the middle of the space and street trees line either side. The original landscaping has been removed, 2012 (ERDC-CERL).

Figure 110. West Park looking toward the Officers' Club, showing the extensively planted medians, undated (Norfleet Giddings Bone Papers, University of Texas at San Antonio Libraries Special Collections).

Figure 111. Lt. Bone also designed cactus gardens near the Administration Building, shown in the 1930s (NARA RG342 Box 1072 B20845).

Figure 112. A median in the road network that has a few trees planted, 2012 (ERDC$\mathrm{CERL}$ ). According to Lt. Bone's planting plans for the base, many of these areas were vegetated.

Figure 113. A median in the road network with a single tree planted in the center of the space, 2012 (ERDC-CERL).

Figure 114. Because of the intricate circular road network, there are many dividers and medians throughout the base. The extensive planting strategies of Lt. Bone had many of these small spaces planted. Maintenance on these spaces has been gradually reduced to mowing grass or, as this image shows, being filled with no-maintenance lava rocks, 2012 (ERDC-CERL).

Figure 115. View north along the entrance boulevard toward the main entrance (center top of photo), 1958 (NARA RG342-B Box300).

Figure 116. Trees line the main entrance boulevard, Harmon Drive, 2012 (ERDC-CERL).

Figure 117. Line of small street trees along Fifth Street West, east of the hangars in the 1930s (NARA RG342 Box 1071 B20681).

Figure 118. Palms line the street along the row of hangars, 2012 (ERDC-CERL).

Figure 119. A few trees have been planted around the hangars, 2012 (ERDC-CERL).

Figure 120. Main entrance to the Administration Building showing the elaborate planting patterns most likely designed by Lt. Bone, undated (NARA RG342 Box1072 B20821).

Figure 121. The "Taj Mahal" in the 1970s showing a change in the planting pattern in front of the building. The variety of plants evident in the 1930s has been replaced with a hedge row of a single species (Norfleet Giddings Bone Papers, University of Texas at San Antonio Libraries Special Collections).

Figure 122. The "Taj Mahal” in 2012. The north façade plantings have again changed. The entrance between the hedge row has been widened and a few evergreens have been planted on either side of the arched entrance, 2012 (ERDC-CERL).

Figure 123. Landscaping around the base's flagpole includes rows of small shrubs with annuals planted in a bed of river rocks, 2012 (ERDC-CERL).

Figure 124. The chapel was another important area in the base. By the 1950s, the front of the chapel had been elaborately landscaped with a variety of evergreen shrubs and small trees, 1958 (NARA RG342 Box 300).

Figure 125. Chapel landscaping in 2012 (ERDC-CERL).

Figure 126. The landscaping around the Post Exchange was varied in height and type in the 1930s (NARA RG342 Box 1072 B20769)...

Figure 127. One of the entrances to the former PX courtyard, 2012 (ERDC-CERL)...................... 118

Figure 128. Planting pattern along the southern side of the former PX building, 2012 (ERDC-CERL).

Figure 129. Interior courtyard of the Post Exchange building in the 1930s planted with a variety of species (NARA RG342 Box 1072 B20770). 
Figure 130. The current planting design of the PX courtyard consists of boxwood hedges pruned into cubes and a few ornamental trees, 2012 (ERDC-CERL).

Figure 131. The landscaping around the fire house, on the left side of the image, was as elaborate as the planting plan for the PX building to the northwest (on the right side of the photo), 1930s (NARA RG342 Box 1072 B20772).

Figure 132. Even the post garage was landscaped, with evergreens planted between the garage bays, 1930s (NARA RG342 Box 1072 B20773).

Figure 133. Two palms placed on either side of an entrance to one of the former warehouses, 2012 (ERDC-CERL).

Figure 134. Thick, low hedges line the front of the Quality Assurance building, 2012 (ERDC-CERL).

Figure 135. The planters that were incorporated onto the east and west sides of this building now have a few scattered species on one side and box hedges on the other, 2012 (ERDC-CERL).

Figure 136. Extensive vegetation was planned for the officers' quarters, in this undated drawing (Norfleet Giddings Bone Papers, University of Texas at San Antonio Libraries Special Collections).

Figure 137. Officers' quarters with foundation plantings in the1930s (NARA RG342 Box 1072 B20784)

Figure 138. Current planting design in the officers' residential area, 2012 (ERDC-CERL)............ 125

Figure 139. More extensively planted officers' quarters, 2012 (ERDC-CERL). 125

Figure 140. Landscaping along the North Park median that blended well with the residential landscaping around the housing quarters, 1930s (NARA RG342 Box 1072 B20757).

Figure 141. Landscaping along the park boulevards, 1930s (NARA RG342 Box 1072).

Figure 142. Rock gardens were also part of the landscaping in the officers' housing area, 1930s (NARA RG342 Box 1072).

Figure 143. South Park median looking toward Taj Mahal, 2012 (ERDC-CERL)............................. 128

Figure 144. NCO quarters landscaping, 2012 (ERDC-CERL).

Figure 145. The BOQ buildings were landscaped around their foundations with evergreens that were used to emphasize building entrances, 1930s (NARA RG342 Box 1072).

Figure 146. The BOQ mess was landscaped like the other buildings in the complex with evergreen trees and shrubs around the foundation, 1930s (NARA RG342 Box 1072).

Figure 147. The former BOQ mess hall retains some foundation plantings and the space south of the entrance has been lined with palms, 2012 (ERDC-CERL).

Figure 148. One of the barracks buildings with foundation plantings. Evergreen trees emphasize the architectural division in the building, while shrubs and hedges delineate entrances, 1930s (NARA RG342 Box 1072).

Figure 149. Original amphitheater drawing, 1930s (Norfleet Giddings Bone Papers, University of Texas at San Antonio Libraries Special Collections).

Figure 150. The current plantings around the former enlisted men's barracks buildings are unified in a cohesive design. Many ornamental plants stand alone or are part of broken hedges, 2012 (ERDC-CERL).

Figure 151. The administration building in the Cadet Complex. The Cadet Circle, in the foreground, has been planted with palms while the buildings in the complex have a variety of plants surrounding their foundations, 1930s (NARA RG342 Box 1072). 
Figure 152. Annuals are now planted extensively around the Base. The Cadet Circle is filled with petunias and snapdragons as well as low-growing evergreen hedges along with the palm trees lining the circle, 2012 (ERDC-CERL).

Figure 153. The Cadet Complex barracks were originally surrounded by open green spaces, but by the 1940s parking lots had been introduced along the barracks while retaining some of the original green space. By 2012, the east and west spaces between the buildings has been converted to parking lots with a strip of open space and a few trees, 2012 (ERDC-CERL).

Figure 154. The School of Aviation Medicine had a well-developed landscaping by the late 1930s (NARA RG342 Box 300).

Figure 155. The Post Hospital and School of Aviation Medicine were elaborately planted with evergreens, but currently, there are a ornamental trees and shrubs around these buildings, 2012 (ERDC-CERL)

Figure 156. The first view of Randolph Field looking toward the Taj Mahal that new cadets would see upon arrival, undated (NARA RG342).

Figure 157. View toward the main entrance from the Administration Building, 1958 (NARA RG 342 Box 300).

Figure 158. The most dominant view at Randolph AFB is still the view between the main entrance and the Administration Building, 2012 (ERDC-CERL).

Figure 159. Aerial view of the west flight line with the Taj Mahal in the background, undated (NARA RG 342 Box 1071 B 20681).

Figure 160. View of Randolph's eastern flight line, taken from the southeast corner of the installation, 2012 (ERDC-CERL).

Figure 161. Views and viewsheds in the Randolph Field Historic District. Numbering corresponds to the aforementioned views list, 2013 (ERDC-CERL).

Figure 162. Base flagpole north of the Taj Mahal, 2012 (ERDC-CERL).

Figure 163. Markers surrounding the base flagpole north of the Taj Mahal, 2012 (ERDC-

CERL)

Figure 164. Inscription on the Taj Mahal flagpole area marker commemorating the $50^{\text {th }}$ anniversary of Randolph AFB and the 2001 designation of the Randolph Field Historic District, 2012 (ERDC-CERL).

Figure 165. Flagpole and Randolph Field sign in front of the Taj Mahal, 2012 (ERDCCERL) 150

Figure 166. Detail of the large Randolph Field sign lettering in front of the Taj Mahal, 2012 (ERDC-CERL). 150

Figure 167. Flagpole in front of the west flight line's former stage house, 2012 (ERDCCERL)

Figure 168. Fence used to separate the flight lines from the cantonment, 2012 (ERDCCERL).

Figure 169. Concrete planters in front of the Taj Mahal, 2012 (ERDC-CERL). 152

Figure 170. Concrete benches in front of the Taj Mahal, 2012 (ERDC-CERL) 152

Figure 171. Decorated concrete bench located near the Taj Mahal, 2012 (ERDC-CERL). 153

Figure 172. Example of a type of concrete bench located throughout the base, 2012 (ERDC-CERL). 153

Figure 173. Park bench near the Taj Mahal, 2012 (ERDC-CERL). ............................................... 154

Figure 174. Planter outside the entrance of a barracks, 2012 (ERDC-CERL). 154 
Figure 175. Planters on either side of an entrance to one of the former barracks buildings, 2012 (ERDC-CERL).

Figure 176. Randolph Oaks sign at the base golf course, 2012 (ERDC-CERL)............................. 155

Figure 177. Trash can near tennis courts, 2012 (ERDC-CERL)..................................................... 156

Figure 178. Drinking fountain near tennis courts, 2012 (ERDC-CERL)......................................... 156

Figure 179. Base theater sign, 2012 (ERDC-CERL). .................................................................... 157

Figure 180. Modern sign along the west side of Harmon Drive, welcoming visitors to Randolph AFB, 2012 (ERDC-CERL). ....................................................................................... 157

Figure 181. Commemorative granite bench, 2012 (ERDC-CERL)................................................ 158

Figure 182. Airplane on display in front of the BOQ area, 2012 (ERDC-CERL) ............................ 159

Figure 183. The Missing Man Monument on the west side of Washington Circle, 2012

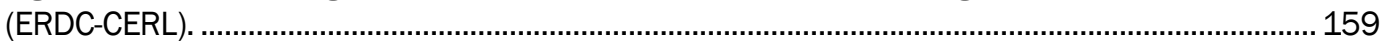

Figure 184. Building 100, Texas State Historical Commission plaque, 2012 (ERDC-CERL).......... 160

Figure 185. DAR marker in association with the Chapel, 2012 (ERDC-CERL)............................... 160

Figure 186. Air Training Command monument in front of the former Cadet Complex

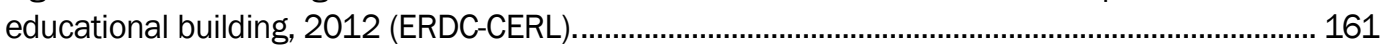

Figure 187. Harmon Drive dedication marker and Flag Plaza, 2012 (ERDC-CERL). ...................... 161

Figure 188. Dedication marker of Harmon Drive, 2012 (ERDC-CERL)........................................... 162

Figure 189. Flag Plaza marker and Avenue of American States marker, 2012 (ERDCCERL).

Figure 190. Flags marking Avenue of American States down the median of Harmon Drive,

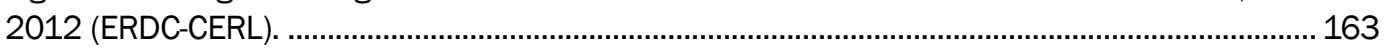

Figure 191. Wright Memorial Pavilion and plaque, 2012 (ERDC-CERL).......................................... 163

Figure 192. The Youth House plaque commemorating the site of Randolph Field's nursery and honoring Lt. Norfleet Bone, the base landscape architect (ERDC-CERL, 2012). The adjacent Youth House building was constructed in 1940 by the WPA and was determined eligible for listing on the NRHP.

Figure 193. The Youth House plaque in association with the WPA building, 2012 (ERDCCERL).

Figure 194. Marker dedicating the Chapel to the men and women of Randolph AFB from 1934-1984, 2012 (ERDC-CERL).

Figure 195. The Randolph Field Historic District is delineated with a dark blue line, 2012

(Randolph AFB Cultural Resources). .............................................................................................171

Figure 196. Example of median degraded by added parking, 2012 (ERDC-CERL)........................ 175

Figure 197. Randolph Field runways are the junction of open space and the built environment, 1930s (Norfleet Giddings Bone Papers, University of Texas at San Antonio Libraries Special Collections)

Figure 198. Loss of grassed area, sidewalks, and trees between roads and hangars, 2012 (ERDC-CERL).

Figure 199. Enlisted men's barracks on the west side, 2012 (ERDC-CERL)..................................177

Figure 200. Extensive vegetation around the buildings and in the medians, 1930s (NARA RG342 Box 1072 B20780).

Figure 201. North Park median, with street trees, 2012 (ERDC-CERL)........................................ 179

Figure 202. Historic planting designs emphasized native shrubs and grasses, 1930s

(NARA RG342 Box 1072). 
Figure 203. Annuals planted in Cadet Circle, 2012 (ERDC-CERL)................................................ 181

Figure 204. Annuals planted in the median in front of the Chapel, 2012 (ERDC-CERL)............... 182

Figure 205. Overall component landscape management guidelines, 2013 (ERDC-CERL)........... 191

Figure 206. Diagram of a potential planting scheme for the medians, 2013 (ERDC-CERL)......... 194

Figure 207. Proposed median planting plans, 2013 (ERDC-CERL)................................................. 195

Figure 208. Overall historic planting strategy for Washington Circle, 2013 (ERDC-CERL).............. 199

Figure 209. Administration building proposed planting plan, 2013 (ERDC-CERL)........................ 203

Figure 210. Administration building proposed elevation planting plan, 2013 (ERDC-CERL)......... 205

Figure 211. Proposed planting plan for the chapel, 2013 (ERDC-CERL). ...................................... 209

Figure 212. Proposed elevation planting for the chapel, 2013 (ERDC-CERL)................................ 211

Figure 213. Proposed planting plan for the former PX, 2013 (ERDC-CERL).................................. 215

Figure 214. Planting diagram for the warehouse and shops area. Not to scale, 2013

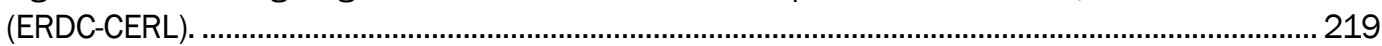

Figure 215. One-story ranch style officers' quarters, proposed planting plan, 2013 (ERDC-

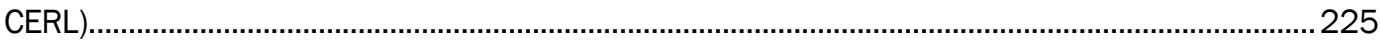

Figure 216. One-story ranch style officers' quarters, elevation planting plan, 2013 (ERDC-

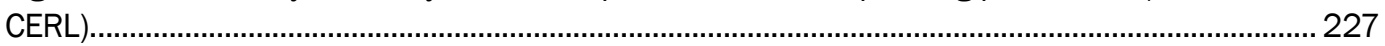

Figure 217. Two-story officers' quarters, proposed planting plan, 2013 (ERDC-CERL).................. 229

Figure 218. Two-story officers' quarters, elevation planting plan, 2013 (ERDC-CERL).................. 231

Figure 219. NCO quarters, proposed planting plan, 2013 (ERDC-CERL)......................................... 235

Figure 220. NCO quarters, elevation planting plan, 2013 (ERDC-CERL)..................................... 237

\section{Tables}

Table 1. Types of lighting used around Randolph AFB............................................................... 145

Table 2. Component landscape within Randolph AFB................................................................. 183

Table 3. Current Randolph AFB plant list, 2012 ............................................................................. 249 


\section{Preface}

This study was conducted for the Conservation and Restoration Branch, Environmental Division, Randolph AFB, TX under Project Number 370647, "Historic Landscape Contexts, Inventories, and Management Plans for Randolph AFB \& Maxwell AFB." The Randolph AFB technical monitor was Deborah Tharp, Cultural Resources Specialist, AETC/ A7CAN (later reorganized as AFCEC-West Region) and Scott Shepherd III, Cultural Resources Manager, Conservation and Restoration Branch, Environmental Division, Randolph AFB, Texas.

The work was performed by the Land and Heritage Conservation Branch (CN-C) of the Installations Division (CN), U.S. Army Engineer Research and Development Center - Construction Engineering Research Laboratory (ERDC-CERL). The ERDC Project Manager was Mr. Adam Smith. At the time of publication, Dr. Christopher White was Chief, CEERD-CN-C; Ms. Michele Hanson was Chief, CEERD-CN; and Mr. Alan Anderson was the Technical Director for Military Ranges and Lands, CEERD-CV-T. The Deputy Director of ERDC-CERL was Dr. Kirankumar Topudurti and the Director was Dr. Ilker Adiguzel.

The Commander of ERDC was COL J effrey R. Eckstein, and the Director of ERDC was Dr. J effery P. Holland. 


\section{Unit Conversion Factors}

\begin{tabular}{|l|c|l|}
\hline Multiply & By & To Obtain \\
\hline acres & $4,046.873$ & square meters \\
\hline degrees Fahrenheit & $(\mathrm{F}-32) / 1.8$ & degrees Celsius \\
\hline feet & 0.3048 & meters \\
\hline gallons (U.S. liquid) & $3.785412 \mathrm{E}-03$ & cubic meters \\
\hline inches & 0.0254 & meters \\
\hline miles (U.S. statute) & $1,609.347$ & meters \\
\hline miles per hour & 0.44704 & meters per second \\
\hline square feet & 0.09290304 & square meters \\
\hline square miles & $2.589998 \mathrm{E}+06$ & square meters \\
\hline square yards & 0.8361274 & square meters \\
\hline yards & 0.9144 & meters \\
\hline
\end{tabular}




\section{Abbreviations}

$\begin{array}{ll}\text { Term } & \text { Spellout } \\ \text { ADC } & \text { Aerospace Defense Command } \\ \text { AFB } & \text { Air Force Base } \\ \text { AFI } & \text { Air Force Instruction } \\ \text { ATC } & \text { Air Training Command } \\ \text { BOQ } & \text { Bachelor Officers' Quarters } \\ \text { BX } & \text { Base Exchange } \\ \text { CERL } & \text { Construction Engineering Research Laboratory } \\ \text { ERDC } & \text { Engineer Research and Development Center } \\ \text { NCO } & \text { noncommissioned officer } \\ \text { NHL } & \text { National Historic Landmark } \\ \text { NHPA } & \text { National Historic Preservation Act } \\ \text { NPS } & \text { National Park Service } \\ \text { NRHP } & \text { National Register of Historic Places } \\ \text { PX } & \text { Post Exchange } \\ \text { SAC } & \text { Strategic Air Command }\end{array}$




\section{Methodology}

\subsection{Background}

Congress codified the National Historic Preservation Act of 1966 (NHPA), which has been the most effective cultural resources legislation to date in providing guidelines and requirements to preserve tangible elements of our past. The benefits derived from this legislation were the result of a broader need for preserving historic cultural resources. Contained within the NHPA are Sections 106 and 110 which outline specific requirements for federal agencies to address their cultural resources. In the NHPA cultural resources are defined as any prehistoric or historic district, site, building, structure, or object. These resources have been identified primarily through creation of the National Register of Historic Places (NRHP). Section 106 requires the determination of the effect of federal undertakings on properties deemed eligible or potentially eligible for the NRHP. Section 110 requires federal agencies to inventory and evaluate their cultural resources.

Randolph Air Force Base (AFB) is located in south-central Texas in Bexar County, about 18 miles northeast of San Antonio. When the air base was originally established by the Army as Randolph Field in 1928, it was placed under the jurisdiction of the Army Air Corp Training Center.

Within Randolph AFB is the Randolph Field Historic District, an approximately 405-acre site that includes 350 contributing buildings, sites, and structures as well as 47 non-contributing ones. ${ }^{1}$ The predominant architectural styles of the historic district are Mission Revival, Spanish Colonial Revival, and Art Moderne. Because of its distinctive architecture, the Base Administration Building is individually listed on the NRHP. The historic Randolph Field area was declared a National Historic Landmark (NHL) in 2001.

\footnotetext{
1 Jody Cook, National Historic Landmark Nomination, “Randolph Field Historic District,” John H. Sprinkle, ed., (Atlanta, GA: National Park Service Southeast Regional Office), August 2001, 4. Accessed online: http://pdfhost.focus.nps.gov/docs/NHLS/Text/96000753.pdf ed., (Atlanta, GA: National Park Service Southeast Regional Office, 2001), 4. Accessed online: http://pdfhost.focus.nps.gov/docs/NHLS/Text/96000753.pdf
} 


\subsection{Objectives}

The objectives of this historic landscape evaluation are to complete archival research determining the original design and planning intentions for Randolph AFB; inventory and document the landscape features; evaluate the landscape components and assess the landscape's eligibility for the NRHP; and then to make recommendations for the preservation and maintenance of Randolph AFB's historic landscapes.

\subsection{Approach}

For a property to qualify for the NRHP, it must meet at least one of the National Register Criteria for Evaluation, must be significantly associated with an important historic context, and must retain sufficient integrity to convey its significance under that context.

This report establishes the process by which the historic landscapes of Randolph AFB were inventoried and evaluated according to the criteria set forth for the NRHP. To be eligible or listed on the NRHP, cultural resources must meet certain requirements establishing their importance to American history and heritage. The cultural importance of Randolph's landscape is determined through the base's historic context. Next, using the historic context as a reference point, the physical site is analyzed and inventoried to determine the original design intentions. In doing this, the historic landscapes are identified and their features are documented through mapping, diagramming, and image collection. With this information, the historic qualities are determined and evaluated according to NRHP criteria. This process establishes the historic importance of the landscape and determines its historic integrity. With the analytical results, recommendations are made that are appropriate for the preservation and maintenance of the historic landscape features.

\subsubsection{Site visits}

An initial site visit was conducted in February 2012. During this visit the team conducted a windshield survey documenting the site with photographs. Researchers were also given a guided tour of Randolph AFB during which photography, sketches, and note taking were used to compile an overall understanding of the Randolph's built environment. 


\subsubsection{Archival research}

The first phase of archival research established the historic context of Randolph AFB. This research included finding, gathering, and reviewing all sources relevant to the project. The next phase indentified and located primary sources that document the original design and planning intentions of Randolph AFB.

\subsubsection{Literature review}

Researchers used secondary sources to determine the general history of Randolph AFB. Secondary sources included published materials found on the region and about Randolph AFB and its landscapes.

\subsubsection{Research material}

The research team located primary materials including historic maps, plans, and photographs of Randolph AFB. Additional primary and secondary sources were used to describe how the landscape of Randolph AFB was used and how the land was constructed to meet those needs. These sources were found in the Randolph AFB historic archives and the National Archives in College Park, MD.

\subsubsection{Analysis and evaluation}

Using the information from the historic context, an overarching NRHP integrity was determined. Cultural resources can retain or lose historic integrity, meaning that a resource's current condition either does or does not convey its historic significance. By establishing a historic context, individual resources can be evaluated along similar physical metrics. The physical features of each component landscape were documented and evaluated to establish the character-defining features of the site, and whether those features did or did not contribute to the established historic context. From this evaluation, a recommendation of eligibility to the National Register was made, if not already included under the NHL. The evaluation followed guidelines in the following National Park Service briefs and bulletins:

- National Register Bulletin \#15, How to Apply the National Register Criteria for Evaluation²

\footnotetext{
2 NPS, National Register Bulletin \#15: How to Apply the National Register Criteria for Evaluation (Washington, DC: US Department of the Interior, National Park Service, 1991).
} 
- National Register Bulletin \#16A, How to Complete the National Register Registration Form ${ }^{3}$

- National Register Bulletin \#18: How to Evaluate and Nominate Designed Historic Landscapes ${ }^{4}$

- Bulletin \#30: Guidelines for Documenting and Evaluating Rural Historic Landscapes 5

- Preservation Brief \#36: Protecting Cultural Landscapes, the National Register Bulletin: How to Prepare National Historic Landmark Nominations, The Secretary of the Interior's Standards for the Treatment of Historic Properties with Guidelines for the Treatment of Cultural Landscapes ${ }^{6}$

- The National Park Service's Guide to Cultural Landscape Reports7

- The Department of Defense guidance, Guidelines for Documenting and Evaluating Historic Military Landscapes: An Integrated Landscape Approach 8

The guidelines were applied to identify and list the character-defining features of the Randolph AFB landscape by noting the cumulative loss of character, the alternation/ masking of prominent features, or the introduction of new elements. Additionally, the landscapes were ranked high, medium, or low based on their significance to the overall history of Randolph AFB, the US military, and the United States and then ranked on their ability to convey that historic significance.

\footnotetext{
3 NPS, National Register Bulletin \#16A: How to Complete the National Register Registration Form (Washington, DC: US Department of the Interior, National Park Service, 1997).

4 NPS, National Register Bulletin \#18: How to Evaluate and Nominate Designed Historic Landscapes, prepared by J. Timothy Keller and Genevieve P. Keller (Washington, DC: US Department of the Interior, National Park Service, n.d.).

5 NPS, National Register Bulletin \#30: Guidelines for Documenting and Evaluating Rural Historic Landscapes (Washington, DC: US Department of the Interior, National Park Service, 1999).

6 National Park Service, Preservation Brief \#36: Protecting Cultural Landscapes, prepared by Charles A. Birnbaum (Washington, DC: US Department of the Interior, National Park Service, 2000).

7 NPS, Guide to Cultural Landscape Reports: Contents, Process, and Techniques, credited authors: Robert R. Page, Cathy Al. Gilbert, Susan A. Dolan (Washington, DC: US Department of the Interior, 1998).

8 Suzanne Keith Loechl, Samuel A. Batzli, and Susan I. Enscore. Guidelines for Documenting and Evaluating Historic Military Landscapes: An Integrated Landscape Approach. Army Environ-mental Command (AEC) Technical Guideline. (Champaign, IL: US Army Construction Engineering Research Laboratory, 2009). Accessed online: http://aec.army.mil/Portals/3/preserve/milland.pdf.
} 


\subsubsection{Recommendations}

The report concludes with general recommendations to assist managers in preserving and maintaining historic landscapes. This section evaluates the impacts of new construction on historic landscapes including evaluating the impacts of environmental and large-scale landscape interventions. These recommendations ensure that construction and deconstruction impacts to historic landscapes are evaluated and appropriately managed.

\subsection{Researchers}

This project was conducted by the U.S. Army Corps of Engineers, Engineering Research Development Center, Construction and Engineering Research Laboratory (ERDC-CERL) based in Champaign, IL. The research team included Adam Smith, M.Arch, as project manager and lead historian; Megan Weaver Tooker, MLA, as historic landscape architect; and Ellen Hartman, MLA, as assistant landscape architect. 
(This page intentionally left blank.) 


\section{Historic Context}

This chapter outlines the historic context of Randolph AFB's landscape development by identifying important historical themes, people, events, and periods of time influential in the growth of the base. The historic context shows how Randolph AFB's mission affects the built environment of the base and, in turn, the execution of landscape elements. As a result, historically important landscapes are identified within the scope of the history and planning of Randolph AFB.

\subsubsection{The pre-military landscape}

Randolph AFB is located in the Cibolo Valley area in south-central Texas. The written record for the Cibolo Valley extends over 300 years where human developments were greatly influenced by the environmental conditions of the area. Although Native Americans had long populated the area, it was the Spanish expeditions crossing the Río Grande that began humans' influence on the environment of the Cibolo Valley. The beliefs of the subsequent societies and the value they placed on the land would characterize significant stages in Texas' history. The documentary trail started by the Spanish explorers would extend through early settlements on the site, the founding of San Antonio, and the development of colonial roads, cattle ranching, statehood conflicts, and eventually the cotton fields planted by Anglo-American farmers. ${ }^{9}$

As Spanish explorers were moving into Texas, the San Antonio River watershed was an important geographical feature that drew people to the plains around what is now the city of San Antonio. Much of the San Antonio River watershed was fed from springs, but Cibolo Creek was an important stream within this system. Cibolo Creek wound across the prairie before cutting into the Balcones Escarpment which is the beginning of Texas Hill Country. In this area is the transition zone between the West Gulf Coastal Plain and the grasslands of the Great Plains. The terrain was comparatively flat and about 700 feet above sea level. The soils, predominantly Houston Black clay and Lewisville silty clay in the Taylor and Navarro formations, would later support large-scale agriculture. However,

\footnotetext{
9 Joseph P. Sánchez, Bruce A. Erickson, Joseph E. King, and Robert L. Spude. The Cibolo Valley, Texas, 1690-1928: Randolph Air Force Base Pre-Base History Study of the Spanish, Mexican, and Texan Periods (Washington, DC: National Park Service, 1996), 4-5.
} 
before agriculture, these soils sustained a mixture of grass types such as grama, bluestem, and buffalo grass that supported herds of bison and later cattle. The modified subtropical climate combined with favorable natural resources to create a rich base for human inhabitants. ${ }^{10}$

Over the last 300 years, the ecosystem of the area has changed significantly since Euro-Americans first witnessed it. Early travelers would often comment on the lush grasses of the tall grass prairie and the live oak and hickory groves that grew in sandier soils. In 1843 and 1844-just before major changes would begin — naturalist William Bollaert crossed Cibolo Creek and noted what he saw. In his notes, he remarks on the fine pastures of mesquite and grama grass, the live oak and mesquite trees, cactus, and a clover-like plant. ${ }^{11}$

Soon after Bollaert's travels, early settlers moved to the region after the Texas Revolution, and they introduced cattle and the first farms. Andrew J ackson Sowell, a member of an early family in Guadalupe County, described the development of the land from the 1830s through the 1880s. The country he described was "clear of brush and the view unobstructed from the creek [Guadalupe River valley] to the York's creek hills." By 1884, when he was writing, the area was covered with a dense growth of mesquite. With his writing, Sowell lamented the changes to the landscape and continued his descriptions of the early environment by writing "the prairie stretched away from the river without a bush to obstruct the view as far almost as the eye could reach, dotted here and there with small motts of liveoaks. At times vast herds of buffalo could be seen crossing the prairie earth and coming towards the river." 12 The influences of the early settlers would eventually cause the most ecological change to the area because the flat plains provided good farmland.

\subsubsection{Initial construction at Randolph AFB}

Flight training in the Army began as early as 1909 when the Signal Corps received delivery of its first airplane that summer. The airplane had been built by the Wright brothers and the contract stipulated that, in addition to the plane's construction, the Wright brothers would provide flying training for two Army officers. For this training, the Army leased 160 acres near

\footnotetext{
10 Sánchez et al., The Cibolo Valley, Texas, 6-8.

11 Sánchez et al., The Cibolo Valley, Texas, 8.

12 Sánchez et al., The Cibolo Valley, Texas, 9.
} 
College Park, Maryland. In February 1910, the Signal Corps was transferred to San Antonio, Texas, because of the mild climate and the large Army post at Fort Sam Houston. The flying training at Fort Sam Houston only lasted for a few years when it was canceled after the death of $2^{\text {nd }}$ Lieutenant G.E.M. Kelly in a 1911 airplane accident. Subsequent efforts by the Army to establish an aviation program resulted in the establishment of 27 flying fields by the end of WWI. However during the demobilization following WWI, most flight training programs were cancelled and post-war training was not well organized. ${ }^{13}$

By the early 1920s, five Army airfields were authorized to begin operations for a two-tiered flight training system. The Primary Flying Schools offered four-month classes at either Carlstrom Field in Arcadia, Florida, or March Field in Riverside, California. The Advanced Flying Schools provided three months of specialized training at Rockwell Field, California (Pursuit School); Ellington Field, Texas (Bombardment School); and Post Field, Oklahoma (Observation School). After primary and advanced training, a final three months of training was required in a tactical organization. This two-tiered system of flight training was cancelled on 28 J une 1922.14

Austerity measures throughout the Army following WWI resulted in deplorable conditions at Army posts and Air Service stations. Almost all airfields still in operation had temporary buildings that had been built during the war and were programmed to last between two and five years. Adding to the problem of substandard facilities were power struggles between aviation proponents and the other branches of the military that saw flying programs as merely support for ground forces. Although the problems of supporting and funding Air Service programs continued to exist through the interwar years, the passage of the Air Corps Act in 1926 provided a five-year expansion program that allowed the newly named Army Air Corps to expand considerably. The result was the first real commitment for permanent occupation infrastructure for Army aviation facilities. The funding from the Air Corps Act and the Army Housing Program (also enacted in 1926) allowed almost all 32 existing stations and depots retained after WWI to undergo significant improvements. Also included with the

13 Cook, "Randolph Field Historic District," 36-37.

14 Cook, "Randolph Field Historic District," 37. 
five-year development program were plans for two new airfields-one to house a new attack wing for combat forces and one for flying training. ${ }^{15}$

Flying training was assigned to the Air Corps Training Center, a newly formed organization in the Army. The three existing aviation schools in San Antonio, Texas, were assigned to the new training center. In reality, discussions regarding consolidating the training schools in San Antonio had been discussed at least as early as 1924. After the Chief of the Air Corps, Major General Mason Patrick, visited San Antonio in December 1926, "the establishment of the largest flying field in the world" was recommended. ${ }^{16}$ To meet the growing demands of flying training, Patrick wanted a field large enough for 500 planes, a number that required a minimum 2,000-acre site.

By 1927 a board of five officers had been appointed to submit plans and specifications for a model Air Corps Training Center flying field. The plans were to include barracks, shops, officers' and noncommissioned officers' quarters, school and administration buildings, hangars, and landing field. Concurrently, the board also considered several plans that had already been drawn up. From these previous plans, the board decided the plan would assume a circular shape. The final plans for Randolph Field were developed with this design idea, which was the "first form of the circular type field with buildings in the center." The intention was to divide the circle into four quadrants, where each would be dedicated to a distinct function. Three quadrants would accommodate the primary, basic, and advanced flying schools, with the fourth quadrant defining the shop and service area.

The circular plan that had caught the board's attention had been sketched by a dispatch officer in the motor pool at Kelly Field. The officer was 1st Lieutenant Harold Clark who had trained as an architect before entering the military during WWI. Clark's ideas were for a perfect "Air City" with the runways aligned with the prevailing winds and facilities located by function between the runways to keep planes from having to make landing approaches over hangars. Two flight lines with aircraft hangers and runways bracket the central housing, administrative, and service area.

\footnotetext{
15 Cook, “Randolph Field Historic District," 38.

16 Army Air Forces Central Flying Training Command, History of the Army Air Forces Central Flying Training Command, 1 January 1939-7 December 1941, 1st Installment (Randolph Field, Texas, April 1945), 10-11 in Cook “Randolph Field Historic District," 39.
} 
Specific functions of the base such as housing, warehouses and shops, and training areas were concentrated to facilitate base operations and training missions. Much of the circular design and layout of what would become Randolph Field was retained throughout the approval and construction process (Figure 1). ${ }^{17}$

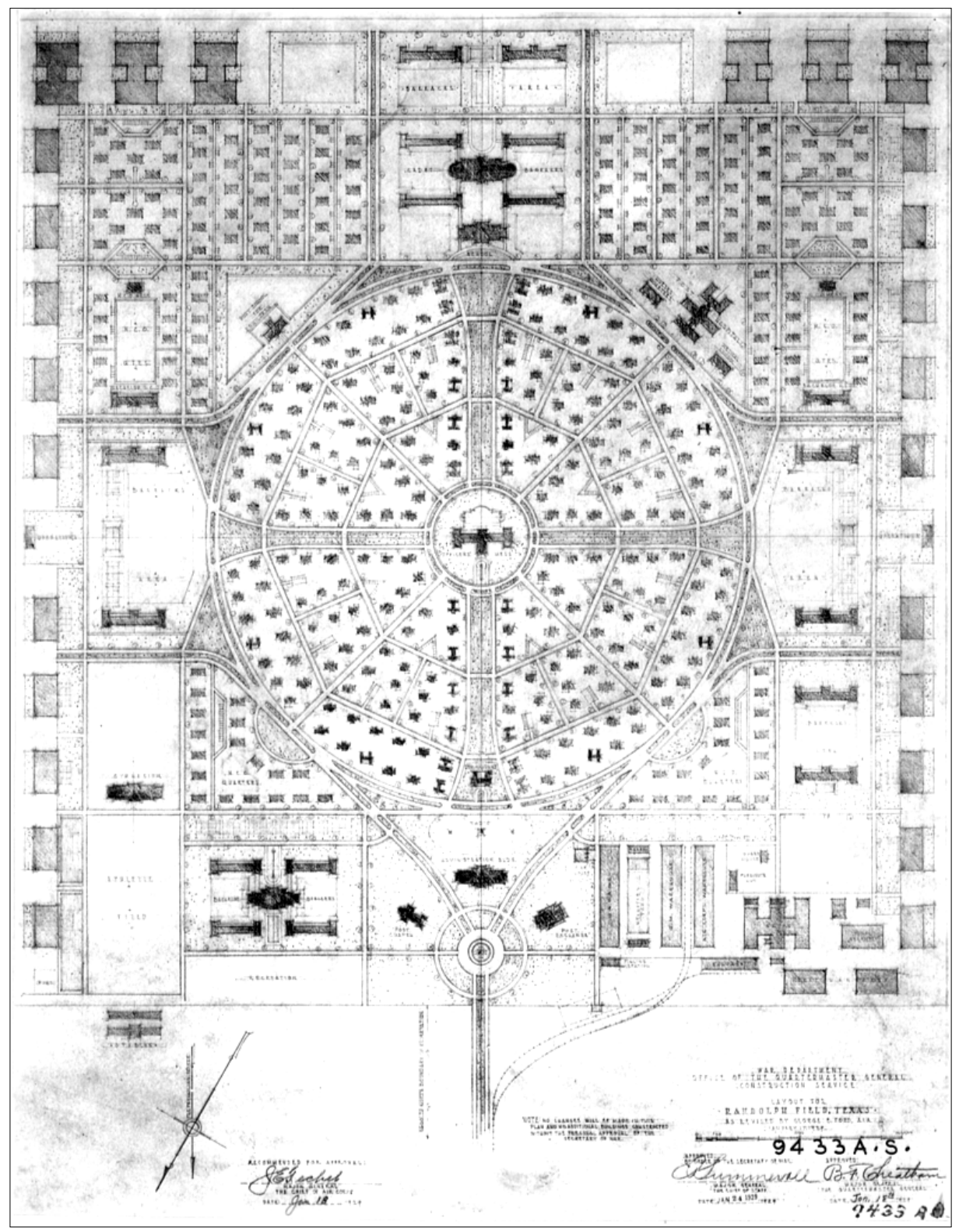

Figure 1. The 1929 plan of Randolph Field showing that changes occurred between the finalization of this plan and the field's construction. The changes included the organization of buildings in what was to be the Bachelor Officers' Quarters area, the Cadet Complex area, and a reduction in the officers' and NCO housing (NARA RG 342-FM Box 1071).

17 Cook, “Randolph Field Historic District," 40. 
Although the plan for the base was agreed upon, the site selection stretched into 1928. Rather than fitting a base plan to the natural features of a site, the plan for the new airfield had been established first; what remained was for a site to be found that could accommodate the plan. The initial site search, conducted in May 1927, examined eight possible sites and concluded that a tract called Calf Hill, about nine miles east of San Antonio, would most effectively meet the needs of the new flying school.

However, problems with the Calf Hill site were discovered, and a new site search was organized in October 1927. New specifications enlarged the allowable location of the flying field to within 30 miles of San Antonio. Within this radius, the search identified a site near the town of Schertz, Texas, about 18 miles northeast of San Antonio. In late December 1927, Colonel W.B. Tuttle, Chairman of the Chamber of Commerce's Military Affairs Committee, offered a tract of about 2,300 acres of land near Schertz to the War Department. In early J anuary 1928, Secretary of War, the Honorable Dwight F. Davis, accepted the donation with the provision that the City of San Antonio furnish title to the property. After several months of clearing titles to the land, the Acting Secretary of War accepted the gift in August 1928. The final donation was a 2,318 acre plot of land, roughly octagonal in shape. ${ }^{18}$

In September 1928, the War Department designated the planned flying field as Randolph Field for construction purposes, and it was placed under jurisdiction of the Air Corps Training Center on 13 October 1928. The field's name was in honor of Captain William Millian Randolph, who was on the naming committee at the time of his death in an airplane crash. The cost to construct Randolph Field was originally calculated to be more than $\$ 10$ million. At the time, it was the largest construction project undertaken by the Army, with the exception of the Panama Canal. Construction on Randolph Field began in November 1928 under the direction of Colonel Arthur W. Parker of the Quartermaster Corps and the Constructing Quartermaster for the San Antonio vicinity. ${ }^{19}$

The circular design for the base that had been drawn up by 1 st Lieutenant Clark was submitted for any necessary revisions and approval to noted planner and civilian advisor to the Construction Service, George B. Ford.

18 Cook,"Randolph Field Historic District," 40-41.

19 Cook,"Randolph Field Historic District,, 41. 
The new layout, which was unlike any other in the Army, underwent extensive revisions by Ford. The only remaining features of the original sketch that were kept were the circular roads at the center of the layout and the location of flight lines at the edges of the base. Ford's reworking of the initial plan included adding an impressive entrance that terminated at a roundabout, formerly called North Circle, and the siting of three important and architecturally distinct buildings around North Circle on the east, west, and south. ${ }^{20}$ The result was that Lieutenant Clark's plan and the final layout of Randolph Field had few major features in common.

The official post layout was signed by Ford and approved by the Chief of the Air Corps, the Quartermaster General, and the Chief of Staff for the Secretary of War in J anuary 1929. The result was an operational Air Corps Training Center that combined the training mission needs with advanced city planning principles which reflected the work of a master planner. The bird's-eye view in Figure 2 shows that the base plan was still being modified even as late as August 1929.

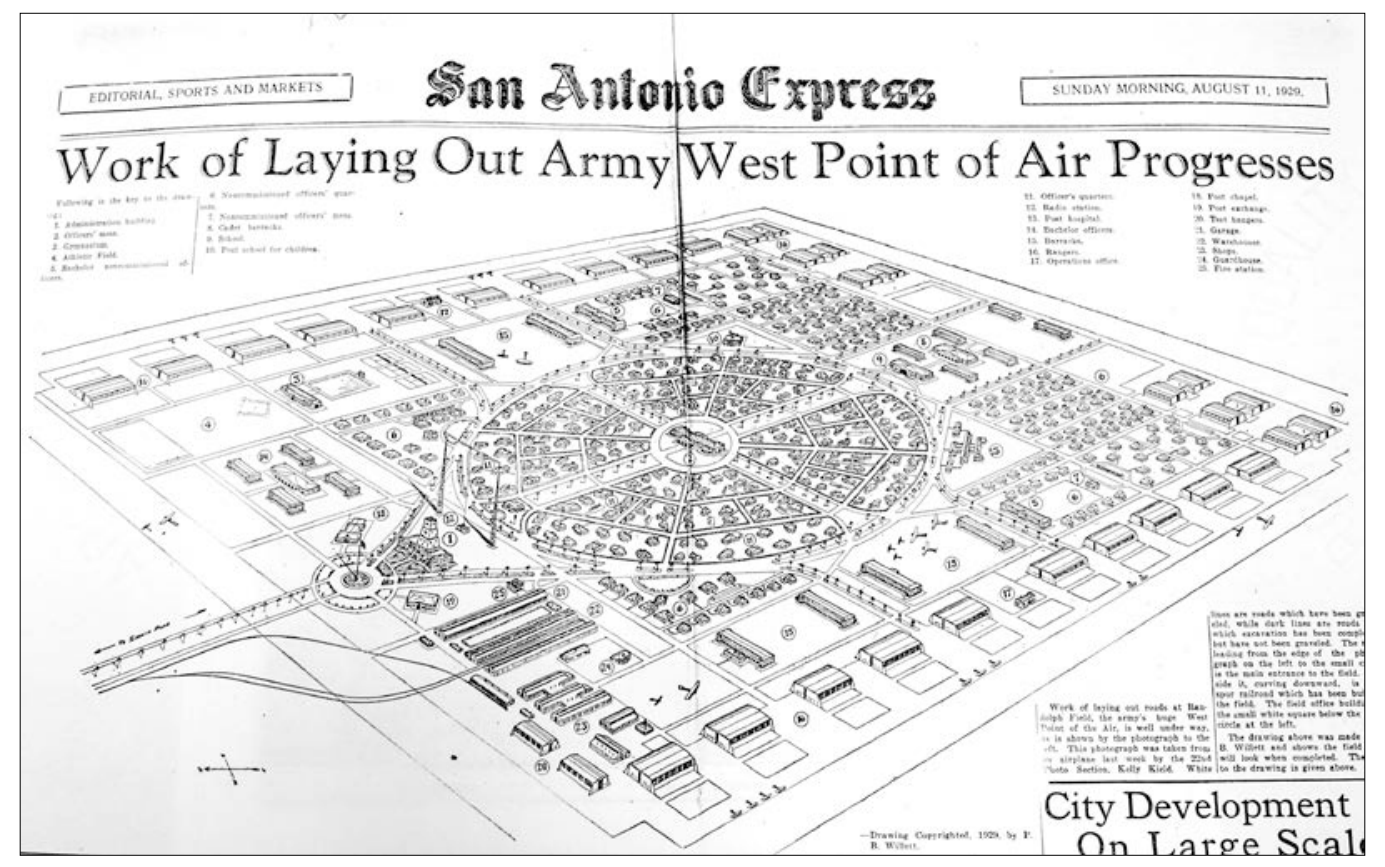

Figure 2. The plan for Randolph Field published in the San Antonio Express in 1929 (Norfleet Giddings Bone Papers, University of Texas at San Antonio Libraries Special Collections).

The first phase of construction was clearing the land. The site included 180 acres of timber and 17 farmsteads with residences, barns, and other relat-

20 North Circle is now called Washington Circle. 
ed improvements that needed to be removed before construction began. After the site was cleared, the infrastructure of the base was installed and included the roadway system, underground power and communication lines, wells, and railroad track. The entire 31-mile road system was finished in 1929 before any building construction began (Figure 3). Because of the road system, George B. Ford remarked that the plan for Randolph would take on the "appearance of some of the rose windows in the great cathedrals of Europe."21 By J uly 1929, approximately \$8 million was available for building construction; the first bids were received in October 1929 for the Quartermaster and Air Corps warehouses and six barracks for enlisted men. Throughout 1930 and 1931, construction at the base was steady in spite of the nation's depressed economy. ${ }^{22}$

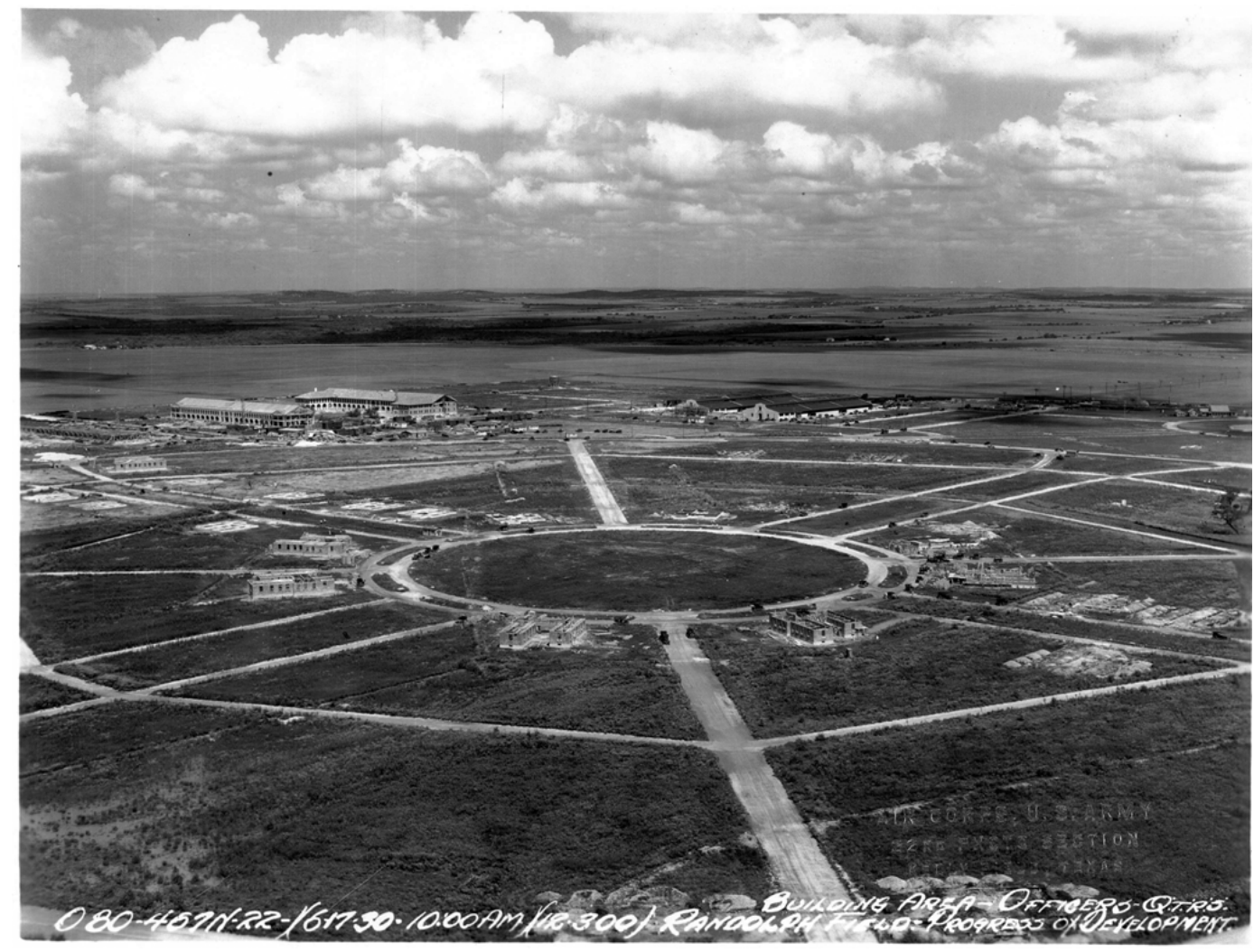

Figure 3. The road system was laid out and constructed by 1929 , before building construction started, 1930 (University of Texas San Antonio, Norfleet Glddings Bone Papers).

By the summer 1930, construction had begun on the Officers' Quarters in the Main Circle and the Noncommissioned Officers' Quarters in the south-

\footnotetext{
${ }^{21}$ Casey Gallagher. Randolph Air Force Base: Preserving the "Showplace of the Air Force" (University of Texas: Preservation Planning and Practice, Spring 2008), 5, quoting from The Architecture of Randolph Field, 1928-1931, 12.

22 Cook, "Randolph Field Historic District," 41.
} 
ern corner. By October 1930, the Officers' Club, Administration Building, various shop buildings, and the Academic Building were well underway as well as the foundations for the cadet barracks, Cadet Administration Building, and most of the hangars. By year's end, the exteriors of the buildings in the shop area and the enlisted men's barracks were done, and foundations were poured for the Post Exchange and one unit of the Bachelor Officers' Quarters (BOQ). Six months later, almost all structural elements of the buildings were finished, although the interiors, landscaping, and paving remained to be completed by November 1931, when the first cadets would begin to arrive (Figure 4 ). ${ }^{23}$

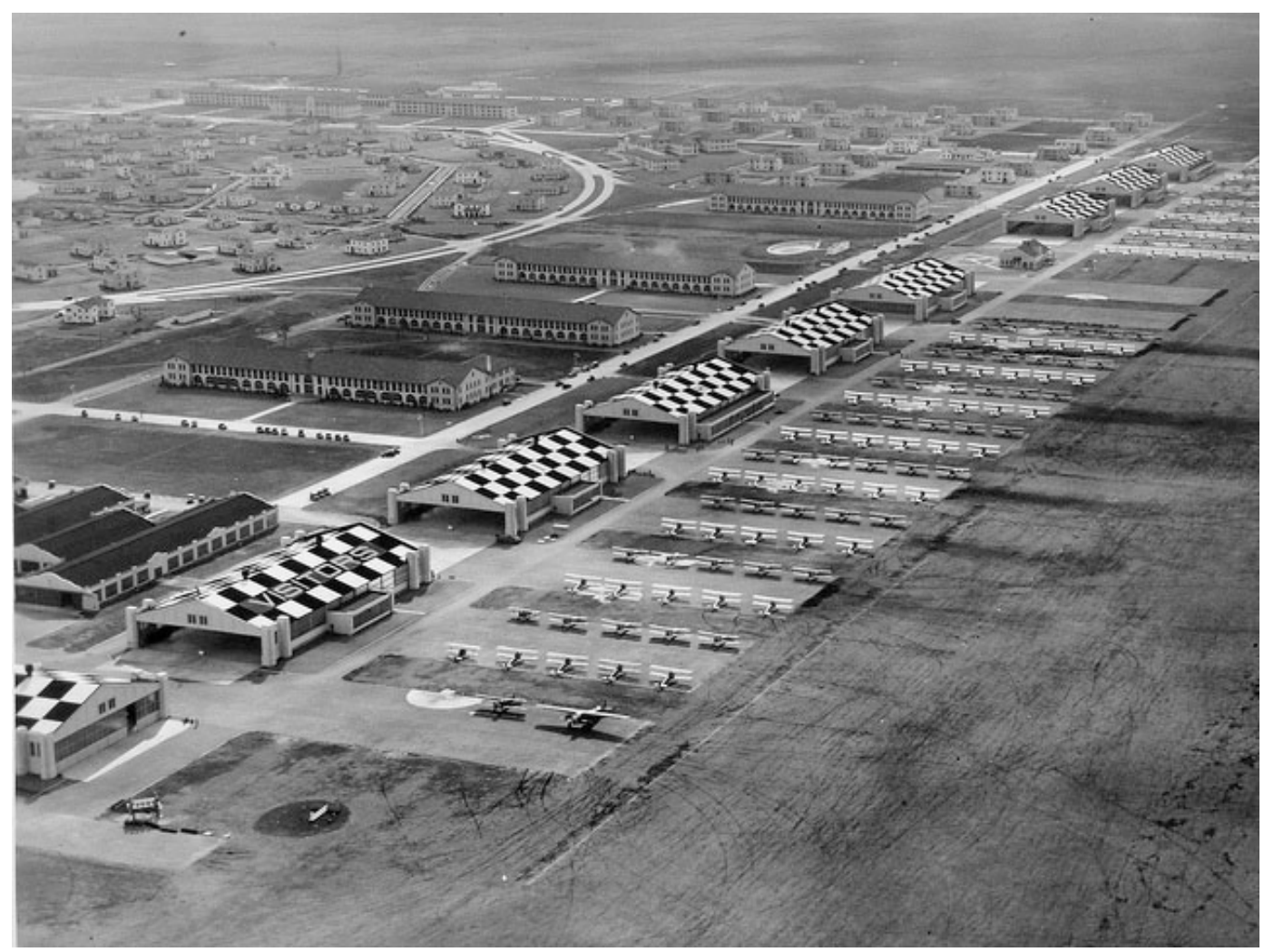

Figure 4. Aerial view of the hangars and aprons on the west flight line, undated but soon after construction, undated (NARA RG 342 Box 1071 B20672).

The planning and layout of Randolph Field was complemented by the extensive landscaping that was developed by Lieutenant Norfleet Bone. In late 1928, Lt. Bone was placed on special duty as assistant to the Chief Quartermaster while he was stationed Fort Sam Houston in San Antonio, Texas. In this role, Lt. Bone became the supervising landscape architect for Randolph Field. Although some landscape plans had been developed for

23 Cook, “Randolph Field Historic District," 41-42. 
Randolph Field, Lt. Bone quickly began researching the climate, soils, and groundwater of San Antonio to find plants that would flourish in those conditions. Lt. Bone's research was detailed, and it included recording climatological data and examining meteorological data that had been collected for San Antonio from 1885 to 1928. With the findings from his research, Lt. Bone developed plans for rows of Spanish oaks and live oaks, wide park-like boulevards, rock gardens with fountains, and desert gardens. Over the next four years, Lt. Bone worked to enhance the landscape of Randolph Field by establishing and maintaining a base nursery, finding regionally-appropriate plants, and developing unique landscape designs. ${ }^{24}$

The initial groups of cadets would go through a flying training system that was based on the training developed by the Air Corps in the 1920s. This training system had three levels of instruction: primary, basic, and advanced. The Primary Flying School at Randolph included both the primary and basic levels on instruction. Each level of instruction covered four months of training, so cadets would stay at Randolph for eight months to complete both levels of training. Randolph's innovative layout accommodated this by separating the runways on the east and west sides of the cantonment. The primary level of flight instruction was conducted on the west flight line, with the basic level on the east flight line. Both flight lines were also called "stages" and each had a "stage house" in the middle of each line that served as centers for flight training. The stage houses also housed offices for the Stage Commanders, Assistant Stage Commanders, and Flight Commanders. These areas also served as an informational area with boards that displayed each student's progress. ${ }^{25}$

Flying training throughout both levels of instruction also included ground school and military instruction. Ground school courses were taught in the Cadet Academic Building with four departments: engineering, armament, navigation, and radio. Military instruction was integrated throughout all training and traditions at Randolph Field and included "rigorous standards of technical training, strict discipline, punctilious discharge of duty, and scrupulous standards of honor, and service to country." 26 This train-

\footnotetext{
24 Victoria G. Clow, Peter E. Duane, and Lila Knight,. The Architecture of Randolph Field, 1928-1931. (Plano, TX: Geo-Marine, Inc., Spring 1998), 63-64.

25 Cook, "Randolph Field Historic District," 42.

26 Lt. Gen. Henry H. Arnold and Brig. Gen. I. C. Eaker, This Flying Game (New York: Funk and Wagnall, 1942), 87.
} 
ing contributed to the growing reputation of Randolph as the West Point of the Air (Figure 5). ${ }^{27}$

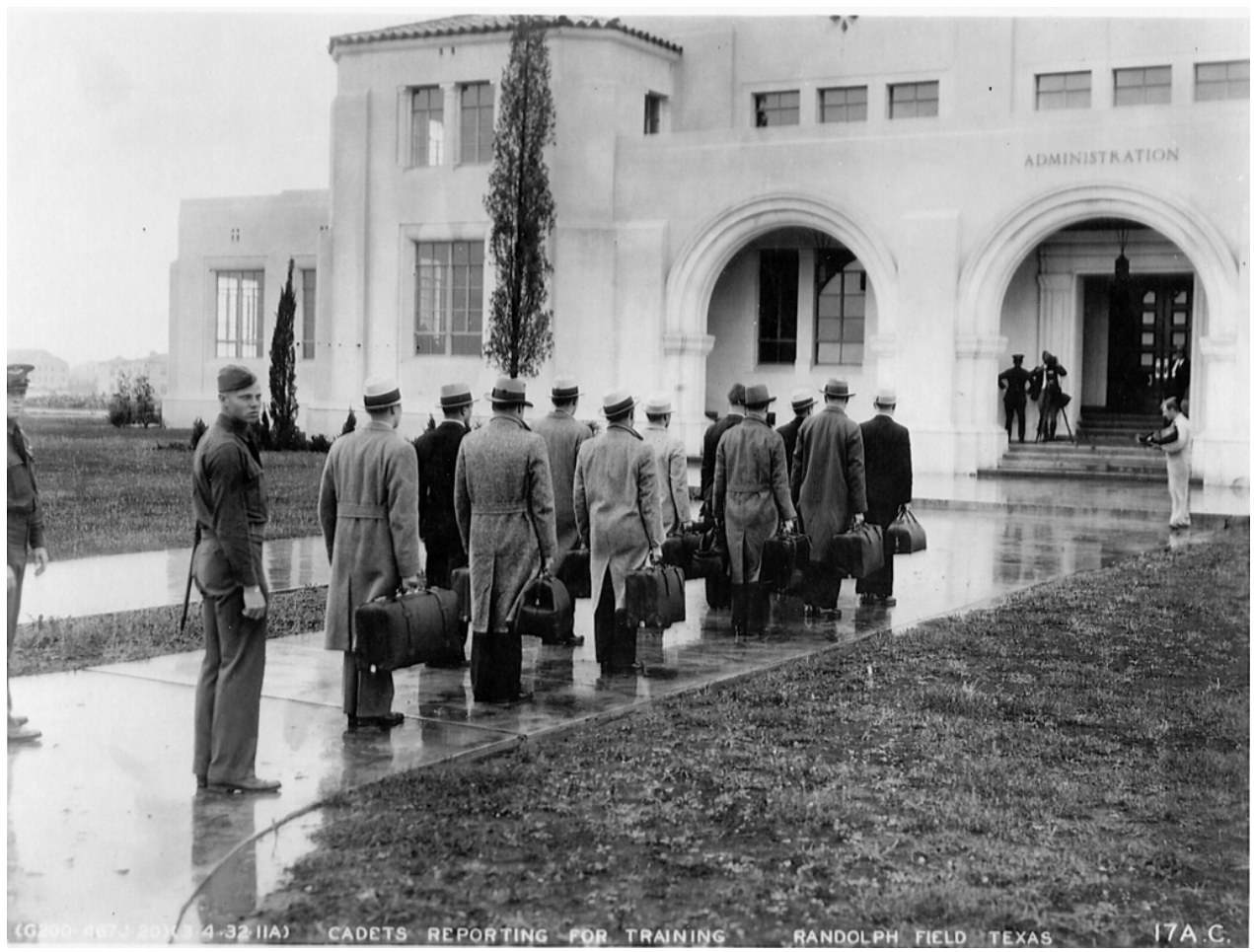

Figure 5. Cadets arrive at Randolph for training, 1932 (NARA B12335 Box 1042).

Although the training program at Randolph had started small, the events in Europe during the late 1930s led to dramatic changes in the Air Corps' training program. In 1938, the number of cadets at Randolph Field doubled. As a response to the growing tensions, the Air Corps rapidly expanded with new pilot training programs, new administrative organizations, and the expansion of physical facilitates. Randolph Field, with its administrative organizations and exceptional facilities, became the foundation for the unprecedented development of the Army's air arm and greatly influenced pilot training programs of WWII. 28

\subsubsection{Randolph Air Force Base since World War II}

In the late 1940s, aviation supporters within the military called for the establishment of a separate military service dedicated to flying. After much political debate, the Air Force was established as a separate military

27 Cook, "Randolph Field Historic District," 44.

28 Texas State Historical Association, Randolph Air Force Base, accessed online at http://www.tshaonline.org/handbook/online/articles/abrO1 
branch in September 1947. Several months later, Randolph Field was renamed Randolph Air Force Base. From December 1945 to March 1948, Randolph continued to host primary and basic levels of pilot training. In March 1948, the primary pilot training program was cancelled, and the following August, the 3510th Basic Pilot Training Wing became the host wing at Randolph.

However, in the post-WWII contraction of military activities, most Air Force flying training bases were closed across the country. The few that remained open were retained because of their size and the quality of their facilities. Randolph was one of those retained, and the demand for pilots once again increased due to the Korean War (1950-1953).

In 1957, the Air Force moved the headquarters of the Air Training Command (ATC) from Scott AFB in Illinois to Randolph AFB. However, as a reflection of national defense priorities during the 1950s, the Air Force was focused more on Strategic Air Command (SAC) and Aerospace Defense Command (ADC) rather than on pilot training programs. Randolph AFB continues to serve as a flying training facility as well as housing the Air Force Personnel Center, Air Force Manpower Agency, Air Force Recruiting Service, and the Air Force Office of Special Investigations Field Investigations Region 4 . Changes to training requirements and added units have been reflected in the physical development of the base.

Currently, Randolph AFB has grown beyond the boundaries of the 1930s planned and constructed post. A map of the base is shown in Figure 6. The historic district is outlined with a dark blue line, the currently eligible buildings are colored red, the potentially eligible buildings are red and yellow striped (at the map's far right), and the tan buildings are noncontributing. 


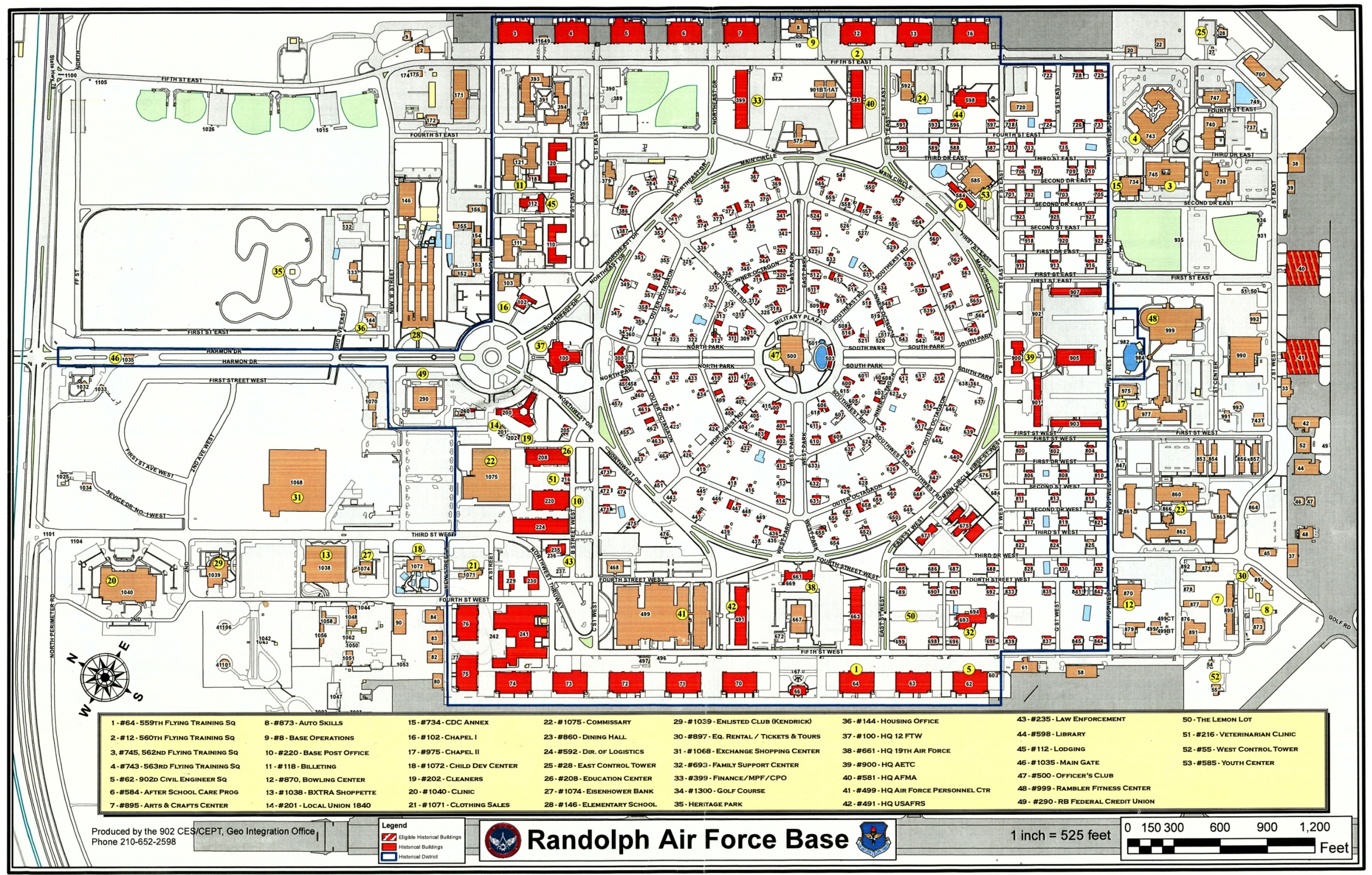

Figure 6. Randolph Air Force Base historic district is outlined with a dark blue line. Historical buildings are colored red, and eligible historical buildings are striped in red and yellow, 2011 (Randolph AFB Cultural Resources). 


\section{Historic Landscape Inventory}

The National Park Service (NPS) defines historic character-defining features of a landscape as "prominent or distinctive aspects, qualities, or characteristics of a cultural landscape that contribute significantly to its physical character." 29 Through the study of landscapes, the built environment is explained by the physical remains of the natural and cultural shaping forces. The historic landscapes of Randolph AFB are significant because they describe the adaption of the built environment to the cultural values and the educational and military mission of Randolph. Understanding the factors that influenced and composed the landscape of Randolph AFB informs the preservation of its historic qualities. This chapter identifies the historically significant features and characteristics of the Randolph AFB landscape which are used to evaluate the built environment and to establish the historic eligibility of the site.

To identify the prominent or distinctive characteristics that make a landscape historic, the physical features of the site are divided into eight areas: site and layout, land use, expressions of military cultural values, transportation networks, views and viewsheds, buildings and structures, vegetation, and small-scale features. These landscape characteristics combine to form the built environment that is the primary image of Randolph AFB.

\subsubsection{Designed historic landscapes}

A landscape is considered designed if it meets the following criteria, as summarized from the National Register Bulletin \#18, How to Evaluate and Nominate Designed Historic Landscapes: 30

- It has significance as a design or work of art.

\footnotetext{
29 Birnbaum, Charles A., National Park Service Preservation Brief \#36 - Protecting Cultural Landscapes: Planning, Treatment and Management of Historic Landscapes, (Washington, DC: National Park Service 1996), 4.

$30 \mathrm{~J}$. Timothy Keller and Genevieve P. Keller, National Register Bulletin \#18 - How to Evaluate and Nominated Designed Historic Landscapes, (Washington, DC: US Department of the Interior, National Park Service, n.d.)
} 
- It was consciously designed and planned by a landscape architect, master gardener, architect, horticulturalist, or other design professional in accordance with design principles.

- It was planned by an amateur using a recognized style or tradition.

- It has a historical association with a significant person, trend, event, etc. in landscape architecture or landscape gardening.

\subsection{Site and layout}

In historic landscape studies, the term "landscape characteristic" has a specific meaning. Landscape characteristics are defined as the "tangible evidence of the activities and habits of the people, who occupied, developed, used, and shaped the land to serve human needs; they may reflect the beliefs, attitudes, traditions and values of these people."31 Identifying the characteristics of the military landscape requires an understanding of the natural and cultural forces that have shaped it. This section will describe these processes and the resulting landscape features that together comprise the military landscape. The purpose of this section is to help define the overall character of the landscape and indentify the many features which make it significant.

Sites for military installations are selected because a location meets the physical requirements of the mission. The landscape is then spatially organized to accommodate the land use needs of the inhabiting military forces. The design of a military installation's built environment incorporates relationships between environmental features with the necessities of the specific military mission. ${ }^{32}$ The layout of any military installation is based on the relationships among the pre-existing landscape's predominant landforms, topography, climate, water bodies, and vegetation and the military's lands use requirements. ${ }^{33}$ The mission and needs of the military actions dictates the spatial organization of an installation and the way the military uses the land.

\footnotetext{
31 National Park Service, National Register Bulletin \#30 - Guidelines for Evaluating and Documenting Rural Historic Landscapes, (Washington, DC: US Department of the Interior, National Park Service, 1999), 3.

32 Suzanne Keith Loechl, Samuel A. Batzli, and Susan I. Enscore. Guidelines for Documenting and Evaluating Historic Military Landscapes: An Integrated Approach, an Army Environmental Command Technical Guideline, (Champaign, IL: Construction Engineering Research Laboratory 1996), 67.

33 ibid.
} 
The site and layout of Randolph AFB was strongly influenced by the environmental requirements needed for flight training. The Army selected the site in the 1920s because of its favorable climate, level topography, and proximity to San Antonio, Texas. The plan for the base had been designed before a site was selected, so unlike with other military bases, military planners worked to find a site that could accommodate the existing plan. As previously stated, the plan had been sketched by Lieutenant Clark as a model Air City that incorporated the environmental considerations necessary to maximize flying training. That sketched plan was then extensively revised by planner George Ford, and the resulting plan was eventually constructed.

The base was designed by Clark to be symmetrical along a dominant north-south axis and a secondary east-west axis. An interior circle was bounded by a large square that was defined on the east and west sides by the flight lines. These strong geometries defined the site layout and created a unique base plan unlike any other in the military (Figure 7).

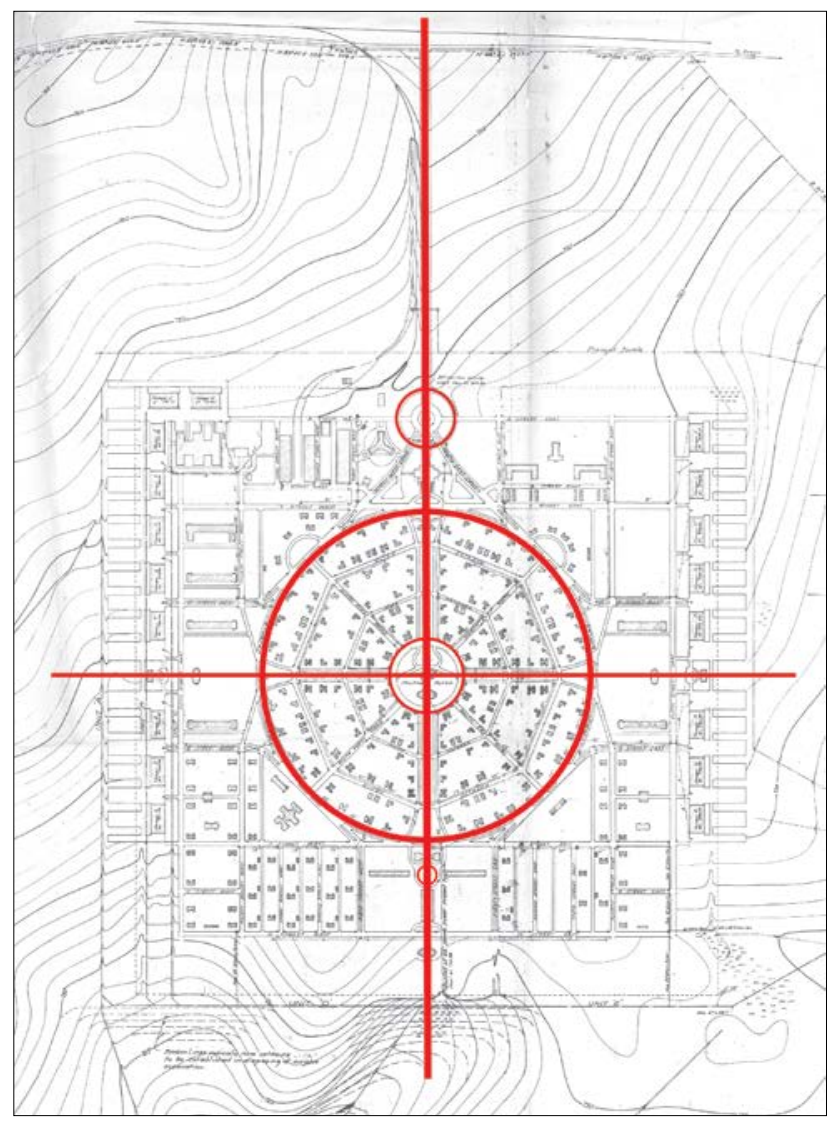

Figure 7. The strong geometrical organization of Randolph Field was centered on two dominant axes; the primary axis extended northwest to-southeast and the secondary axis extended northeast to southwest (ERDC-CERL). 


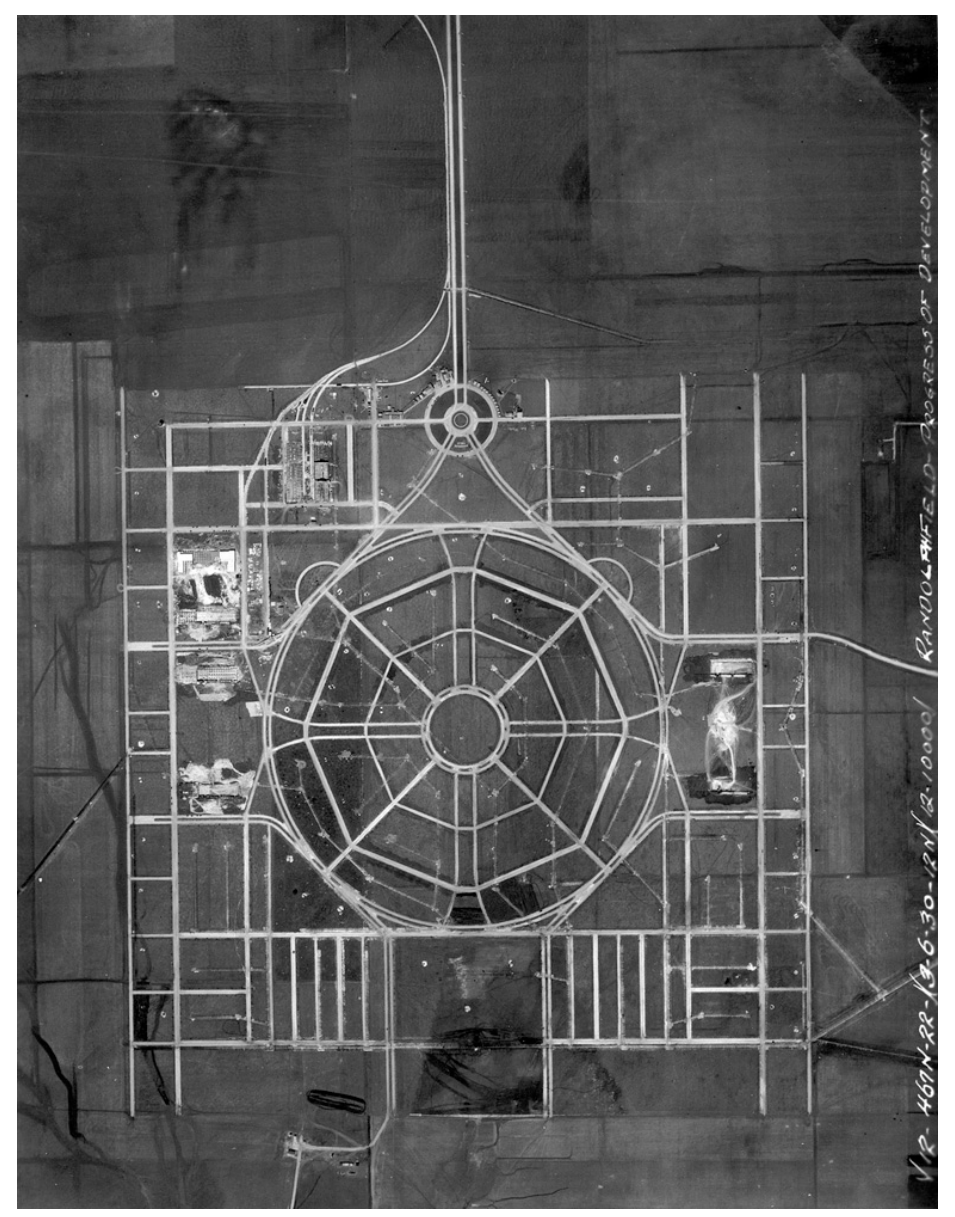

Figure 8. Aerial view of the Randolph street network before the major building construction phase began (Bone Collection 123535, Randolph AFB Cultural Resources).

The striking and unconventional plan for Randolph AFB was formally structured around the road system of a centrally located array of concentrically arranged circles and octagons. Arranged in a rectangle around this central circle were the functional buildings of the base and along the eastern and western edges of the cantonment were the two flight lines. The ring roads were connected through parkways and boulevards in a network that allowed for beauty and convenience (Figure 8). The plan was described in 1942 as scientifically planned, with full regard for aesthetics, but the layout was best appreciated from the air. ${ }^{34}$

\footnotetext{
34 Writers' Program of the Work Projects Administration (WPA) in the State of Texas, Randolph Field A History and Guide, sponsored by the Commanding Officer, Randolph Field, New York: Devin-Adair Co, 1942, 24.
} 


\subsection{Land use}

The military mission directs how the military uses the land, making how the land is used another important landscape feature of a site. Because military installations are planned and organized to efficiently accommodate the military mission, the landscape is often utilitarian where function is prioritized over aesthetics. Most landscape changes on a military installation are related to military mission; some mission-related land use changes occur directly while others occur indirectly. Land use areas that are directly related to the mission at Randolph AFB include the flight lines and educational areas. Areas that support the military mission include the housing areas, administrative areas, recreation, retail/commercial, and education. 35

Land use planning at the inception of Randolph Field was dictated by the initial concept sketch of an ideal Air City. In this sketch, Lieutenant Clark's basis for the ideal aviation city was that all components of the city would efficiently support the flying mission. As George Ford later refined this basic design concept, he grouped similar land uses so that base operations were consolidated throughout the compact layout. Ford's modifications were an example of the city planning movement of the 1930s meant to emphasize comprehensive planning by uniting all elements of a city into one aesthetic design. Also called City Beautiful, the movement was translated into military planning through the integration of community interaction, the importance of vegetated open space, and the expression of military values.

As a result, the geometrical layout of Randolph AFB physically delineates specific land use areas through a distinct form. In the original 1930s plan, land use areas were divided according to the main operational functions of Randolph Field. These land use areas were roughly grouped into warehouses and shops; administration; residential areas of officers' housing, noncommissioned officers' housing, bachelor officers' quarters, and barracks; post support services like the post exchange (PX), chapel, hospital complex, and school; the Cadet Complex-a mix of barracks, aviation school, and administration functions; and aviation land uses that included

35 Loechl, et al.,2009, 70. 
hangars, service buildings, and the stage houses. These areas are indicated by color overlays on the base map in Figure 9.36

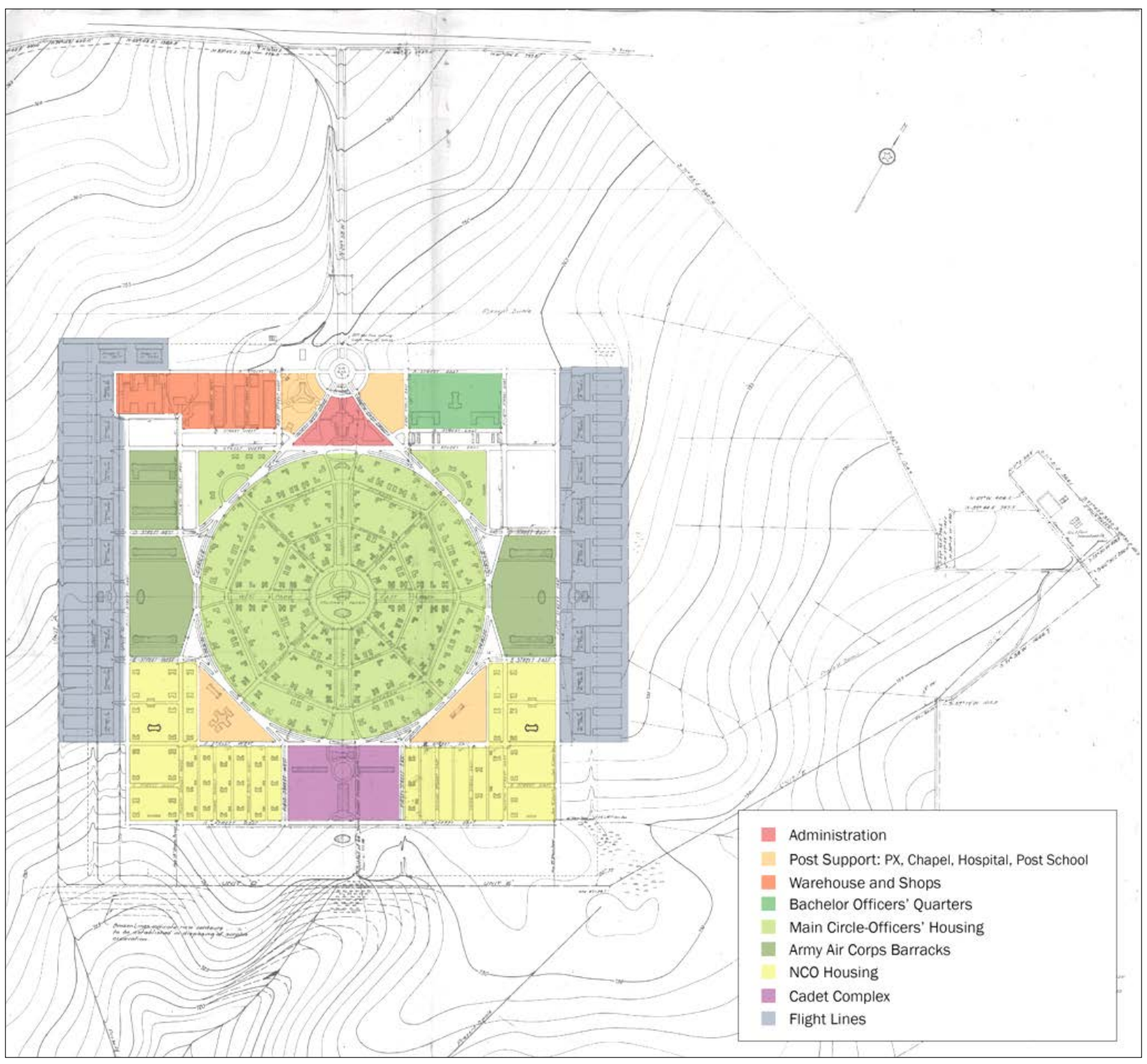

Figure 9. Land use designations of the 1930s base plan, 2012 (ERDC-CERL).

Integral to the 1930s base plan was the use of open spaces to define the intricate boulevard and street system (Figure 9). These open spaces not only contributed to the distinct geometrical layout of the base, but also provided a park-like atmosphere throughout the cantonment. Randolph Field was also unique because it had a base nursery where many of the plants used to landscape the base were grown (Figure 11).

\footnotetext{
36 Writers' Program of the Work Projects Administration (WPA) in the State of Texas, Randolph Field A History and Guide, sponsored by the Commanding Officer, Randolph Field, New York: Devin-Adair Co, 1942, 24.
} 


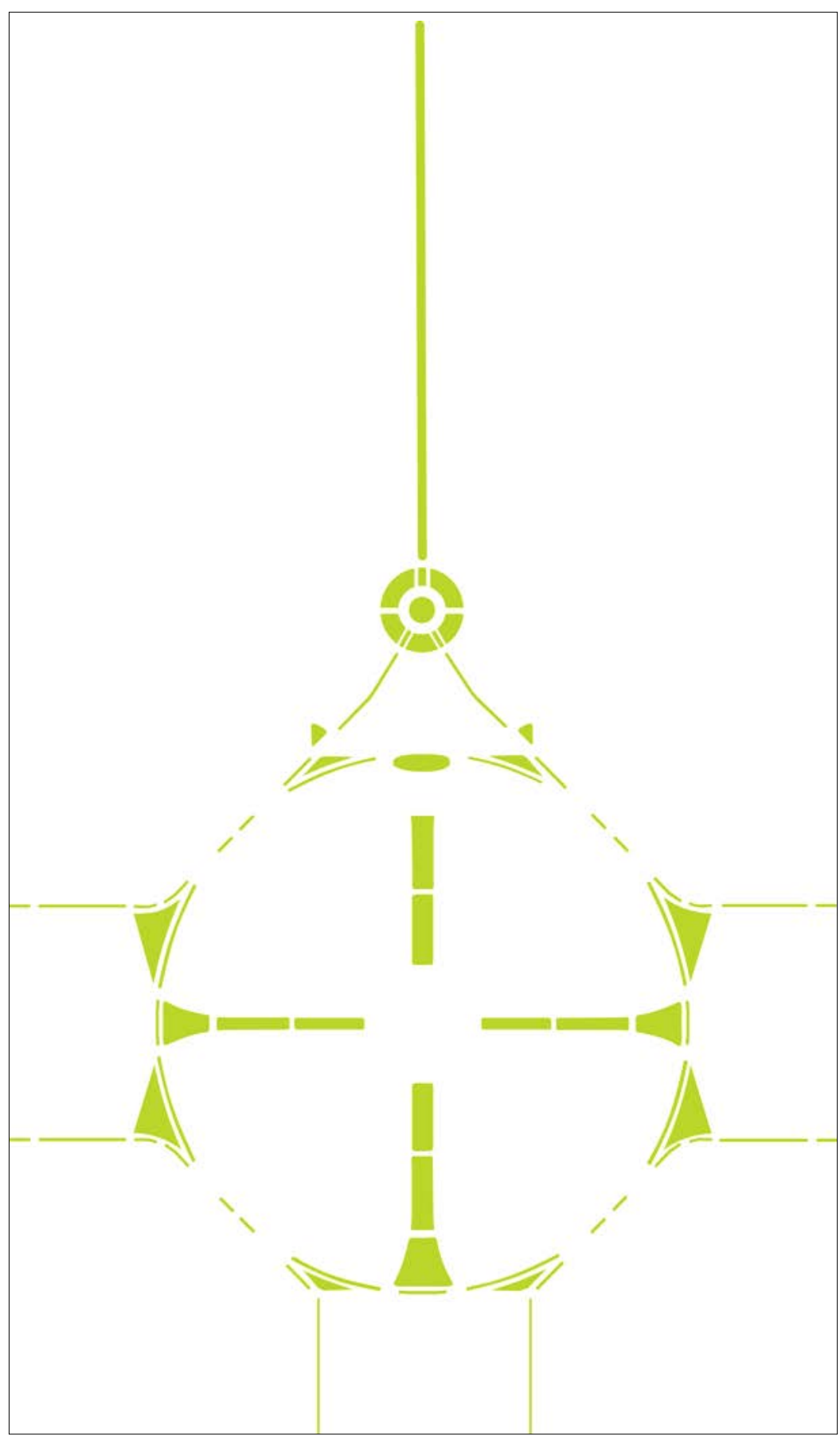

Figure 10. The medians created by the road system provided Randolph Field with distinct open areas that are diagrammed here, 2012 (ERDC-CERL). 


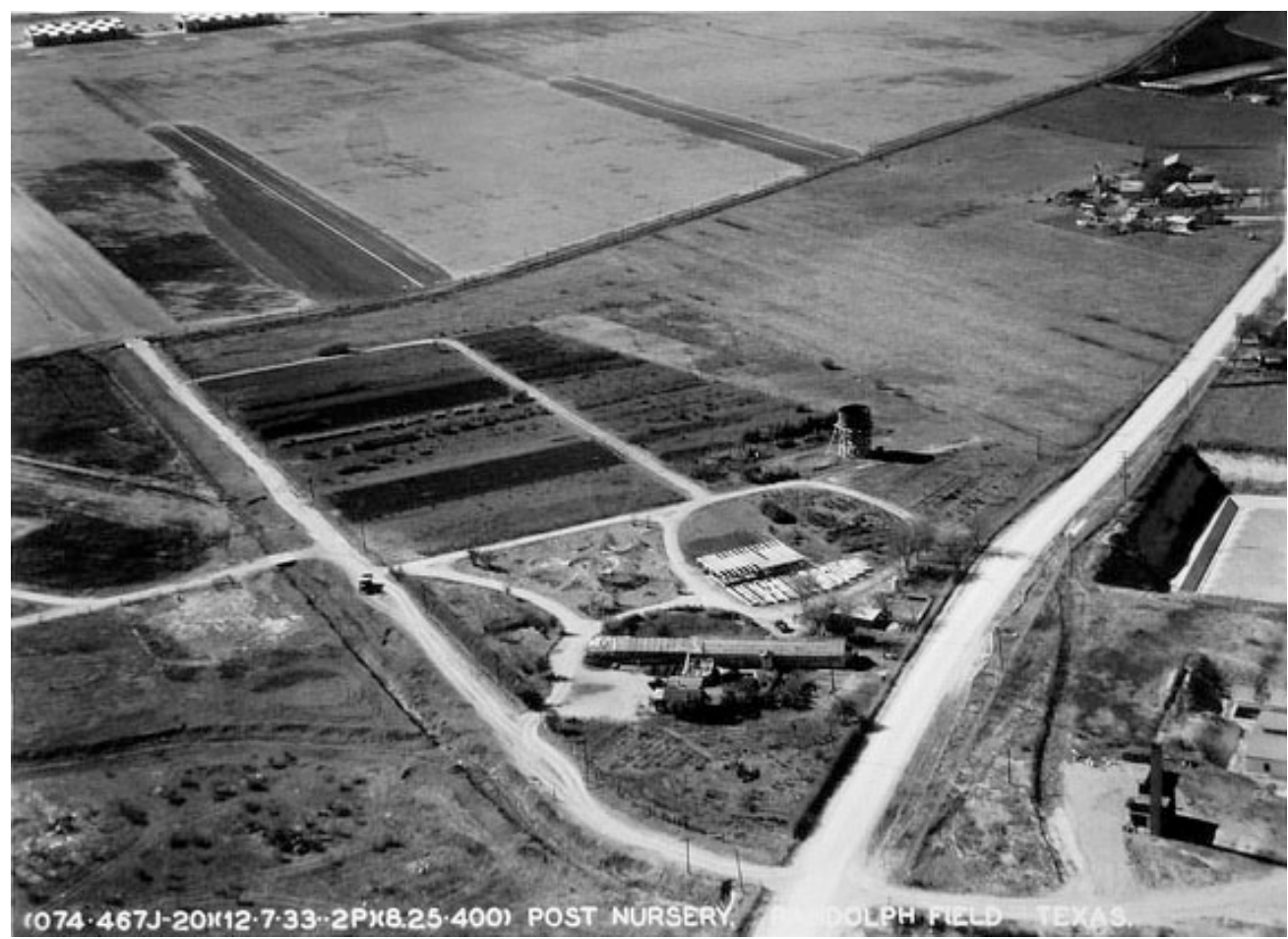

Figure 11. The base nursery was located east of the cantonment (as shown in the center foreground), undated (NARA RG 342, Box 1071 B20671).

As the base grew in response to the military buildup for WWII, the original land uses of the 1930s were expanded, and new areas were added. The areas that expanded the most during the late 1930s and early 1940s were the warehouse area and the flight lines. New areas that were added were a south apron with hangars, housing in the northeast sections of the base, and WWII temporary buildings along the southern edge of the base. Intermixed in the original land uses designations were recreational areas such as swimming pools, ball fields, and a golf course south of the main cantonment. Other base support infrastructure included a sewage disposal plant, ordnance magazines, and a sanitary landfill (Figure 12). 


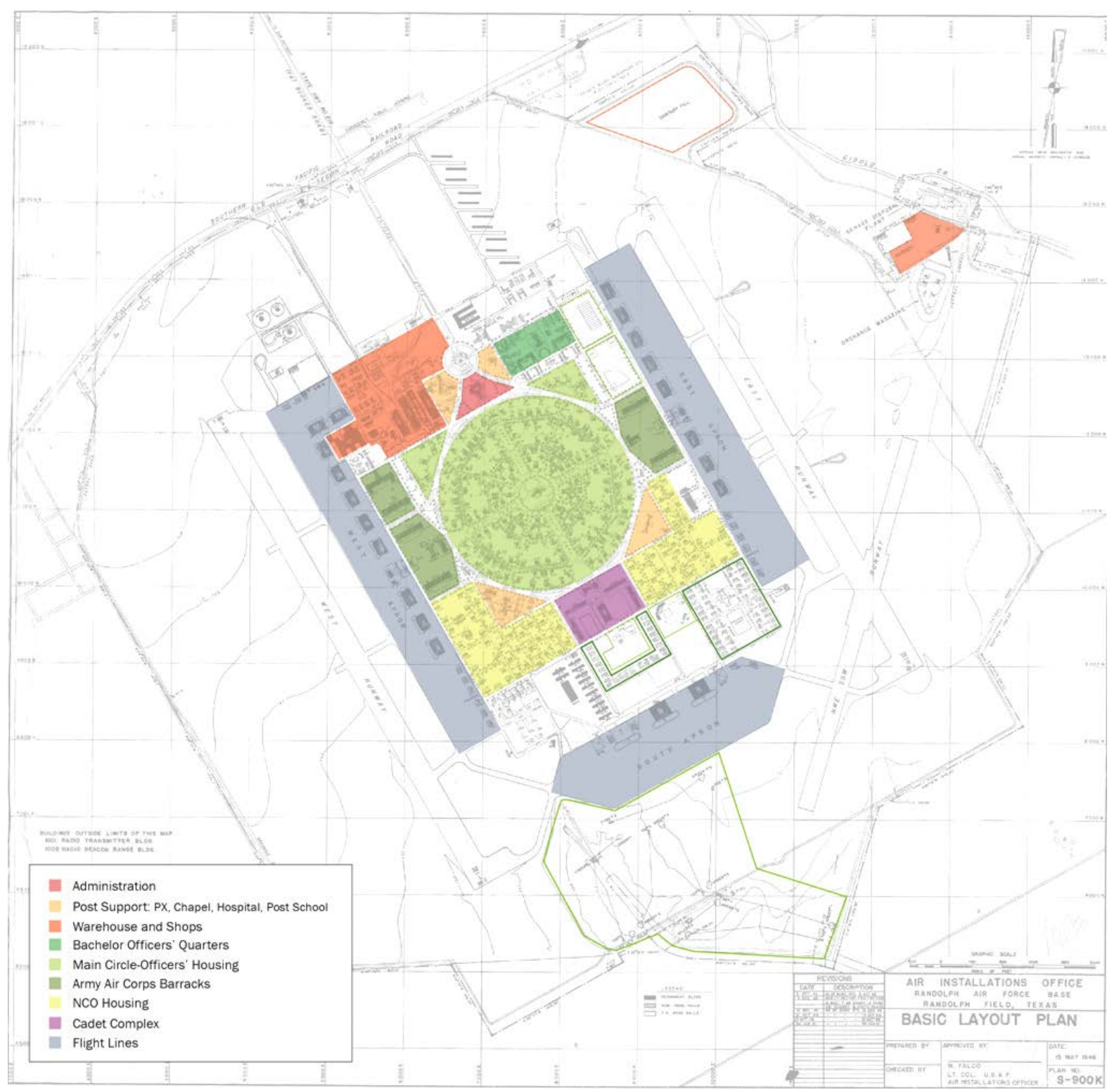

Figure 12. As Randolph Field expanded during WWII, land uses were still grouped together. Much of the Field's growth was along the northern and southern edges and included a ninehole golf course (outlined here with a green line toward bottom of figure), 2012 (ERDC-CERL).

Many of the original land use areas have retained their historic land use associations. From the land use patterns of the original base plan, current component landscape areas were determined to illustrate the organization of the base and how land uses have developed as Randolph AFB has grown (Figure 13). Discussed in the following sections are the changes that have occurred in these component landscapes. 


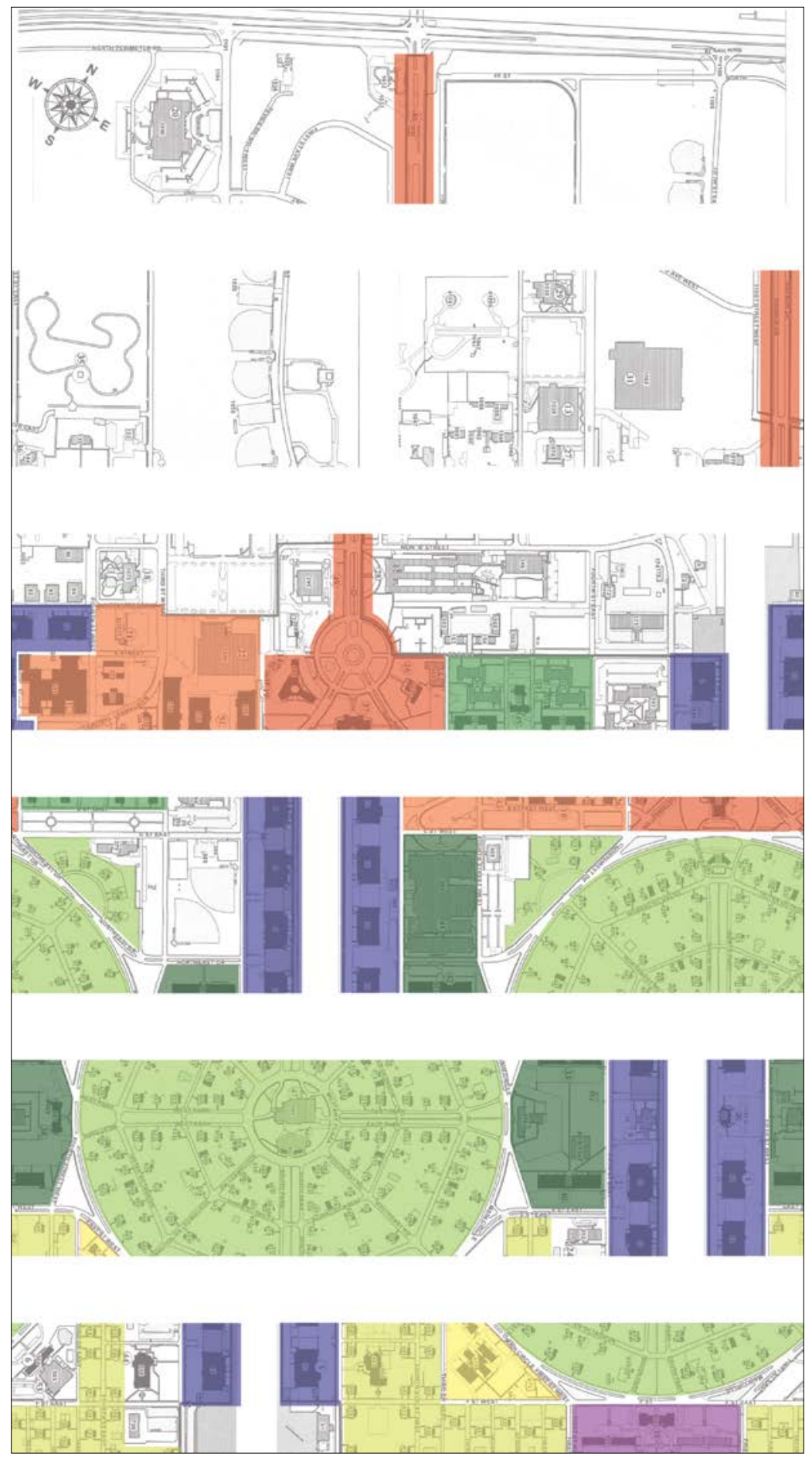

Figure 13. Component landscapes within Randolph AFB historic district. Red is the entrance sequence and administration areas. Orange is the shops and warehouse area. Dark purple marks the flight lines. Light purple marks the Cadet Complex. Yellow highlights the hospital complex. Shades of green delineate the residential areas: dark green marks the original barracks, medium green is the $\mathrm{BOQ}$ area, light green marks the SOQ area, and yellow-green marks the NCO areas. , 2012 (ERDC-CERL). 


\subsubsection{Overall layout of the "Airfield Plan"}

The original plan for Randolph Field is still evident in the built environment of the base. However, significant growth has occurred to the north and south of the main core. To the north, housing was added on either side of the main entrance boulevard in response to troop buildups for WWII, the Vietnam Conflict, and the Korean War. Additionally, the warehouses and shops area was developed toward the north, and today that northern area includes a new base exchange, fast food restaurants, shops, and a gas station. The housing near the main entrance was built throughout the midtwentieth century and was eventually torn down between 2004 and 2010. Currently, on the east side of the entrance boulevard is the Randolph Elementary School, housing office, and a park with a walking trail where the housing used to be. Baseball fields now line the far eastern edge of this area.

Randolph AFB has also developed to the south. During the buildup to WWII, temporary buildings were added in many of the open areas around the base. South of the Cadet Complex were recreational fields which provided the space for these temporary building programs. However, the area was permanently developed when a south apron and hangars were built in the mid-1940s. Now this formerly open area, located between the former Cadet Complex and noncommissioned officer (NCO) housing and the 1940s hangars, consists of barracks, a new recreational complex with a baseball field and track, and administration buildings.

Because of changing aviation technologies, the grassed landing fields of the 1930s were paved by the 1940s and then extended by the late twentieth century to accommodate new aircraft. As a result, the boundary of Randolph was extended to the south. Figure 14 shows the growth of Randolph AFB from the 1930s through 2012. 

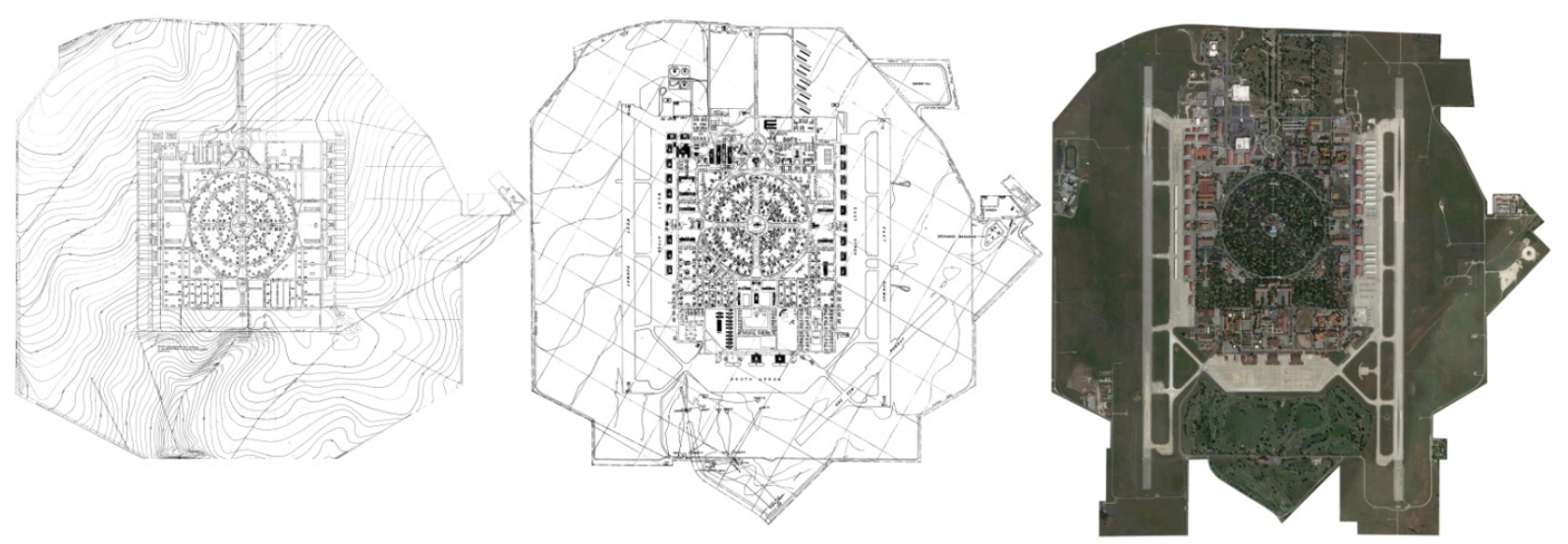

Figure 14. The overall layout of Randolph AFB has remained consistent with the original design concept of the ideal Air City. Although the base has grown since initial construction, the basic form of the airfield remains shown here (from left) in the 1930s, 1946, and 2012

(ERDC-CERL).

\subsubsection{Road system}

The road system that creates the distinct geometry of Randolph AFB has remained consistent throughout the base's growth. However, the development to the north and south of the main core of the base has altered the road system somewhat. The road system planned in the 1930s consisted of a large circle with four interior, concentric, octagonal roads. This main circle was divided by two major boulevards, North and South Park and East and West Park, and four minor streets. This circular system was then surrounded by a rectangular grid of streets that allowed for easy access to both the east and west flight lines. The base road system was then connected by a half-mile long entrance boulevard that had a wide median to the highway that ran north of the base.

As housing was added north of the base, connecting streets and roads were added to access these areas. By the 1960s, the result was that several streets crossed the long boulevard. The development south of the base also introduced a new grid of streets where $5^{\text {th }}$ Street East, $4^{\text {th }}$ Street East, $2^{\text {nd }}$ Drive East, $1^{\text {st }}$ Street East, $1^{\text {st }}$ Street West, $3^{\text {rd }}$ Drive West, and $5^{\text {th }}$ Street West are the north-south roads through this area. In this area, the only east-west roads running all the way through are H Street West and J Street West that turns into the Southwest Thruway (Figure 15). 


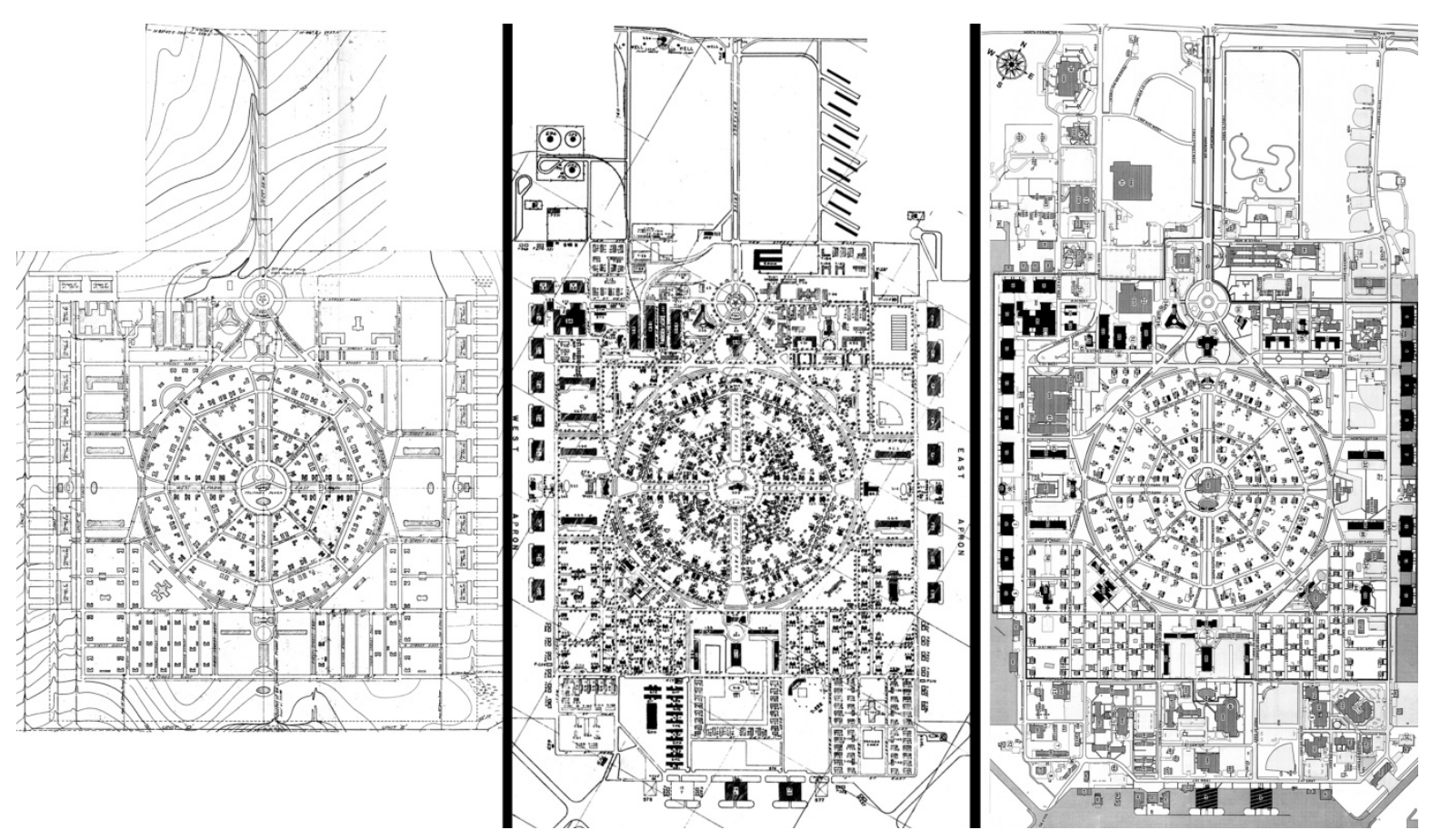

Figure 15. Changes in road system layouts of Randolph AFB (from left): initial construction in the 1930s, the build-up for WWII, and growth in the later part of the twentieth century

(ERDC-CERL, 2012).

\subsubsection{Harmon Drive and Washington Circle area}

The entrance boulevard has remained relatively unchanged as Randolph AFB has developed around it. The road is still divided by a wide grassed median and oaks line the east and west sides of the road. However, the median now has two lines of flagpoles extending its length, and the tree lines have been broken where the connecting east-west roads now cross Harmon Drive.

The entrance boulevard terminates in Washington Circle, once known as North Circle, which has always been a roundabout with an outer road and an inner road. Between these roads were wide grassed and planted islands. Around the southern edge of the circle were prominently arranged the Chapel, the Administration Building which is more commonly referred to as the "Taj Mahal," and the Post Exchange (PX) with associated service buildings. These areas were important to the base and consequently, were less likely to be developed or changed. During WWII, temporary buildings were built to the east behind the Chapel, and the PX building received an addition between two of its three wings. During the mid-twentieth century, changes were made to the parking lots around the PX, Taj Mahal, and Chapel. Eventually one of the temporary buildings behind the Chapel was 
removed, and the service buildings associated with the PX were changed to other functions. In the late-twentieth century, a new Base Exchange (BX) was built north of the original PX and many of the associated service facilities were added to the north of the new BX. Figure 16 shows the development along the entrance boulevard.

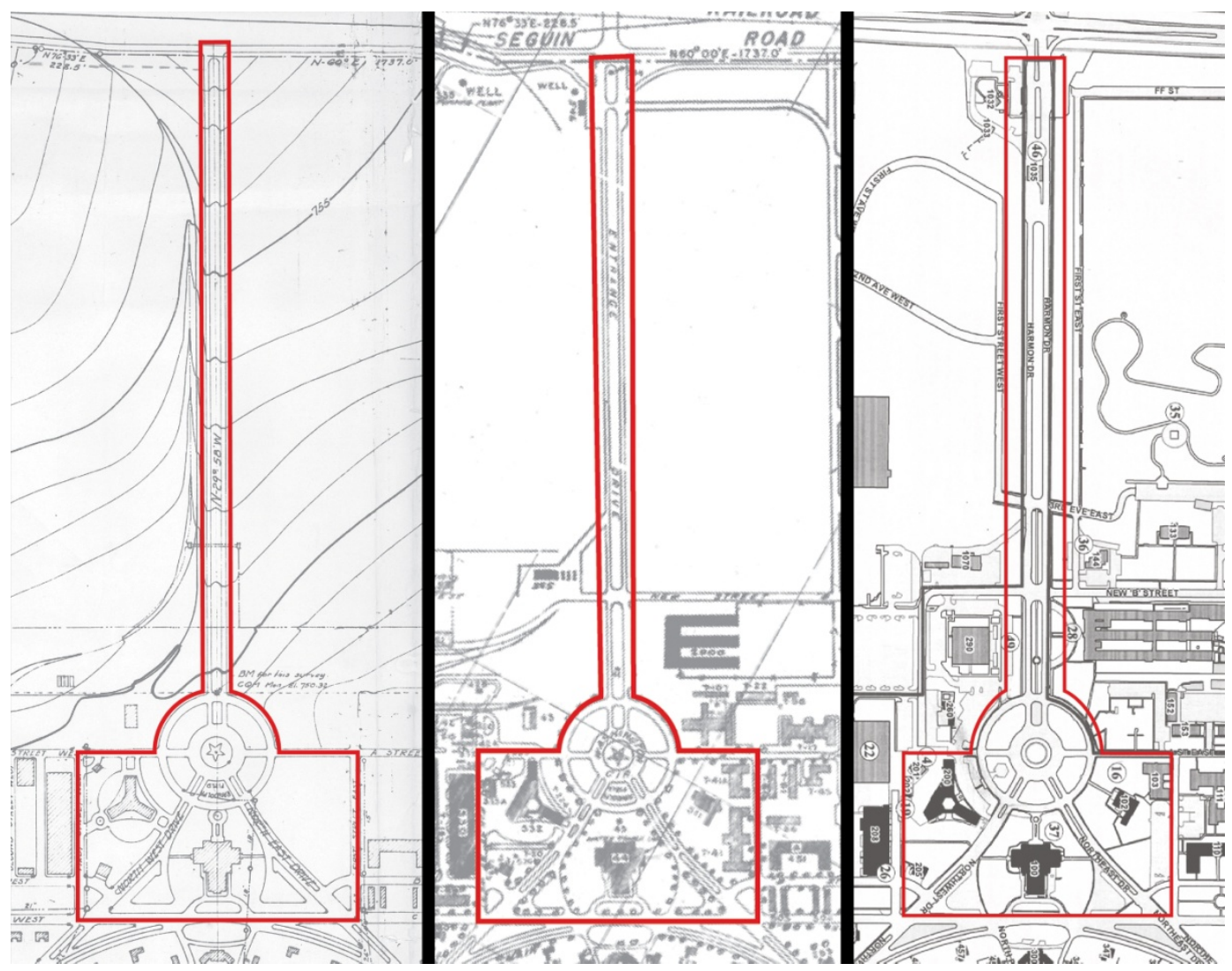

Figure 16. The entrance boulevard (from left) in the 1930s, 1946, and 2012. Harmon Drive and Washington Circle comprise the entrance sequence to Randolph AFB. While some changes have been made, the overall land use has remained consistent since the base's initial construction. North is to the top of the diagram (ERDC-CERL, 2012).

\subsubsection{Warehouses and shops area}

The warehouses and shops area was established west of Washington Circle. This location provided the most efficient layout for spur railroad lines to enter the base. Figure 17 illustrates the sequence of growth in the warehouse and shops area from the 1930s through 2012. 


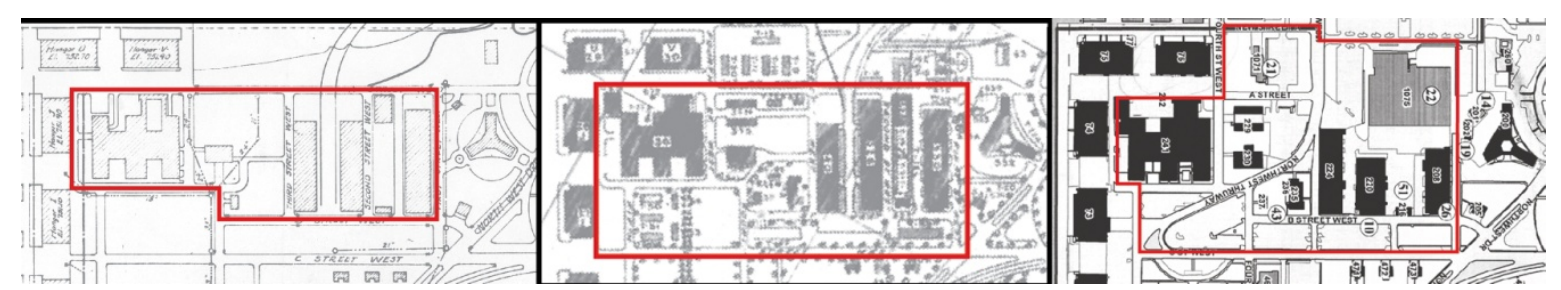

Figure 17. From left, the red outline depicts the warehouses and shops area in the 1930s, 1946, and 2012 located west of Washington Circle. North is to the top of the drawing (ERDCCERL, 2012).

\subsubsection{Runways}

Because the original landing fields were grassed and lacked any defining boundaries, the early flight line can only be defined through the concrete aprons that extended from the hangars. The concrete runways that were added during the 1940s have since provided the basis on which the current runway system is based. The 1940s system included adding a south apron in front of two hangars along the southern boundary of the base.

As aircraft technologies dictated longer runways, the two primary east and west runways of the 1940s system were expanded to the southeast, and a shorter northeast to southwest runway (shown at bottom right of the left drawing in Figure 18) was eliminated. The current runway system has been changed to include shade structures for the airplanes parked on the aprons. Figure 18 compares the 1940s runway layout with the expansions that led to the 2012 configuration. 


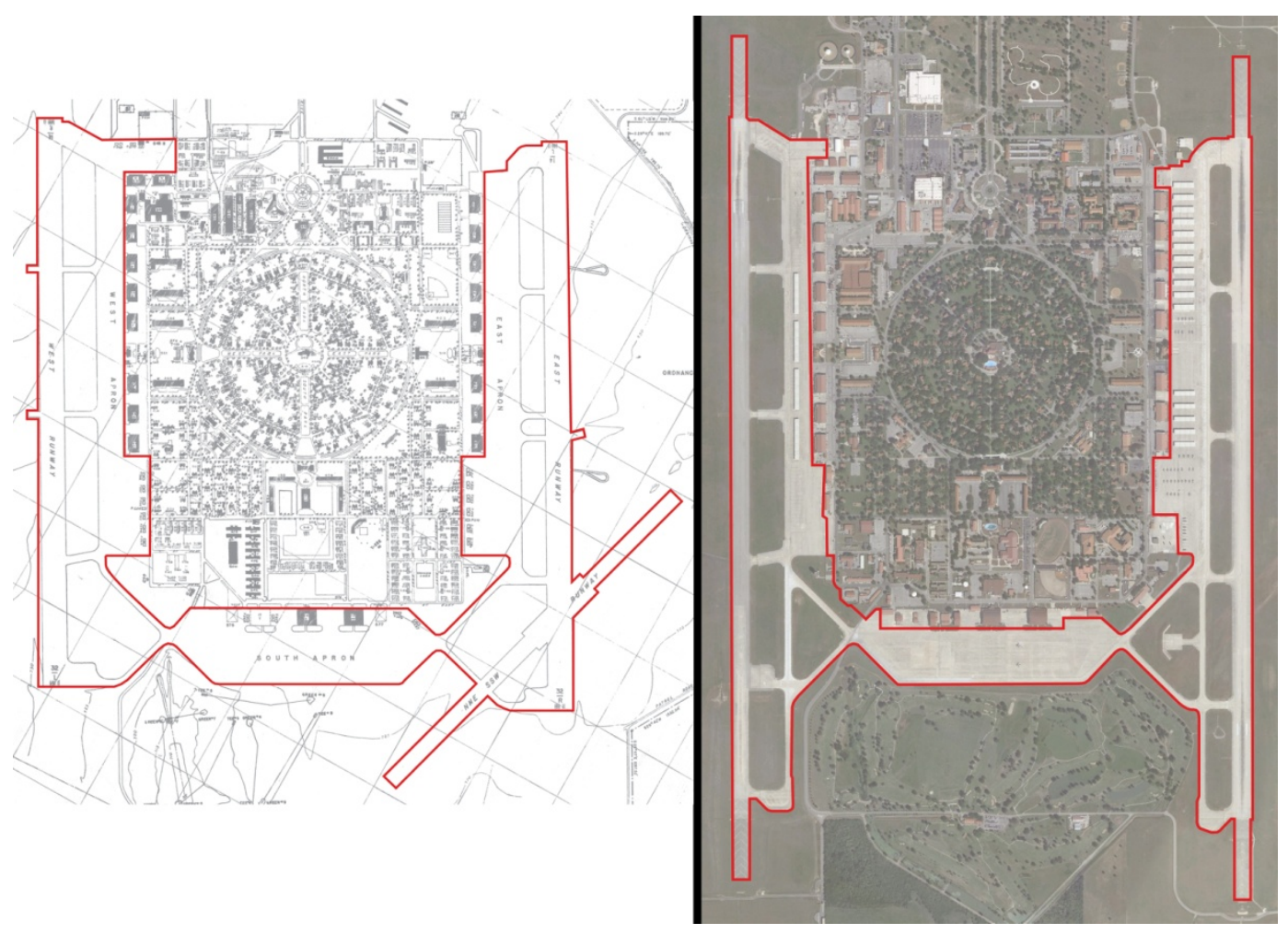

Figure 18. Comparison of the runways in 1946 (left) and 2012 (right). Prior to the construction of formal runways, grassed fields on the east and west flight lines accommodated takeoffs and landings. As a result, the only infrastructure needed for these grassed fields were the aprons extending out from the lines of hangars, which can be seen in the hangar line component landscape (ERDC-CERL).

\subsubsection{Hangars}

The original plan for Randolph included two flight lines on the east and west sides of the base. This plan accommodated the two flight training programs at the base as well as allowed for nearly continuous flight time. The hangars that supported the flight lines were symmetrically arranged along either side of the flight lines. Two types of hangars were used, and they were arrayed lengthwise north to south. On the east flight line, five hangars were lined to the north and three to the south, with the stage house located between the two groups. The west flight line reflected this pattern, but differed slightly with the addition of two hangars to the north that were oriented east-west in their length. With the addition of concrete runways and a south apron in the 1940s, two additional hangars were added along the southern boundary of the base (Figure 19). 

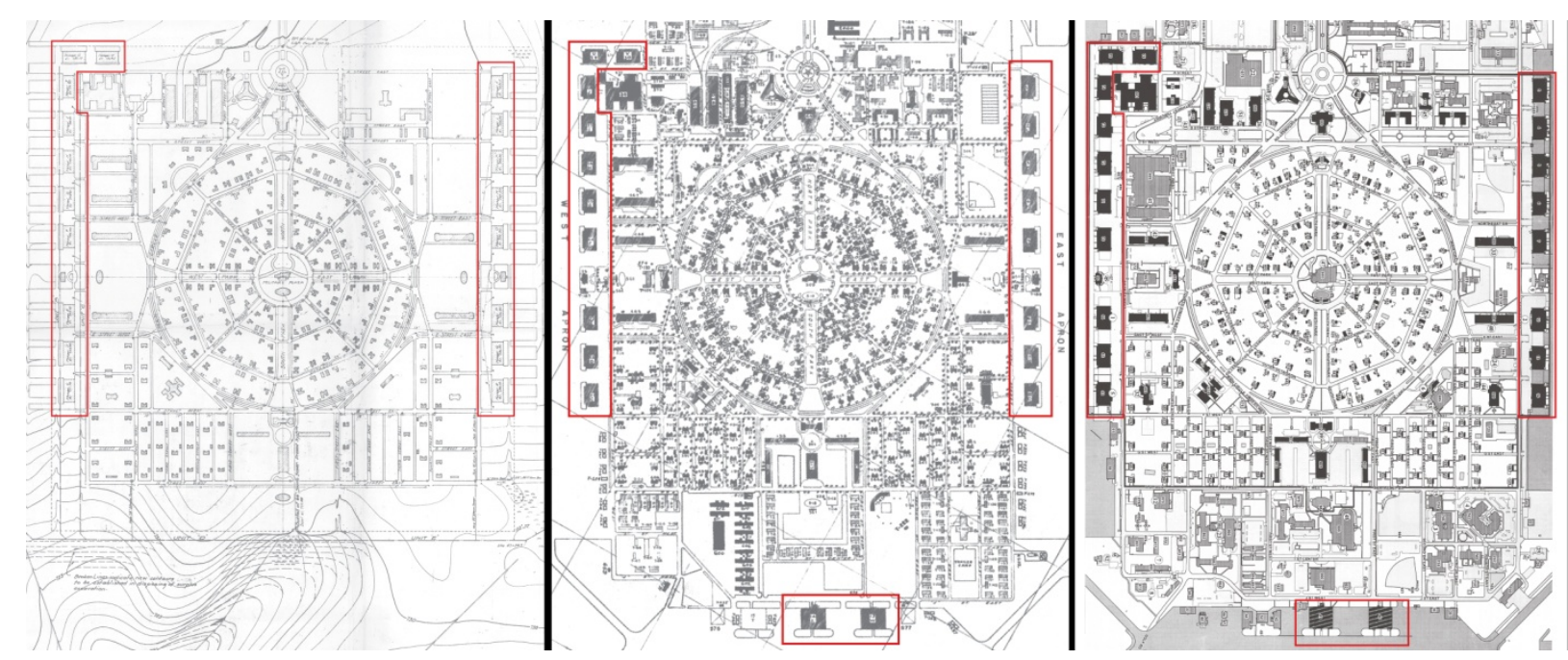

Figure 19. From left, the hangar sequence in the 1930s, 1946, and 2012 is outlined in red, 2012 (ERDC-CERL).

\subsubsection{Officers' quarters}

The most striking element of the Randolph Field plan was the organization of the officers' quarters within the Main Circle and two triangular pieces to the northeast and northwest of the circle. The geometry of the circle was created by the road system, and included four interior streets. The officers' quarters were evenly arrayed along these streets and included evenly spaced communal garages. At the center of the circle was the Officer's Club, which was on axis with the "Taj Mahal" to the south and the Commanding General's quarters to the north. Boulevards on the north-south and east-west axis divided the residential space and provided open vegetated areas within the housing. The boulevards were originally landscaped with planting designs by Lt. Bone, but by the 1940s and 1950s were only lined with street trees. In the first decade of the 2000s, sidewalks had been constructed down North Park, South Park, and East Park.

The officers' housing area has remained relatively unchanged (Figure 20). The previously open spaces in the triangular corner pieces of officers' housing have been slowly appropriated for other uses; these corner pieces now have buildings or parking built on them. Changes to the residential units have included enclosing some porches and adding free-standing garages to the quarters. The Officers' Club building, in Military Plaza, has expanded many times, and it no longer reflects the architectural symmetry of the original plan. The parking and entrance drive to the Officers' Club has also been modified to accommodate the club's growth. 


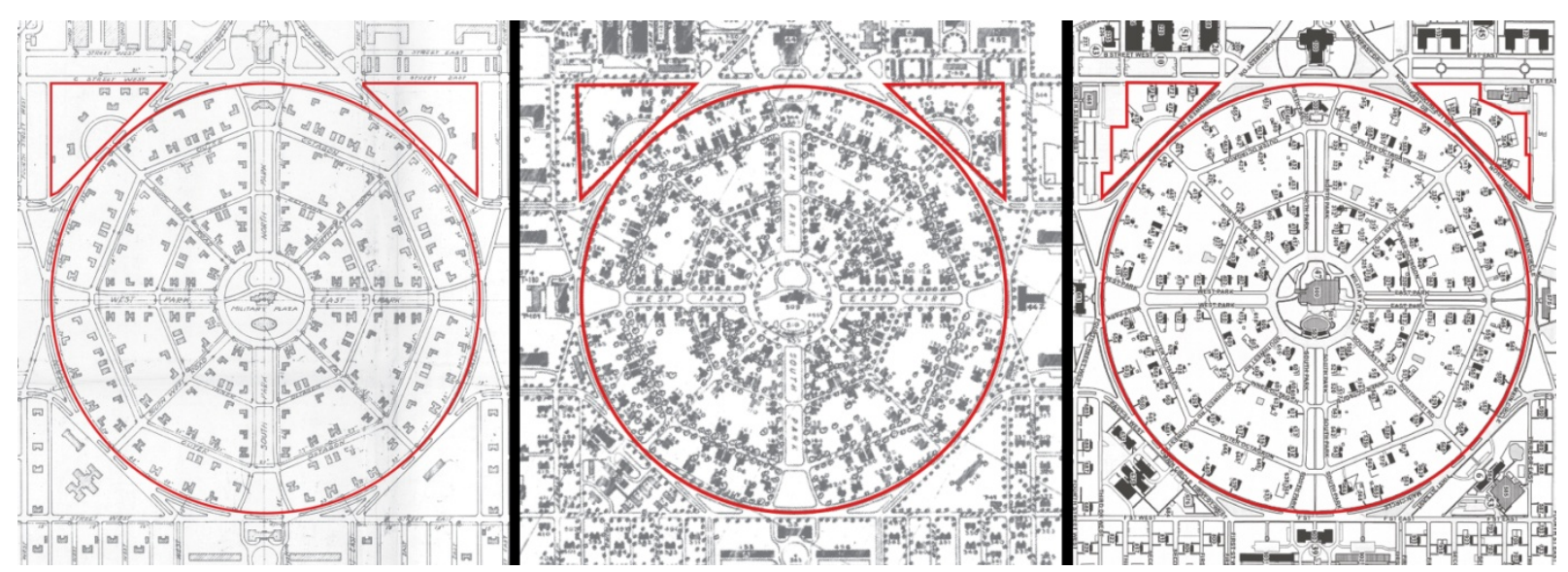

Figure 20. From left, the land use outlined in red of officers' housing in the Main Circle has remained the same from the 1930s, the 1946 installation plan, and the 2012 plan. The only major change has been the appropriation of land in the northern triangles for other uses by 2012 (ERDC-CERL).

\subsubsection{Noncommissioned officers' quarters}

The NCO quarters were located in two L-shaped groups on the east and west sides of the base. These residential units were all two-story duplexes with shared garages. Two NCO Clubs were associated with the east and west groups. As Randolph grew throughout the 1940s, the NCO housing areas remained relatively unchanged, but by 1946 the east NCO Club was expanded to the north. By the late twentieth century, these two areas were still residential, but the NCO Clubs had been adapted for other uses. Additionally in the east grouping, some of the open spaces had been appropriated for new buildings and additional parking lots (Figure 21).

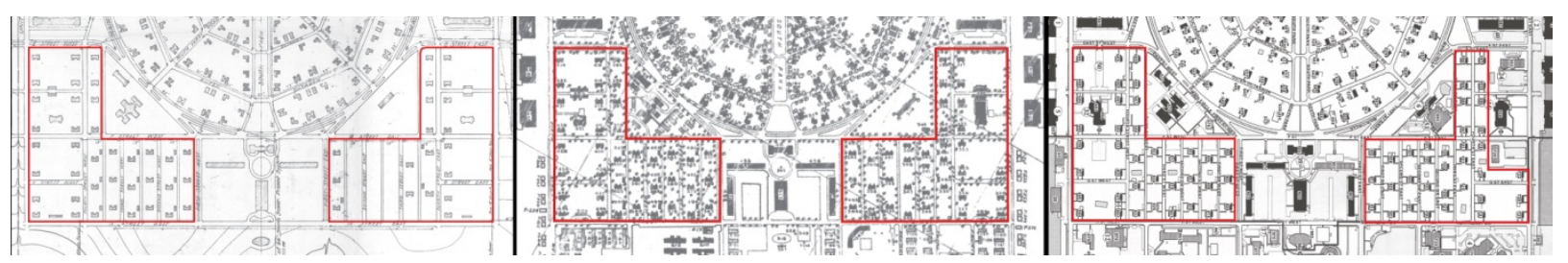

Figure 21. The NCO housing areas have mostly retained their original usage boundaries from the initial construction of the base in the 1930s (left) through the 2000s (right). Only a portion of the eastern section of NCO housing has been appropriated for other uses (ERDC-CERL).

\subsubsection{Bachelor Officers' Quarters}

The 1930s plan of Randolph Field shows three buildings in the BOQ complex. Two buildings were barracks, and the building between them was the mess hall. The area was bounded by streets with garages built across the street to the south. During the 1940s, the open spaces that had surrounded the three original buildings of the BOQ complex had been filled with WWII 
temporary construction. Additionally during this time, an entrance drive and parking was constructed around the mess building. By the late twentieth and early twenty-first centuries, the BOQ complex underwent further changes, including changing the mess hall to lodging and building new barracks to the north of the original quarters buildings. Figure 22 shows the growth sequence of the BOQ complex.

East of the BOQ complex was originally open space in the original plan. By the 1940s, the area had playing fields and served as a recreational area for the BOQ and the enlisted men's barracks to the south. By the mid-1990s, more barracks were constructed in the area.

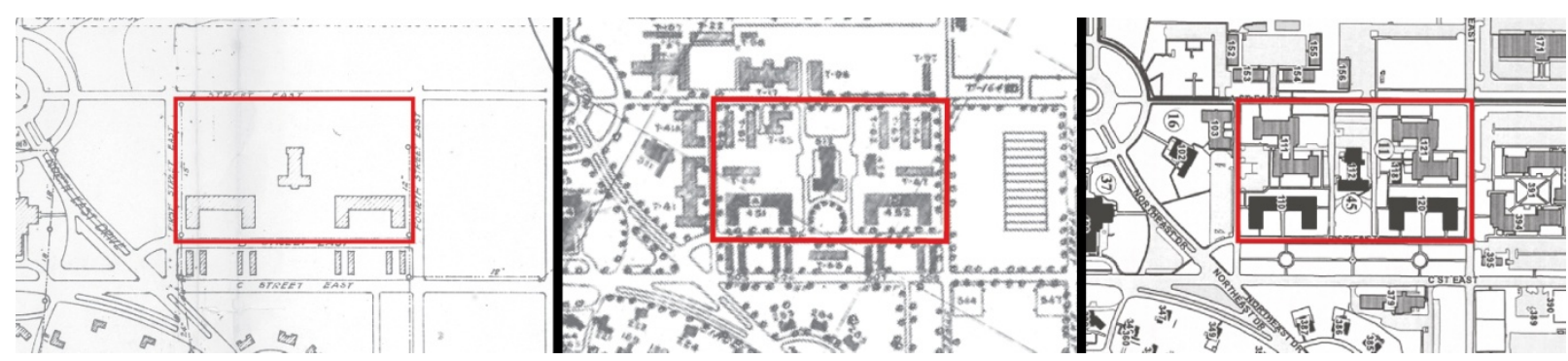

Figure 22. Land use changes in the BOQ area in the 1930s, 1946, and 2012 (ERDC-CERL).

\subsubsection{Enlisted men's barracks}

The enlisted men's barracks were symmetrically aligned on the east and west sides of Randolph Field, making them centered on the east-west organizing axis through the base. Although each side had a group of buildings that was reflected on the other side, the barracks complex along the west flight line had two additional barracks buildings to the north. In the 1930s, the symmetrical areas were comprised of two rectangular barracks - one on the north side and one on the south of the area. The northern building was accessed by a road running along its south side, and the southern building also was accessed by a road to its south. An open grassed area was maintained between the buildings, and in this area, on alignment with the east-west axis, were two oval swimming pools located between the barracks buildings. In the late 1930s, an amphitheater had been built near the pool for the east barracks complex.

By the late 1940s, the open grassed areas were beginning to be filled with buildings. Continuing the east-west axial alignment, one building was built in the east-side complex and two buildings were built on the west side. Parking areas had also been added off the access drives. 
Throughout the twentieth century, development of these areas continued as they were converted from barracks to office areas. The open grassed spaces between the original barracks buildings have been filled with additional buildings and parking lots, and the swimming pools have been removed. The northern barracks along the west side were also extensively modified to form a large office building that now houses the Headquarters of the Air Force Personnel Center (Figure 23).

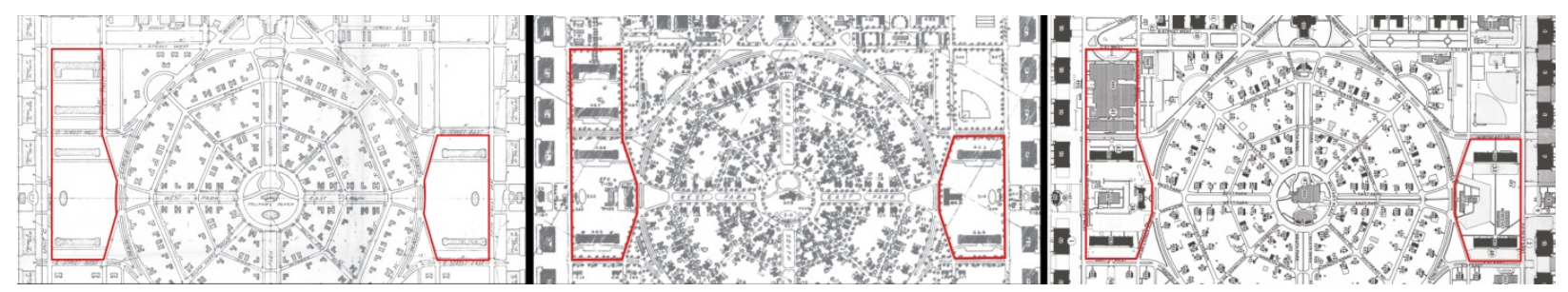

Figure 23. From left, enlisted men's barracks in the 1930s, 1946, 2012 (ERDC-CERL).

\subsubsection{Cadet Complex}

The Cadet Complex was originally designed with two barracks buildings, an administration building that housed recreational spaces and a small PX, and an educational building. This complex was aligned on the primary north-south organizational axis through the base. The educational building faced the main circle and around it were two entrance drives. These drives connected through a circular courtyard around which the other buildings connected. Behind the cadet administration building was another small drive. Parking for these buildings was kept to the H Street West, south of the complex. Across H Street West was a large oval swimming pool, also centered on the north-south axis. By the late 1930s, two additional barracks buildings were built at right angles to the original barracks and parking lots had been built in the interior spaces.

By the late 1940s, the area south of the Cadet Complex had been ringed with WWII temporary buildings and associated parking lots. The pool remained south of the complex situated in a small open space. Throughout mid-twentieth century the Cadet Complex remained relatively unchanged. However, by the late twentieth century, new building initiatives changed the use of the complex from residential to administrative office space. The area was developed to maximize parking around the buildings. The result was that the open spaces between the former barracks were converted to parking with only thin islands of grass between lots. In front of the original two barracks, on either side of the former educational building, were added two smaller parking lots that were accessed from the north off F Street 
East. While some trees and grassed areas remain in this complex, a significant amount has been converted to asphalt parking. Figure 24 illustrates the changes to the Cadet Complex as the base has developed.

South of the former Cadet Complex has been filled with newer buildings including a large gymnasium and administrative buildings that have been constructed around the previously existing pool, pool house, and tennis courts. Parking lots have been added to the spaces between these buildings (Figure 24).

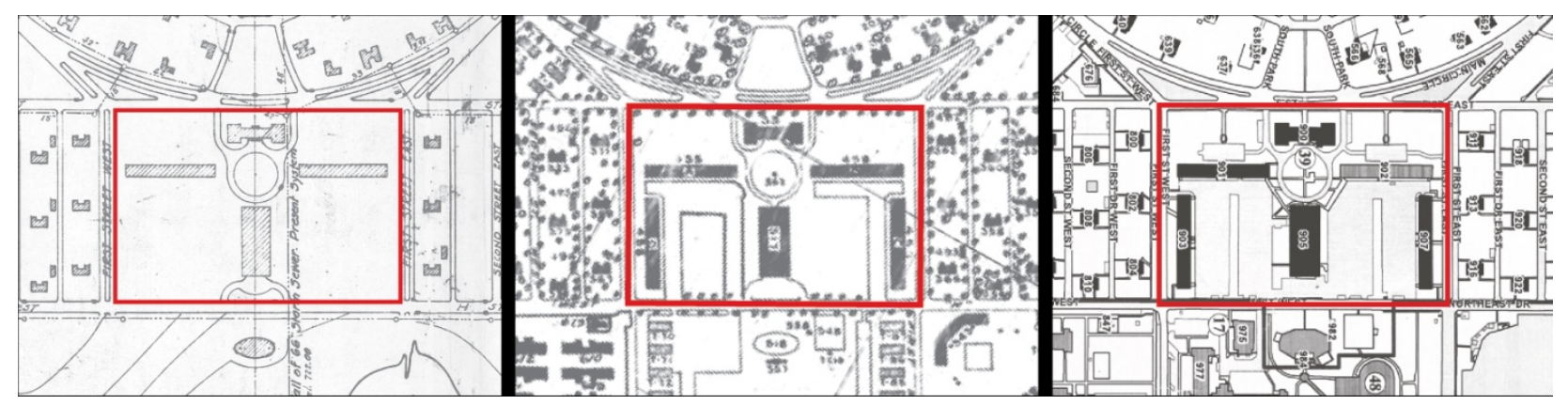

Figure 24. From left, the Cadet Complex development through the 1930s, 1946, and 2012 (ERDC-CERL).

\subsubsection{Hospital complex}

In the original plan for Randolph Field, the Post Hospital and the School of Aviation Medicine were located in the southwestern triangle around the main circle. The Post Hospital was a large, three-winged building that was aligned with Southwest Road. The School of Aviation Medicine was housed in a smaller building located north of the hospital. Initially the area was surrounded by open space, but during the buildup for WWII the area was filled with WWII temporary buildings. The area was lined with street trees, and the Post Hospital was accessed by either a front drive off Main Circle or a rear approach from either F Street West or $3^{\text {rd }}$ Drive West.

The WWII temporary buildings were demolished, and the areas on either side of the Post Hospital were turned into surface parking lots. Eventually the Post Hospital and School of Aviation Medicine were converted to office and administrative space, and the early twenty-first century configuration of the triangular space reflects this change. Although parking consists of a large portion of this space, the former School of Aviation Medicine building is surrounded by grass and trees, while the building southeast of the former Post Hospital is also surrounded by some grass and trees (Figure 25). 


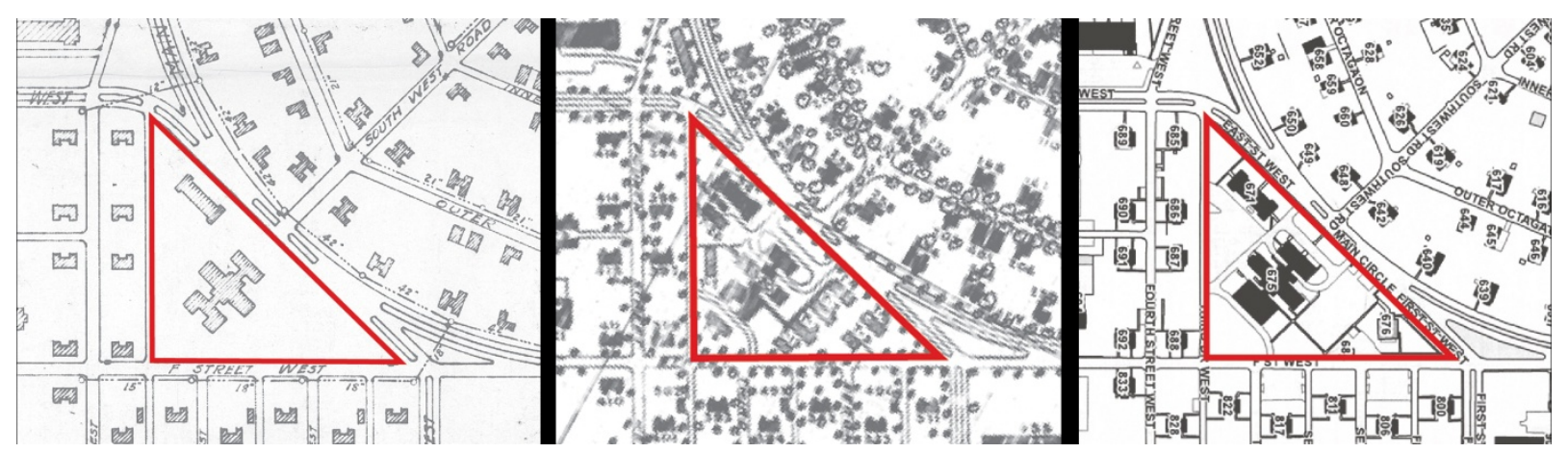

Figure 25. From left, the Post Hospital and the School of Aviation Medicine in the 1930s, 1946, and 2012 (ERDC-CERL).

\subsection{Expression of military cultural traditions}

Military cultural traditions are reflected on military installations through both spatial organization and design aesthetics. The military is a unique culture that values hierarchy, discipline, utility, and patriotism. These ideologies are physically reinforced in the landscape, giving military installations a distinct appearance and sense of place that makes their design easily recognizable. ${ }^{37}$

The main principle of Randolph Field's development was to accommodate the mandated mission as quickly and efficiently as possible. 38 This often led to a utilitarian landscape in which function was emphasized over aesthetics. Physically representing the military values of hierarchy, discipline, utility, and patriotism in the landscape can occur at the sitewide scale and at the building scale. For example, hierarchy can be displayed though the organization of land uses and building placements as well as through an individual building's scale, massing, and architectural styling. Because Randolph Field was designed using strong organizational geometries, these physical characteristics are used to emphasize hierarchy. Figure 26 illustrates that Randolph Field's most important buildings were aligned on the axial system.

37 Loechl et al.,1996, 73.

38 Loechl 1996, 70. 


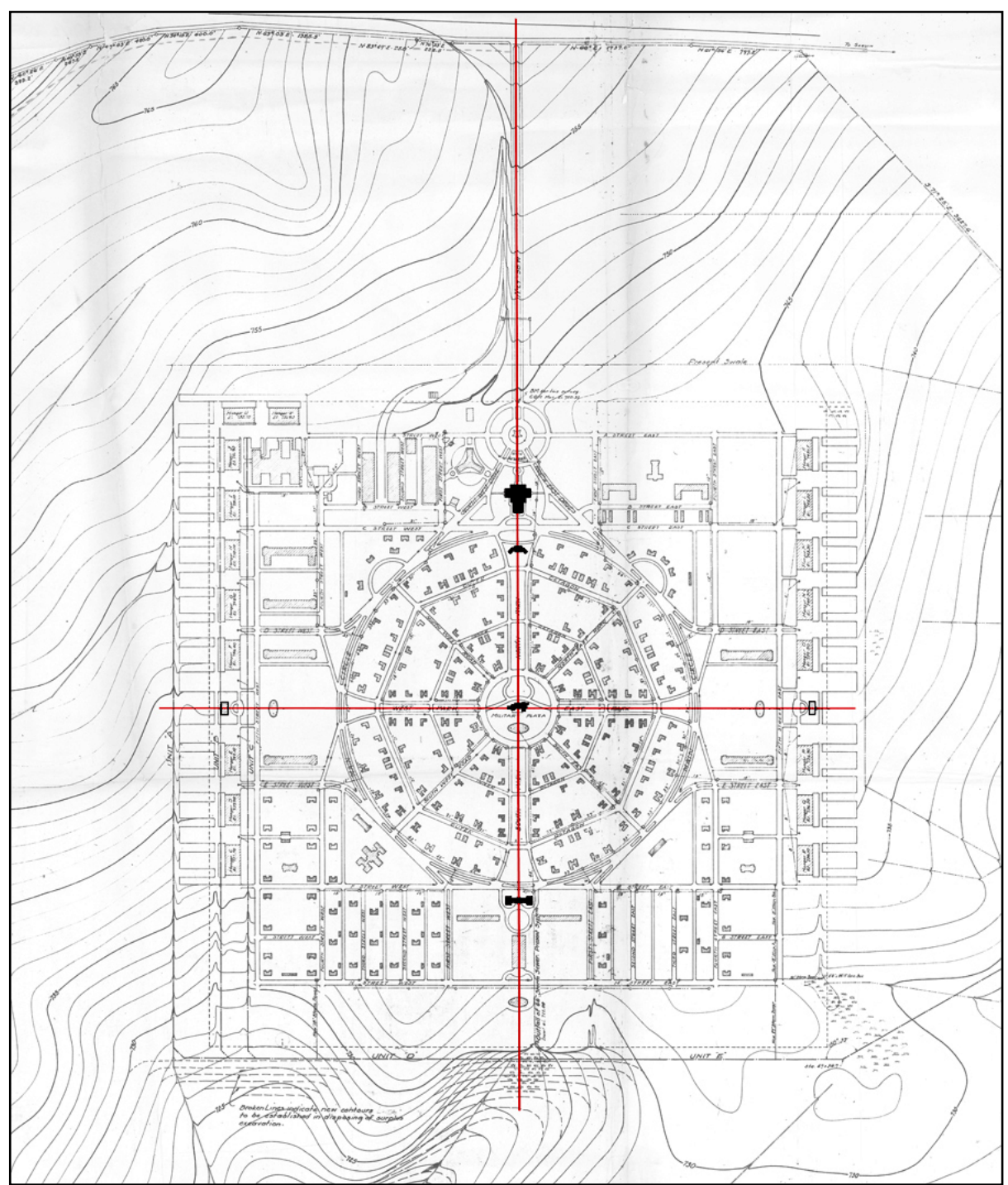

Figure 26. Aligned on the primary north-south axis through the base were the prominent areas and buildings, such as the Administration Building, Commanding General's quarters, Officers' Club, and Cadet Education Building in the Cadet Complex. On the secondary east-west axis were the stage houses for the east and west flight lines, as well as the barracks complexes. Axial lines drawn on an undated, but pre-WWII plan of the base (ERDC-CERL).

Randolph Field was organized so that similar functional uses were combined. These areas were arranged over the site to take advantage of spatial relationships which could further emphasize rank or importance. For example, the officers' housing and club are consolidated at the center of the base in a highly landscaped area that affords a lot of open space. Likewise, buildings that house functions that were important to base operations were prominently located. For example, the Administration Building was located at the terminus of the entrance drive, and in the housing area, the Commanding General's residence is prominently located and more ornamented and landscaped than the surrounding quarters (Figure 27). Utili- 
tarian spaces were located at the edges of the cantonment and featured less decoration in both landscaping and architectural ornamentation. This spatial organizational hierarchy physically reflects the mission of both the Army, and later, the Air Force.

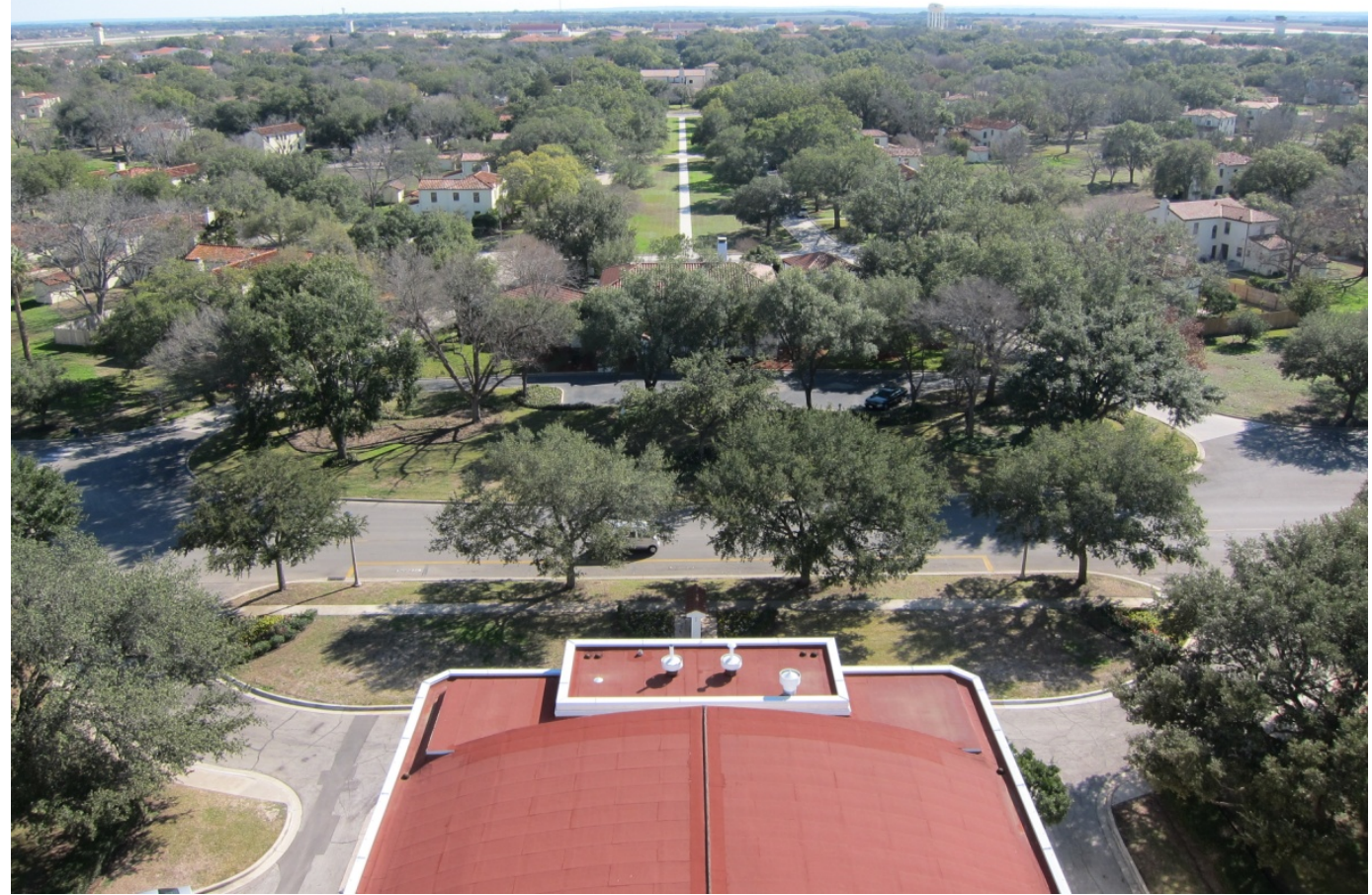

Figure 27. View south from the Taj Mahal along the primary north-south axis, emphasizing the alignment of the Main Circle officers' housing, 2012 (ERDC-CERL).

Like hierarchy, the cultural value of uniformity also is highly visible throughout Randolph AFB at several scales. The base plan was designed with concise geometries aligned on an axial structure. The result means the plan is mostly symmetrical on the east and west sides as well as the north and south sides. Within the organizational symmetry, buildings of similar types (e.g., residential, administrative, academic, or utilitarian) feature the same arrangement, building materials, and architectural style. Uniformity is further emphasized with the widespread use of buff-colored adobe and red tile roofs in building construction throughout the base. Although the buildings might vary slightly in their detailing or exterior ornamentation, the overall visual effect is unified through these physical characteristics (Figure 28 and Figure 29). 


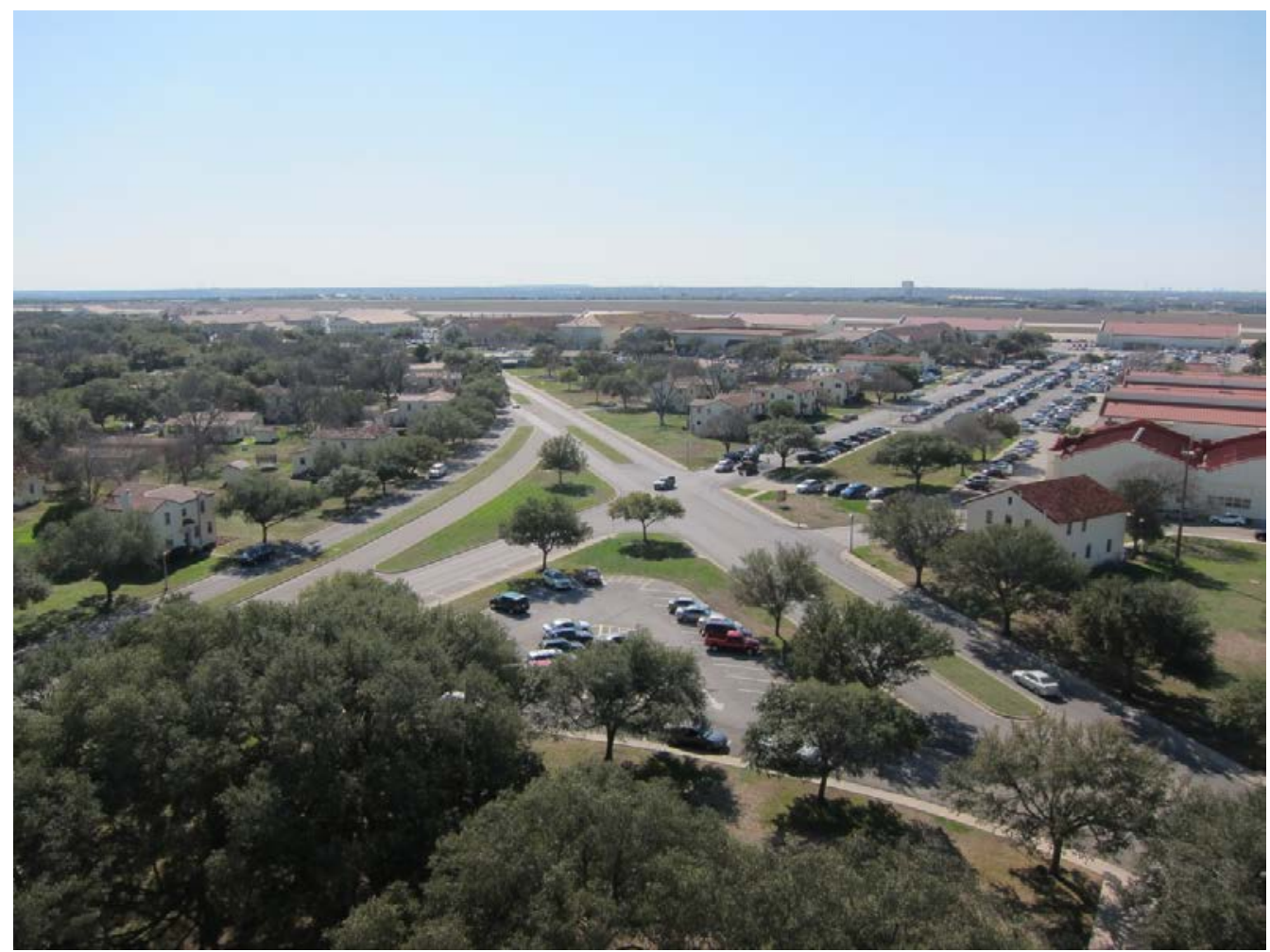

Figure 28. The warehouse and shop area, on the right, conveys the same uniform visual aesthetics as the officers' housing area, on the left, 2012 (ERDC-CERL).

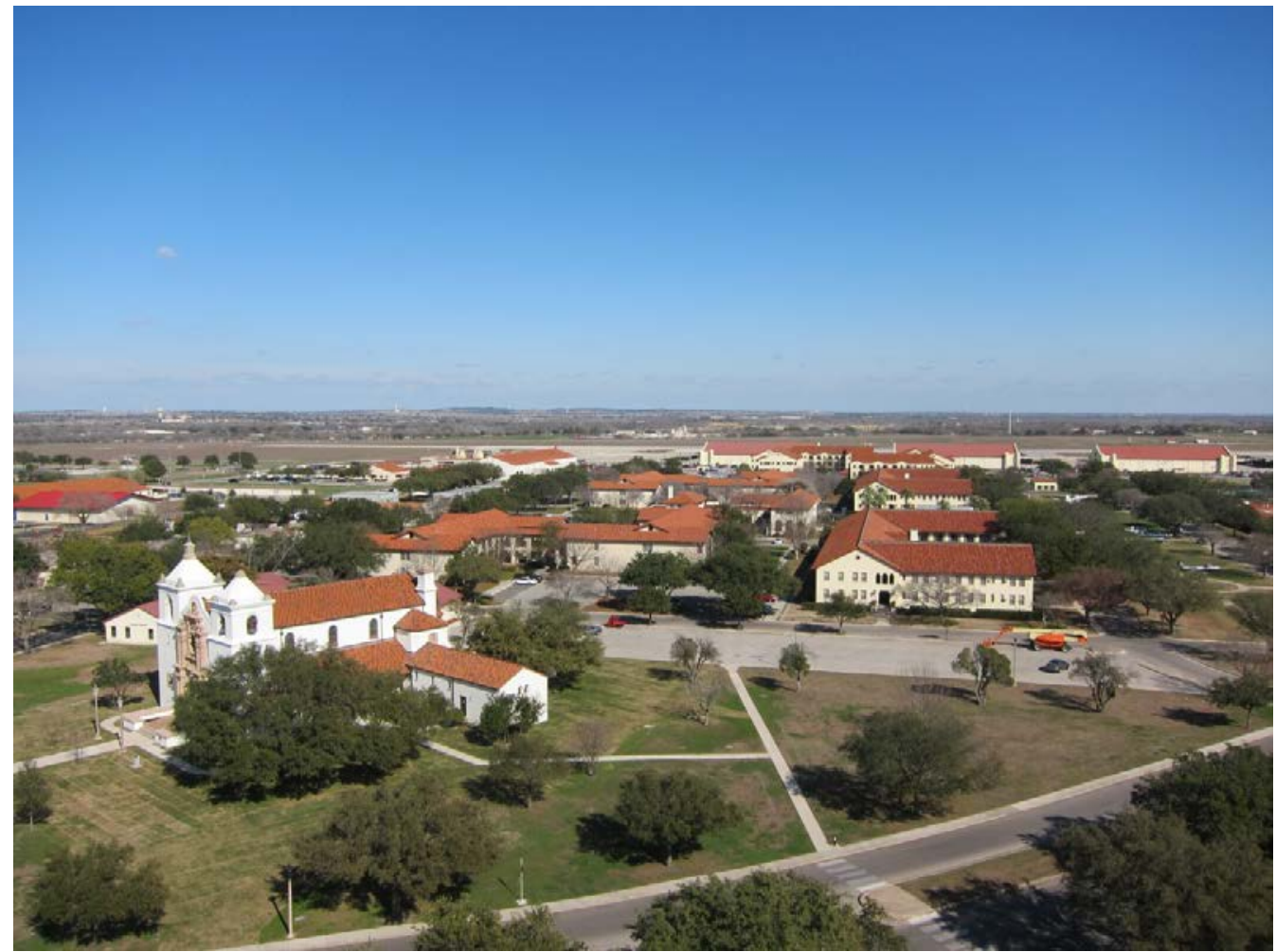

Figure 29. Although the chapel is highly ornamented, it blends into the overall aesthetic of the base through the use of similar construction materials and vegetation, 2012 (ERDC-CERL). 
Utility is another standard prioritized by the military. In base layout, utility is translated into a logical arrangement of spaces. Randolph's base planning and design choices represent this in the arrangement of buildings and their associations to the air field, schools, and residential areas.

Patriotism can be physically represented though symbols, flags, and monuments. These are small-scale details that are arranged throughout Randolph AFB and are often associated with important or significant buildings (Figure 30, Figure 31, and Figure 32).

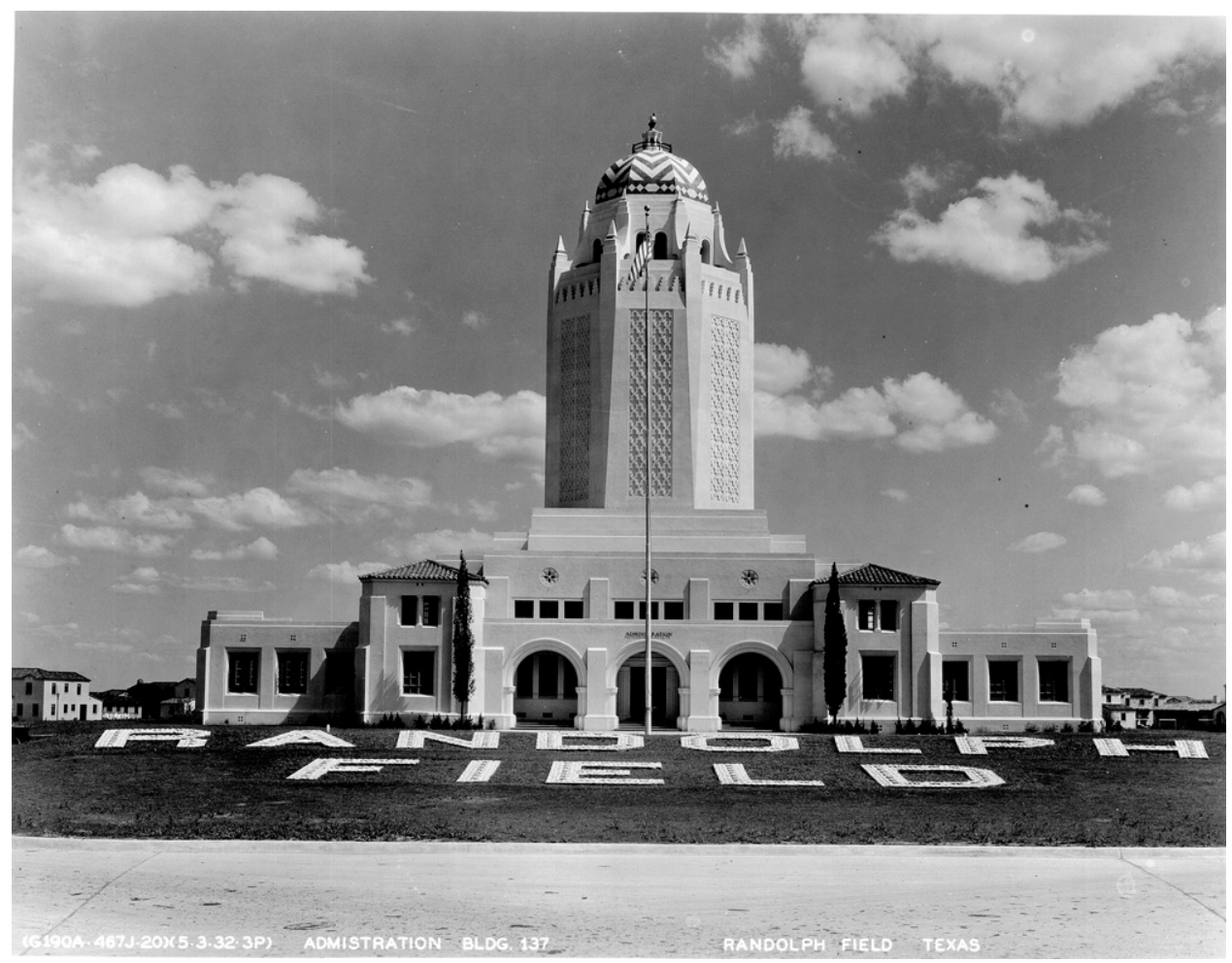

Figure 30. The highly ornamented and visually distinct Administration Building, also known as the Taj Mahal (Bone Collection Randolph AFB Cultural Resources). 


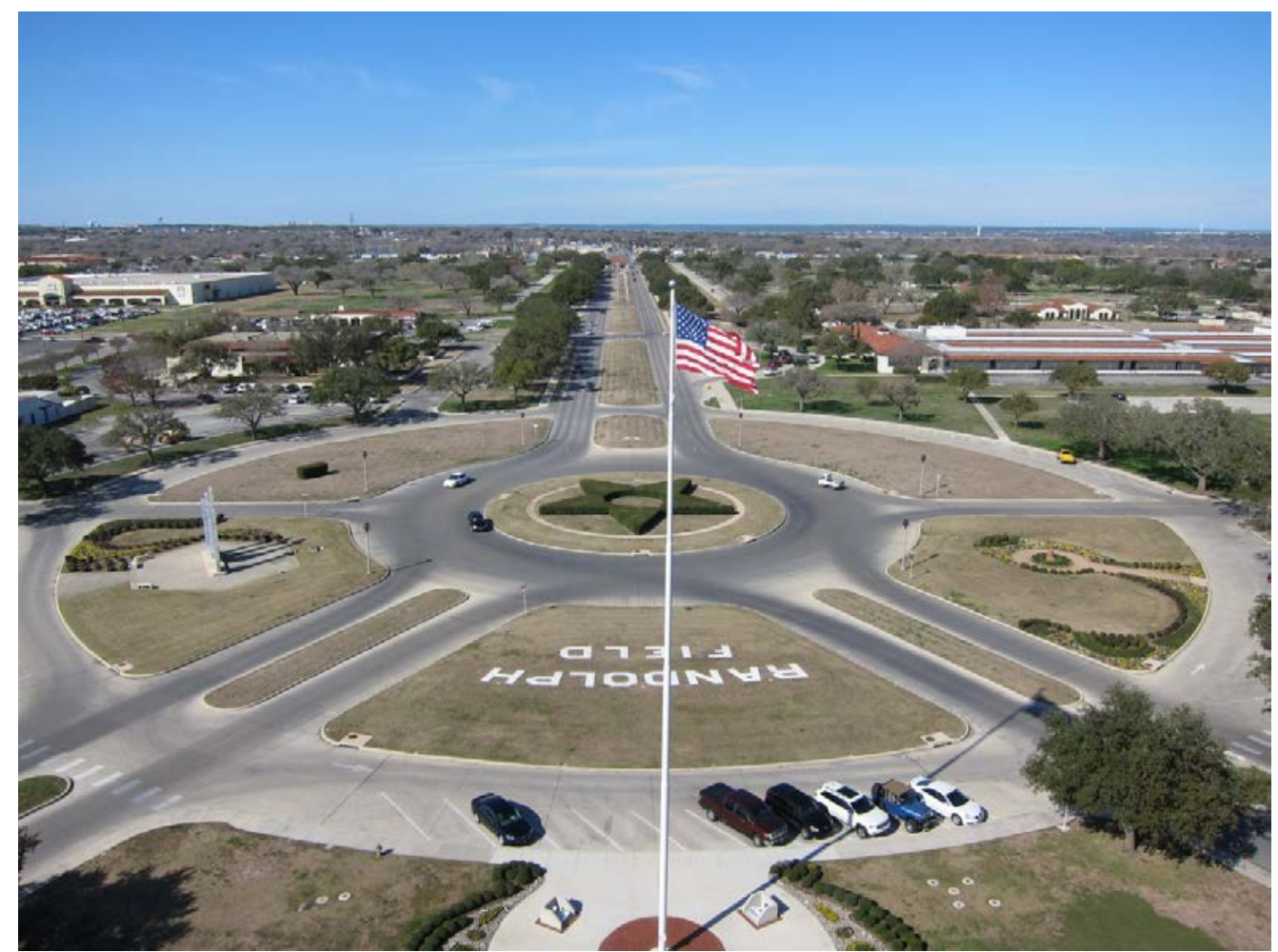

Figure 31. View from the Taj Mahal toward the main entrance. The base flagpole is located north of the Administration Building, on axis with the main entrance, 2012 (ERDC-CERL).

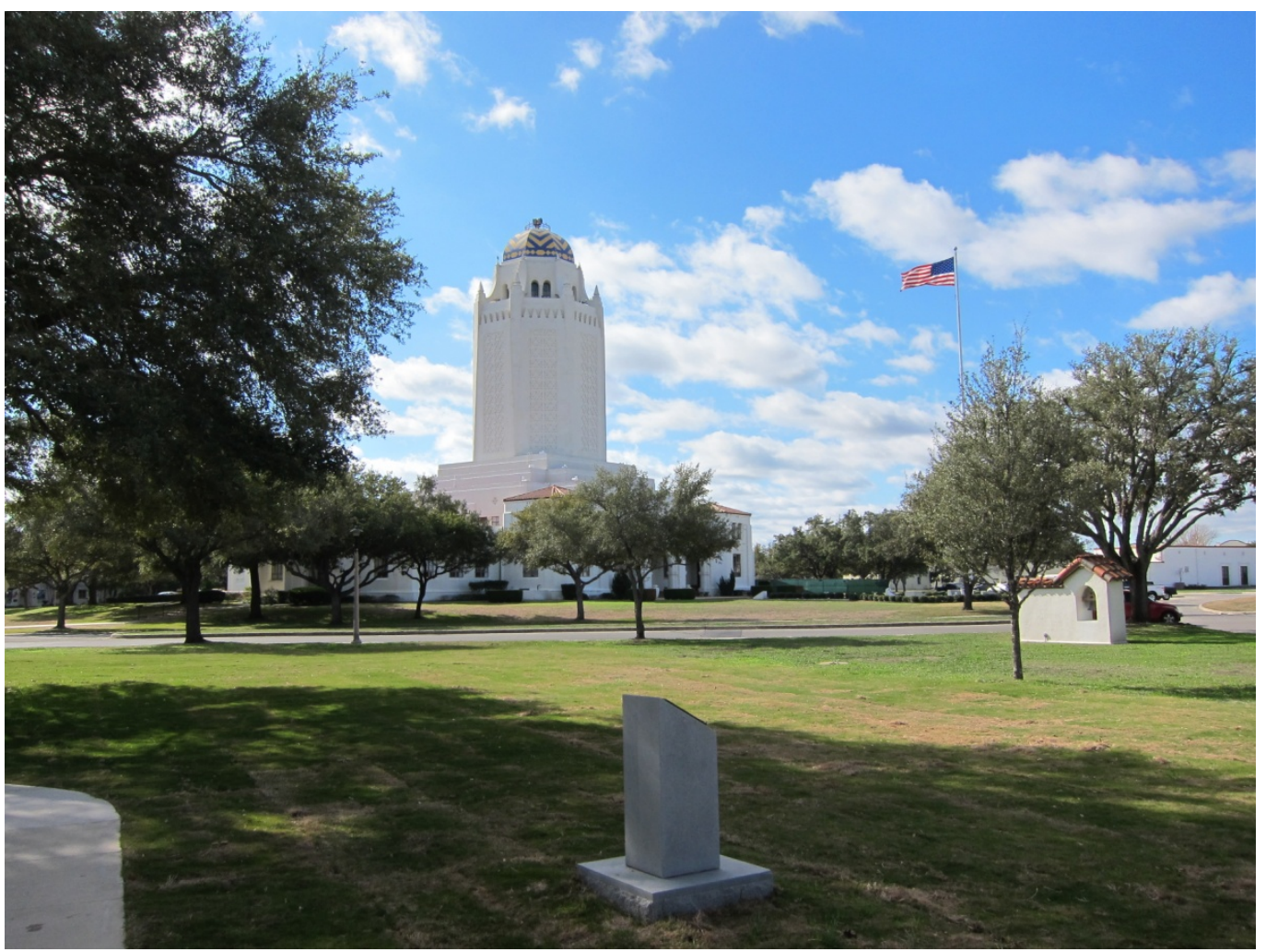

Figure 32. View of the Taj Mahal from the chapel, 2012 (ERDC-CERL). 


\subsection{Transportation networks}

Transportation networks on military installations are an important characteristic of military landscapes because the movement of troops and equipment is vital to the military mission. Most military transportation systems have a distinct hierarchy to facilitate efficient mobilization of troops and distribution of supplies. ${ }^{39}$ In general, Army installations were planned to connect with regional systems of trails, primary and secondary roads, railroads, or navigable waterways.

The site for Randolph was chosen because it would most easily accommodate the existing design for the base. State Highway 218 would eventually terminate at the base entrance, and the Old Seguin Road ran on the north side of the base and connected the base to San Antonio (Figure 33). J ust north of Old Sequin Road was a Southern Pacific Railroad line that was connected to Randolph Field through several spur lines (Figure 34).

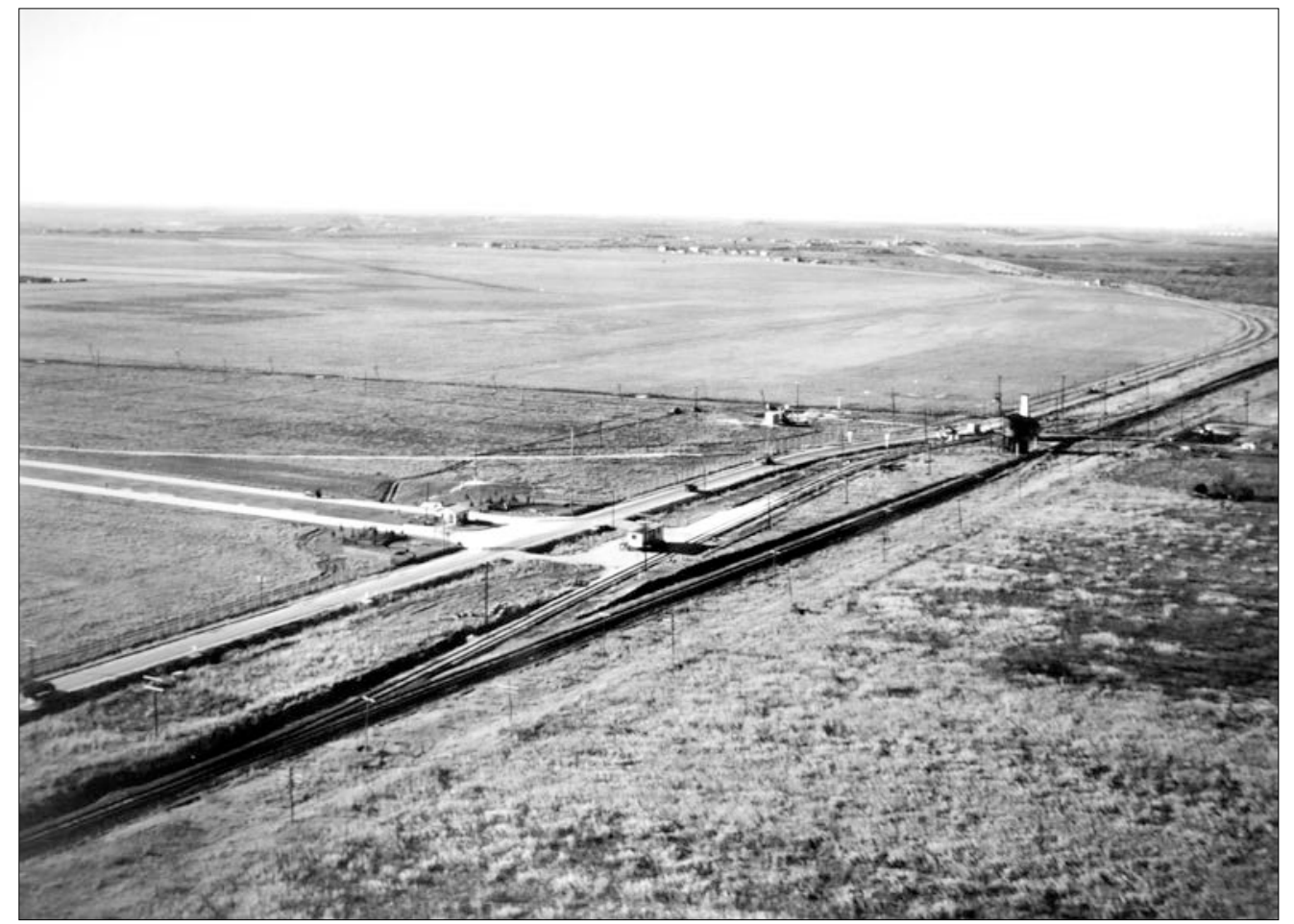

Figure 33. Main entrance to Randolph Field during the 1930s showing the Old Seguin Road and the Southern Pacific Railroad (Norfleet Giddings Bone Papers, University of Texas at San Antonio Libraries Special Collections).

39 Loechl et al.,2009, 77. 


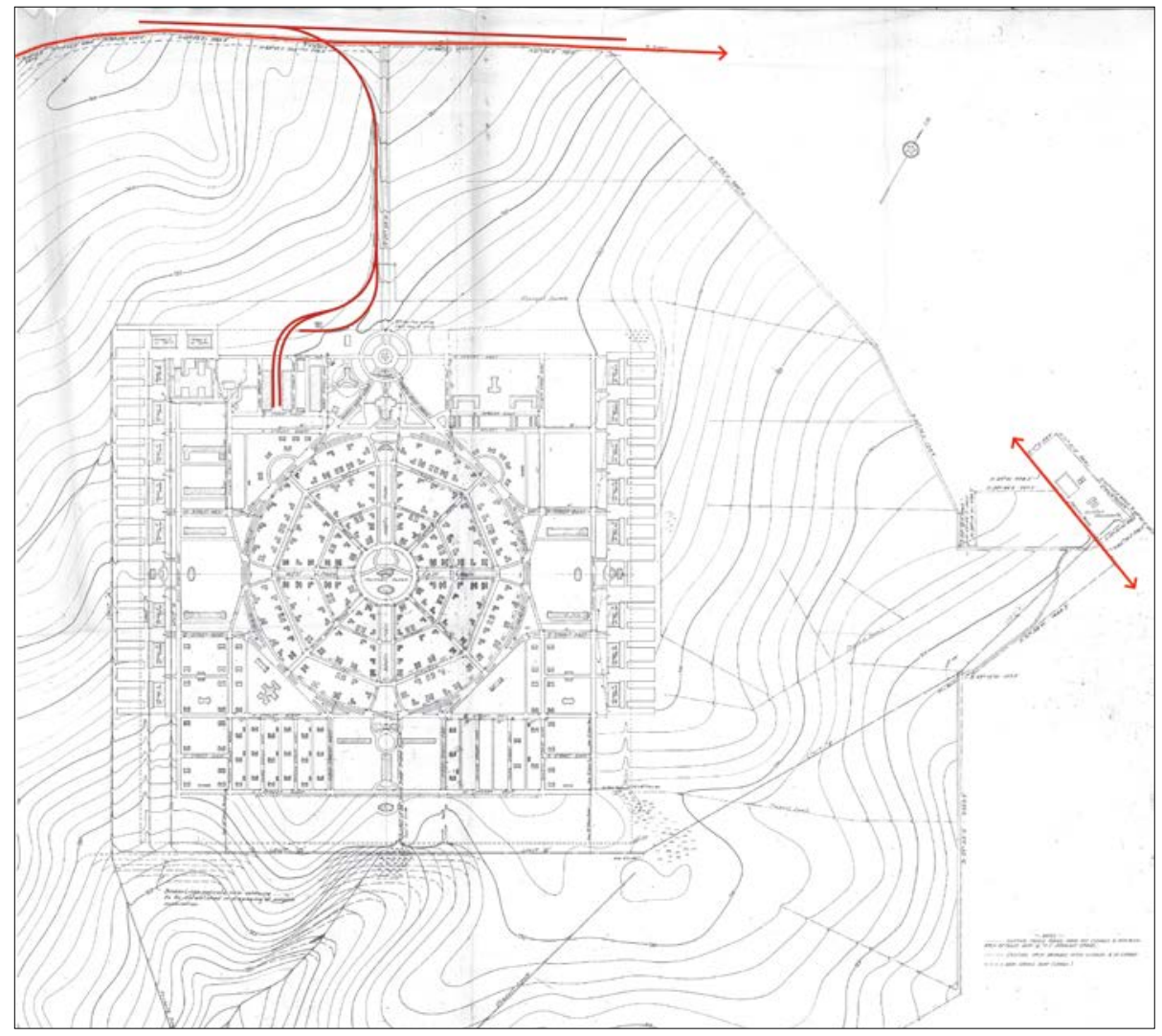

Figure 34. County roads and the rail spur leading into Randolph Field, 1930s (ERDC-CERL).

Randolph Field's network of roads is what gives the base its distinct organization. The main entrance to the base was at the intersection of State Highway 218 and Old Seguin Road. From the entrance gate, a divided boulevard extended for half a mile before reaching the main built areas of the base. At this point was located a roundabout, called North Circle, that consisted of a small circular road that accommodated through traffic within a larger outer road that offered parking. Located at the southern terminus of the entrance drive were the Administration Building, Chapel, and Post Exchange. The main road through the base split on either side of the Administration Building and circumscribed the outer boundary of the centralized circular officers' housing area. Surrounding the Main Circle was a rectangular grid of streets that were divided into east and west. All streets east of the central north-south dividing line were prefixed east and those west were prefixed west (Figure 35). 40 


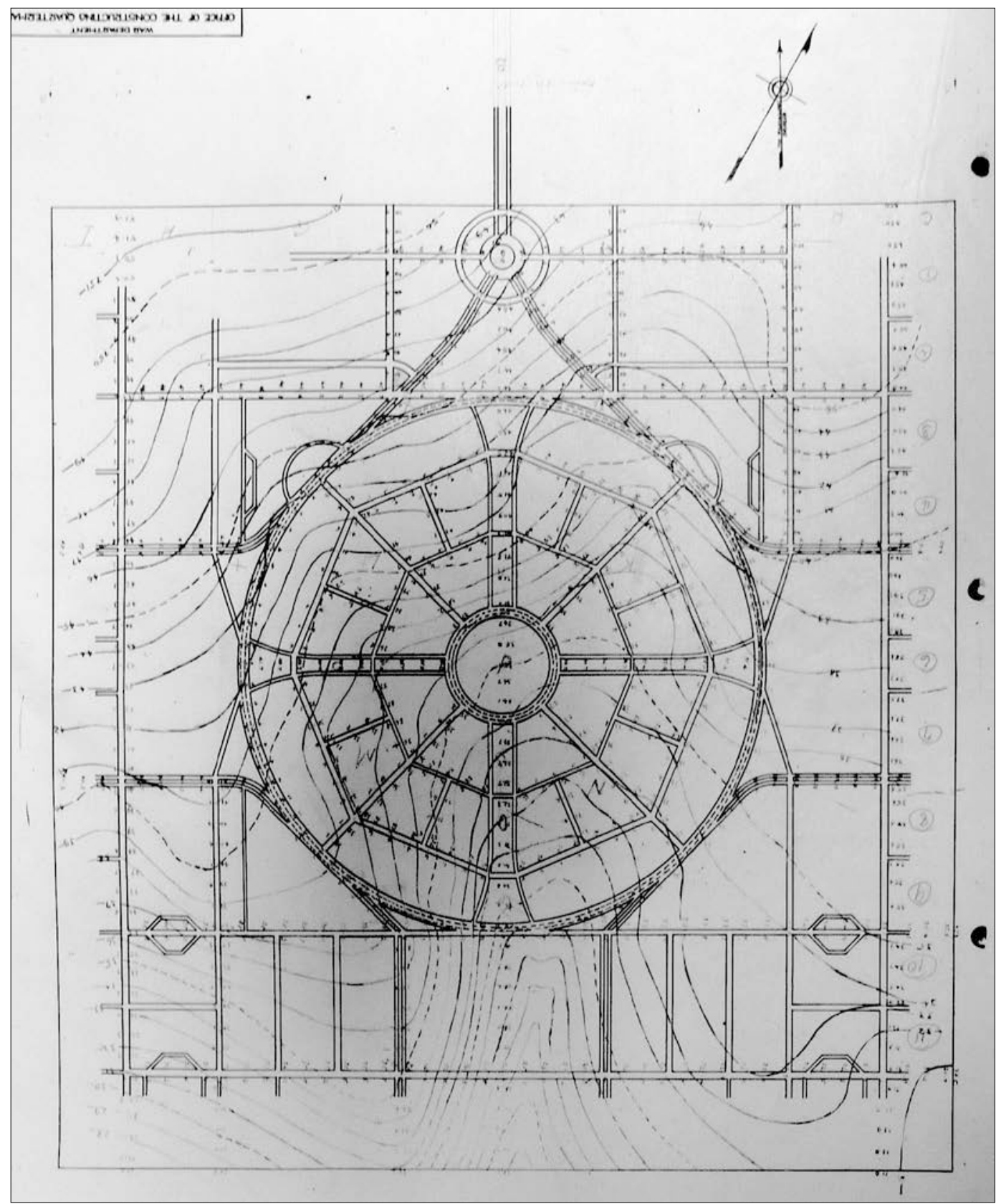

Figure 35. Plan of Randolph Field's road network in the 1930s (Norfleet Giddings Bone Papers, University of Texas at San Antonio Libraries Special Collections)

The circular officers' housing area was divided into quarters by the northsouth and the east-west organizational axes. These axial divisions were spatially emphasized by divided parkways. The interior of this area was further divided by two octagonal roads, called Outer Octagon and Inner Octagon. At the center of the housing area was a roundabout called Military Plaza in which was located the officers' club. Figure 36 highlights the 
roads that bounded Randolph Field in 1946. Figure 37 illustrates how the railroad entered the airfield in 1946.

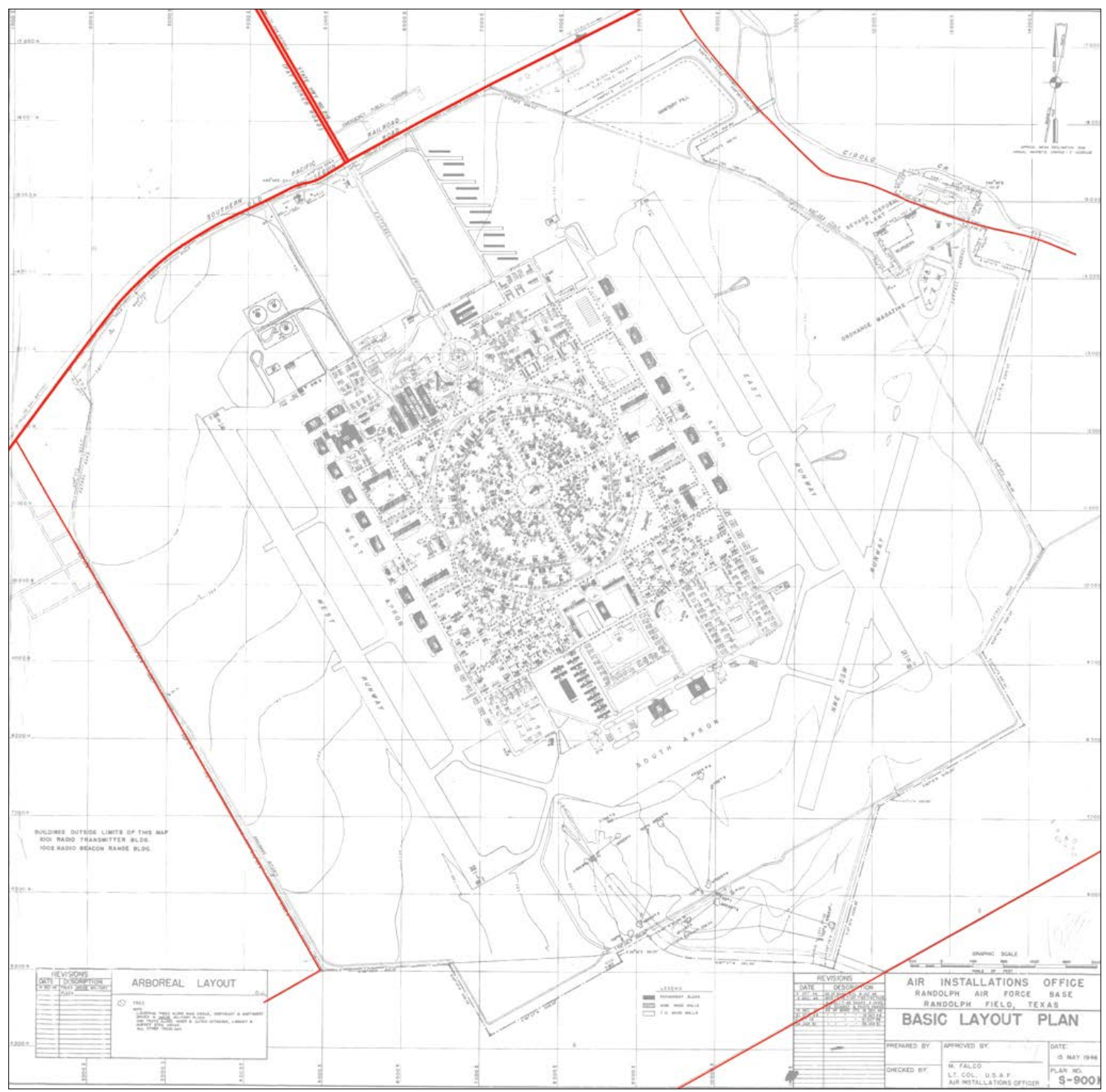

Figure 36. In 1946 county roads still bounded Randolph Field on the east, west, and south sides while Seguin Road to the north was widened and State Highway 218 now connected to the base's main entrance (Randolph AFB Cultural Resources). 


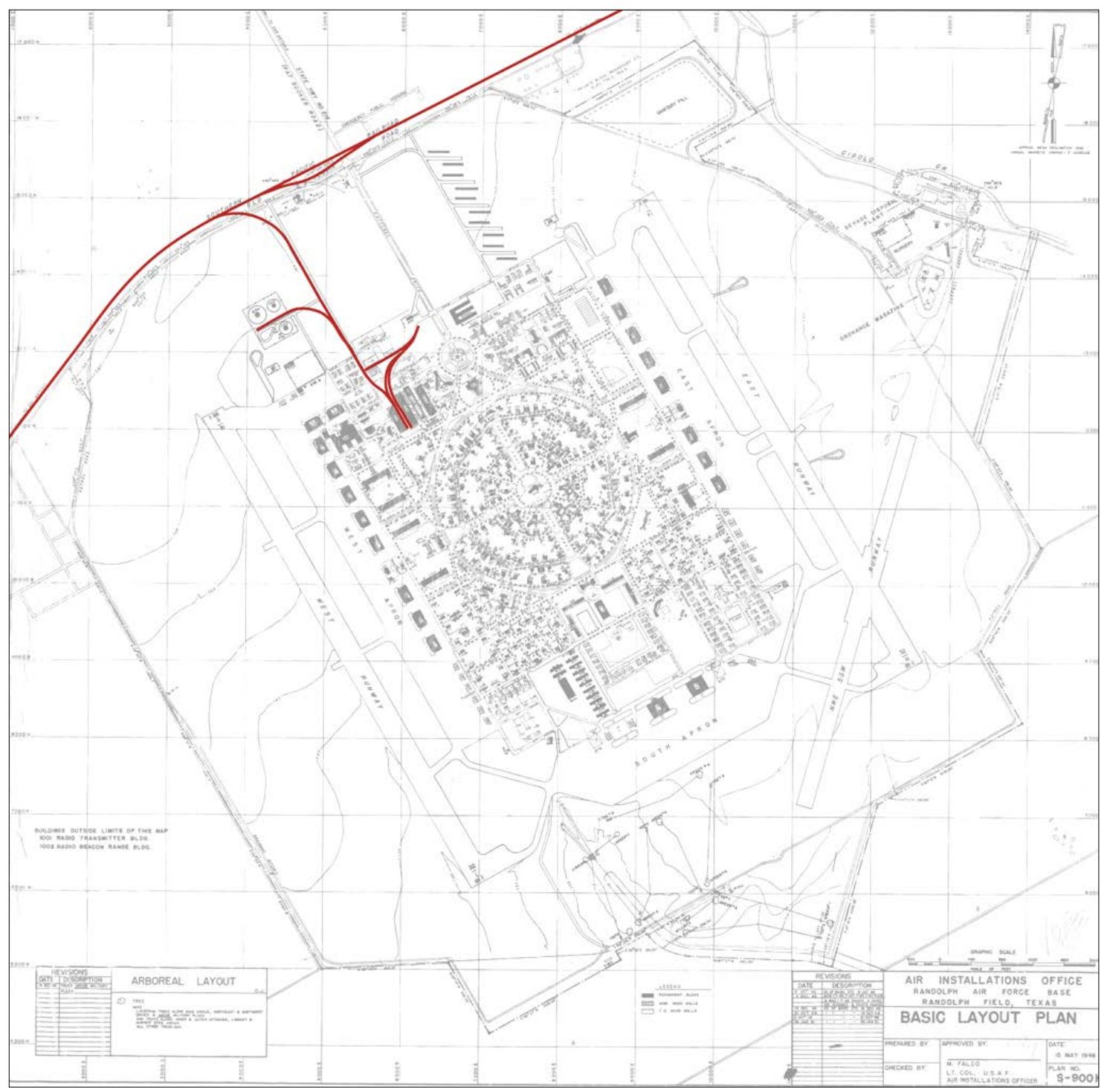

Figure 37. By 1946 the rail spur into Randolph Field had been expanded, but still directly served the warehouse and shop area in the northwestern corner of the base (Randolph AFB Cultural Resources). 


\subsection{Clusters of buildings and structures}

Clusters of buildings and structures are often similar in style and function as a cohesive unit. Clusters are usually designed to create a symbiotic relationship with the buildings' exteriors and interiors relating to one another through similar scales, mass, styles, or functions. ${ }^{41}$ The footprints of buildings, their masses, the spaces in between the buildings, and the circulation between buildings are integral to defining the historic landscape.

A problem common to military installations is the need to construct new buildings within historic districts. The problem needs to be addressed so that these new buildings do not seem out of place and detract from the integrity of historic districts. New buildings can be designed to minimize negative effects on a historic district. Design elements such as massing, materials, colors, roof type, and others can be manipulated so that new construction will be less intrusive than buildings designed without regard for the historic environment. Much like the art of camouflage - where one does not attempt to look like a tree but rather to blend in with the trees new buildings, while not attempting to recreate or mimic the historic style, can be designed in such a way that they appear to fit into their historic surroundings. ${ }^{42}$

Also important, is how buildings architecturally relate to one another. Because adobe was a predominant construction material building at Randolph, there is an architectural compatibility throughout the base. Also consistent are the massing and architectural detailing of these buildings and open spaces because similarly functioning buildings are grouped together (Figure 38).

41 Loechl, et al.,1996, 87.

42 Loechl, et al.,1996, 87. 


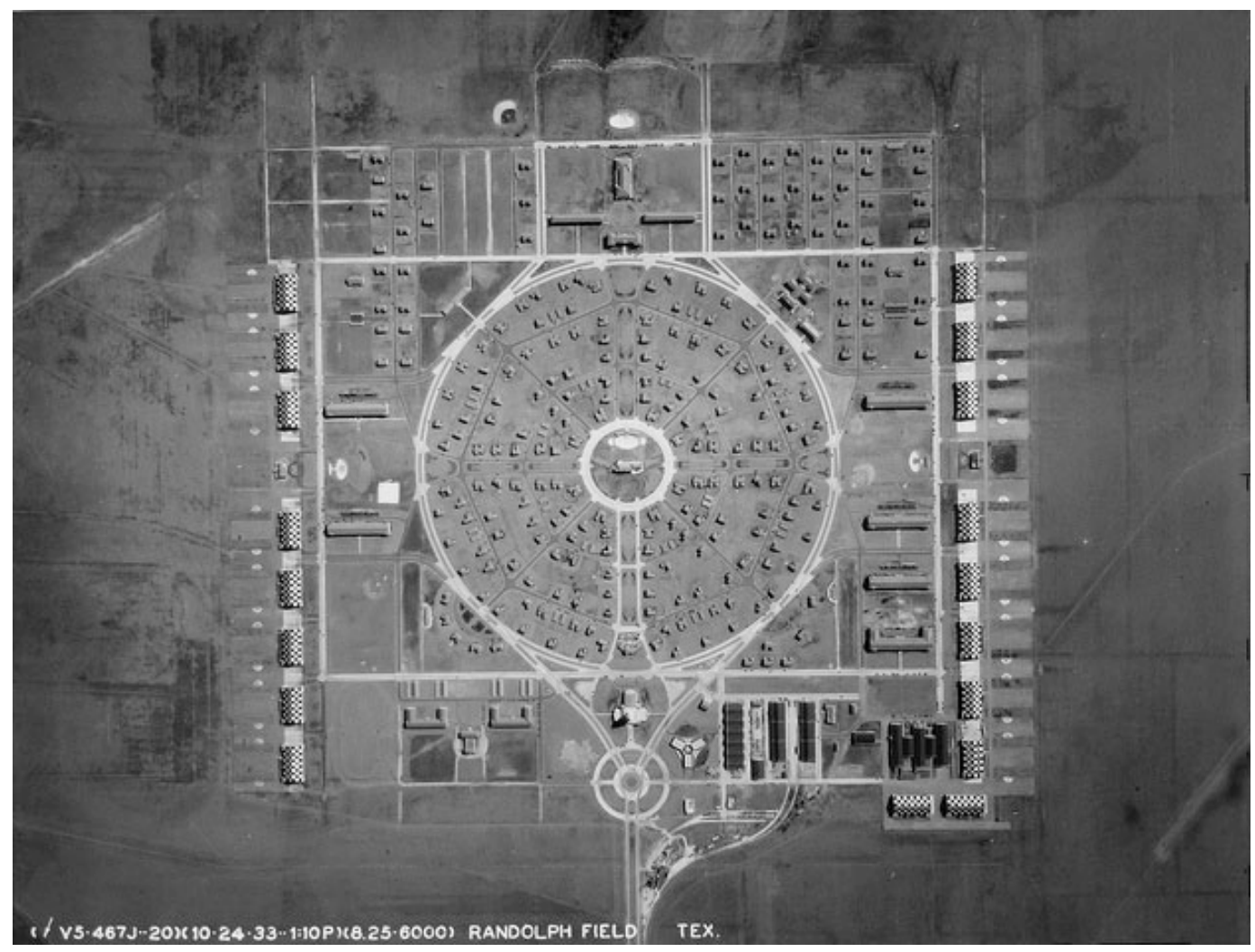

Figure 38. Randolph's buildings were clustered according to functional use and aesthetically unified through shared architectural styles and construction materials, undated (NARA RG 342, Box 1071 B20624).

\subsubsection{Administrative, service, and operations facilities}

Randolph's main entrance drive terminates at Washington Circle around which are arrayed the base's administrative and support buildings. The focal point of this area is the Administration Building, commonly referred to as the Taj Mahal because of its grand appearance in its Spanish Mission architectural styling (Figure 39). The building was built to be an important symbol to potential aviation cadets who wanted to train at the premier Army Air Corps facility. However, the design and construction of the building was technically difficult and further constrained by limited funding. The final design was a two-story building flanked by one-story wings and surmounted by an octagonal tower. Another wing extended from the southern face of the building to house the base theater. The octagonal tower created a monumental piece of architecture, but also served the pragmatic need of concealing the base's water tower. The Taj Mahal was completed in 1931 and combined architectural influences from Spanish Mediterranean and Spanish Colonial Revival. The tower was crowned with 
a blue and gold tile mosaic which was surrounded by ornamental, precast concrete grillwork.

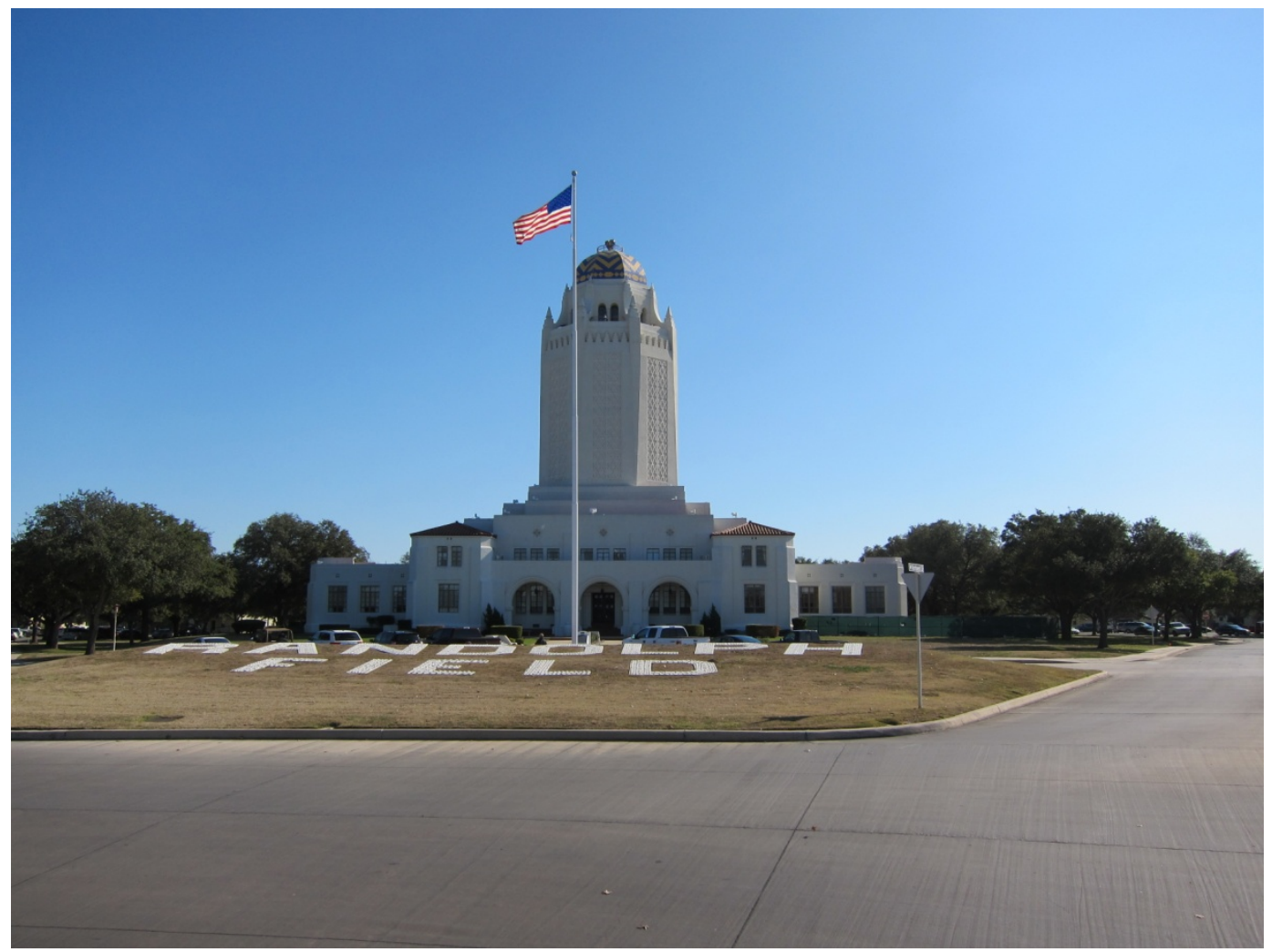

Figure 39. The Administration Building, known as the Taj Mahal because of its distinct design and architectural treatments, 2012 (ERDC-CERL).

The Post Chapel was constructed east of the Taj Mahal and also along Washington Circle. The Chapel was completed in 1934 under difficulties in obtaining construction funding. Because the Chapel served a non-military function, the building did not need to conform to the restrained ornamentation of the other facilities on base (Figure 40). As a result, the Quartermaster Corps architects modeled the Chapel after Mission Concepción and Mission San J osé. The design was dominated by the heavily ornamented entrance reflective of the Spanish Baroque style and was flanked by asymmetrical bell towers (Figure 41). 


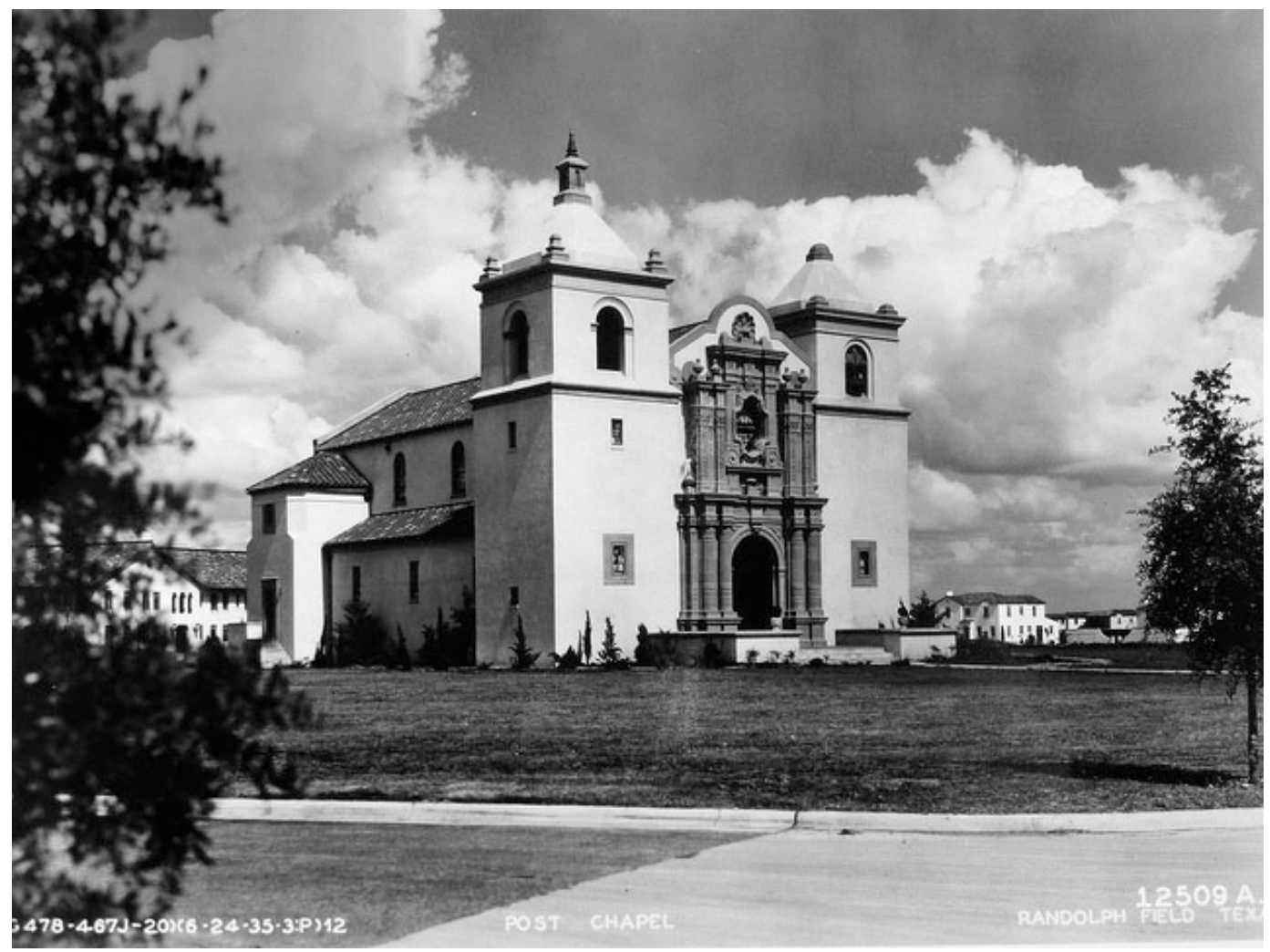

Figure 40. The Post Chapel in the early 1940s (NARA RG342 Box 1072 B20767).

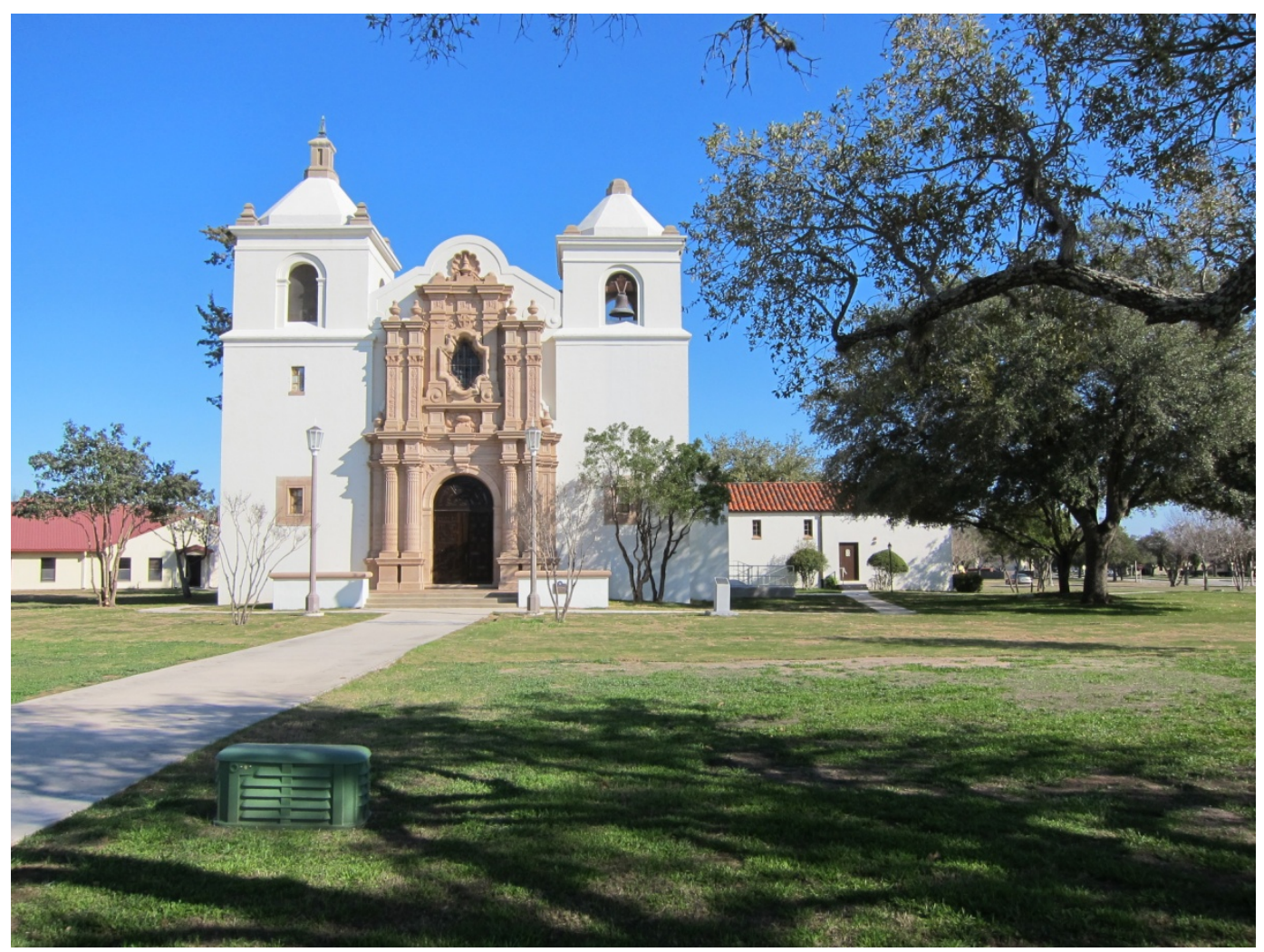

Figure 41. Post Chapel, 2012 (ERDC-CERL). 
West of the Taj Mahal was the Post Exchange, constructed in 1931 as part of a complex with three wings radiating from an octagonal patio. Originally, the PX was located in the southwest wing, the grocery store in the southeast wing, and a large restaurant in the north wing. The covered, colonnaded walkway surrounding the patio offered additional services such as a shoe shop, a tailor, an exchange office, a beauty shop, and restrooms in addition to entrances to the three wings (Figure 42).

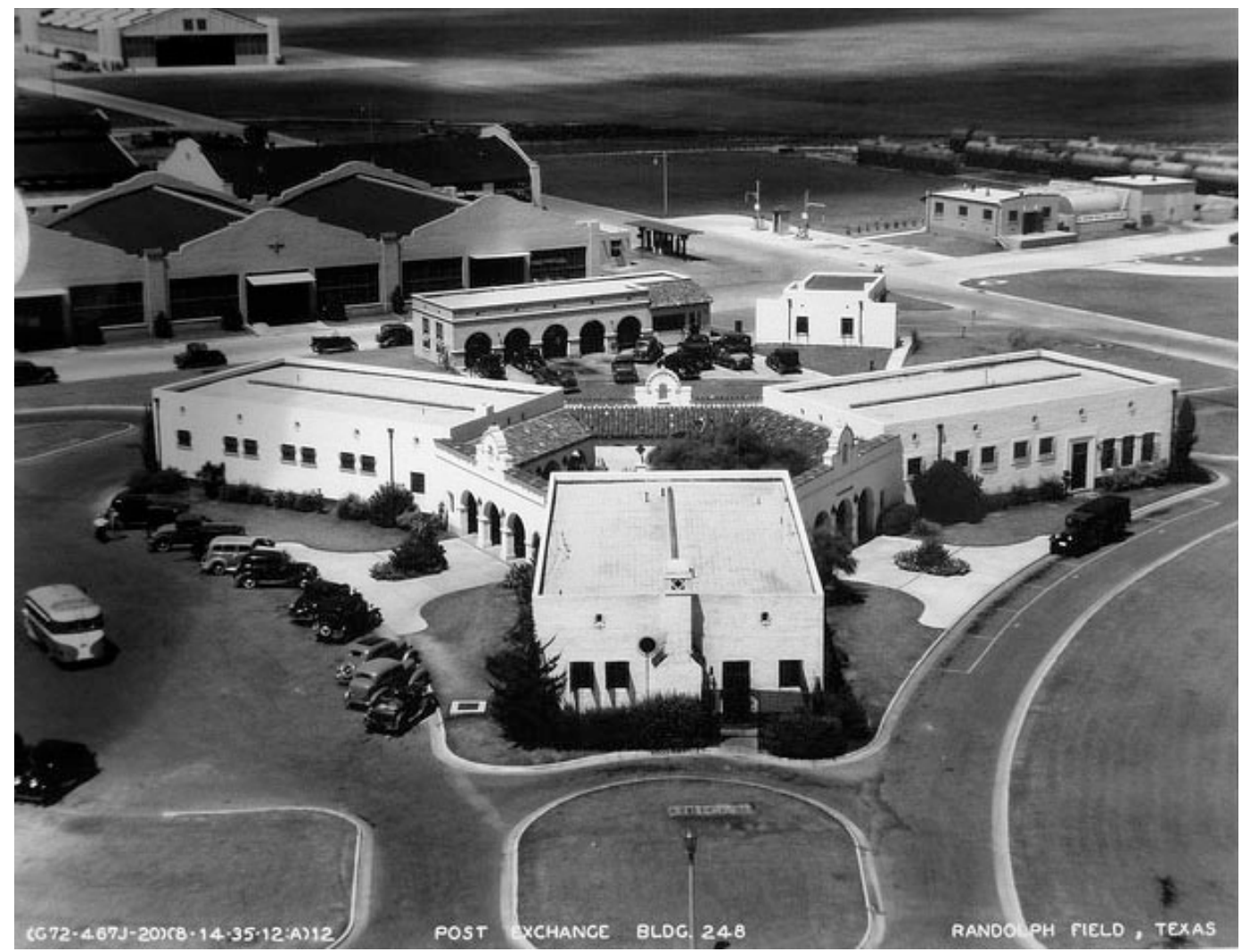

Figure 42. Post Exchange in the 1930s (NARA RG342 Box 1072 B20769).

The design of the PX included an extensively ornamental courtyard that included a wide variety of plant material with a water fountain at the center (Figure 43).

The PX was visually related to the administration building and chapel through common materials, such as stucco and red tile roofs (Figure 44). Although the PX was relocated, the building still serves as an important building in the administrative, service, and operations area. 


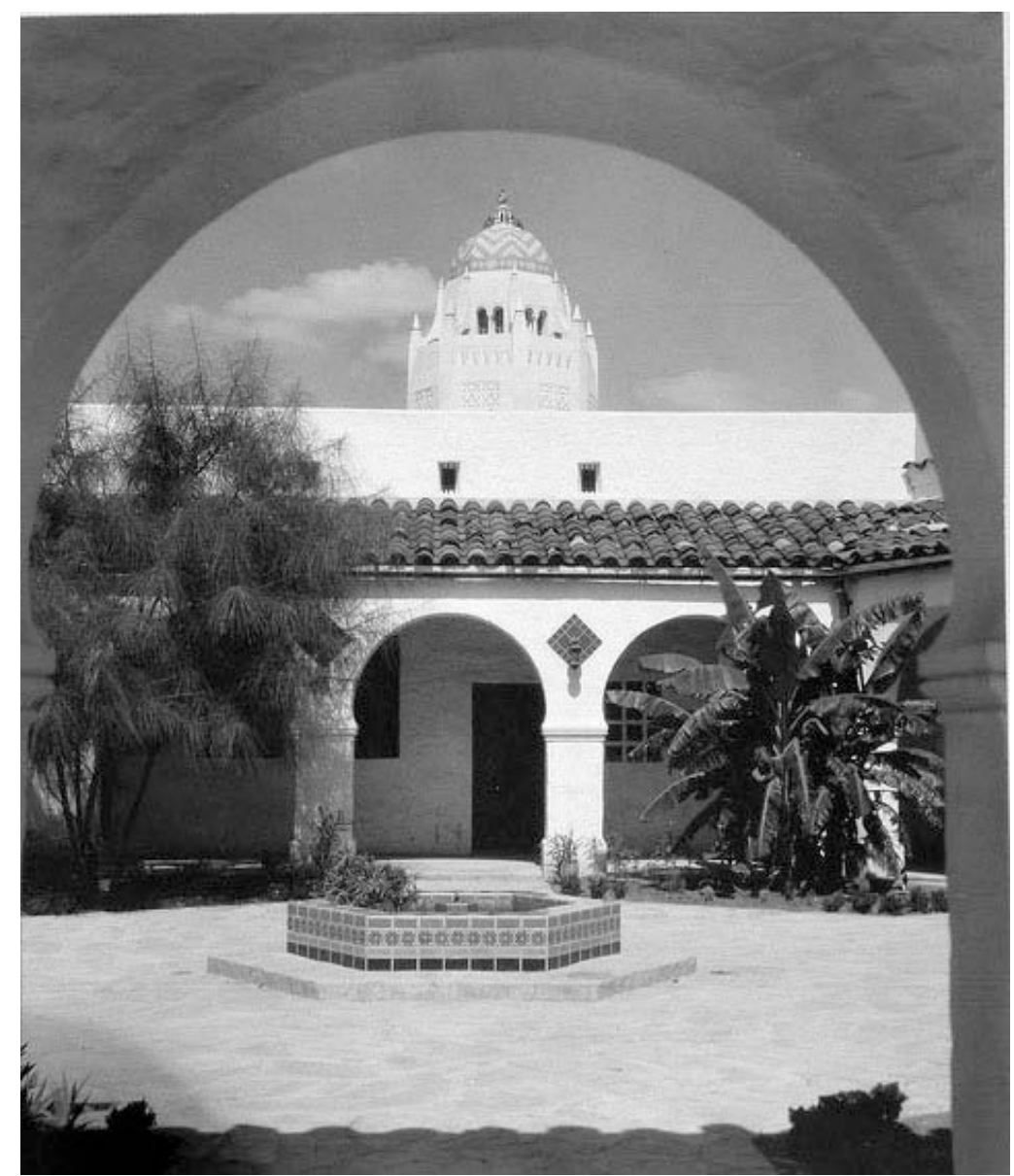

Figure 43. Interior courtyard of the Post Exchange in the 1930s (NARA RG342 Box 1072 B20770).

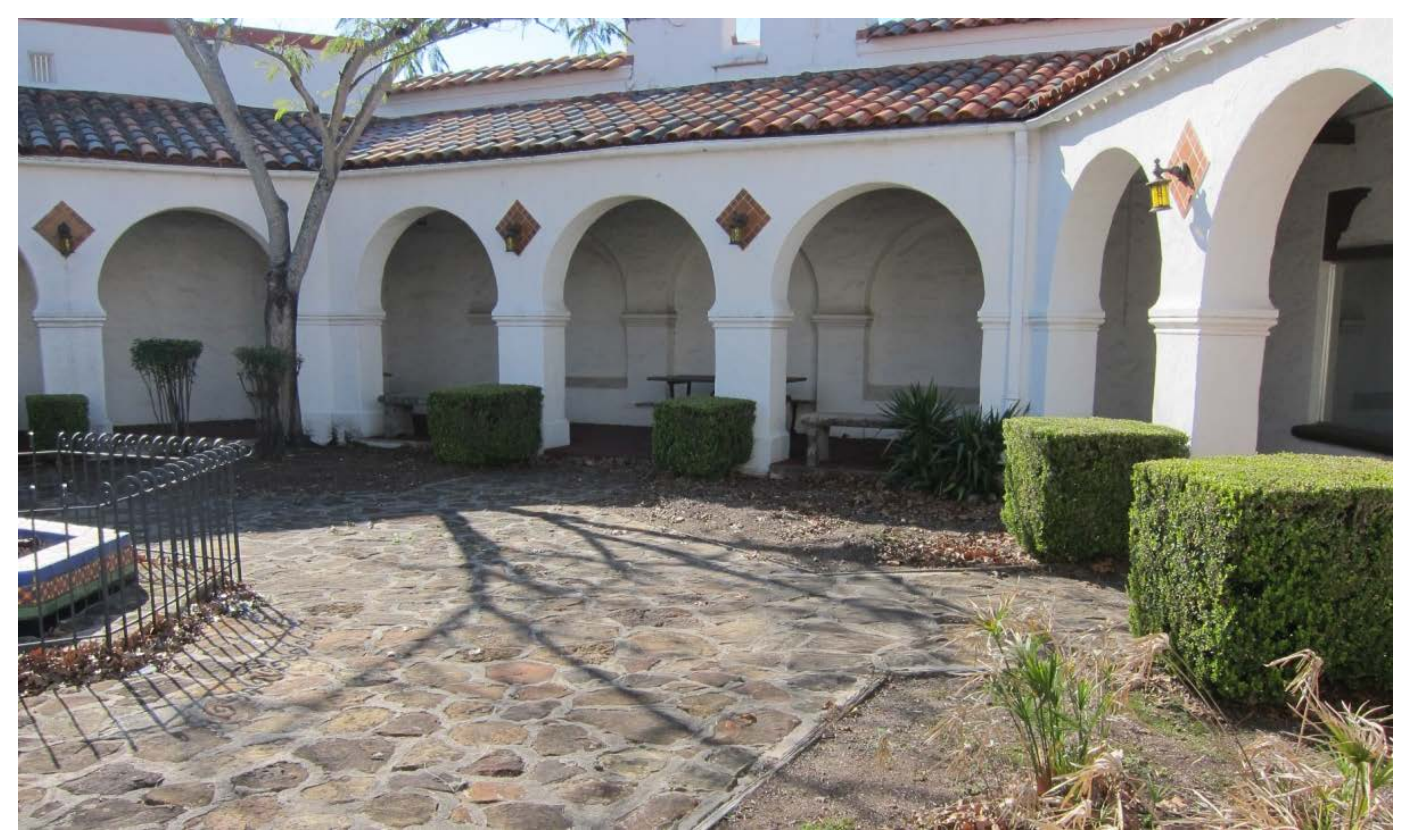

Figure 44. Courtyard of the former Post Exchange, 2012 (ERDC-CERL). 
Associated with the PX were other service and operations buildings. These buildings were primarily grouped west of the PX and included the gas station (Building 201), the bakery (Building 216), and the fire station (Building 205). These buildings were also built according to plans by the Quartermaster Corps and architecturally finished with elements of Spanish Colonial Revival (Figure 45and Figure 46). Also located in this area were a series of warehouses and shops, including the Engineering shops (Figure 47). Although these buildings were functional in nature, they featured details that were more elaborate than other military utilitarian areas. The area continues to convey a sense of the original spatial relationships among the buildings (Figure 48).

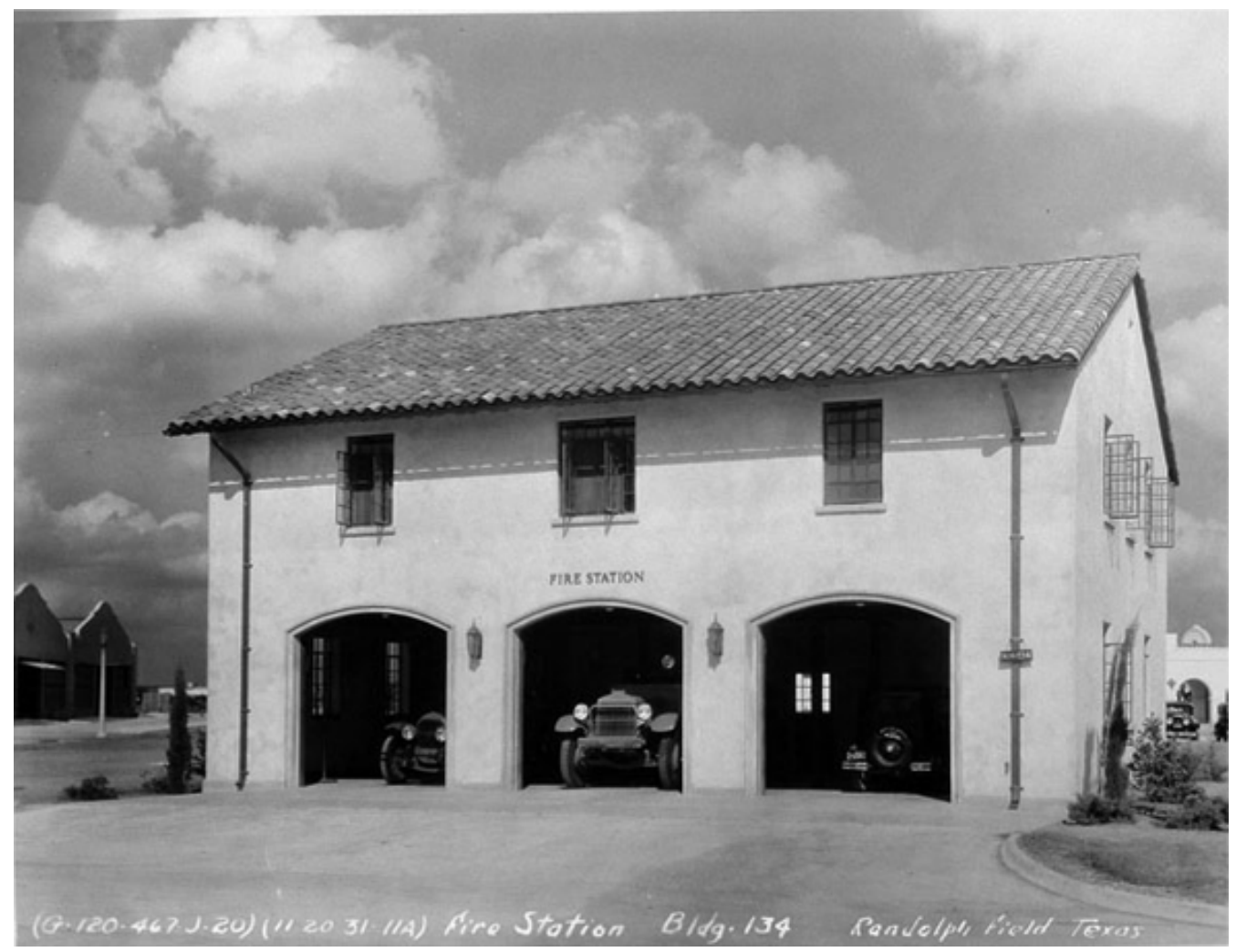

Figure 45. Fire station building in the 1930s (NARA RG342 Box 1072 B2077). 


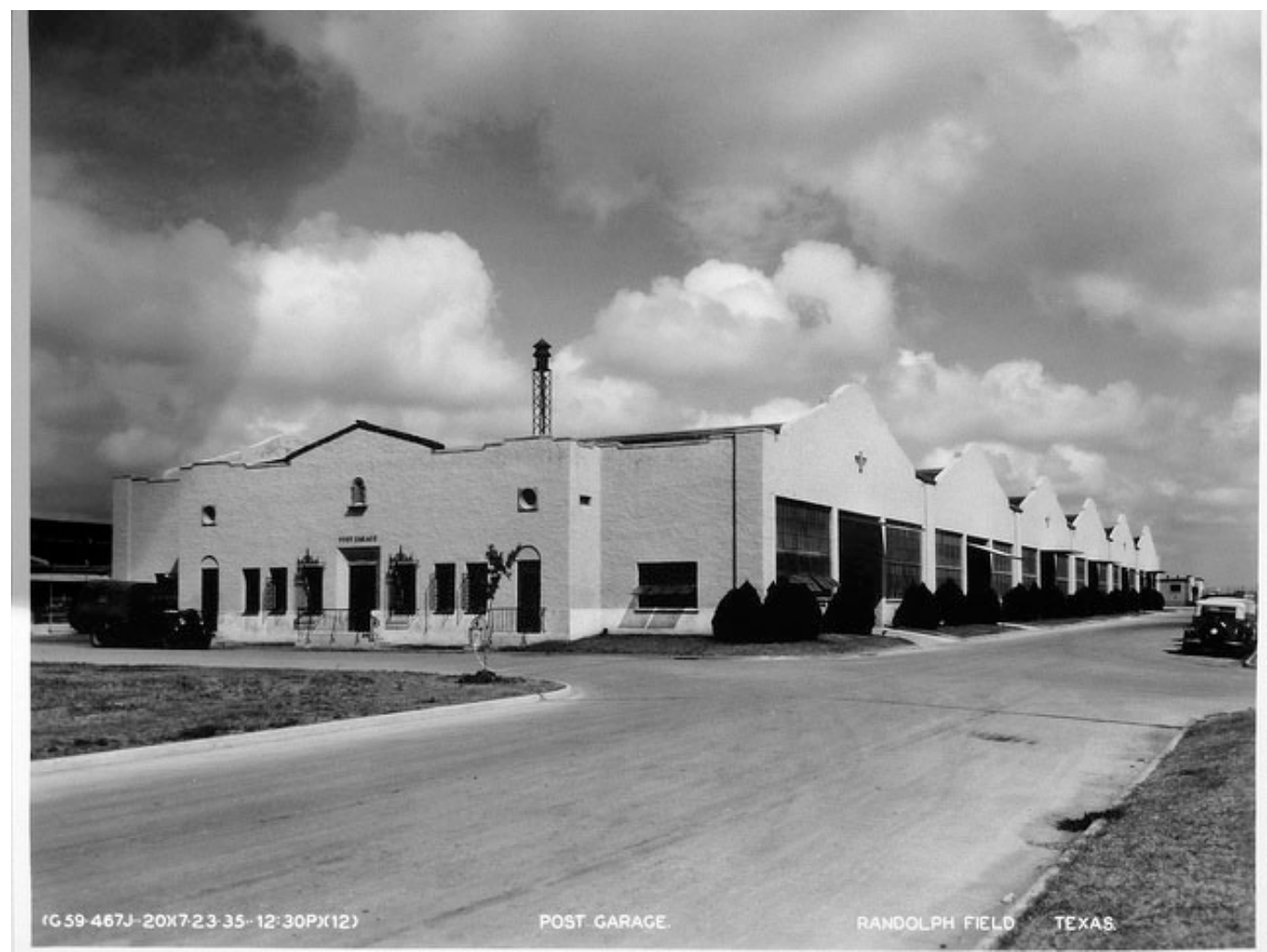

Figure 46. Post garage in the warehouse and shop area in the 1930s (NARA RG342 Box 1072 B20773).

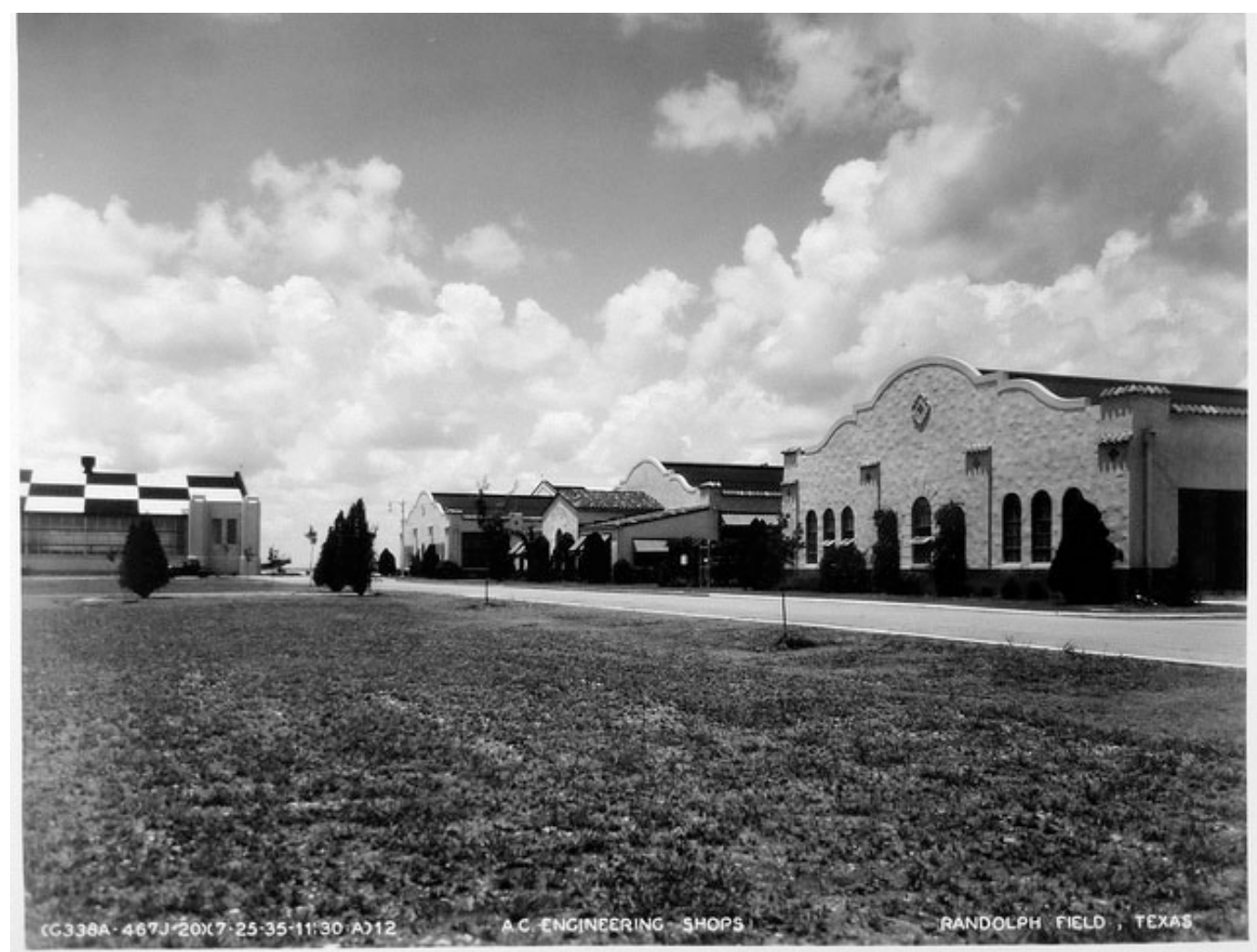

Figure 47. Engineering shops in the 1930s (NARA RG342 Box 1072 B20800). 


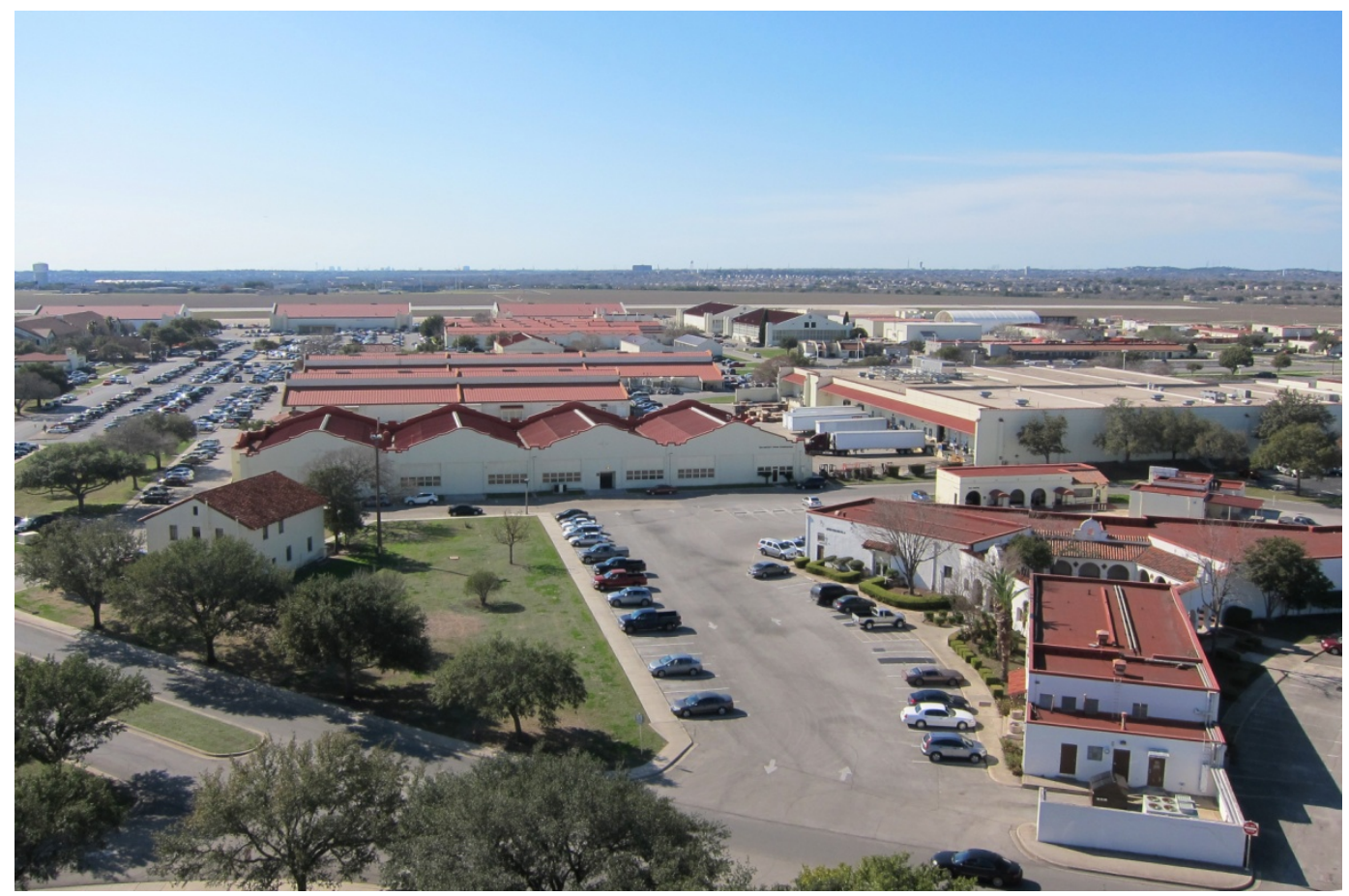

Figure 48. The warehouse and shop area conveys the same visual aesthetics as the rest of the base, 2012 (ERDC-CERL).

\subsubsection{Flight line}

The east and west flight lines were each served by a row of hangars; each flight line was designed to have its own control tower. The organization of the flight lines was symmetrical, except the west flight line had ten hangars while the east flight line had eight. On both flight lines, the hangars were evenly spaced in rows along the edge of the cantonment. Both rows of hangars had a stage house located at the mid-points where the east-west axis through the Main Circle terminated at the flight lines. The stage houses (Building 8 and Building 66) originally served as classroom and meeting space for pilot training. The additional hangars on the west flight line were located around a corner north of the Engineering shop.

The hangars were constructed during the summer of 1931 using Art Moderne styling. Art Moderne was an architectural style of the 1930s that lacked excessive ornamentation and used streamlined designs, strong horizontal elements, rounded corners, and asymmetrical massing to create buildings that seemed to invoke the future (Figure 49). Although these hangars were clad in stucco, the overall effect contrasted with the Mission and Spanish Colonial Revival architectural styles used throughout the rest of the base. However, the characteristics of Art Moderne were appropriate for the design of such massive, linear structures as the large hangars. 
Two different standardized plans were chosen by the Quartermaster Corps to construct the eighteen hangars-the Type X hangar and the Type $\mathrm{Y}$ hangar. The Type X hangar was designed with a one-story area for offices and storage that extended the full width of one of the façades. The Type $Y$ hangar was similar, but only had a 60 -foot wide office area. At the time they were constructed, both hangar types accommodated 30 planes.

The two hangar lines still bound the east and west sides of Randolph AFB (Figure 50).

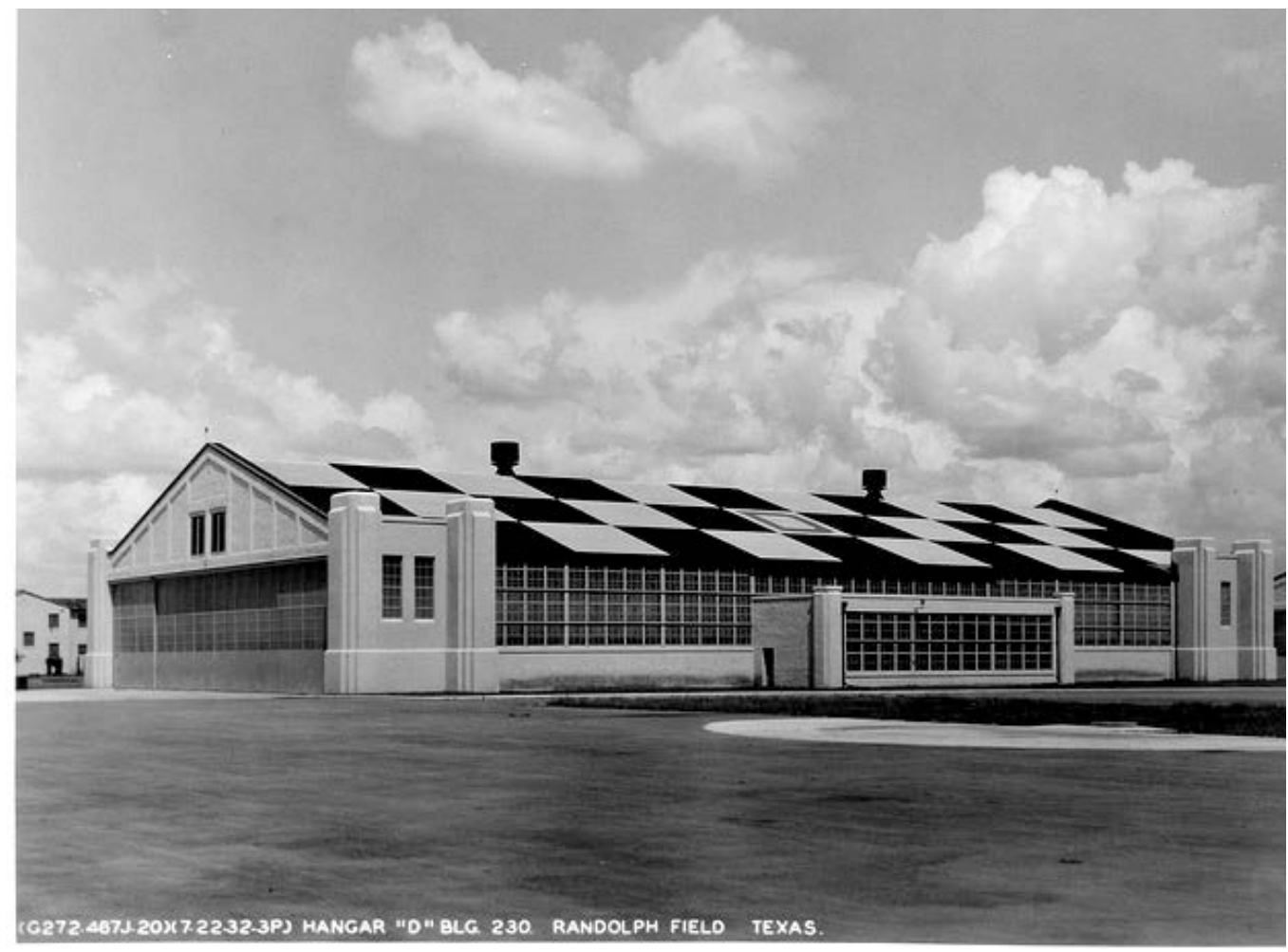

Figure 49. Hangar “D” in the 1930s (NARA RG 342 Box 1072 B20803). 


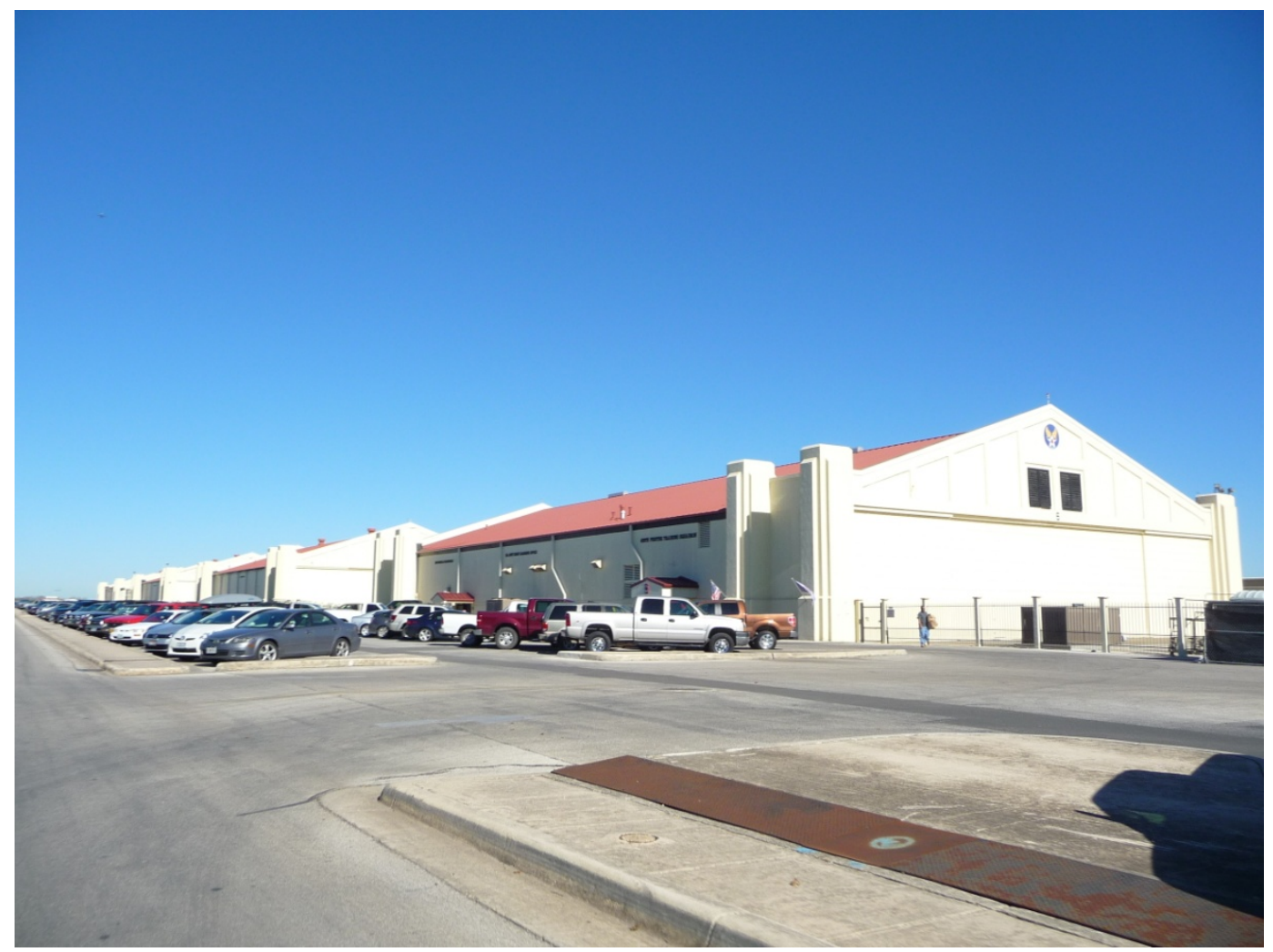

Figure 50. Row of hangars, 2012 (ERDC-CERL).

Midway along the lines of hangars were buildings that provided classroom spaces and operations offices for the flight lines. These buildings were called stage houses and were designed in the Spanish Colonial Revival architectural style of the rest of the base (Figure 51). The stage houses continue to be an important spatial element of the flight lines (Figure 52). 


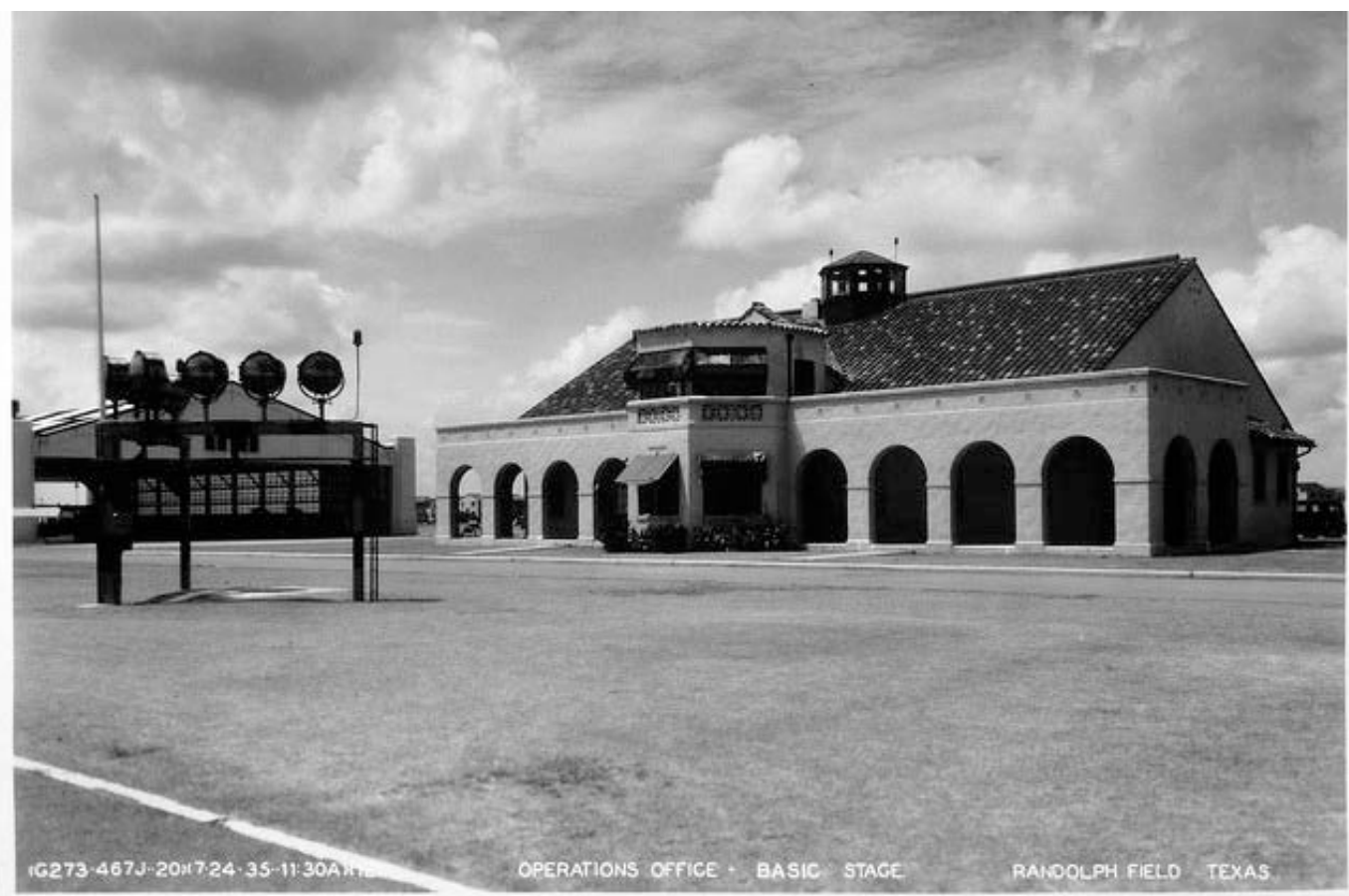

Figure 51. Stage house and operations office on one of the flight lines, 1935 (NARA RG342 Box 1072 B20809).

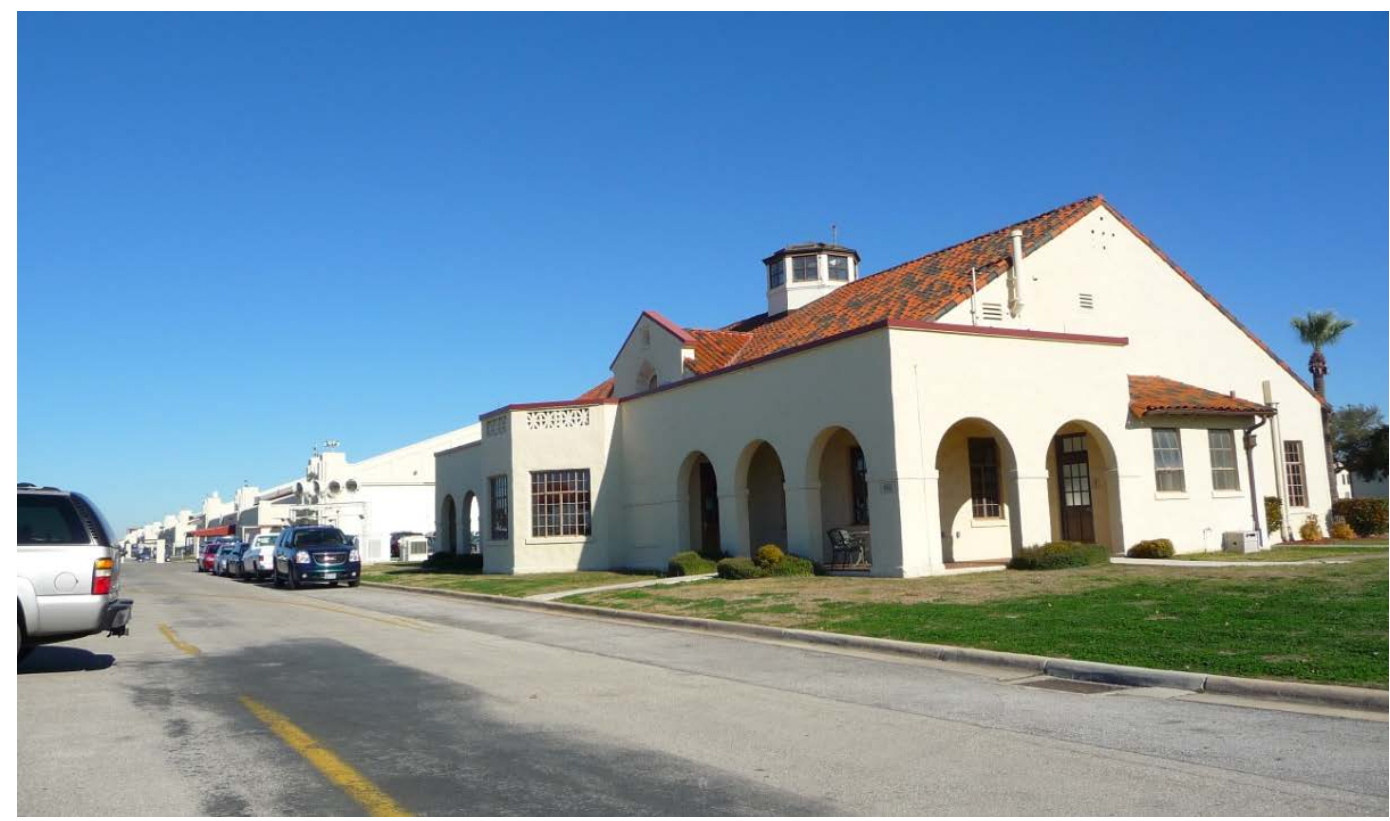

Figure 52. Former stage house with hangars in the background, 2012 (ERDC-CERL).

\subsubsection{Army Air Corps barracks}

The Air Corps barracks were constructed along the east and west flight lines in 1930 and 1931. Four barracks were planned and located along the west flight line, but only two were planned on the eastern edge of the base. 
The main barracks complexes were aligned on the east-west axis through the Main Circle, with the two additional barracks on the west flight line constructed to the north.

The six buildings were built from identical sets of plans provided by the Quartermaster Corps. Each building's design accommodated enlisted flight and ground crews, a mess hall, a kitchen, and recreational facilities. The two-story rectangular barracks featured a long row of arched bays on each floor to provide shade (Figure 53). The barracks had cross-gabled, red clay tile roofs and wrought iron balustrades between the arched bays.

The barracks have been altered since their original construction and now serve as administrative spaces (Figure 54).

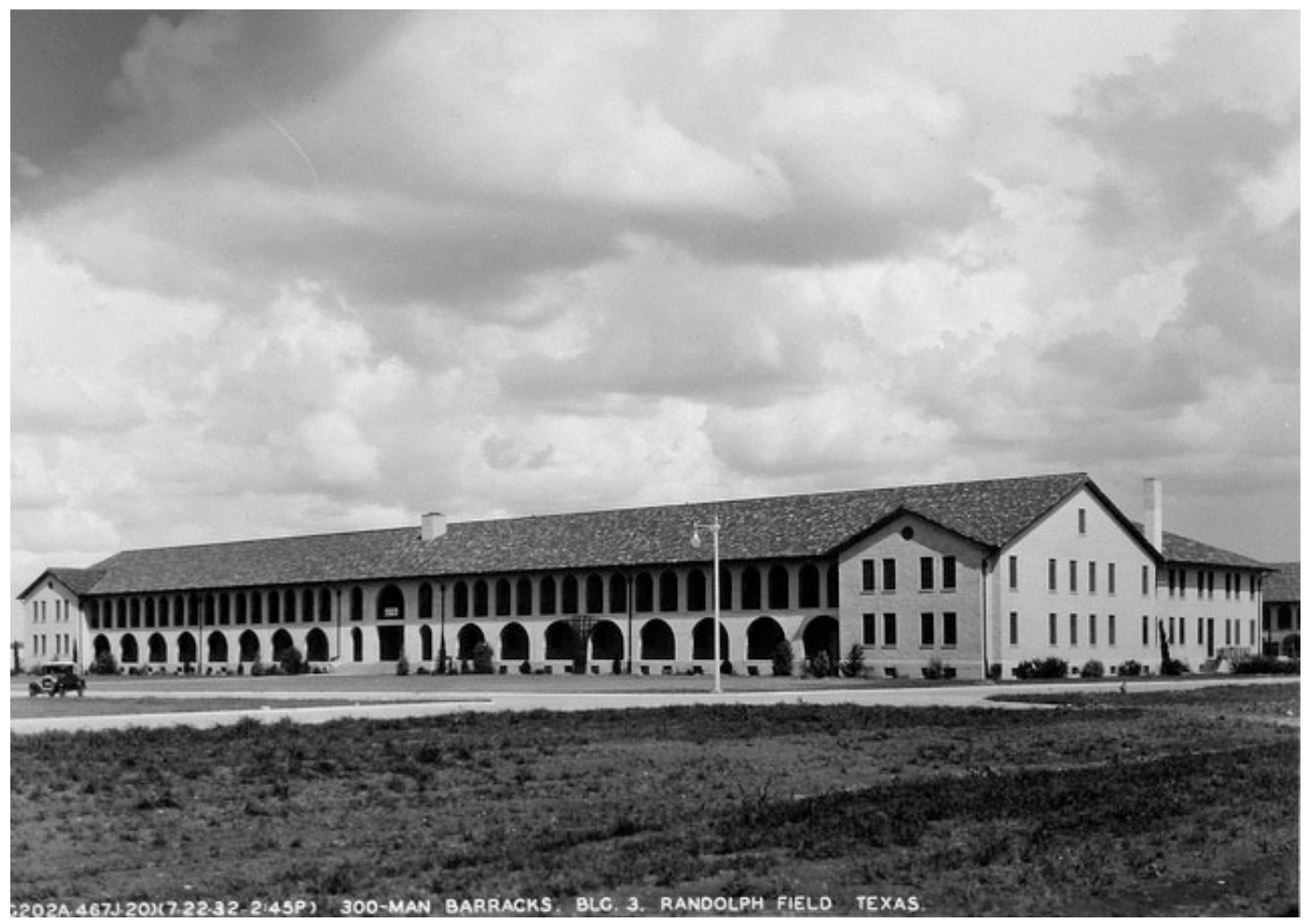

Figure 53. Enlisted men's barracks complex in the 1930s (NARA RG342 Box 1072 B20807). 


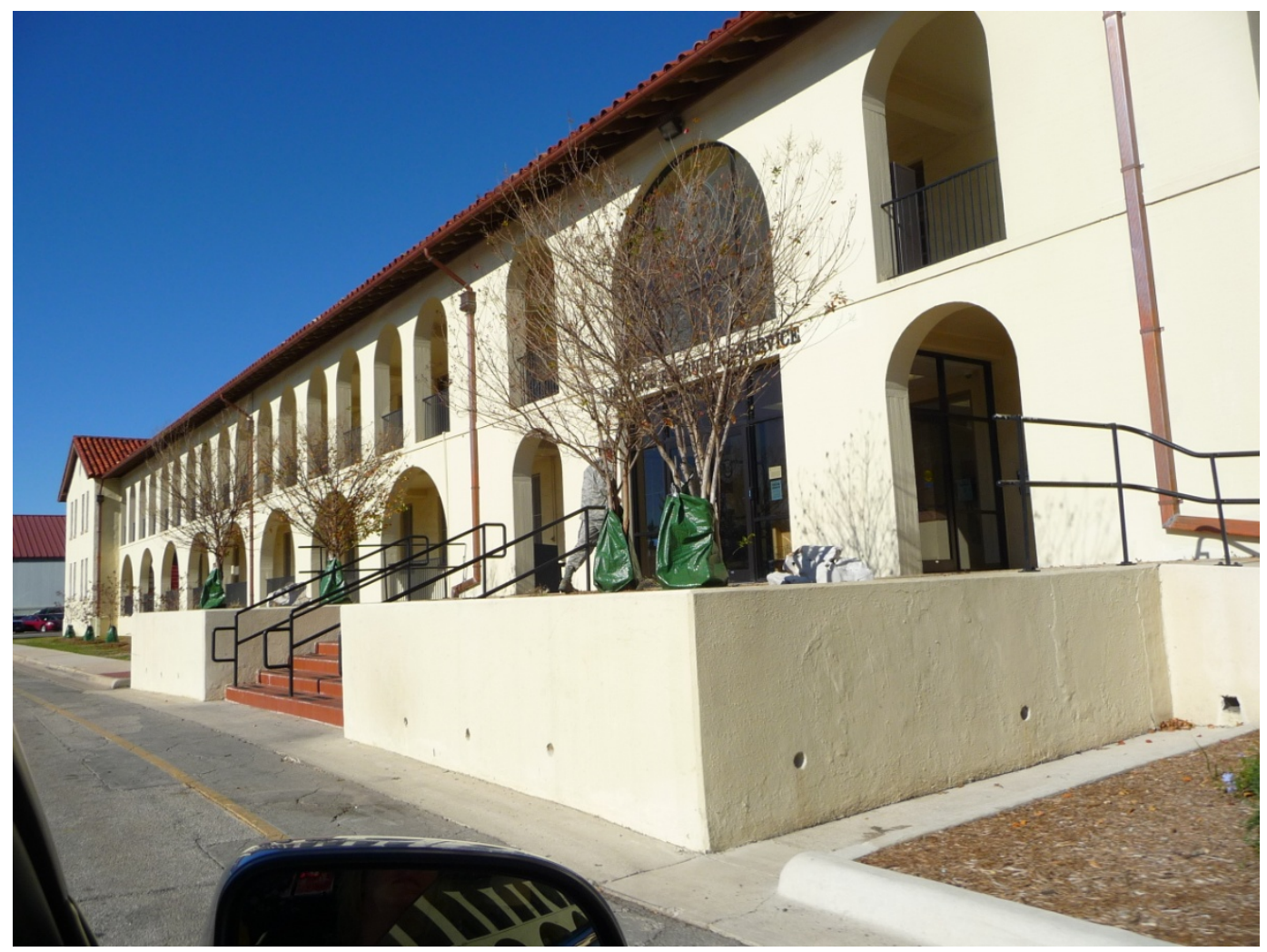

Figure 54. Former enlisted men's barracks altered to serve as administrative spaces, 2012 (ERDC-CERL).

\subsubsection{Cadet Complex}

The Cadet Complex was a group of cadet-related buildings located at the southern end of the Main Circle. The area was the center of cadet life and included barracks, classrooms, and administrative offices for the Army Air Corps in the 1930s and 1940s. The buildings were arranged around a circular courtyard and were completed in 1931 (Figure 55). Located south of the complex was a swimming pool, and tennis, basketball, and handball courts. Southeast of the Cadet Complex was the Grater Athletic Field. ${ }^{43}$ In 1939, two additional barracks (Buildings 903 and 907) were constructed at right angles to the original barracks (Figure 56).

The 1939 configuration of the Cadet Complex buildings continues to be evident, although the buildings have been adaptively redeveloped into office spaces (Figure 57).

\footnotetext{
43 Grater Athletic Field was named in honor of Lieutenant Grater who was the first officer to die in an accident at Randolph Field.
} 


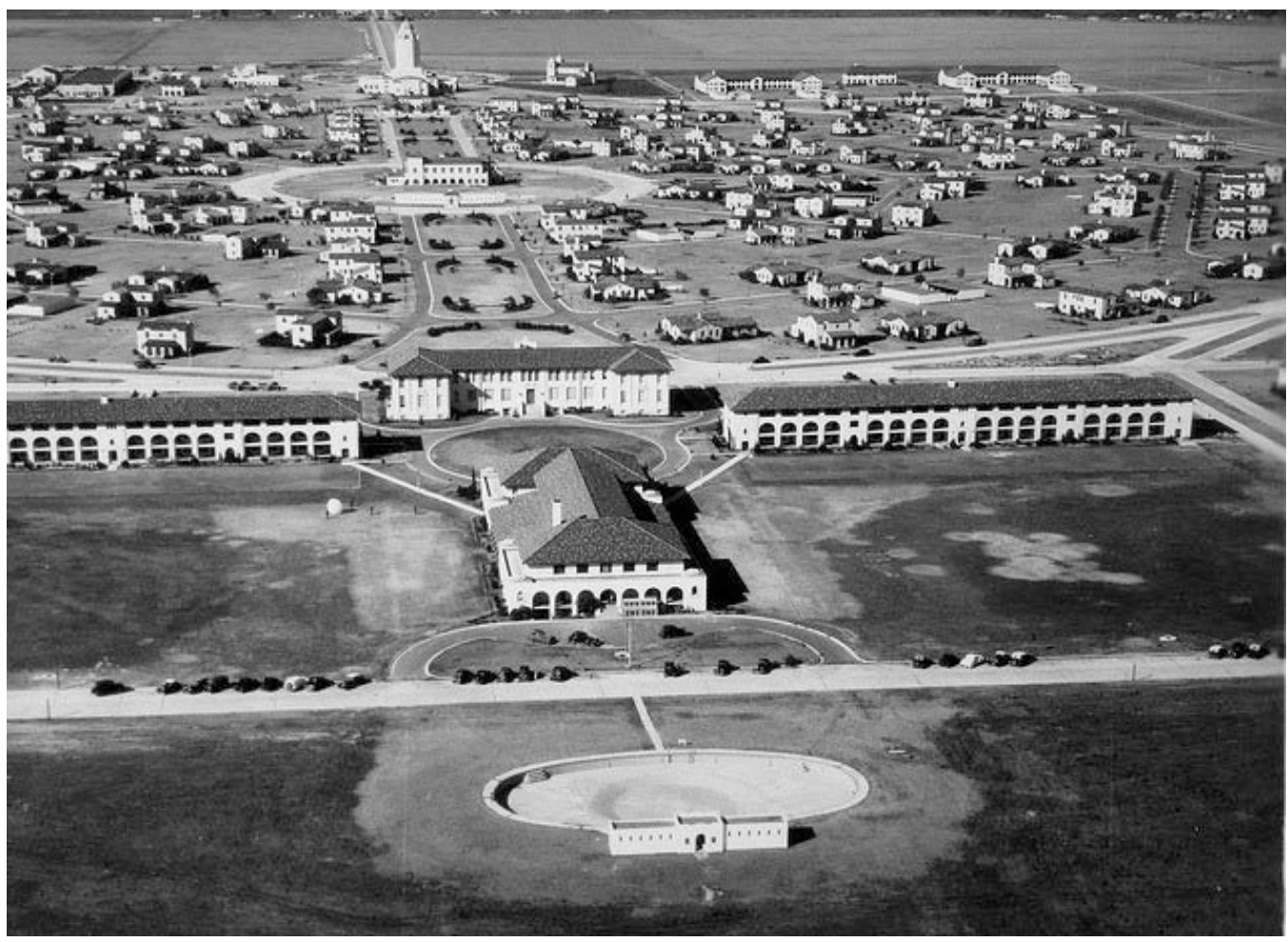

Figure 55. Cadet Complex during construction in the 1930s, before the additional barracks were added (NARA RG342 Box 1071 B20695).

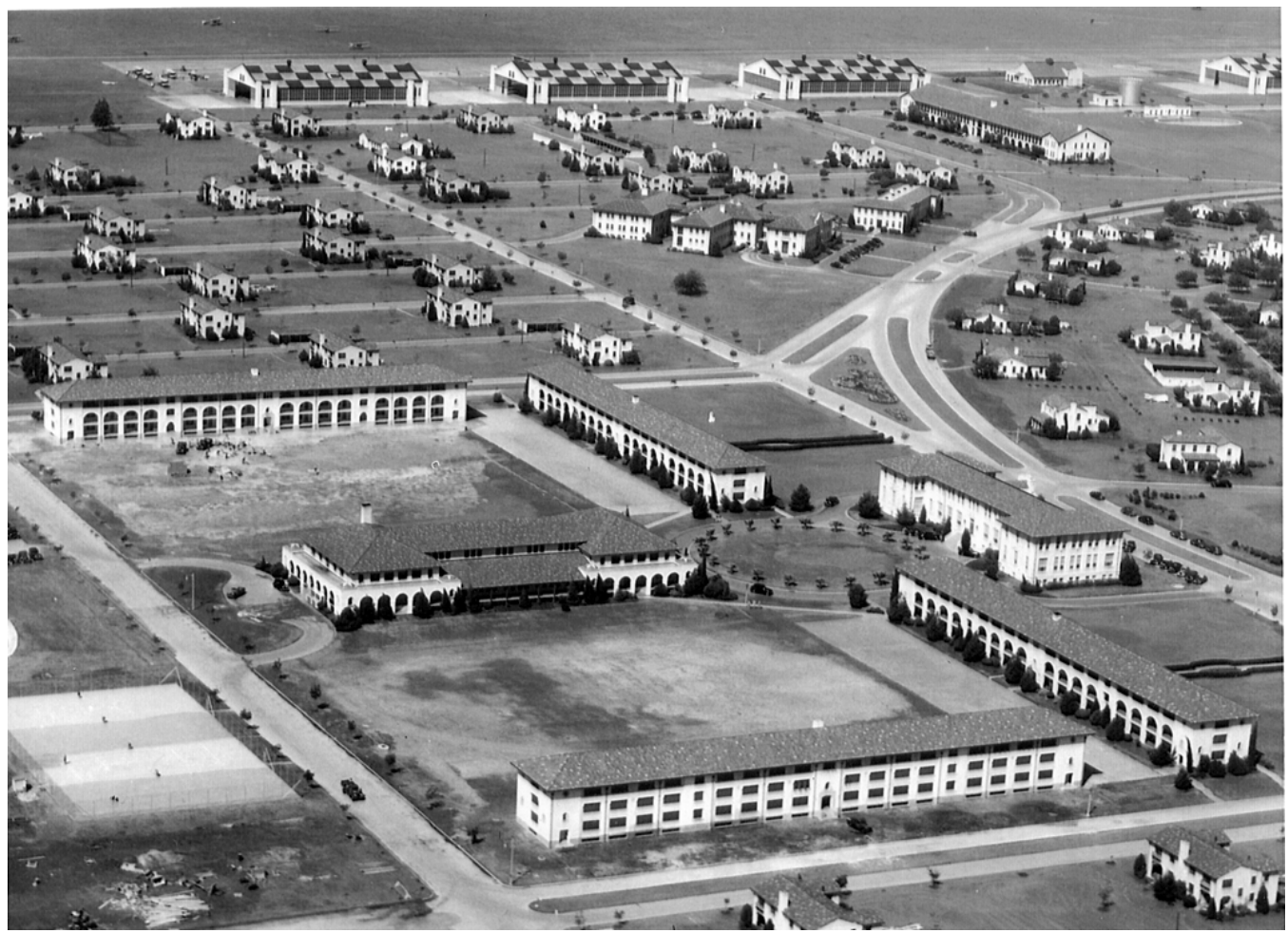

Figure 56. Aerial view of the Cadet Complex looking toward the west flight line. By 1939, when the photograph was taken, two additional barracks had been added at right angles to the original barracks buildings, 1939 (NARA Box 1042 B12329). 


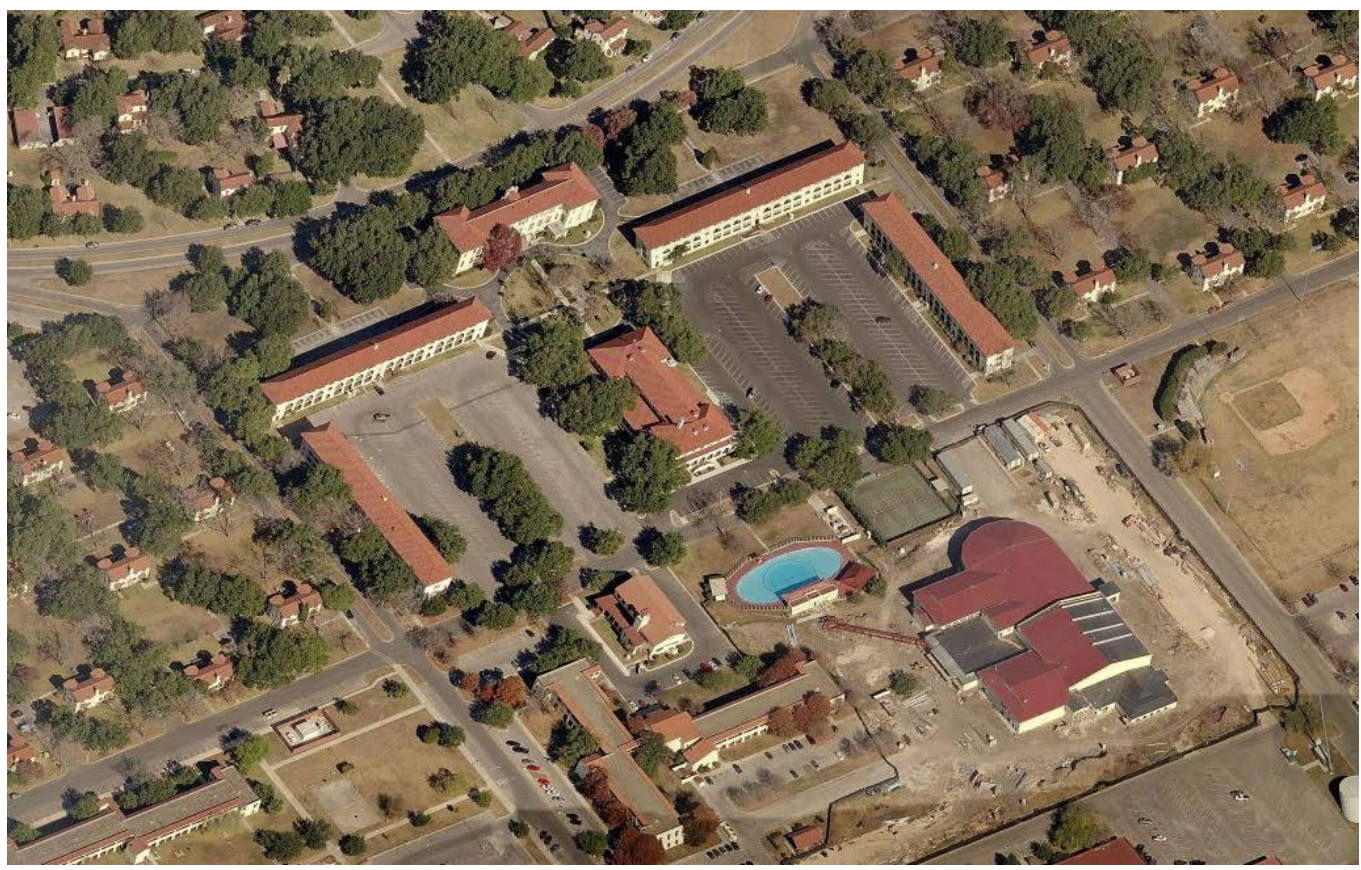

Figure 57. Aerial view of the former Cadet Complex, 2012 (bing.com/maps).

The buildings were constructed in the Spanish Colonial Revival architectural style that was predominant throughout most of the base. The Cadet Academic Building (Building 900) was located directly on the Main Circle and served as the entrance to this building group. The academic building was completed in 1931 and housed classrooms, a library, instructors' offices, and a radio room (Figure 58).

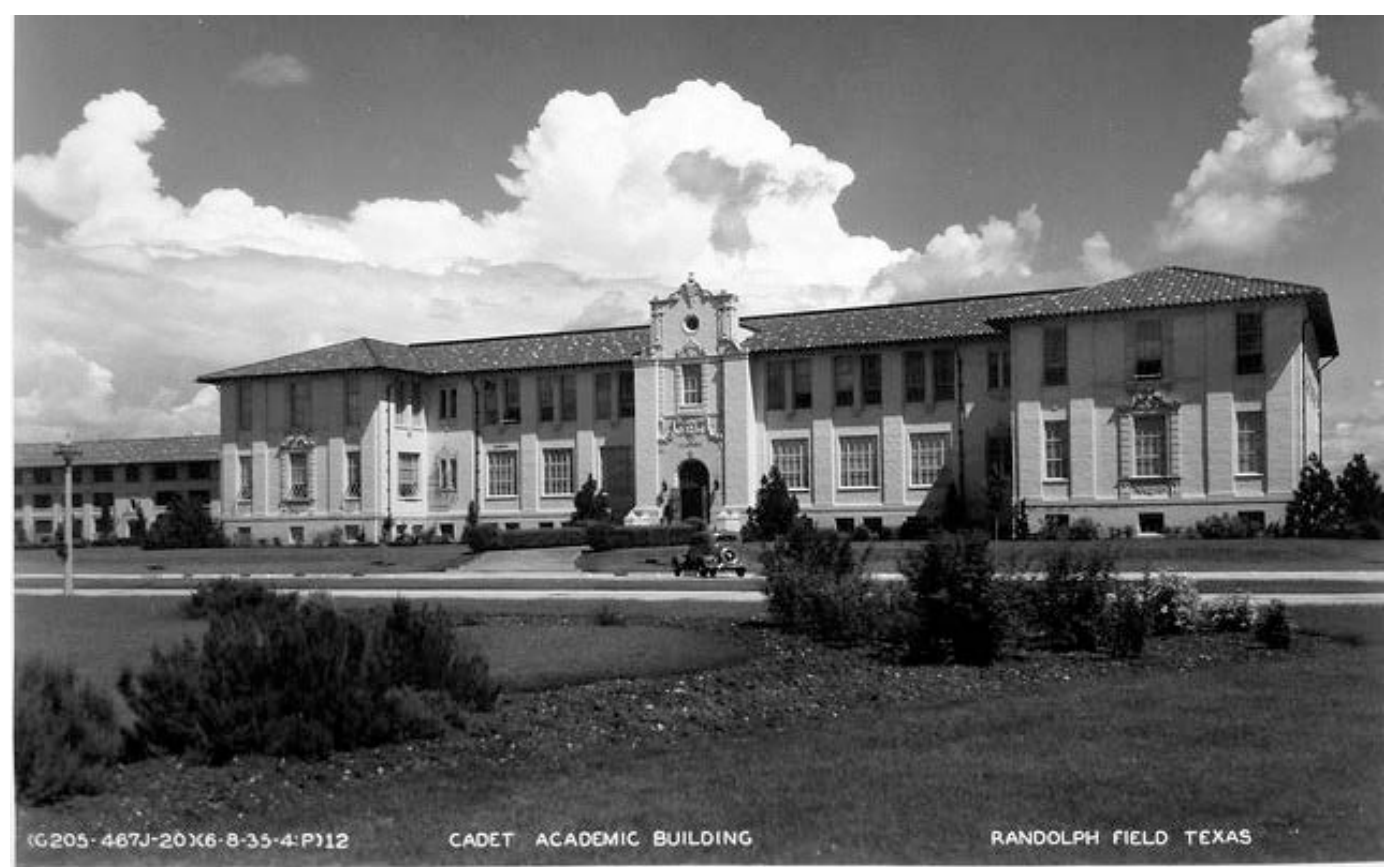

Figure 58. Cadet Academic Building in the 1930s (NARA RG342 Box 1072 B20837). 
The Cadet Administration Building (Building 905) was located across the courtyard from the Cadet Academic Building. It housed supply rooms, administrative offices, a mess hall, and kitchens. The basement also contained recreational services including a branch of the PX, a barber shop, a gymnasium, and a bowling alley. The rectangular building was blocky and surrounded by an arched veranda with wrought iron balustrades (Figure 59). The corners of the veranda were capped with ceramic tile domes bearing a yellow star in a blue background. South of the Cadet Administration Building was a large oval swimming pool (Figure 60). Figure 61 shows the former Cadet Administration Building in 2012.

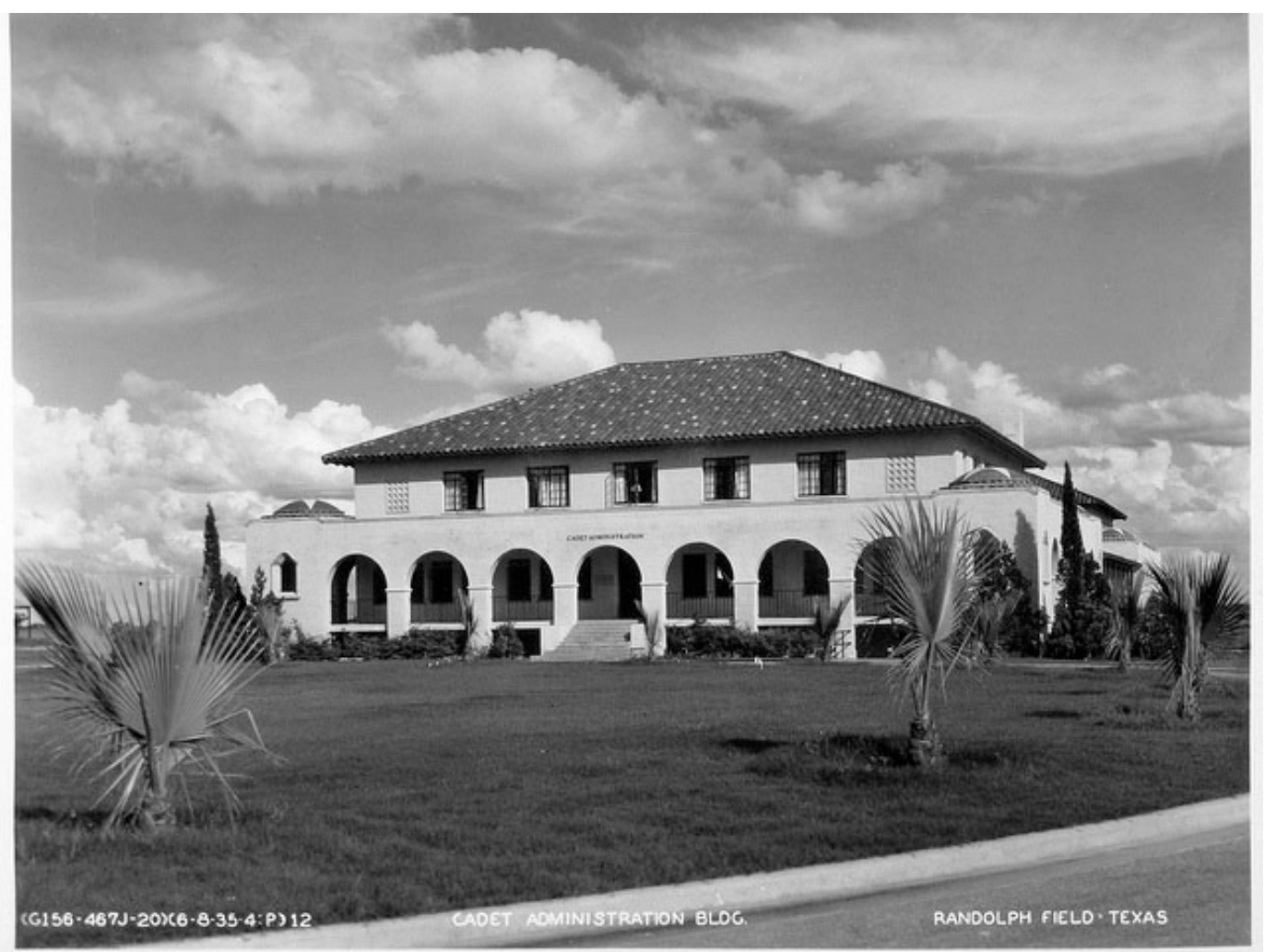

Figure 59. Cadet Administration Building, undated (NARA RG342 Box 1072 B20835). 


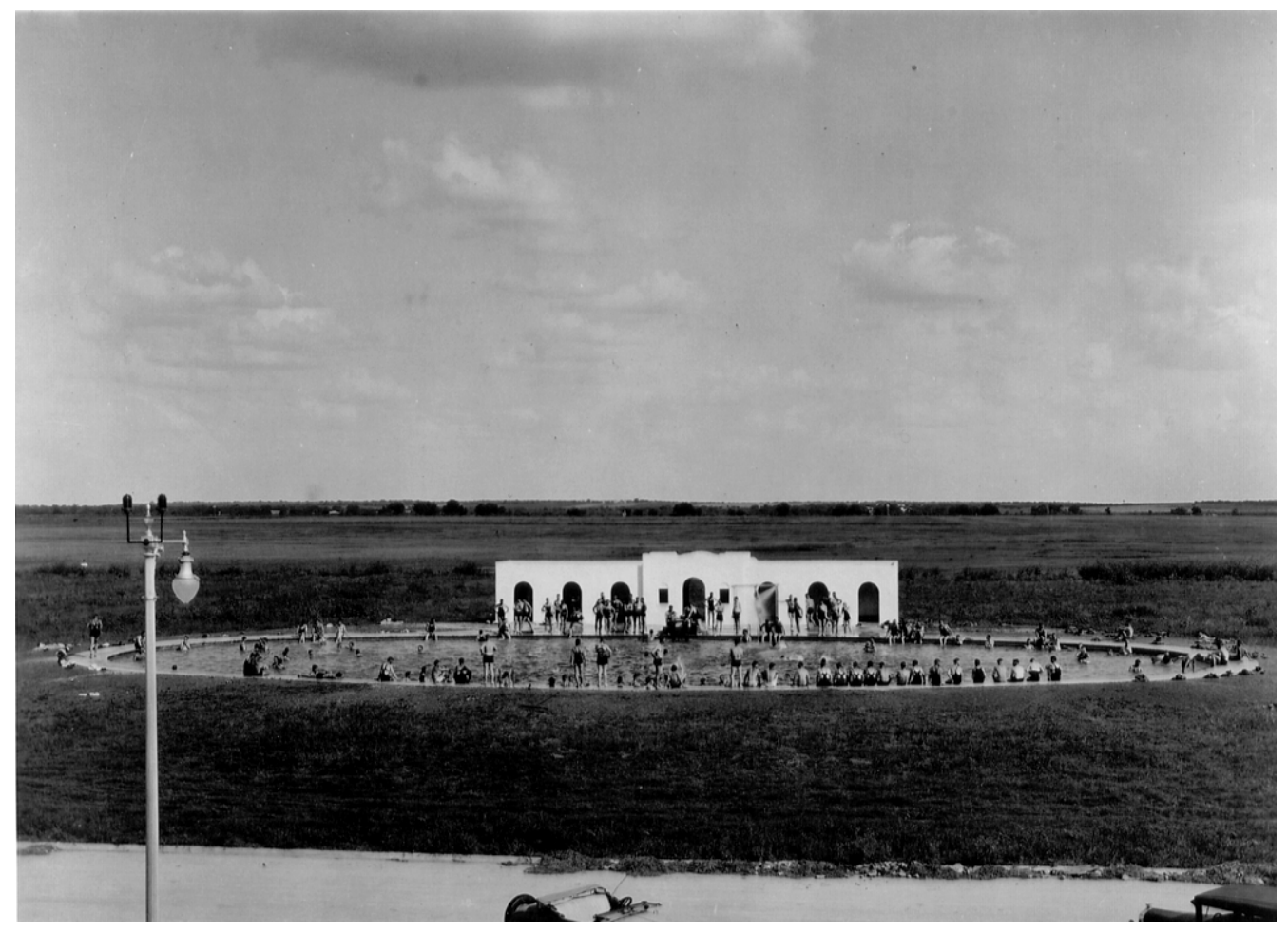

Figure 60. Swimming pool south of the Cadet Administration Building, 1932 (NARA B12354).

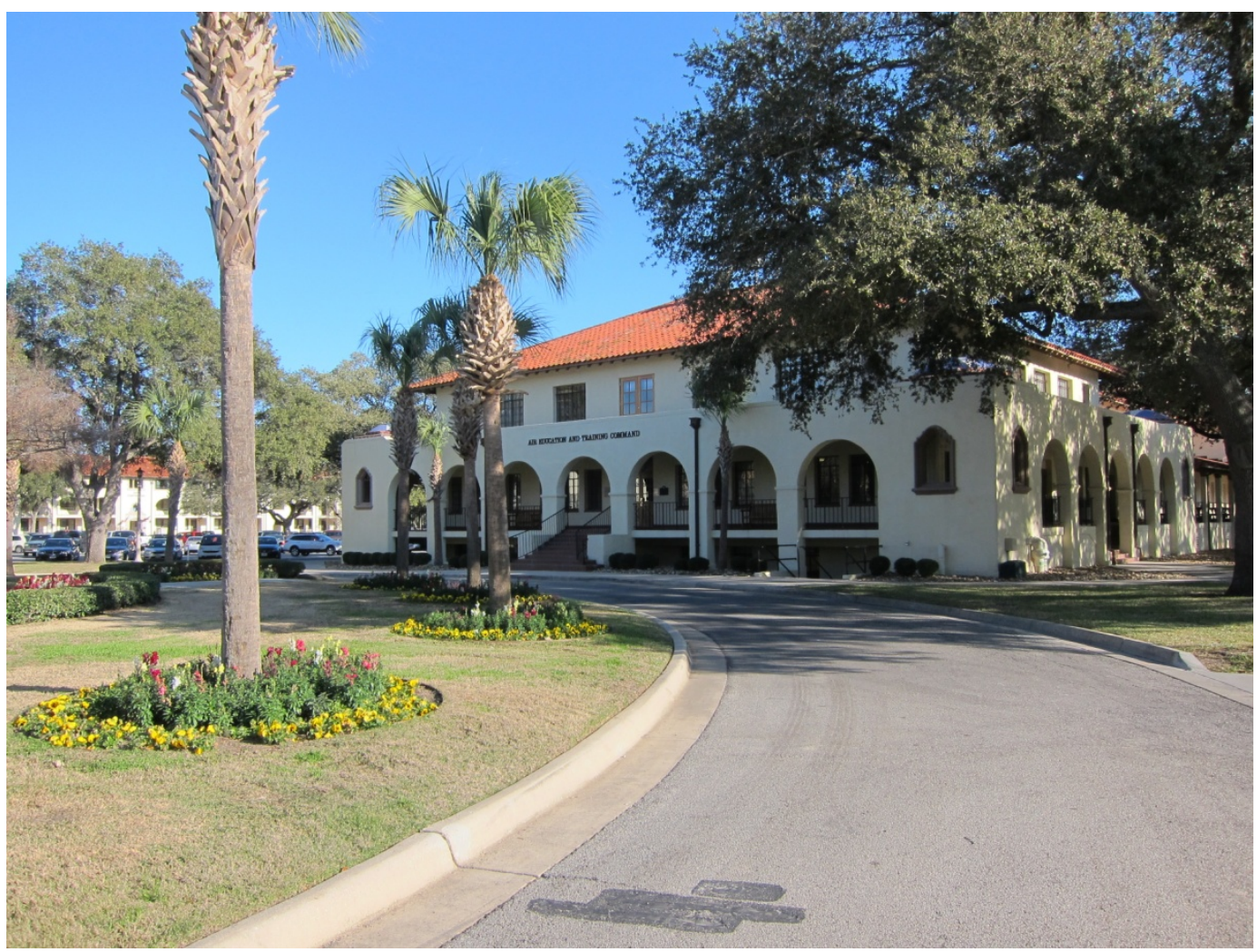

Figure 61. The former Cadet Administration Building, 2012 (ERDC-CERL). 
The Cadet Barracks in the Cadet Complex were designed by Emmitt T. J ackson and consequently were not entirely typical of Army barrack designs. The buildings were three-story rectangles, constructed without the projecting wings that were common to standardized Army barracks (Figure 62). All four buildings, though, have stucco exteriors, hipped clay tile roofs, exposed rafter ends, and long, arched (second-story) and square (first- and third-story) verandas. Each of the barracks could accommodate approximately 106 men, with two cadets per room; however, during WWII, four cadets were housed in each room. In addition to cadet rooms, each of the barracks had a day room, a mess hall, a kitchen, storerooms, and administrative offices. Behind each barrack was a wide concrete area extending the full length of the building where cadets would walk off demerits on the "ramp."

Figure 63 shows the 2012 conditions of one of the Cadet Complex barracks, now converted to offices.

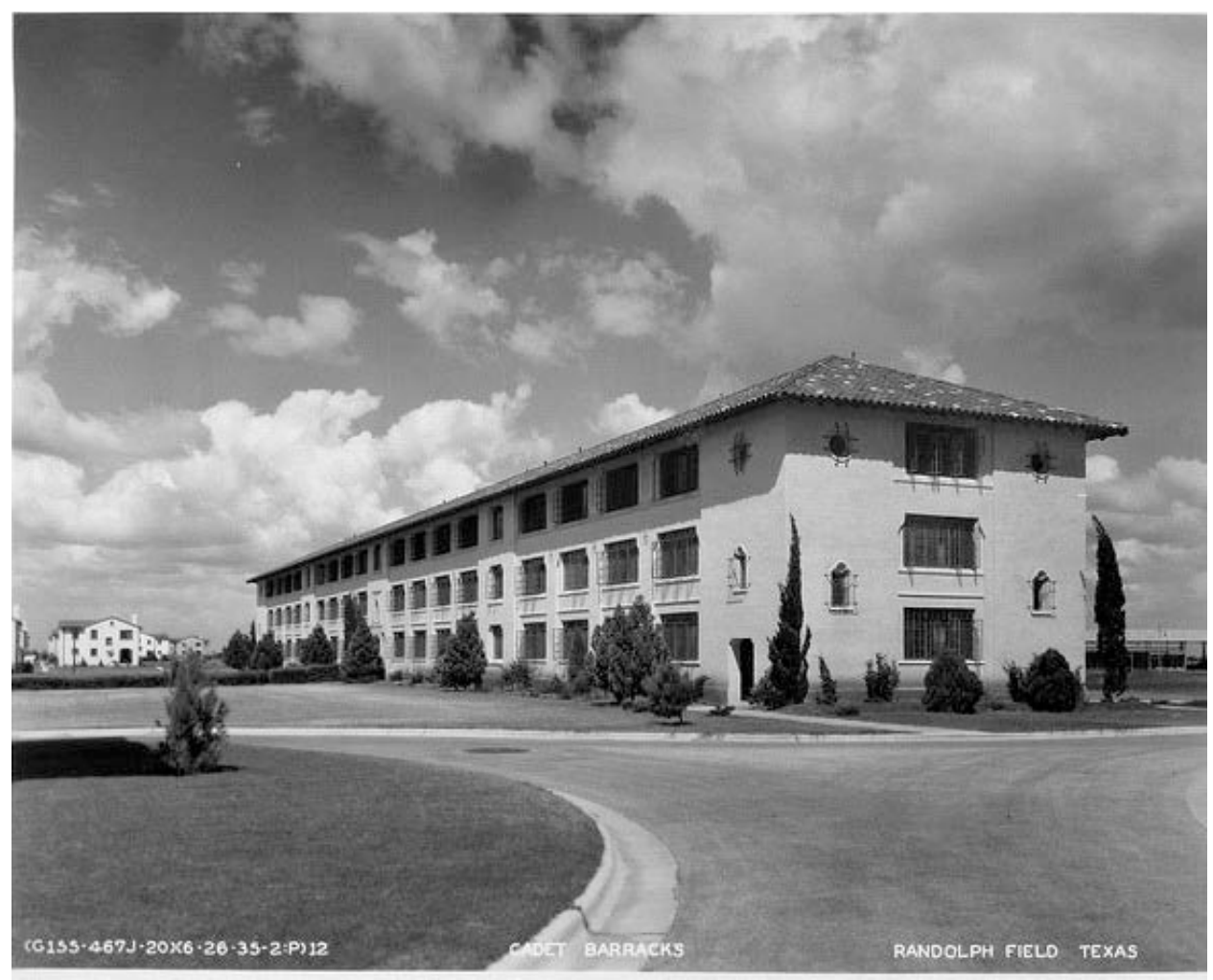

Figure 62. Cadet Barracks in the 1930s (NARA RG342 Box 1072 B20848). 


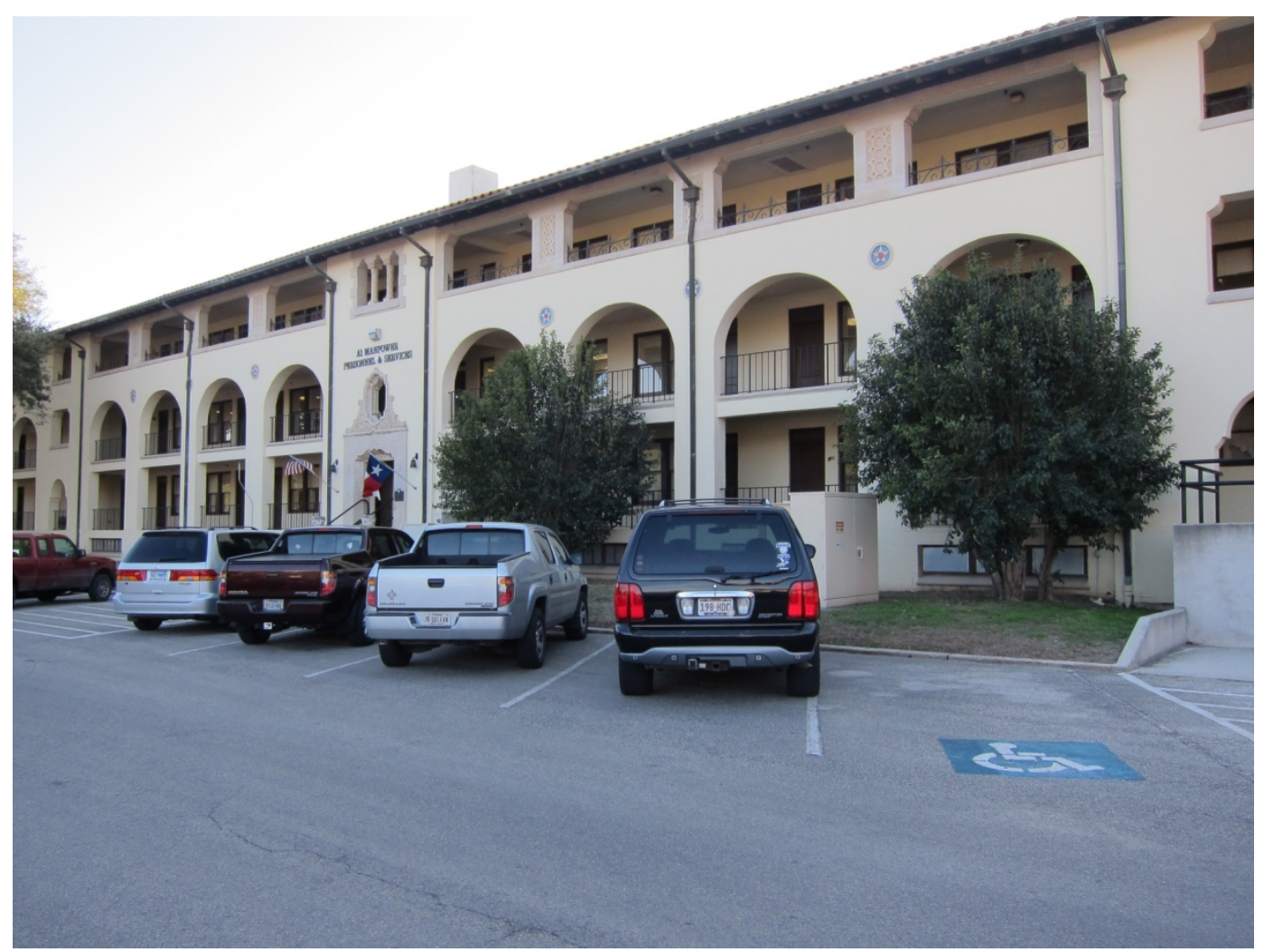

Figure 63. Cadet Complex Barracks, now converted to offices, 2012 (ERDC-CERL).

The buildings in the Cadet Complex were unified through their grouping and architectural styling. The Cadet Academic Building and the barracks each had elaborate entrances surrounded by cast stone and a cartouche that was crowned with heavily ornamented parapet that extended above the roof line. The ornamentation of the Cadet Academic Building reflected Spanish Colonial Revival architectural influences more strongly than many of the other buildings on the base. The buildings were grouped around a circular courtyard, which continues to be the focal point of the complex (Figure 64). 


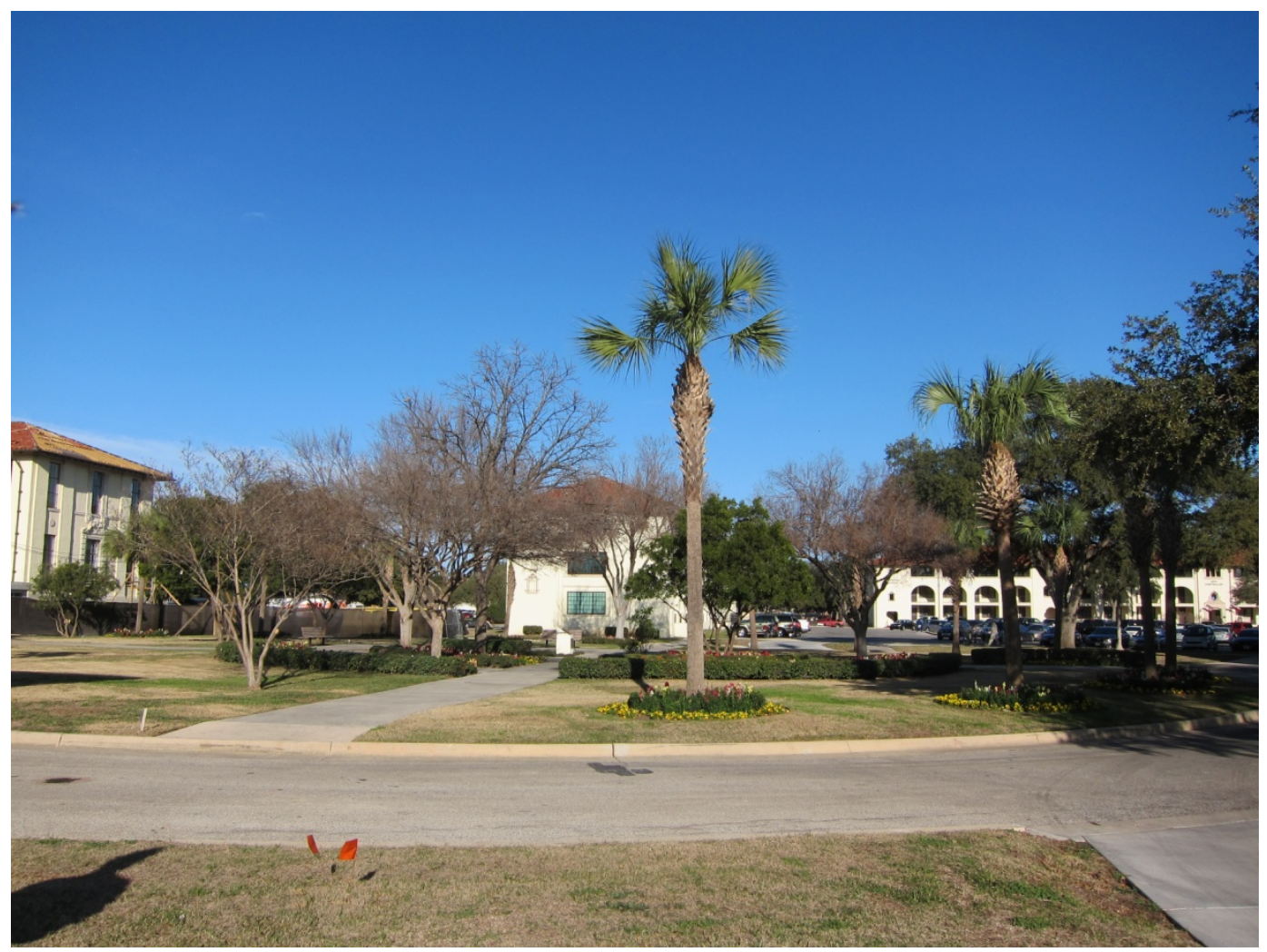

Figure 64. Circular courtyard of the Cadet Complex, 2012 (ERDC-CERL).

\subsubsection{Medical facilities}

In the original plan, Randolph Field's medical facilities were grouped together in the southern corner of the base. The complex was comprised of two buildings: the Randolph Field Hospital and the School of Aviation Medicine.

The Randolph Field Hospital (Building 675) was situated on the southwest radial street through the Main Circle. The building was designed by George Willis, and construction was completed in 1931. The hospital provided the base with all medical and surgical needs and offered a capacity of 200 beds. The design for the building was two-story, asymmetrical building composed of three interconnecting sections. A drive-through entrance was located between the first and second wings. The front entrance was ornamented with elaborately carved columns topped by an intricate entablature typical of Spanish Colonial architecture (Figure 65). 


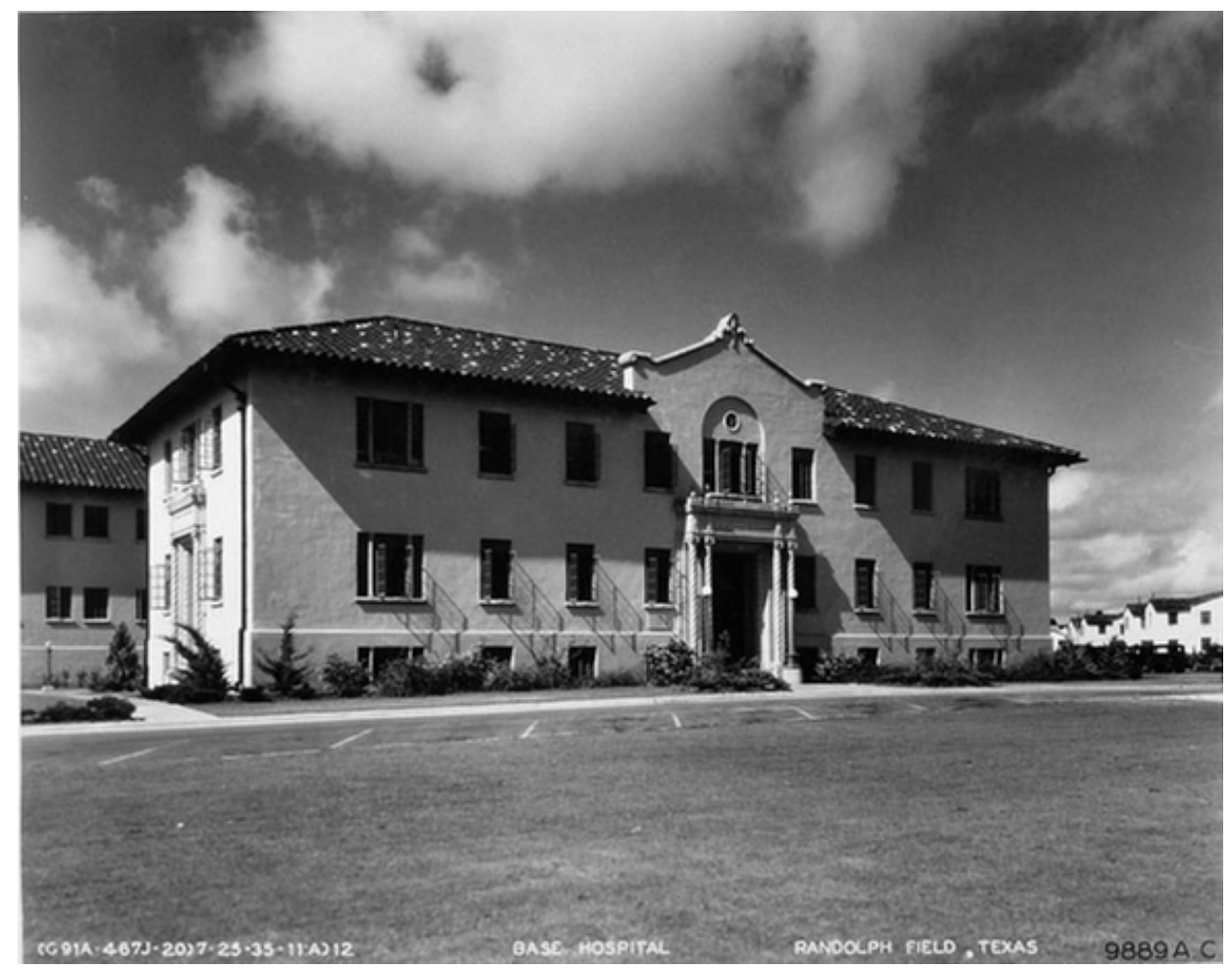

Figure 65. Post hospital in the 1930s (NARA RG 342 Box 1072 B20832).

The former post hospital has been adaptively repurposed for office space. The current (2012) conditions of the hospital are shown in Figure 66.

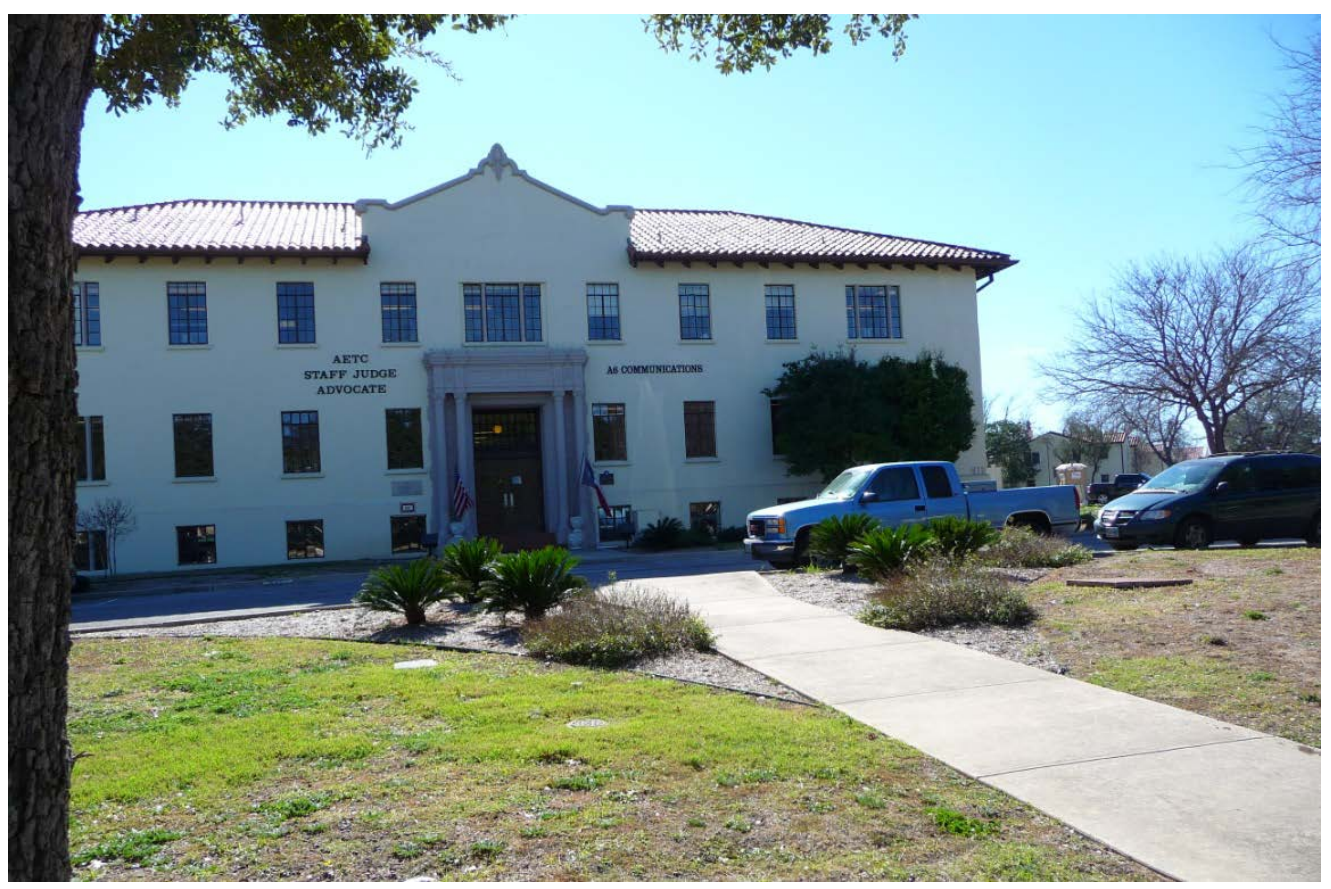

Figure 66. The former Post Hospital, 2012 (ERDC-CERL). 
The School of Aviation Medicine (Building 671) was located to the northwest of the Randolph Field Hospital. The building was also completed in 1931 and was designed by the San Antonio architectural firm of Adams and Adams. The building was designed as a two-story, tile-roofed building that was restrained in the use of ornamentation. The only ornamentation on the building was at the primary and secondary entrances which were decorated with cast stone surrounds. Some of the second-story windows on the wings featured nonfunctional metal balconets. Figure 67 and Figure 68 compare the conditions of Building 671 in the late 1940s and in 2012.

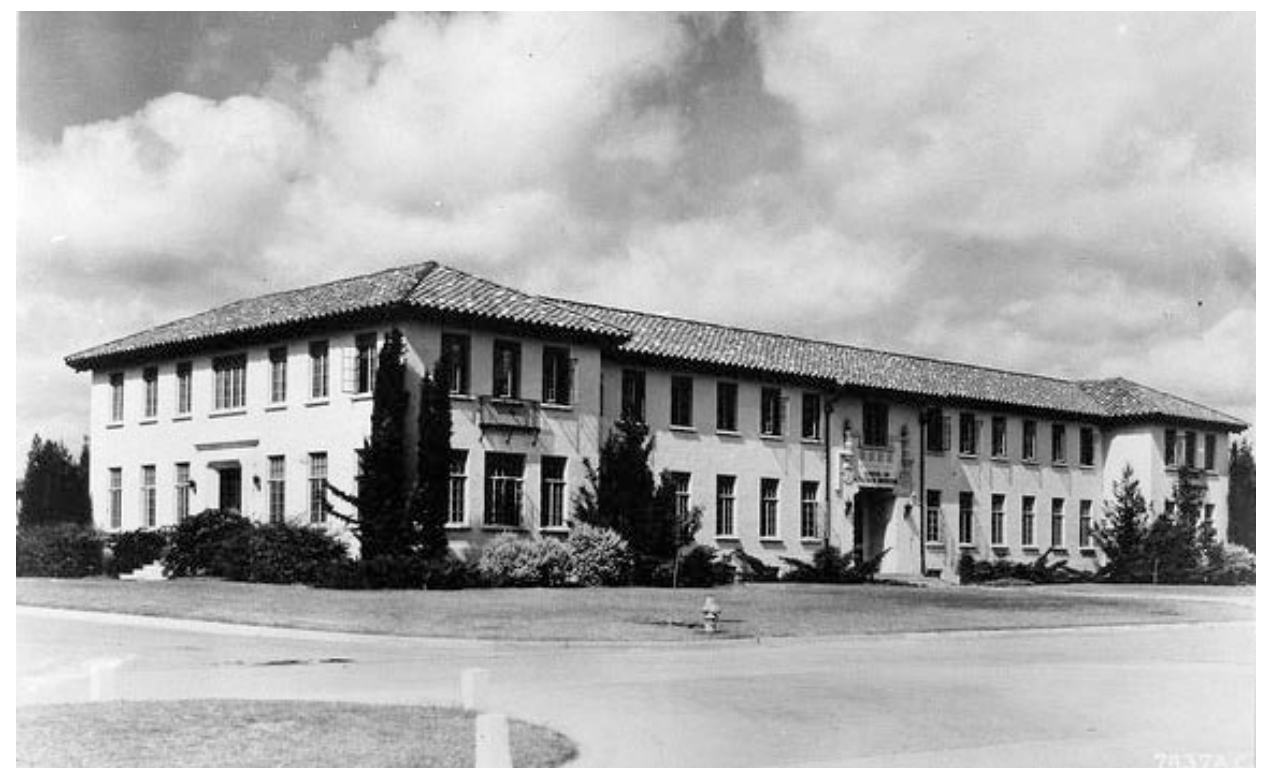

Figure 67. School of Aviation Medicine, 1948 (NARA RG342 Box 1072 B20820).

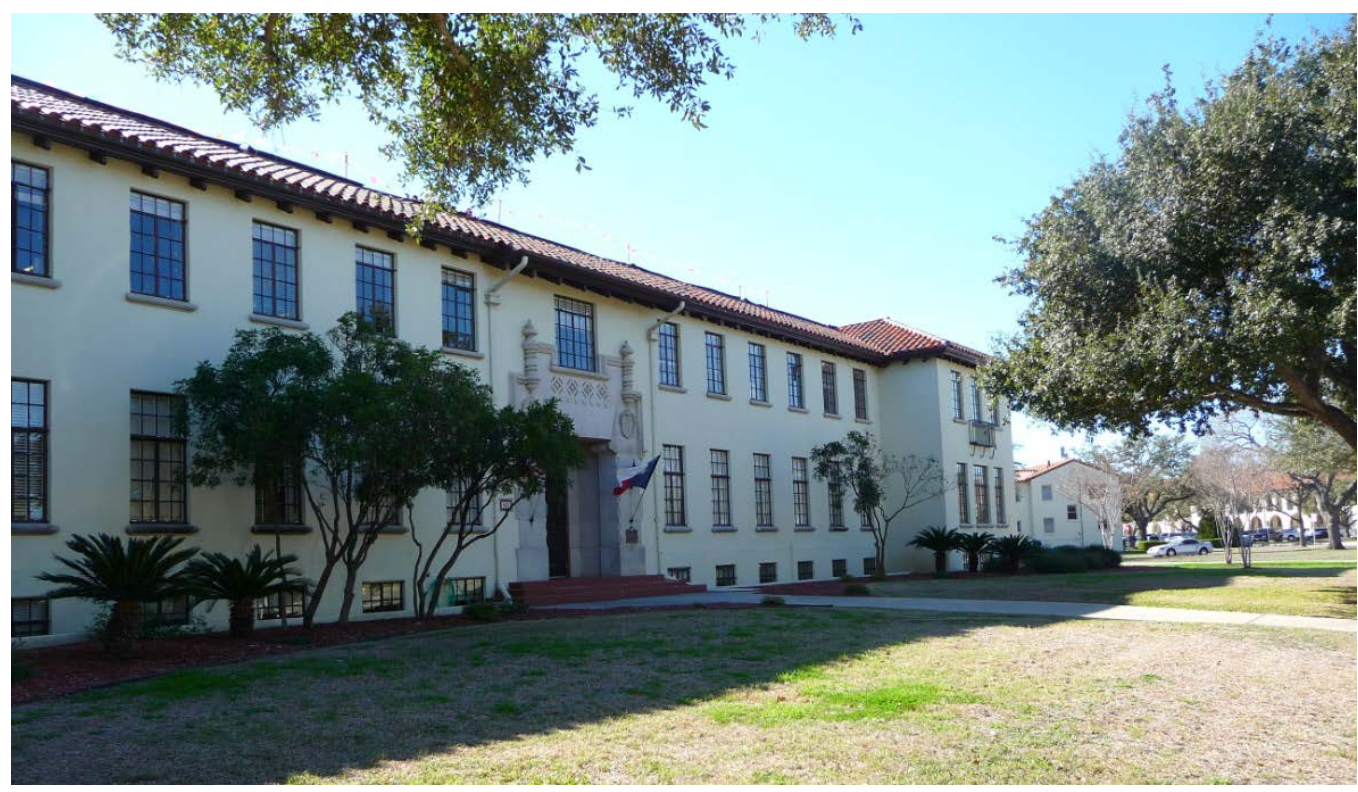

Figure 68. The former School of Aviation Medicine building, 2012 (ERDC-CERL). 


\subsubsection{Residential areas}

The unique layout of Randolph Field grouped larger service, administrative, and operational areas along the other perimeter of the base which provided a buffer zone for the residential area located in the Main Circle. The Main Circle was the location for the single-family officers' quarters with the noncommissioned officers' multi-family residences located at the southern end of the base.

\subsubsection{Commanding General's residence}

The largest residence built at Randolph Field was the Commanding General's house (Building 300). The Commanding General's house was located behind the Administration Building at the northern end of the north-south axis through the Main Circle housing area. The two-story house was designed by Herbert S. Green and was built between April and November 1931. The completed house was clad in stucco and its architectural detailing reflected the Spanish Colonial Revival style used throughout the base. The house had a hipped, clay tile roof with box eaves and an arched porch entry that was ornamented with colorful clay tiles. Two wings radiated off the central core at a slight angle giving an overall effect of asymmetrical massing (Figure 69).

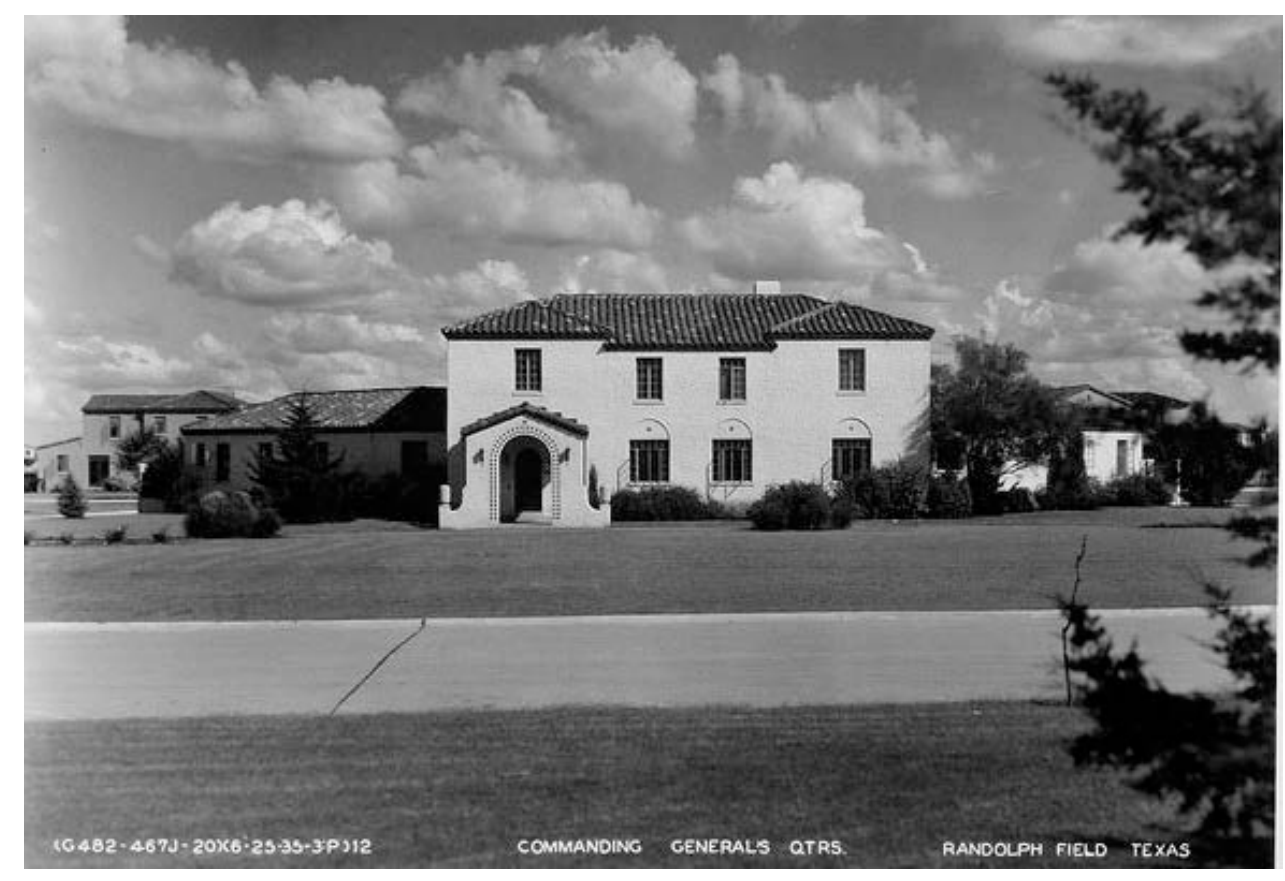

Figure 69. Commanding General's house main façade, undated (NARA RG342 Box 1072 B20781). 


\subsubsection{Officers' Housing-in Main Circle area}

The officers' housing located in the Main Circle was designed as singlefamily residences (Figure 70). The designs for the houses were selected from nine Quartermaster Corps standardized plans. For variety, the architects modified the housing designs by either reversing the floor plan, varying the design of the entries, interspersing one- and two-story buildings, and introducing different types of ornamentation and various exterior stucco colors. Each of the houses contained a living room, a dining room, a kitchen, two to four bedrooms, and one or two bathrooms. Interior finishes included hardwood flooring, plaster walls and ceilings, fireplaces, and wrought-iron staircase railings. All houses were constructed with hollow clay tile walls, poured concrete foundations, and clay tile roofs.

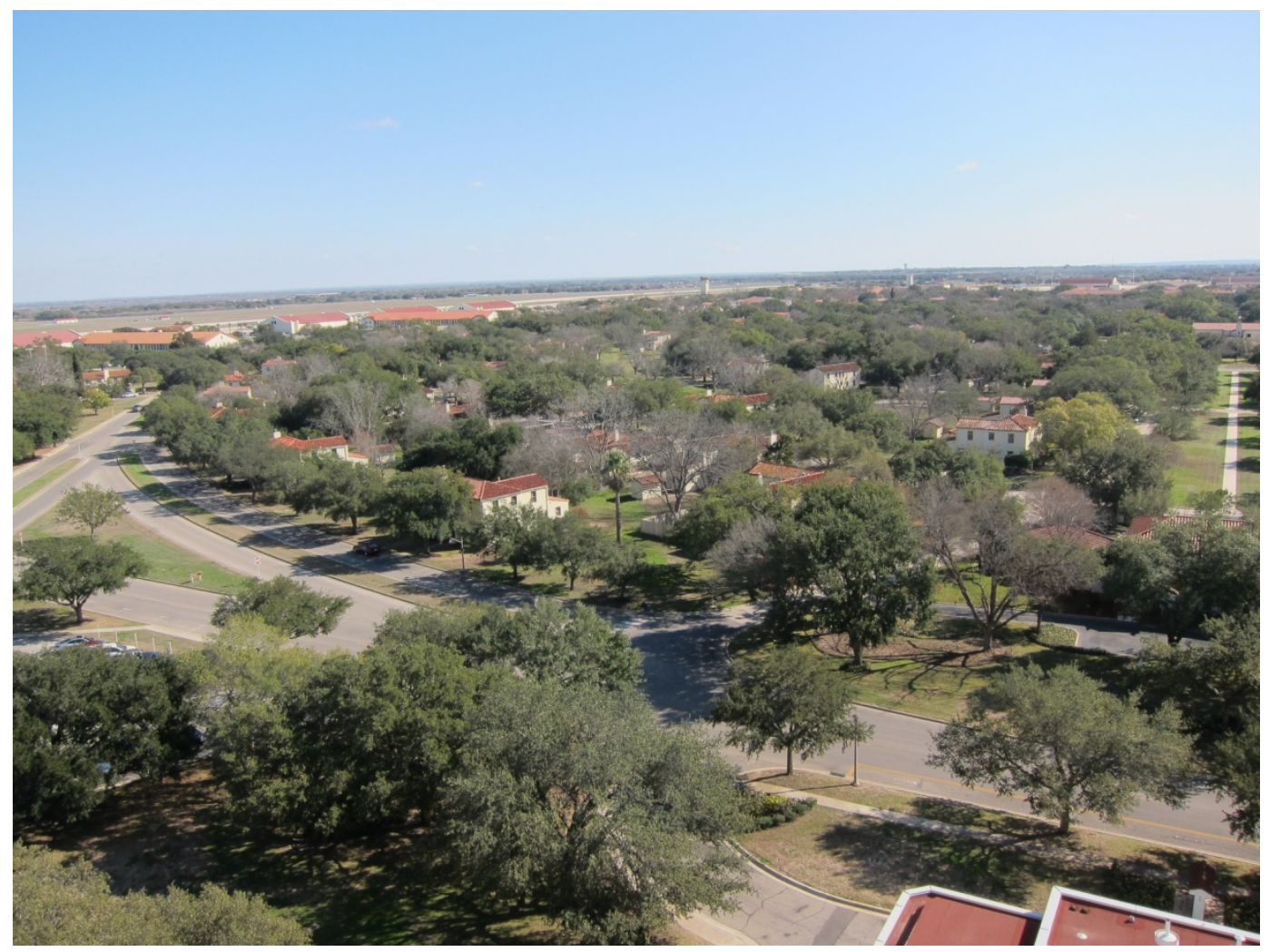

Figure 70. Main Circle officers' housing, 2012 (ERDC-CERL).

The most common standardized plan for houses in the Main Circle area was the Quartermaster Corps Standardized Plan No. OQ-51. Fifty-two of the one-story residences were built by the Quartermaster Corps according to the plan specifications. The house plans featured two projecting wings that were connected in the middle (Figure 71). One wing contained bedrooms, while the other contained the kitchen and dining room, and the liv- 
ing room connected both sides of the house. The floor plan looked like the letter H. The exteriors of these houses consisted of Spanish Colonial Revival detailing of hipped, clay tile roofs with projecting gabled wings, stucco clad walls, and tripartite picture windows. Similar quarters were also constructed at Fort Sam Houston, Texas; Fort Bragg, North Carolina; and March and Rockwell Fields in California. Figure 72 shows an example of one of the single-story houses in 2012.

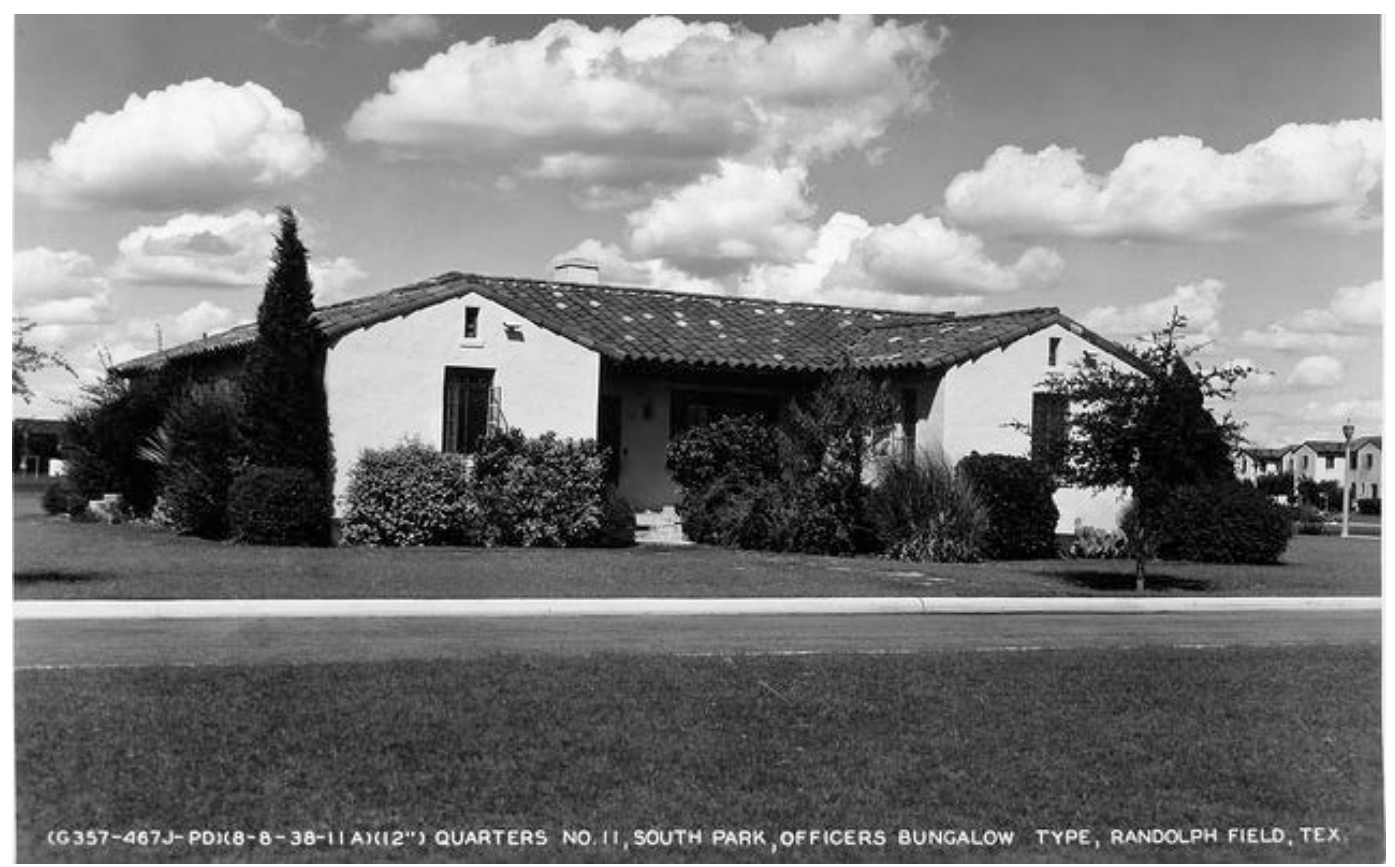

Figure 71. Quarters No. 11 on South Park, late 1930s (RG342 Box 1072 B20758).

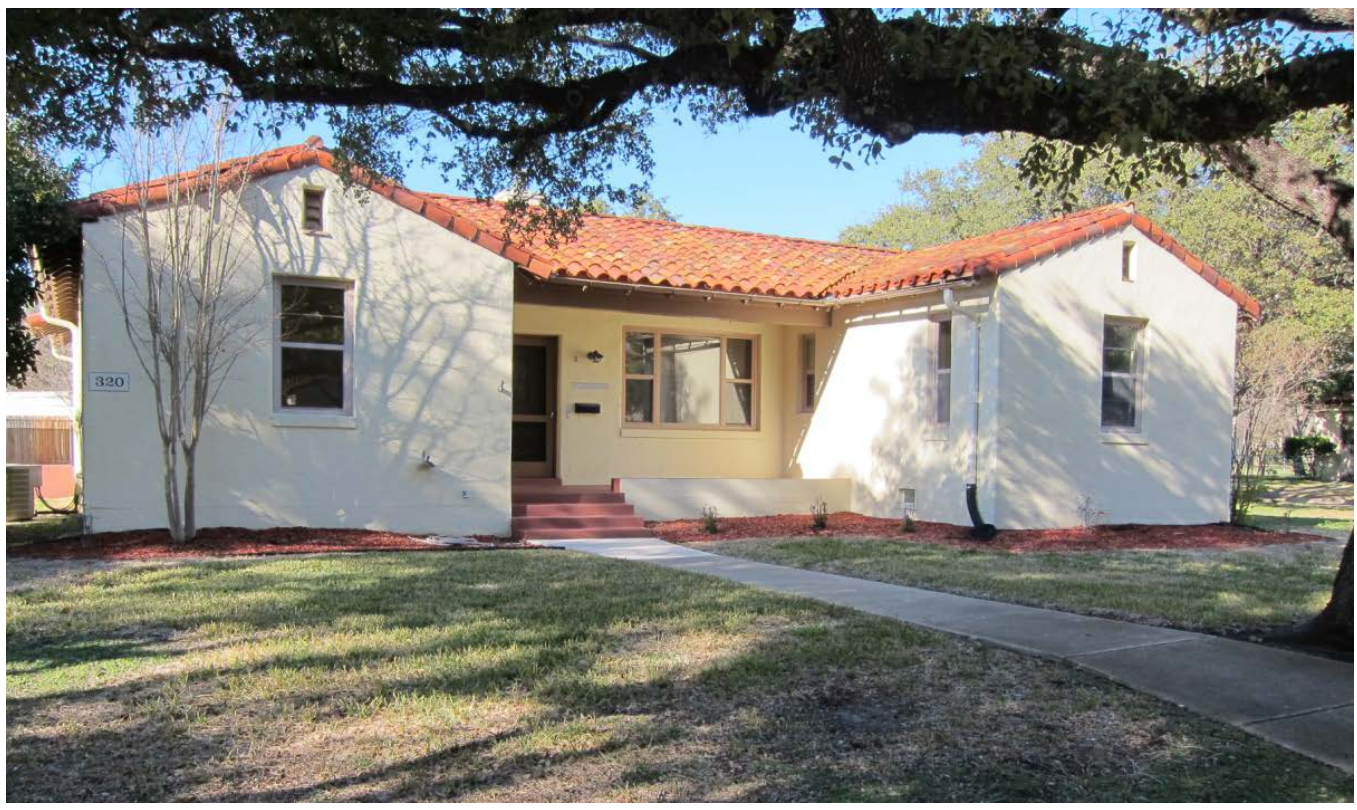

Figure 72. Example of the single-story type of officers' quarters, 2012 (ERDC-CERL). 
Some of the two-story houses in the Main Circle were decorated more extensively than others. A local architect, J ohn M. Marriot, designed 26 of the two-story houses in the Main Circle area. Marriot's designs were based on a modified version of the Quartermaster Corps Plan No. OQ-59. The most noticeable difference provided by Marriot was the use of one of two variations on the main entrance. One entrance style was used for twelve houses and featured an inset doorway with an arched door surround which was decorated with ceramic tiles under a gabled, clay tile canopy (Figure 73). Fourteen other houses received the second entrance variation that featured an inset rectangular doorway surrounded by tiles and framed by attached boxed piers with Doric capitals. This entry was also set under a gabled, clay tile canopy. In some instances, Marriot also added iron balconets below one of the second-story windows, as well as inset ceramic tiles around another second-story window for further ornamentation on the primary façades.

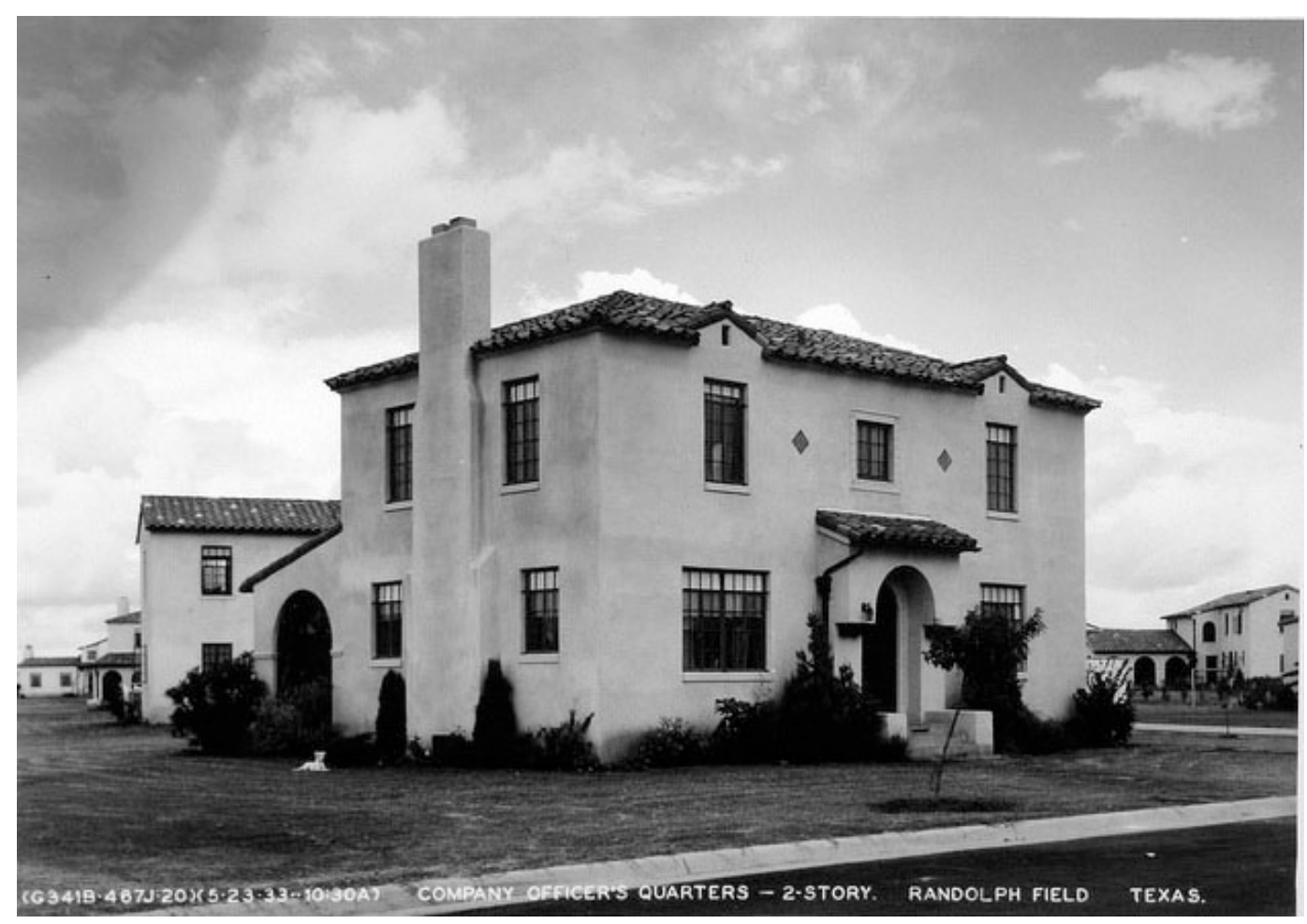

Figure 73. One of Marriot's variations of the two-story officers' quarters had an arched door surround, 1930s (NARA RG342 Box 1072 B20784).

Figure 74 illustrates the squared door surround on a two-story officers' quarters. Figure 75- Figure 78 provide examples of the different variations in the Marriot designs for the two-story officers' quarters. 


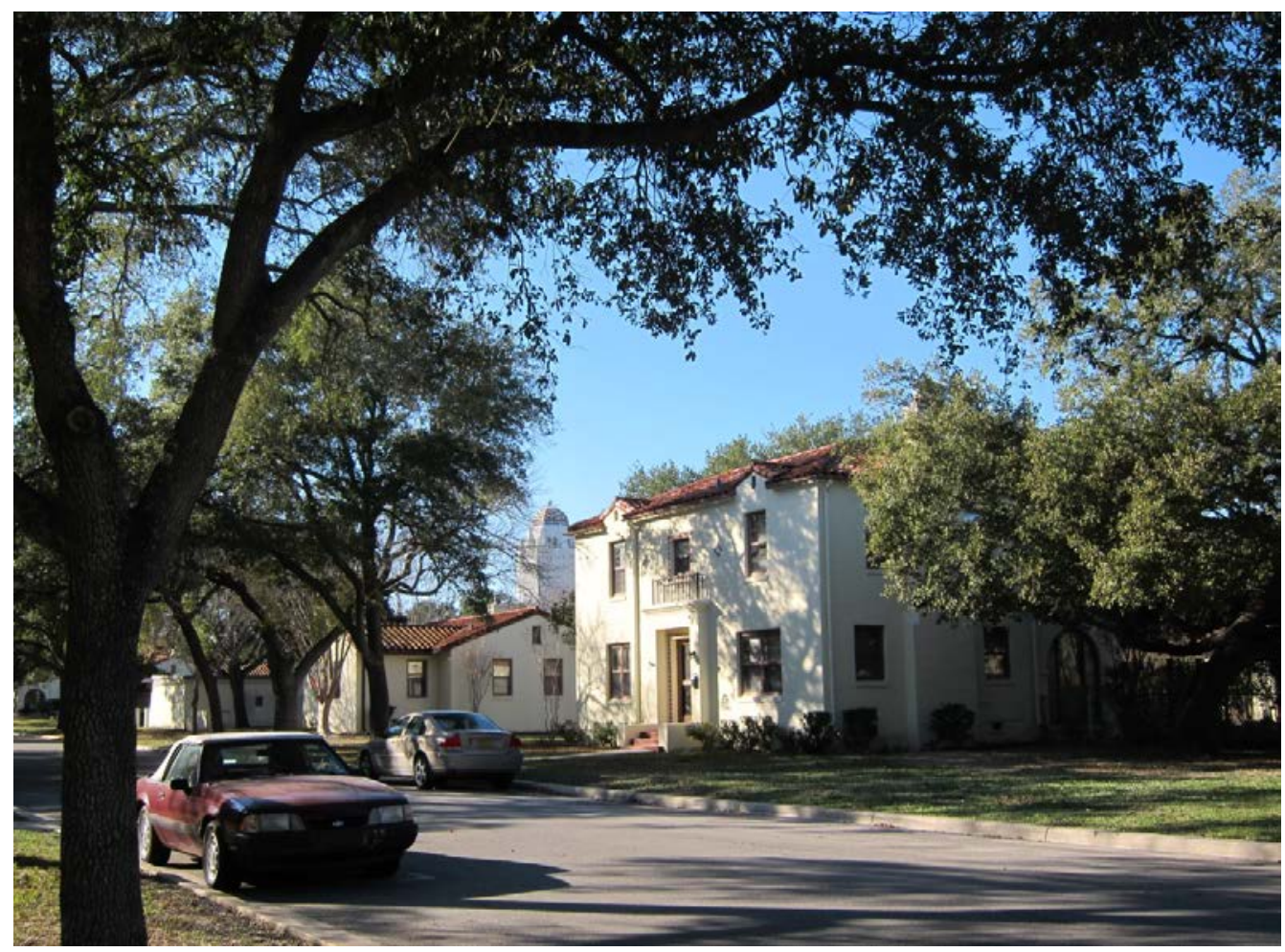

Figure 74. One of Marriot's variations of the two-story officers' houses, featuring a squaredentrance surround, with balconet and tile-decorated window above, 2012 (ERDC-CERL). 


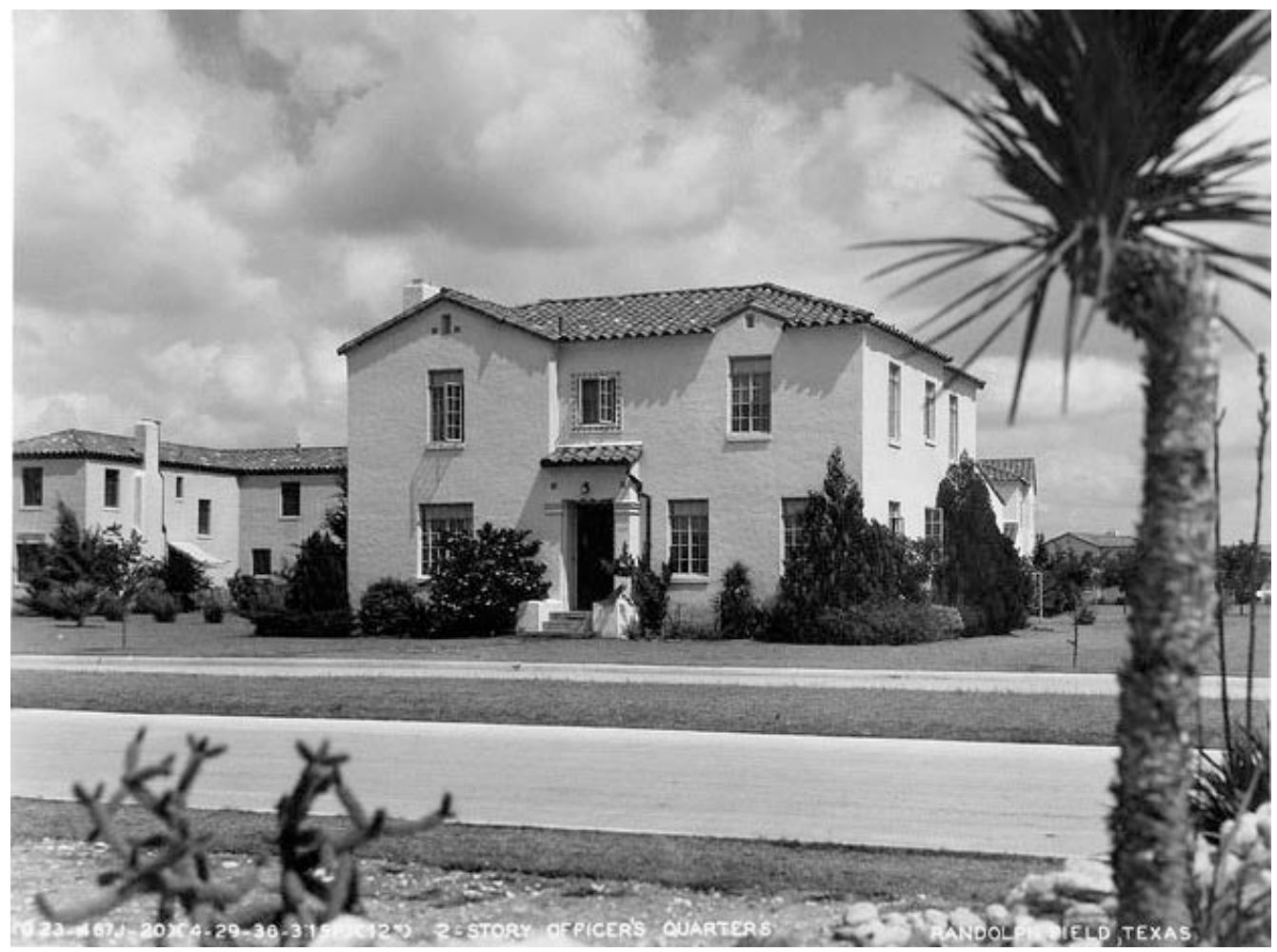

Figure 75. Another of Marriot's two variations on two-story officers' quarters, showing the squared-door surround, with tile-decorated window above, 1930s (NARA RG342 Box 1072 B20755).

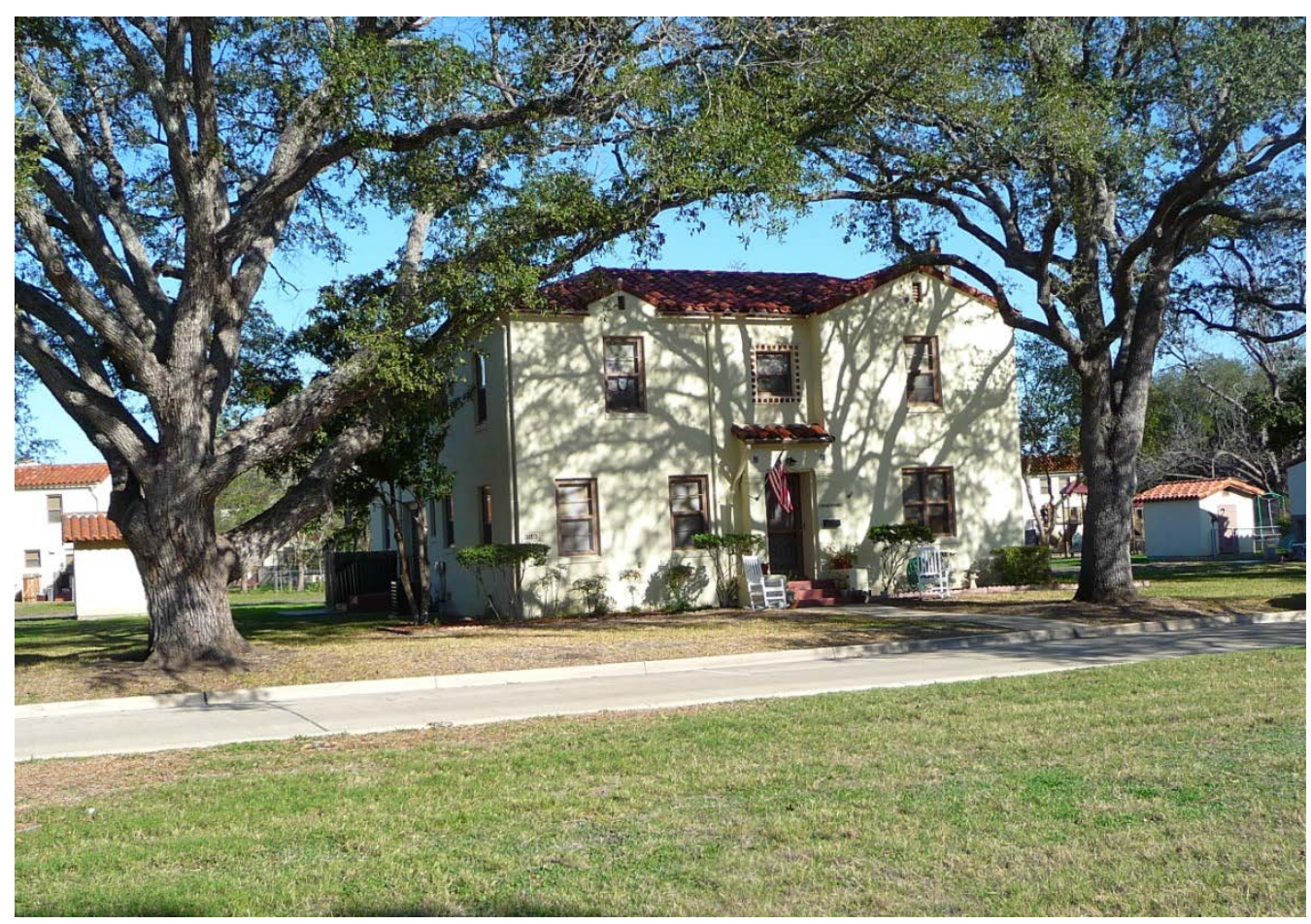

Figure 76. Another current example of Marriott's variation of two-story officers' quarters,with squared-door surround and tile-decorated window above, 2012 (ERDC-CERL). 


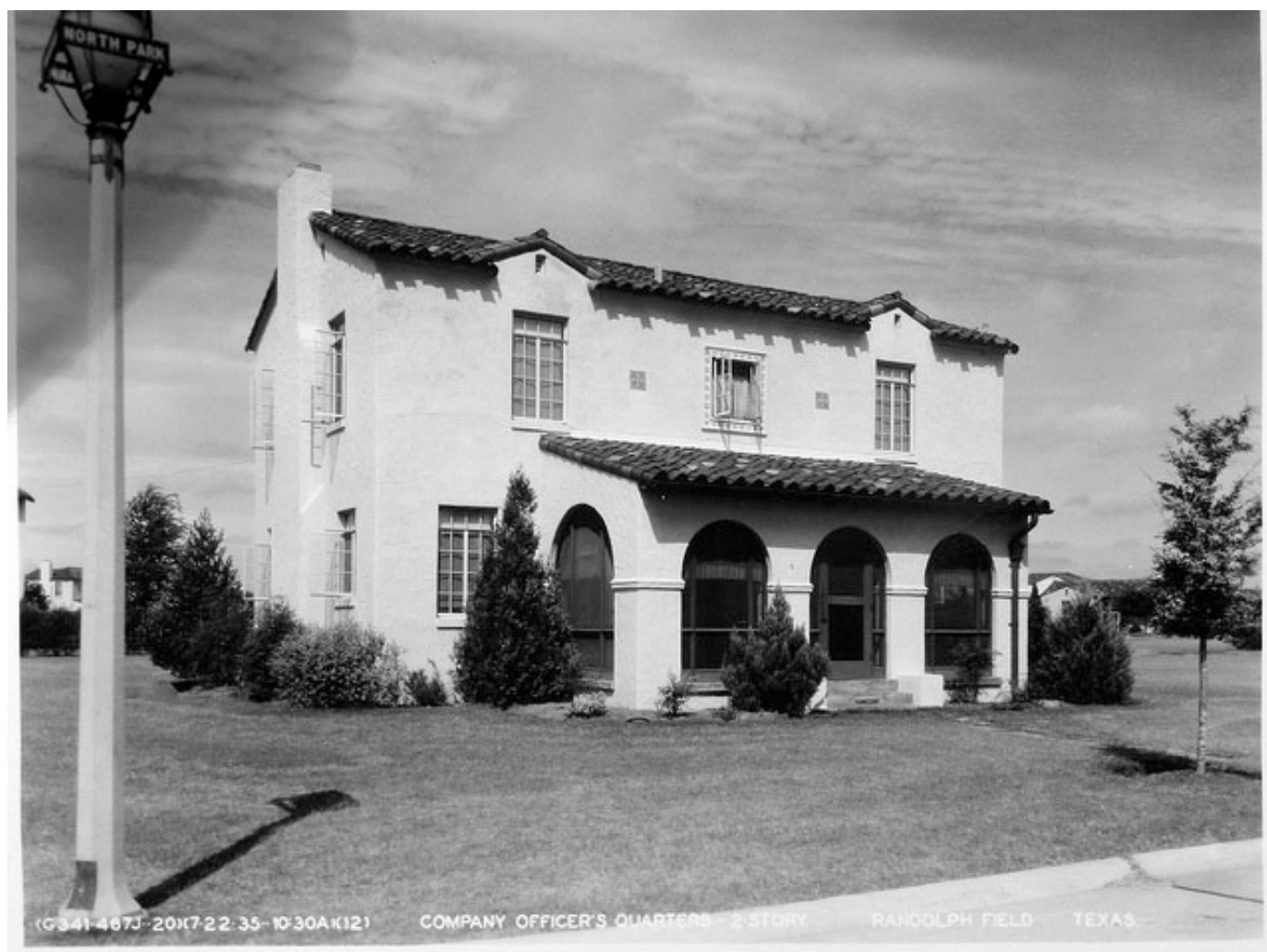

Figure 77. Example of one variation on the two-story officers' quarters in the 1930s (NARA RG342 Box 1072 B20785).

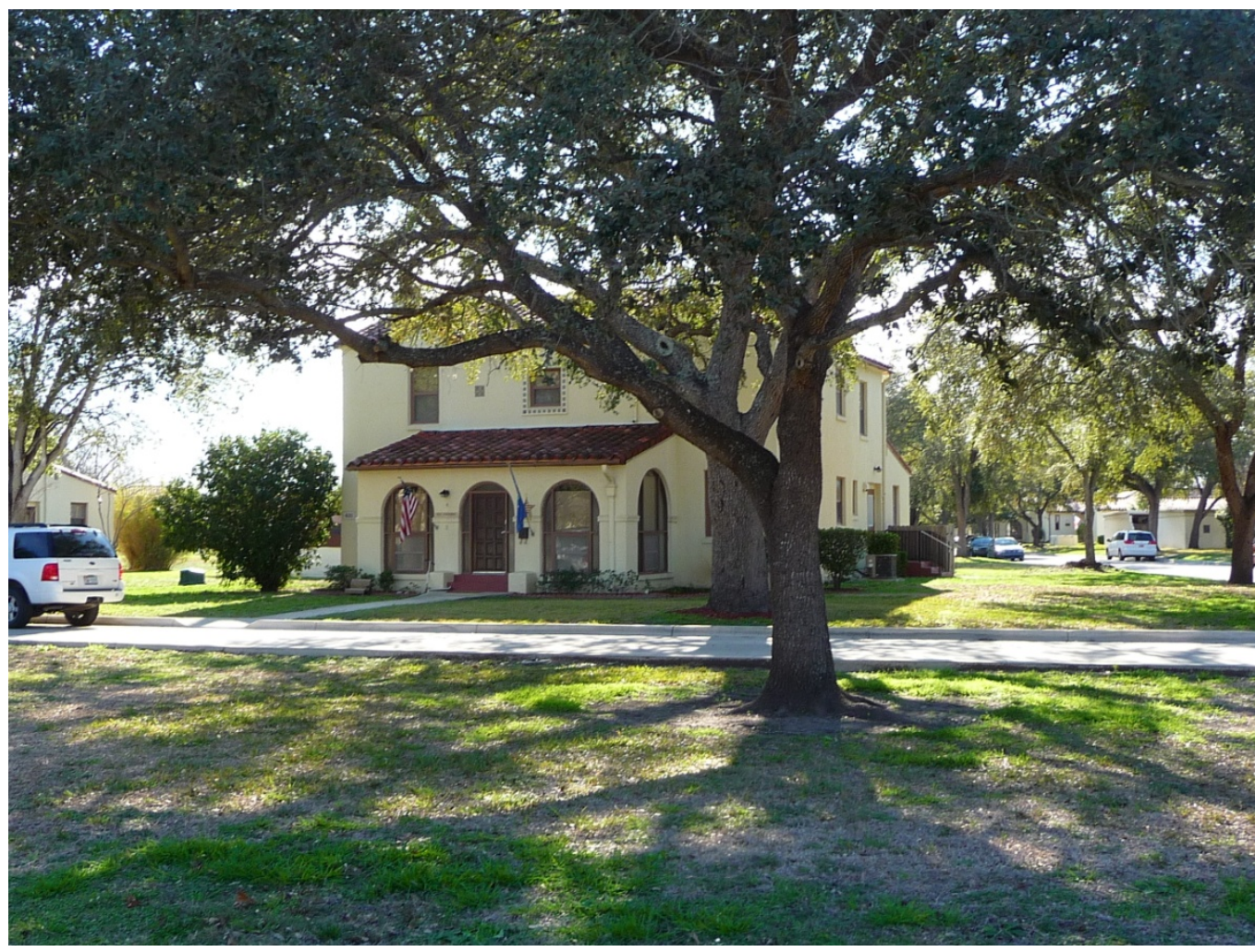

Figure 78. Two-story officers' quarters, 2012 (ERDC-CERL). 
Herbert S. Green, the architect of the Commanding General's residence, also designed modifications for ten of the single-family officers' houses. Each of these houses was built according to a modified version of the twostory Quartermaster Corps Plan No. OQ-58, which featured a single-story porch with single- or multiple-arched doorways on the primary façade (Figure 79). The other two-story houses in the Main Circle had finished designs by architect J ohn Marriot. Because the two architects used similar design attributes, the individual houses blended together to create the residential environment of the Main Circle. Figure 80 and Figure 81 are examples of the Herbert Green variations on the remaining officers' quarters.

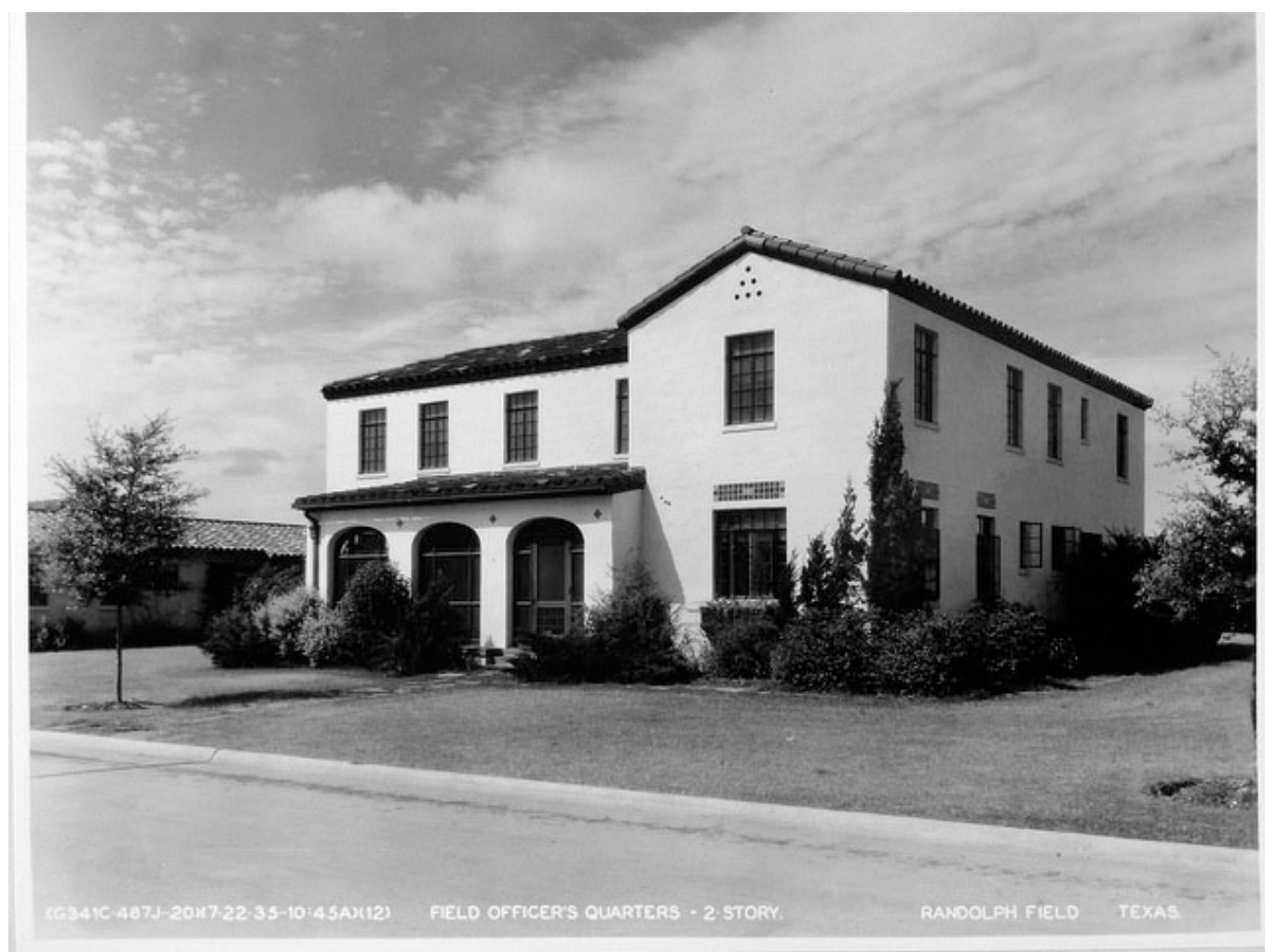

Figure 79. An example of one of the variations on the two-story officers' quarters in the 1930s (NARA RG342 Box 1072 B20783). 


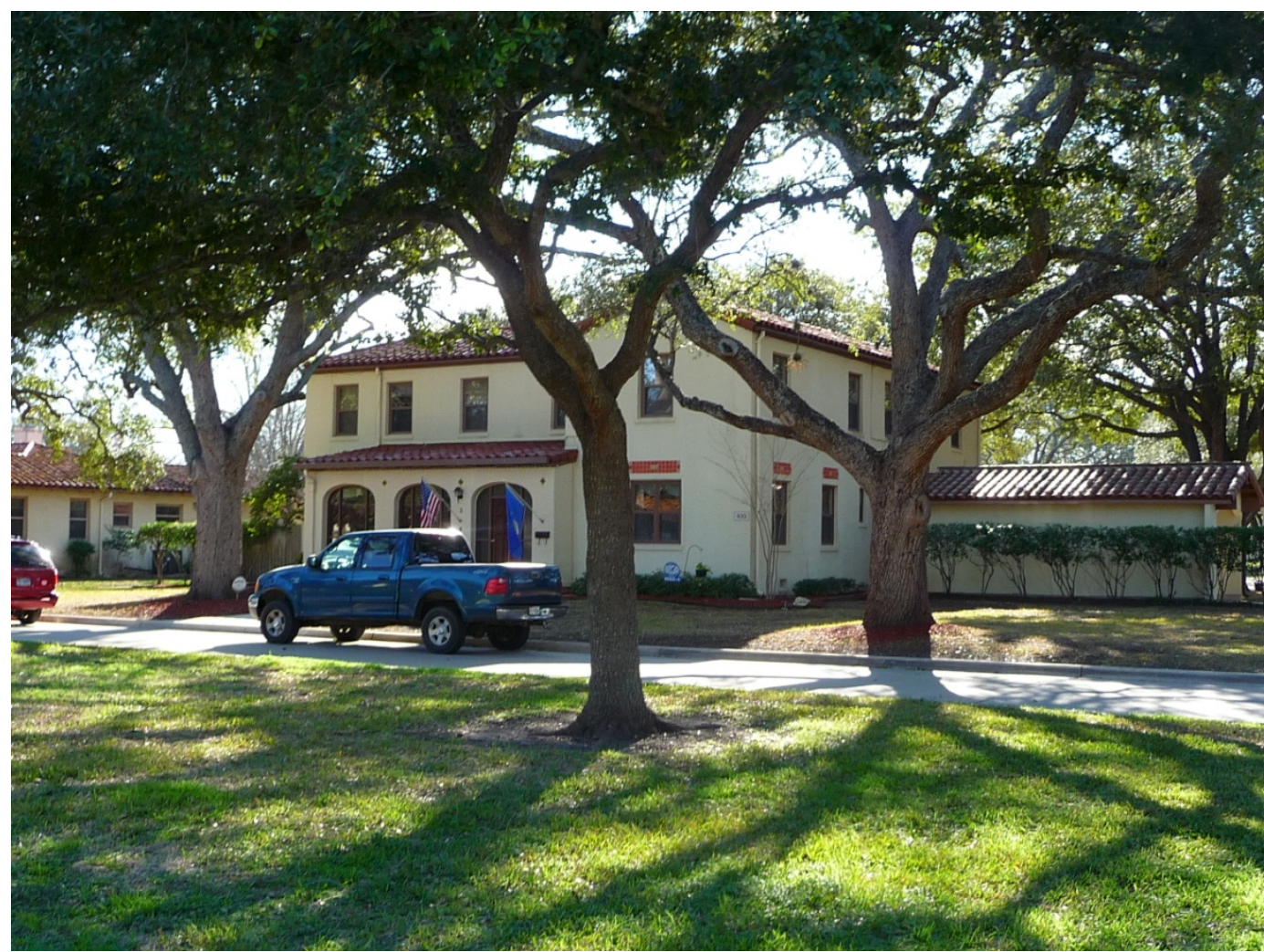

Figure 80. Current view of Green's variation on two-story officers' quarters, 2012 (ERDCCERL).

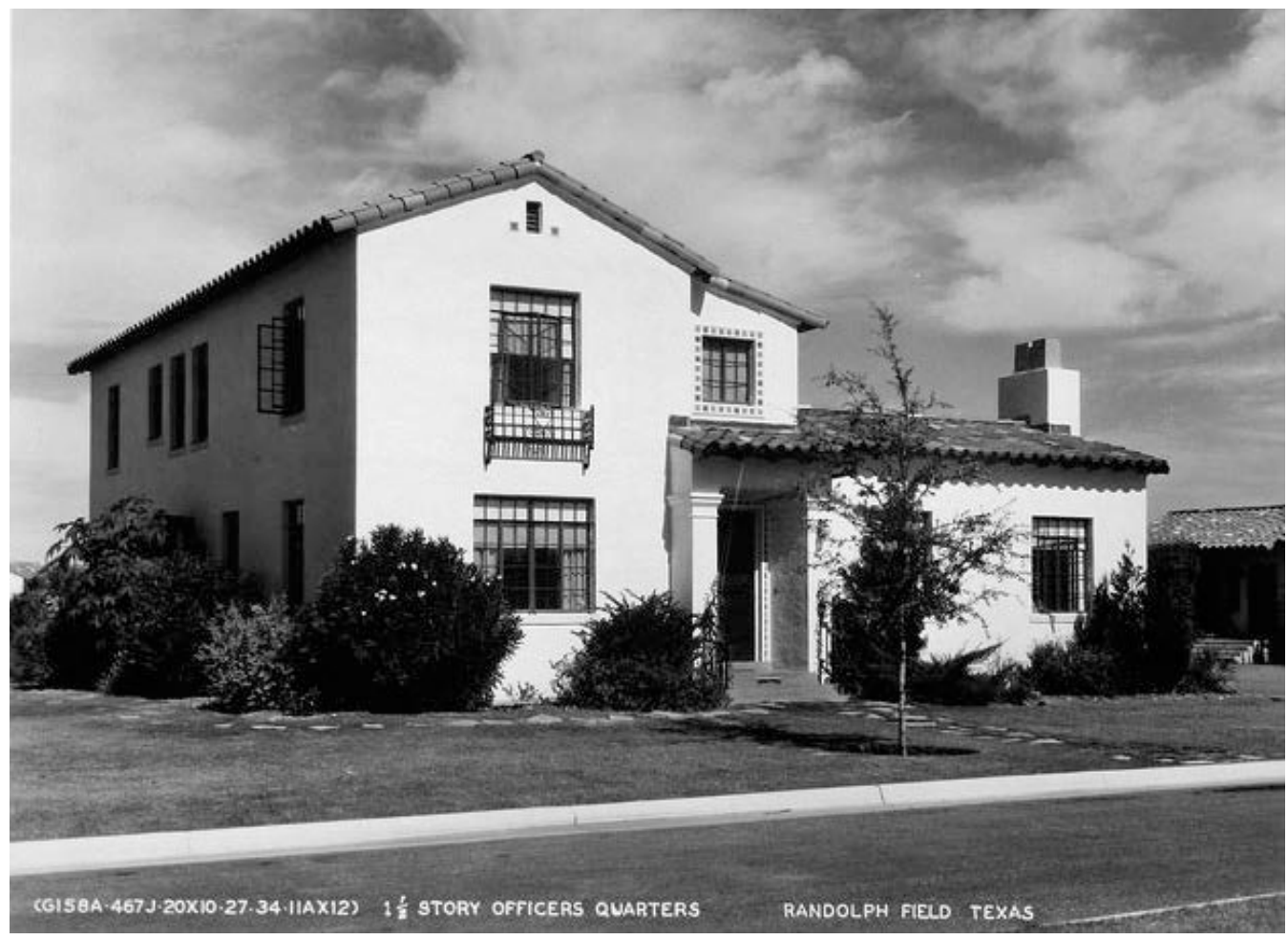

Figure 81. An example of one of Green's variations on the two-story officers' quarters in the 1930s (NARA RG342 Box 1072 B20787). 
The officers' quarters were organized closely along the streets, which contrasted with the large open areas behind the housing (Figure 82).

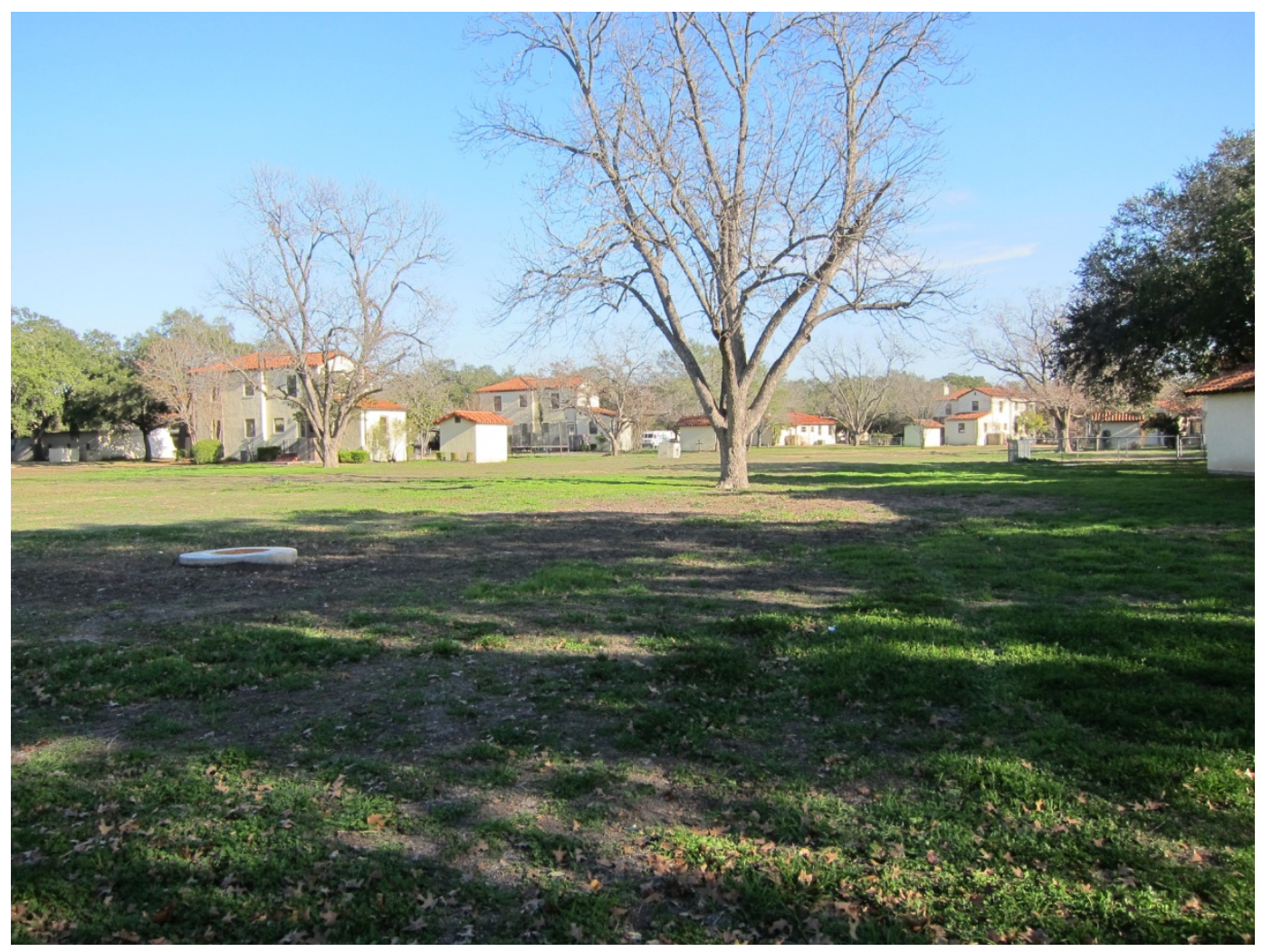

Figure 82. Open area behind the officers' housing showing the regular spacing of the quarters, 2012 (ERDC-CERL).

\subsubsection{Officers' Club}

The Officers' Club (Building 500) was located in Military Plaza at the center of the Main Circle where it was easily accessed by the officers' housing that surrounded it. The club was designed by architect Harvey P. Smith and completed in 1931. The original design for the building had irregular massing created by a two-story, gabled wing abutting a one-story entrance wing that was emphasized by a tall, hipped, crenellated tower (Figure 83). It is finished in the Spanish Colonial Revival styling with stucco walls and a red tiled roof. The Officers' Club was an important social center that contained a ballroom, a grill, lounges, and a swimming pool. The club has been significantly altered over time to accommodate new user needs (Figure 84). 


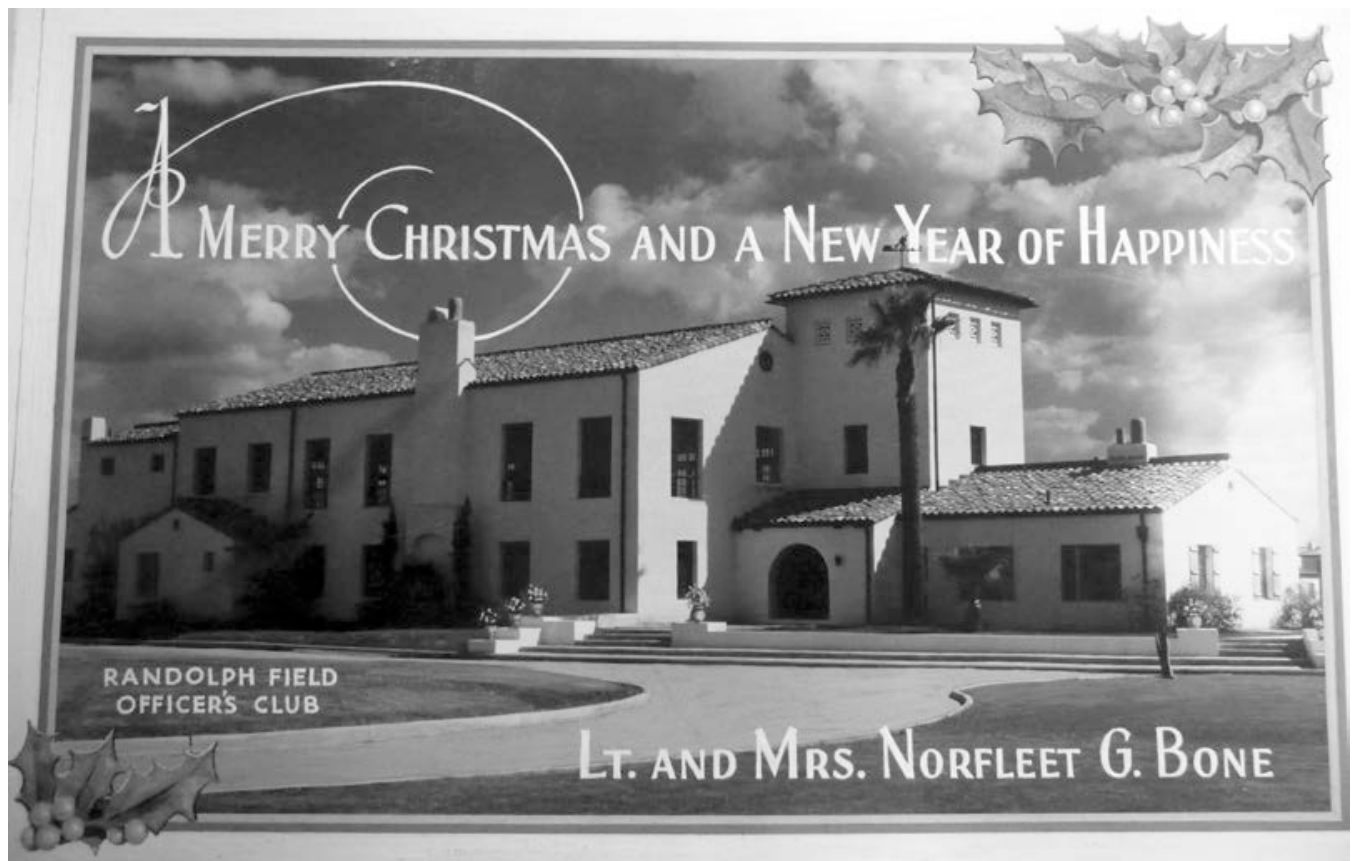

Figure 83. Main entrance of the Officers' Club, undated (Norfleet Giddings Bone Papers, University of Texas at San Antonio Libraries Special Collections).

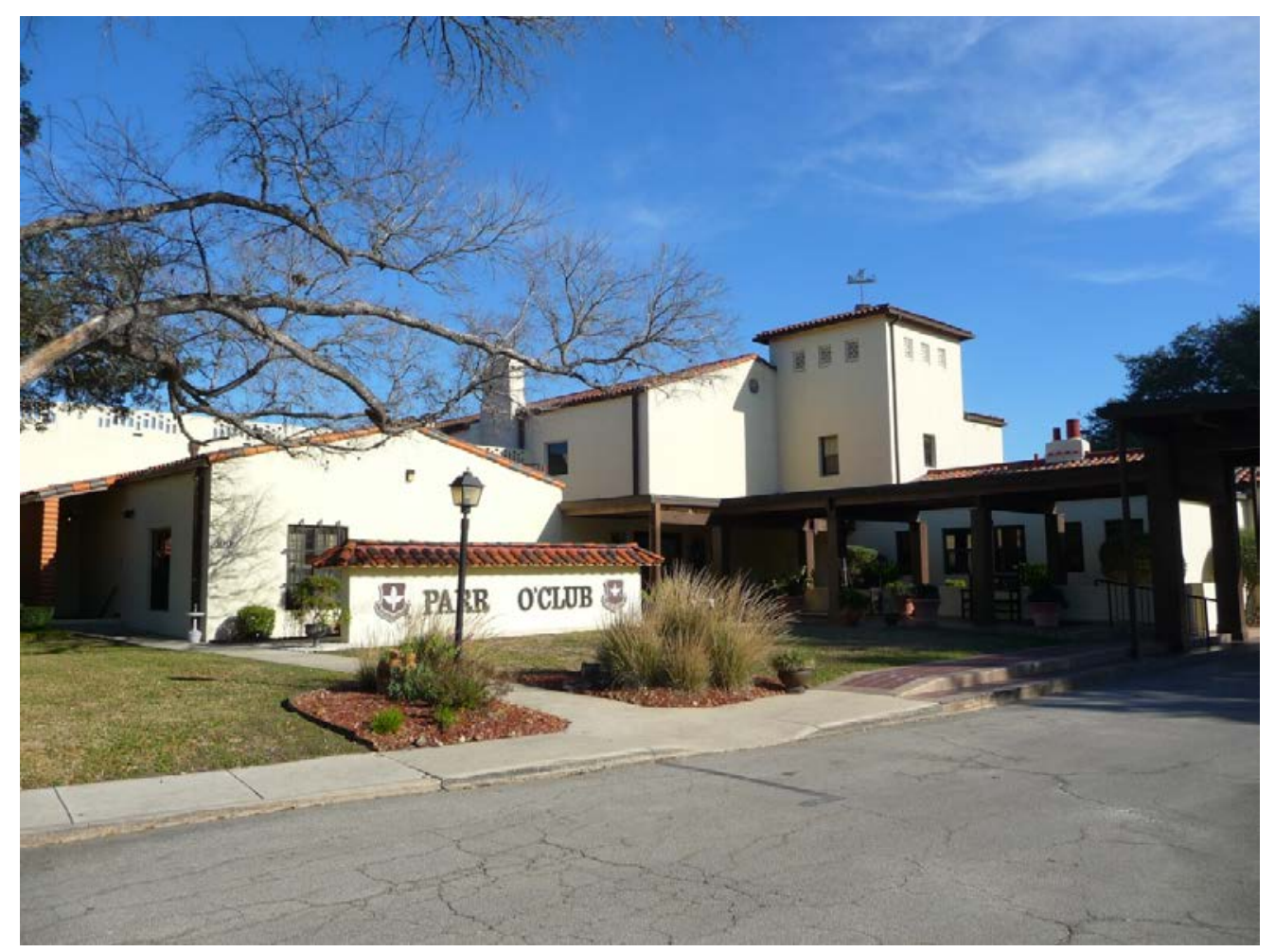

Figure 84. Officers' Club, 2012 (ERDC-CERL).

Figure 85-Figure 89 provide other historic and contemporary views of the Officers' Club. 


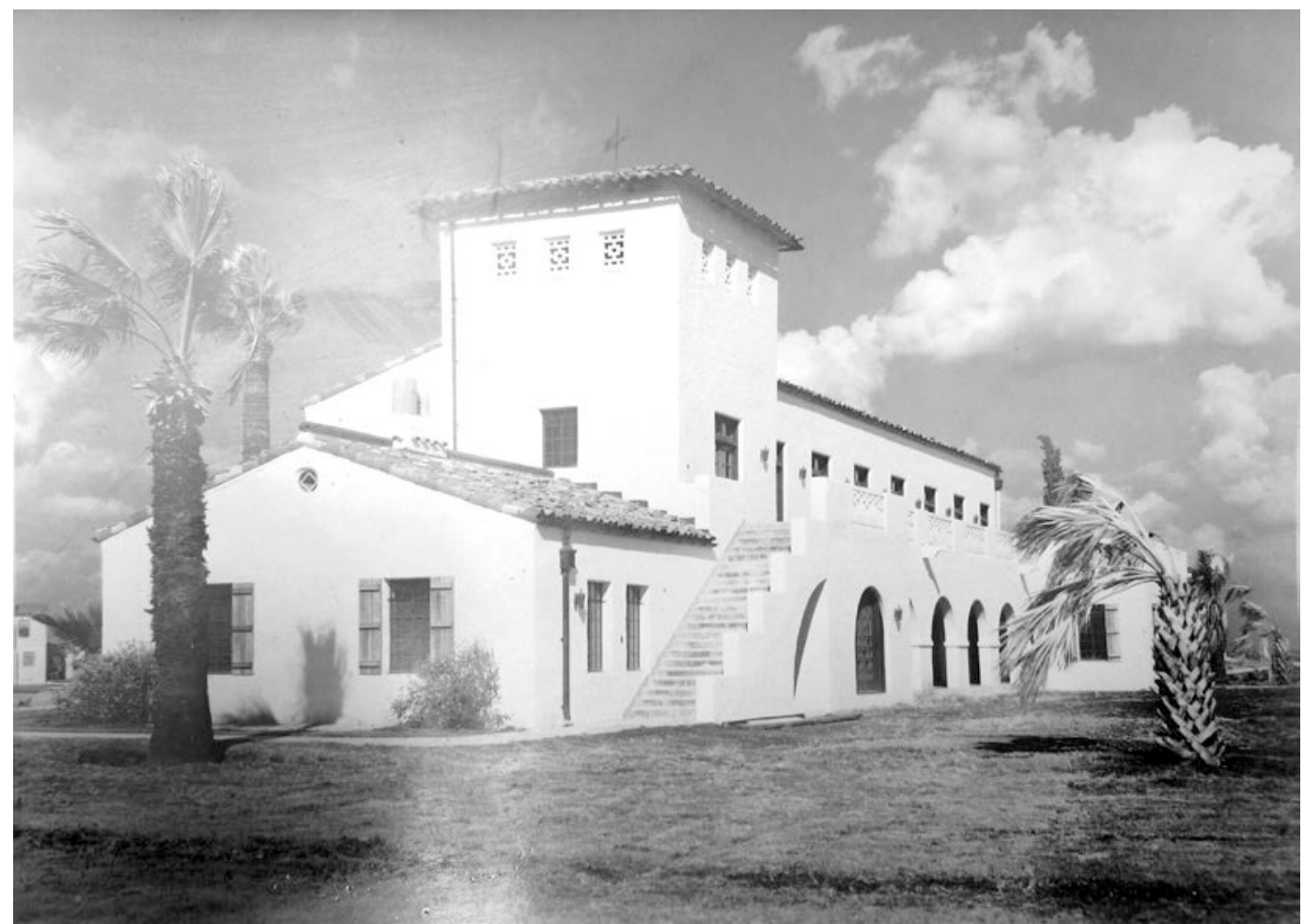

Figure 85. Officers' club, undated (Norfleet Giddings Bone Papers, University of Texas at San Antonio Libraries Special Collections).

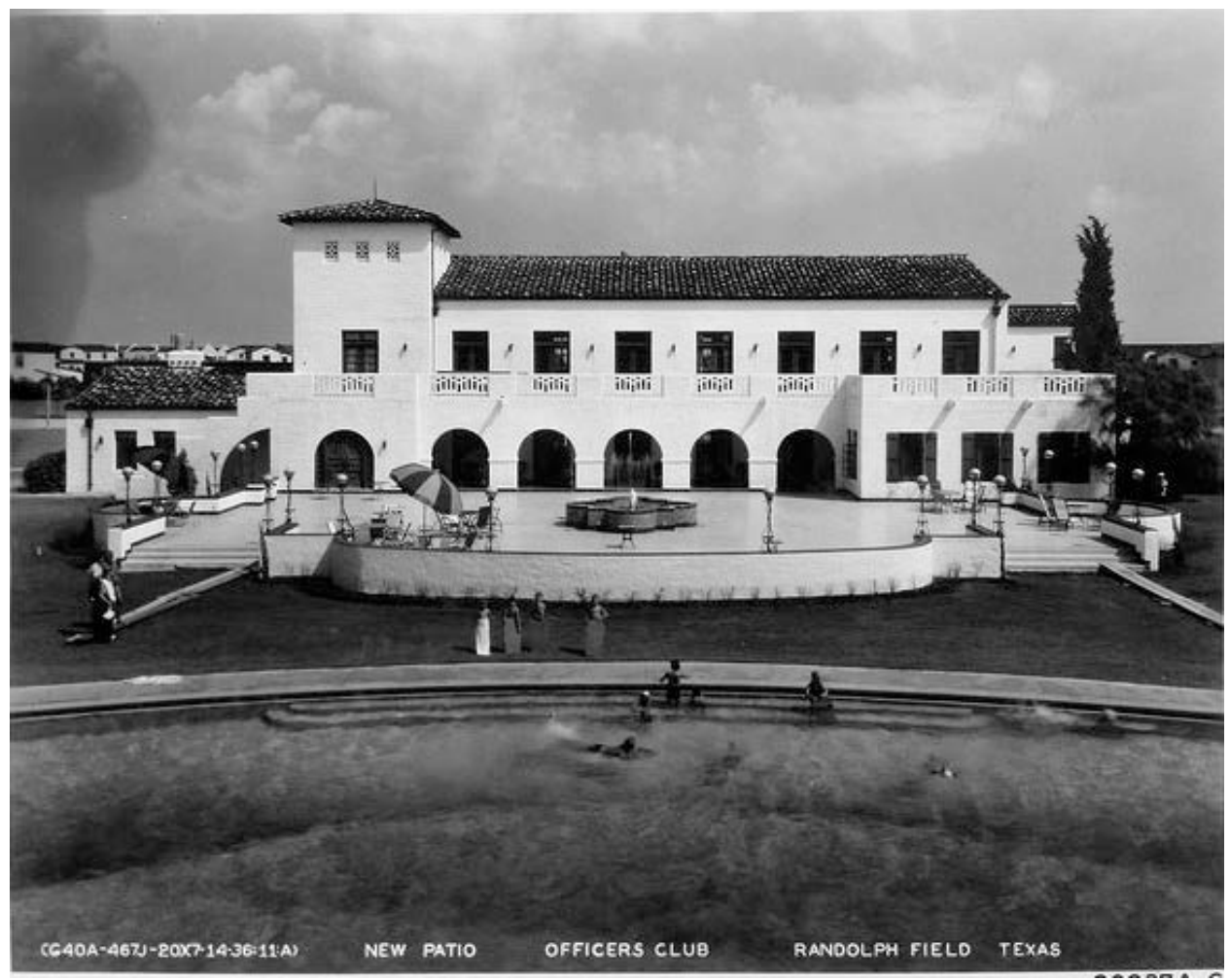

Figure 86. New patio behind the Officers' Club in the 1930s (NARA RG342 Box 1072 B20847). 


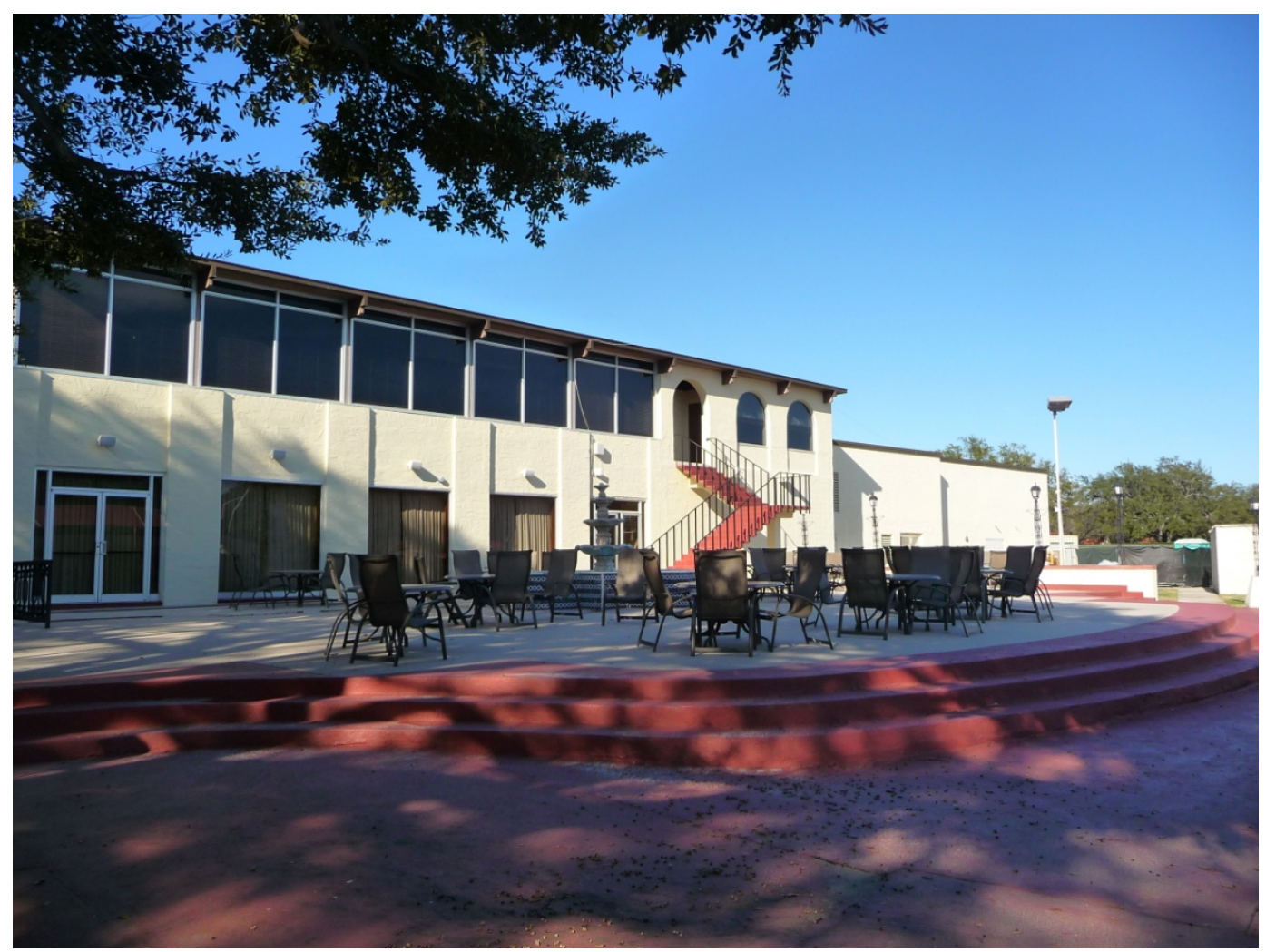

Figure 87. Back of the Officers' Club, 2012 (ERDC-CERL).

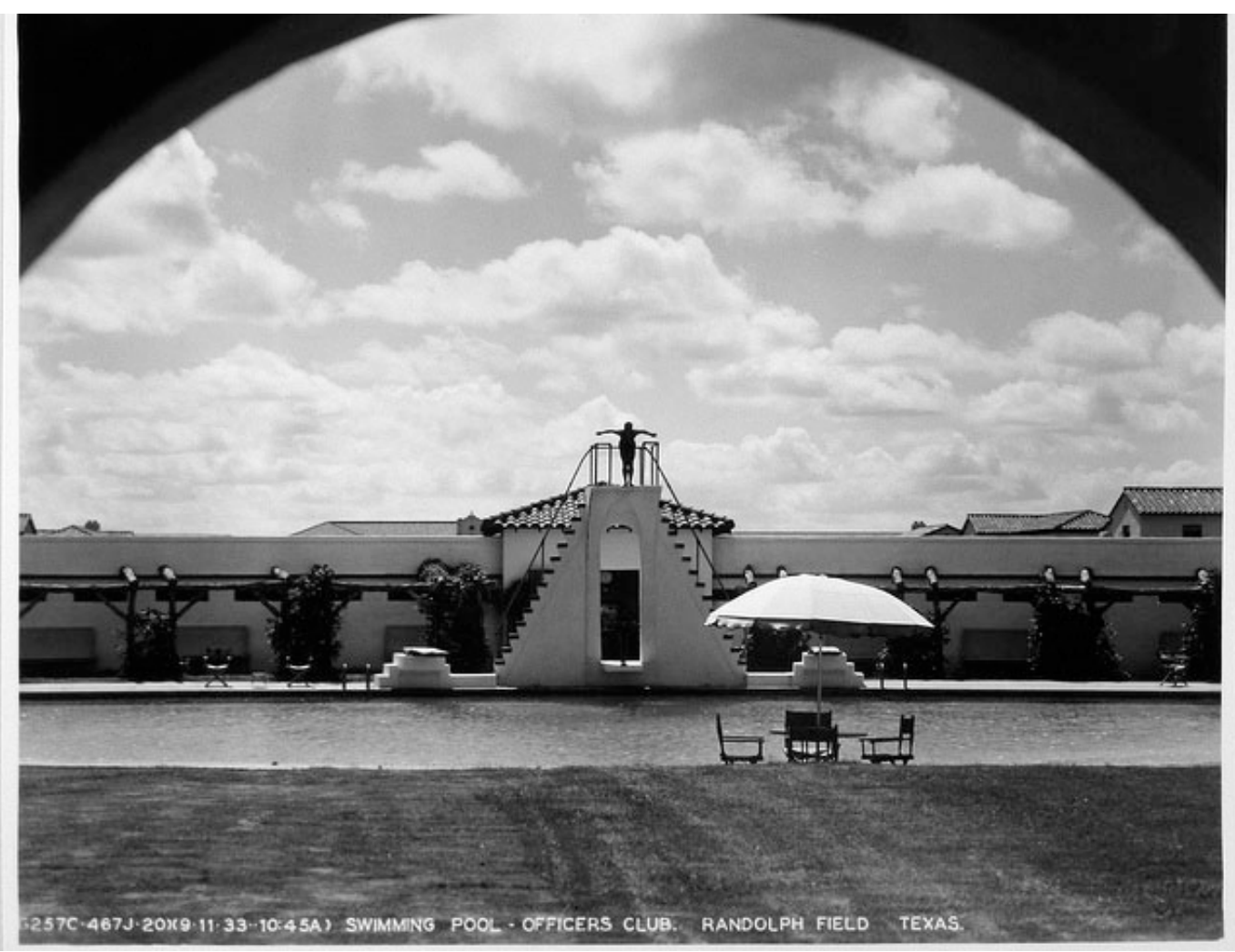

Figure 88. Officers' Club swimming pool with elaborate diving stand in the 1930s (NARA RG342 Box 1072 B20799). 


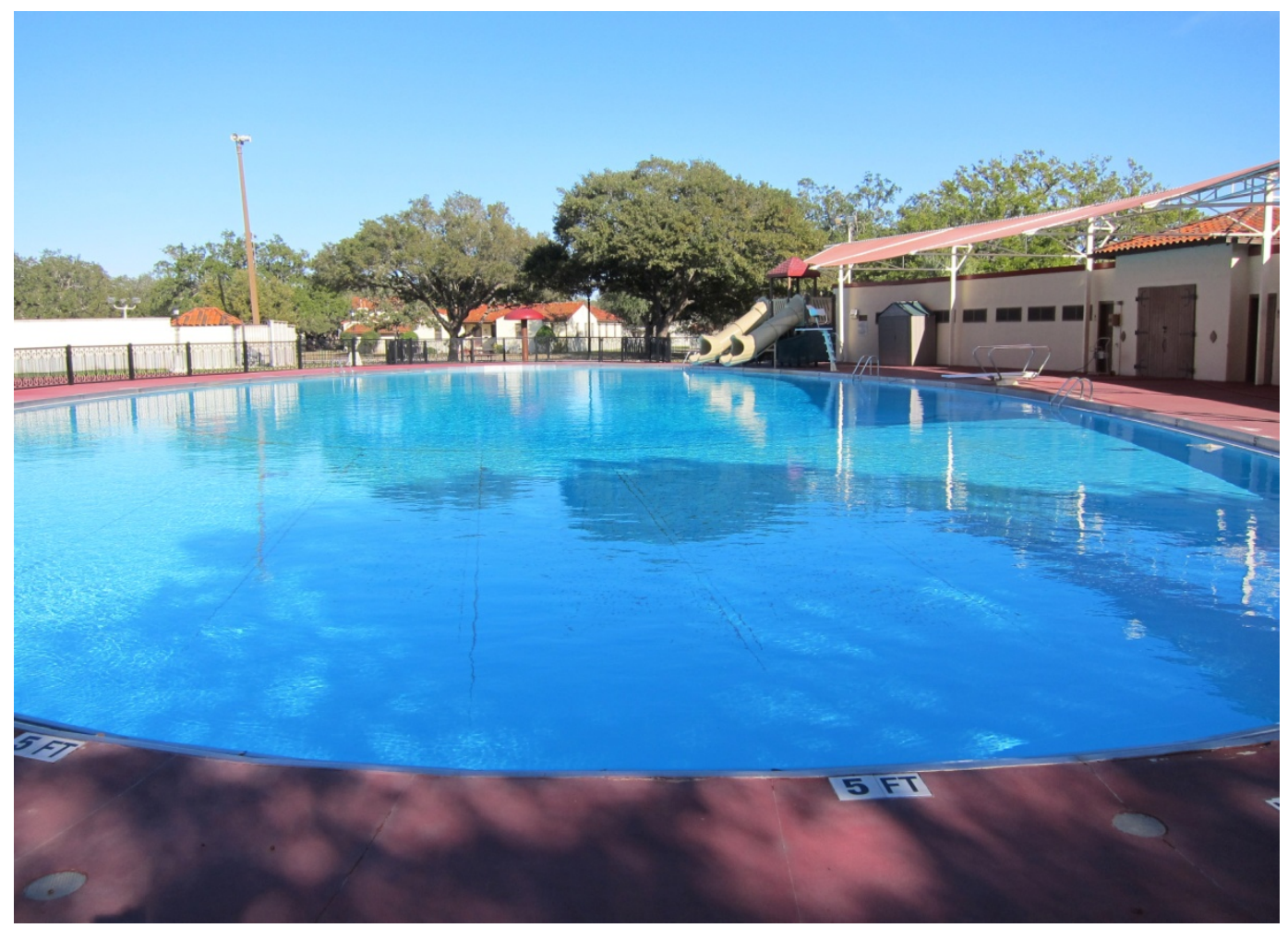

Figure 89. Officers' Club pool and pool house, 2012 (ERDC-CERL).

\subsubsection{Noncommissioned officers' housing}

The noncommissioned officers' housing was located outside of the Main Circle and at the southern end of the base. The housing was split into two groups on either side of the Cadet Complex (Figure 90). The housing consisted of eighty-four two-story duplexes built in either 1931 or 1934. The housing was built according to Quartermaster Corps Plan No. NCO-13. Each duplex was U-shaped and architecturally styled in the dominant Spanish Colonial Revival style. As a result, the exteriors had a gabled, clay tile roof, stucco-clad walls, and an eave-wall chimney that divided the individual units (Figure 92). Originally, the front porches were open with wrought-iron rails. Three bedrooms and a sleeping porch were located on the second floor, and the living room and kitchen were located on the first floor.

Changes to the NCO duplexes include enclosing the sleeping porch to create a fourth bedroom as well as enclosing the front porches and adding a clay tile canopy over the front door (Figure 91). 


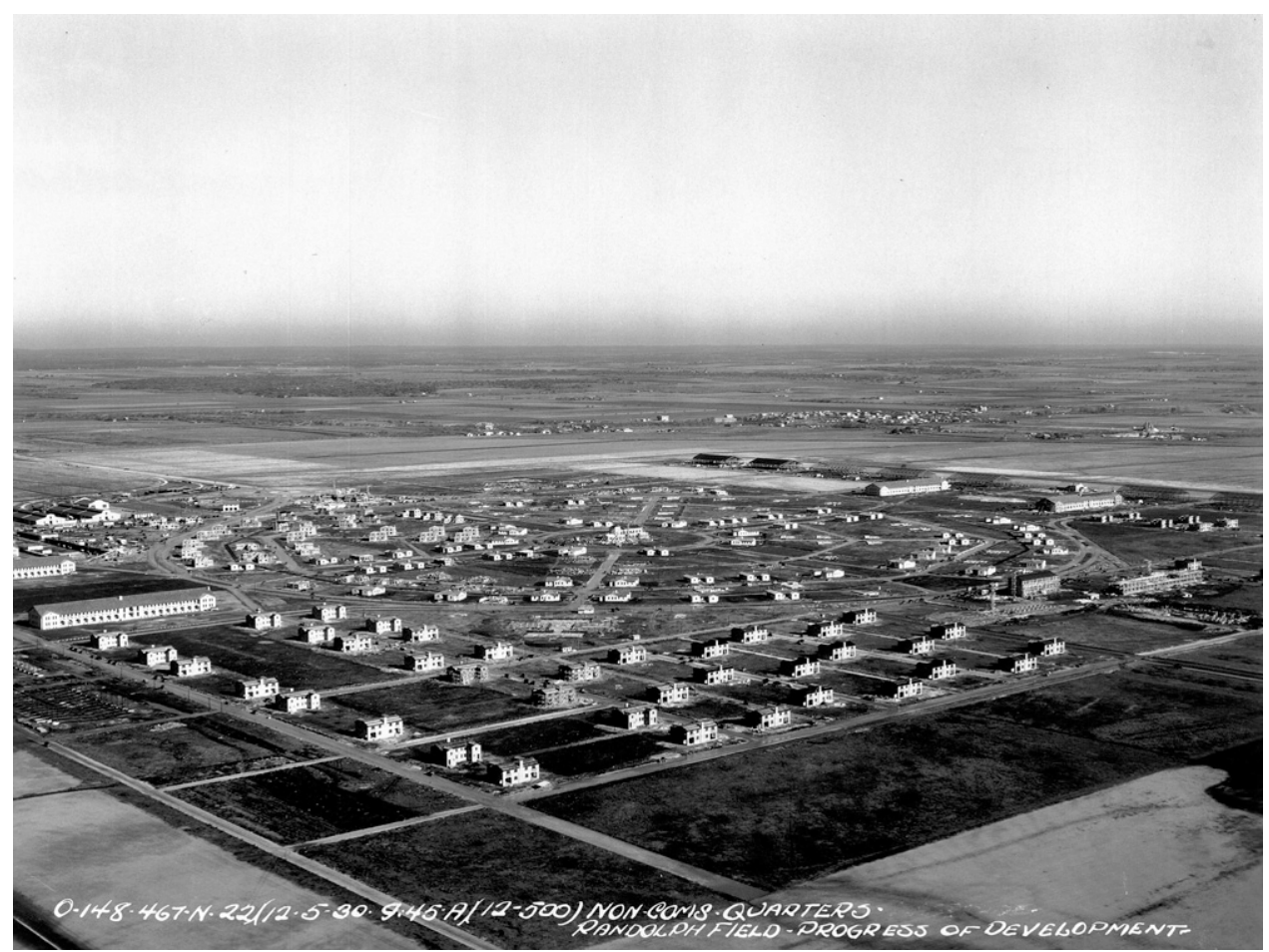

Figure 90. Western section of the noncommissioned officers' quarters in December 1930, looking northeast (Bone Collection Randolph AFB Cultural Resources).

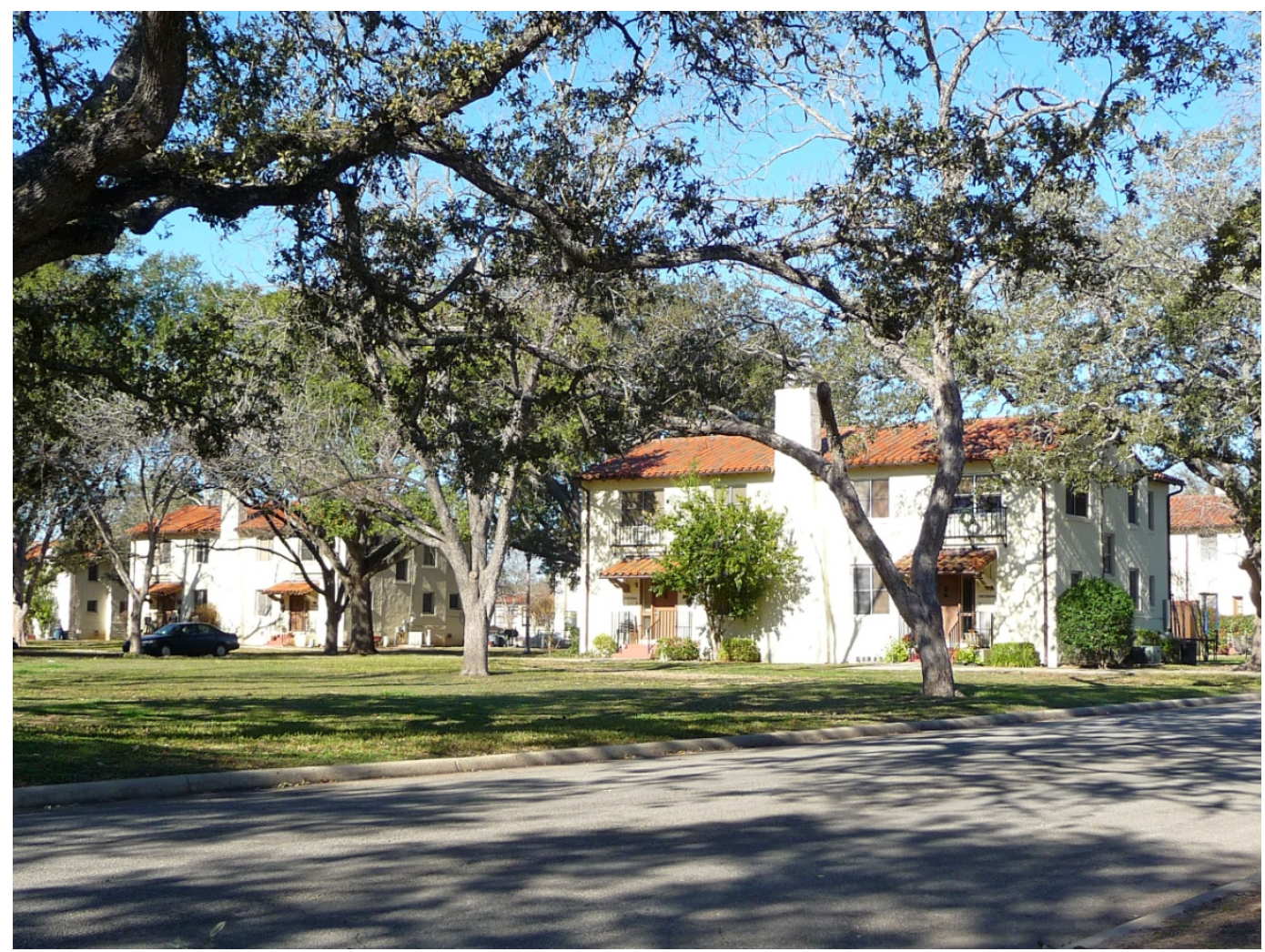

Figure 91. Two-story duplex NCO quarters, 2012 (ERDC-CERL). 


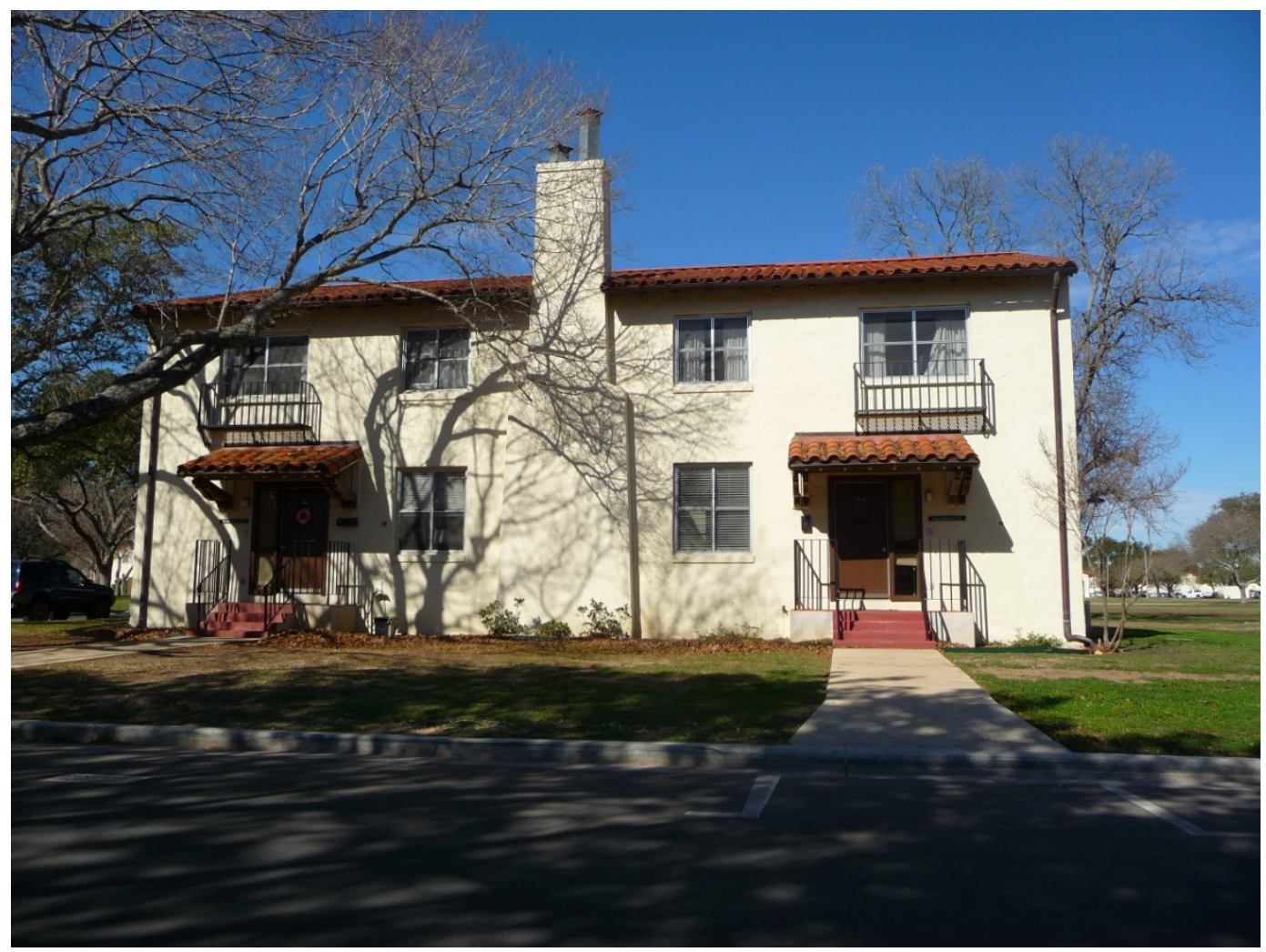

Figure 92. Two-story duplex NCO quarters, 2012 (ERDC-CERL).

\subsubsection{Noncommissioned Officers' Clubs}

Randolph Field was planned with two NCO Clubs, one in the eastern section of NCO quarters and one in the western section. The buildings were identical (Buildings 598 and 693) and were completed in 1931 according to Quartermaster Corps designs. Both clubs were clad in stucco, and each had a five-bay, arched entry set under a gabled, clay tile roof (Figure 93). The clubs served as social centers for the surrounding housing areas and included assembly and dance halls. The NCO clubs have been converted to other uses and have received additions to the original structure. Figure 93Figure 96 compare historic images of the clubs to conditions in 2012. 


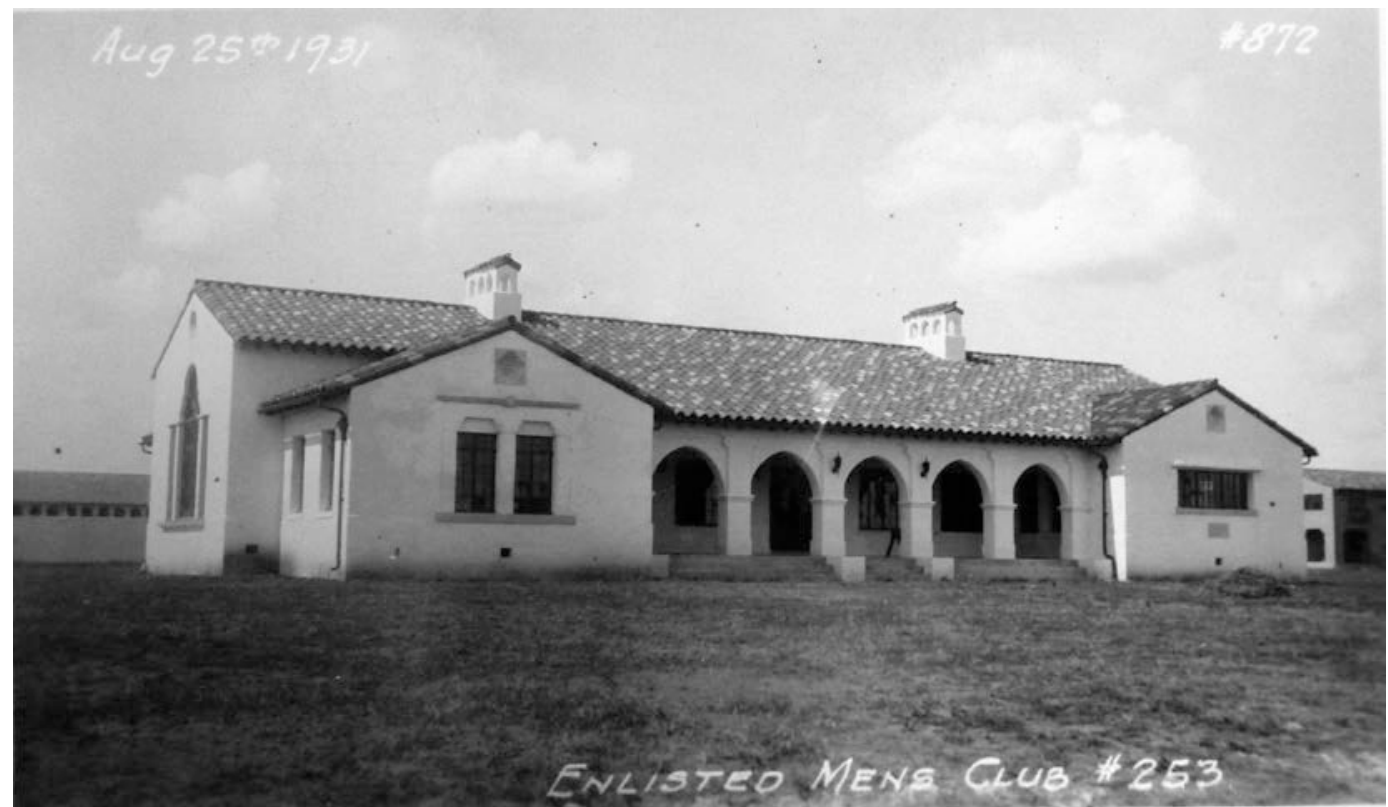

Figure 93. Exterior of the western enlisted men's club in 1931 (then designated as Building \#253), (Norfleet Giddings Bone Papers, University of Texas at San Antonio Libraries Special Collections).

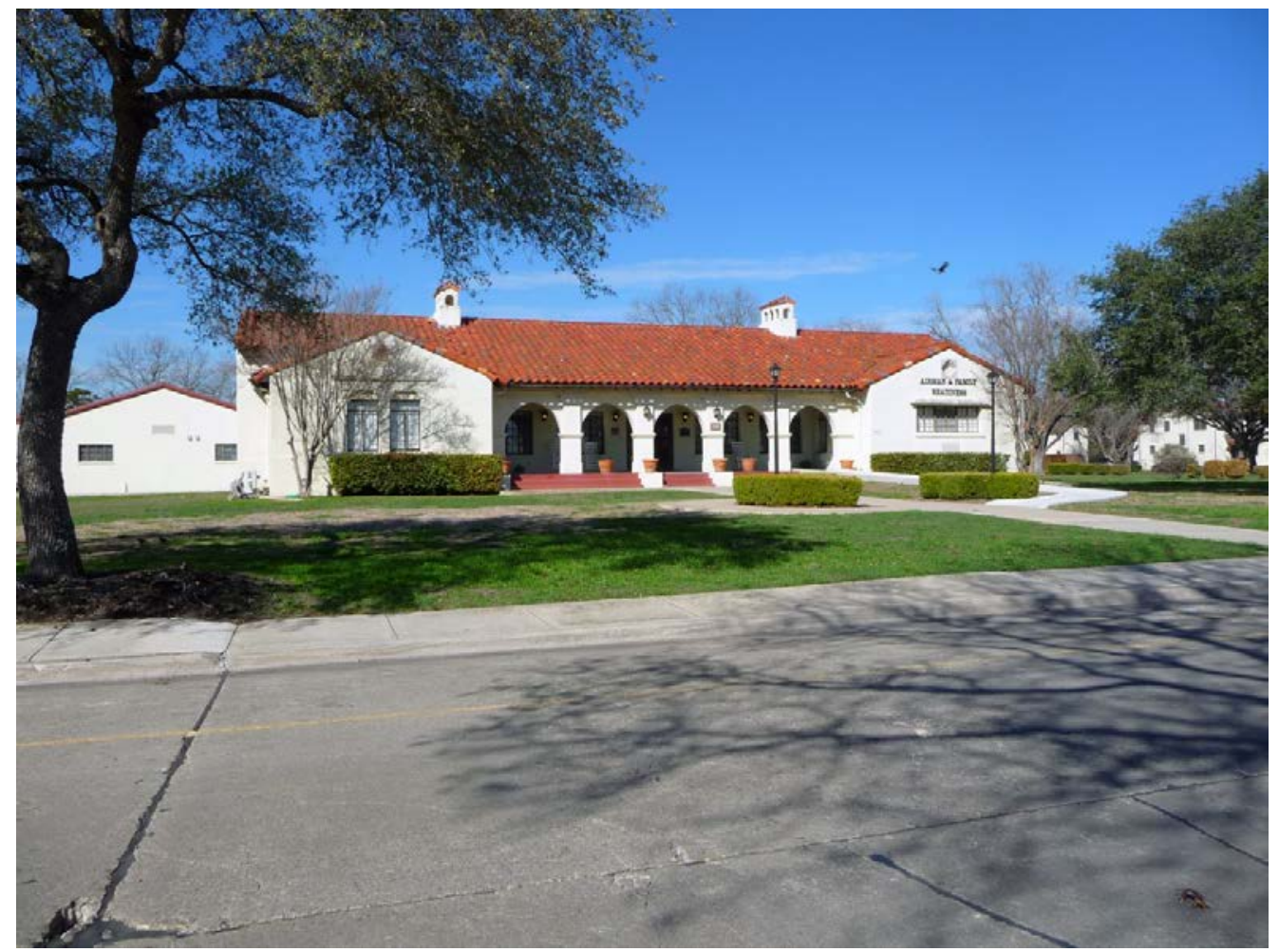

Figure 94. Former NCO club near the west flight line. Additions to the original structure have been made on the north side of the building, 2012 (ERDC-CERL). 


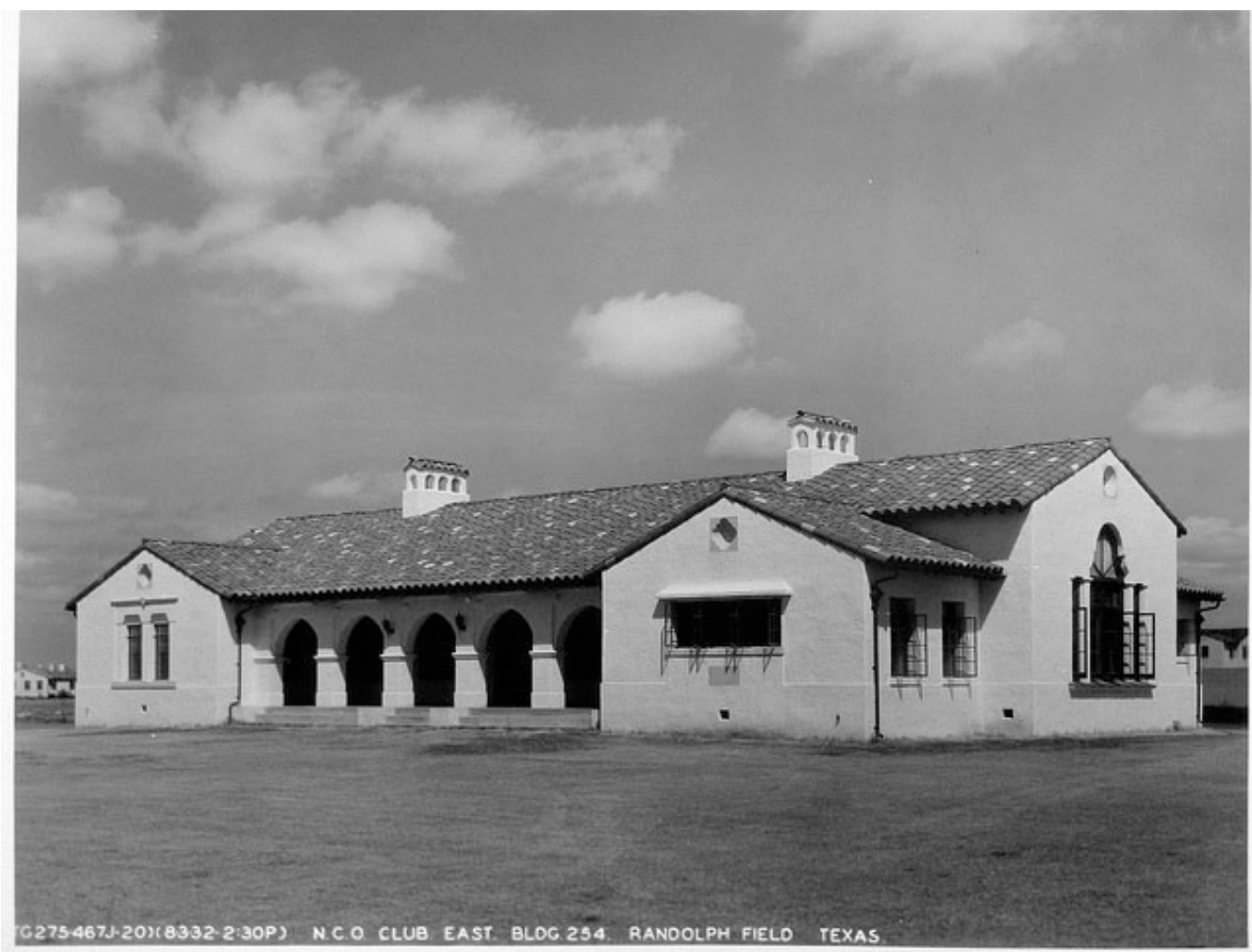

Figure 95. NCO club on the east side of the base in the 1930s (then designated as Building \#254), (NARA RG342 Box 1072 B20806).

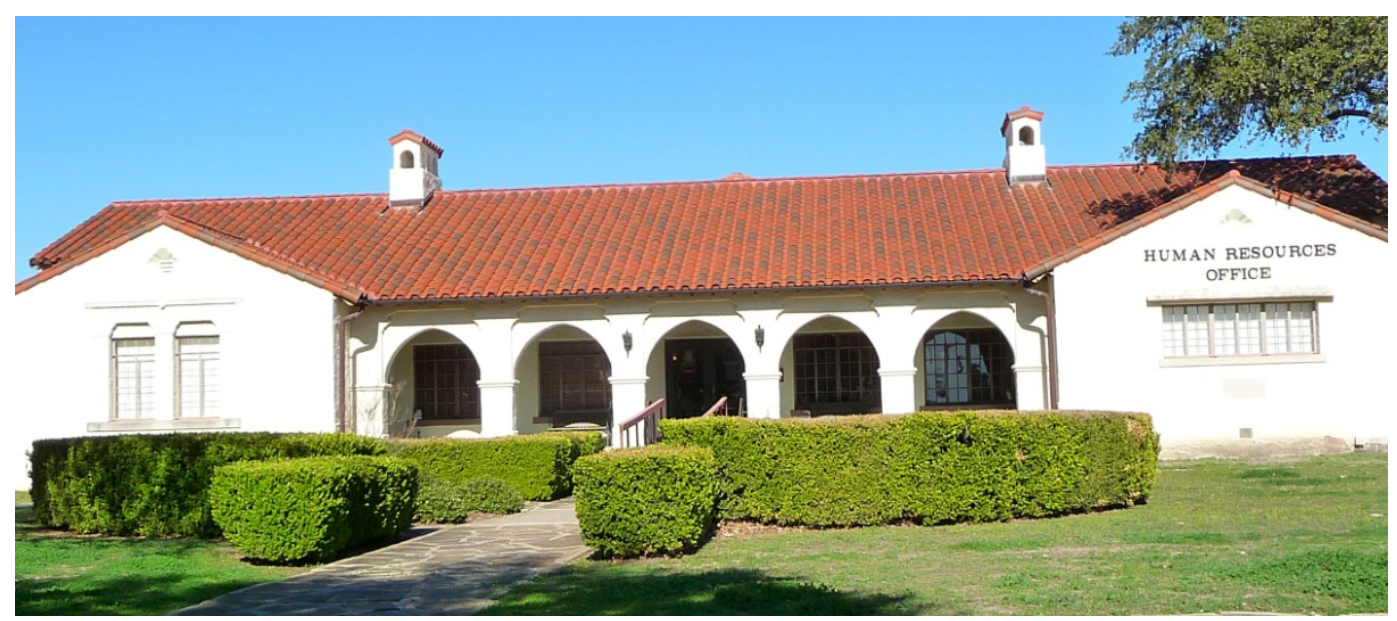

Figure 96. South façade of the former NCO club near the east flight line, now converted to office space. An addition has been added to the north (ERDC-CERL, 2012).

\subsubsection{Bachelor officers' quarters}

The BOQ area was designed as a cohesive complex that included two winged barracks buildings with the mess hall located between, and four garage buildings located south of the barracks (Figure 97). The complex 
was located east of the Chapel and Washington Circle, and it provided officers with access to the flight lines, the Officers' Club, and recreational fields to the southeast. As the base grew in the latter half of the twentieth century, four more barracks buildings were added north of the original buildings.

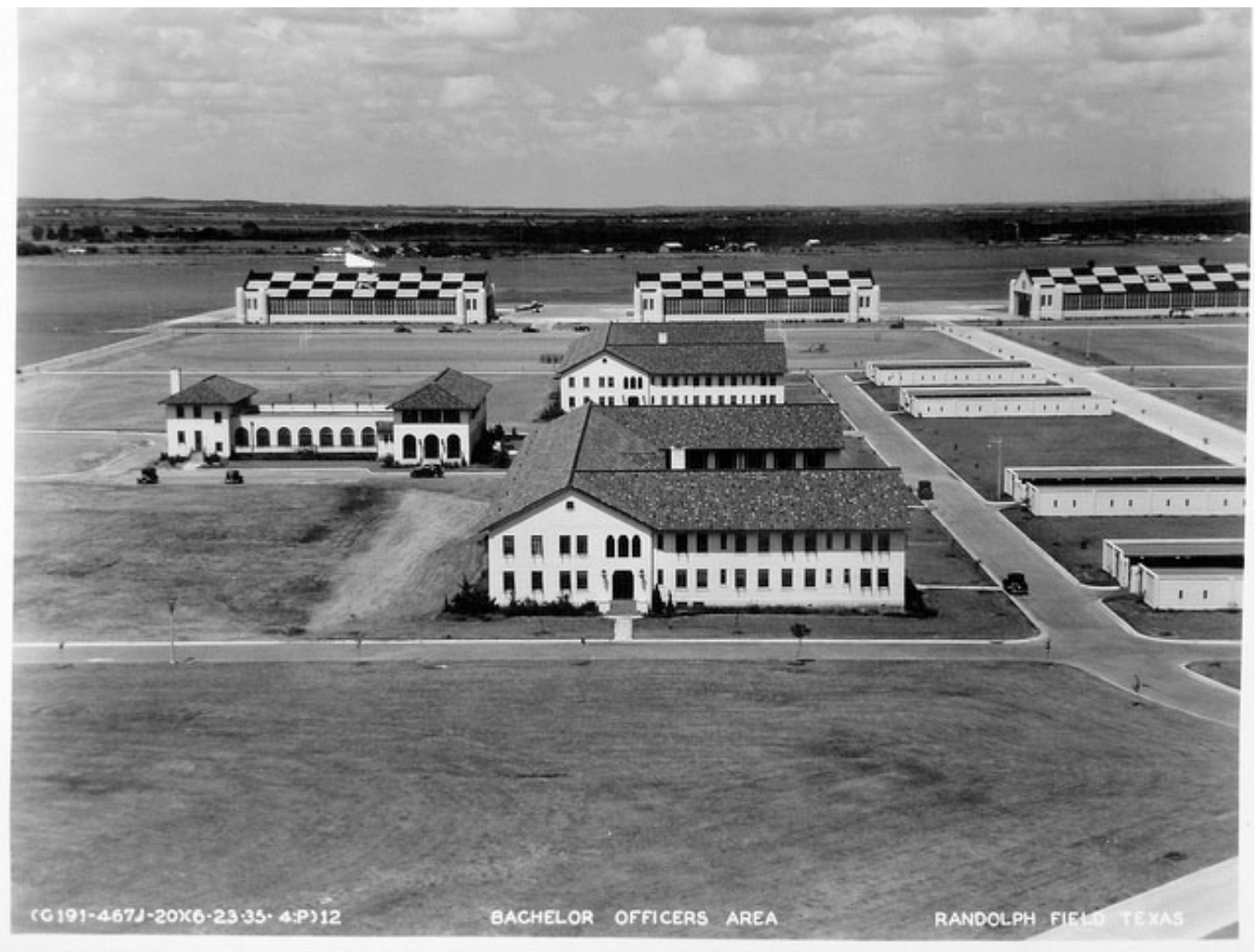

Figure 97. Bachelor Officers' Quarters (center) in the 1930s. Mess hall is to the left, garage buildings are to the right, and hangars are in the background of this photo (NARA RG342 Box 1072 B20792).

The original buildings of the BOQ were designed in the Spanish Revival style used across the rest of the base. The buildings featured stucco walls, red tile roofs, and decorative wrought-iron accents (Figure 98). Many of these architectural features have been retained on the mess hall and BOQs (Figure 99 and Figure 100). 


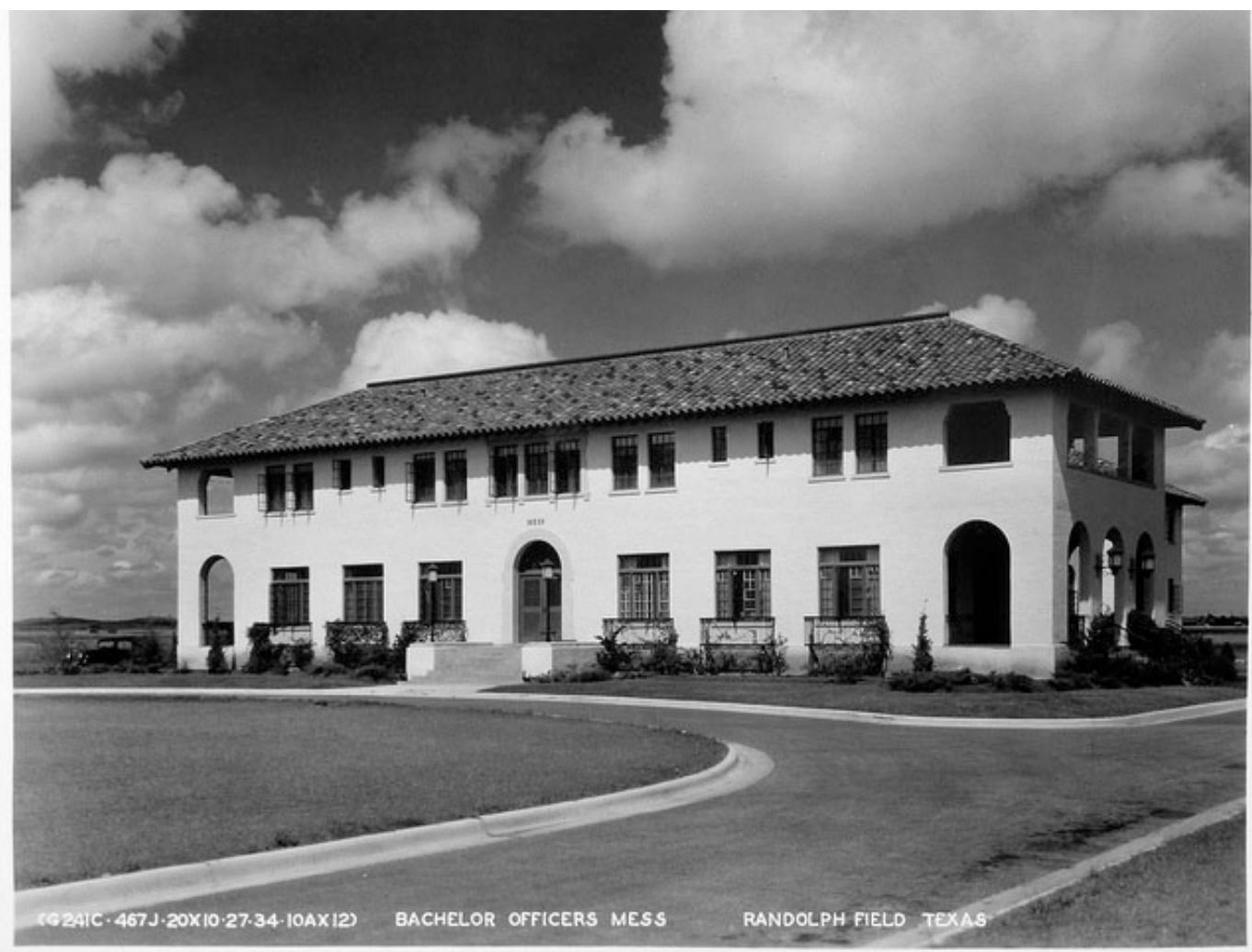

Figure 98. Bachelor Officers' Mess Hall in the 1930s (NARA RG342 Box 1072 B20793).

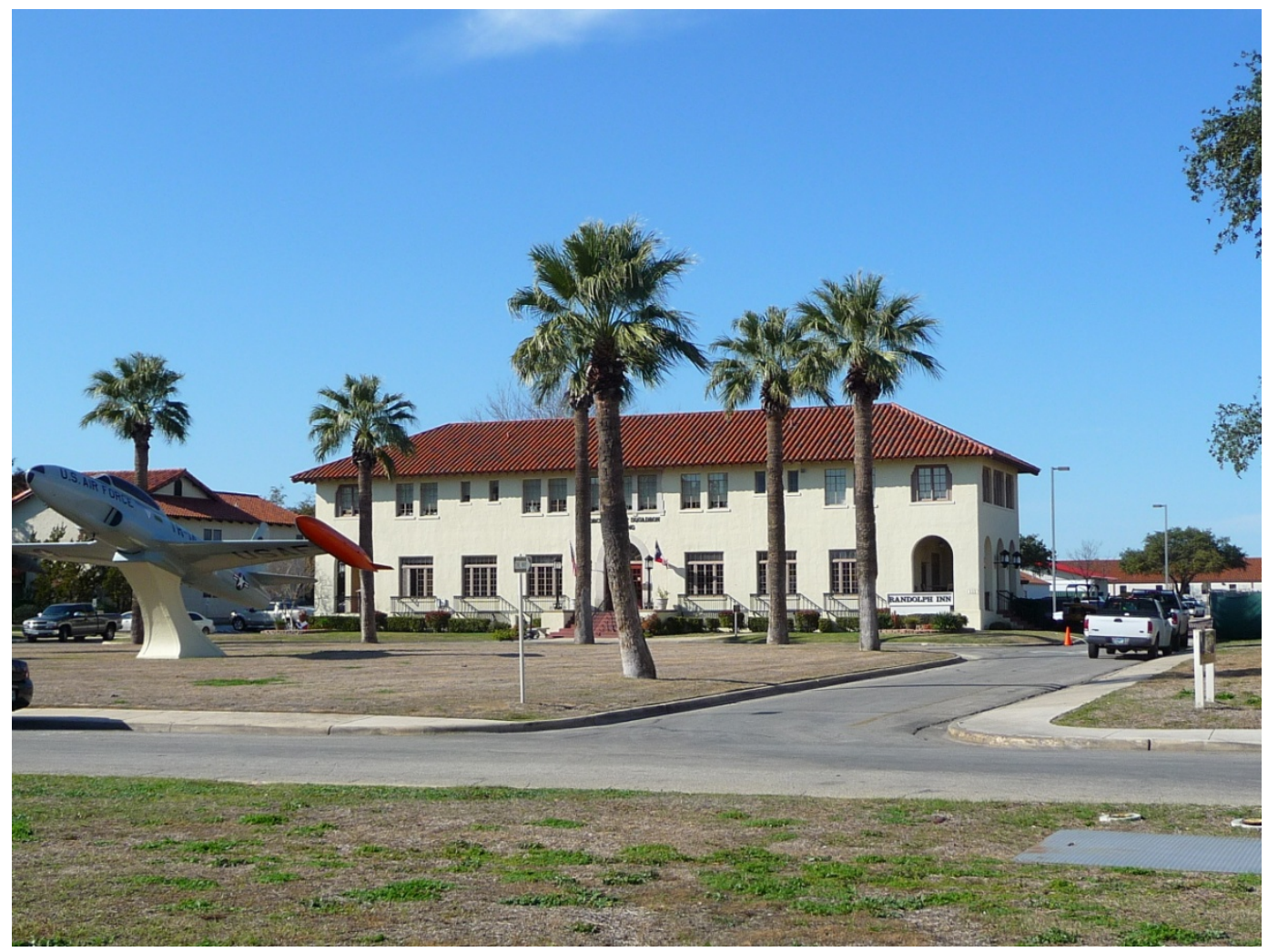

Figure 99. Former BOQ Mess Hall, now Randolph Inn, 2012 (ERDC-CERL). 


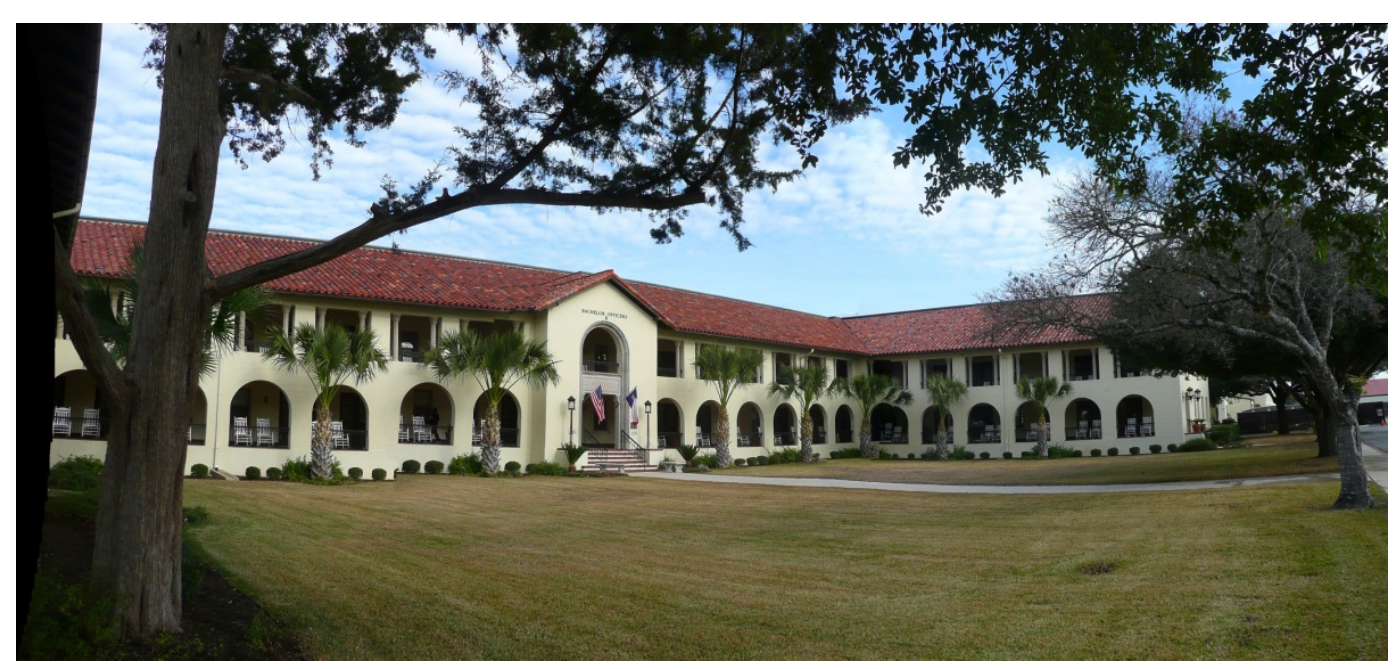

Figure 100. South elevation of the BOQ, 2012 (ERDC-CERL).

\subsection{Vegetation}

Vegetation is a characteristic of the landscape that has a relationship to land use patterns. ${ }^{44}$ Differences in vegetation patterns can delineate boundaries, land use areas, and natural areas such as streams or ravines. In the military context, how vegetation is used can connote ceremonial, residential, training, or utilitarian areas. For example, residential neighborhoods are often the most heavily planted areas on military installations while open spaces allow for gatherings or training. Additionally, prominent support buildings such as headquarters, chapels, hospitals, and officers' clubs tend to have more decorative landscaping than utilitarian buildings such as motor pools, flight lines, and the warehouse and shop areas.

The high level of planning and attention to architectural detailing that characterized the construction of Randolph Field was also extended to the landscape. The well designed base plan had been augmented with rows of oak trees, green boulevards, extensive plantings, gardens, and fountains. The landscape design, like Randolph's architecture, was based on regional themes that highlighted the environment of the Southwest. According to one description, the landscaping consisted of "trees and shrubbery, green lawns and bright flower beds." 45 As Randolph Field was constructed, every landscape detail was addressed to enhance the beauty of the base.

44 Loechl, et al., 2009, 83.

45 Writers Program of the WPA, Randolph Field, 1942, 23. 
Consideration was given to Randolph Field's landscape early in the planning phases. By 1928, during the initial phases of base construction, Lieutenant Norfleet Bone was placed on special duty as assistant to the Chief Quartermaster and became Randolph's landscape architect. As part of the master plan, twenty acres had been set aside and plans drawn for a base nursery (Figure 101). By the time Lt. Bone assumed his new duties in the fall of 1928, he began finding plants that would grow well in the soils and climate of south-central Texas. To create the catalog of these plants, Lt. Bone recorded climatological data, examined San Antonio's meteorological data from 1885 to 1928, analyzed soil samples, and examined the ground water supply. ${ }^{46}$

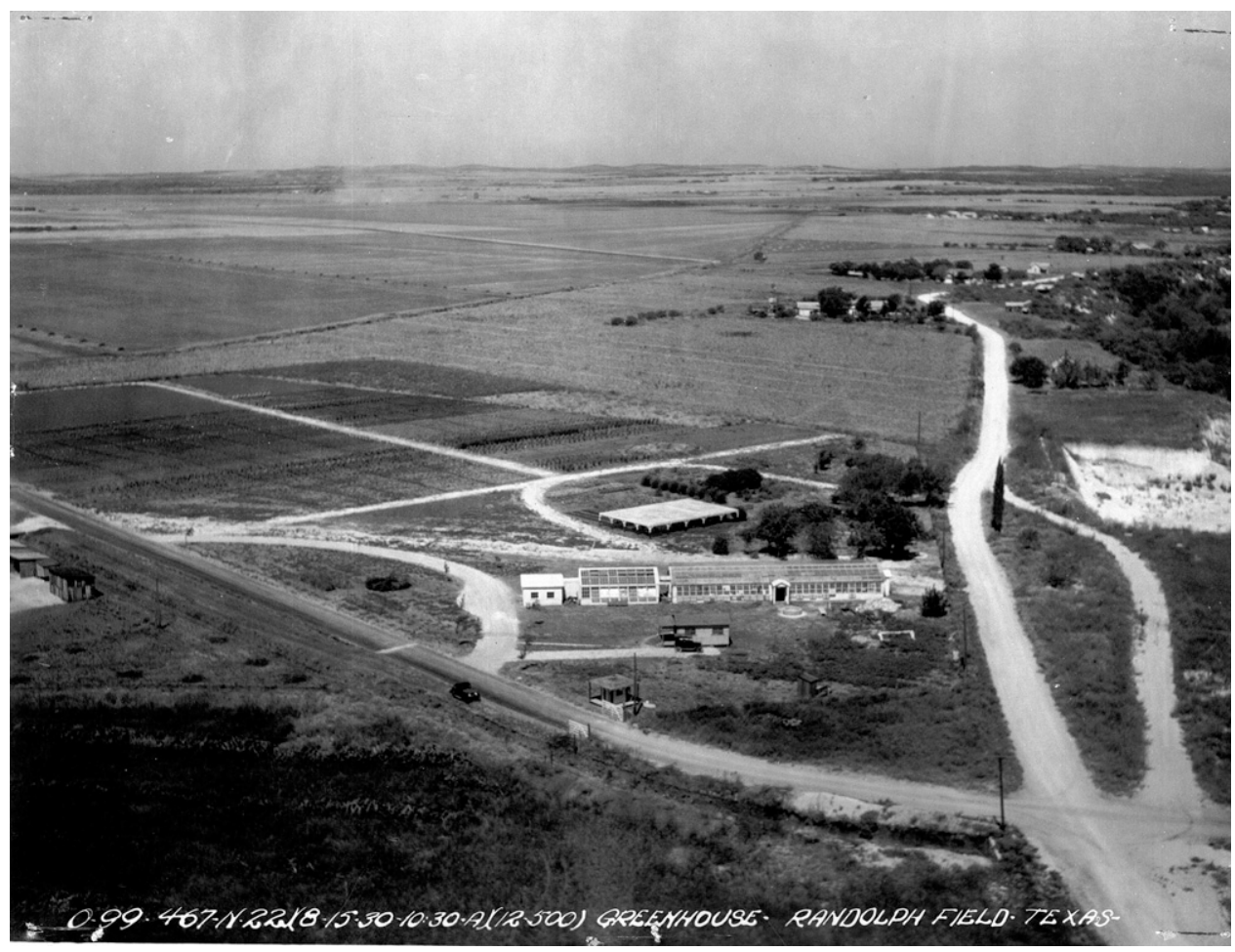

Figure 101. Aerial view of Randolph Field's nursery and greenhouse, 1930 (Bone Collection Randolph AFB Cultural Resources).

Lt. Bone was born in Gainesville, Texas, in 1892. His education included two Bachelor of Science degrees-one in civil engineering from New Mexico A\&M College in 1915 and the second in landscape architecture from Texas A\&M College in 1923. Lt. Bone initially entered the Air Service in 1917, where he became a commissioned pilot serving with the First Aero Squadron until 1920. After his service and education in landscape

\footnotetext{
46 Victoria G. Clow, Peter E. Duane, and Lila Knight,. The Architecture of Randolph Field, 1928-1931. (Plano, TX: Geo-Marine, Inc., Spring 1998), 63.
} 
architecture, Bone was employed as a landscape designer and engineer with McGinnis and McGinnis in Dallas, Texas, until he reapplied for military service in 1927. Although he was stationed at Fort Sam Houston for his second tour, Lt. Bone's background and expertise led him to serve as the Supervising Landscape Architect and Landscape Engineer for Randolph Field and for Barksdale Field at Shreveport, LA.

In addition to collecting environmental data at Randolph Field, Lt. Bone was also directing the planting and grading of the east and west landing fields. The fields covered 1,900 acres which were sodded with Bermuda grass. Bermuda grass was chosen because it could withstand the repeated wear of many takeoffs and landings, but also because it would be green throughout most of the year. Drainage for the landing fields was directed by swales that were approximately six inches deep with a one foot drop in grade every forty feet. After the construction of the landing fields, Lt. Bone began work on a park water system and landscaping the main entrance gate. Records show that for the main gate, Lt. Bone used silverberry, jasmine, sawtooth yucca, Spanish dagger, Italian cypress, Pfitzer juniper, quinine bush, and ten varieties of cacti in complement to the Spanish Colonial Revival style of the gatehouse. According to Lt. Bone's records located in Special Collections (MS 141) of the University of Texas at San Antonio Libraries, 528 plants were used to create the landscape of the gatehouse area, entry side parks, and the Army Air Corps insignia at the main entrance (Figure 102). 


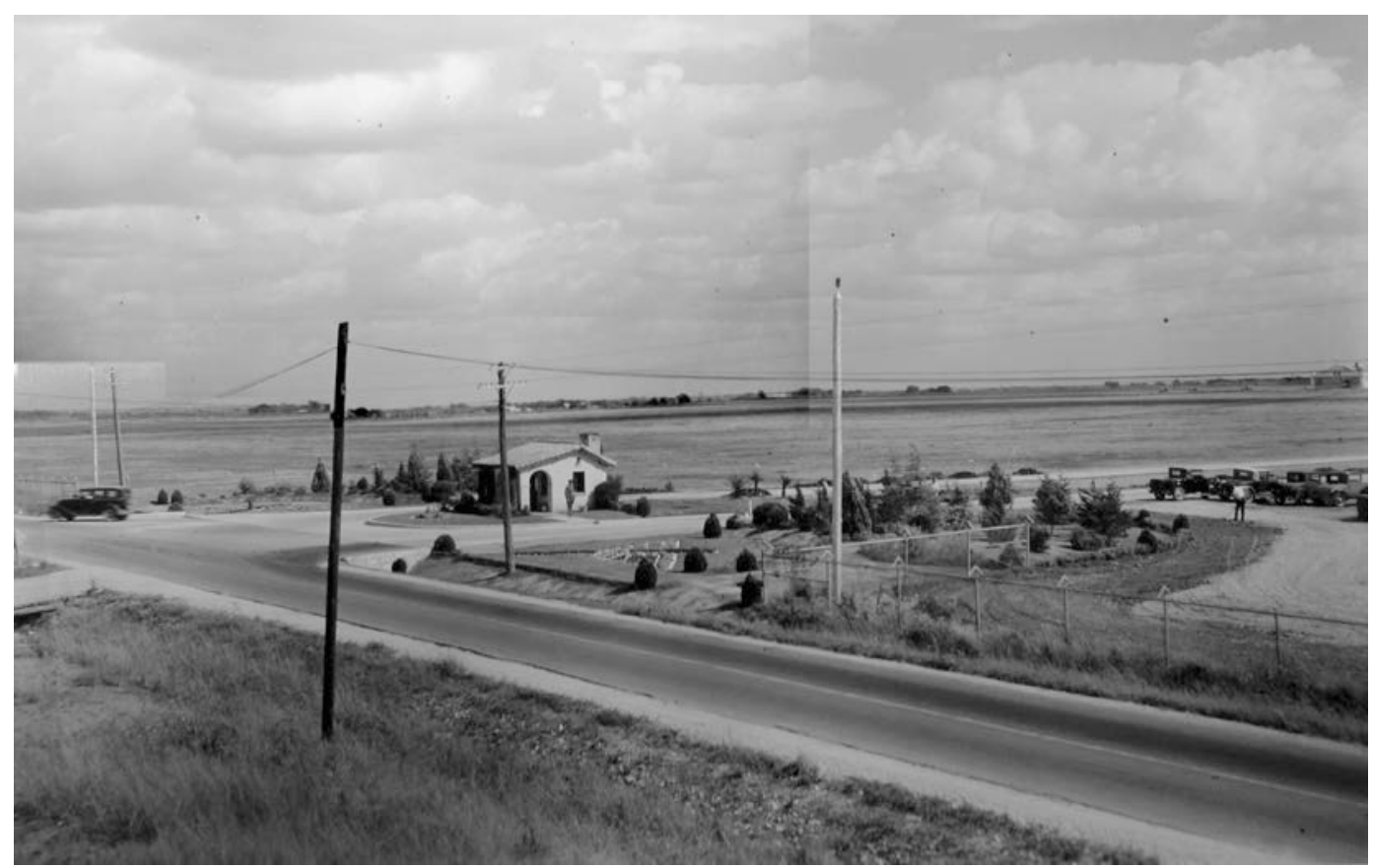

Figure 102. View of the extensive plantings around the main gate, 1930s (Norfleet Giddings Bone Papers, University of Texas at San Antonio Libraries Special Collections).

Lt. Bone incorporated many plants native to Bexar County into Randolph's landscape and to source this plant material he used native plants that had previously been established in the nursery, tree and shrubs from Camp Stanley, as well as transplanting Spanish oak and live oak trees from nearby Leon Creek. Although Lt. Bone placed an emphasis on regionally appropriate plants, he also chose numerous plants that grew outside of south-central Texas. In fact, for unexplained reasons and just days before Randolph's dedication, Lt. Bone and Lt. T.V. Foster flew to New Mexico and west Texas to collect a variety of cacti, sotol, yucca, and other desert plants. An issue of the San Antonio Light summarized the unusual use of cactus at the new flying field.

Some of the rarest specimens of the cactus family known to Western States were brought to San Antonio. Among the plants are three of the giant cacti known in botanical circles as carnegiea gigantea [sic] of sahuaro. One of these, about three inches high, was given to Lieutenant Bone by Professor Forrest Shreve 
of Carnegie institute [sic] and is five years old. Some plants on the desert have grown as high as 70 feet. $^{47}$

Although the cacti were not regional species, Lt. Bone incorporated them along with other Southwestern plants to emphasize the Spanish Colonial Revival and Southwest regional aesthetics of the base.

By 1931, as the base was nearing completion, Lt. Bone focused on landscaping the areas around the completed buildings. Nearly every building on the base was accented with ornamental shrubs and shade trees. Medium-sized vegetation, like hedges and shrubs, was used to screen service areas from the more prominent areas of the base. Hedges and shrubs also lined the central parkway, and hundreds of trees were planted along the streets. In 1932, before many other trees had been planted at Randolph, the Daughters of the American Revolution donated 104 live oak trees to the reservation. The donation was in honor of the George Washington Bicentennial year of 1932, during which patriotic societies planted trees throughout the country in honor of the first president. During the next year, the donation was increased to 120 trees. The trees, referred to as the George Washington Memorial Trees, were planted to border the circles and parkways of the base. The trees were planted at the northern arc of Washington Circle, on the east and west sides, and extended around the Administration Building area, North Park, Military Plaza, and South Park. A native red granite bolder with a bronze plaque was placed in Washington Circle to commemorate the donation. ${ }^{48}$ Although numerous plants came from donations, the majority of around 25,000 plants used at Randolph were cultivated in the base nursery (Figure 103).

47 In Clow, et al. The Architecture of Randolph Field, 1928-1931, 66.

48 Writer's Program of the WPA, Randolph Field: A History and Guide, 1942, 109-110. 


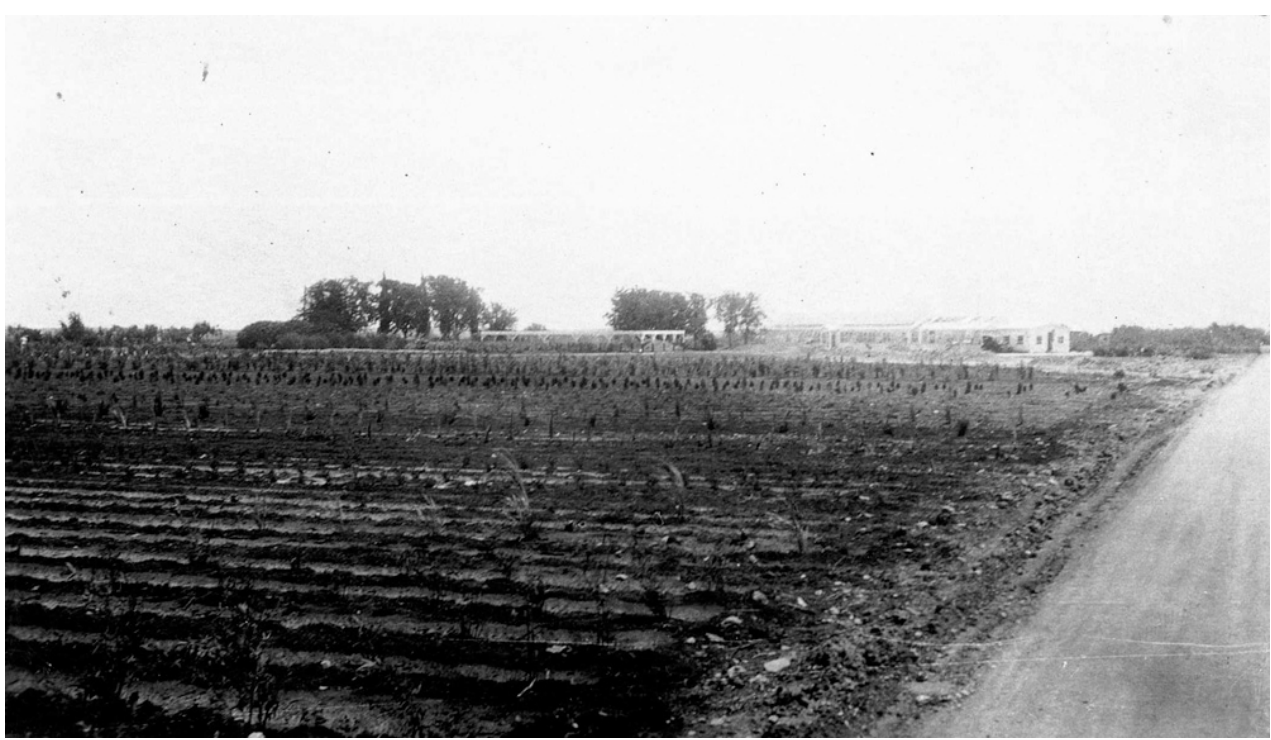

Figure 103. The Randolph Field nursery, undated (University of Texas at San Antonio, Norfleet Bone Collection).

By the summer 1932, the vegetation around Randolph Field was beginning to be established. In addition to the Bermuda grass of the landing fields, the Boulevards radiating from Military Plaza had been sodded and planted with Spanish and live oaks (Figure 104). The planting strategy for the base included 680 ornamental shade trees, 415 Spanish oaks, 74 buildings landscaped using 3,500 to 4,000 plants, 706 J apanese ligustrums set out as hedges, and hundreds of plant replacements. ${ }^{49}$ Although the initial planting effort was extensive, Lt. Bone stated that he still needed $\$ 10,000$ to complete the planned landscape work. The funds were not available in 1932, and the now-promoted Captain Bone was discharged from his second tour with the Army that same year. The landscaping and maintenance efforts at Randolph were thus taken over by interested organizations and individuals until that system was replaced by enlisted men assigned to landscape detail.

49 Clow, et al. The Architecture of Randolph Field, 1928-1931 1998), 69. 


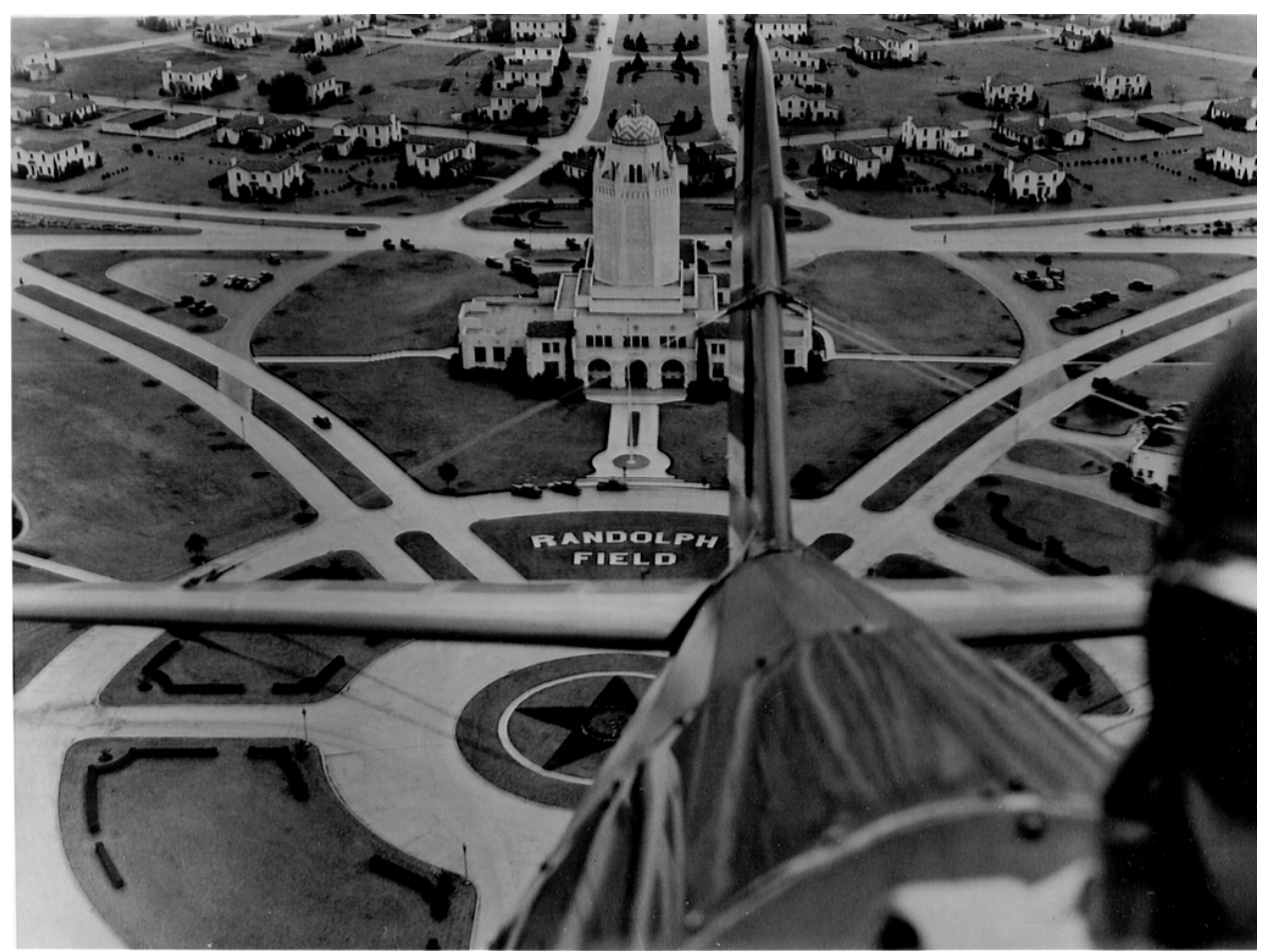

Figure 104. In this aerial view of the Taj Maha/the landscaping around the administration building is illustrated as well as the tree and shrub patterns in the areas around Washington Circle and down the median of North Park, 1939 (NARA B12364).

Over the four years Lt. Bone worked at Randolph at least \$150,000 was invested in landscaping, an amount which included the more than $\$ 80,000$ spent on the landing fields. At the time, the military rarely expended this much money on landscaping, which further underscores the importance placed on the early landscape work at Randolph. The legacy of Lt. Bone's work was continued throughout Randolph's subsequent growth, where his contributions are still evident.

A 1946 Arboreal Layout plan of Randolph shows that trees were still an important component to the base plan (Figure 105). The drawing shows that nearly every street has been lined with trees, and it specifies that ligustrum trees were to be planted along Main Circle, Northeast and Northwest Drives, and inside Military Plaza; Ash trees were planned along the inner and outer octagons, library, and Nurses' Quarters Areas; and all other trees would be oaks. The resulting planting strategies produced a park-like environment that was free from rows of uniform buildings and one in which service and functional areas were screened from view by vegetation. The neighborhoods and many buildings were enhanced by extensive plantings that created a unique site by taking into account the design 
plan, architecture, and regional ecology. However, the extensive 1930s planting designs developed by Lt. Bone have been modified over time.

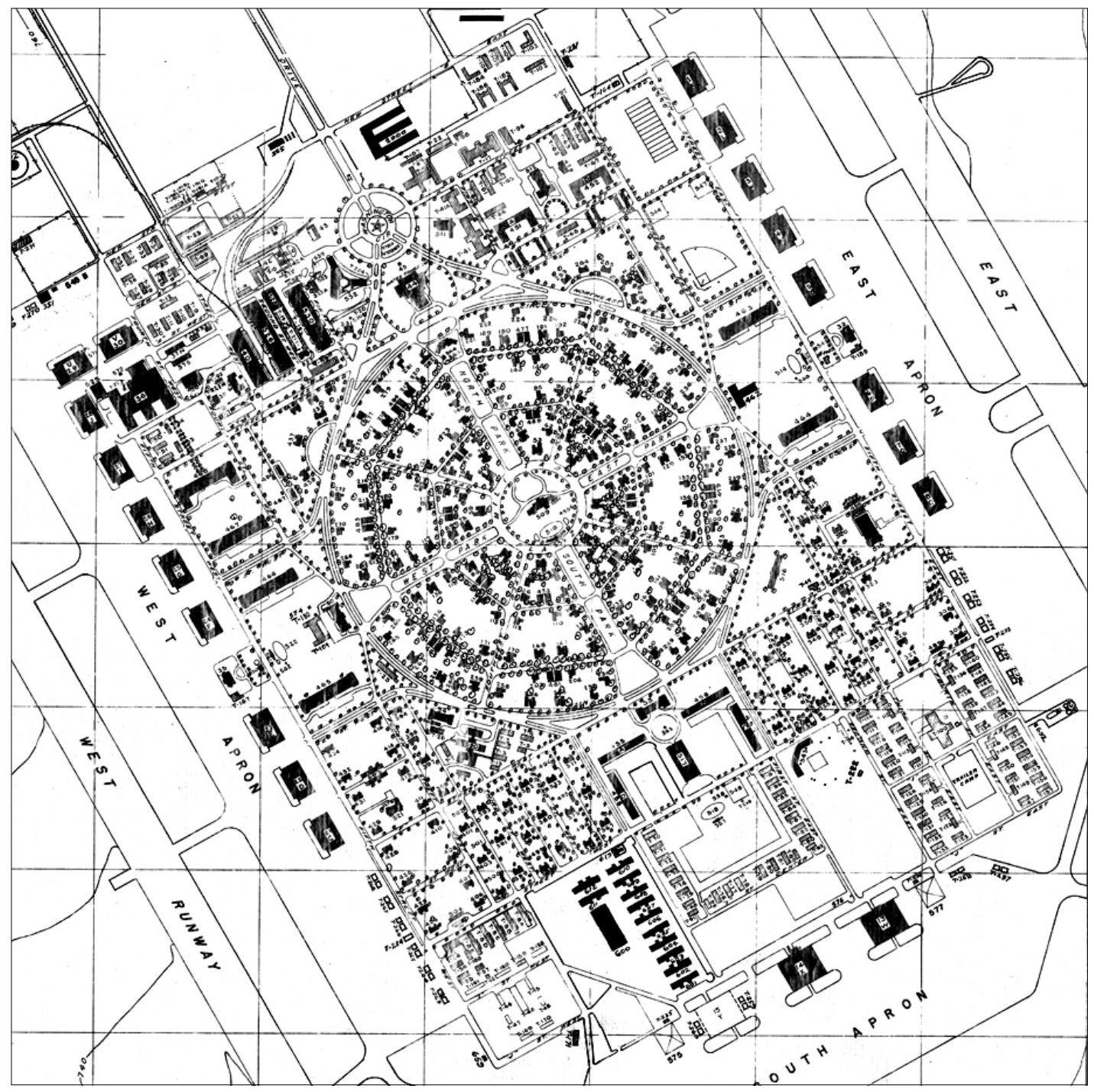

Figure 105. Arboreal layout that shows most of Randolph's streets lined with trees, May 1946 (Randolph AFB Cultural Resources).

In the twenty-first century, the planting requirements for Randolph AFB have changed in response to regional climate requirements. Randolph AFB Instruction 32-7001, released in 2008, established a new landscaping policy that emphasized using sustainable vegetation choices for landscaping. 50 The objective of sustainable vegetation is water conservation through choosing drought-tolerant species and low overall-maintenance requirements. Although Lt. Bone was not actively selecting plants for water con-

50 http://www.e-publishing.af.mil/shared/media/epubs/RANDOLPHAFBI32-7001.pdf 
servation, he did emphasize regional plant material that would highlight the Spanish Revival style of architecture.

Although many of the plants Lt. Bone specified were native to Southwest, changing ecological contexts have required that the historic planting palette be reevaluated. For example, in 2010, Monterey oaks replaced the live oak species that was being attacked by a disease known as oak wilt. The Monterrey oak was chosen because it is not susceptible to the disease, which has no cure and can destroy a 100-year-old tree in six months. ${ }^{51}$ Monterey oaks also grow more quickly while retaining many of the visual characteristics of Live oaks.

In Appendix A is a recommended plant list for Randolph AFB that meets the requirements of Randolph AFB Instruction 32-7001 while also proposing plants that will emphasize and retain the historic characteristics of the base's vegetation. The plants in Appendix A are a compilation of species from Lt. Bone's lists of plants that were grown or purchased for Randolph Field's landscape as well as the current plant list for the Base. These two lists were then compared with recommended sustainable and native plants for the San Antonio and south-central Texas region.

Because Lt. Bone's landscaping initiatives covered much of the base, the following section describes and compares the historic vegetation with current conditions according to the component landscape divisions.

\subsubsection{Boulevards and medians in the road system}

The elaborate boulevard road system created many medians and islands within the base. Lt. Bone designed plantings for the major boulevards of North Park, South Park, East Park, and West Park (Figure 106).

\footnotetext{
51 Tracey P. Adams and Jessica Harig, National Public Lands Day, Project 10-086, Washington, DC: Department of Defense Legacy Resource Management Program, 8 (accessed online at http://www.publiclandsday.org/sites/default/files/docs/resources/dec 2010 legacy final report.pdf)
} 


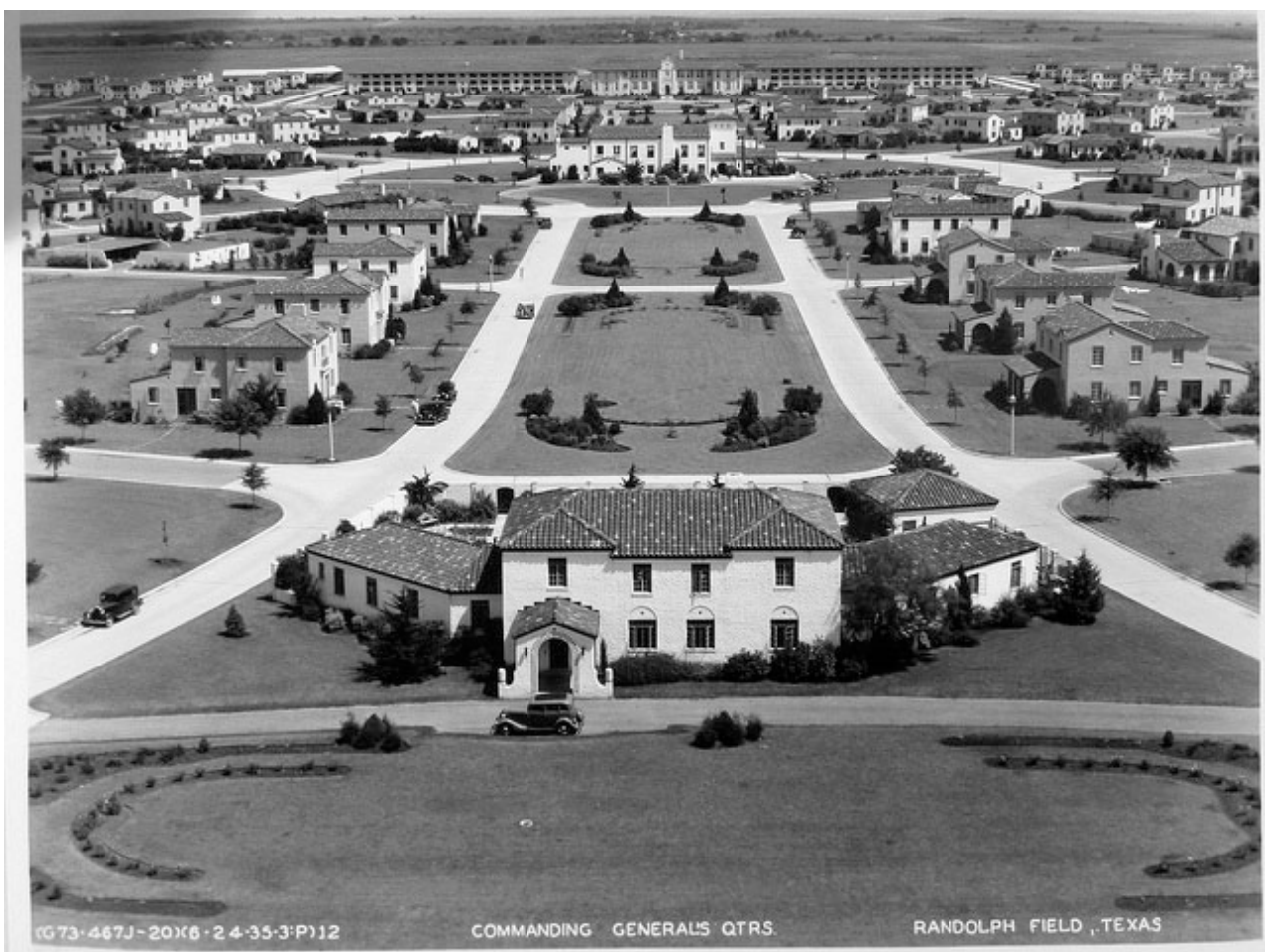

Figure 106. Looking south along the planting designs of North Park in the 1930s. This view also shows trees lining the streets (NARA RG342 Box 1072 B20828).

Figure 107-Figure 111 compares the current conditions of the boulevards with the historic conditions.

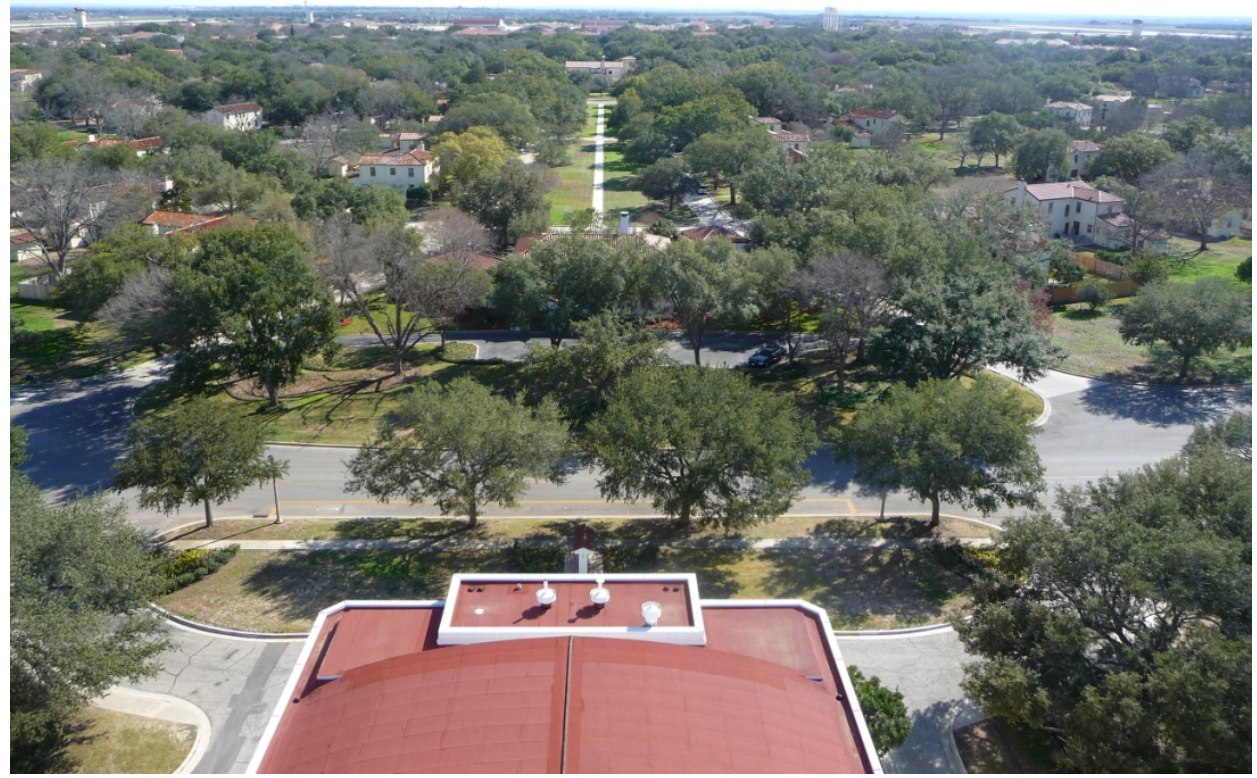

Figure 107. View south along North Park, 2012 (ERDC-CERL). 


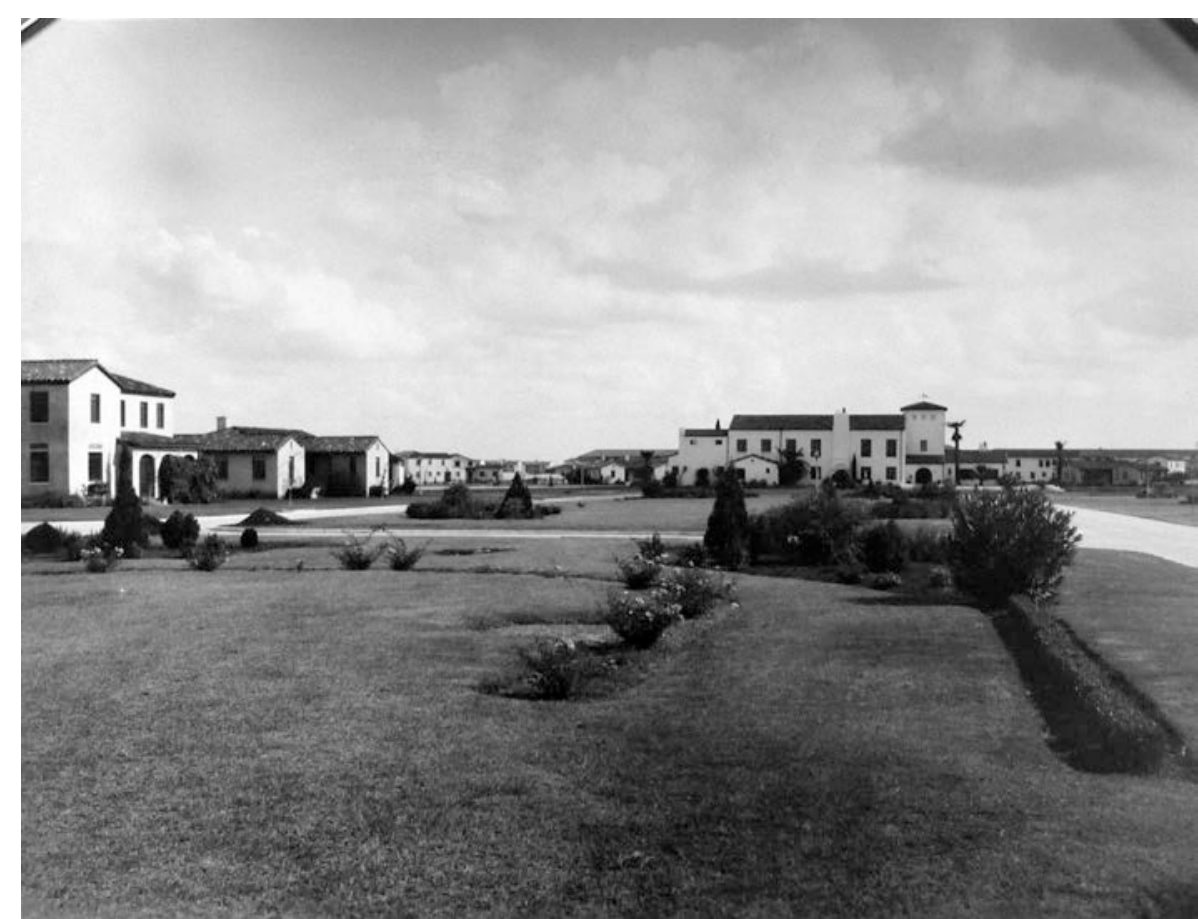

Figure 108. The extensively planted medians on North Park, looking toward the Officers' Club, undated (Norfleet Giddings Bone Papers, University of Texas at San Antonio Libraries Special Collections).

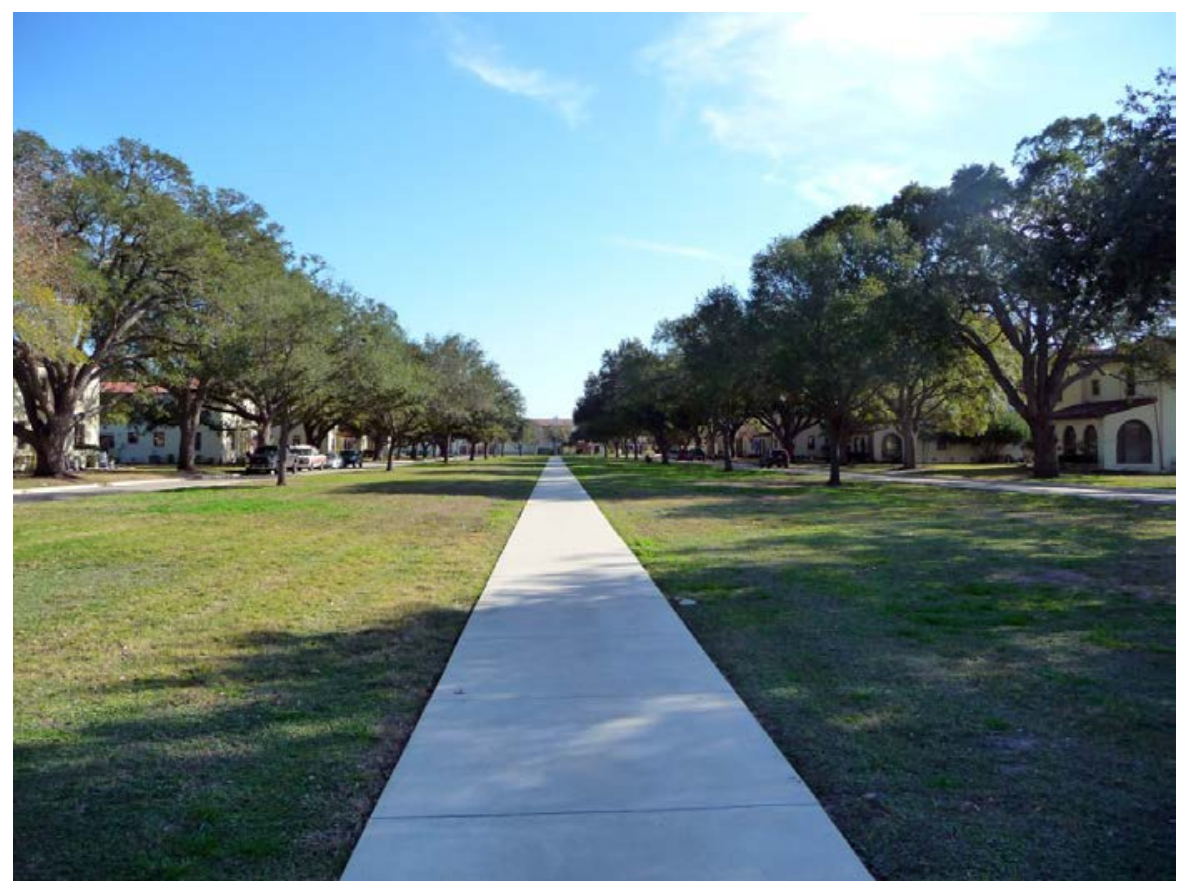

Figure 109. North Park median looking toward the Officers' Club. A sidewalk has been added down the middle of the space and street trees line either side. The original landscaping has been removed, 2012 (ERDC-CERL). 


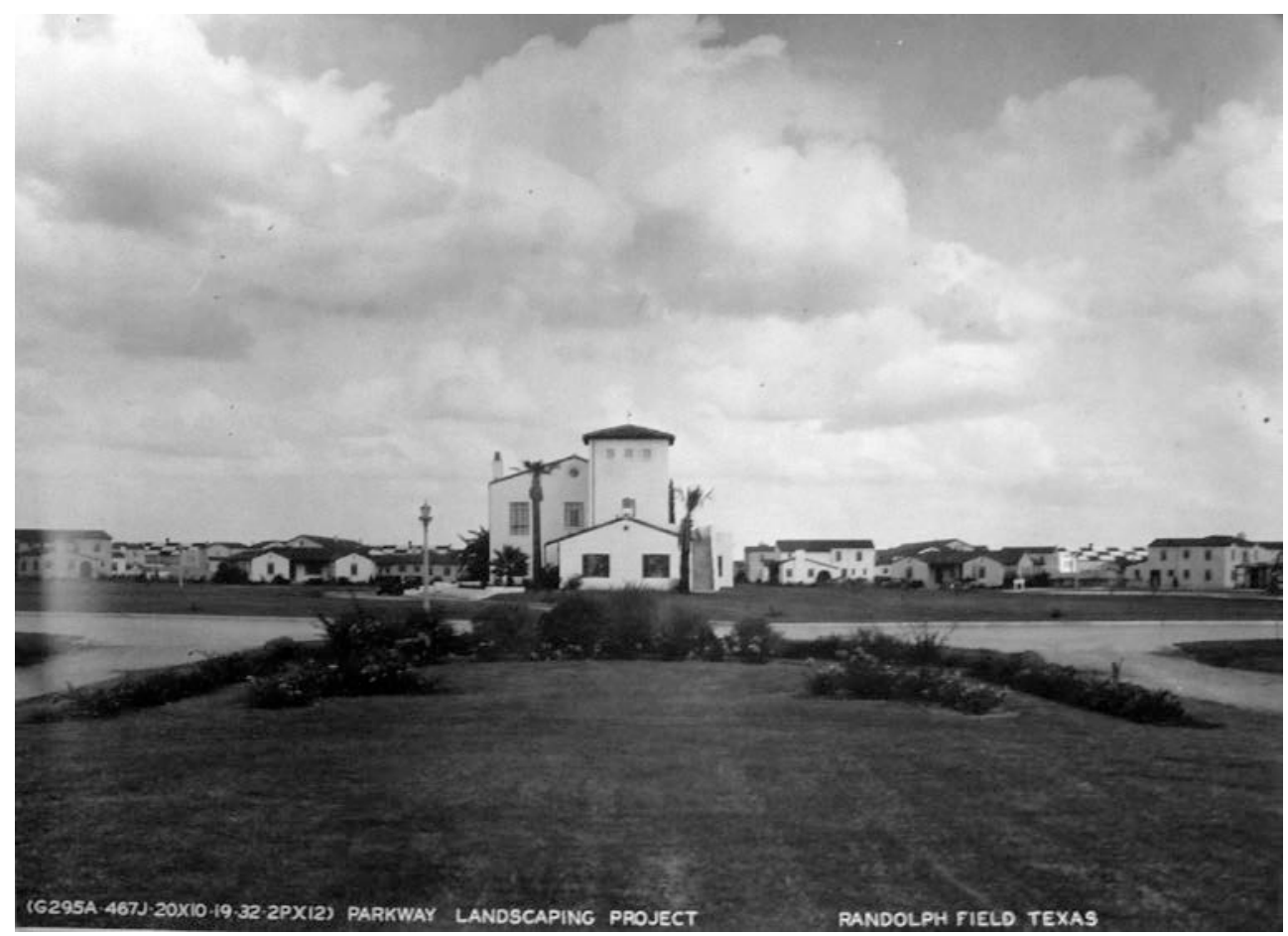

Figure 110. West Park looking toward the Officers' Club, showing the extensively planted medians, undated (Norfleet Giddings Bone Papers, University of Texas at San Antonio Libraries Special Collections).

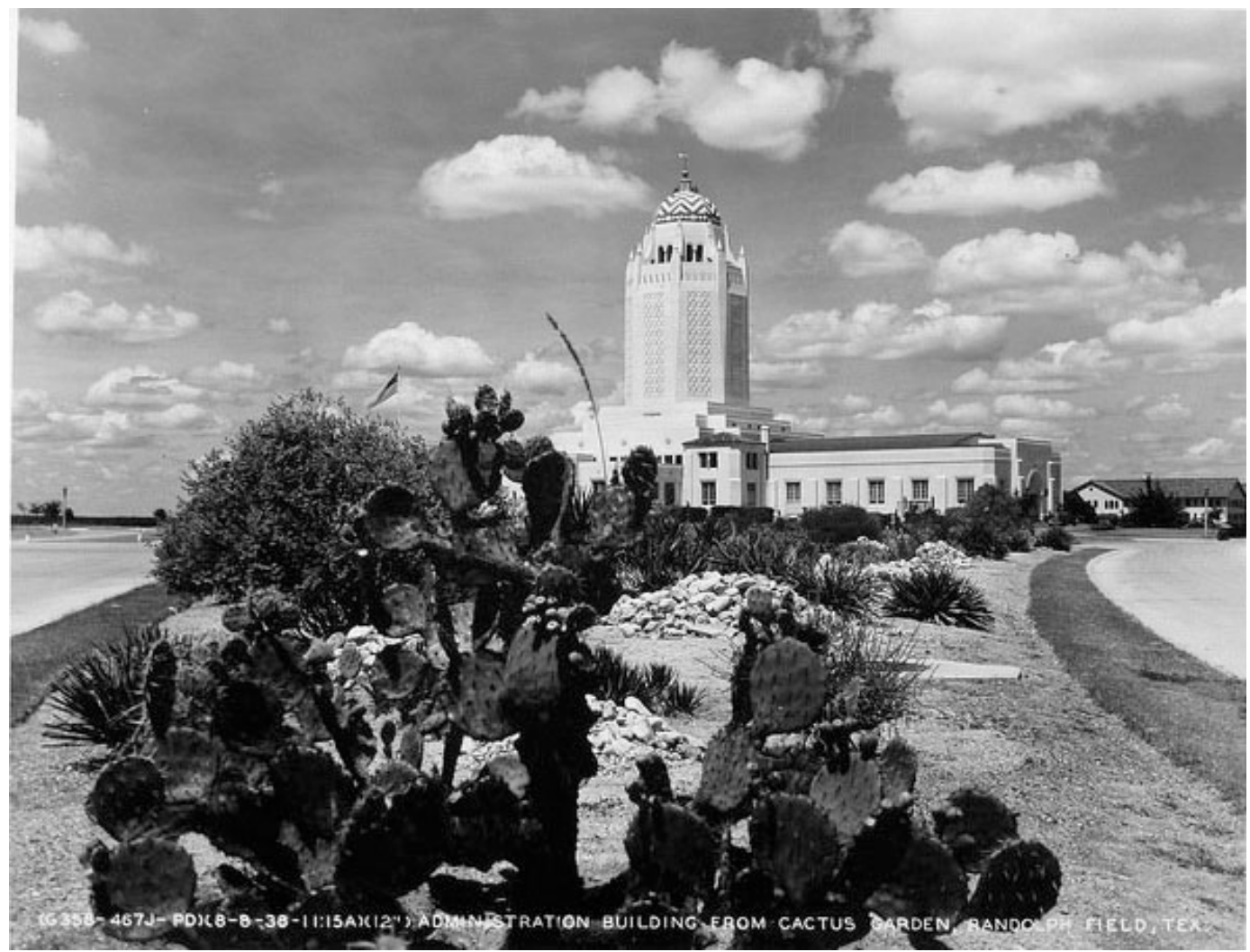

Figure 111. Lt. Bone also designed cactus gardens near the Administration Building, shown in the 1930s (NARA RG342 Box 1072 B20845). 
The medians created by the road network currently feature scattered trees and lack a uniform appearance (Figure 112- Figure 114).

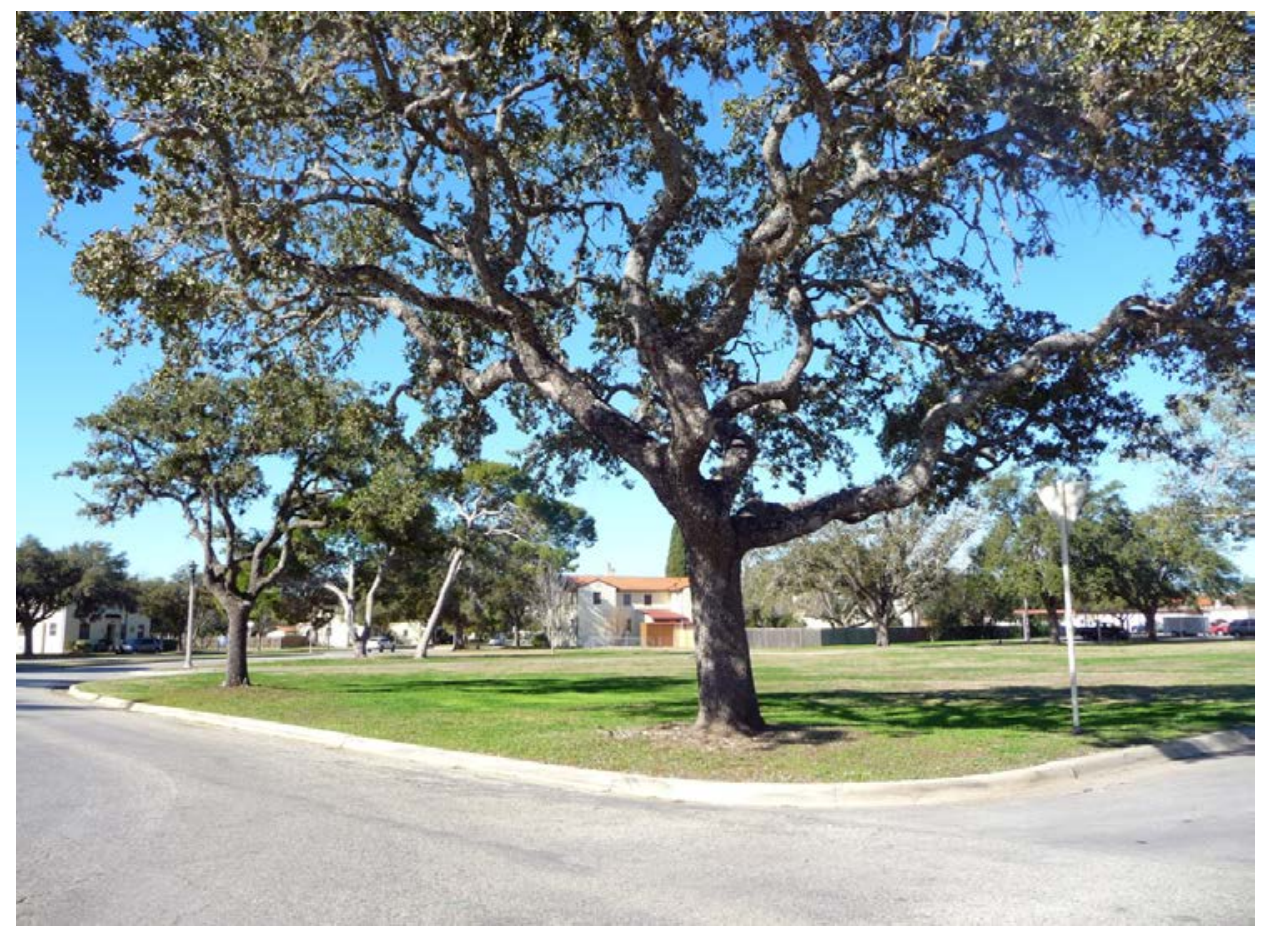

Figure 112. A median in the road network that has a few trees planted, 2012 (ERDC-CERL). According to Lt. Bone's planting plans for the base, many of these areas were vegetated.

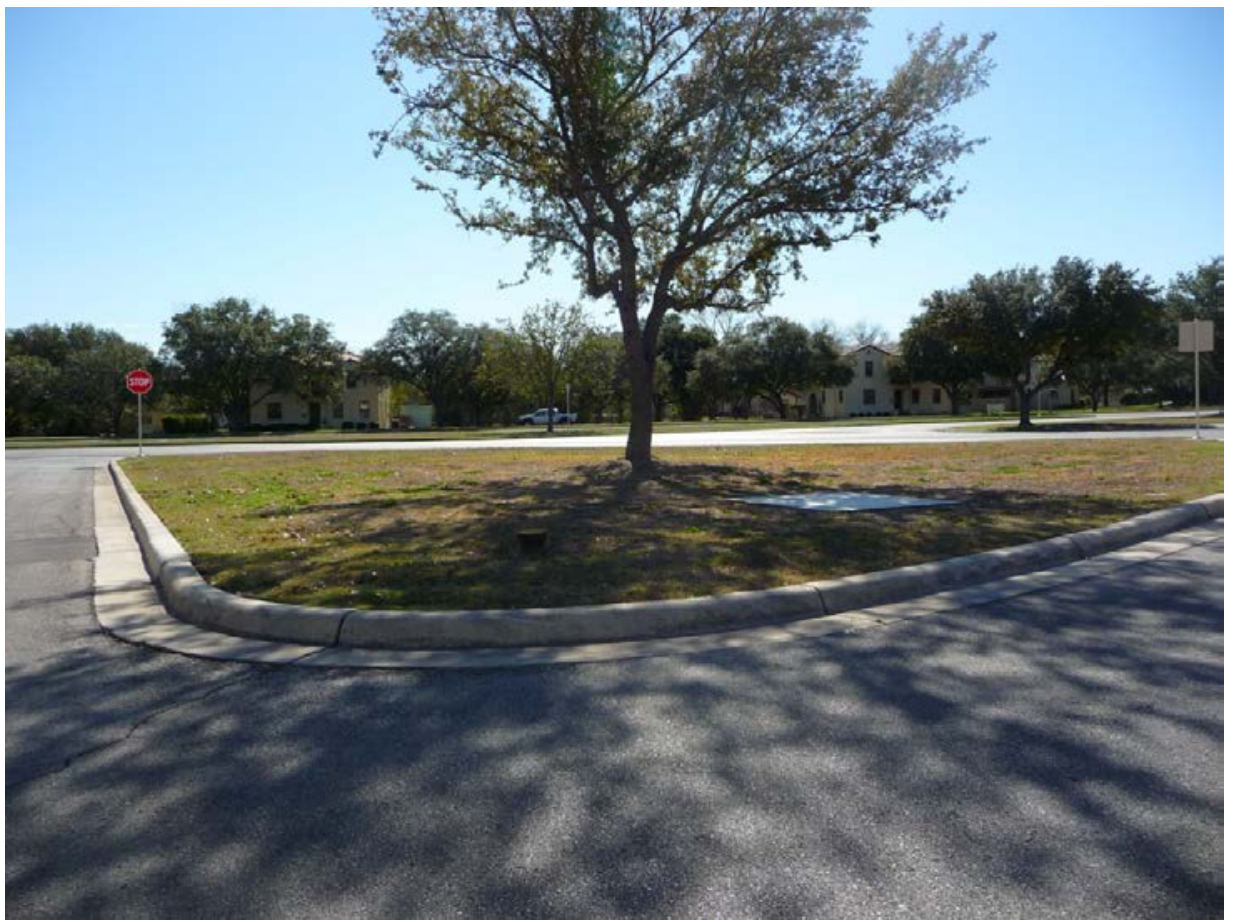

Figure 113. A median in the road network with a single tree planted in the center of the space, 2012 (ERDC-CERL). 


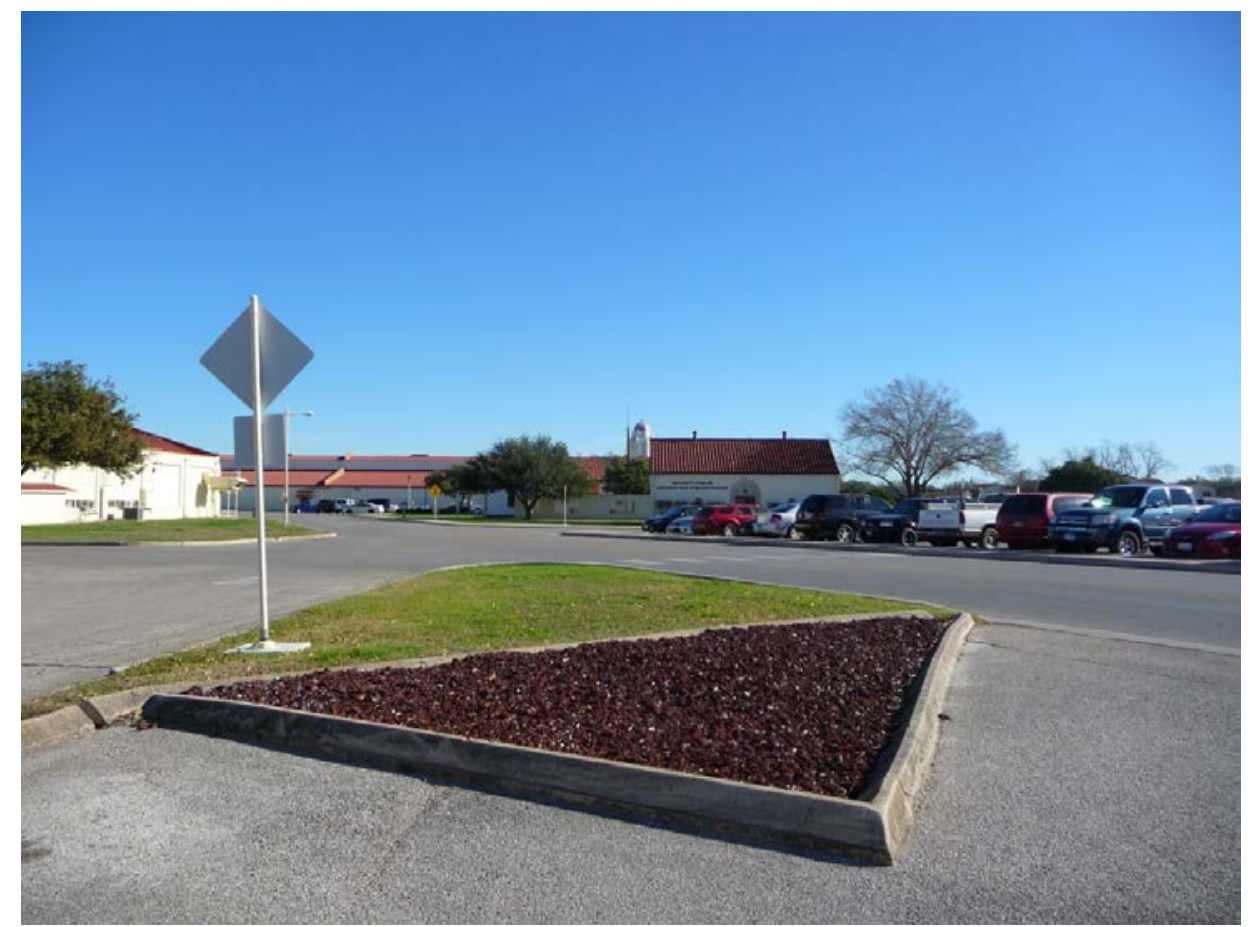

Figure 114. Because of the intricate circular road network, there are many dividers and medians throughout the base. The extensive planting strategies of Lt. Bone had many of these small spaces planted. Maintenance on these spaces has been gradually reduced to mowing grass or, as this image shows, being filled with no-maintenance lava rocks, 2012 (ERDC-CERL).

\subsubsection{Entrance boulevard and Washington Circle}

The entrance boulevard (Harmon Drive) was designed as a strong formal element of the Randolph Field plan. This long axis toward the Administration Building was further spatially emphasized with rows of trees planted on either side of the road. Figure 115 is an image from 1958 that shows the rows of young street trees. In this image, around Washington Circle are the more mature Live oaks that were part of the donation of trees by the Daughters of the American Revolution. The islands created by the roundabout are capped with hedges, while the interior of the circle lacks any vegetation 


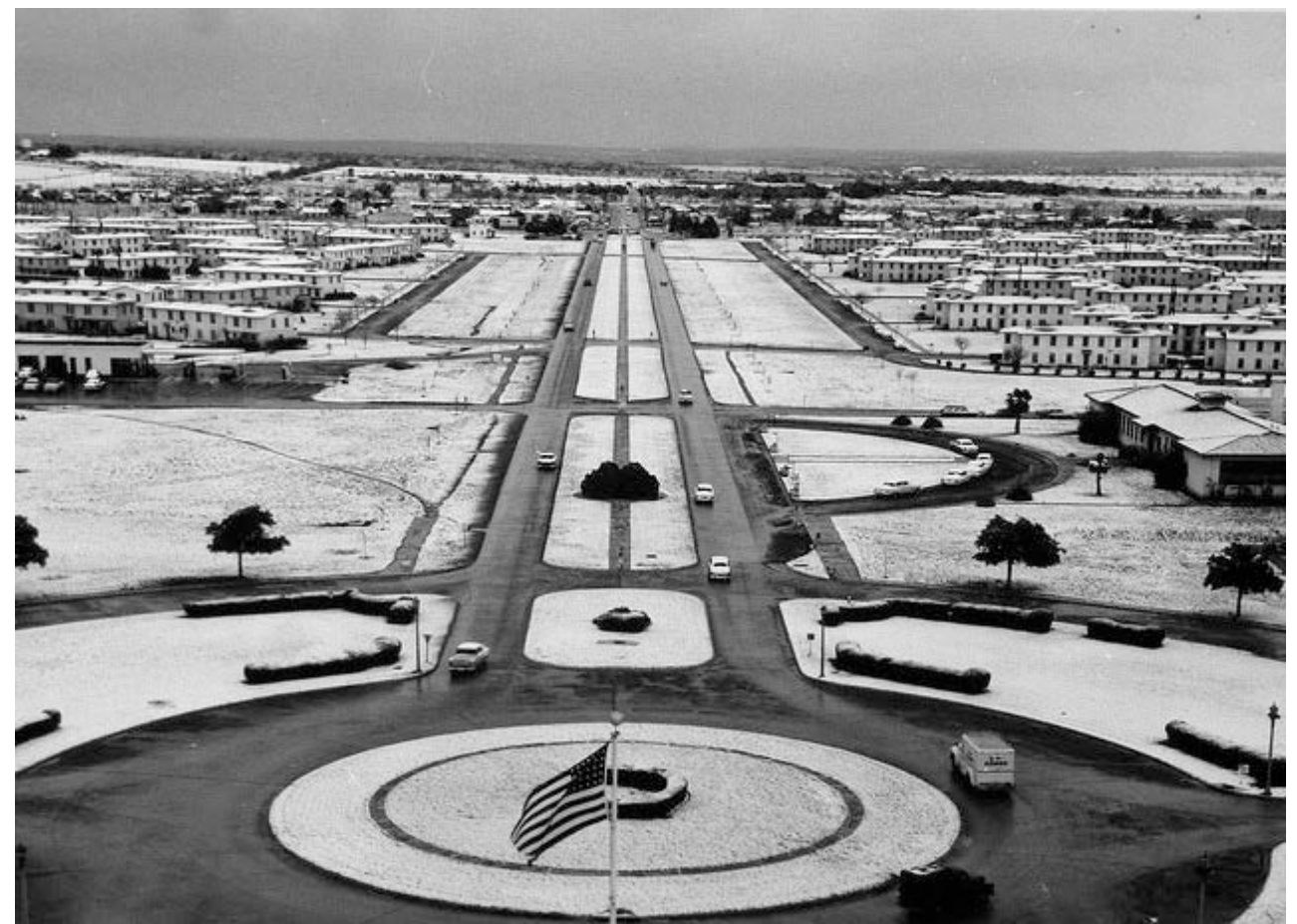

Figure 115. View north along the entrance boulevard toward the main entrance (center top of photo), 1958 (NARA RG342-B Box300).

In Figure 116, the trees lining Harmon Drive have fully matured.

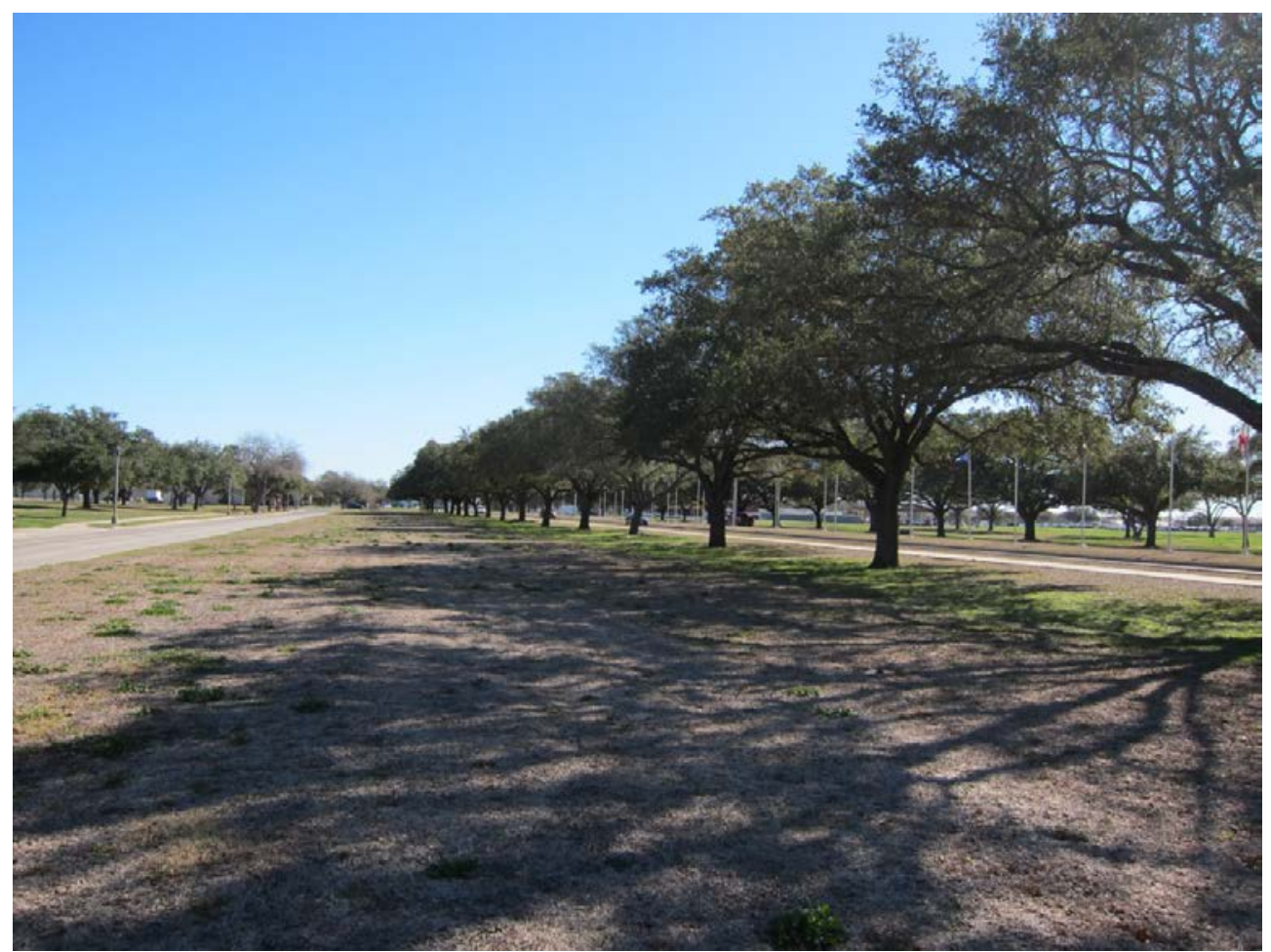

Figure 116. Trees line the main entrance boulevard, Harmon Drive, 2012 (ERDC-CERL). 


\subsubsection{Aviation areas-hangars and flight lines}

The aviation areas of the base were strictly utilitarian and designed to accomplish the mission of Randolph Field. As a result, little vegetation was added to the east and west flight lines except for rows of street trees along Fifth Street West and Fifth Street East (Figure 117) and on the interior sides of the stage houses.

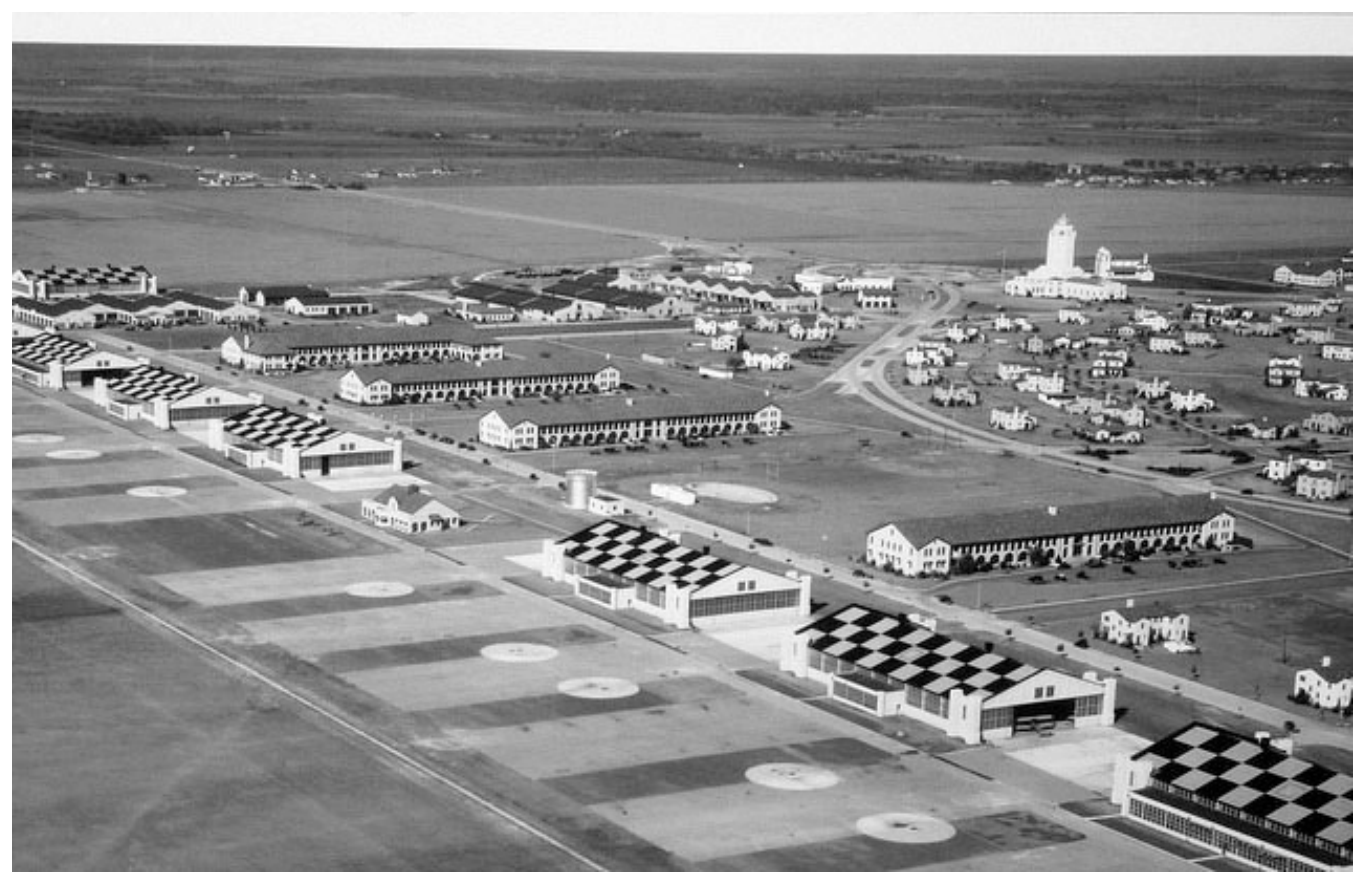

Figure 117. Line of small street trees along Fifth Street West, east of the hangars in the 1930s (NARA RG342 Box 1071 B20681).

Figure 118 and Figure 119 illustrates the current minimal use of vegetation along the flight lines. 


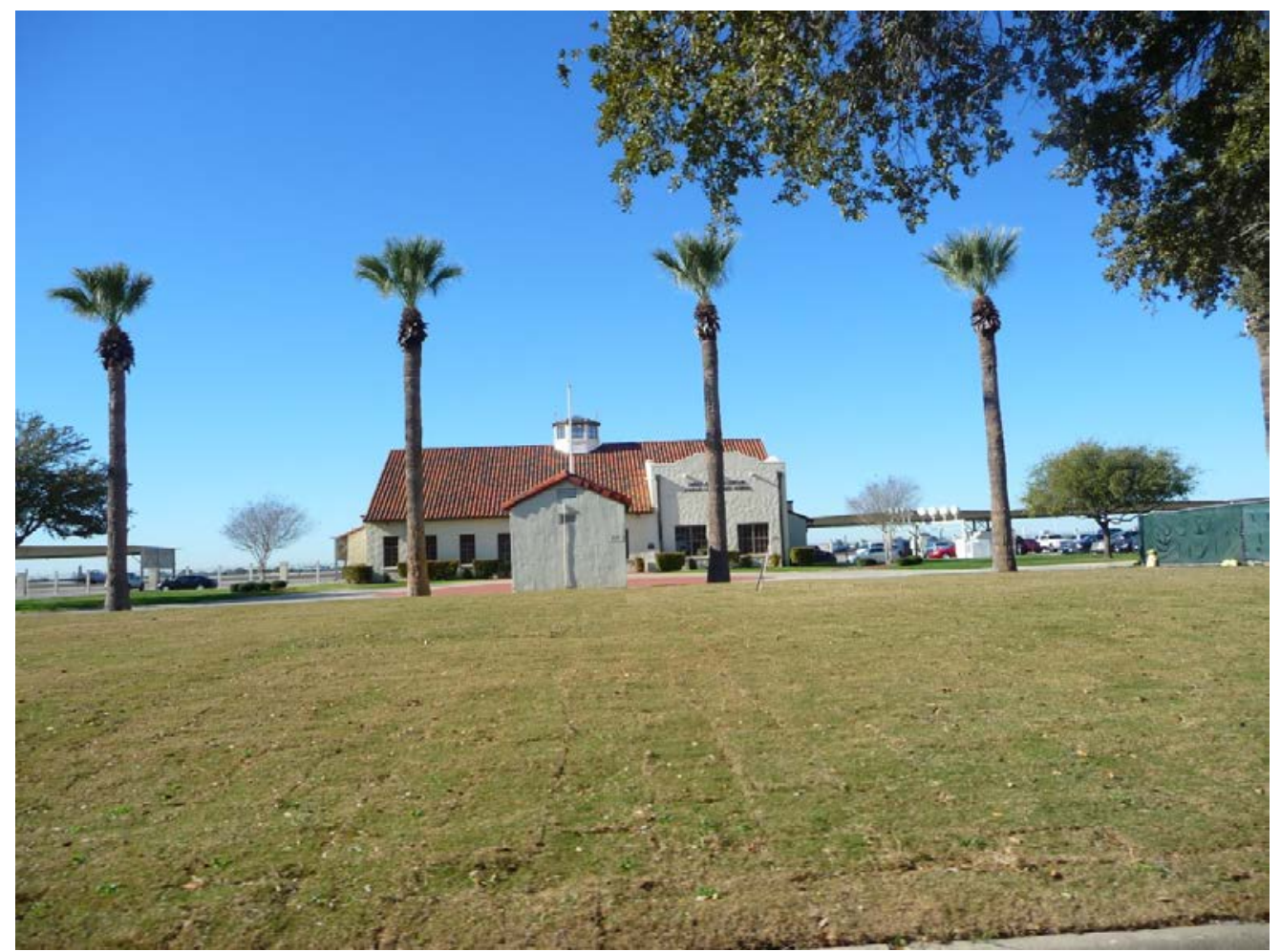

Figure 118. Palms line the street along the row of hangars, 2012 (ERDC-CERL).

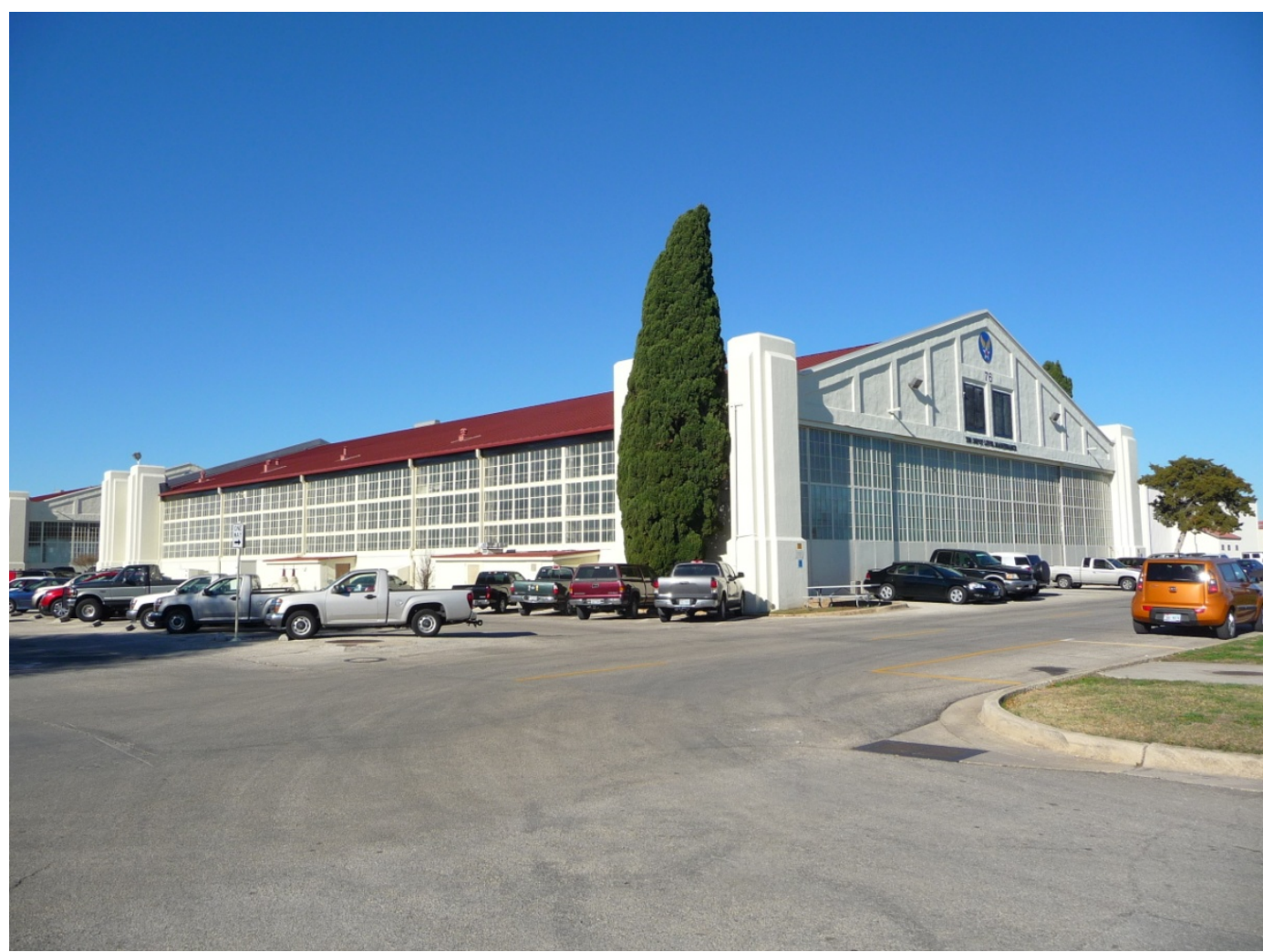

Figure 119. A few trees have been planted around the hangars, 2012 (ERDC-CERL). 


\subsubsection{Administration area}

According to military hierarchical classifications, the administration area was one of the most important areas within the base. Consequently, the Administration Building received extensive landscaping around it, especially on the entrance side (Figure 120).

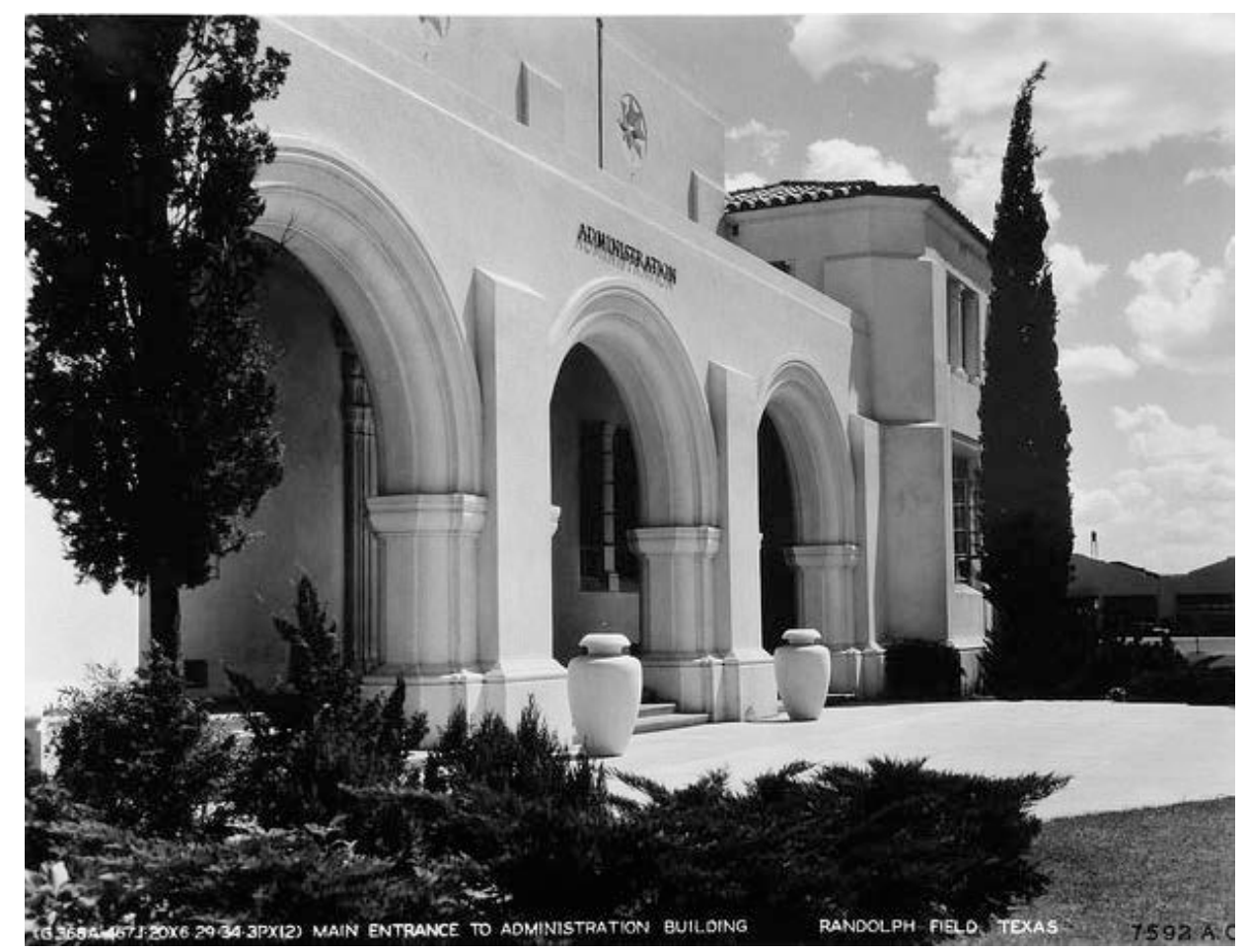

Figure 120. Main entrance to the Administration Building showing the elaborate planting patterns most likely designed by Lt. Bone, undated (NARA RG342 Box1072 B20821).

By the 1970s, the landscaping around the Taj Mahal had been reduced until it consisted of a tall, dense hedge of evergreens (Figure 121). Over the next three decades, the Taj Mahal entrance landscaping was further altered to include the evergreen hedge and a few small evergreens near the building (Figure 122). The flagpole area was also extensively redesigned to include lights and circular flower beds that ring the concrete flagpole area. The flower beds are decorated with medium sized river rocks and are planted with annuals. Outside of the beds are two rows of low-growing spherical evergreen shrubs (Figure 123). 


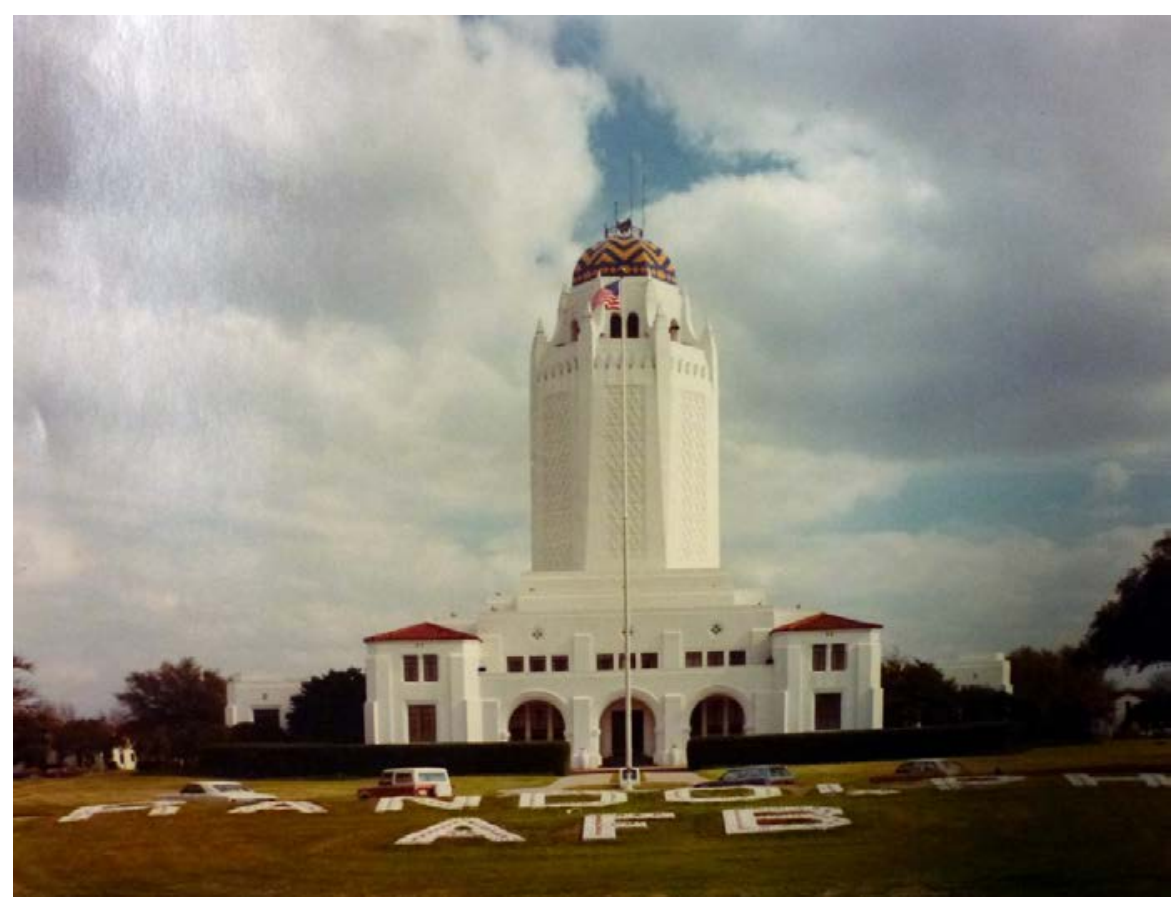

Figure 121. The "Taj Mahal" in the 1970s showing a change in the planting pattern in front of the building. The variety of plants evident in the 1930s has been replaced with a hedge row of a single species (Norfleet Giddings Bone Papers, University of Texas at San Antonio Libraries Special Collections).

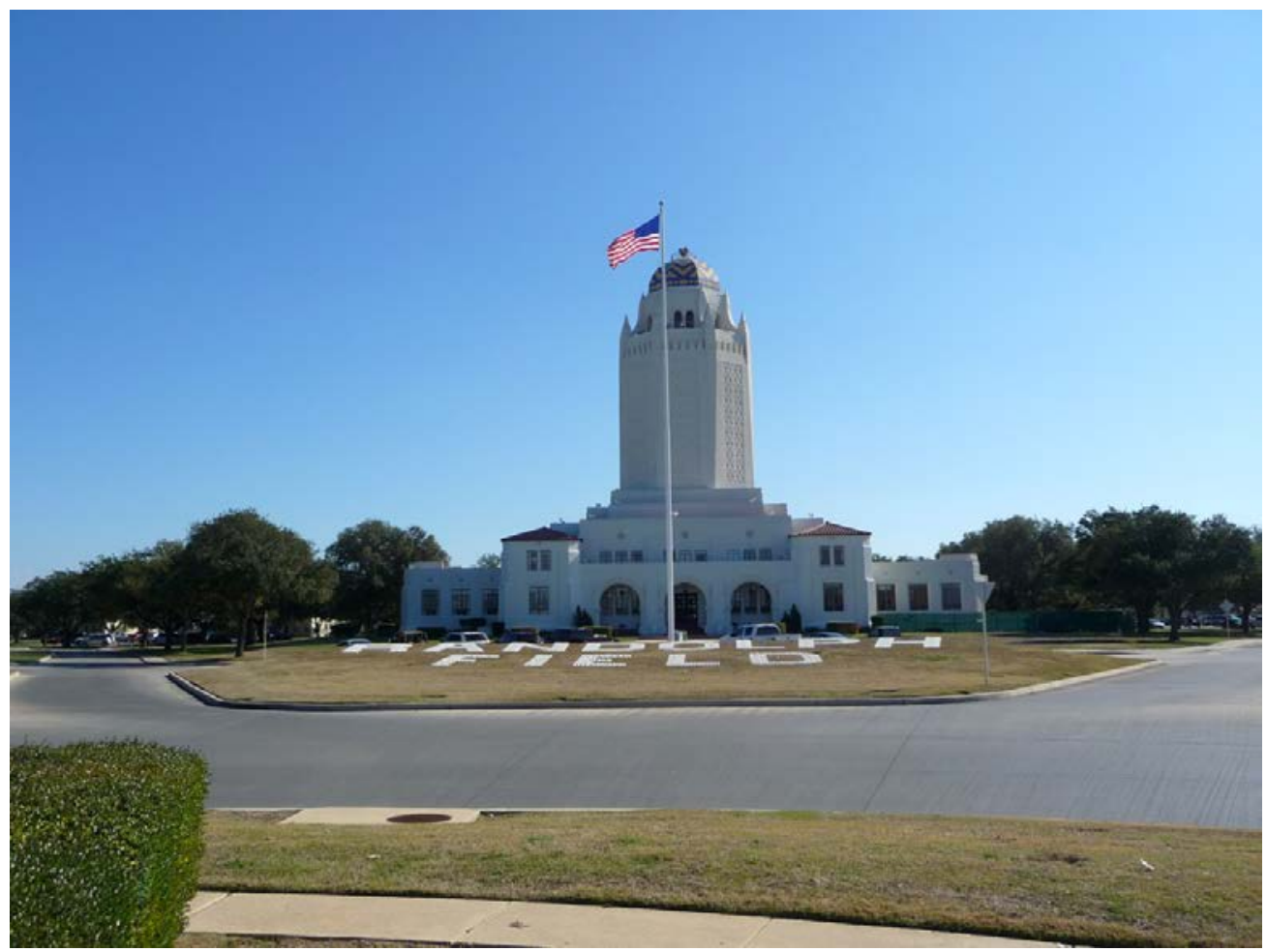

Figure 122. The "Taj Mahal" in 2012. The north façade plantings have again changed. The entrance between the hedge row has been widened and a few evergreens have been planted on either side of the arched entrance, 2012 (ERDC-CERL). 


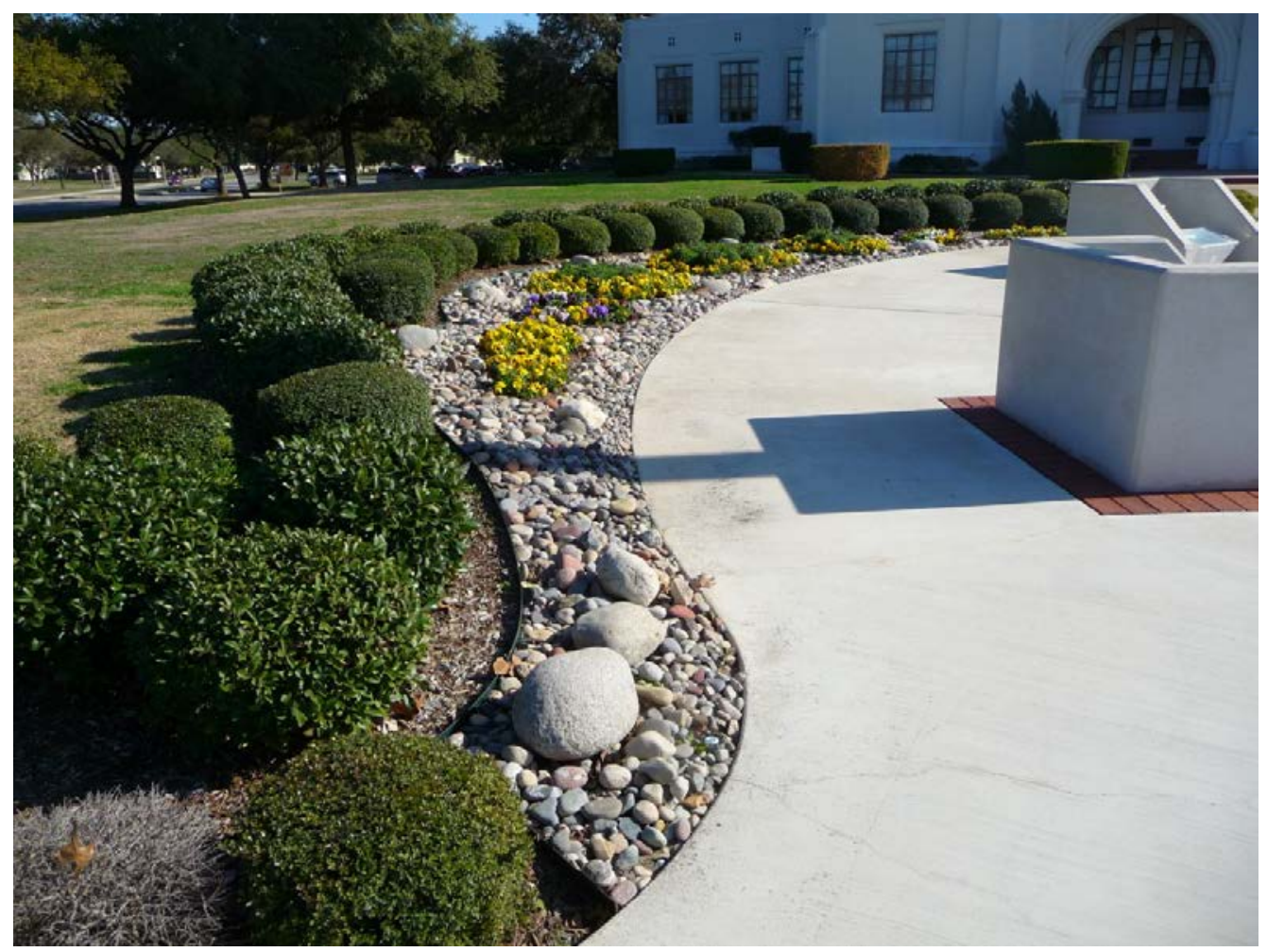

Figure 123. Landscaping around the base's flagpole includes rows of small shrubs with annuals planted in a bed of river rocks, 2012 (ERDC-CERL).

In keeping with the vegetation patterns used for the Taj Mahal, the chapel was similarly planted. By the 1950s, the vegetation had fully developed around the chapel (Figure 124). 


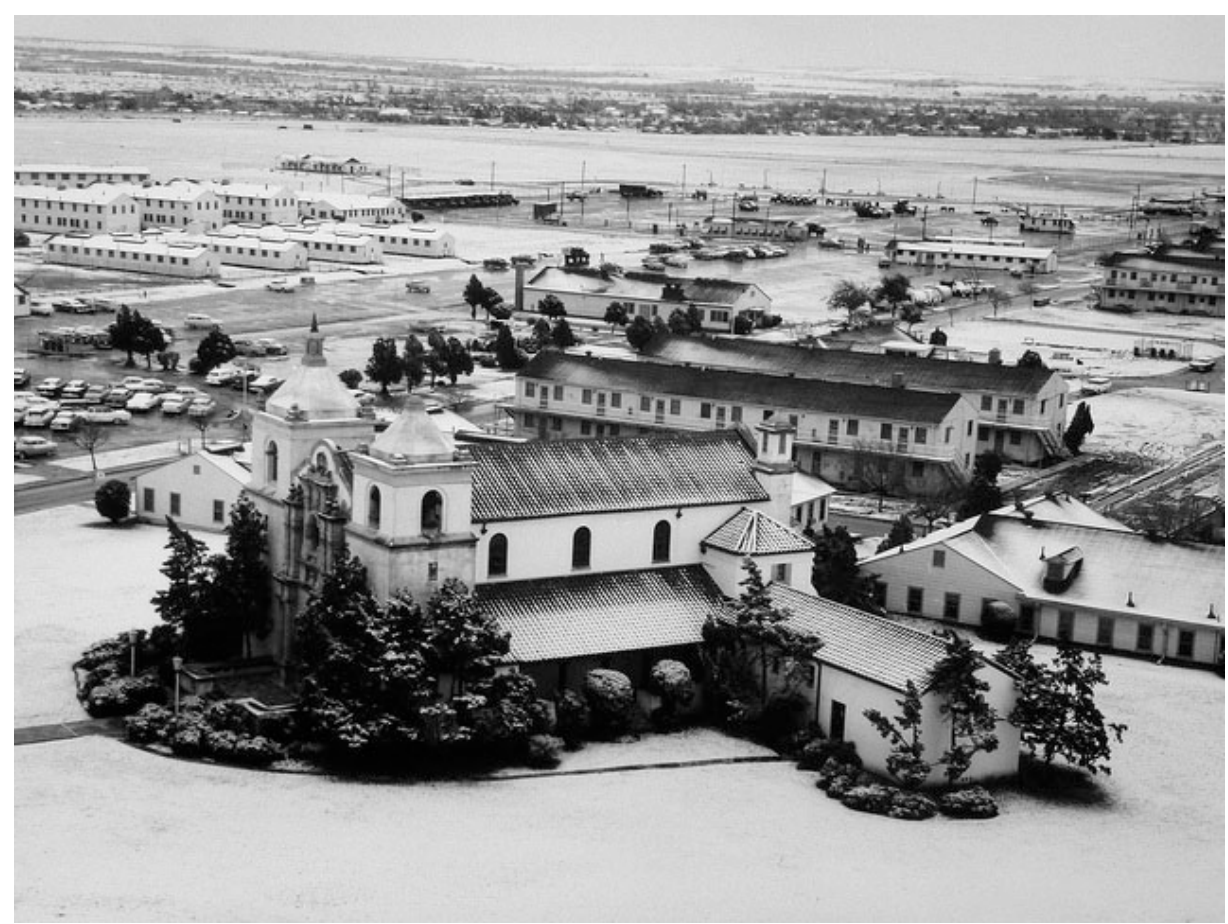

Figure 124. The chapel was another important area in the base. By the 1950s, the front of the chapel had been elaborately landscaped with a variety of evergreen shrubs and small trees, 1958 (NARA RG342 Box 300).

Figure 125 illustrates the stark contrast between the chapel's historic vegetation patterns and those in 2012.

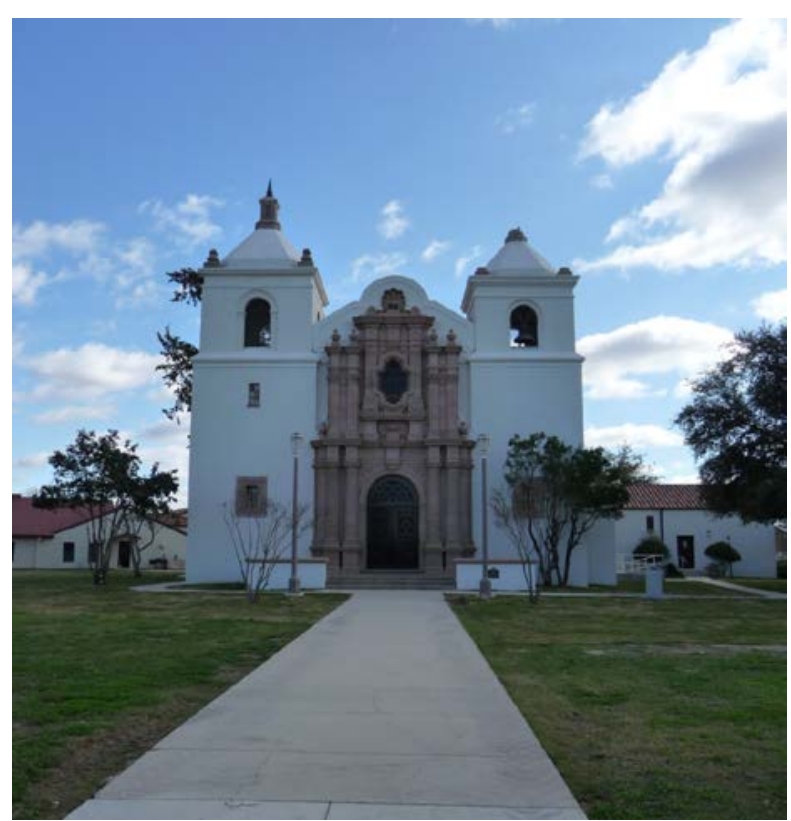

Figure 125. Chapel landscaping in 2012 (ERDC-CERL). 
The Post Exchange was a destination spot within the base and received an extensive amount of landscaping around the building and in the inner courtyard (Figure 126).

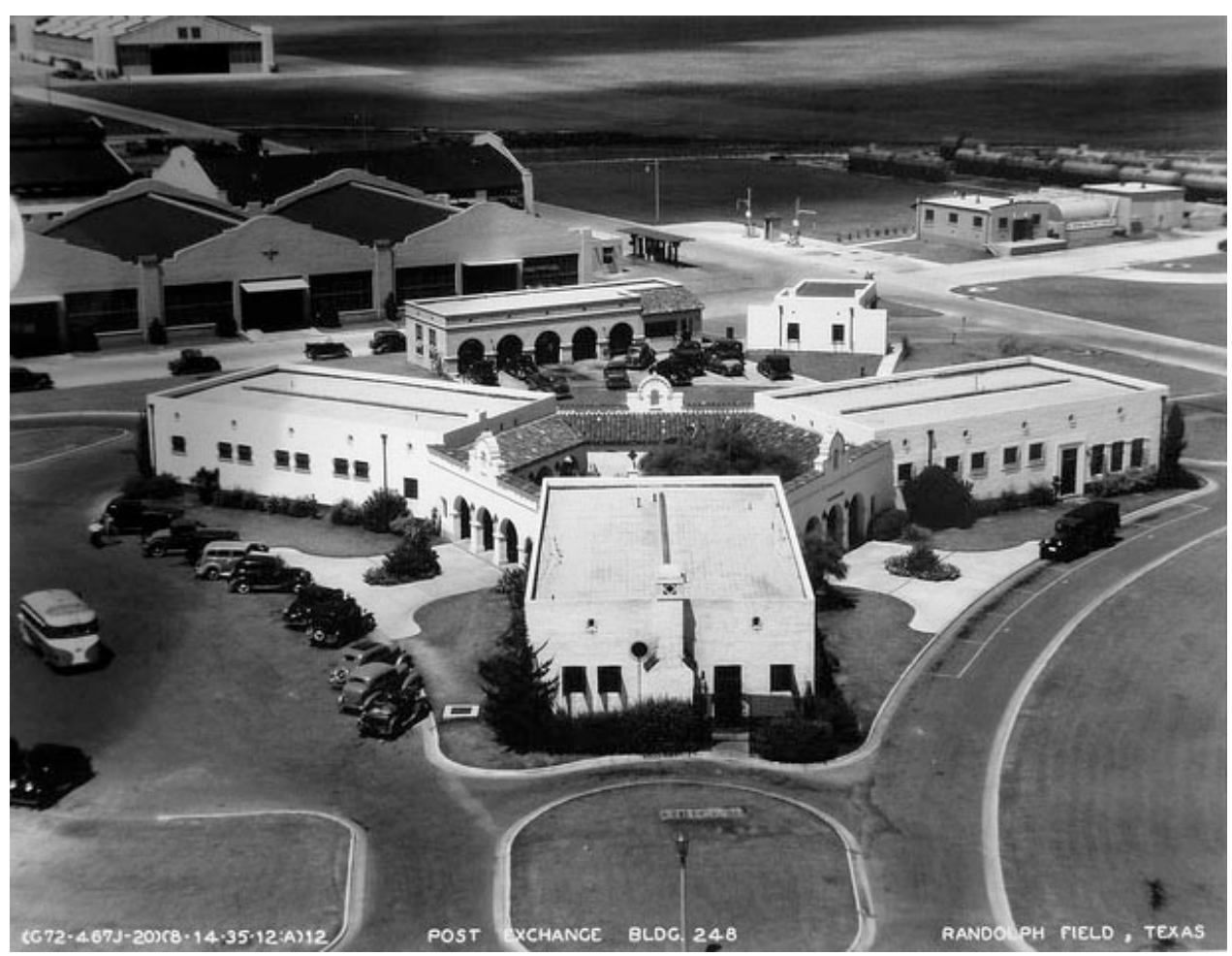

Figure 126. The landscaping around the Post Exchange was varied in height and type in the 1930s (NARA RG342 Box 1072 B20769).

Figure 127 and Figure 128 illustrate the planting designs that the former PX used in 2012. 


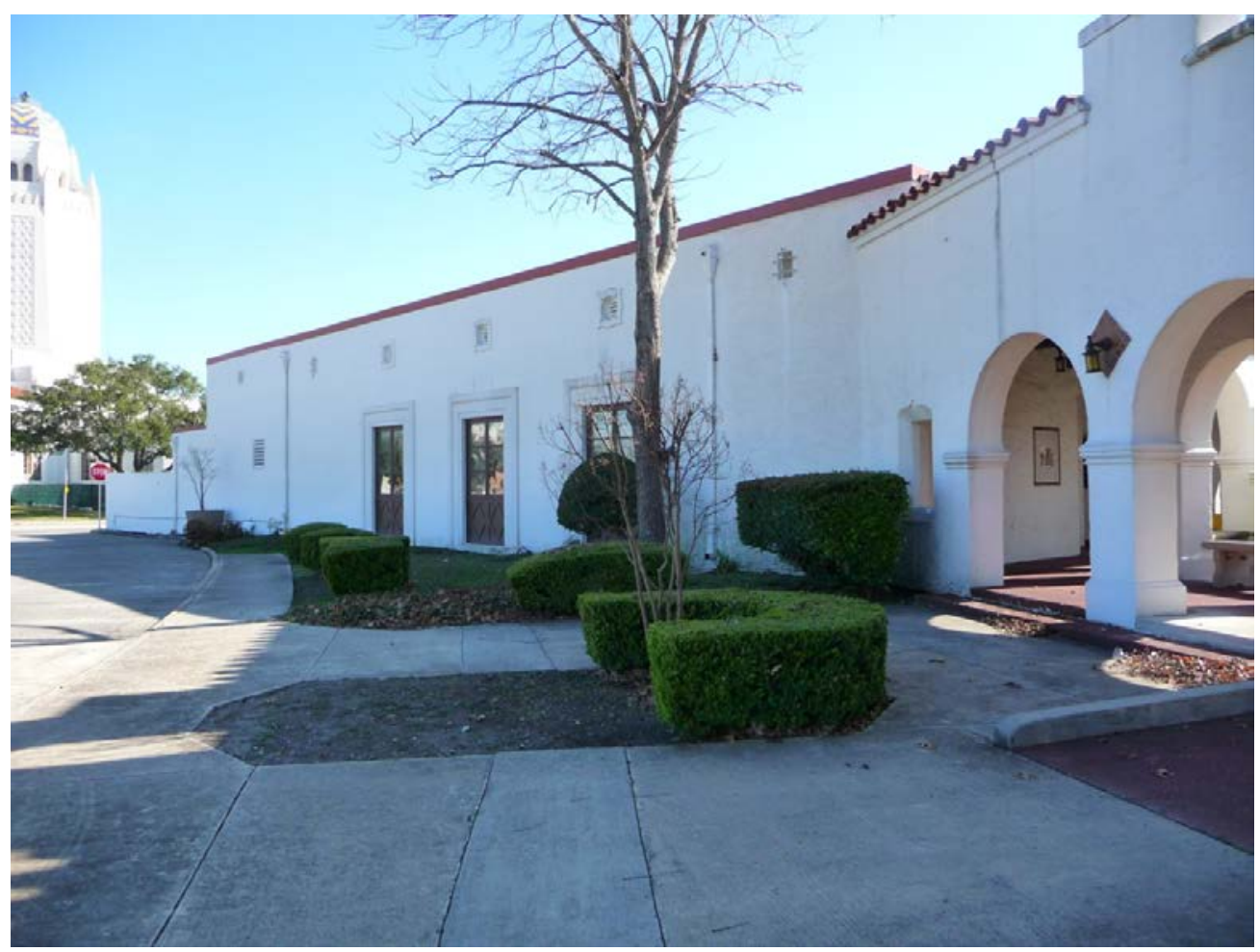

Figure 127. One of the entrances to the former PX courtyard, 2012 (ERDC-CERL).

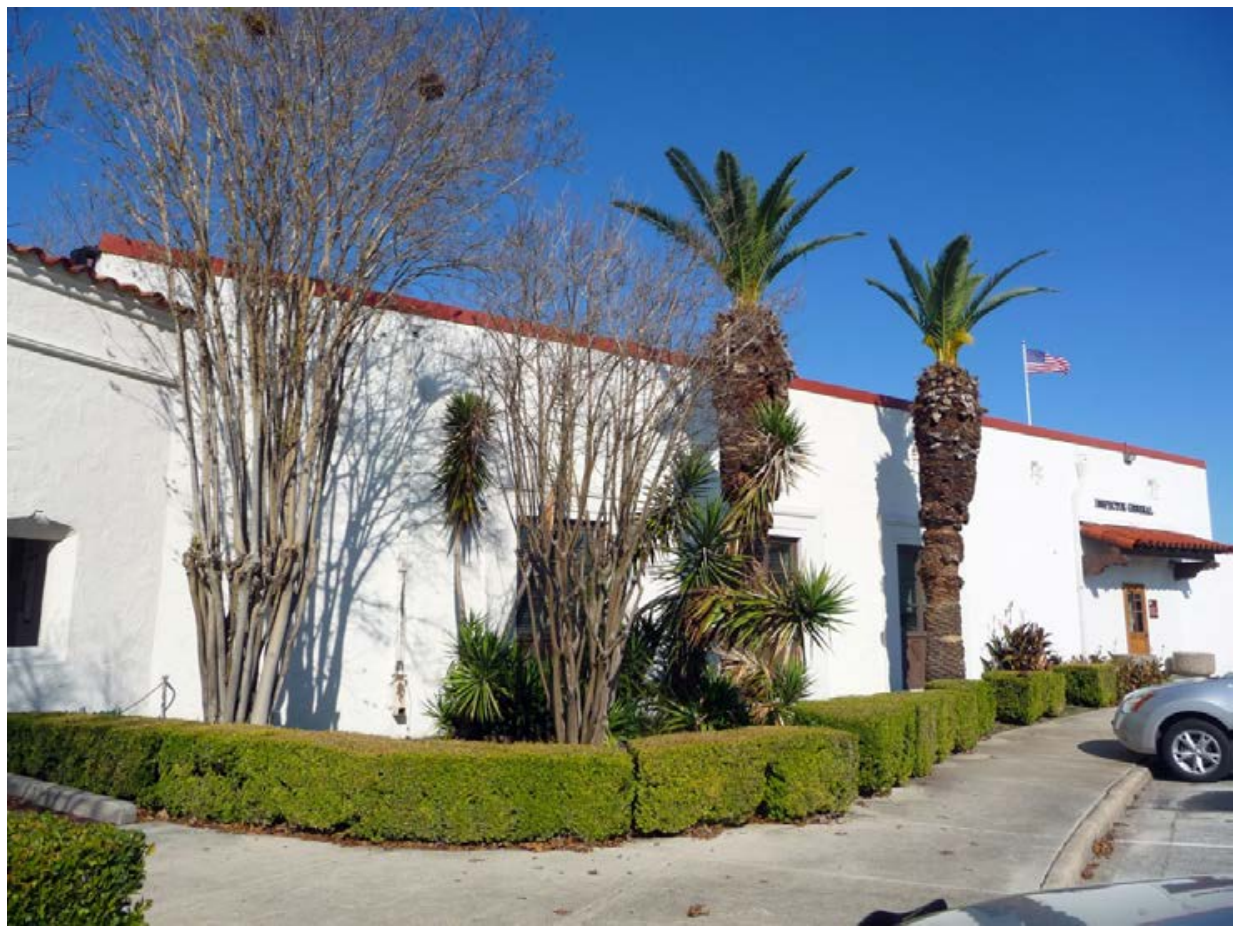

Figure 128. Planting pattern along the southern side of the former PX building, 2012 (ERDCCERL).

The vegetation in the interior courtyard also significantly differs (Figure 129 and Figure 130). 


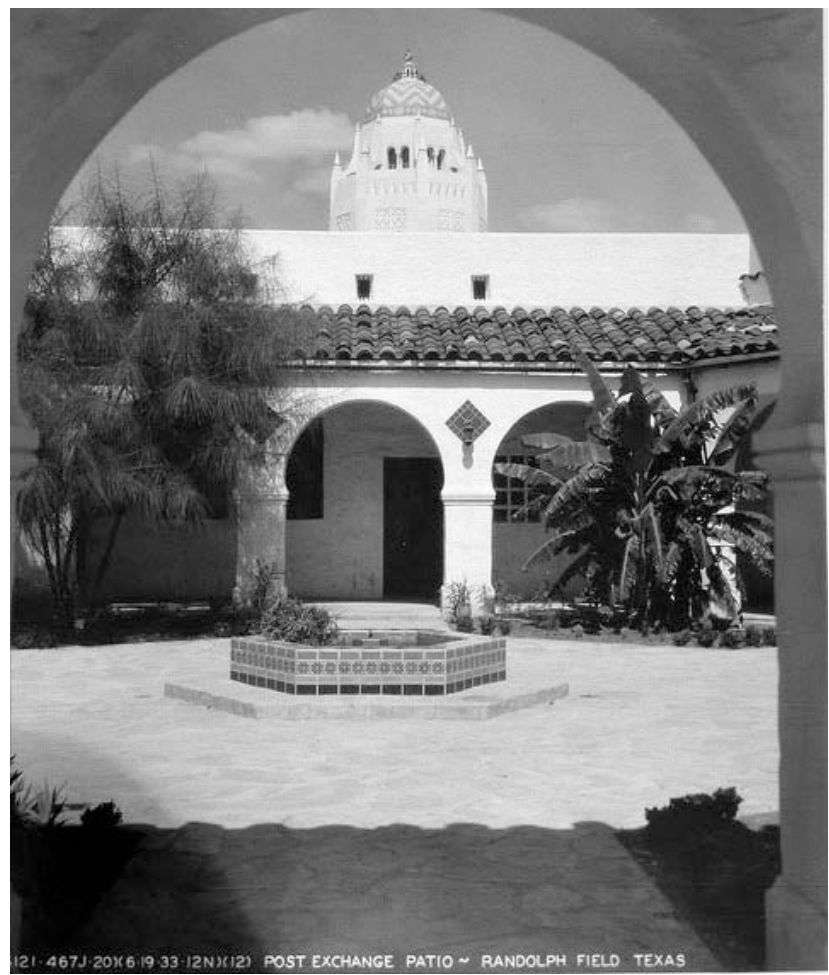

Figure 129. Interior courtyard of the Post Exchange building in the 1930s planted with a variety of species (NARA RG342 Box 1072 B20770).

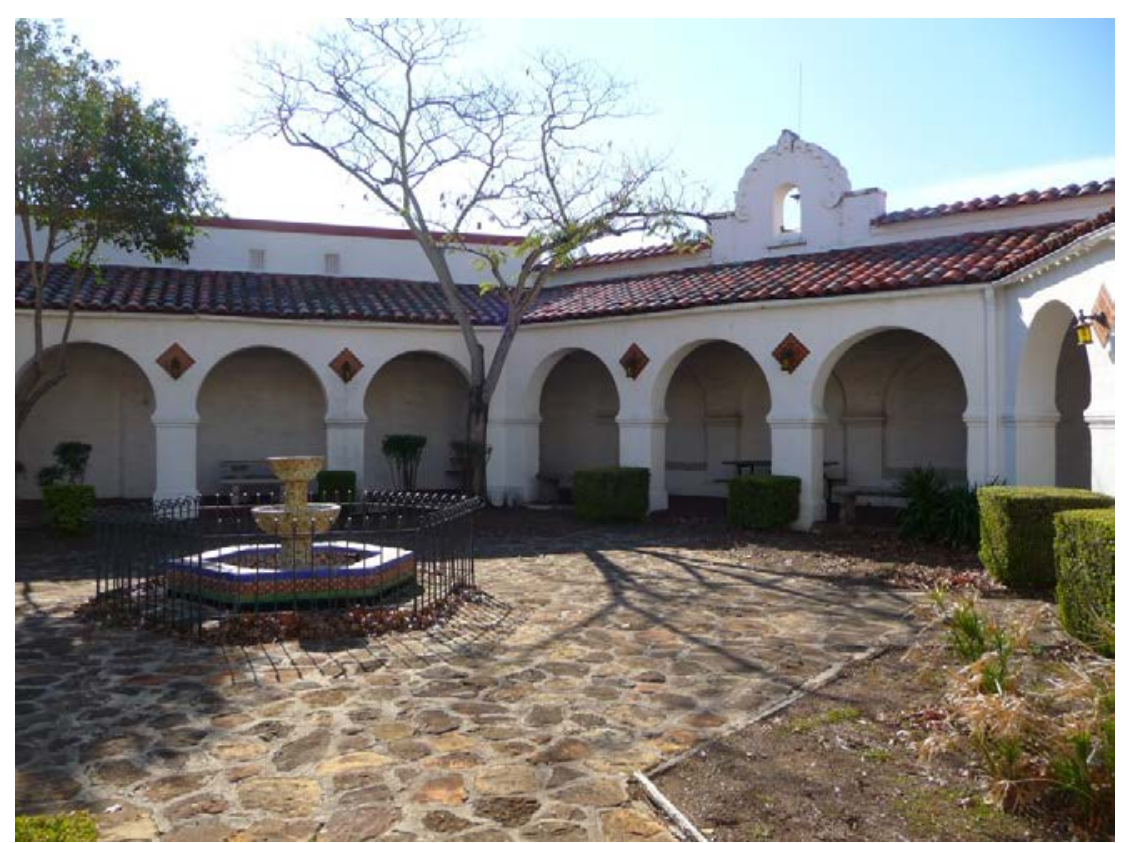

Figure 130. The current planting design of the PX courtyard consists of boxwood hedges pruned into cubes and a few ornamental trees, 2012 (ERDC-CERL). 


\subsubsection{Warehouse and shops area}

The warehouse and shops area was historically a utilitarian area. However, base planners took care to design these buildings in keeping with the architectural style of the rest of the field. Further west in the warehouse area, most of the vegetation was limited to street trees and foundation plantings along the fronts of buildings (Figure 131 and Figure 132).

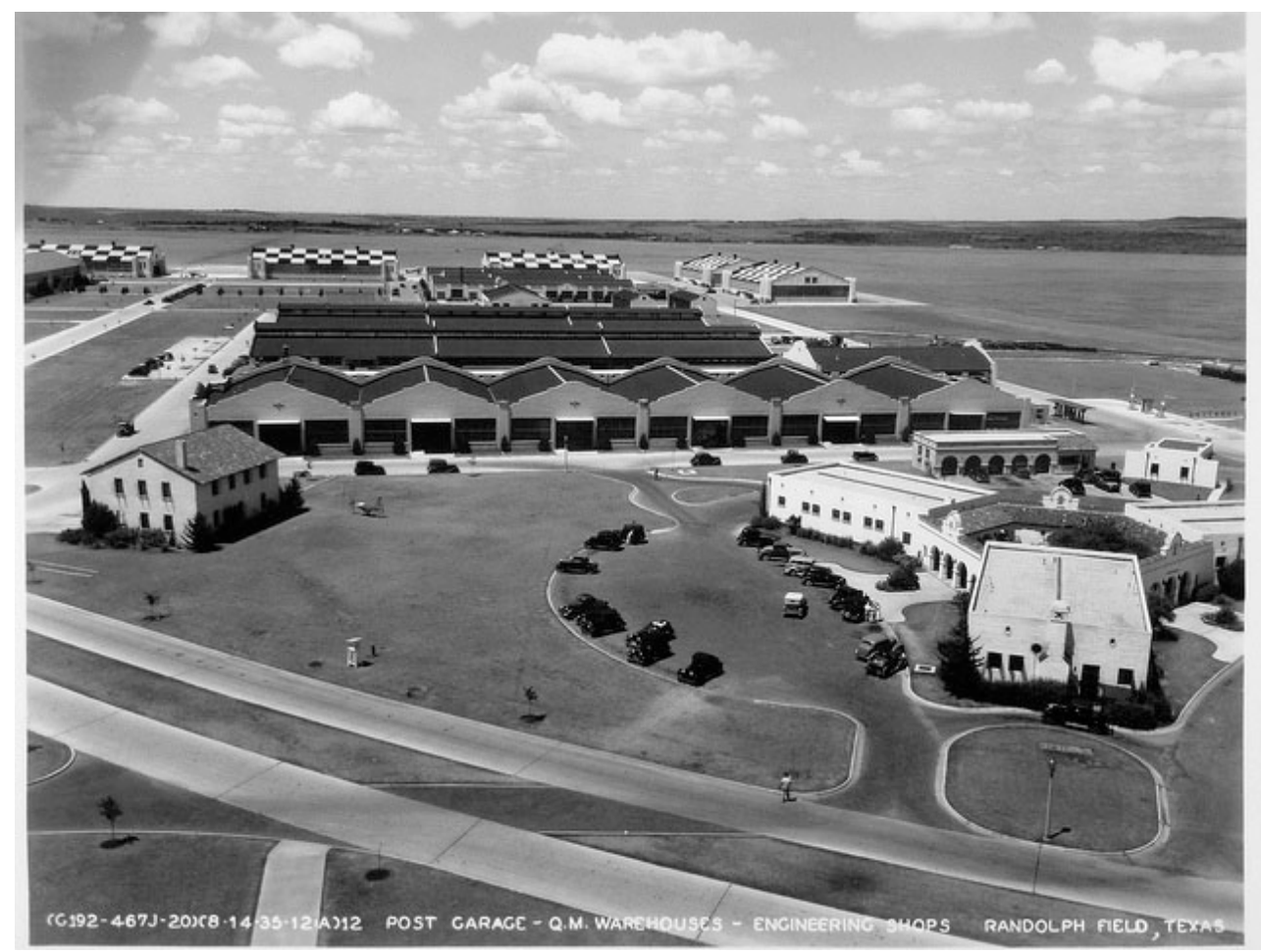

Figure 131. The landscaping around the fire house, on the left side of the image, was as elaborate as the planting plan for the PX building to the northwest (on the right side of the photo), 1930s (NARA RG342 Box 1072 B20772). 


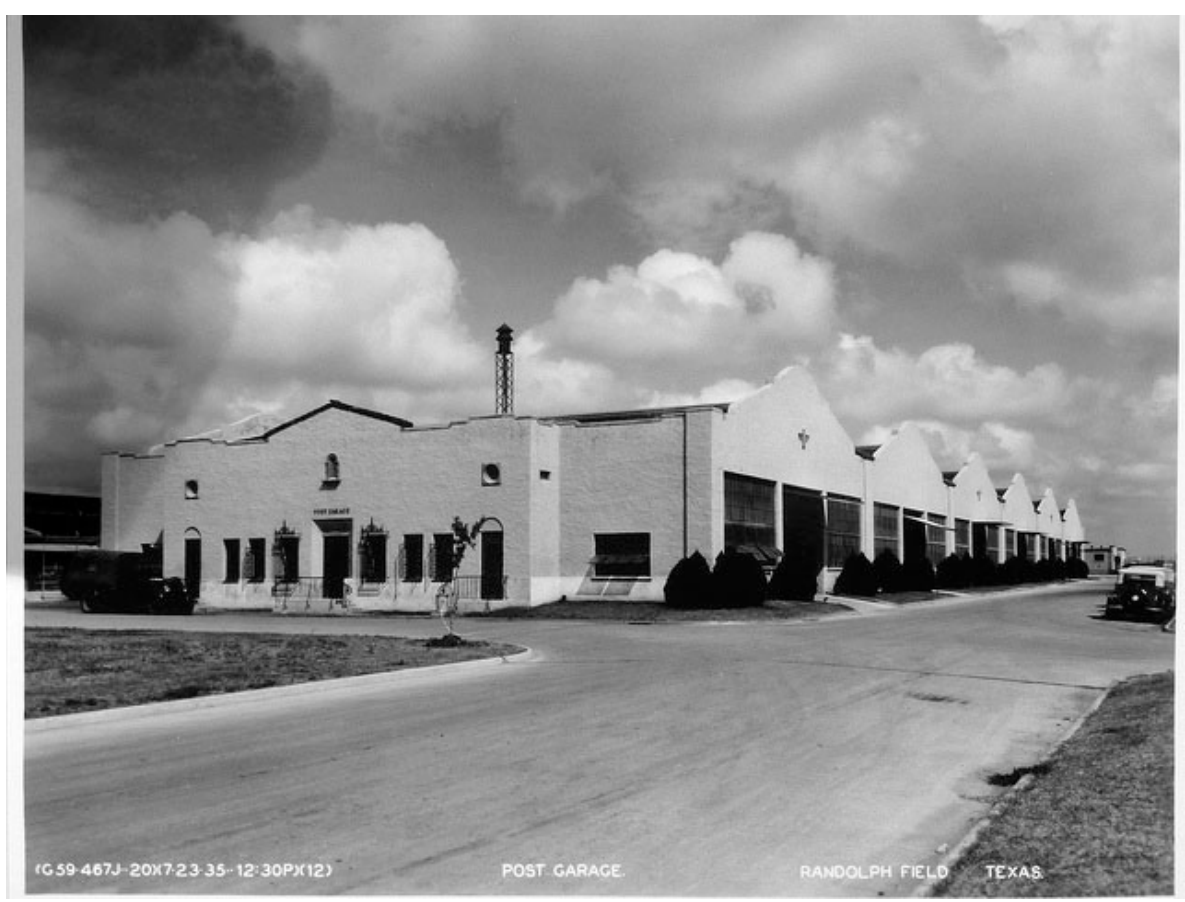

Figure 132. Even the post garage was landscaped, with evergreens planted between the garage bays, 1930s (NARA RG342 Box 1072 B20773).

Currently, the landscaping in the warehouse area varies widely, from a few plants to thick hedges (Figure 133-Figure 135).

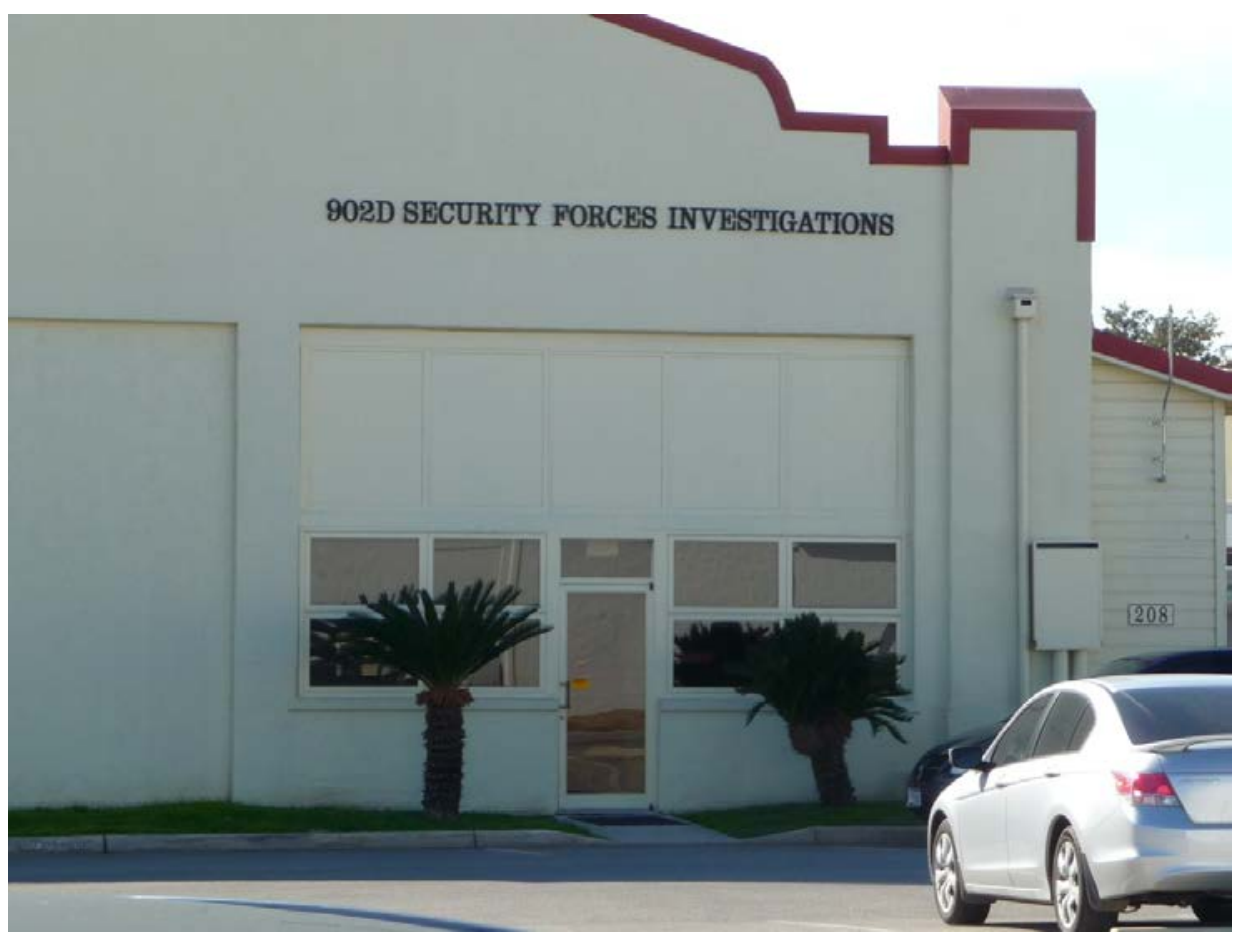

Figure 133. Two palms placed on either side of an entrance to one of the former warehouses, 2012 (ERDC-CERL). 


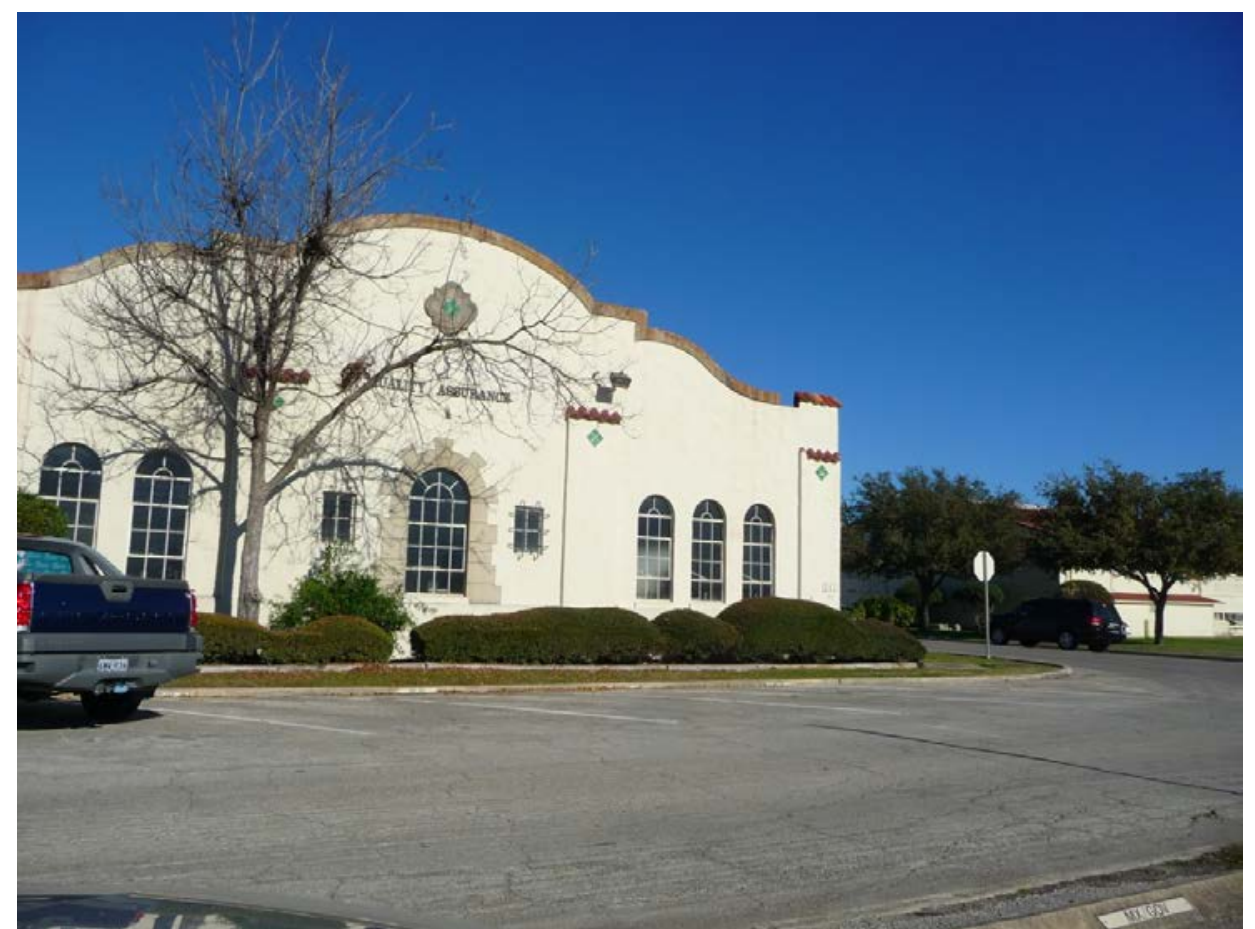

Figure 134. Thick, low hedges line the front of the Quality Assurance building, 2012 (ERDCCERL).

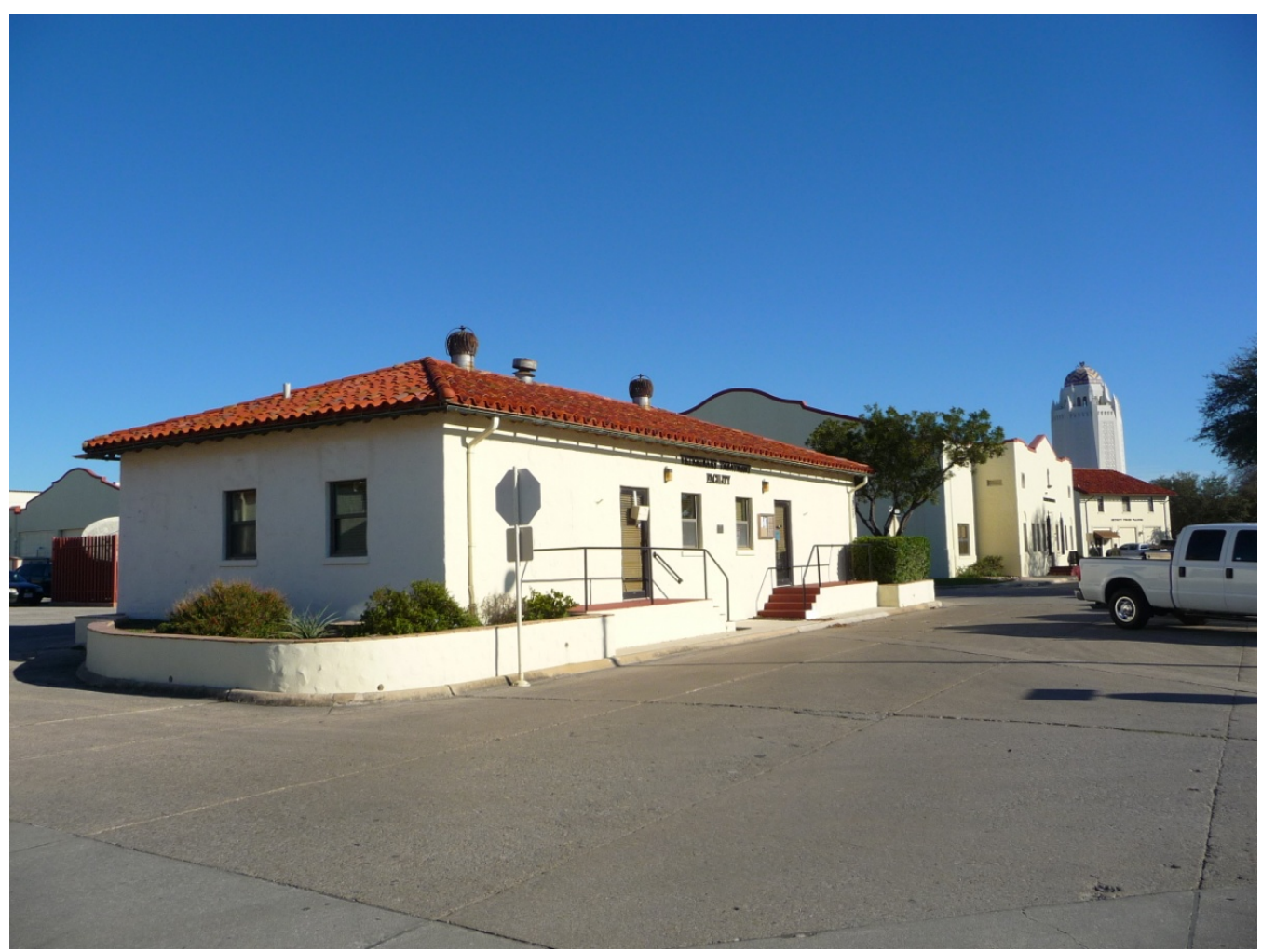

Figure 135. The planters that were incorporated onto the east and west sides of this building now have a few scattered species on one side and box hedges on the other, 2012 (ERDC-

CERL). 


\subsubsection{Officers' residential area}

The officers' residential area in the Main Circle was another important space at Randolph Field. By the late 1930s, the houses had landscaping around their foundations and the area's streets had been lined with Live oak trees. Incorporated into these areas were the wide boulevards of North and South Park as well as East and West Park. Figure 136 is sketch of the vegetation for one of the two story officers' quarters.

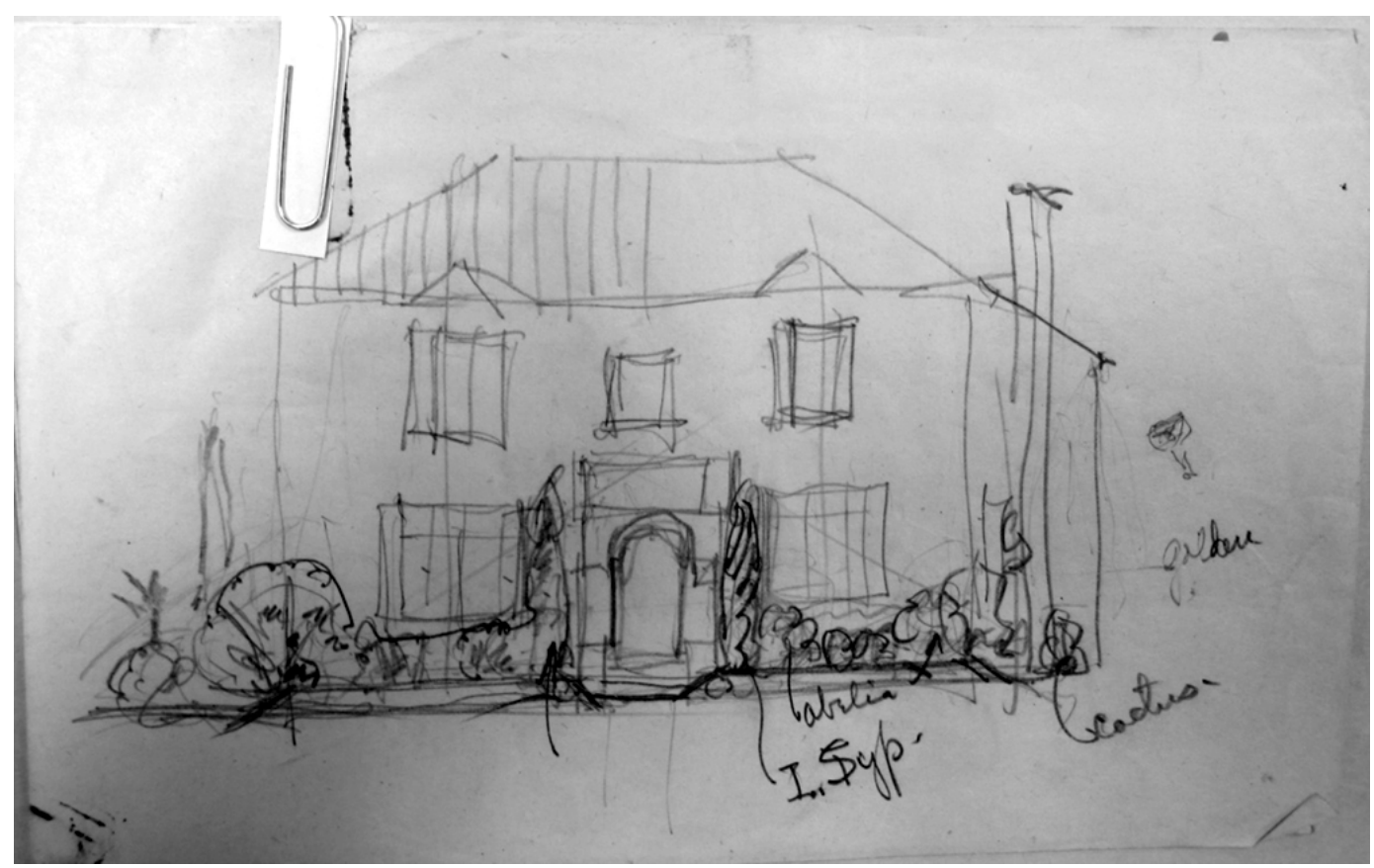

Figure 136. Extensive vegetation was planned for the officers' quarters, in this undated drawing (Norfleet Giddings Bone Papers, University of Texas at San Antonio Libraries Special Collections).

By the 1930s, the vegetation in the officers' housing area was well established and featured evergreen shrubs, hedges, and ornamentals (Figure 137). 


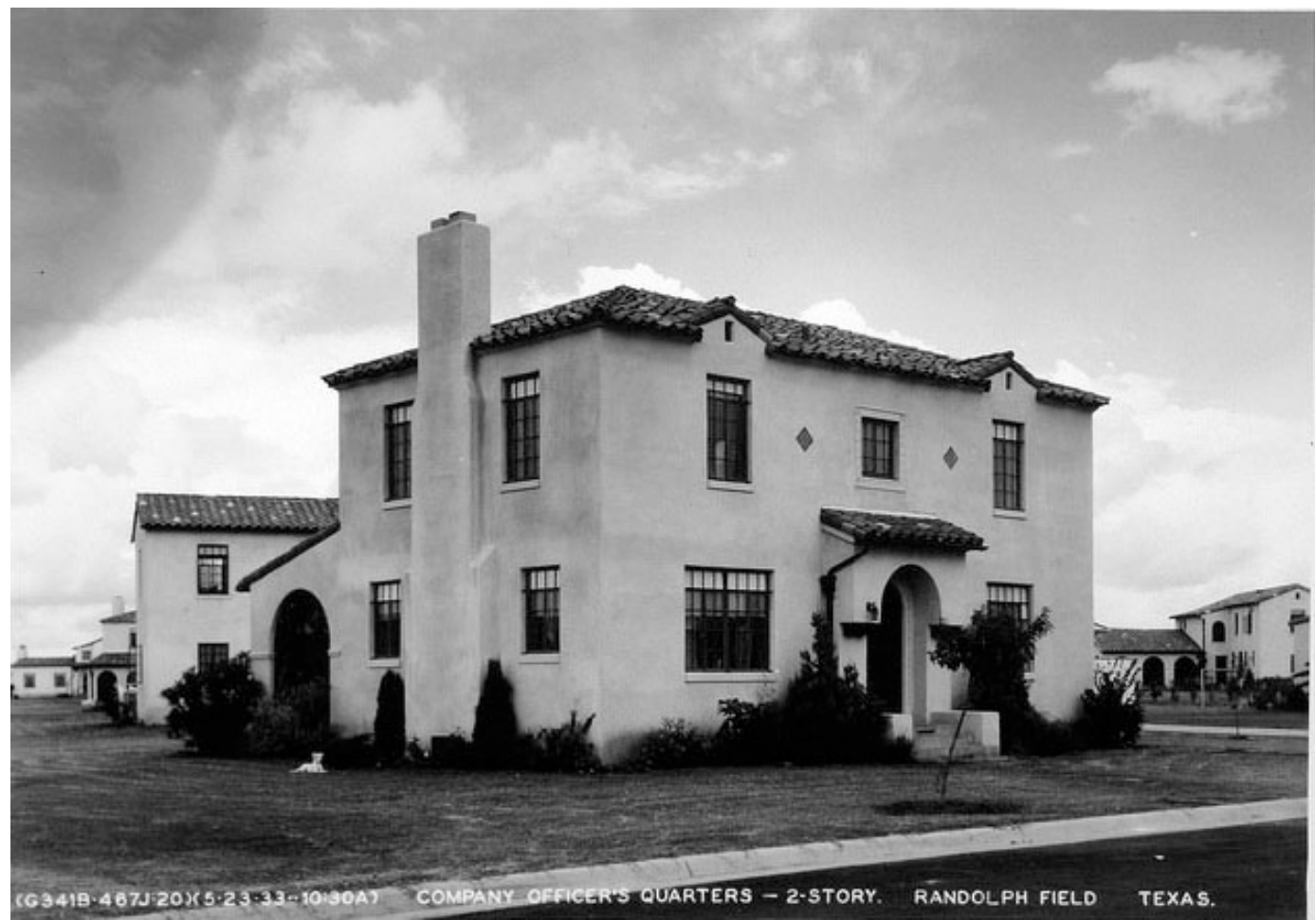

Figure 137. Officers' quarters with foundation plantings in the1930s (NARA RG342 Box 1072 B20784).

The current planting designs for the officers' quarters are not similar to those designed by Lt. Bone. Many of the quarters feature minimal landscaping, and even the more extensively landscaped feature a heavy reliance on boxwood shrubs (Figure 138 and Figure 139). 


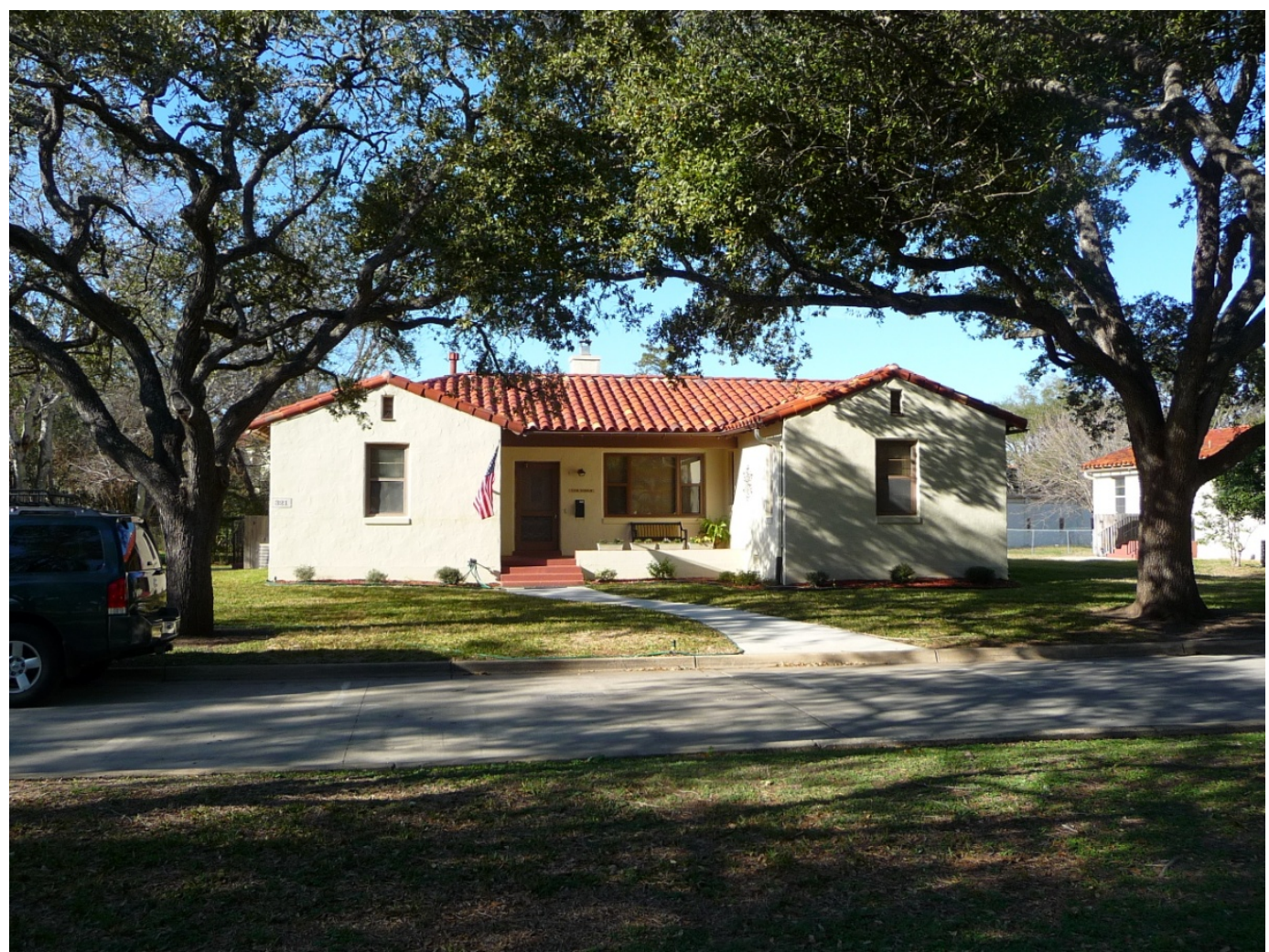

Figure 138. Current planting design in the officers' residential area, 2012 (ERDC-CERL).

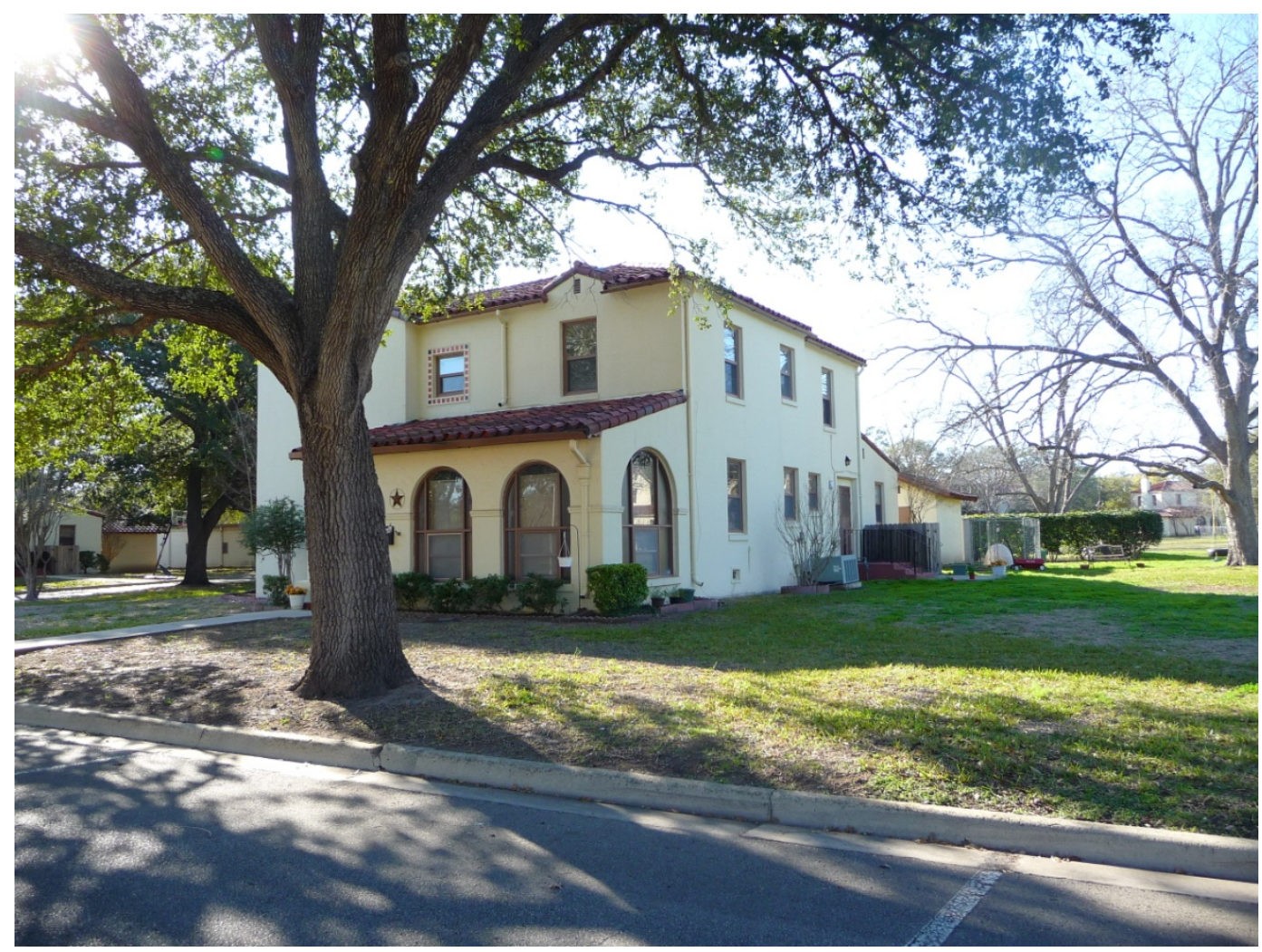

Figure 139. More extensively planted officers' quarters, 2012 (ERDC-CERL). 
Originally, the medians along North and South Parks and East and West Parks were landscaped with hedges, shrubs, ornamentals, and evergreen trees. The planting design specified clusters of plants at the arced ends of the medians. These plant groups helped define the interior open spaces of the medians and provided visual interest along the main residential streets. Figure 140- Figure 142 are images from the 1930s showing the original planting design for the medians. In Figure 140, the pyramidal evergreens reinforce the height of the Taj Mahal. Figure 141 shows the landscaping along East and West Parks, and Figure 142 is an example of the rock gardens that Lt. Bone designed for the officers' housing area.

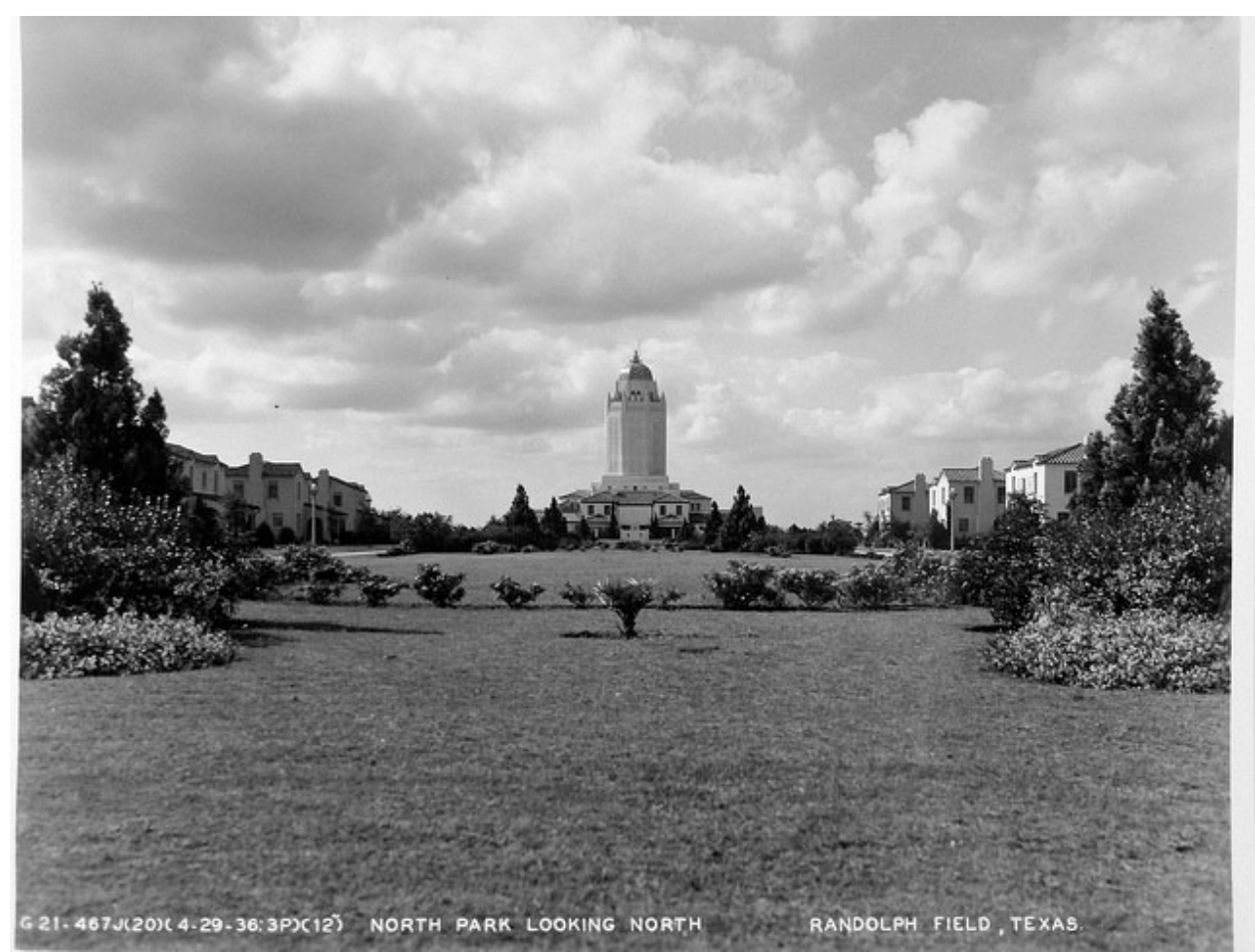

Figure 140. Landscaping along the North Park median that blended well with the residential landscaping around the housing quarters, 1930s (NARA RG342 Box 1072 B20757). 


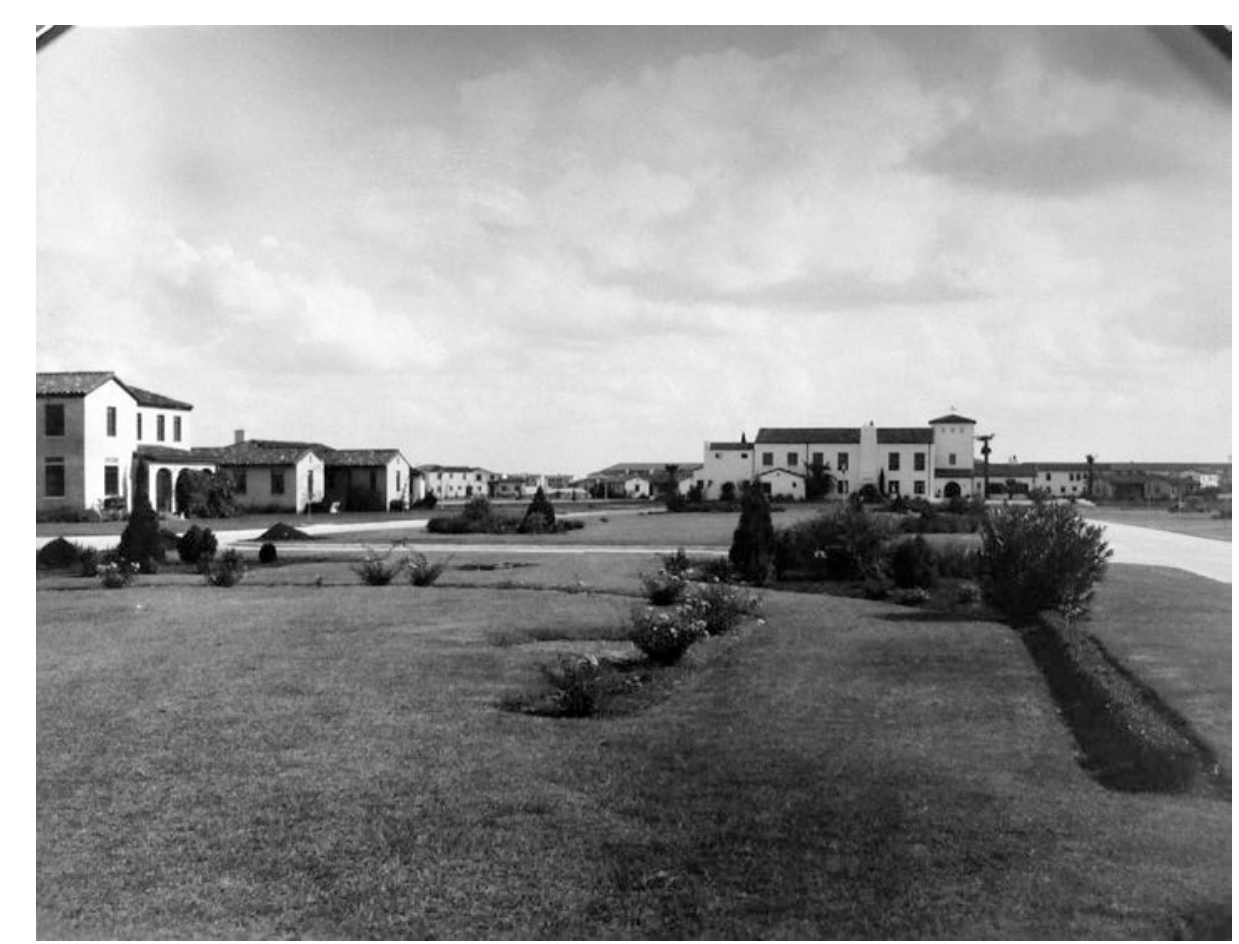

Figure 141. Landscaping along the park boulevards, 1930s (NARA RG342 Box 1072).

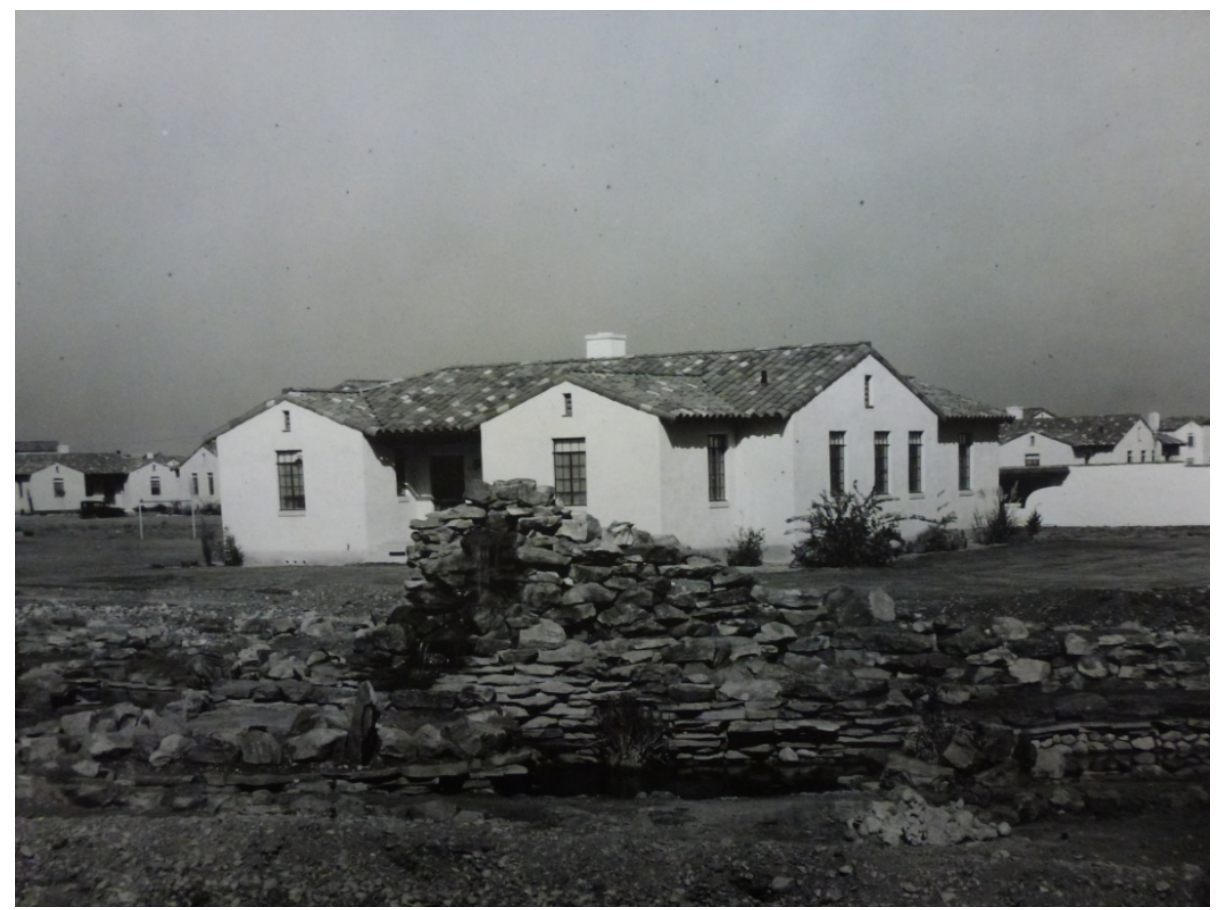

Figure 142. Rock gardens were also part of the landscaping in the officers' housing area, 1930s (NARA RG342 Box 1072).

Figure 143 shows the current conditions of the North-South Park medians. The original planting designs have been removed and sidewalks have been added along the center lines of all the medians. Street trees line the medi- 
ans creating shaded interior open spaces. The turf grass is patchy and in some areas bare soil exposed.

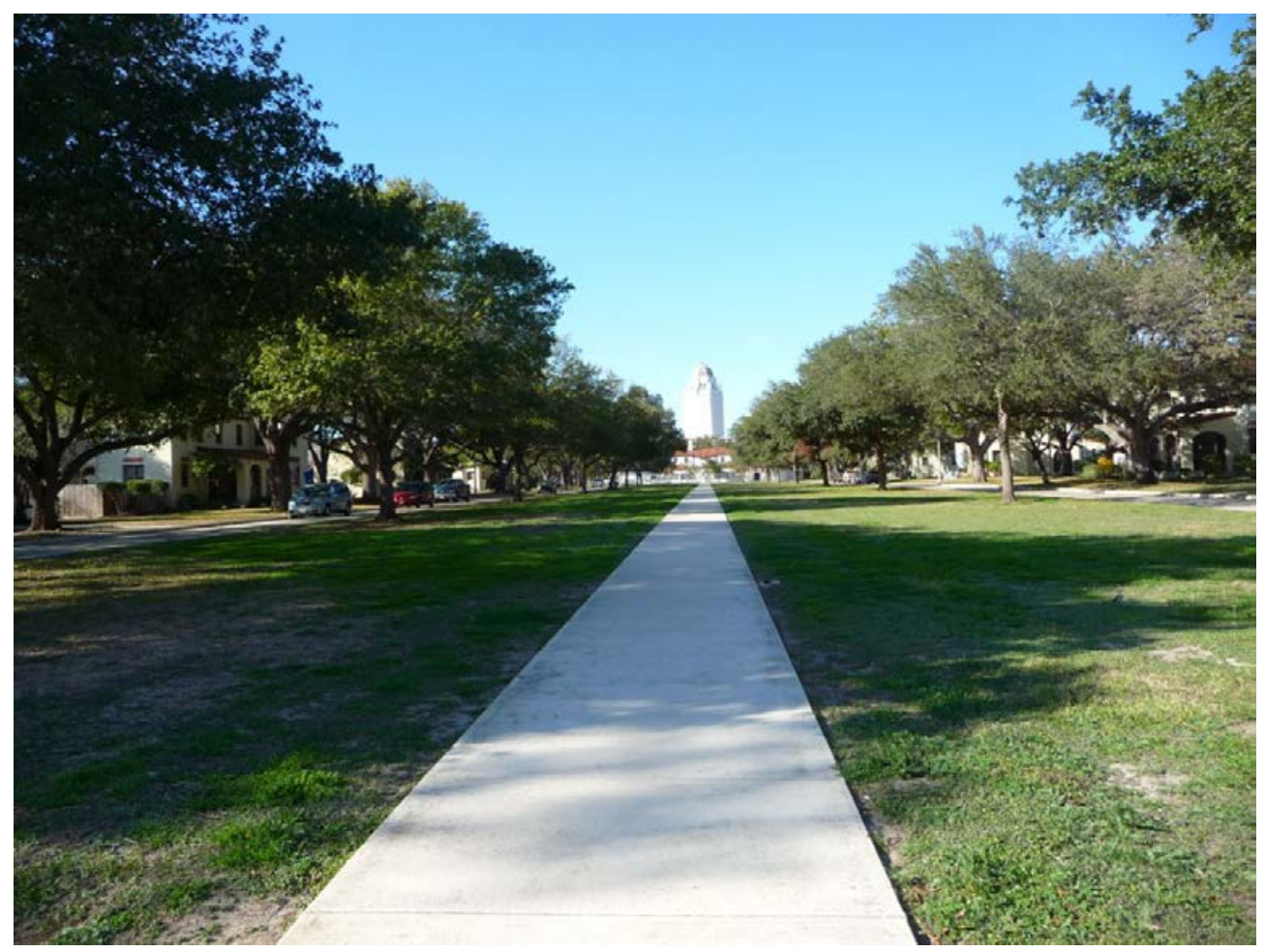

Figure 143. South Park median looking toward Taj Mahal, 2012 (ERDC-CERL).

\subsubsection{NCO residential area}

As a residential area, the NCO quarters were to be planted according to Lt. Bone's landscape designs. Unlike the officers' quarters, the NCO duplexes would be less adorned in both architectural styling and landscaping. Currently, there are street trees in the NCO areas, but there is little ornamental vegetation around the duplexes. Figure 144 provides a typical example of the level of landscaping around the NCO duplexes. 


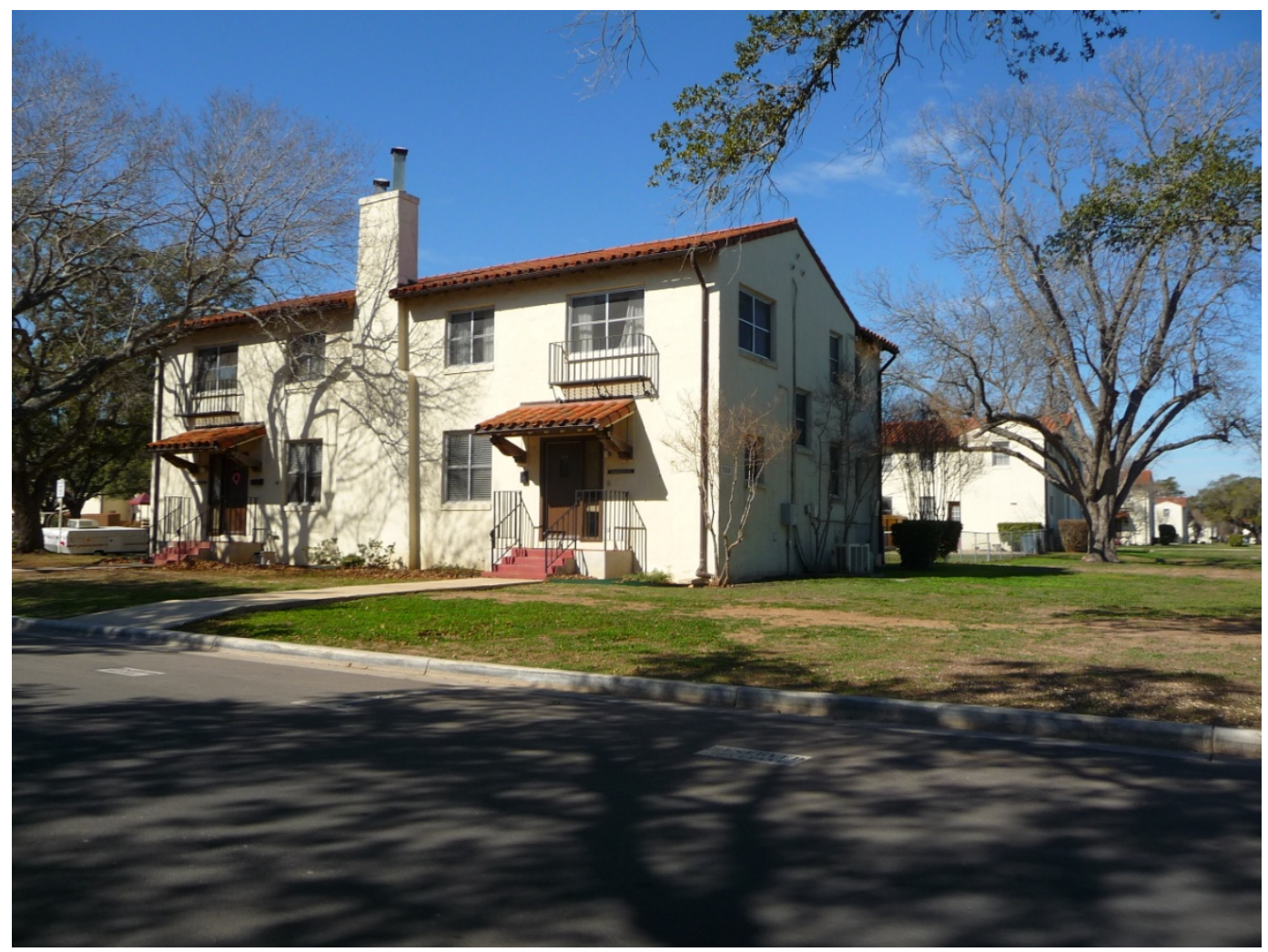

Figure 144. NCO quarters landscaping, 2012 (ERDC-CERL).

\subsubsection{Bachelor Officers' Quarters}

As a residential area, the $\mathrm{BOQ}$ buildings were historically landscaped, but because of the barracks-like arrangement of the buildings, the planting design for the area featured foundation plantings of evergreen trees and shrubs. Figure 145 and Figure 146 are historic images illustrating the planting design for the BOQ area. Figure 147 is compared with the historic images of this area to determine the landscaping changes that have occurred since the original planting plans were executed. By the 1940s a circular drive was built south of the mess hall which was lined with palms. 


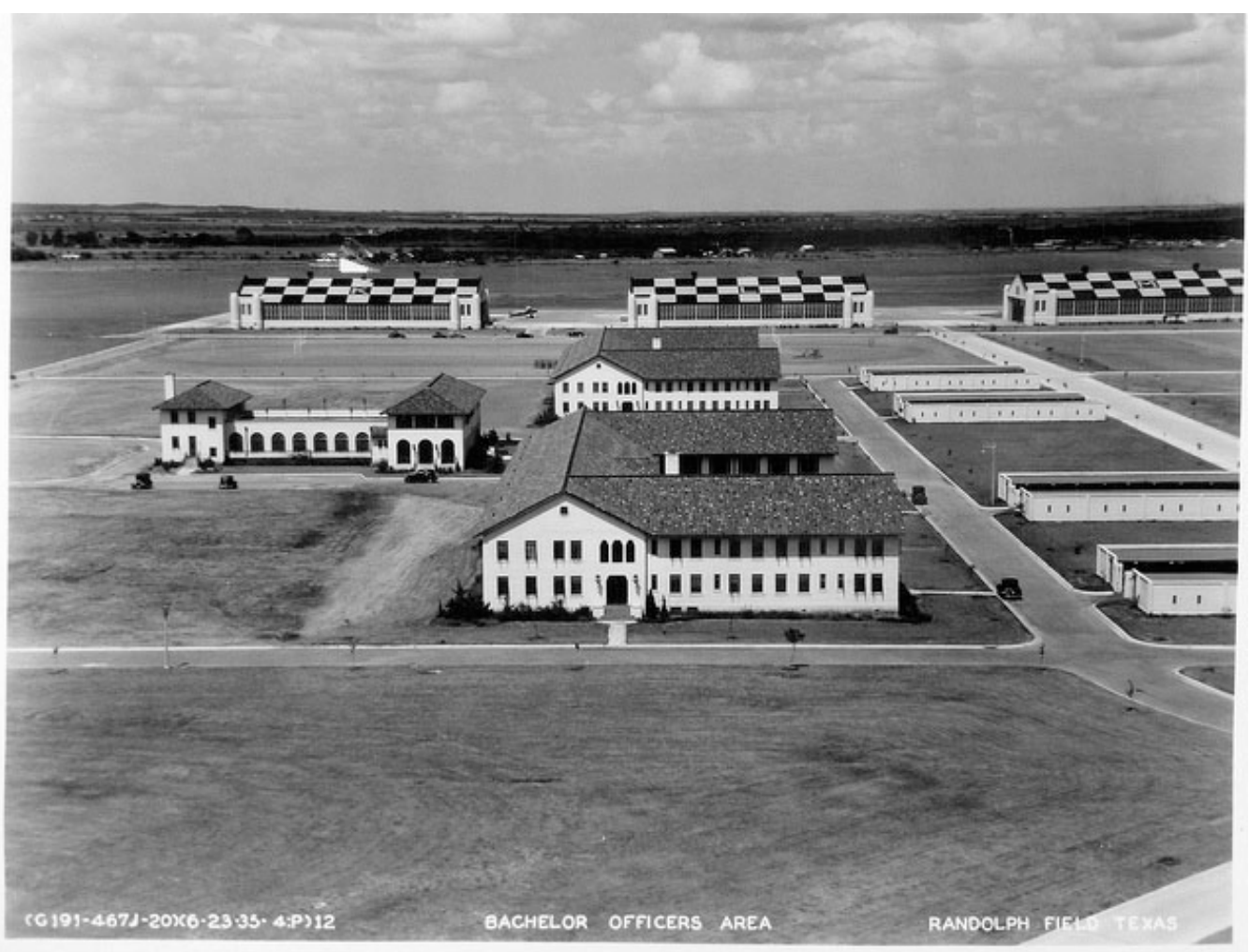

Figure 145. The BOQ buildings were landscaped around their foundations with evergreens that were used to emphasize building entrances, 1930s (NARA RG342 Box 1072).

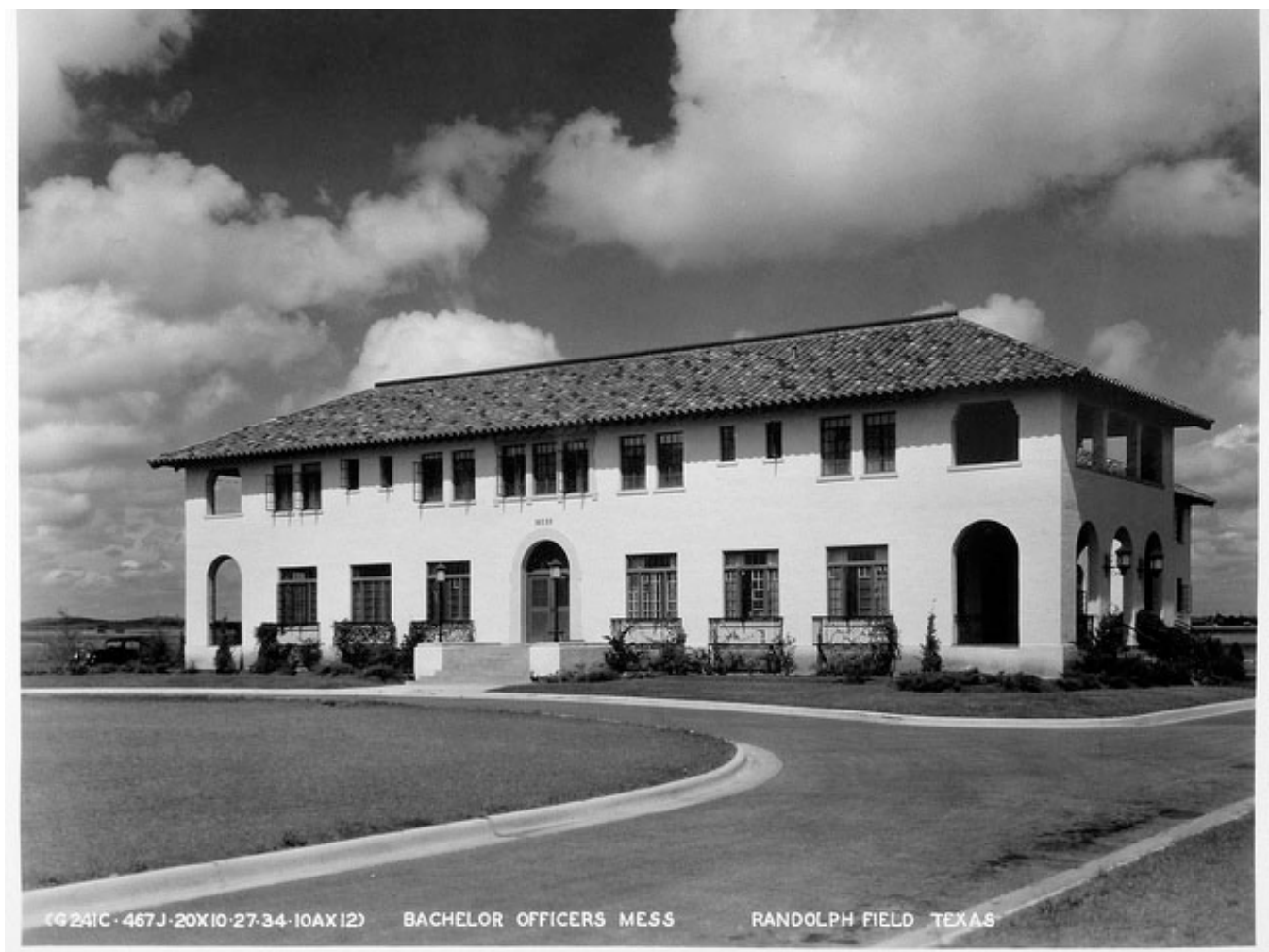

Figure 146. The $B O Q$ mess was landscaped like the other buildings in the complex with evergreen trees and shrubs around the foundation, 1930s (NARA RG342 Box 1072). 


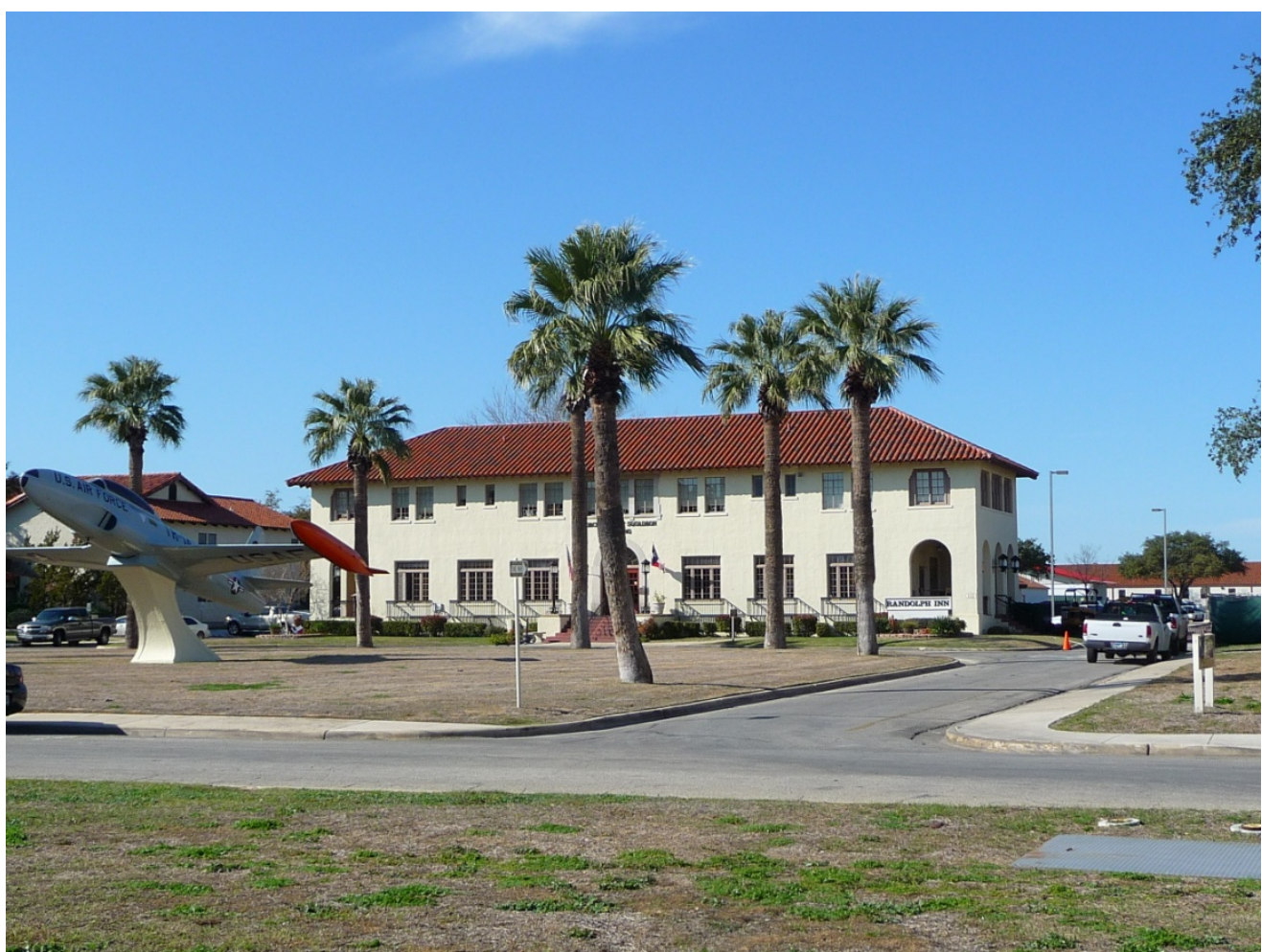

Figure 147. The former BOQ mess hall retains some foundation plantings and the space south of the entrance has been lined with palms, 2012 (ERDC-CERL).

\subsubsection{Enlisted men's barracks}

The enlisted men's barracks buildings were historically landscaped with foundation plantings of evergreen trees and shrubs (Figure 148). Unique to the east barracks area was an amphitheater designed by Lt. Bone. The amphitheater was removed by the 1940s to construct a building. Figure 149 is an image of the original plan for the amphitheater. 


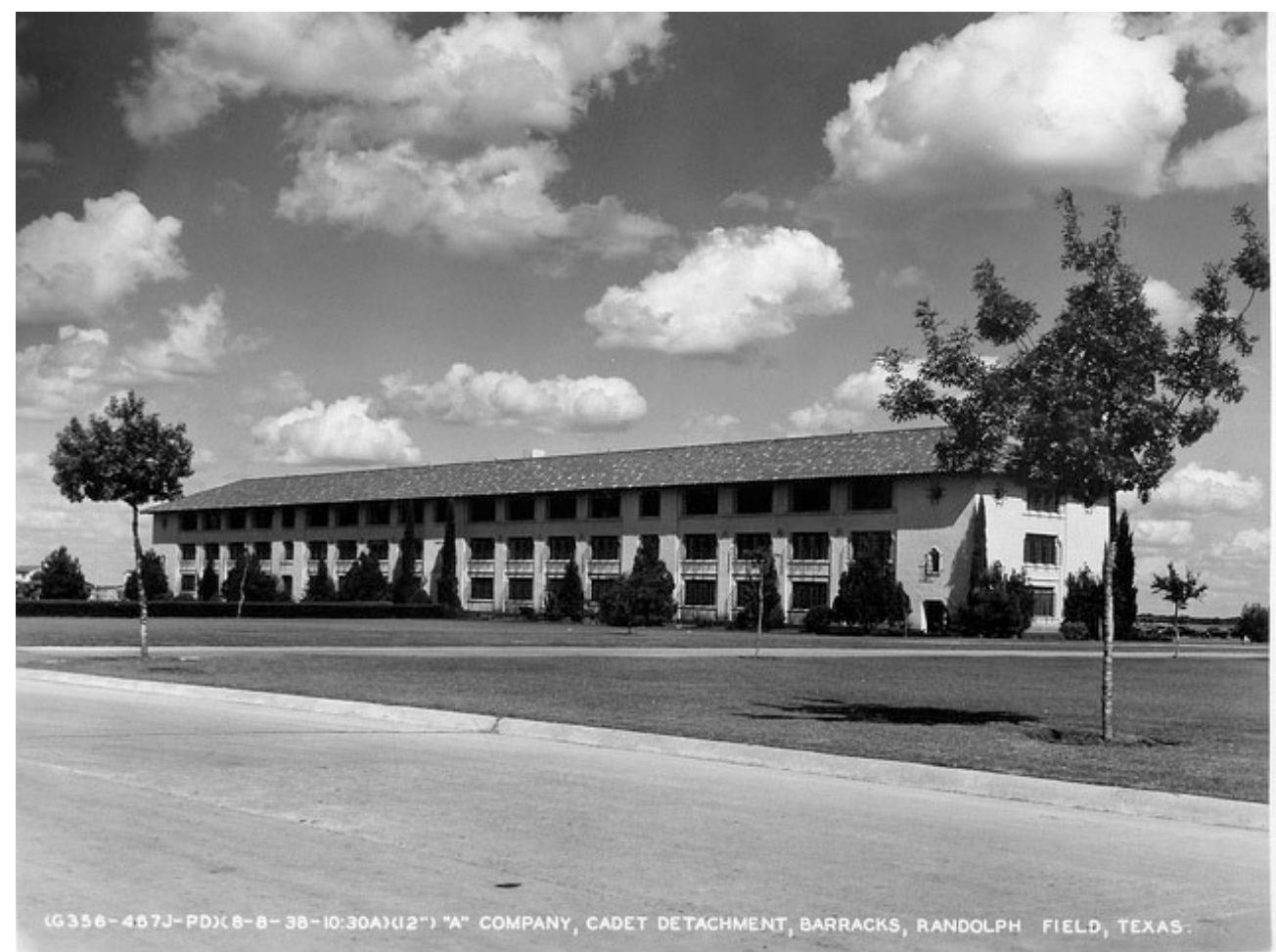

Figure 148. One of the barracks buildings with foundation plantings. Evergreen trees emphasize the architectural division in the building, while shrubs and hedges delineate entrances, 1930s (NARA RG342 Box 1072).

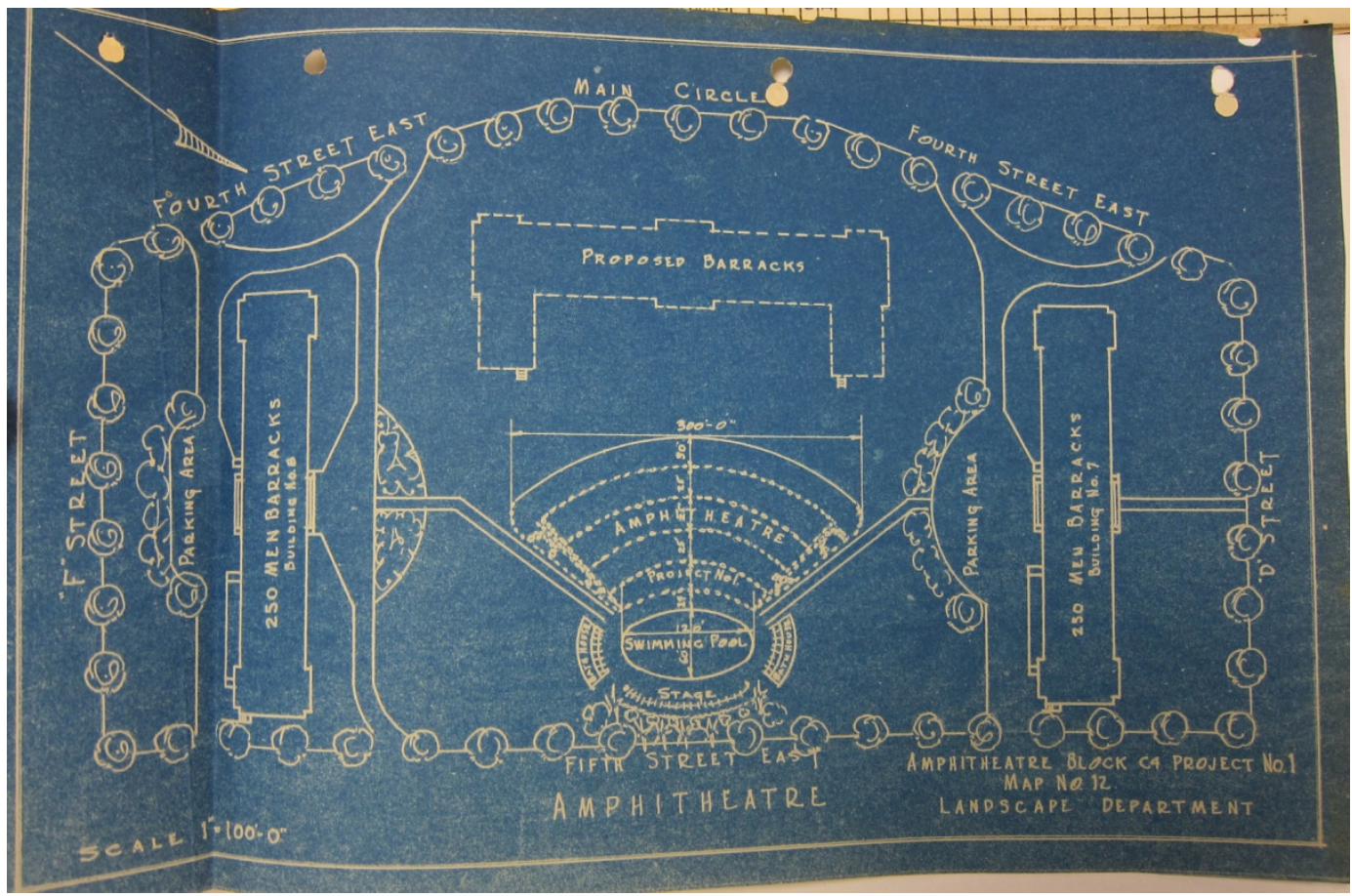

Figure 149. Original amphitheater drawing, 1930s (Norfleet Giddings Bone Papers, University of Texas at San Antonio Libraries Special Collections). 
Currently, the spaces surrounding the former enlisted men's barracks are paved parking lots and the vegetation is limited to sparsely arrayed shrubs and hedges (Figure 150).

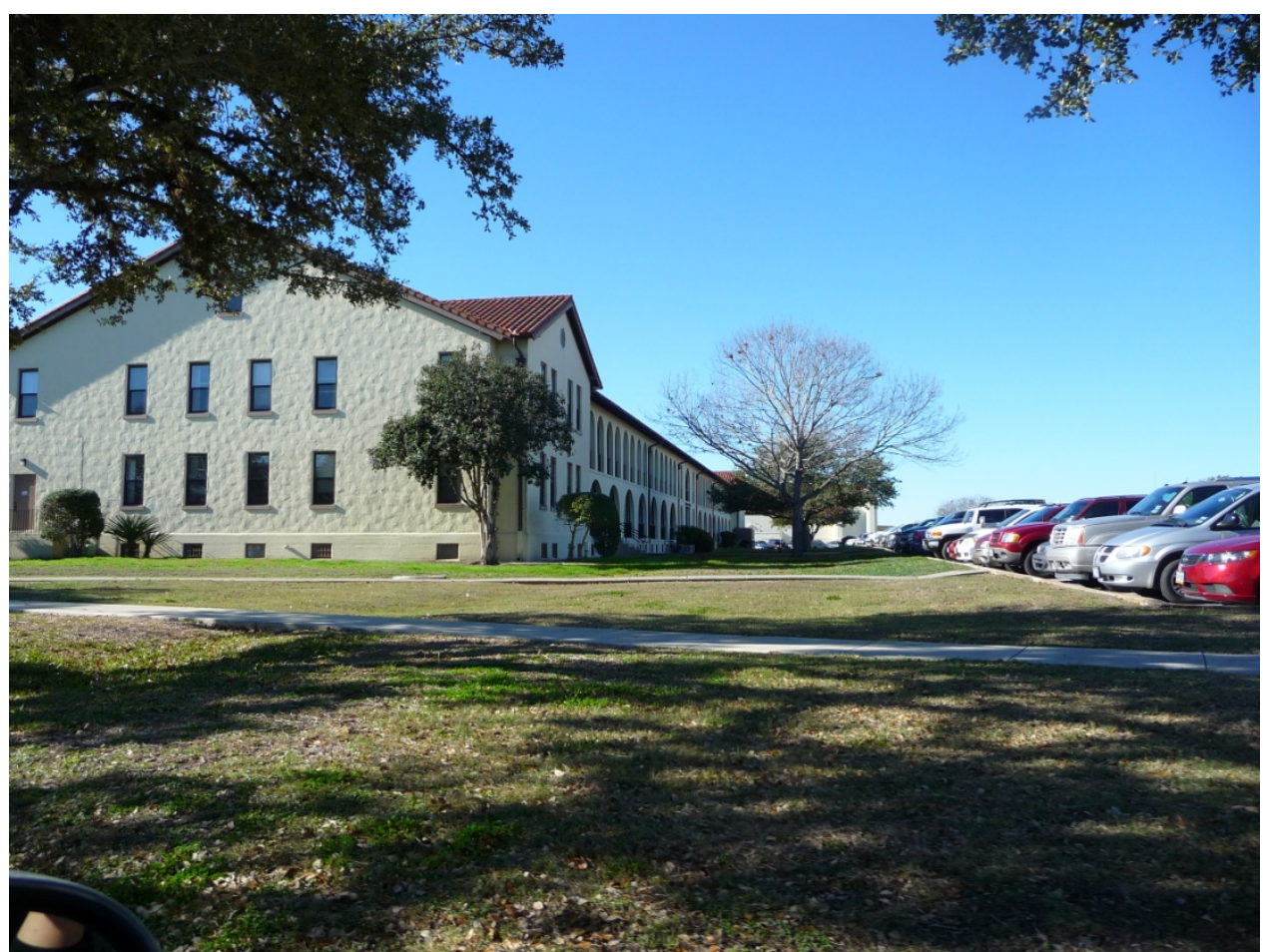

Figure 150. The current plantings around the former enlisted men's barracks buildings are unified in a cohesive design. Many ornamental plants stand alone or are part of broken hedges, 2012 (ERDC-CERL).

\subsubsection{Cadet Complex}

The Cadet Complex was another important area within the Randolph Field. The buildings were built around a circular courtyard which was originally grassed and lined with palms (Figure 151). The buildings received similar landscaping treatments to the other buildings in the Field, foundation plantings of evergreens and ornamentals. Currently, the planting scheme of the former Cadet Complex is ornamental and uses palms, ornamental trees, and hedges to define interior spaces. The interior spaces are then filled with annuals that need to be replaced periodically (Figure 152). The spaces between the former barracks have been converted to surface parking lots. There are grassed strips running down the middle of these lots with scattered shade trees (Figure 153). 


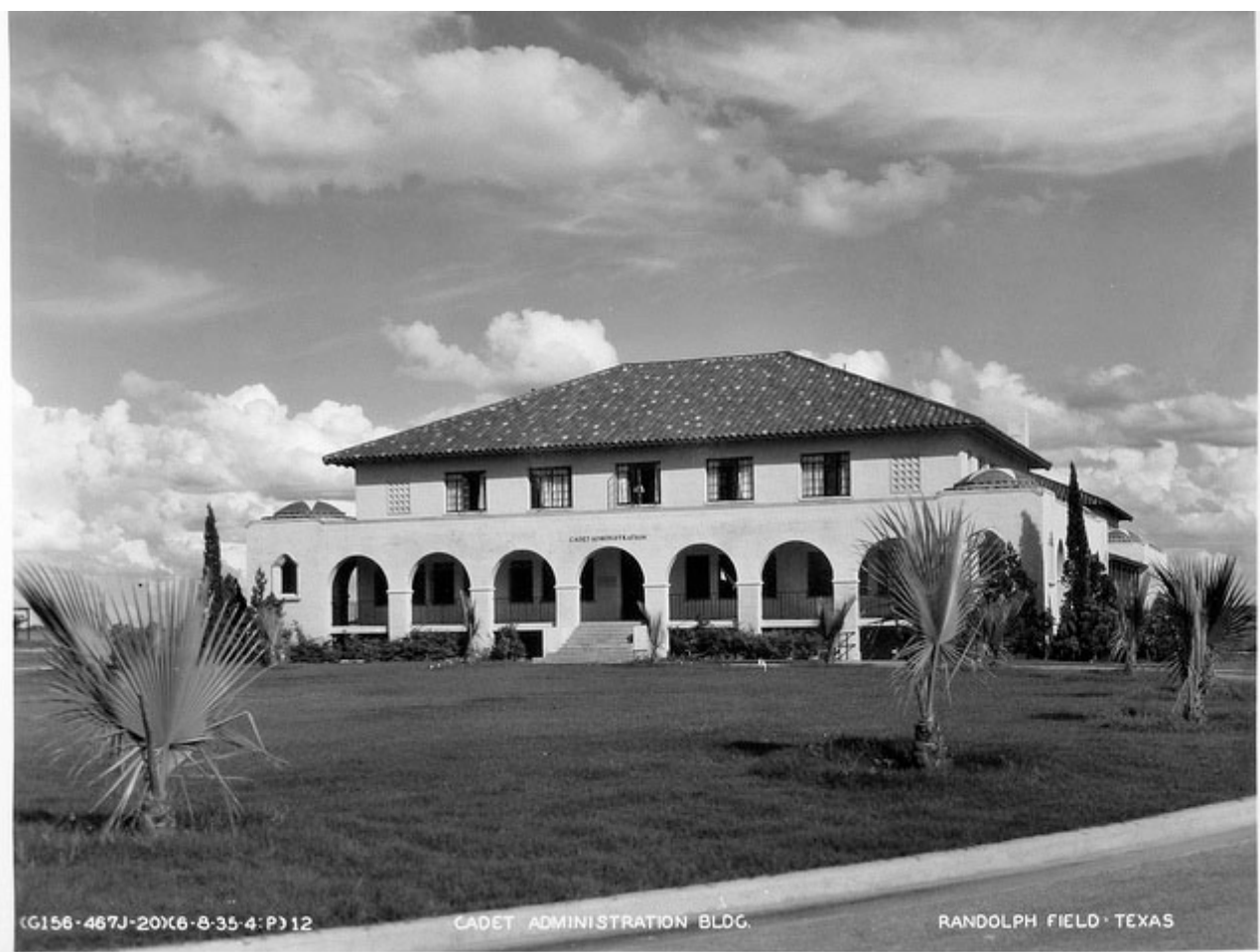

Figure 151. The administration building in the Cadet Complex. The Cadet Circle, in the foreground, has been planted with palms while the buildings in the complex have a variety of plants surrounding their foundations, 1930s (NARA RG342 Box 1072).

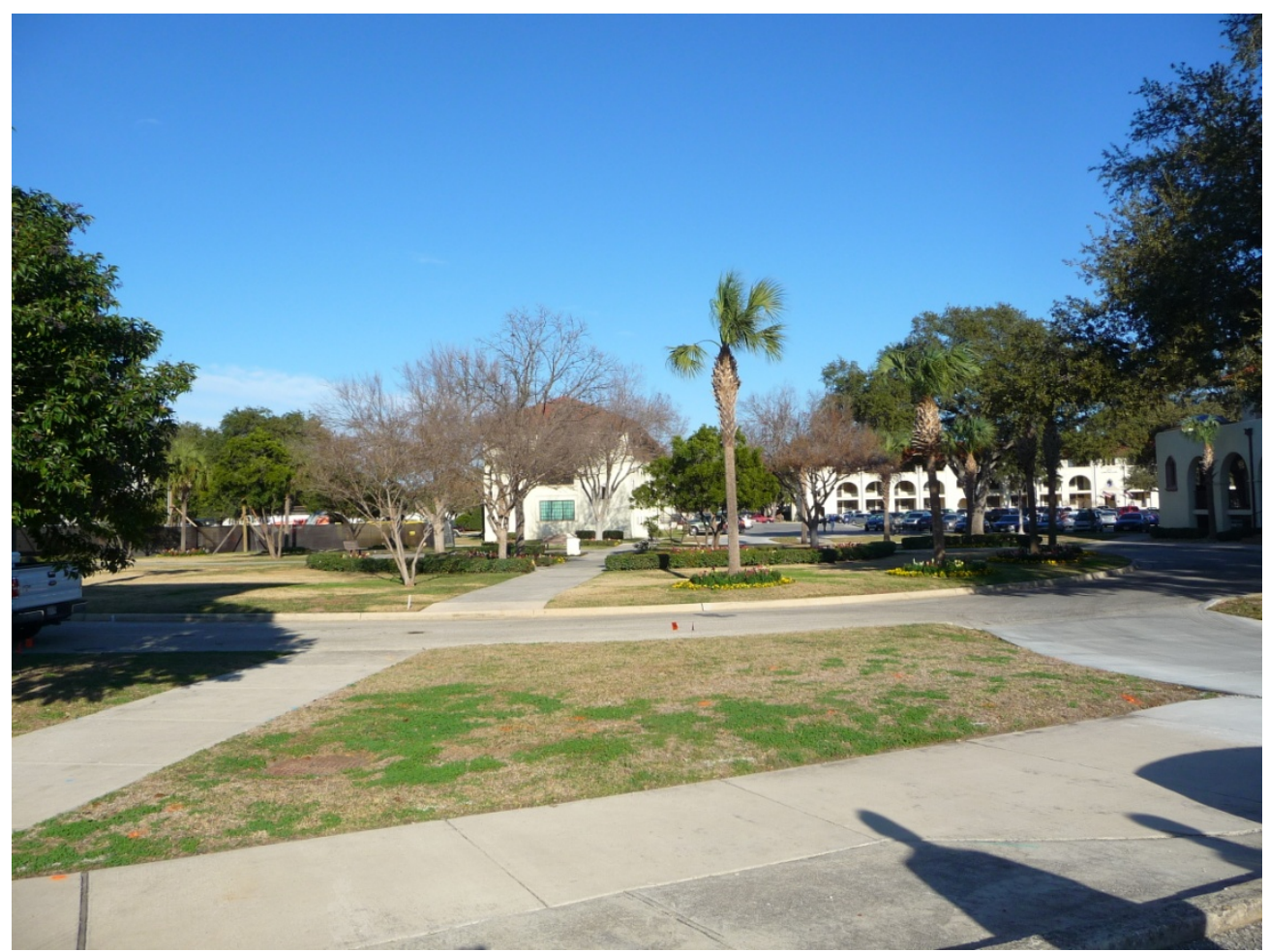

Figure 152. Annuals are now planted extensively around the Base. The Cadet Circle is filled with petunias and snapdragons as well as low-growing evergreen hedges along with the palm trees lining the circle, 2012 (ERDC-CERL). 


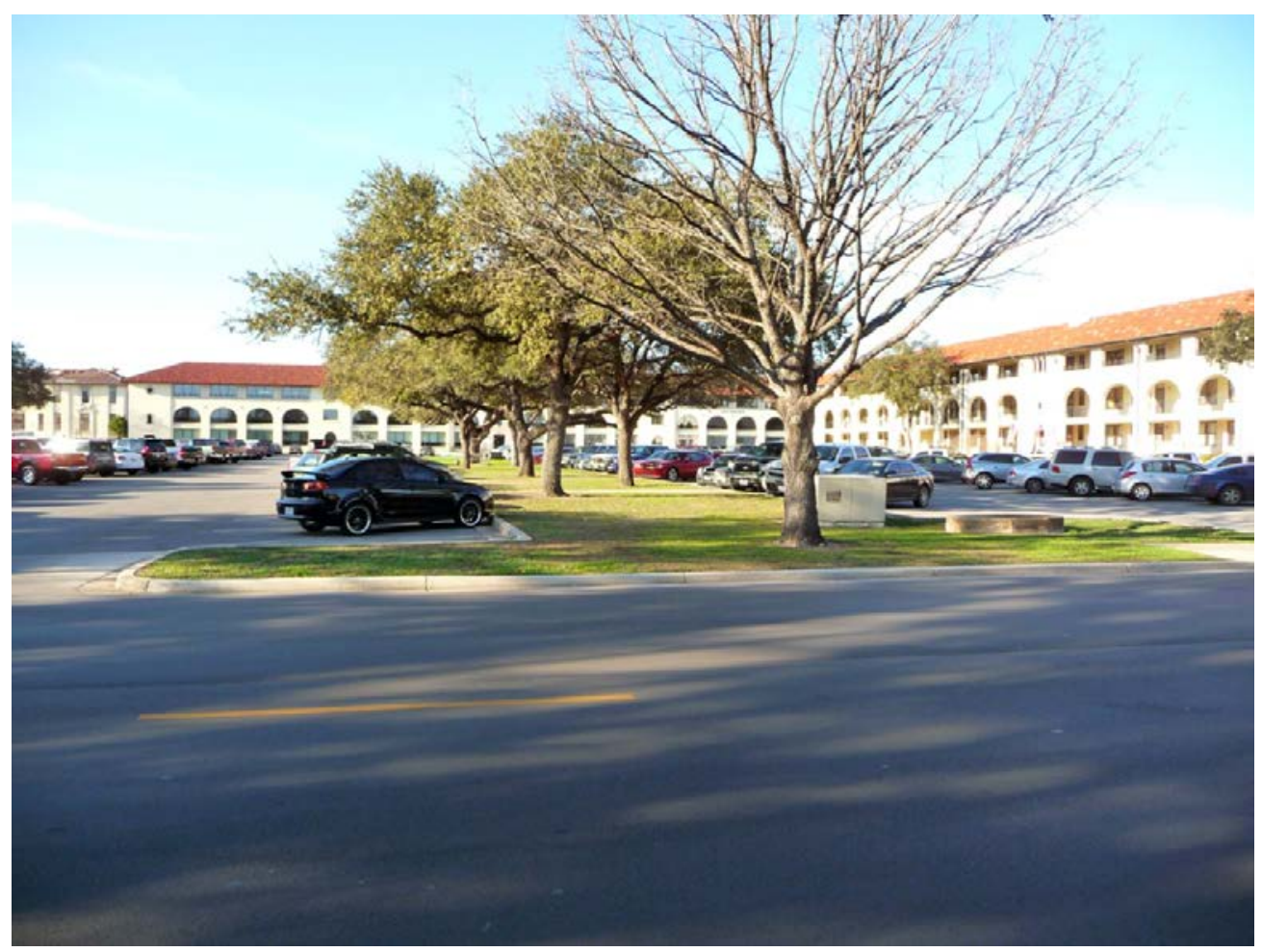

Figure 153. The Cadet Complex barracks were originally surrounded by open green spaces, but by the 1940s parking lots had been introduced along the barracks while retaining some of the original green space. By 2012, the east and west spaces between the buildings has been converted to parking lots with a strip of open space and a few trees, 2012 (ERDC-CERL).

\subsubsection{Hospital complex}

Like many of the other important buildings at Randolph Field, the Post Hospital and the School of Aviation Medicine had distinct planting plans. The historic plantings were concentrated around the foundations of the buildings, but featured a variety of plant material, textures, and heights (Figure 154). While efforts have been made to landscape around these buildings, the area lacks a cohesive planting design (Figure 155). 


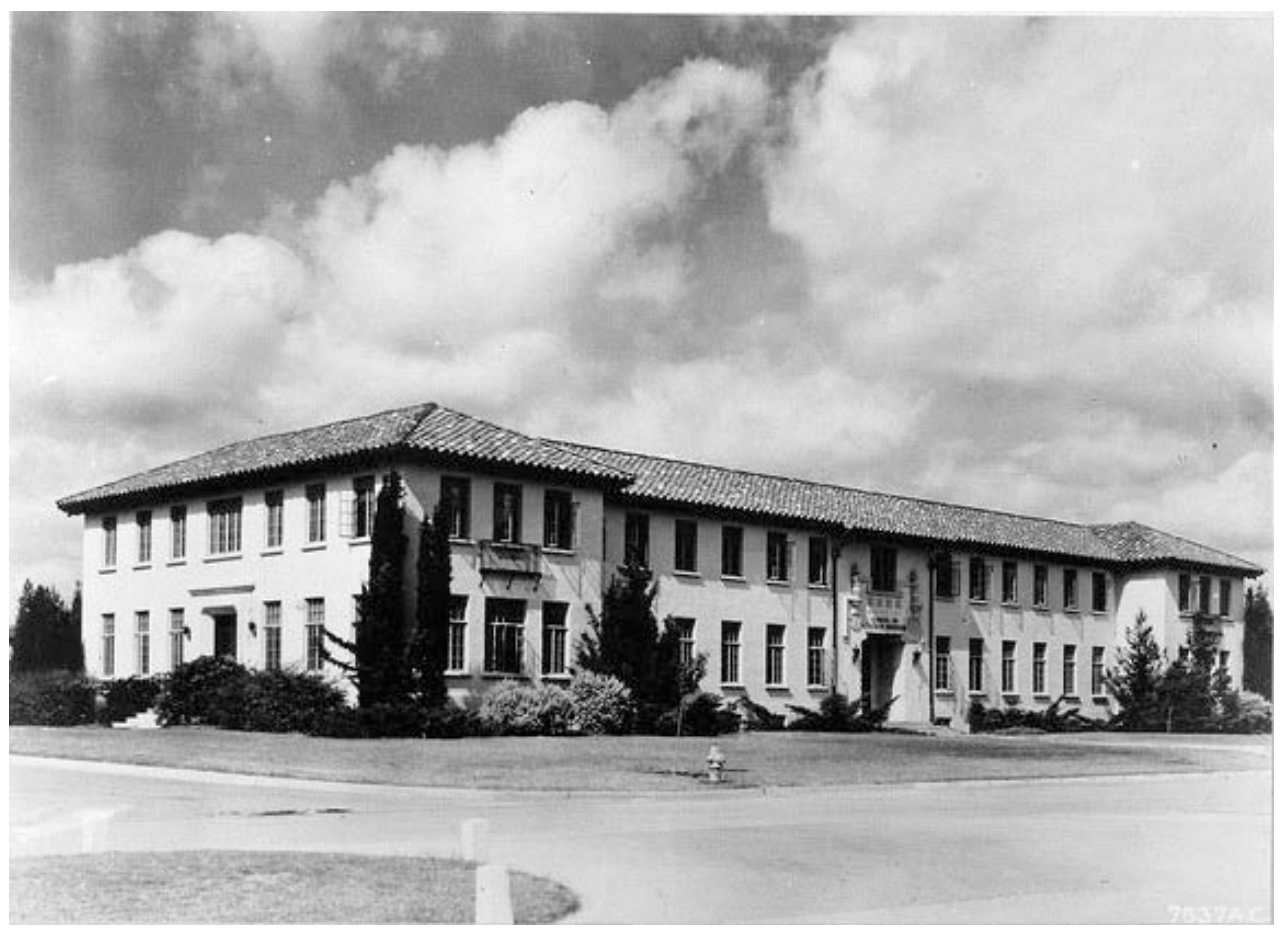

Figure 154. The School of Aviation Medicine had a well-developed landscaping by the late 1930s (NARA RG342 Box 300).

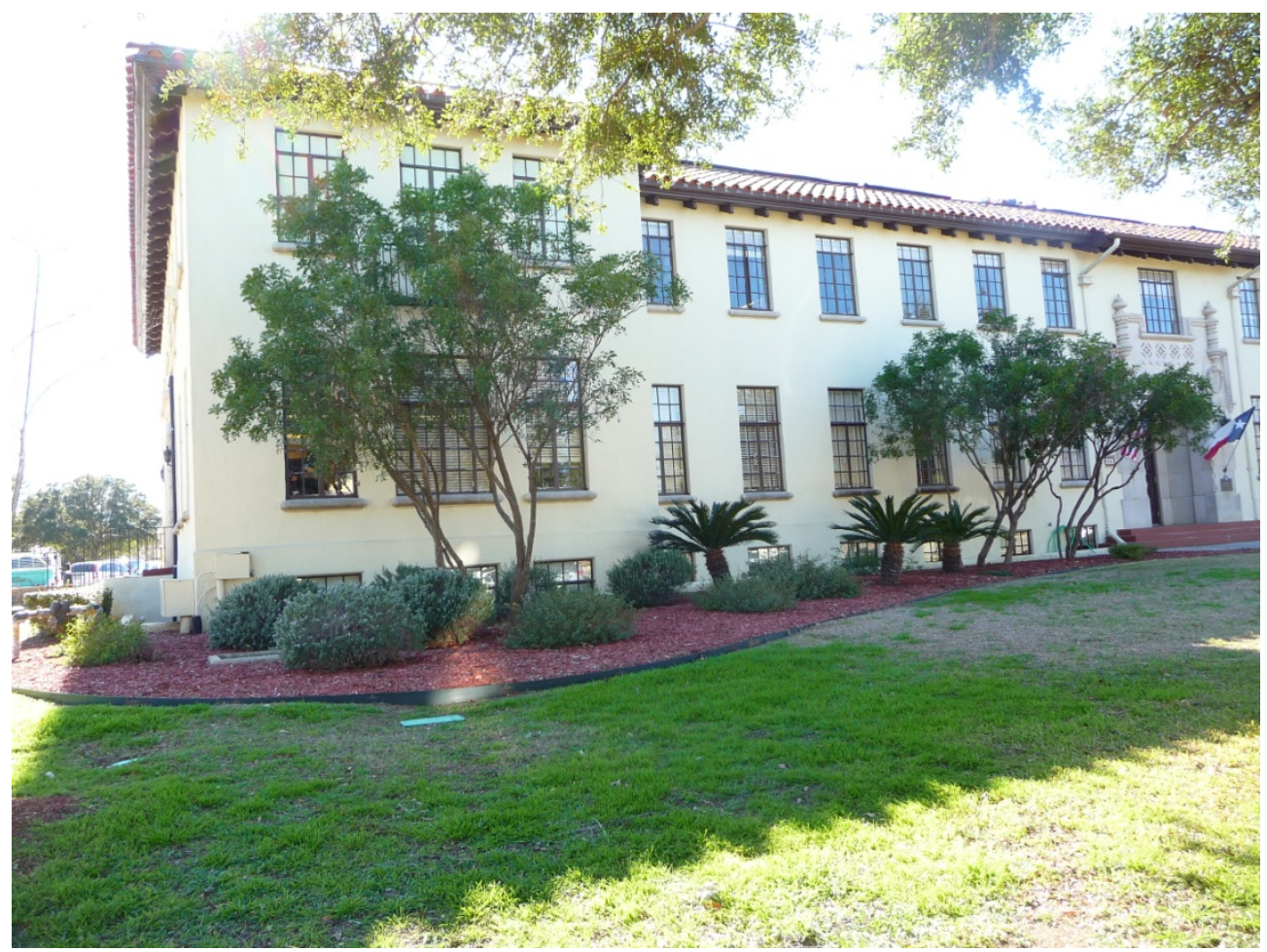

Figure 155. The Post Hospital and School of Aviation Medicine were elaborately planted with evergreens, but currently, there are a ornamental trees and shrubs around these buildings, 2012 (ERDC-CERL). 


\subsection{Views and viewsheds}

Views played a vital role in the site selection, programmatic organization, and character of Randolph AFB. This chapter inventories the views and viewsheds of Randolph by documenting the features and elements that contribute and define them. These components are then analyzed to determine their condition and historic integrity.

Cultural landscapes are a relatively new field of inquiry and as a consequence, the idea of documenting and preserving historically planned views and viewsheds is also a new idea in landscape studies. Views and viewsheds are intentionally designed features in a landscape. Although they are intangible, physical encroachment on them significantly alters the aesthetics of the design.

Views and viewsheds are created by landscape-scale physical elements. In the process of identifying and evaluating historic views and viewsheds, the historic physical elements are compared with the contemporary site context.

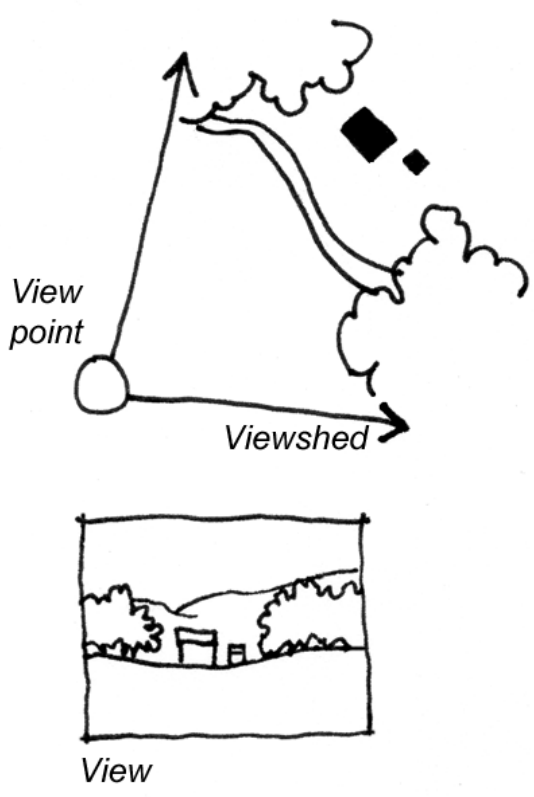

Viewshed: Viewshed refers to all visible elements that can be seen from a certain viewpoint. Viewsheds are both external and internal. External viewsheds are those from viewpoints outside of Randolph AFB, while internal viewsheds are viewpoints from within base grounds.

View: A scene or vista that can be seen when looking in one direction standing at a certain viewpoint.

Viewpoint: is the exact point where a person is standing when looking at a view.

There are many views and viewsheds at Randolph AFB that are integral to the original design of the base. The strong geometrical street network of the base provided ample views to significant features around the base. The axial alignment of the base along a primary north-south axial street and a 
secondary east-west axis emphasized the views along these corridors. The initial view of Randolph Field was down the long entrance boulevard, where the view terminated in the elaborate and striking design of the Administration Building. Likewise, other important buildings were placed along the axes that were meant to be viewed from many locations around the base.

1. The view down Harmon Drive to the southeast starting at the entrance gate and terminating at the Administration Building (Taj Mahal). This view is the primary view of the base (Figure 156).

2. The Harmon Drive view corridor. The main entrance boulevard was constructed as a view corridor between the main entrance and the Administration Building. The divided road was designed with rows of trees on the outer sides to spatially define the visual connections along the corridor (Figure 157 and Figure 158).

3. In the residential areas, the primary views are along North and South Parks and East and West Parks. These boulevards were designed with roads divided by wide, grassed medians which were lined with trees. The views terminated at important base buildings such as the Commanding Officer's quarters, Officers' Club, and the Cadet Education Building that were organized along the northsouth view. The east-west views also terminated at the Officers' Club and were originally designed to extend through the enlisted men's barracks to terminate in the east and west stage houses. The east-west views were altered during WWII when buildings were added to the barracks areas.

4. The views along Fifth Street East and Fifth Street West provide long view corridors that highlight the importance of the flight lines, the spatial uniformity of the hangar layout, and how the flight lines integrate into the overall base design (Figure 159).

5. Secondary east-west view corridors exist along C Street, F Street, and $\mathrm{H}$ Street. These streets provide views across the width of the base from one flight line to the other.

6. Main Circle creates tangential views for vehicular traffic that are circumnavigating the quadrants of the base. As a viewer progresses 
around Main Circle, there is a continuous sequence of views to important buildings and open spaces.

7. The Taj Mahal serves as a visual point of reference from many points around the base (Figure 159).

8. The views toward the cantonment from Perimeter Road, including views from the golf course toward the south edge of the base and the view northwest from Eberle Park across the runways (Figure 160). 
Figure 156 is an early image of the primary entrance view toward the Taj Mahal.

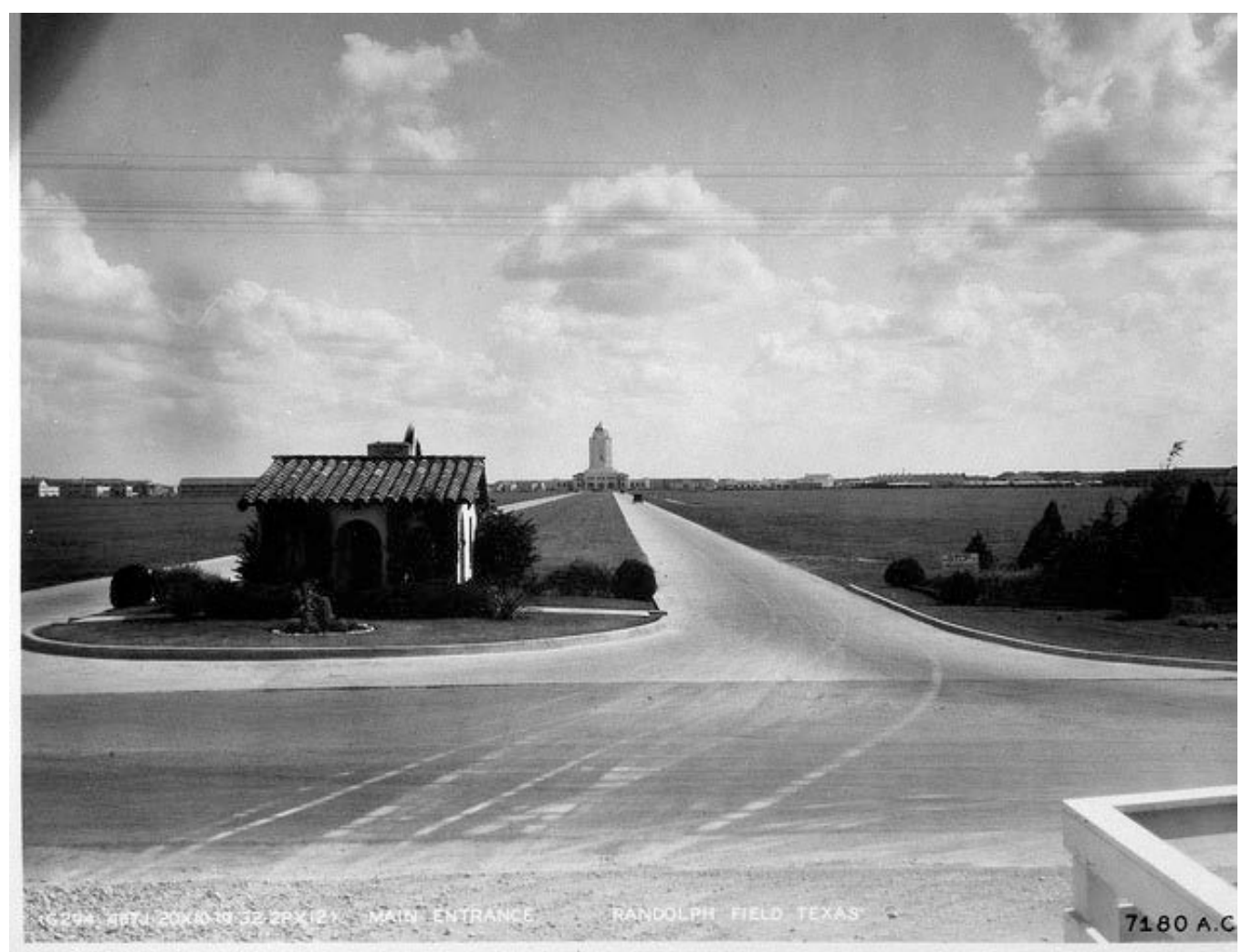

Figure 156. The first view of Randolph Field looking toward the Taj Mahal that new cadets would see upon arrival, undated (NARA RG342).

During WWII, the open areas on either side of the entrance boulevard had been built up with additional housing, but the view corridor was preserved and trees had been planted to vertically frame the axis (Figure 157).

In Figure 158 the view from the Taj Mahal is still an important feature of the Randolph AFB entrance sequence. 


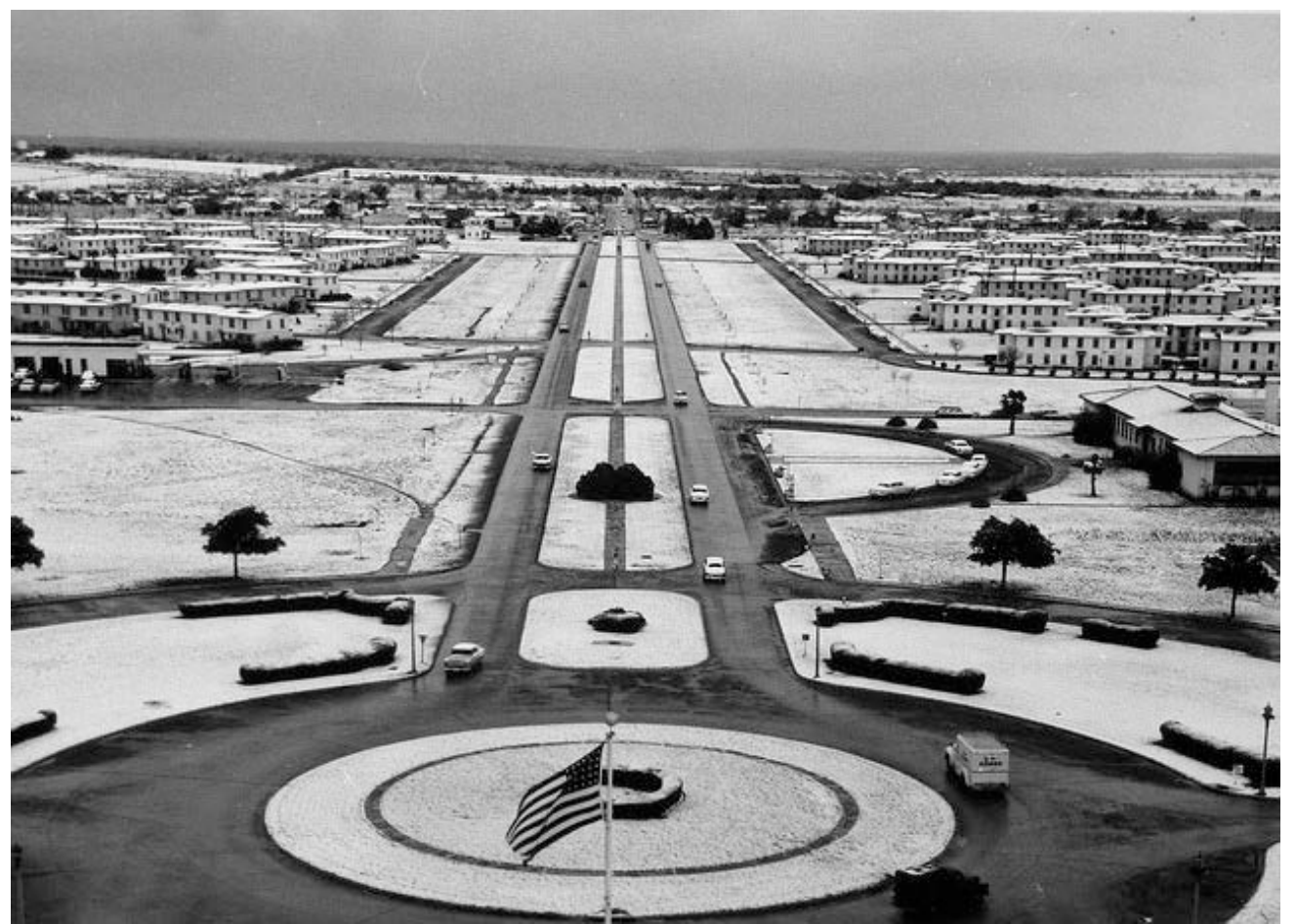

Figure 157. View toward the main entrance from the Administration Building, 1958 (NARA RG 342 Box 300).

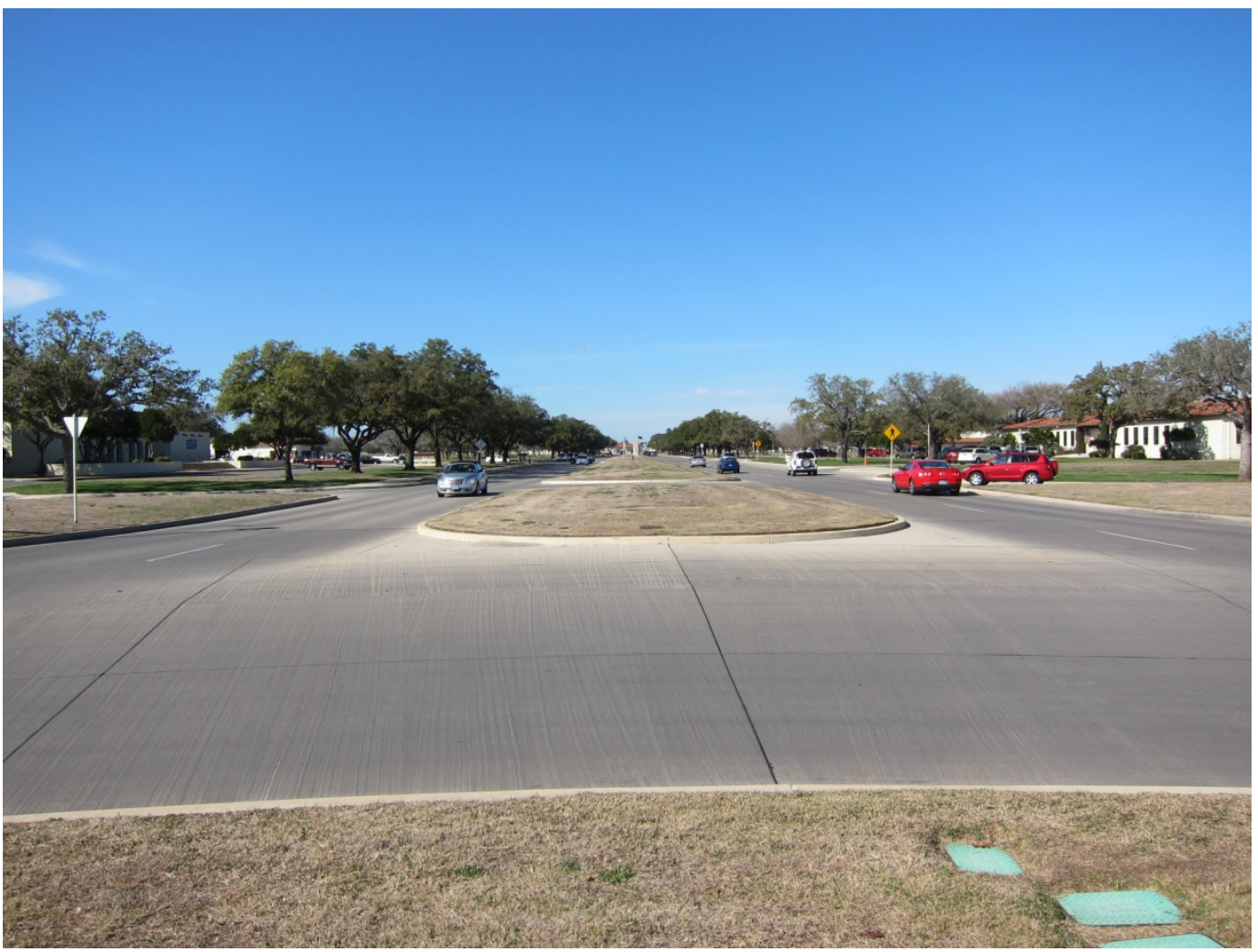

Figure 158. The most dominant view at Randolph AFB is still the view between the main entrance and the Administration Building, 2012 (ERDC-CERL). 
Figure 159 illustrates several views on the west side of the base, including the view along Fifth Street West, the continual views along Main Circle, and views of the Administration Building from multiple points around the base.

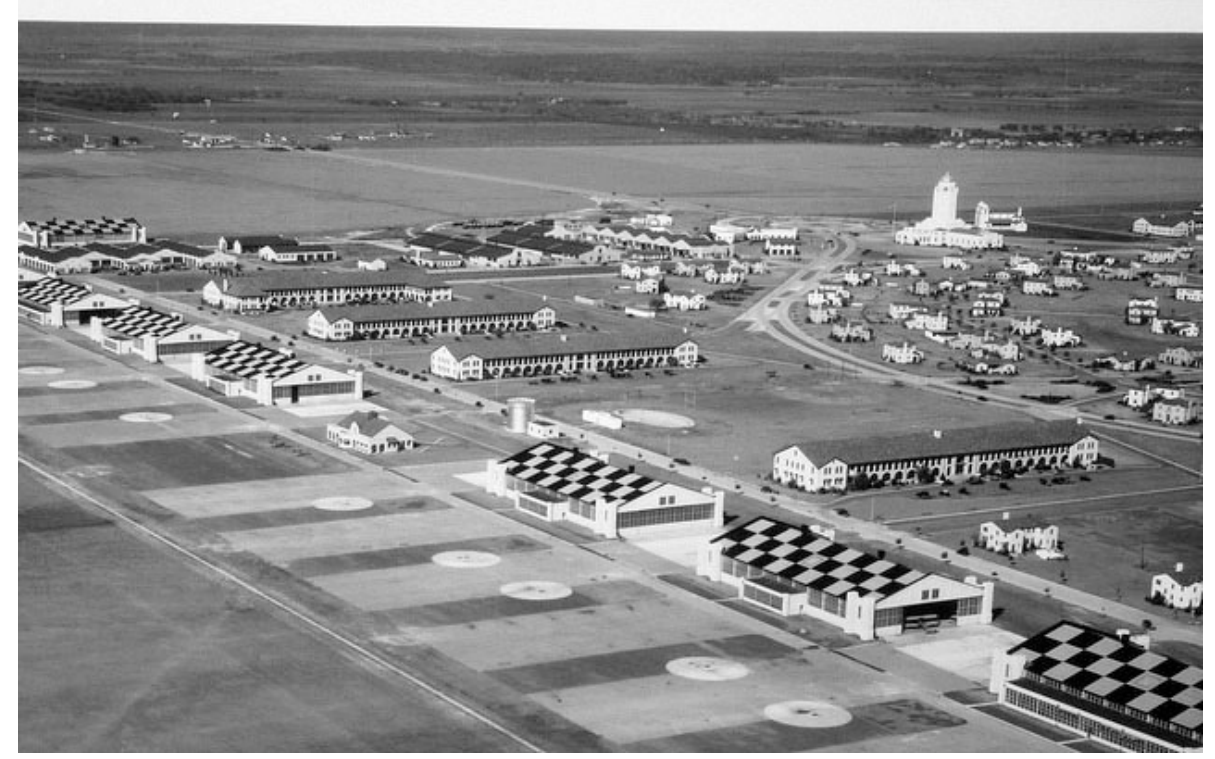

Figure 159. Aerial view of the west flight line with the Taj Mahal in the background, undated (NARA RG 342 Box 1071 B 20681).

Figure 160 is the view from East Perimeter Road toward the eastern flight line.

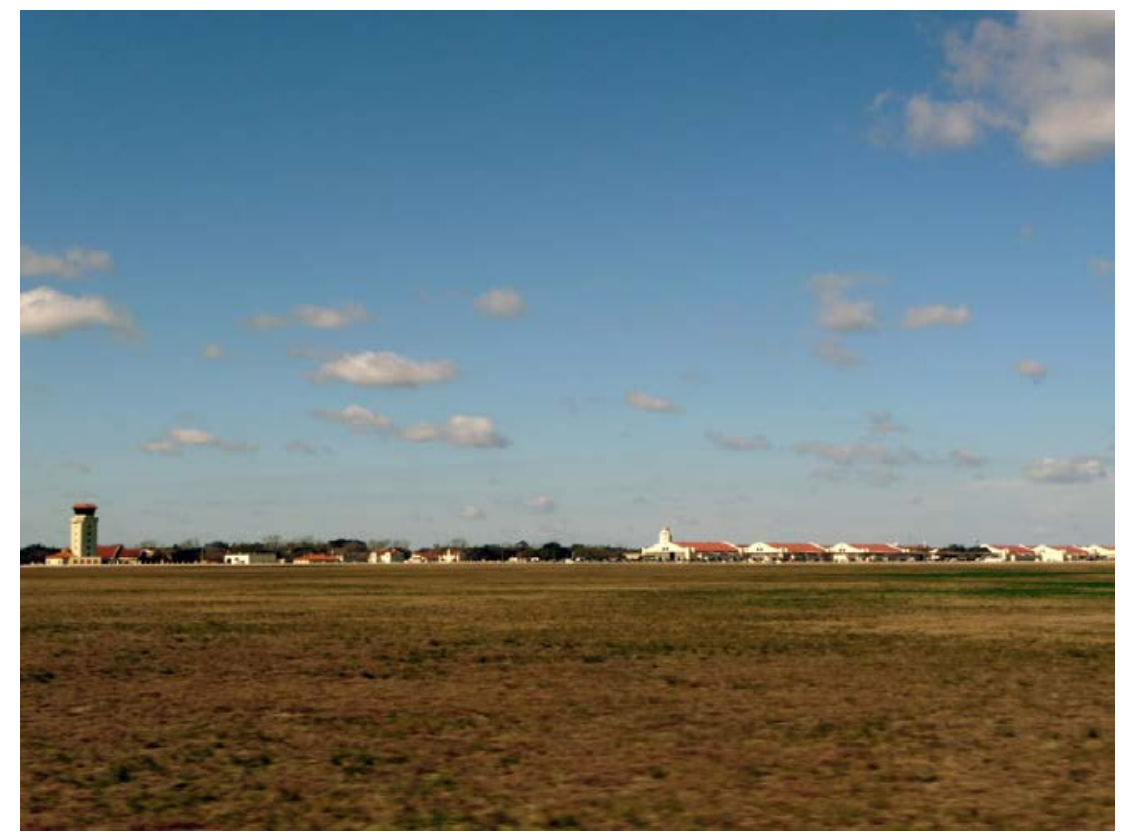

Figure 160. View of Randolph's eastern flight line, taken from the southeast corner of the installation, 2012 (ERDC-CERL). 
Figure 161 diagrams the historic views, viewsheds, and view corridors of Randolph AFB.

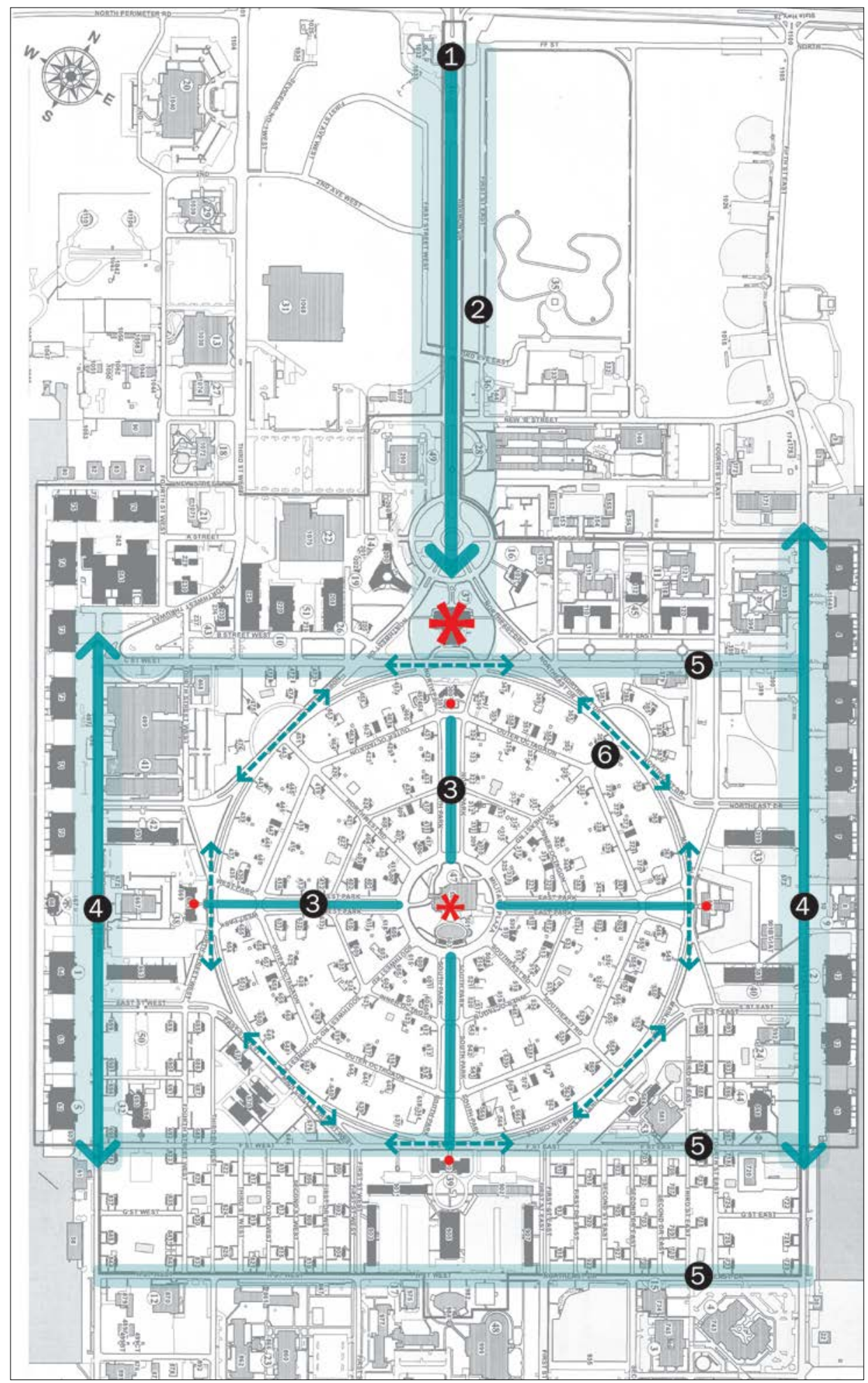

Figure 161. Views and viewsheds in the Randolph Field Historic District. Numbering corresponds to the aforementioned views list, 2013 (ERDC-CERL). 


\subsection{Small-scale features}

Small-scale features can range in size and be stationary or moveable objects that often contribute to the historic character of the installation. ${ }^{52}$ These features may include monuments, light poles, benches, flagpoles, fencing, or signs and can be functional or purely decorative. The pragmatic small-scale features are arranged through the site according to their use; benches, signs, and trashcans are placed where people need them while fences, lighting, and material choices subtly inform the larger landscape.

\subsubsection{Landscape objects}

There are many small-scale landscape features within the built environment of Randolph AFB. The extensive planning of the base included considerations for some small-scale features. Lt. Bone was involved with selecting the lighting choices for the different areas of the base and worked closely with the Office of the Constructing Quartermaster to create this lighting system. Over a six-month period, Lt. Bone considered the placement, design, and specifications for street and residential lighting. The final lighting selections that would be used throughout the field included 216 lantern-type standards, 54 master arm standards, and eight bracket standards. The lantern-type standards would be used in the residential areas while the master arm standards would be used in the service areas. Depending on the location and distance between lights, the candle power varied from 1,000 to 4,000 lumens. Lt. Bone also considered what type of light pole would best reflect the Spanish Colonial Revival architecture of the buildings. He concluded that two types of poles would work; one was of pressed steel and the other was hollow spun concrete. Both types were ordered for about $\$ 14,000$ and another $\$ 16,000$ was spent on installing the lighting system. Table 1 catalogs photos of the different lighting styles found throughout Randolph AFB.

52 Loechl et al. 2009, 90. 
Table 1. Types of lighting used around Randolph AFB.

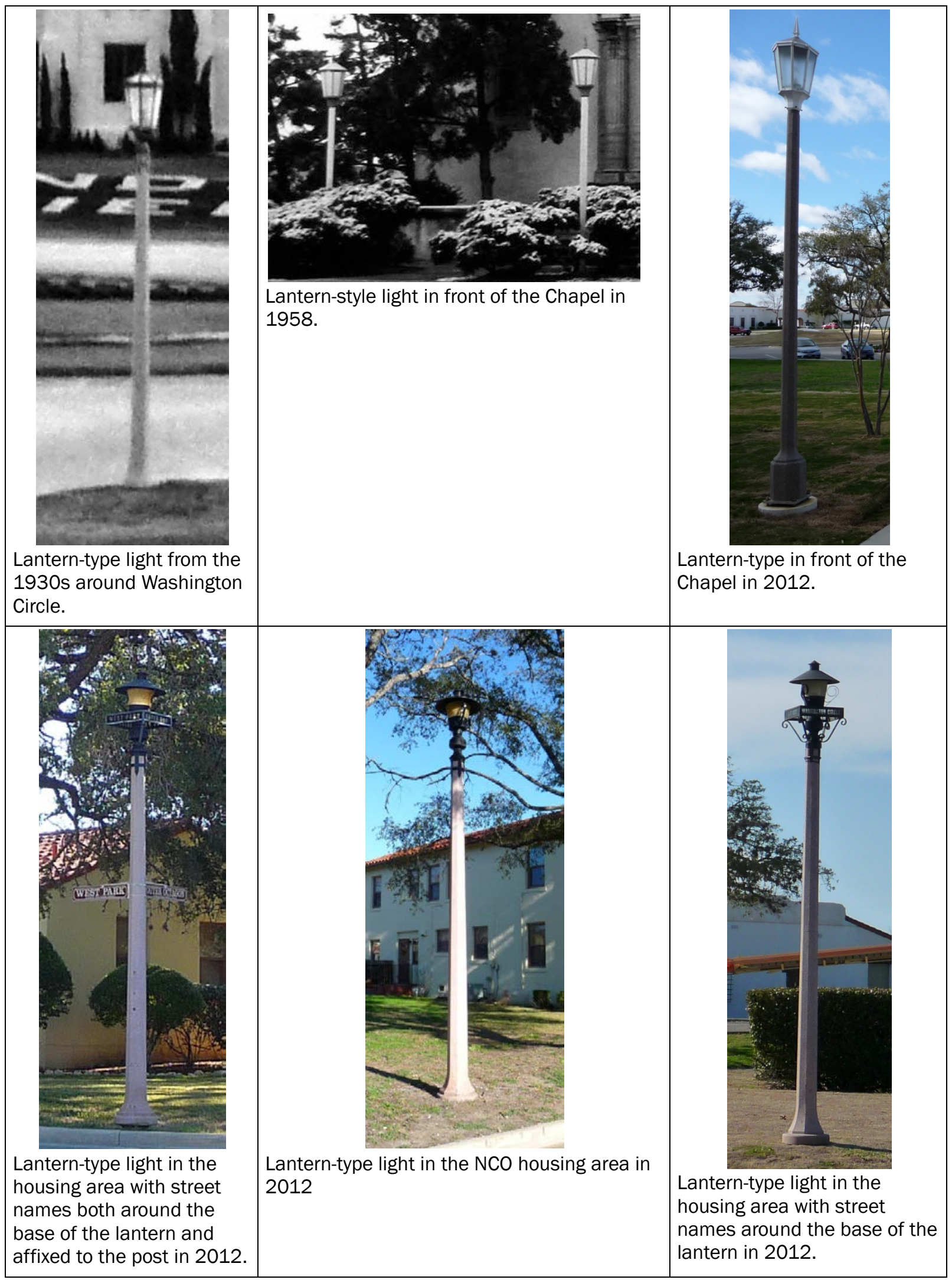




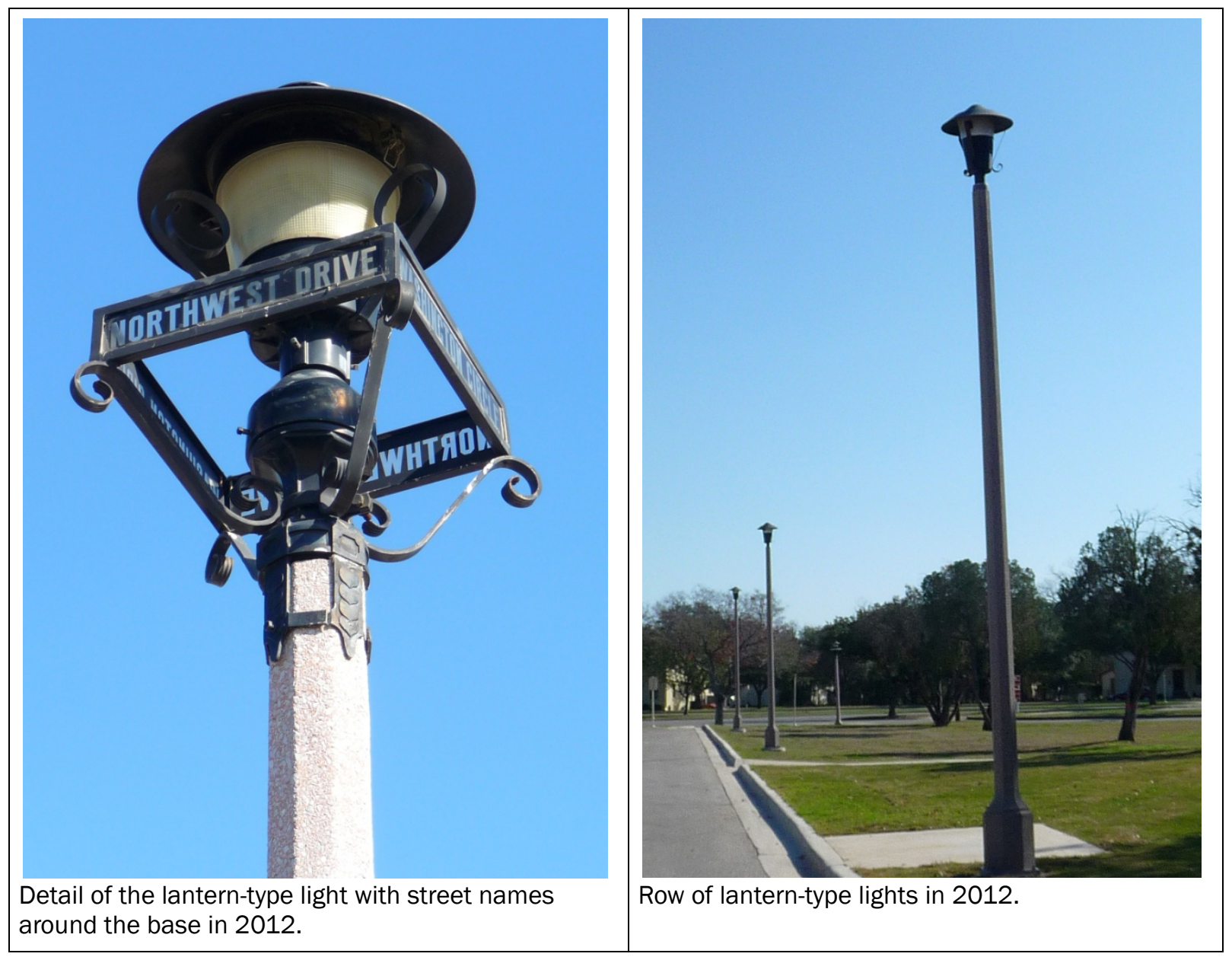




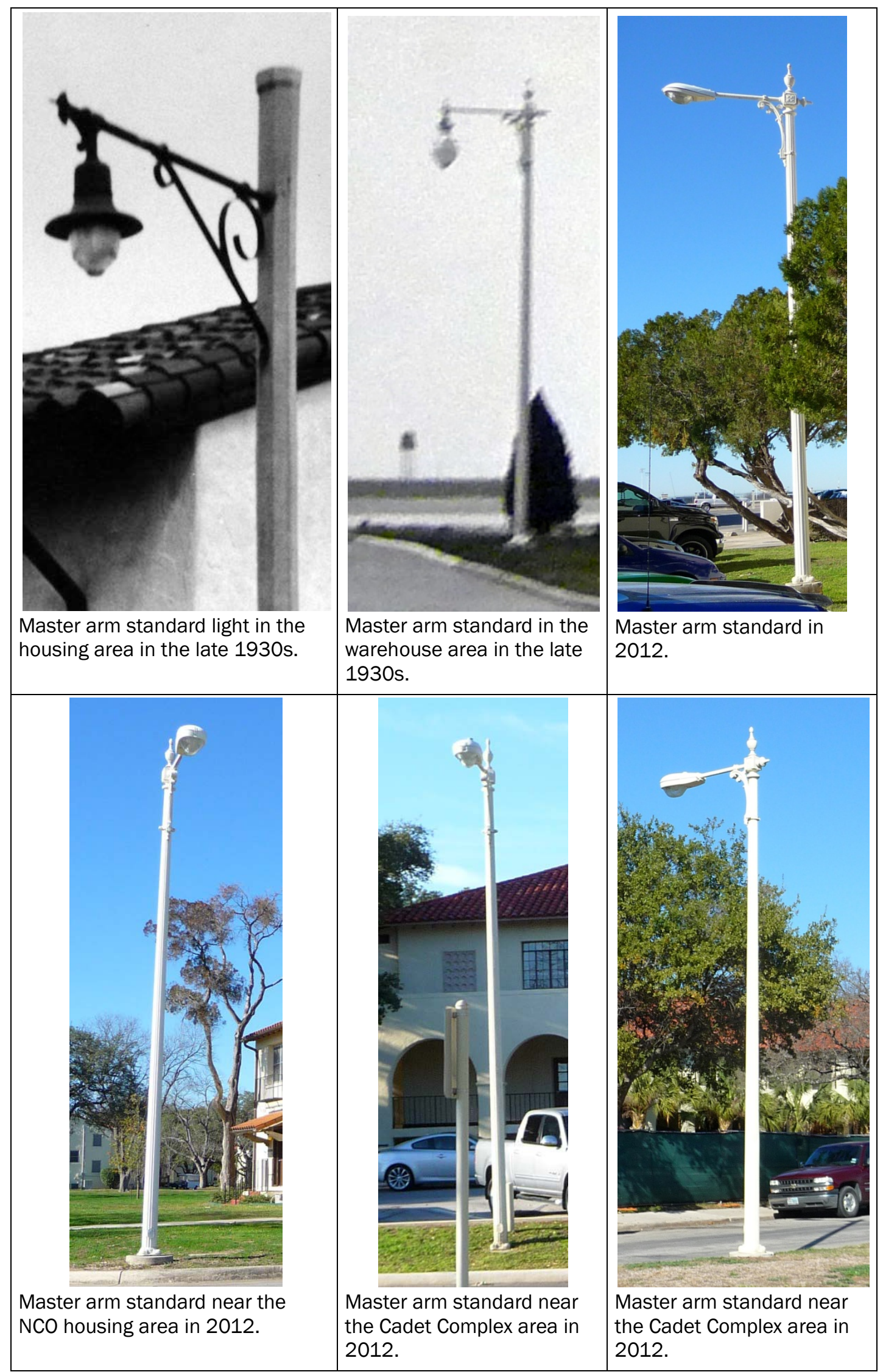




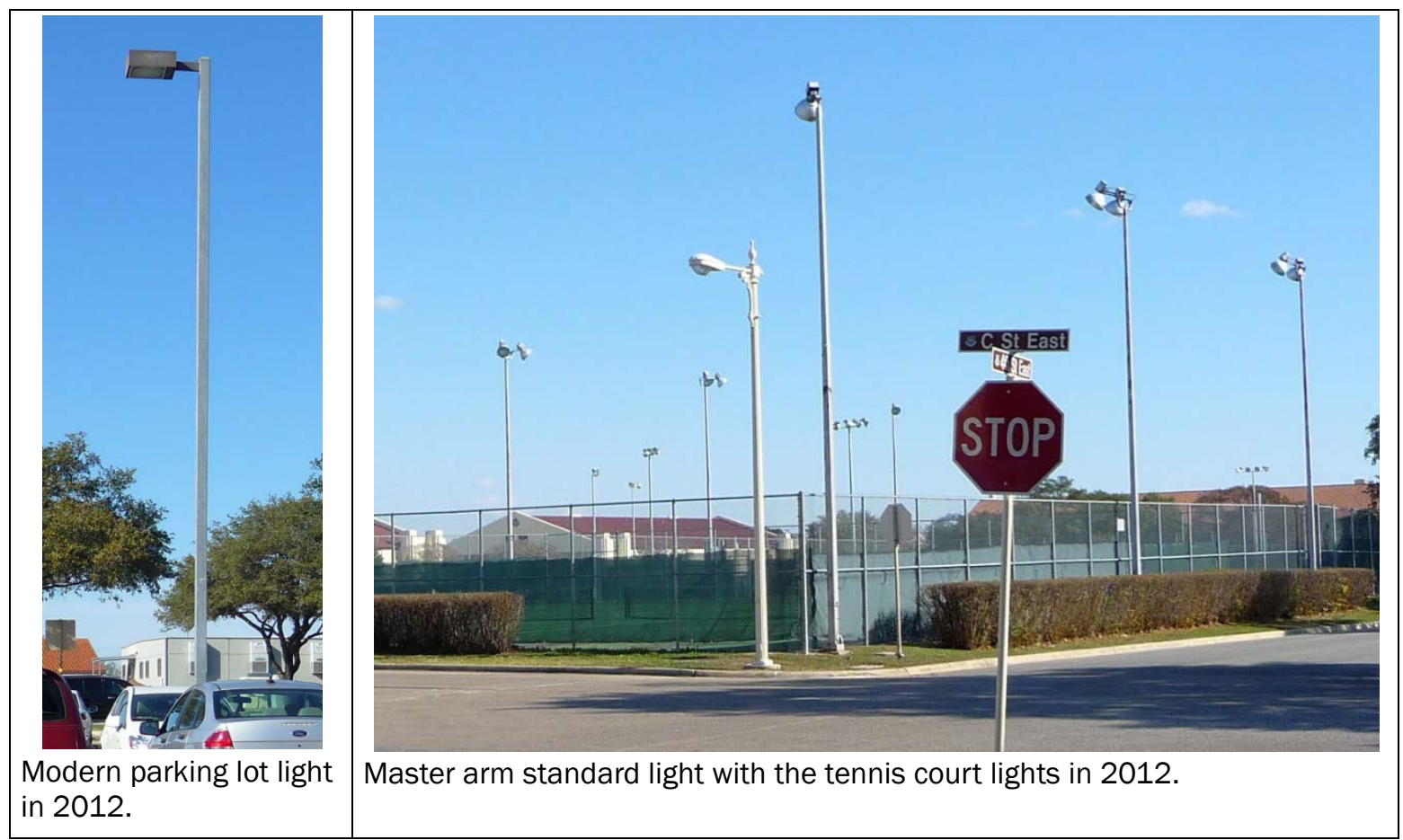

Figure 162- Figure 180 provide examples of the landscape objects found in the Randolph AFB landscape.

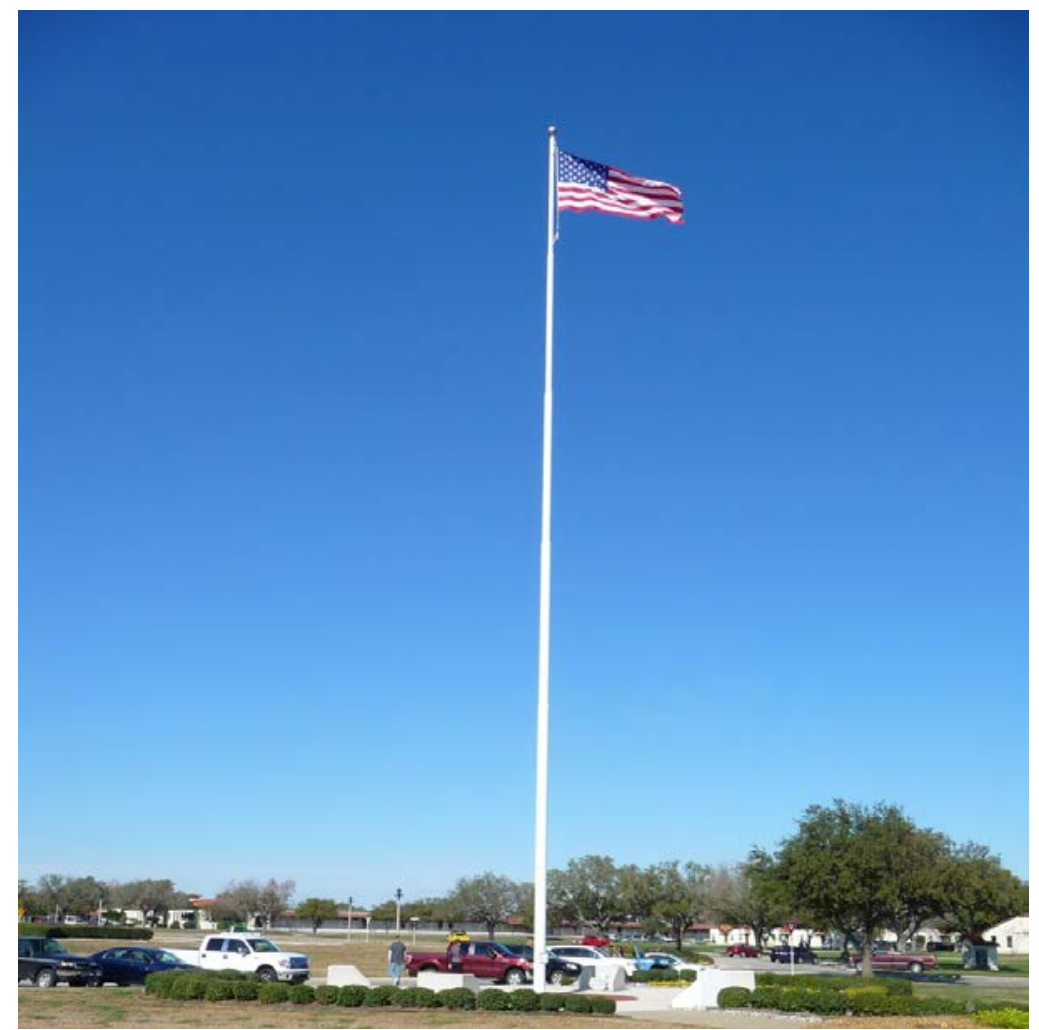

Figure 162. Base flagpole north of the Taj Mahal, 2012 (ERDC-CERL). 


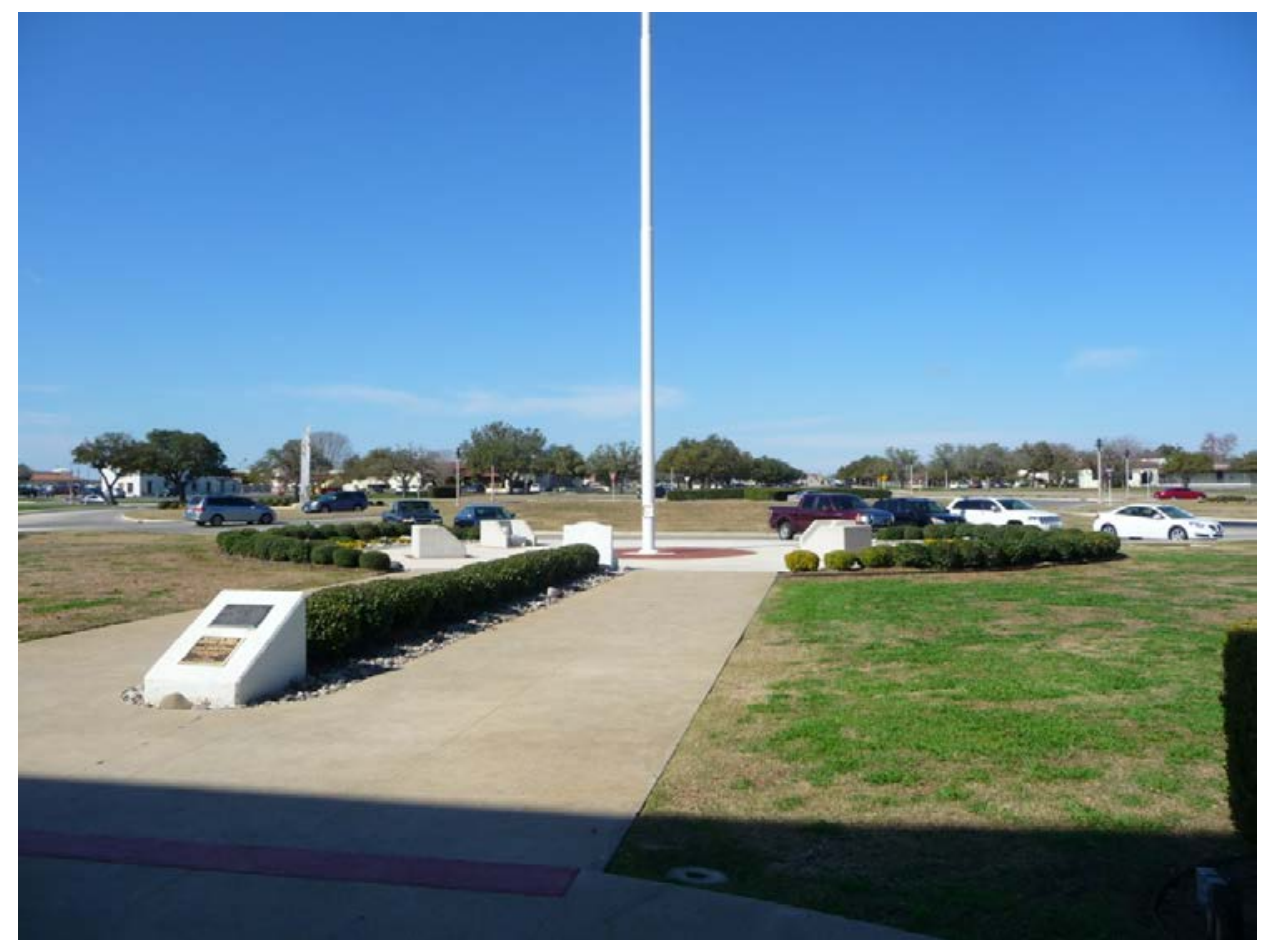

Figure 163. Markers surrounding the base flagpole north of the Taj Mahal, 2012 (ERDCCERL).

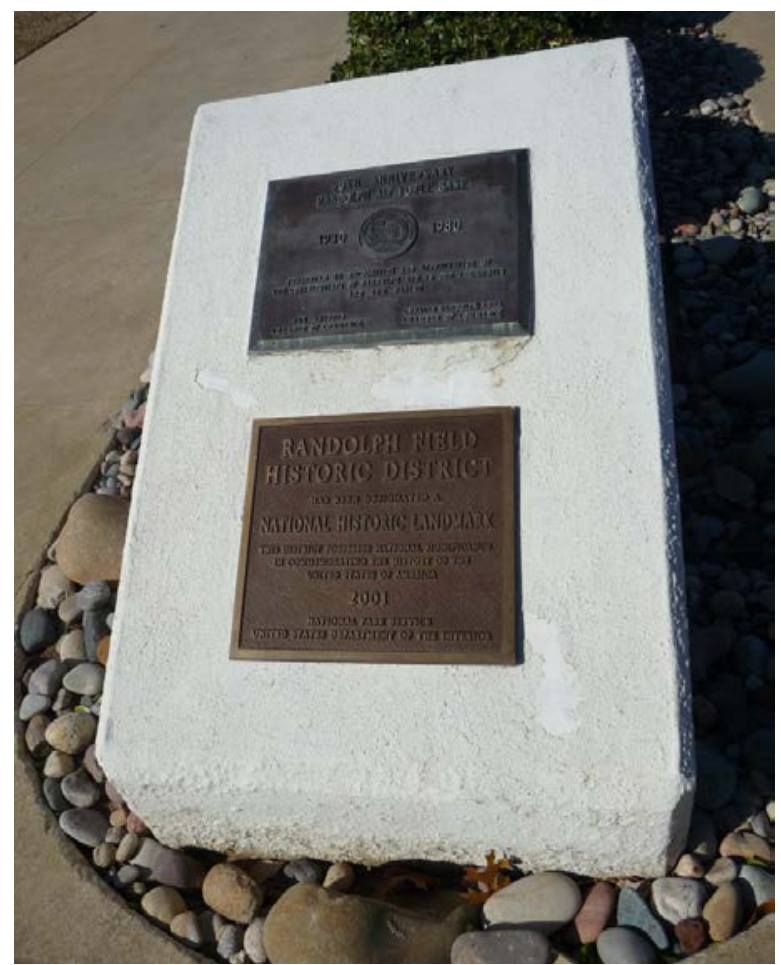

Figure 164. Inscription on the Taj Mahal flagpole area marker commemorating the $50^{\text {th }}$ anniversary of Randolph AFB and the 2001 designation of the Randolph Field Historic District, 2012 (ERDC-CERL). 


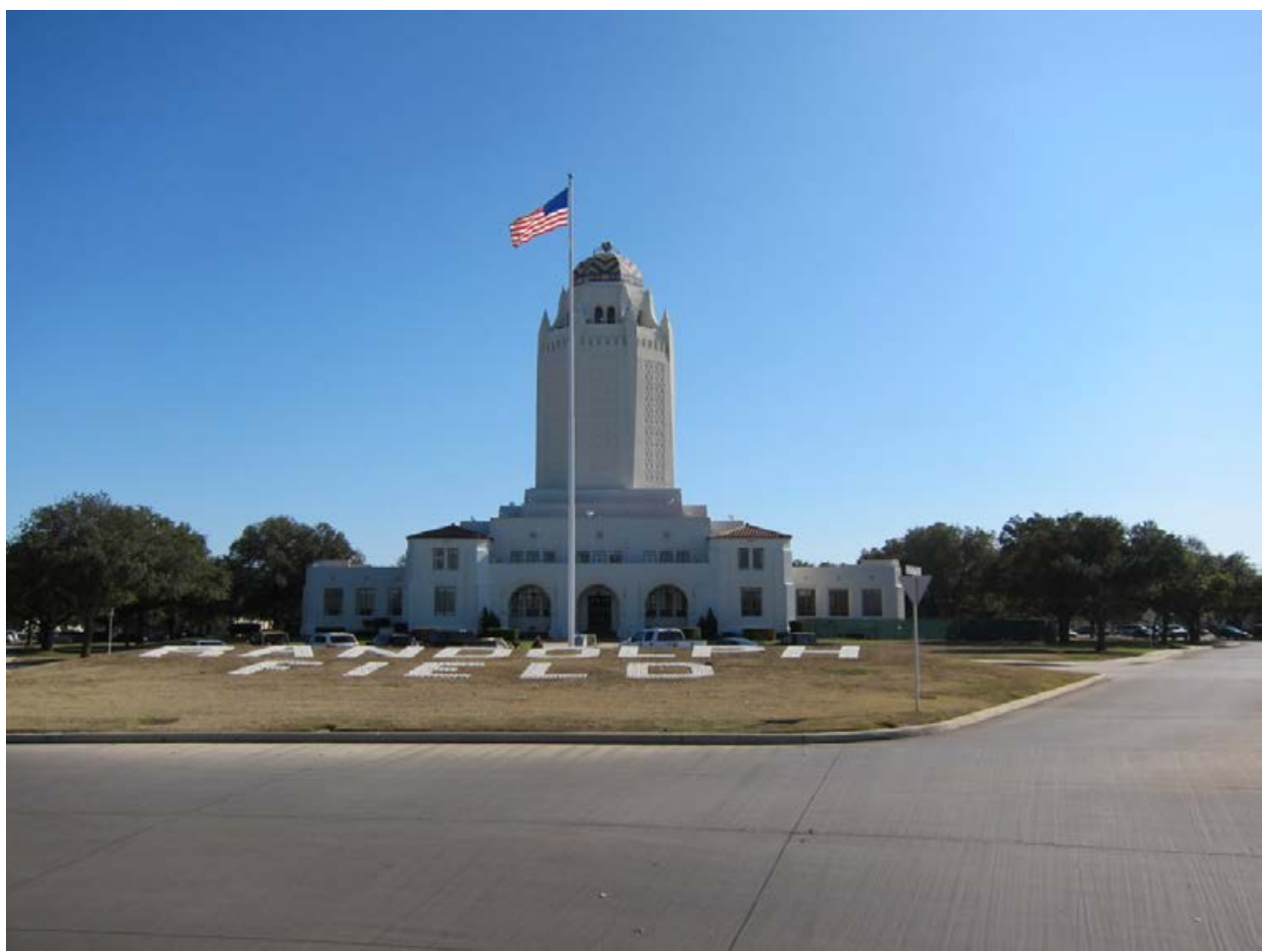

Figure 165. Flagpole and Randolph Field sign in front of the Taj Mahal, 2012 (ERDC-CERL).

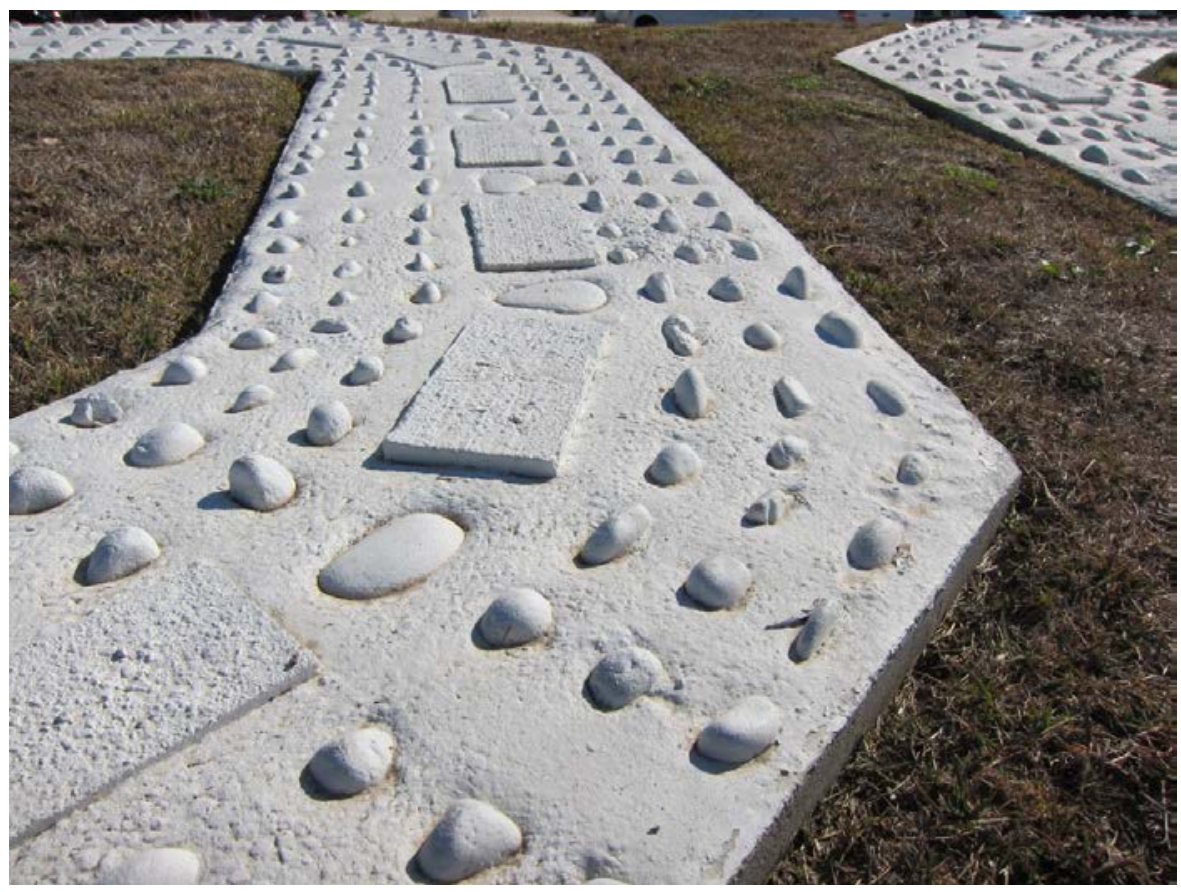

Figure 166. Detail of the large Randolph Field sign lettering in front of the Taj Mahal, 2012 (ERDC-CERL). 


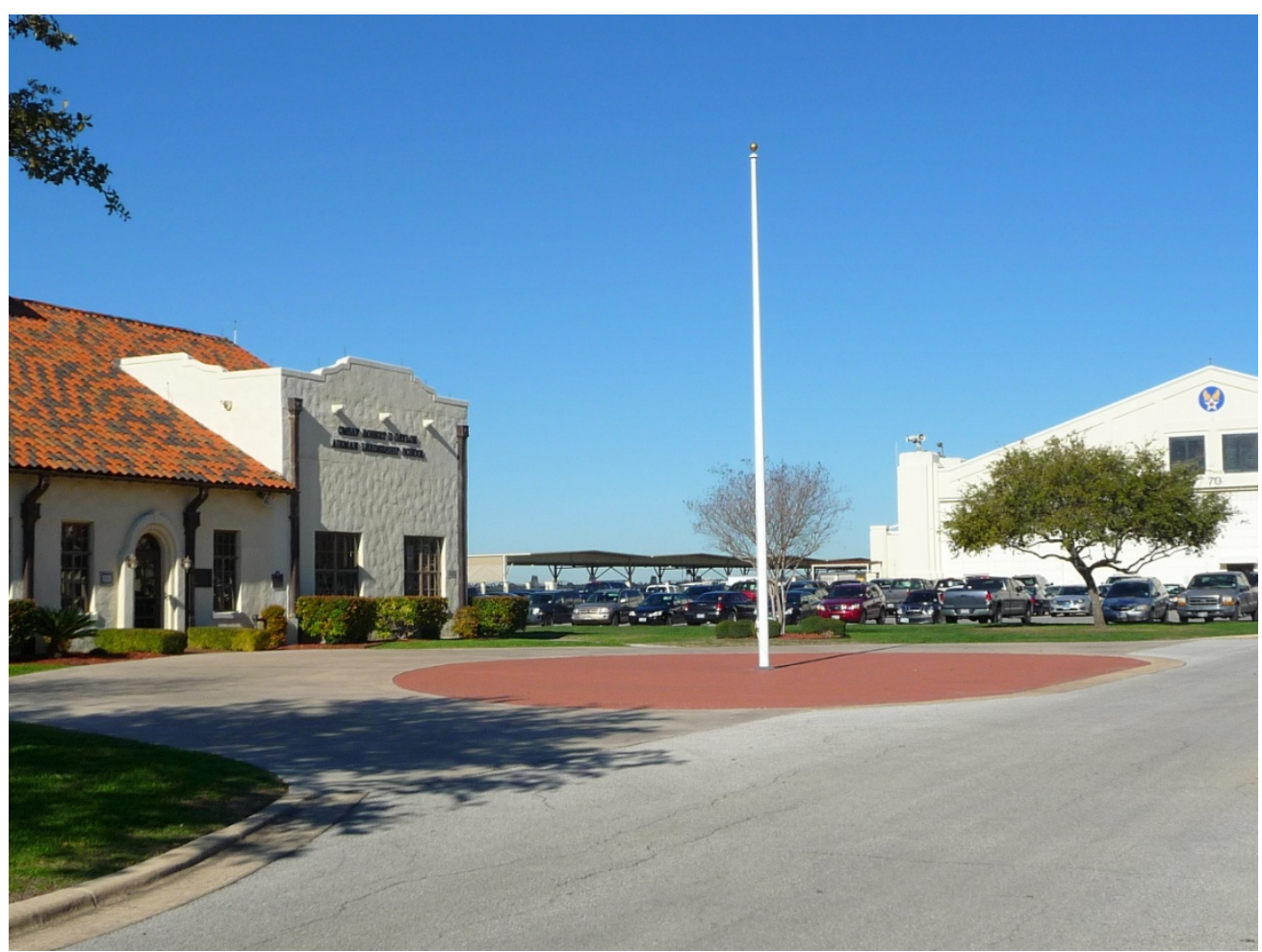

Figure 167. Flagpole in front of the west flight line's former stage house, 2012 (ERDC-CERL).

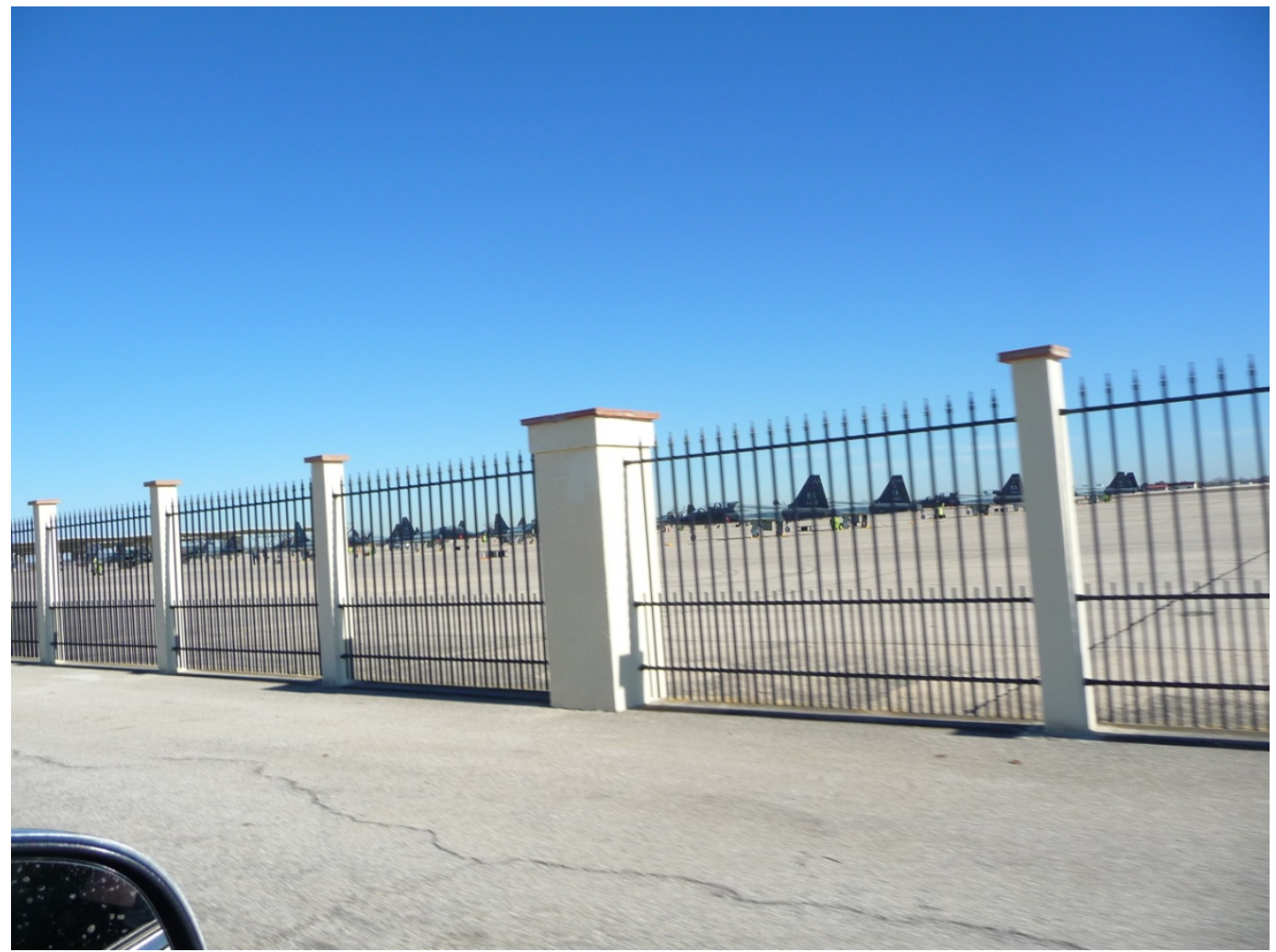

Figure 168. Fence used to separate the flight lines from the cantonment, 2012 (ERDC-CERL). 


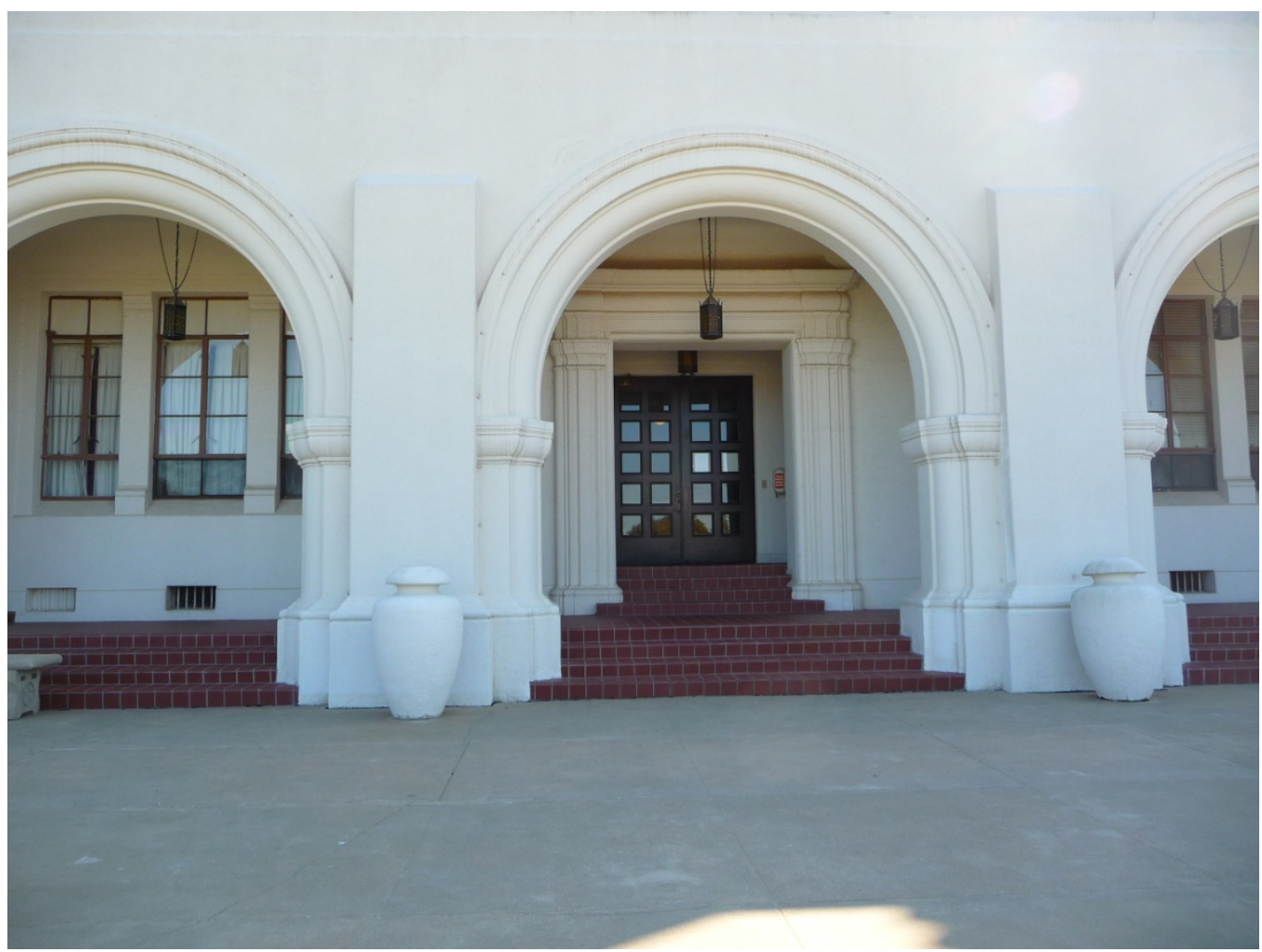

Figure 169. Concrete planters in front of the Taj Mahal, 2012 (ERDC-CERL).

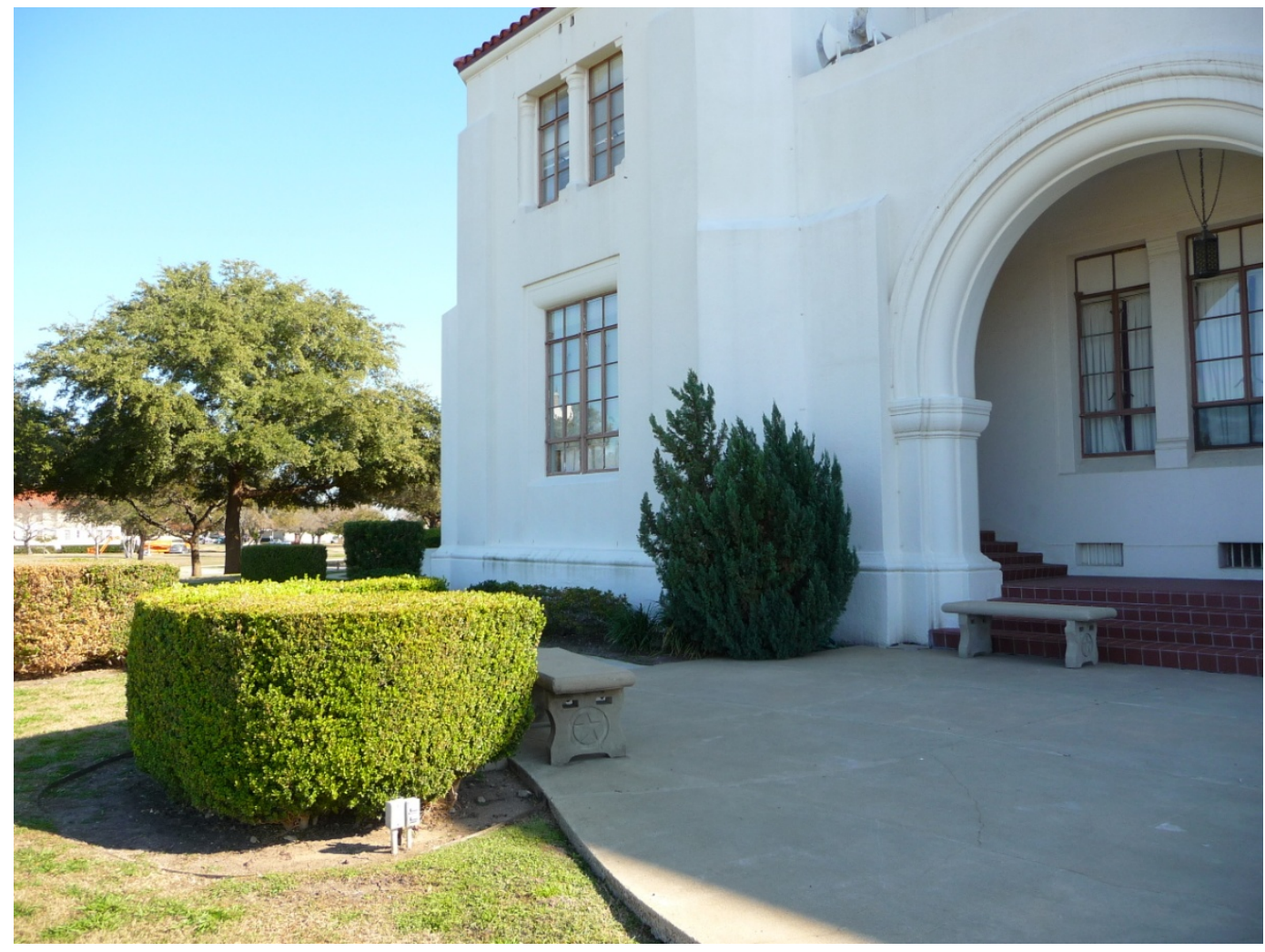

Figure 170. Concrete benches in front of the Taj Mahal, 2012 (ERDC-CERL). 


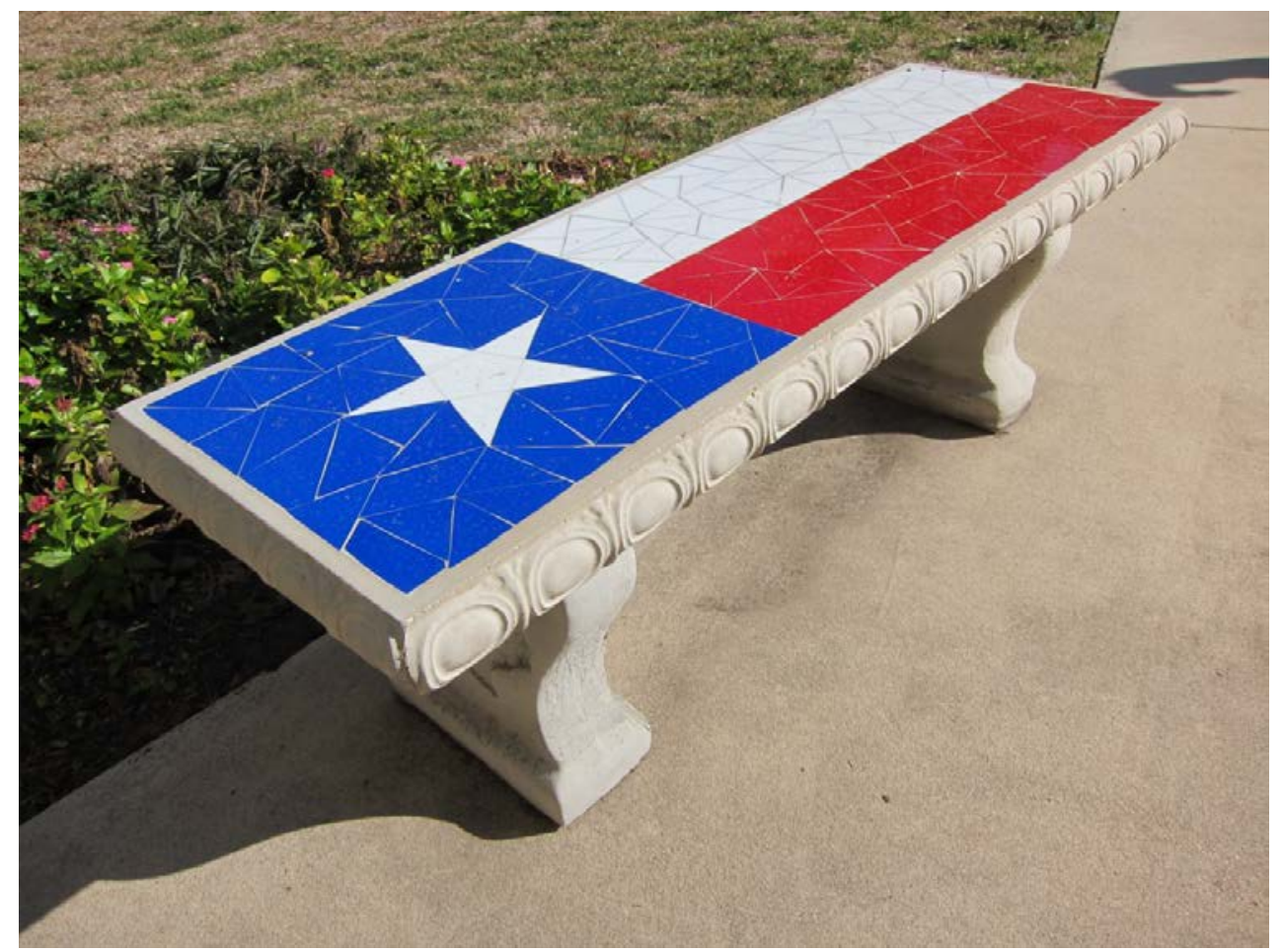

Figure 171. Decorated concrete bench located near the Taj Mahal, 2012 (ERDC-CERL).

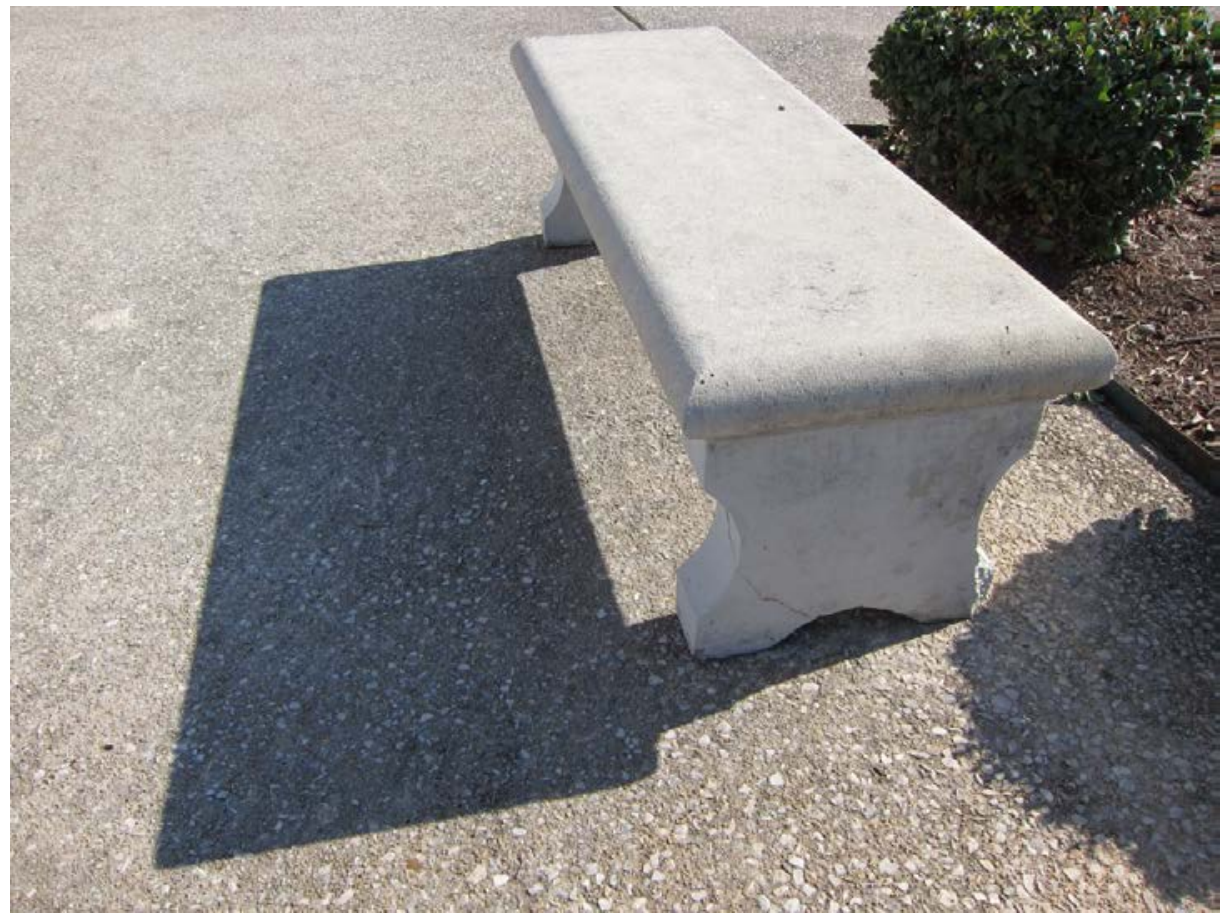

Figure 172. Example of a type of concrete bench located throughout the base, 2012 (ERDCCERL). 


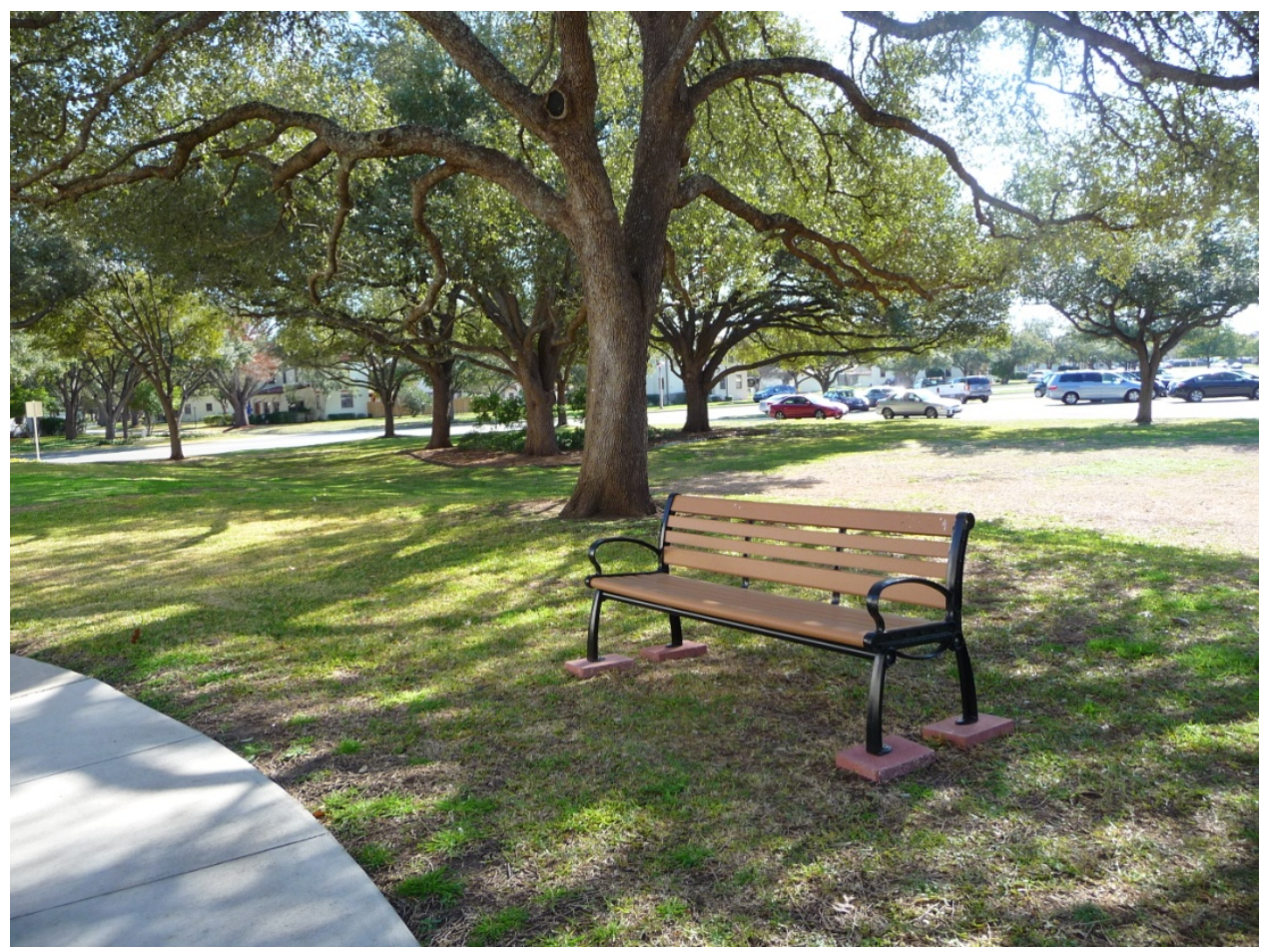

Figure 173. Park bench near the Taj Mahal, 2012 (ERDC-CERL).

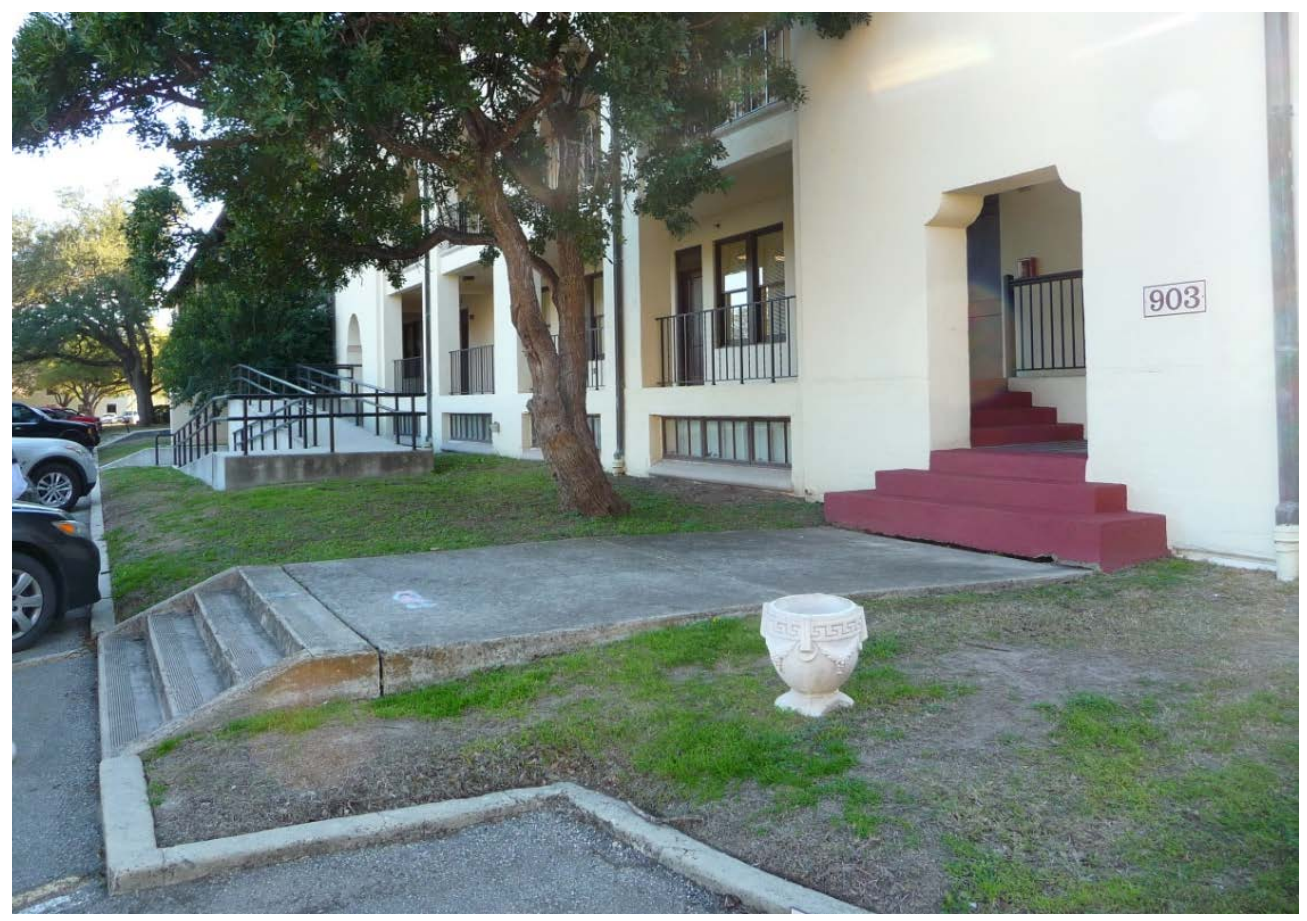

Figure 174. Planter outside the entrance of a barracks, 2012 (ERDC-CERL). 


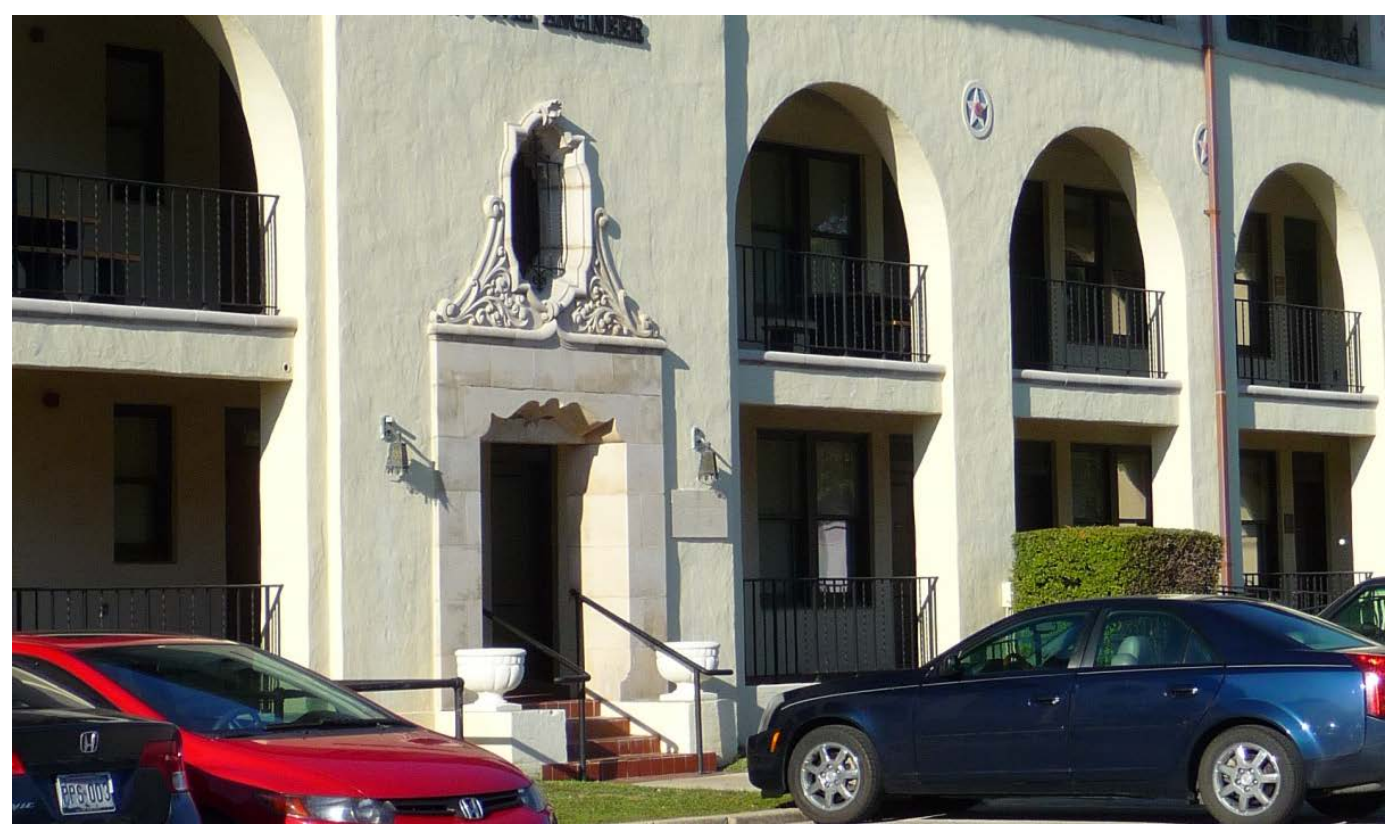

Figure 175. Planters on either side of an entrance to one of the former barracks buildings, 2012 (ERDC-CERL).

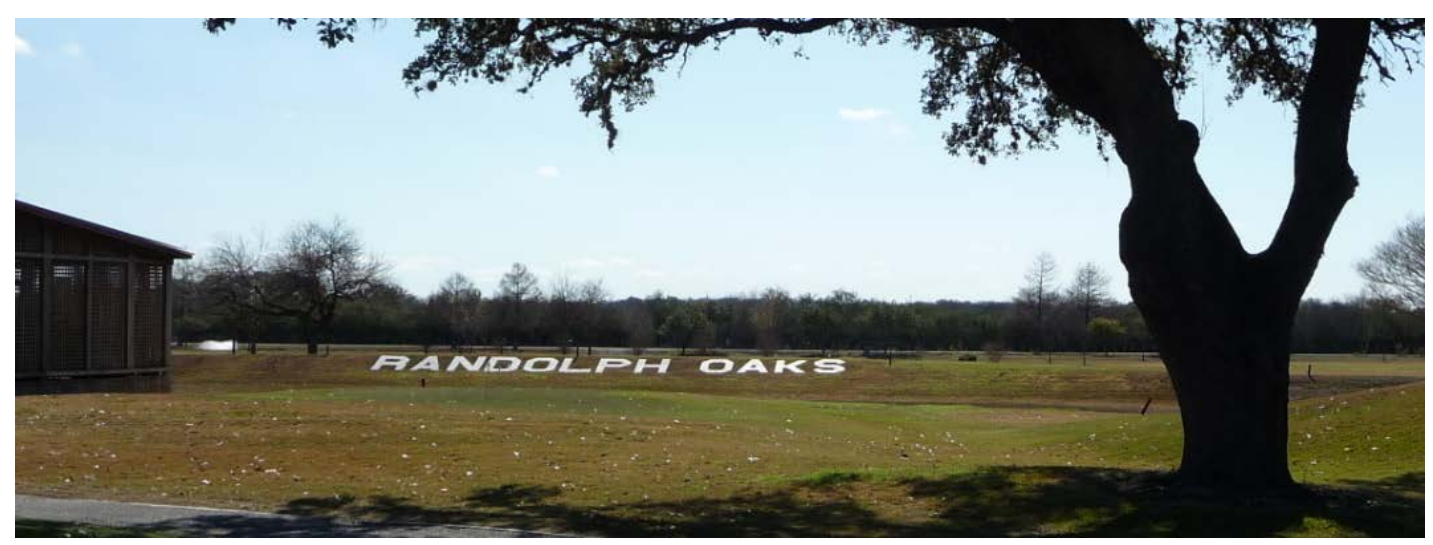

Figure 176. Randolph Oaks sign at the base golf course, 2012 (ERDC-CERL). 


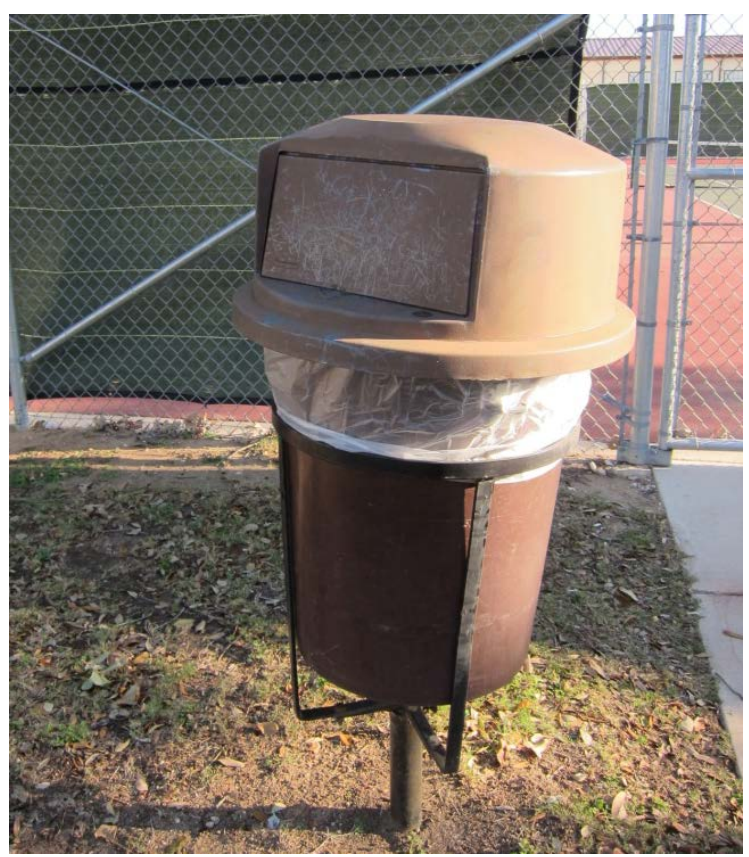

Figure 177. Trash can near tennis courts, 2012 (ERDC-CERL).

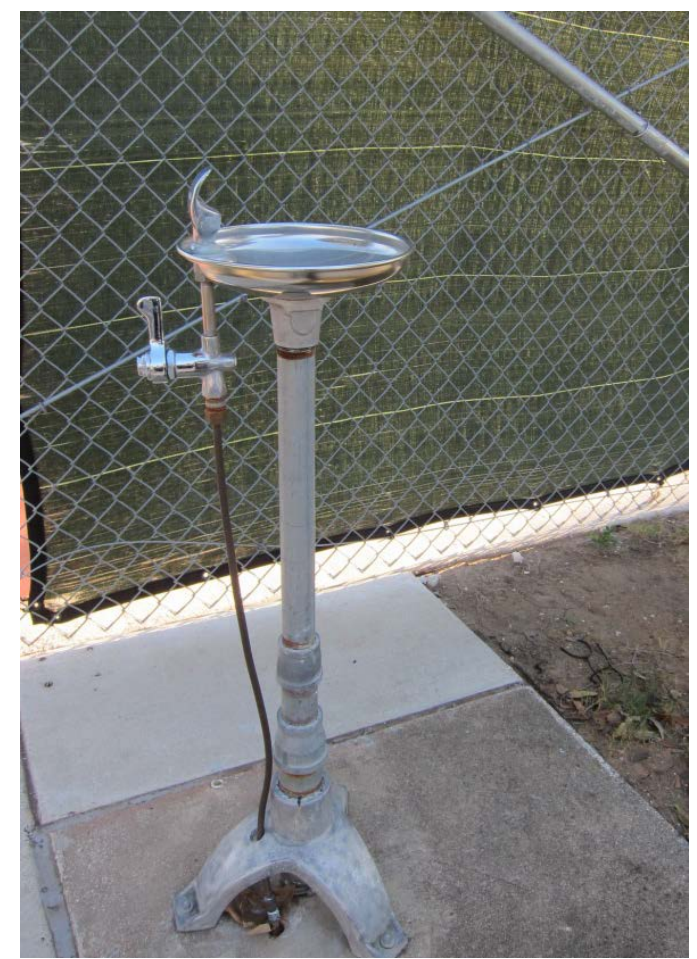

Figure 178. Drinking fountain near tennis courts, 2012 (ERDC-CERL). 


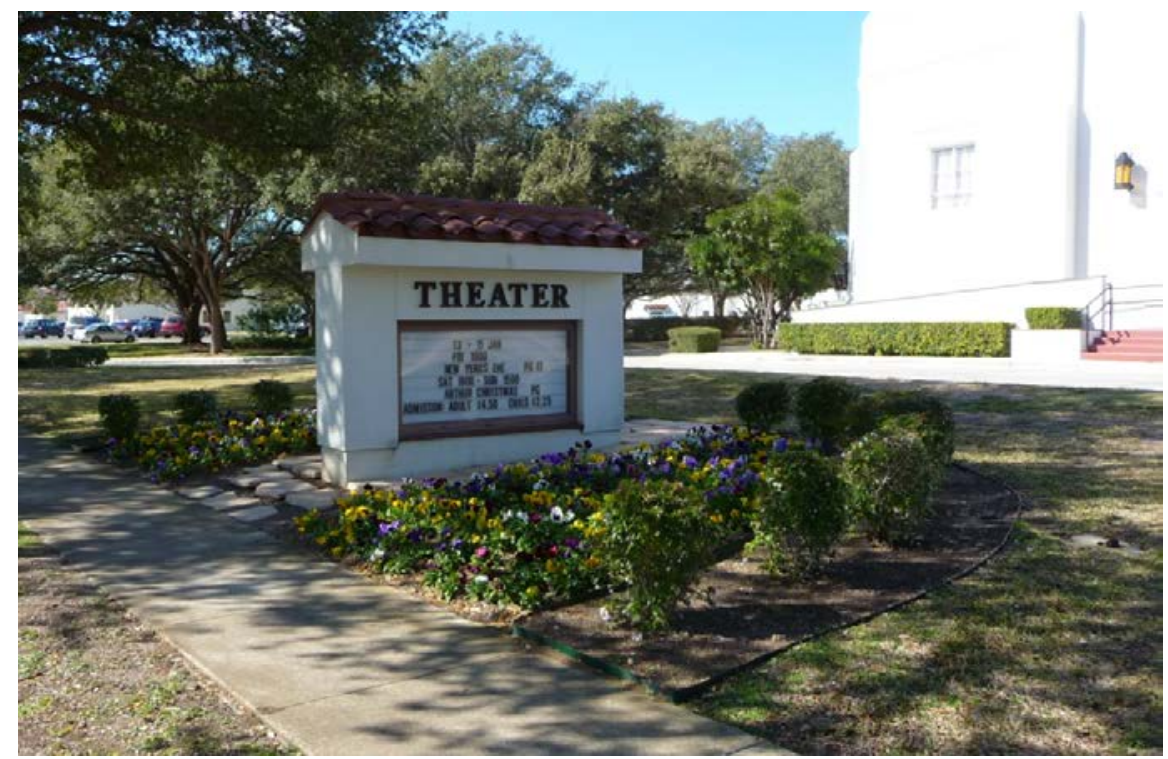

Figure 179. Base theater sign, 2012 (ERDC-CERL).

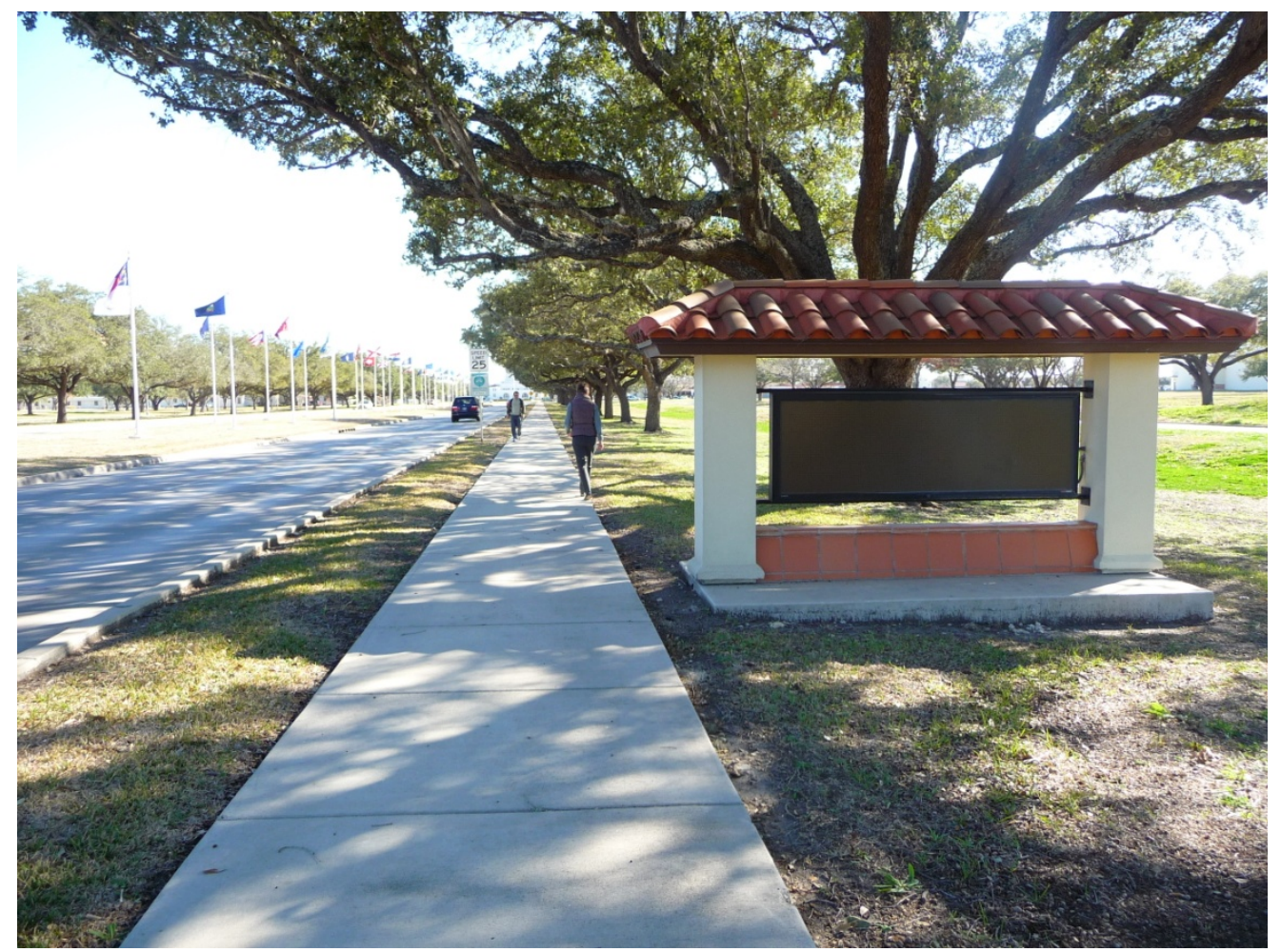

Figure 180. Modern sign along the west side of Harmon Drive, welcoming visitors to Randolph AFB, 2012 (ERDC-CERL). 


\subsubsection{Monuments and ceremonial features}

Monuments and ceremonial features are an important part of Randolph AFB. There are several areas where memorials and markers are concentrated. Many monuments are arrayed around or near Washington Circle, and a row of historic aircraft are displayed in front of the BOQ.

Figure 181- Figure 194 show examples of the monuments and ceremonial features at Randolph AFB.

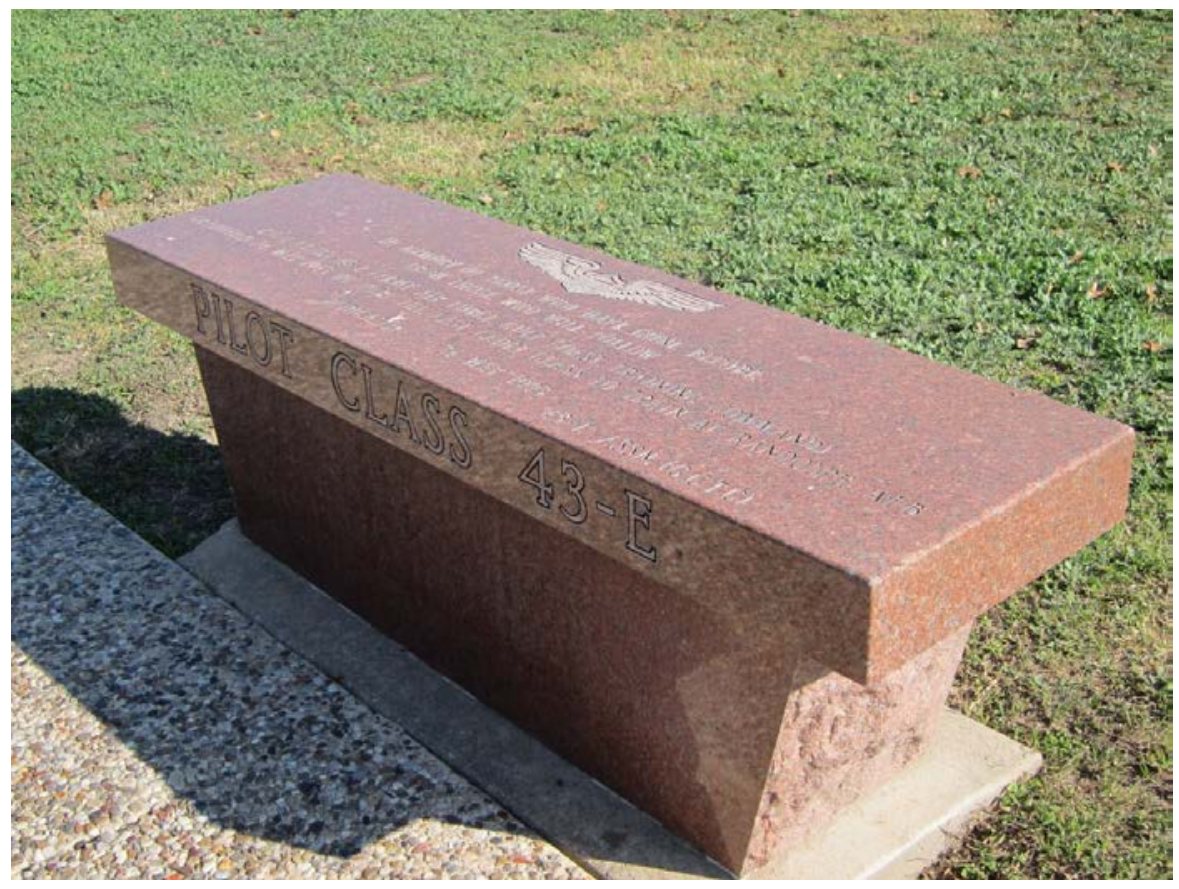

Figure 181. Commemorative granite bench, 2012 (ERDC-CERL). 


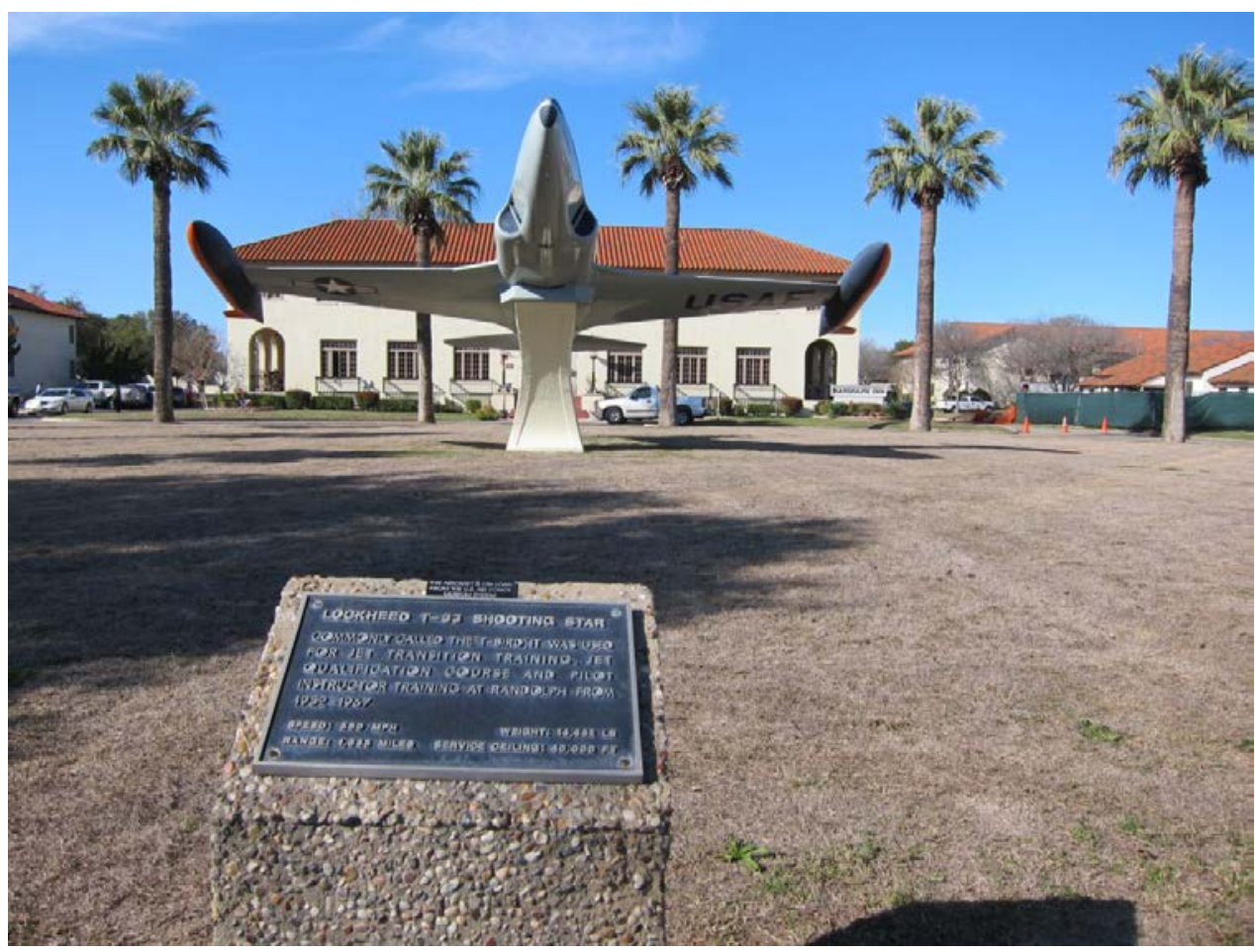

Figure 182. Airplane on display in front of the BOQ area, 2012 (ERDC-CERL).

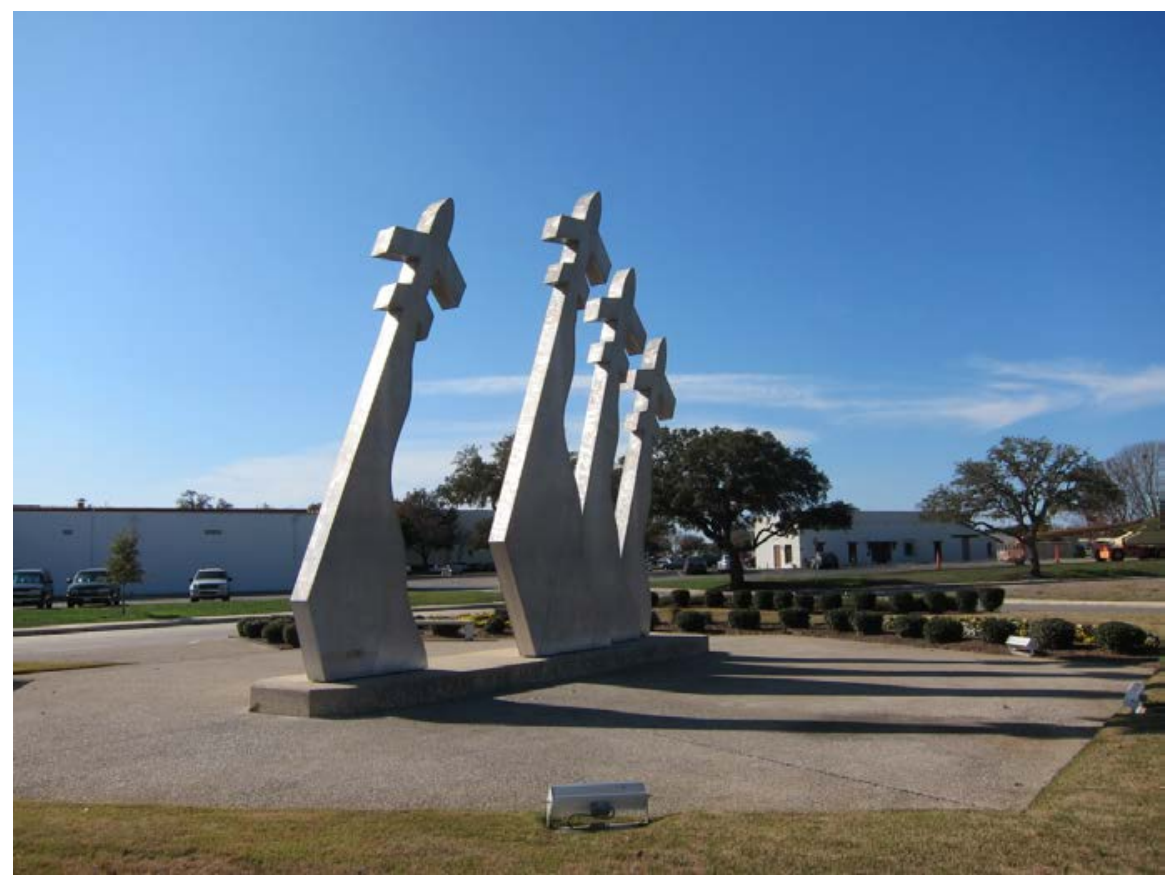

Figure 183. The Missing Man Monument on the west side of Washington Circle, 2012 (ERDCCERL). 


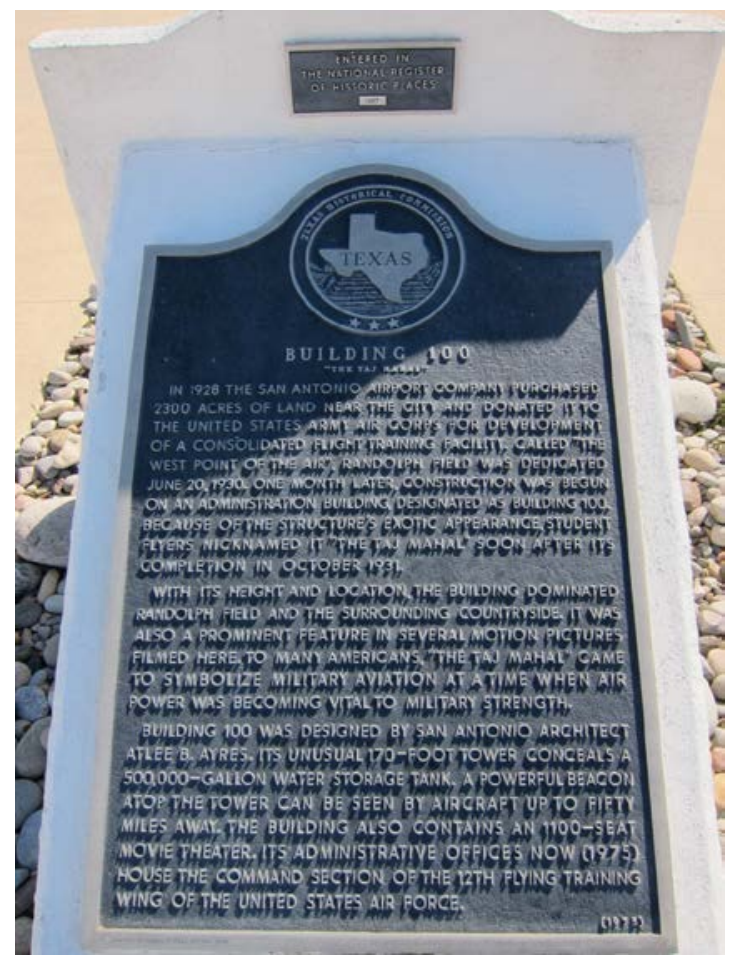

Figure 184. Building 100, Texas State Historical Commission plaque, 2012 (ERDC-CERL).

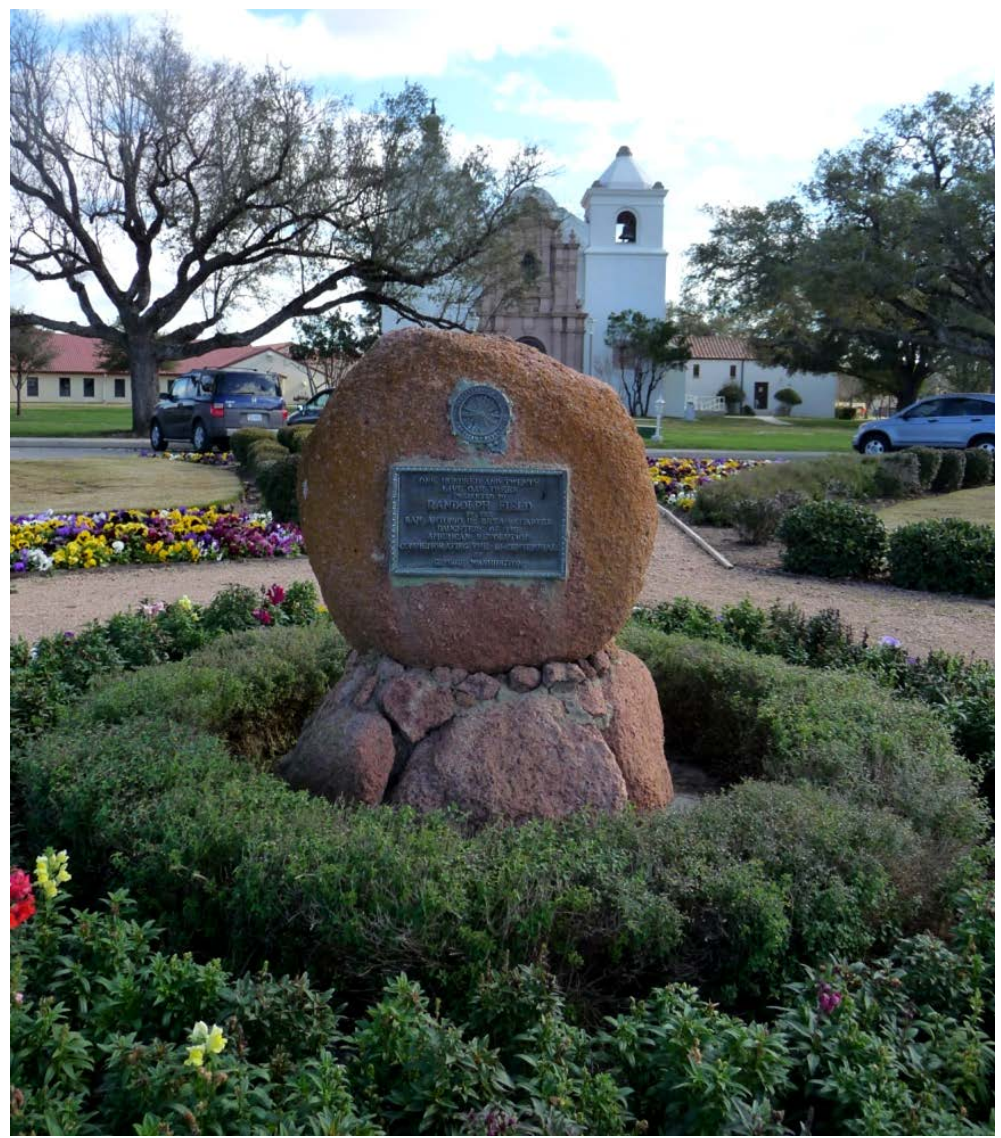

Figure 185. DAR marker in association with the Chapel, 2012 (ERDC-CERL). 


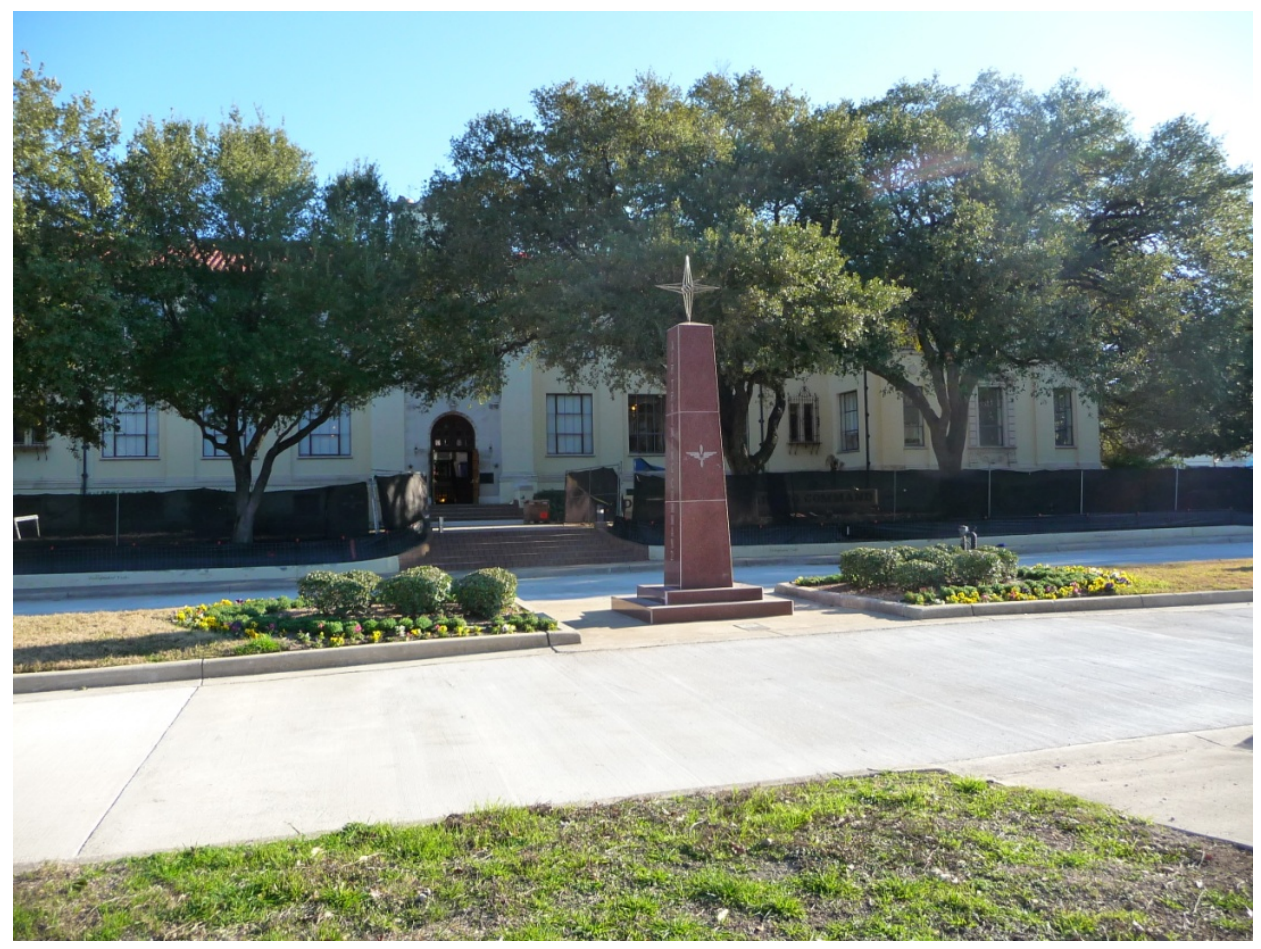

Figure 186. Air Training Command monument in front of the former Cadet Complex educational building, 2012 (ERDC-CERL).

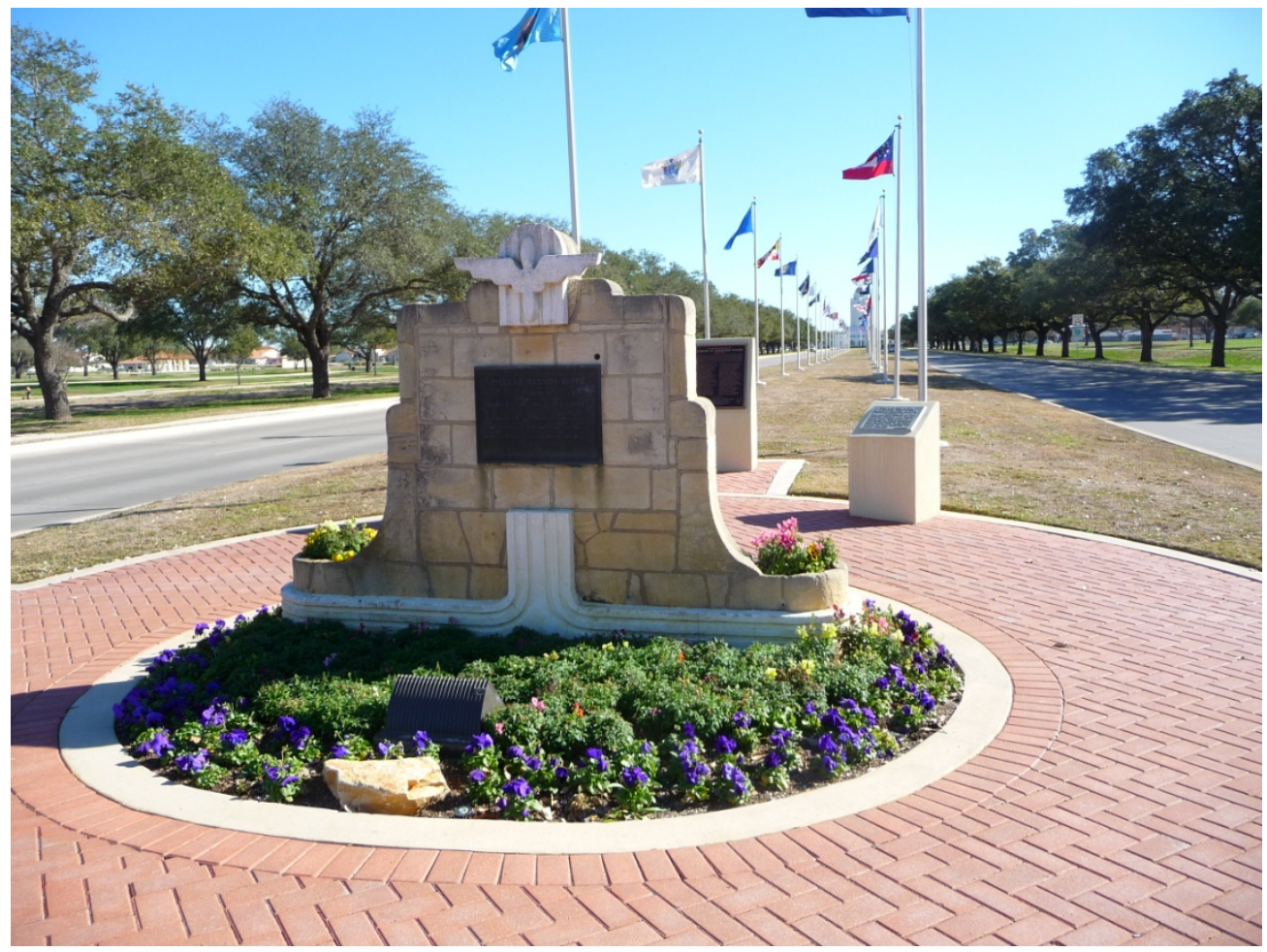

Figure 187. Harmon Drive dedication marker and Flag Plaza, 2012 (ERDC-CERL). 


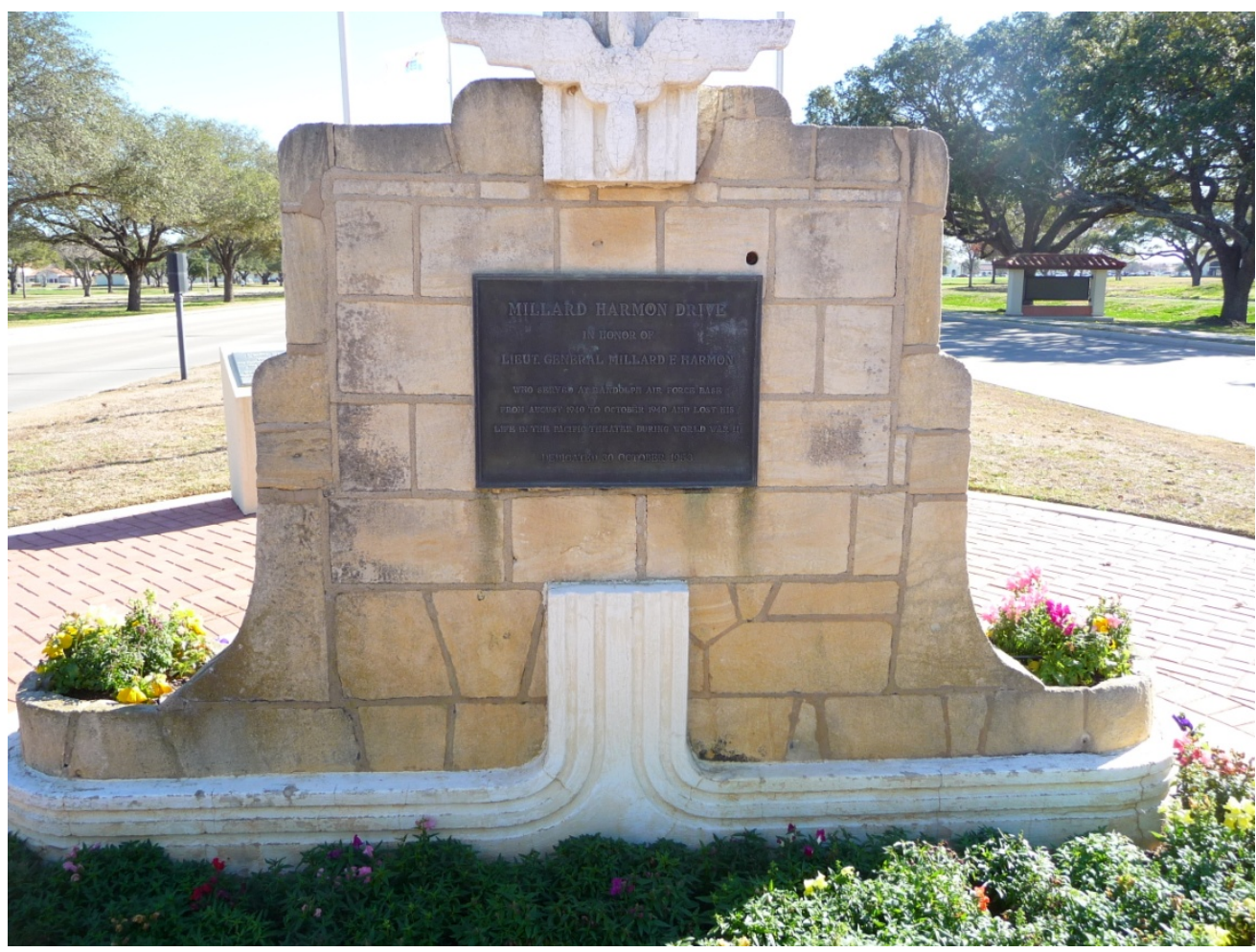

Figure 188. Dedication marker of Harmon Drive, 2012 (ERDC-CERL).

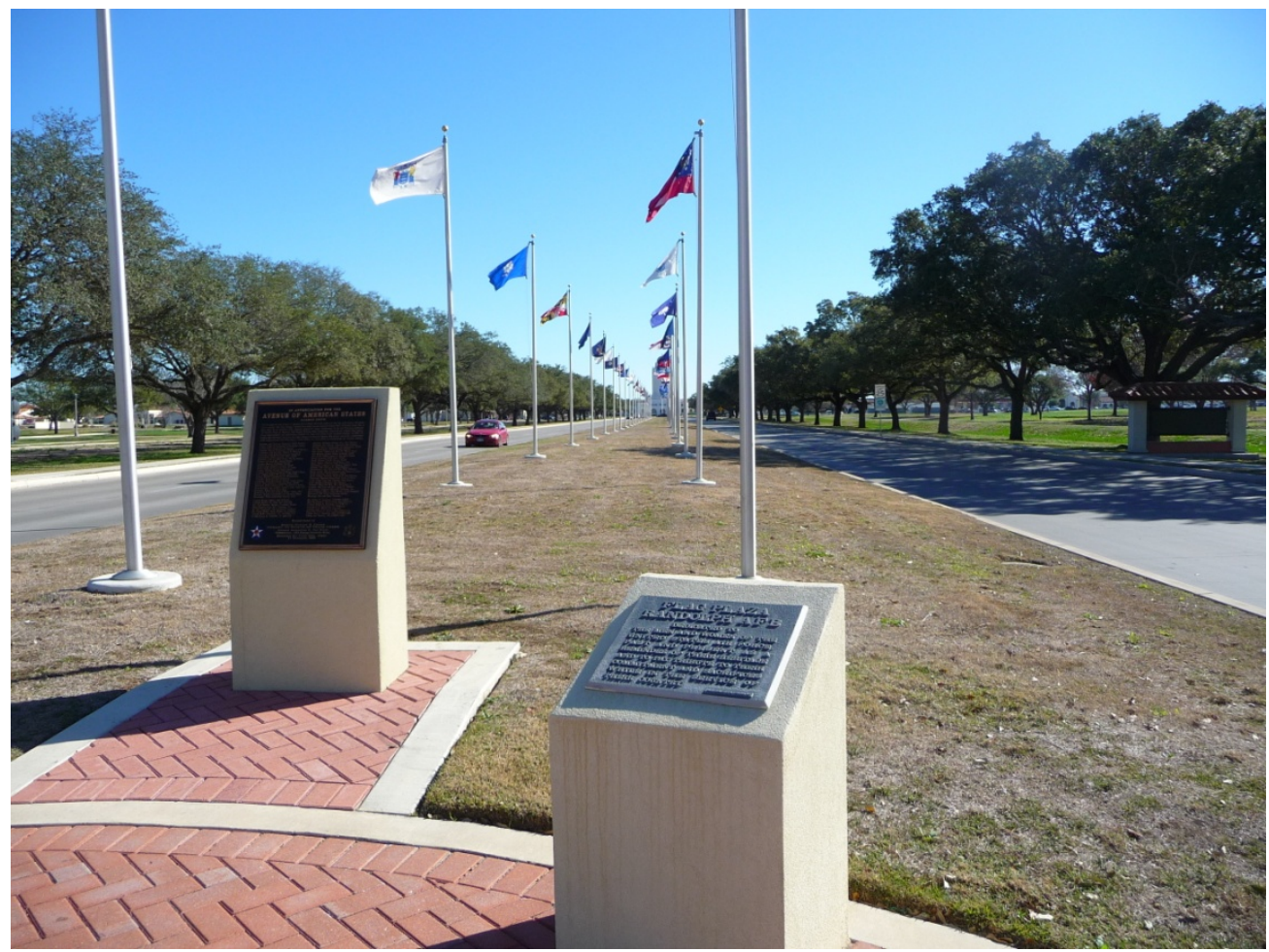

Figure 189. Flag Plaza marker and Avenue of American States marker, 2012 (ERDC-CERL). 


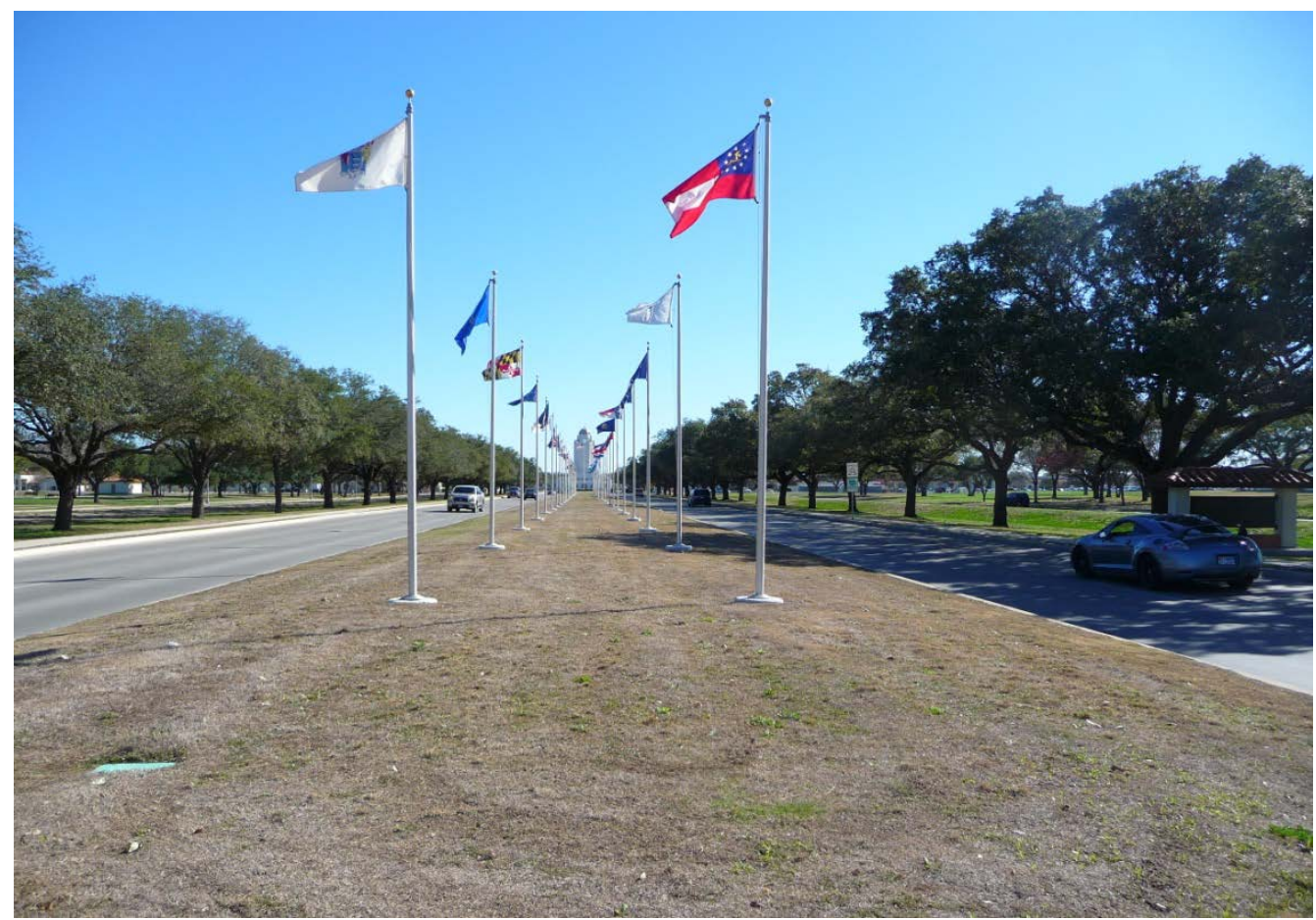

Figure 190. Flags marking Avenue of American States down the median of Harmon Drive, 2012 (ERDC-CERL).

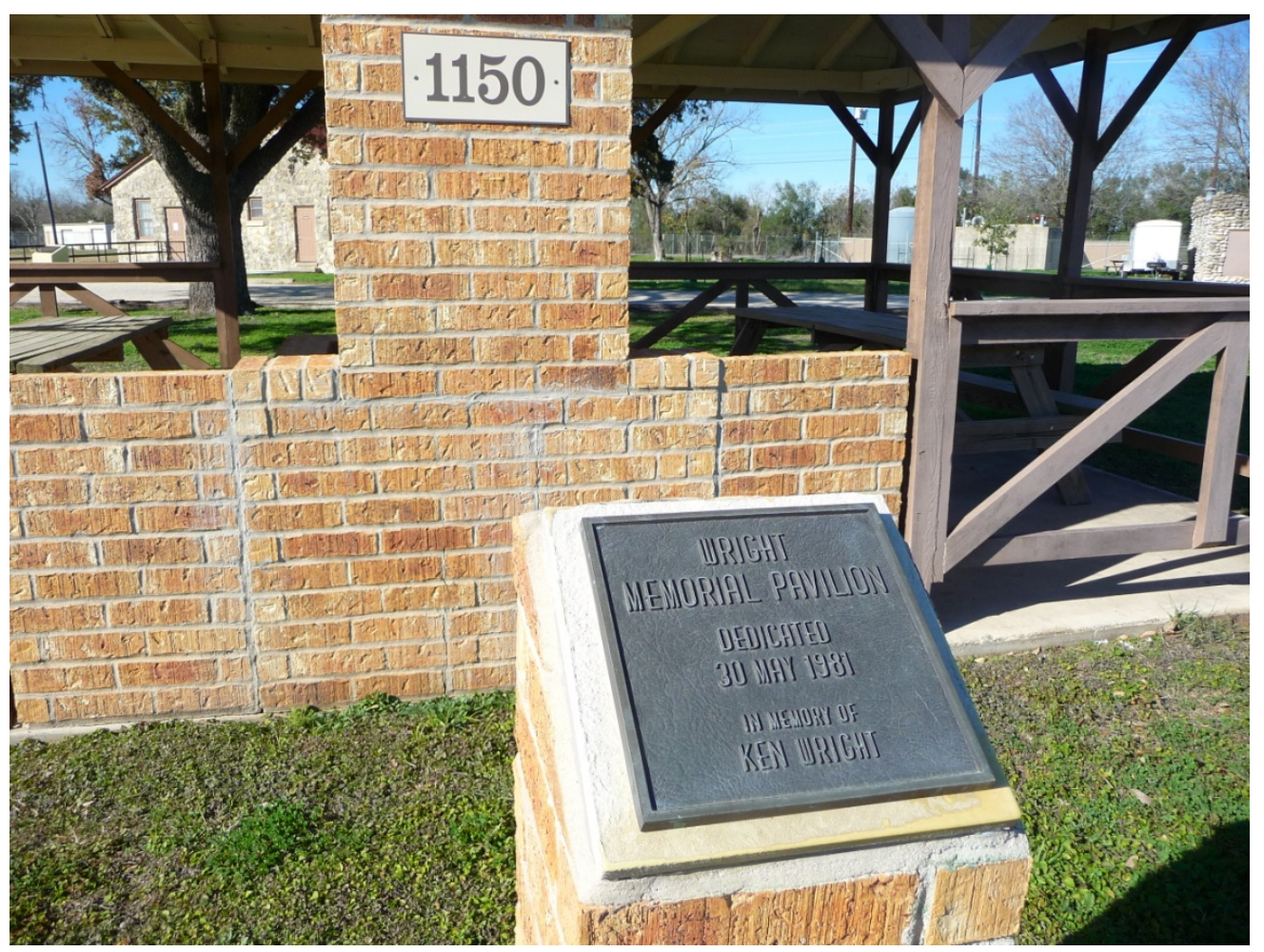

Figure 191. Wright Memorial Pavilion and plaque, 2012 (ERDC-CERL). 


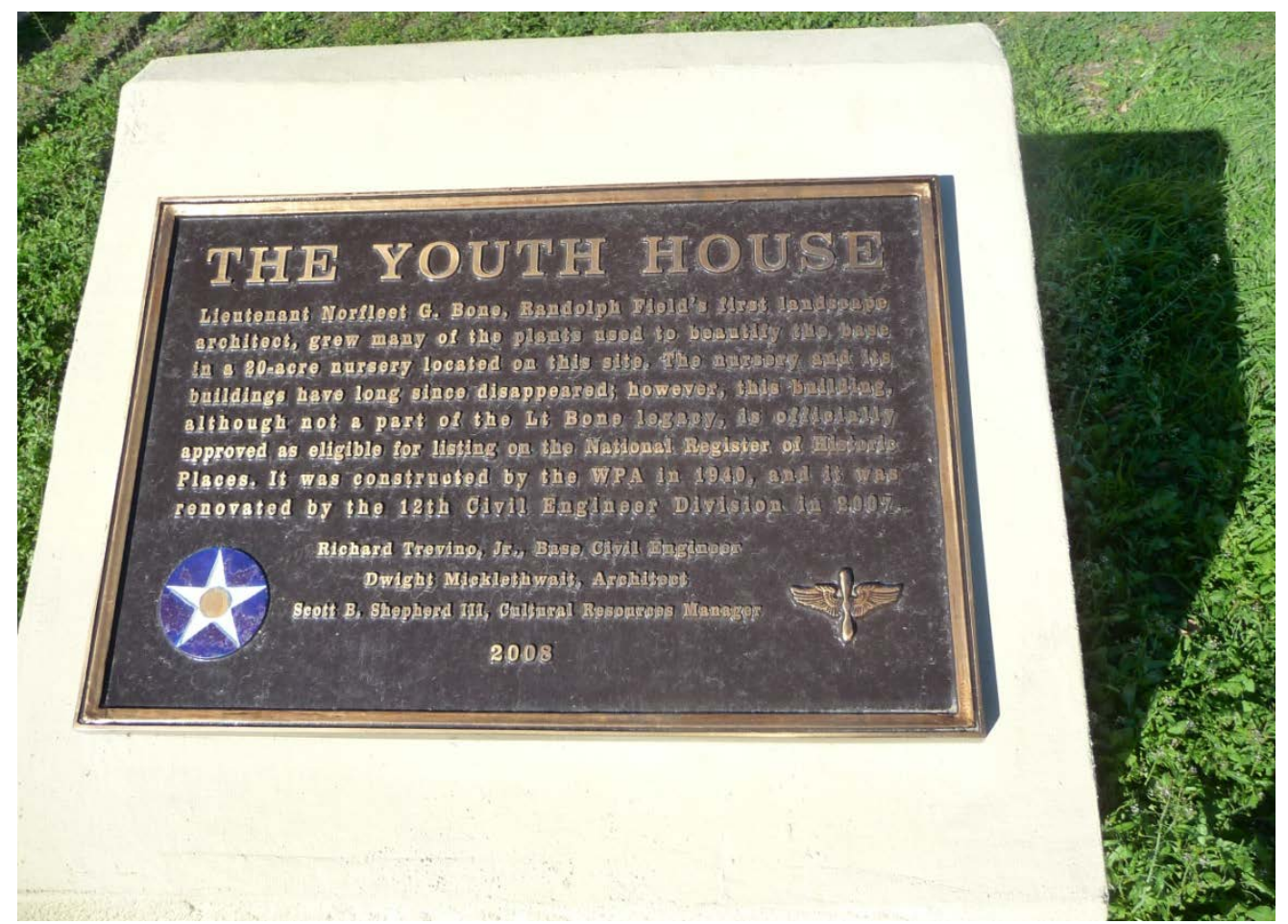

Figure 192. The Youth House plaque commemorating the site of Randolph Field's nursery and honoring Lt. Norfleet Bone, the base landscape architect (ERDC-CERL, 2012). The adjacent Youth House building was constructed in 1940 by the WPA and was determined eligible for listing on the NRHP.

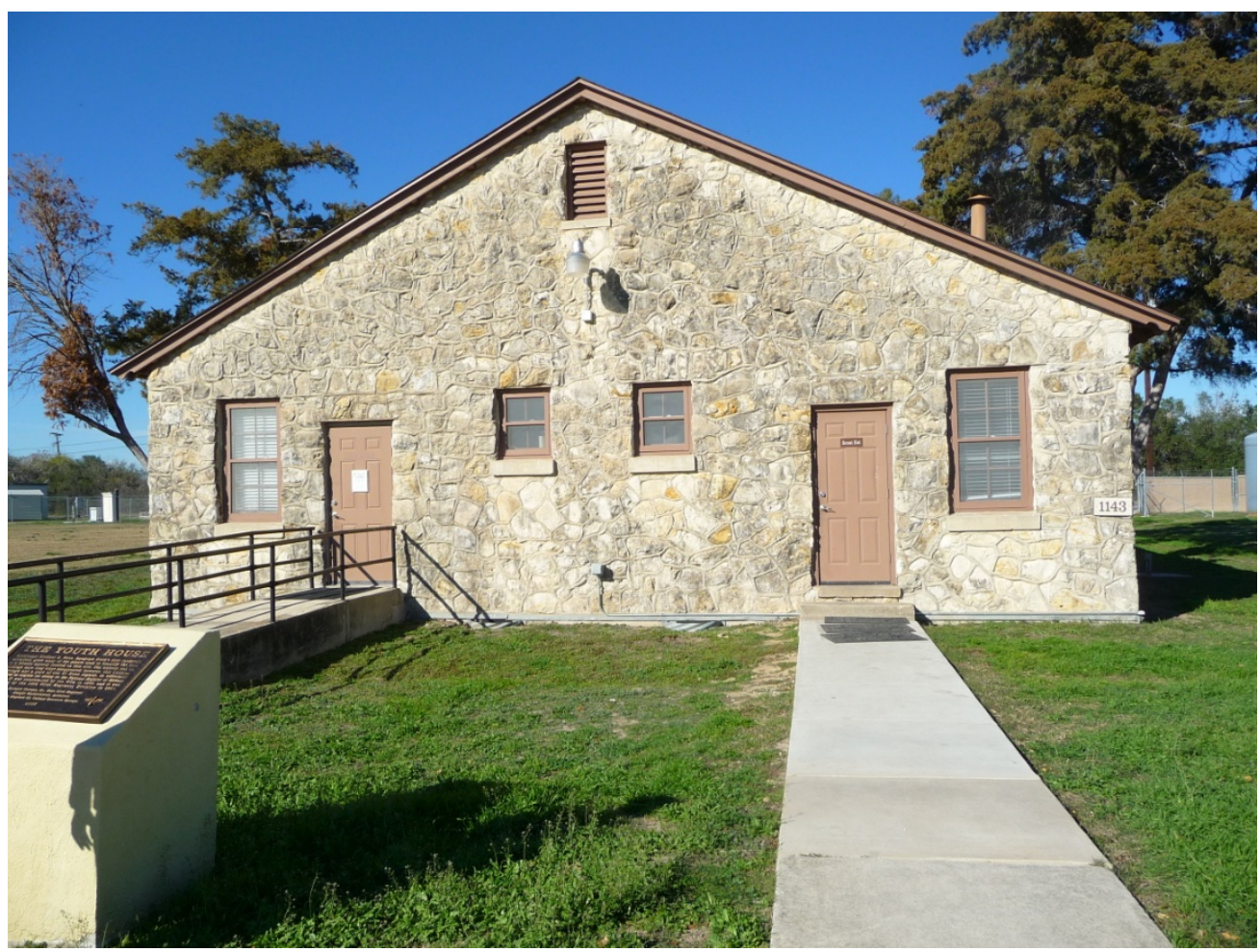

Figure 193. The Youth House plaque in association with the WPA building, 2012 (ERDCCERL). 


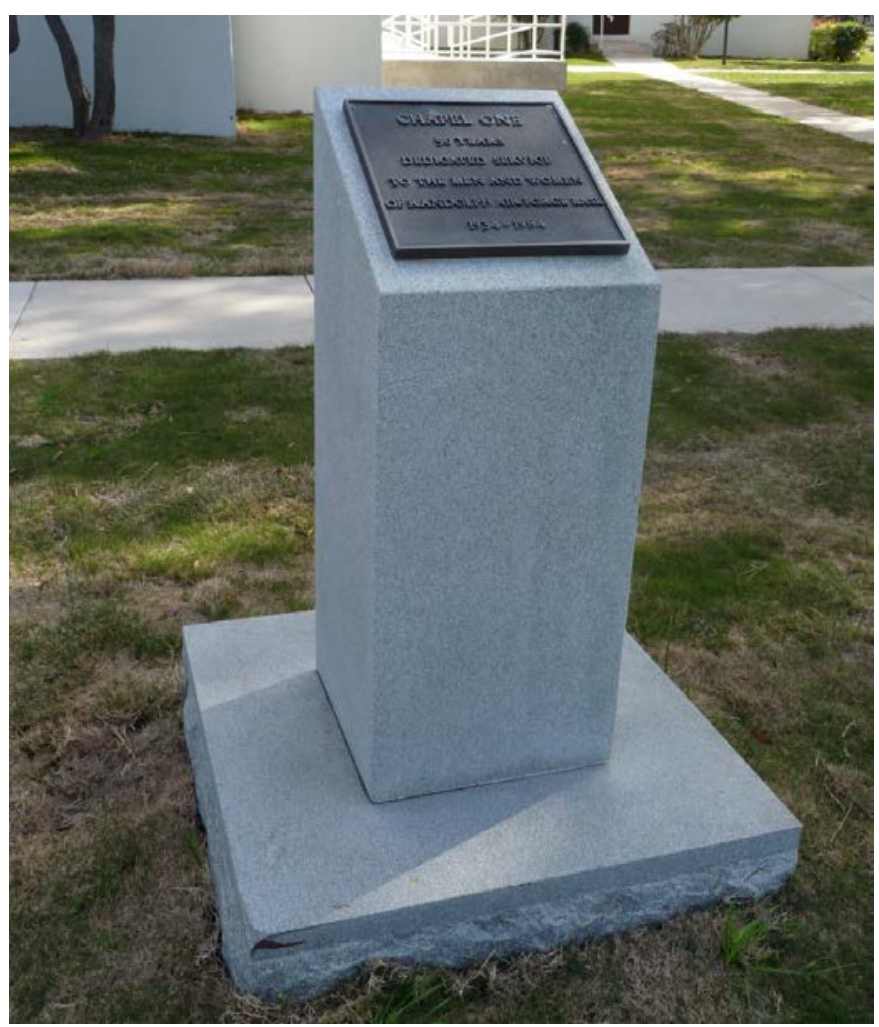

Figure 194. Marker dedicating the Chapel to the men and women of Randolph AFB from 1934-1984, 2012 (ERDC-CERL). 
(This page intentionally left blank.) 


\section{Criteria for Evaluating Historic Landscapes}

The identification of historically significant properties is achieved through evaluation of their position within a larger historic context. According to the NRHP, historic contexts are defined as "...the patterns, themes, or trends in history by which a specific occurrence, property, or site is understood and its meaning (and ultimately its significance) within prehistory or history is made clear. ${ }^{53} \mathrm{~A}$ historic property is determined significant or not significant by applying standardized National Register Criteria for Evaluation to property within its historical context. The National Register of Historic Places categorizes significant properties as buildings, sites, districts, structures, or objects. ${ }^{54}$

\subsection{Criteria for evaluation}

The National Register Criteria for Evaluation define how historic properties are significant by categorizing a property's associations with important historic qualifiers. The National Register Bulletin \#15: How to Apply the National Register Criteria for Evaluation lists four major criteria to which a historic property can be associated; Criterion A-important events, Criterion B-persons, Criterion C-importance in design and construction, and Criterion D-information potential. Although there are other criteria considerations, the four major criteria are described in more detail below:

A. Event-is associated with events that have made a significant contribution to the broad patterns of our history; or

B. Person-associated with the lives of persons significant in our past; or

C. Design/Construction-embody the distinctive characteristics of a type, period, or method of construction, or that represent the work of a master, or that possess high artistic values, or that represent a significant and distinguishable entity whose components may lack individual distinction; or

D. Information Potential-yielded, or is likely to yield, information important in prehistory or history.

53 NPS 1991, 7.

54 NPS 1991, 9. 


\subsection{Aspects of historic integrity}

In addition to possessing historical significance, to be eligible to the NRHP a property must also retain sufficient physical integrity of features in order to convey its significance. ${ }^{55}$ Historic properties both retain integrity and convey their significance, or they do not. The National Register recognizes seven aspects or qualities of a property that define the concept of integrity. To retain historic integrity, a property must possess several, and usually most, of the seven aspects. The retention of specific aspects of historic integrity is paramount for a property to convey its significance. Determining which of these aspects are most important to a particular property requires knowing why, where, and when the property is significant. The seven aspects of integrity are listed in National Register Bulletin \#15: How to Apply the National Register Criteria for Evaluation as:

\section{Location}

Location is the place where the historic property was constructed or the place where the historic event occurred.

\section{Design}

Design is the combination of elements that create the form, plan, space, structure, and style of a property. It results from conscious decisions made during the original conception and planning of a property (or its significant alteration) and applies to activities as diverse as community planning, engineering, architecture, and landscape architecture. Design includes such elements as organization of space, proportion, scale, technology, ornamentation, and materials.

\section{Setting}

Setting is the physical environment of a historic property. Setting refers to the character of the place in which the property played its historical role. It involves how, not just where, the property is situated and its relationship to surrounding features and open space.

\section{Materials}

Materials are the physical elements that were combined or deposited during a particular period of time and in a particular pattern or configuration to form an historic property.

\section{Workmanship}

Workmanship is the physical evidence of the crafts of a particular culture or people during any given period in history or prehistory.

\section{Feeling}

Feeling is a property's expression of the aesthetic or historic sense of a particular time period.

\footnotetext{
55 NPS 1991, 44
} 


\section{Association}

Association is the direct link between an important historic event or person and a historic property.

Integrity has very specific connotations in defining historic and cultural resources. Integrity is the authenticity of physical characteristics from which resources obtain their significance. Historic properties convey their significance through their integrity. Districts and individual resources are considered significant if they possess a majority of these seven aspects. Properties in a historic district are classified as either "contributing or non-contributing" resources. Contributing resources date from the historic period of significance established for the district. They contribute to the significance and character of the district through their historical associations and/ or architectural values. Non-contributing resources are those that due to the date of construction, alterations, or other factors, do not contribute to the district's historic significance or character.

\subsection{Categories of historic properties}

The identification of historically significant properties is achieved through evaluation of their position within a larger historic context. According to the NRHP, historic contexts are defined as "...the patterns, themes, or trends in history by which a specific occurrence, property, or site is understood and its meaning (and ultimately its significance) within prehistory or history is made clear. A historic property is determined significant or not significant by applying standardized National Register Criteria for Evaluation to property within its historical context. The NRHP categorizes significant properties as buildings, sites, districts, structures, or objects. The definitions of these property types follow:

Building: A building is created principally to shelter any form of human activity. Examples of buildings include: administration building, house, barn, stable, train station, church, or shed.

Structure: Structures are distinguished from buildings by being functional constructions made for purposes other than creating human shelter. Examples of structures include: aircraft hangars, bandstands, bridges, canals, fences, kilns, or windmills.

Object: The term object is used to distinguish from buildings and structures those constructions that are primarily artistic in nature or are relatively small in scale and simply constructed. Although it may be, by nature or design, movable, an object is associated with a specific setting or environment. Examples of objects include boundary markers, fountains, monuments, sculptures or statues. 
Site: A site is the location of a significant event, a prehistoric or historic occupation or activity, or a building or structure, whether standing, ruined, or vanished, where the location itself possesses historic, cultural, or archeological value regardless of the value of any existing structure. Examples of sites include: battlefield, campsite, ceremonial site, designed landscape, rock shelter, or village site.

District: A district possesses a significant concentration, linkage, or continuity of sites, buildings, structures, or objects united historically or aesthetically by plan or physical development. A district can comprise both features that lack individual distinction and individually distinctive features that serve as focal points. A group of features lacking in individual distinction may even be considered eligible if the grouping achieves significance as a whole within its historic context. While a district derives its importance from being a unified entity, it can contain buildings, structures, sites, objects, or open spaces that do not contribute to the significance of the district if these properties do not adversely affect the district's integrity.

\subsection{Previous studies and nominations}

The Randolph Field Historic District was first nominated to the National Register in 1996. In 2001, the historic district also was nominated as a National Historic Landmark (Figure 195). 56 The district is listed as significant under Criteria A, B and C with a period of significance that begins in 1928 and continues to 1950. Randolph Field is listed as significant under Criterion A for the role of Randolph Field in the history of American aviation, in the development of the air arm of the United States Army, and in the creation of the Air Force as an independent branch of the United States armed forces. It is listed as significant under Criterion B for the association with Brig. General Frank P. Lahm, the first commanding officer of the Air Corps Training Center established in 1926, leading to the design and construction of Randolph Field. Details of these determinations are given in Section 4.5.1.

56 Cook, Randolph Field Historic District, 2001. 


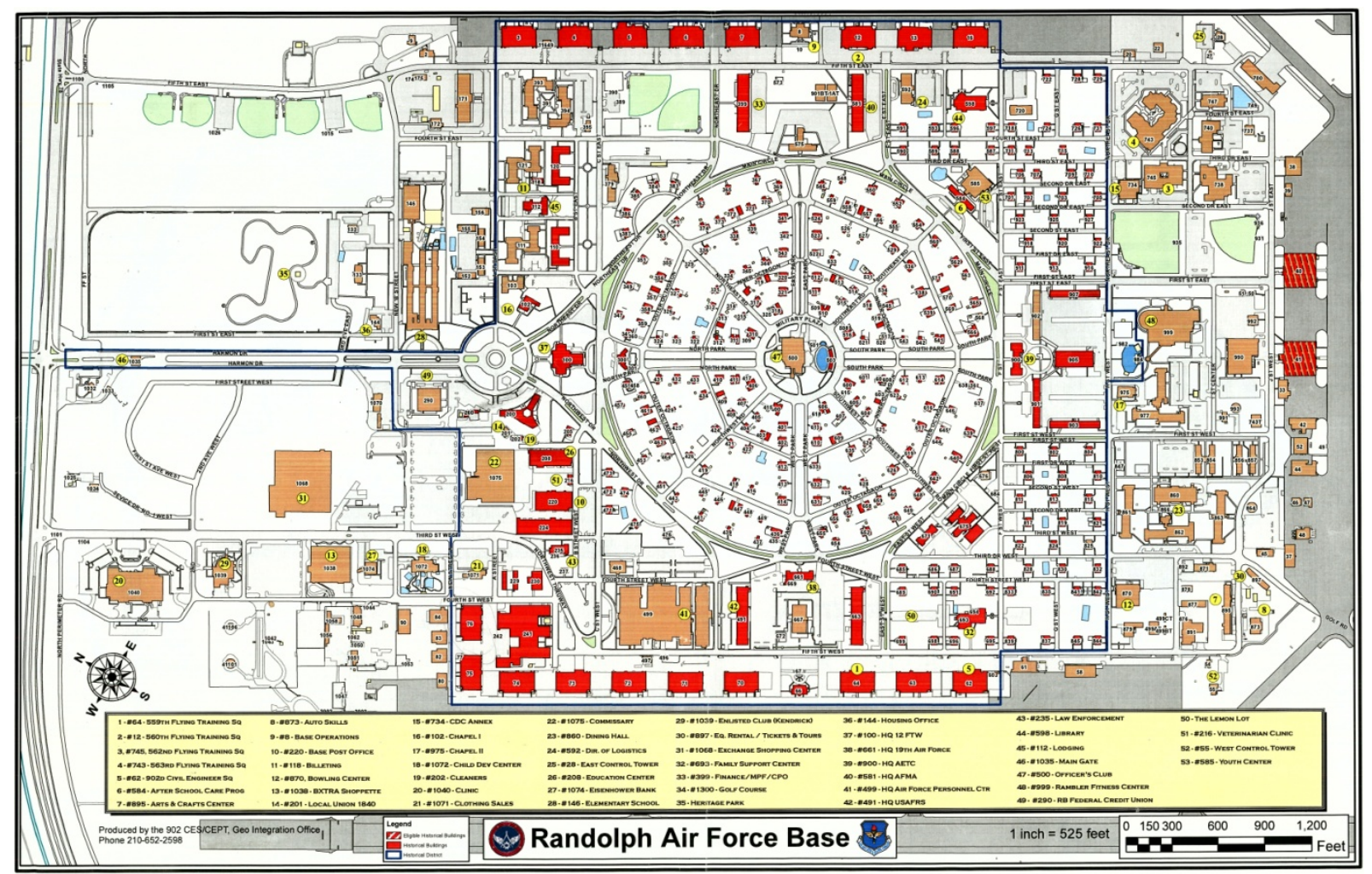

Figure 195. The Randolph Field Historic District is delineated with a dark blue line, 2012 (Randolph AFB Cultural Resources).

Randolph Field is also significant under Criterion C for its architecture, landscape architecture, and urban design. Designed as a model airfield for flying training, the field's initial recommended layout came from officers who were familiar with the special requirements for airfields used for flying training. While the "air city" design is credited to Lt. Harold L. Clark, who was assigned special duty at the Air Corps Training Center Headquarters because of his previous architectural training, the final plan was completed by George B. Ford in his position as City Planning Adviser to the War Department. City Beautiful design principles are clearly visible in the attractive, impressive parkway with wide, tree-lined, parallel roads leading to Washington Circle and the Administration Building, the Post Chapel, and the Base Exchange.

The Randolph Field Historic District nomination documented 342 contributing buildings, one contributing site, and seven contributing structures. Also documented were 22 noncontributing buildings, 23 structures, and two objects. The one contributing site is the Airfield Plan which they define as the original plan for the flying field. The site includes the road layout of almost 32 miles, the park-like areas and boulevards, and the 
placement of pivotal buildings, etc., is a designed landscape with great significance. 57

\subsection{Final determinations of eligibility}

\subsubsection{Historic significance}

The identification of historically significant properties can be achieved only through evaluation of their position within the larger historic context. According to the NRHP, historic contexts are defined as "...the patterns, themes, or trends in history by which a specific occurrence, property, or site is understood and its meaning (and ultimately its significance) within prehistory or history is made clear." 58

Much of America's twentieth-century history is inextricably linked to aviation. America's rise to preeminence in aviation was accomplished through the astonishing achievements of men and women in both the public and private sectors. The pioneers of America's aviation industry built the technological and industrial infrastructure that enabled aviation to succeed, while the exploits of daring flying heroes captured the public imagination and encouraged the support of aviation. The federal government supported the development of military aviation, conducted important aeronautical research, and established, regulated, and encouraged the development of interstate passenger, postal, and freight commerce. ${ }^{59}$

Randolph Field played an exceptional role in the development of the air arm of the United States Army and of the United States Air Force as an armed force. Randolph Field was conceived and designed as a model airfield for flying training in the mid-1920s for the fledgling Army Air Corps. The completed "air city" became the site of unique Air Corps schools for flying training and aviation medicine, as well as a landmark in airfield planning and design. In addition, various administrative headquarters at Randolph Field, including the Air Corps Training Center, the Gulf Coast Air Corps Training Center, and the Army Air Forces Central Flying Training Command were keystones in the organizational structure of the Army Air Corps and the Army Air Forces. Their roles were pivotal in the Army

\footnotetext{
57 Cook, Randolph Field Historic District, 2001.

58 NPS 1991, 3

59 National Park Service, Aviation: From Sand Dunes to Sonic Booms, http://www.nps.gov/nr/travel/aviation/intro.htm.
} 
air arm's 40-year campaign to become an independent branch of the United States armed forces.

\section{Finding for Criterion A - Event or Broad Pattern in History}

The NHL nomination determined Randolph Field was significant for its role in the history of American aviation as well as in the development of the Army Air Corps and the Air Force.

\section{Finding for Criterion B - Person}

The NHL nomination determined Randolph Field was significant for its association with Brig. Gen. Frank P. Lahm, who was the first military officer taught to fly by Wilbur Wright in 1909 and the first American to win an international balloon competition (1906). ${ }^{60} \mathrm{Lahm}$ was one of the two assistants to the Chief of the Air Corps that were authorized by the Air Corps Act, and he became the Air Training Center's first commanding officer.

\section{Finding for Criterion C - Design/Construction/Planning}

The final plan for Randolph Field produced a unique military installation that was an exceptional achievement for Army architects, planners, and Air Corps officers. The NHL nomination details that buildings and structures were generally constructed in the Spanish Colonial Revival style with hollow core tile and concrete block covered with stucco and roofs of Mission red clay tile. Hangars, however, were built in the Art Moderne style and originally had checker-board painted roofs. Most of the buildings were built according to standardized plans designed by the Army Quartermaster Corps in the late 1920s. However, Randolph Field's most prominent buildings - the Administration Building, Chapel, School of Aviation Medicine and Cadet Academic Building - were designed by local architects.

\section{Finding for Criterion D - History}

While Randolph Field is a significant historical site for the Air Force, the military, and the United States, this project provided no determination

\footnotetext{
60 http://www.nps.gov/nr/travel/aviation/ran.htm
} 
that the designed landscape has yielded, or would be likely to yield, any information important in prehistory or history.

\subsubsection{Integrity}

The NHL nomination noted that the district has an exceptional degree of integrity that comes from its cohesive character and small number of noncontributing buildings. The nomination listed elements that contribute to the cohesive architectural character that include its compatible architectural styles, local building materials, low-scale building types, historic landscape design, and the unique roadway layout. In addition to the elements listed in the NHL nomination, the historic landscapes of Randolph Field are equally integral to the character of the historic district. The integral historic landscape features include the planning and design of the "Air City", the organization of land uses and buildings within the distinctive, circular road system, and the vegetation around the clusters of missionspecific, architecturally cohesive buildings.

This report finds the historic integrity of the Randolph Field landscapes to be as follows:

Layout: The original layout of Randolph Field has a high level of integrity. Still highly visible are the double rows of hangers lining the flight lines and the strong circular road system. Most of the new construction over the years has been concentrated to the north and the south of the historic district, with the 1950s-erahousing to the north recently demolished and returned to open space. This was the first and only American military airfield to be designed with such a layout.

Circulation: The circular road system is an integral part of the airfield design and layout, and it is the historic district's most striking and unique feature. A portion of this park and boulevard system has been lost on the west side due to parking needs and new construction (Figure 196). This affects the integrity of the road system in this location. While the runways were originally grass in material, possibly why they were not included in the nomination, the flight lines have remained an integral part of the mission at Randolph Field and as the junction of open space and the built environment (Figure 197). 


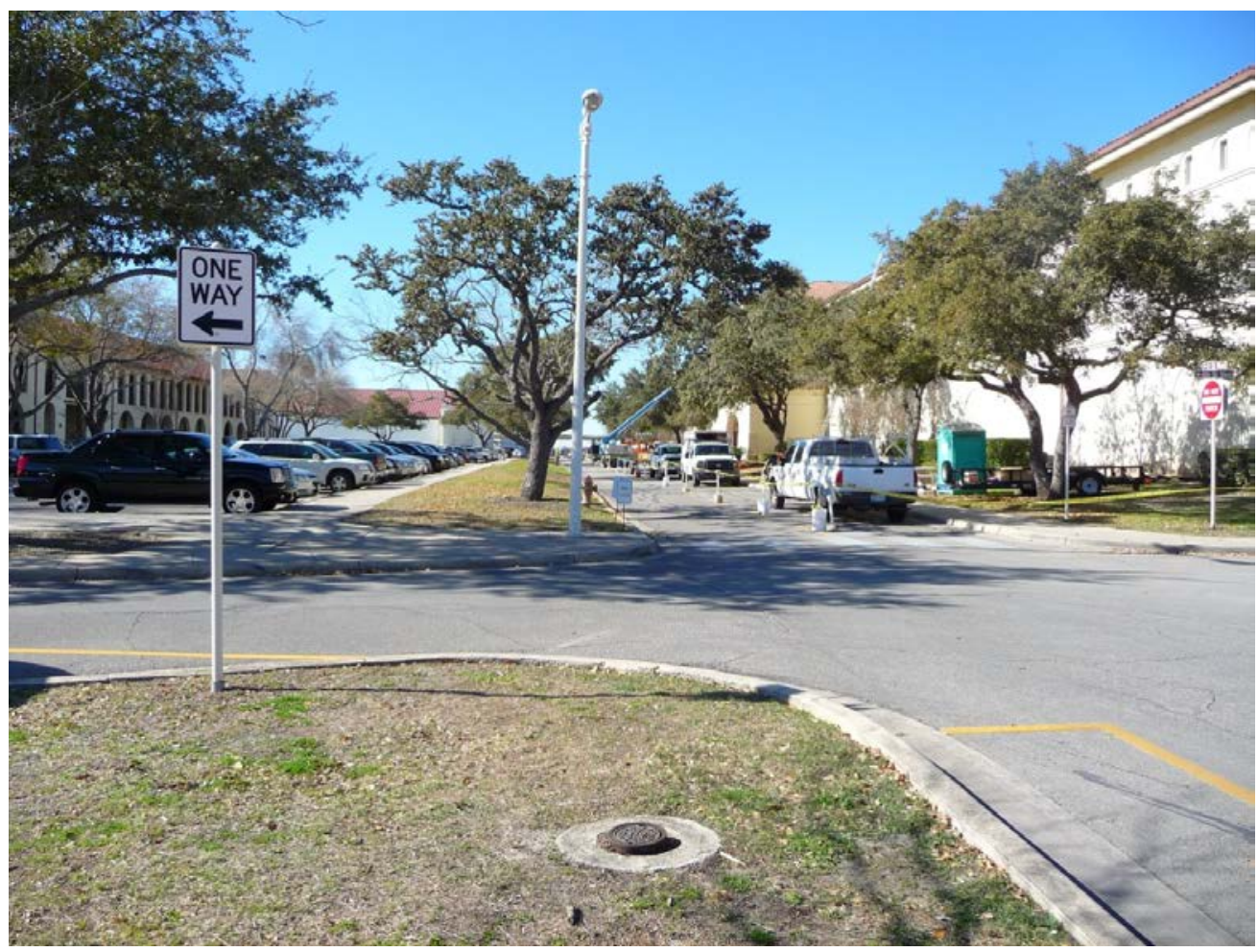

Figure 196. Example of median degraded by added parking, 2012 (ERDC-CERL).

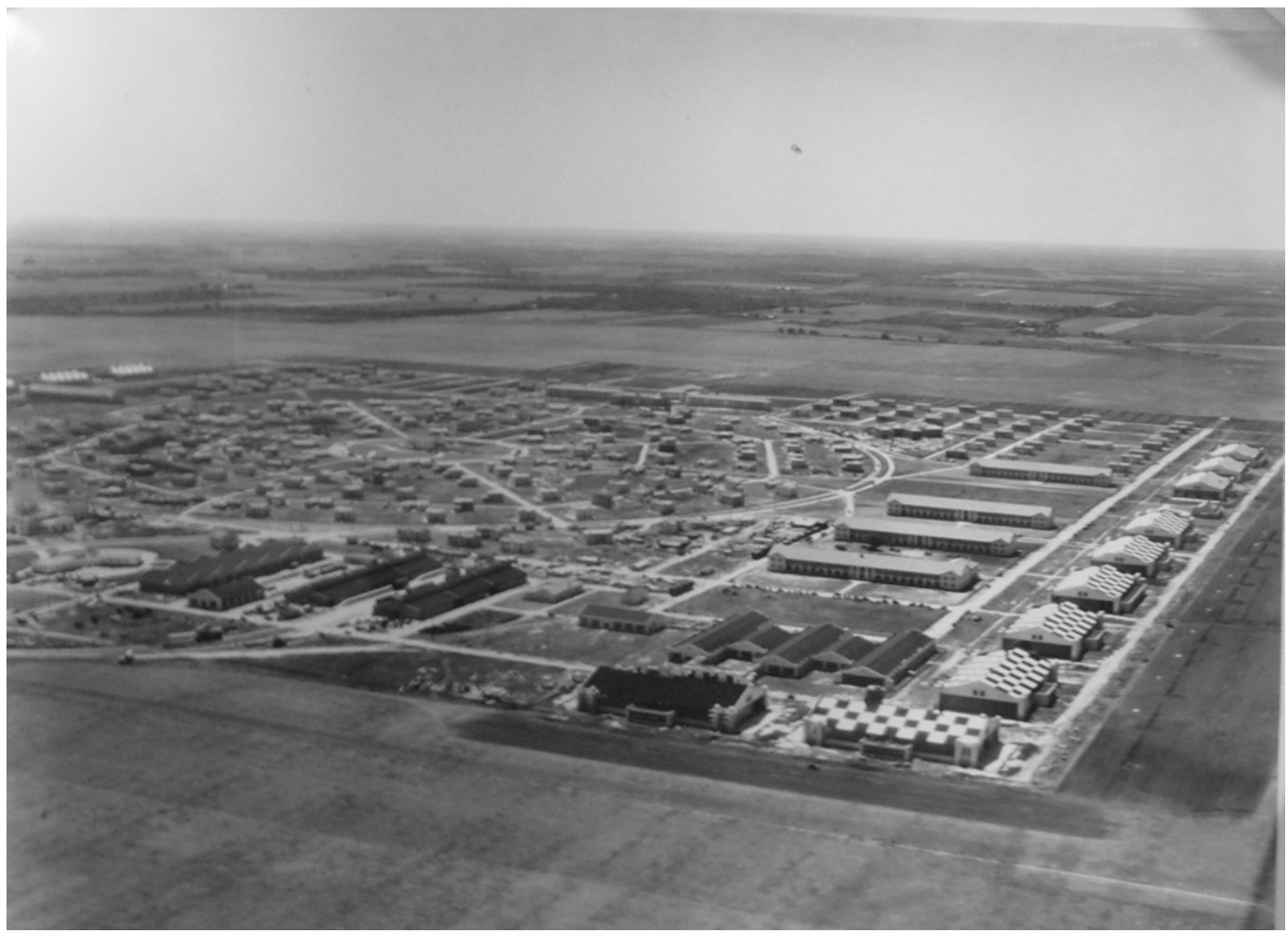

Figure 197. Randolph Field runways are the junction of open space and the built environment, 1930s (Norfleet Giddings Bone Papers, University of Texas at San Antonio Libraries Special Collections). 
Land use: Randolph Field has maintained consistent land use areas over time. The major changes in land use include the use of hangers and barracks on the west side as administration space, the loss of the pools in barracks areas, and the adaptive reuse of the two NCO clubs. The new construction surrounding the barracks on the west side affects the building clusters, with the three barracks becoming one large building. Also notable is the loss of grassy, open space with the addition of sidewalks and street trees between the roadways and the hangers (Figure 198). Today, the landscape is parking and fencing. However, the newly demolished housing areas to either side of the entrance boulevard have been restored to open space as it was in the 1930s and 40s, with the exception of the new BX and associated parking lot, which are set back from Harmon Drive to minimize the visual impact of modern construction along the historic entrance corridor.

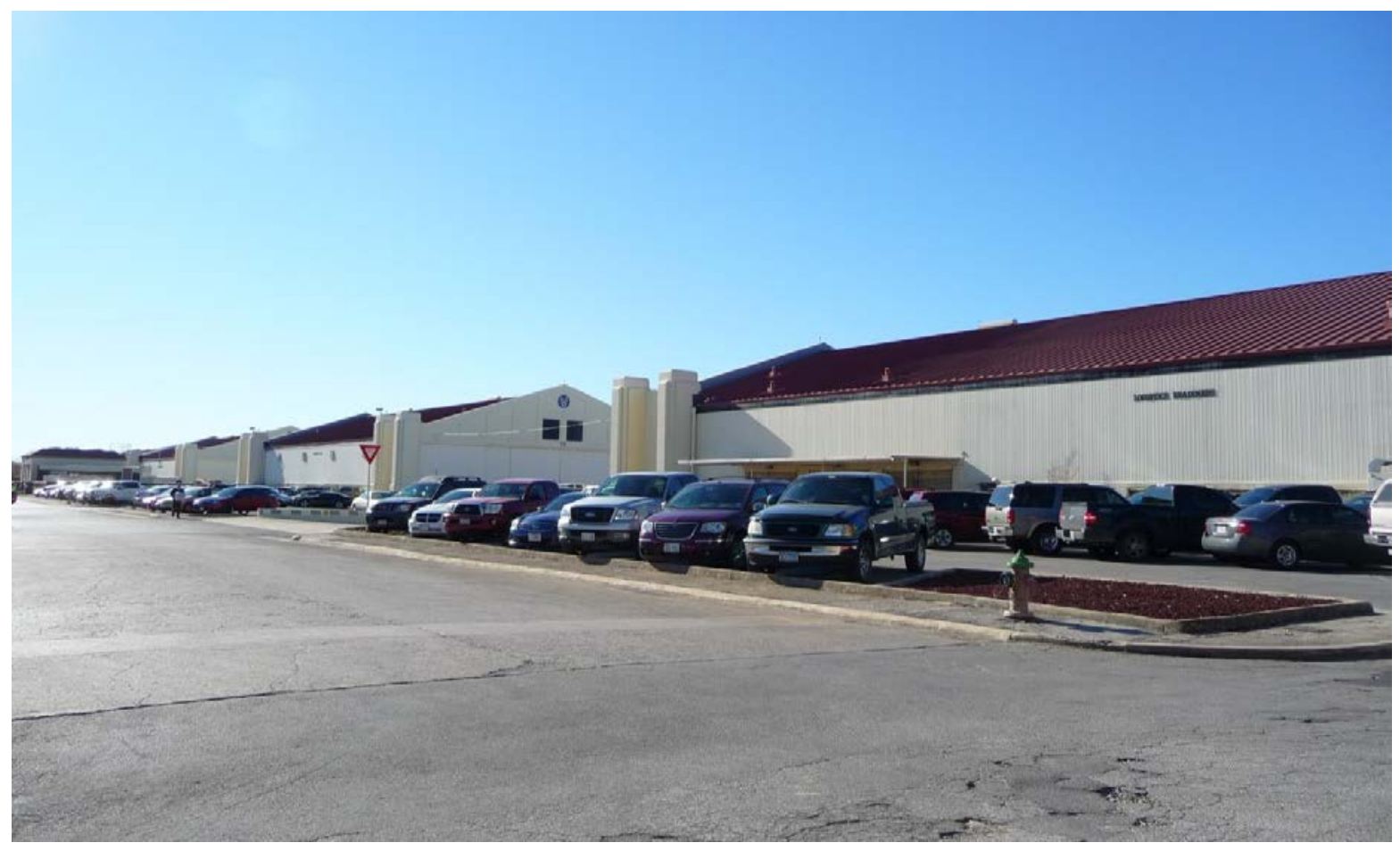

Figure 198. Loss of grassed area, sidewalks, and trees between roads and hangars, 2012 (ERDC-CERL).

Clusters of buildings: The great majority of buildings and structures in the historic district retain their historic integrity. With the exception of the enlisted men's barracks on the west side (Building 499; Figure 199), the cluster arrangement of buildings has a high degree of integrity. There are few non-contributing buildings within the historic district, and loss of integrity is mostly due to the enclosure of porch areas, and the replacement 
of windows and doors, not affecting the relationship of the buildings to the neighboring buildings and the associated open space around the buildings. Most new construction has occurred to the north (now mostly demolished) and to the south of the district.

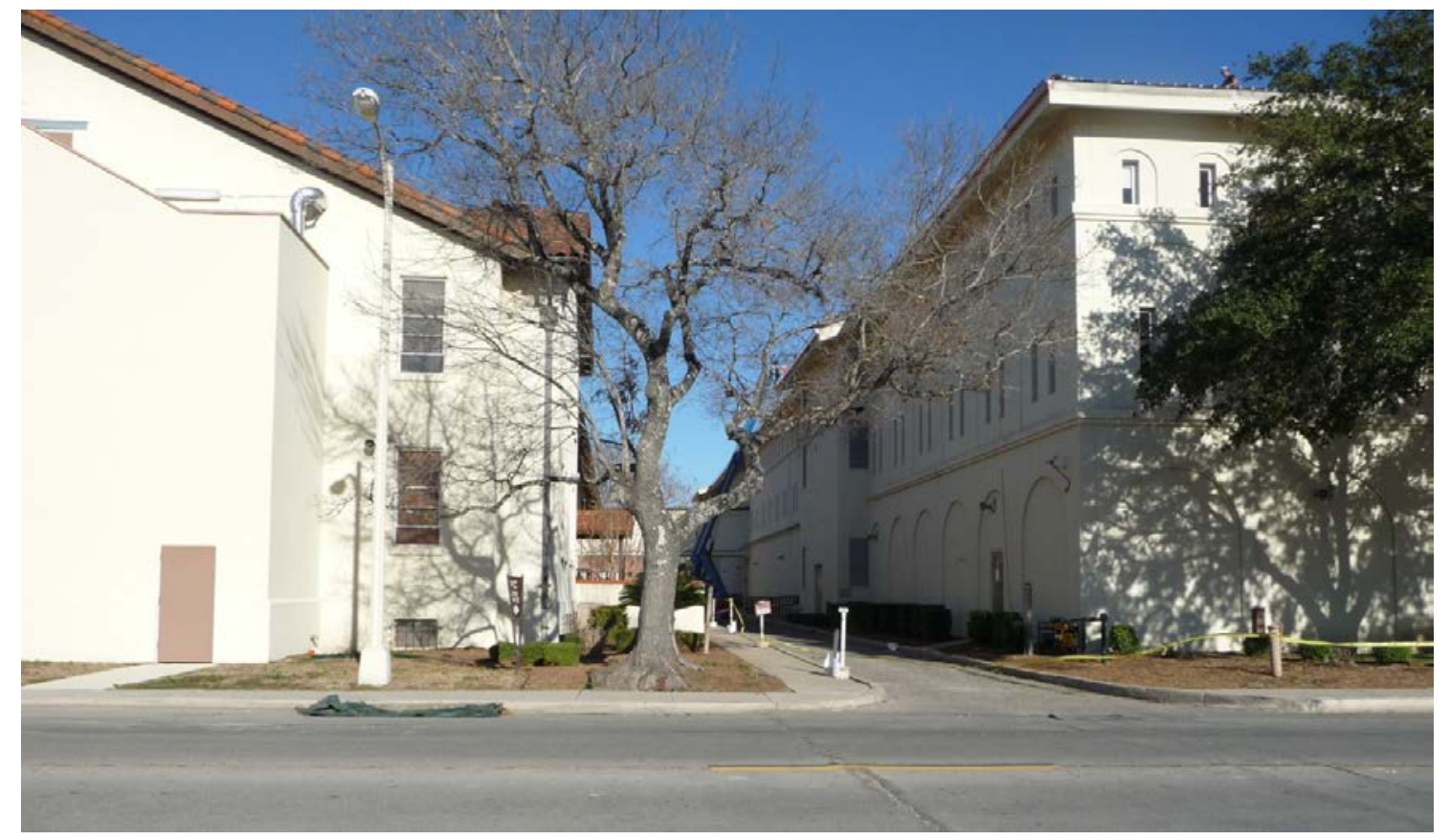

Figure 199. Enlisted men's barracks on the west side, 2012 (ERDC-CERL).

Expressions of military culture: The grand boulevards, beautiful examples of the Beaux Arts style of the early twentieth century, are still intact for the most part and convey their integrity. The relationship between the entrance, Administration Building and Theater, commanding general's residence, officers' quarters, officers' club, and the Cadet School, reinforces the grand mission of Randolph Field and the formality and hierarchy of the military culture and the design (see Figure 200 below "Vegetation" paragraph). The utilitarian, mission-specific buildings are located outside of the historic district.

Vegetation: Very little of the historic vegetation at Randolph Field remains other than street trees. The entrance boulevard (Harmon Boulevard) is a great example of the live oak-lined streets as planned by Lt. Bone's initial landscape design. These initial plans called for street trees on every street, even along streets with hangers, but these do not exist today. Also missing are the carefully chosen perennials, evergreen shrubs, ornamentals, rock gardens, and native cactuses. Focus areas contain too many annuals. For example, the axial boulevards (North Park, East Park, South 
Park, and West Park) were historically capped by evergreen plantings, but today contain just street trees (Figure 201).

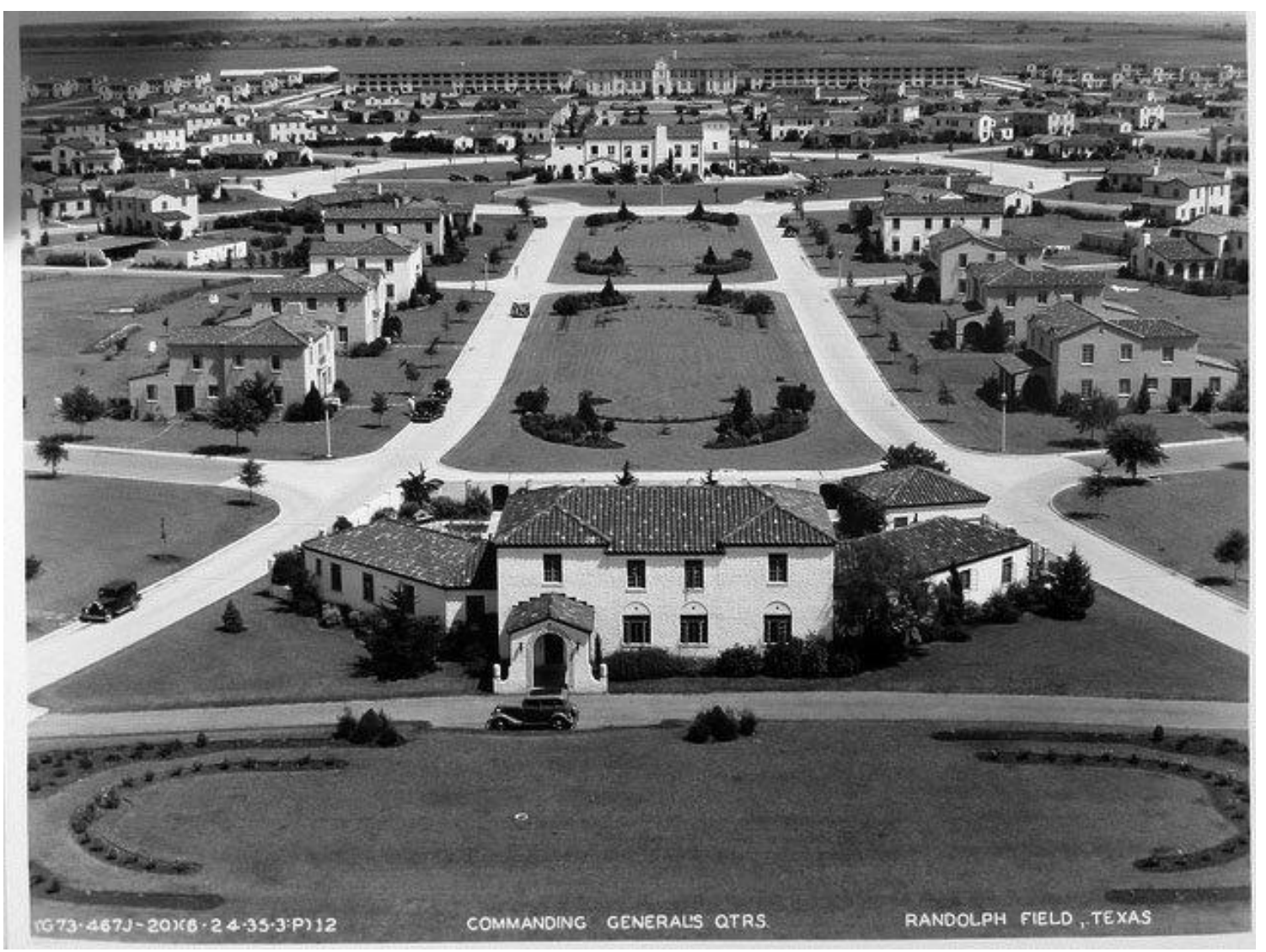

Figure 200. Extensive vegetation around the buildings and in the medians, 1930s (NARA RG342 Box 1072 B20780). 


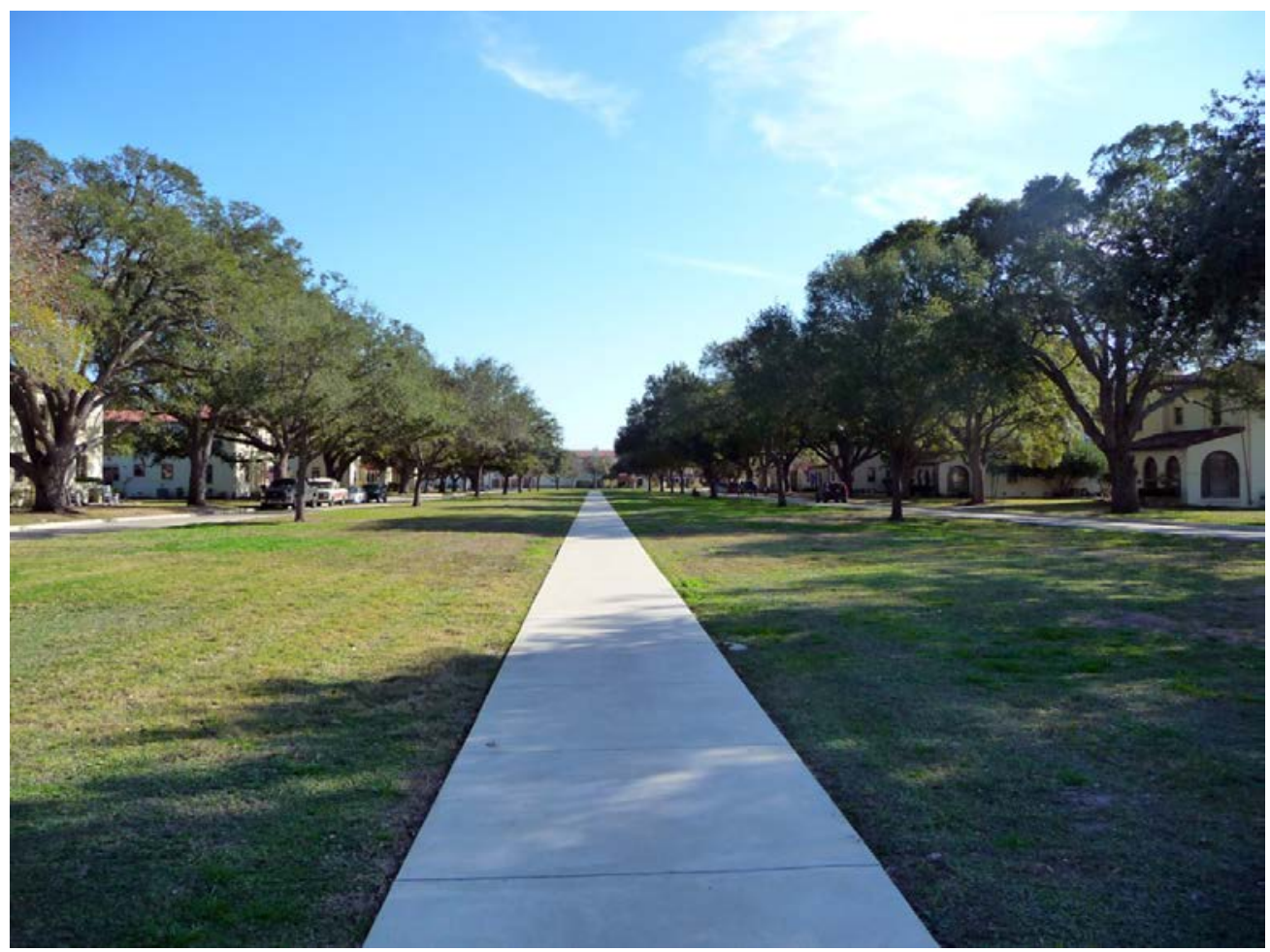

Figure 201. North Park median, with street trees, 2012 (ERDC-CERL).

Small-scale features: the Randolph Field sign in Washington Circle was changed from "Randolph Field" to "Randolph AFB" and back to Field. While the arm-style street lights in the more utilitarian areas appear to be historic, the street lights around Washington Circle and in the residential areas have been replaced. A collection of aircraft has been added in front of BOQ area, and a few monuments and memorials added around Washington Circle. Many small-scale features at Randolph Field have been added over the years such as benches, planters, and trashcans. This wide variety of elements detract from the overall landscape integrity since they were not added according to a specific plan or designed to be compatible to the overall feeling and character of the historic district. To regain the overall landscape integrity but still meet the changing needs of the operational base, design standards and an implementation strategy for those standards should be established so that the small-scale landscape features will be visually uniform and contribute to the character of the historic district.

\subsubsection{Final determination}

The landscape is integral to both the significance and integrity of Randolph Field. From the layout and design to the live oak-lined boulevards, the landscape ties together the mission, the architecture, and the distinc- 
tive layout and road system. While the nomination explicitly discusses the significance of Randolph Field, many aspects of the landscape and the integrity of the landscape could be improved by using consistent materials and restoring many of the historic design concepts of Lt. Bone.

There is currently a disconnection between the significance of the site (layout designed around runways) and the lack of discussion of the runways in the nomination. The runways are integral to the mission, design, and layout of Randolph Field and thus are an integral part of the landscape. The current historic district focuses on the architecture and not on the mission of the base. The runways can either be included in the district boundaries or they can be included as part of a significant viewshed and open space feature. The main concern regarding the runways is that if changes were to occur in the future, such as base closure, a decision could be made that one or more of the runways would no longer be needed. If this were to happen, expansion or construction of more buildings on the runways could take place, resulting in the double line of runways and the association with the double line of hangers would be lost. Historic views and viewsheds that are key to the historic character of the district are discussed in Chapter 3.

The Randolph Field historic district has a high level of integrity due to the cohesive architectural styles (Mission/ Spanish Colonial revival and Art Deco) as well as materials (concrete foundations, stucco walls, and red clay tile or metal roofs). However, these building materials and workmanship could be better reflected in the landscape materials and plantings around the installation.

In addition, the overuse of annuals and carefully trimmed shrubs do not meet today's standards of sustainability. Annuals require water and multiple plantings per year to look their best. Furthermore, the use of annuals does not follow the historic planting design intentions of Lt. Bone and other early landscape architects (Figure 202). Recommendations include the use of more native plants including cactuses, to preserve water, and hedgestyle shrubs which do not need maintenance and trimming. While formalstyle plantings are in keeping with the hierarchy and order inherent in the military, the use of native perennials will achieve a balance of nature and culture (Figure 202). The use of annuals also adds to maintenance costs through increased water use and periodic replacements phases (Figure 203 and Figure 204). Chapter 5 provides recommendations and planting 
plans to improve and maintain the integrity of the historic district while addressing sustainable environmental goals.

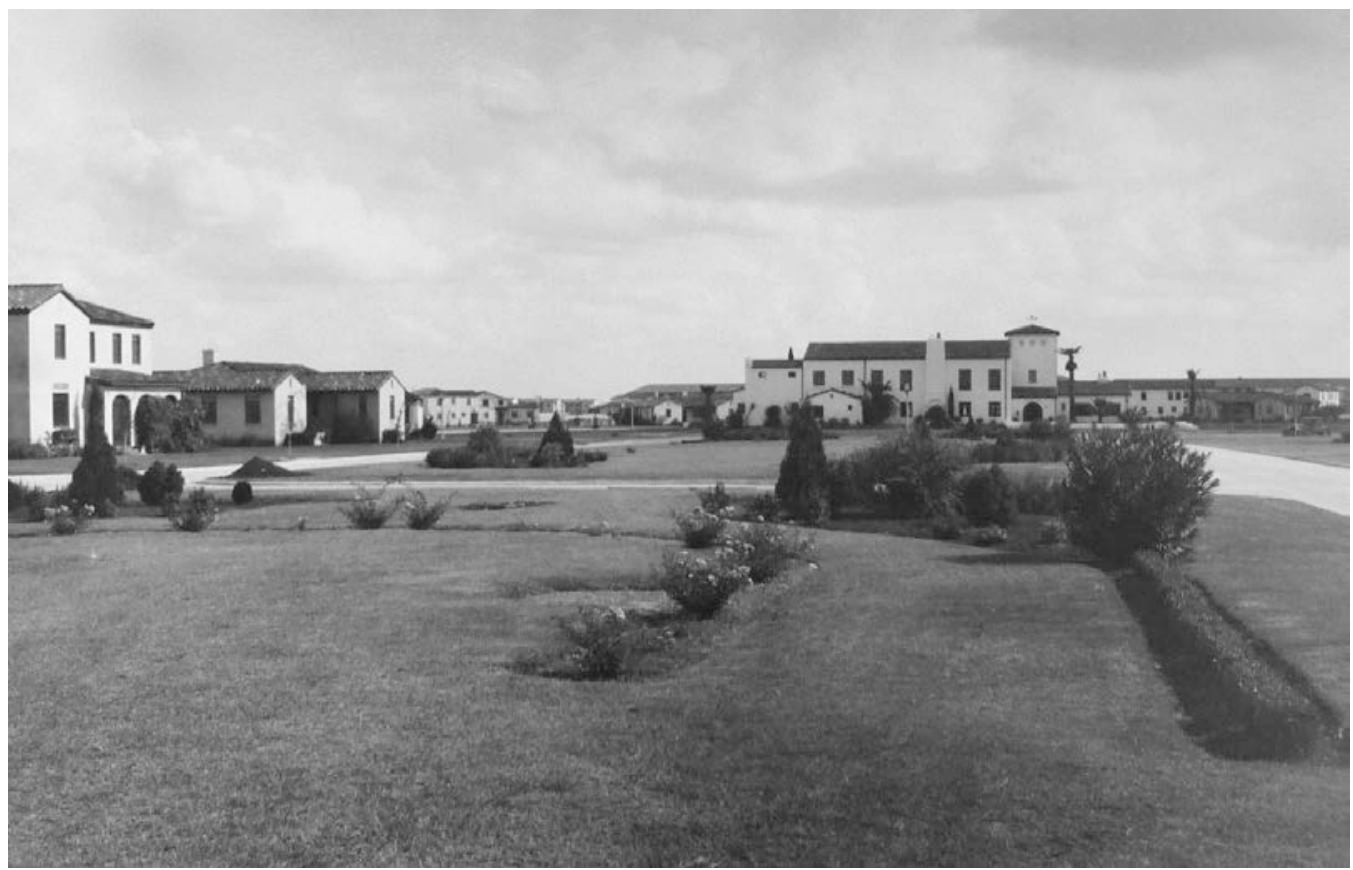

Figure 202. Historic planting designs emphasized native shrubs and grasses, 1930s (NARA RG342 Box 1072).

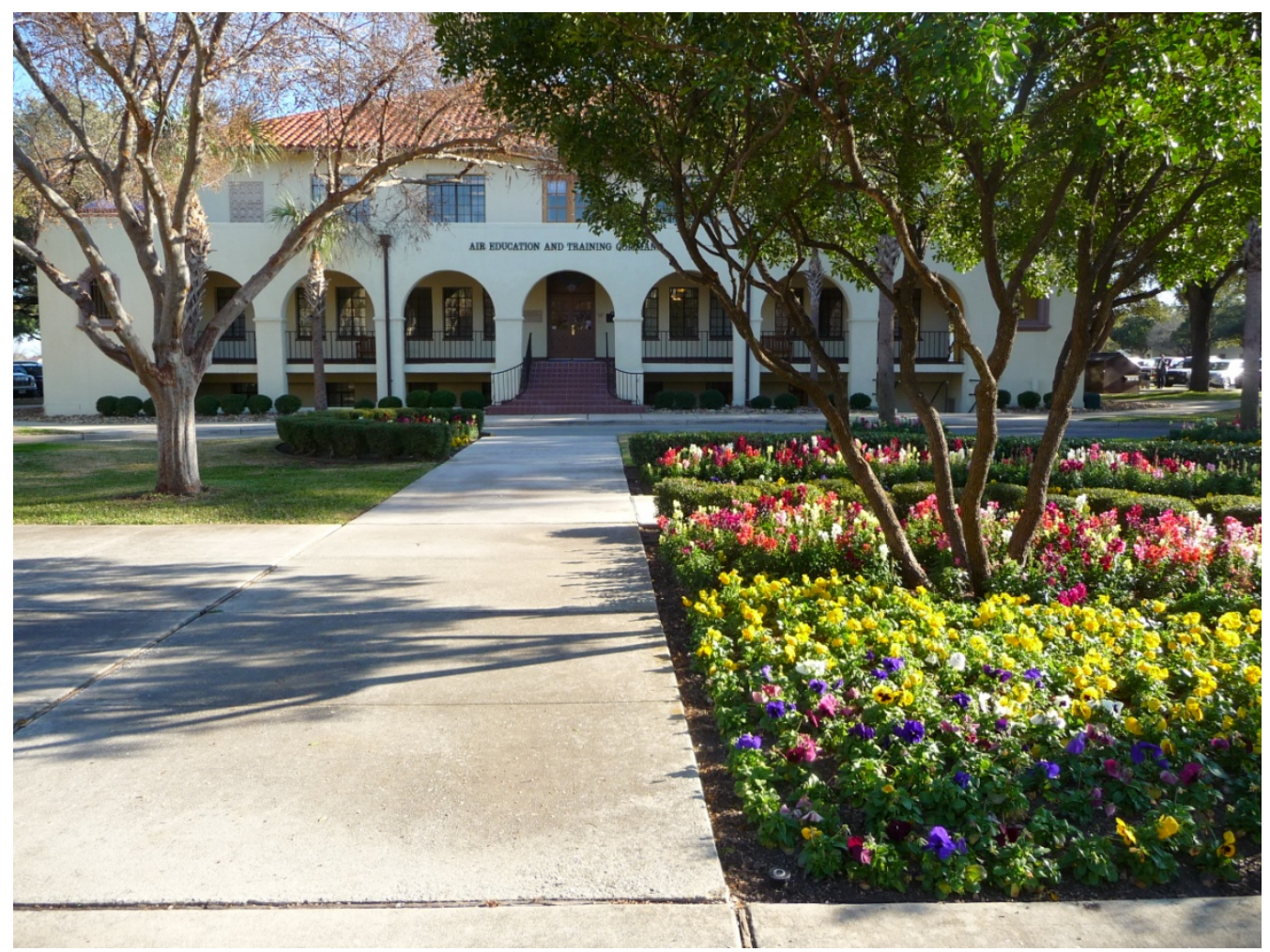

Figure 203. Annuals planted in Cadet Circle, 2012 (ERDC-CERL). 


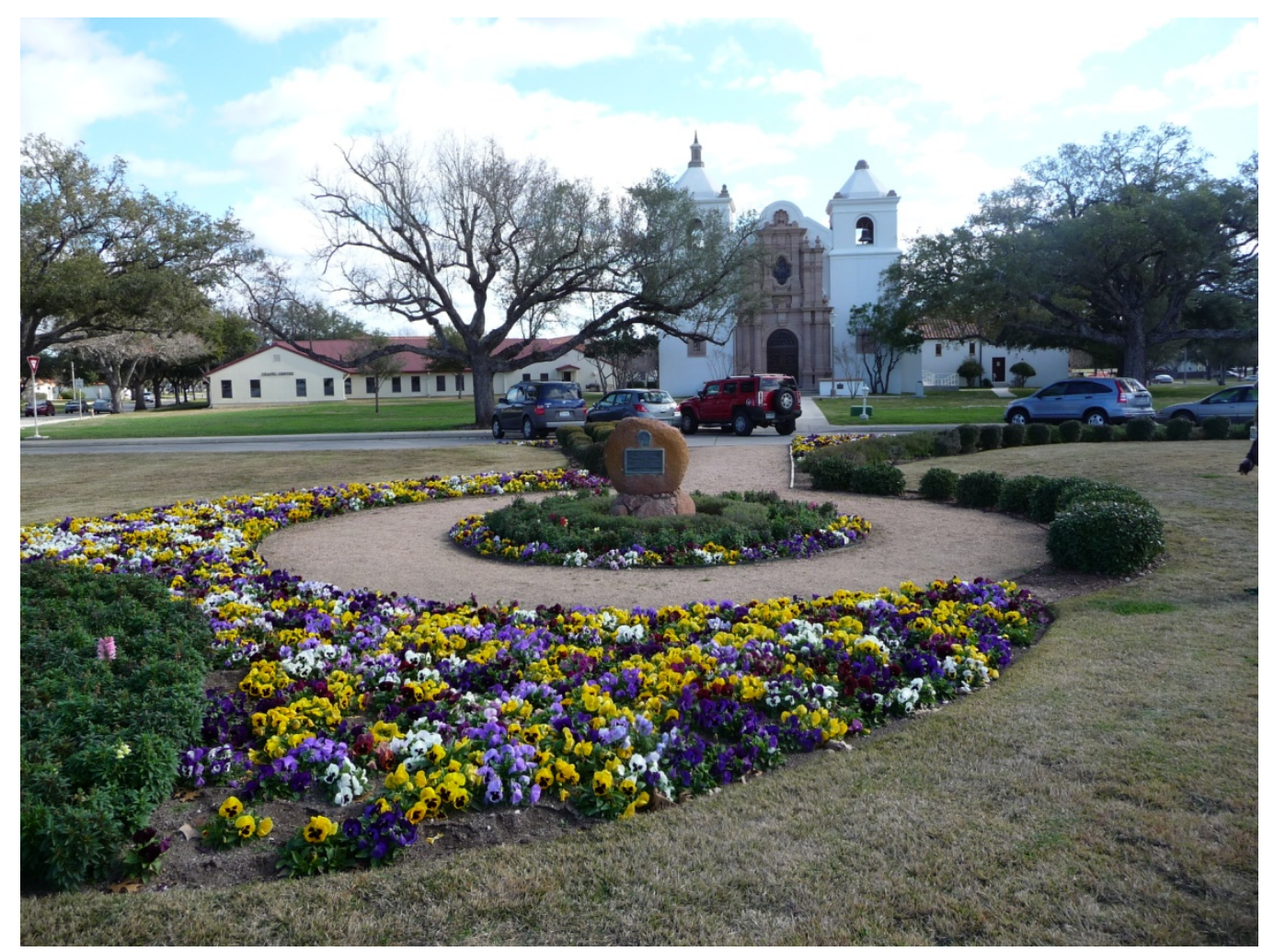

Figure 204. Annuals planted in the median in front of the Chapel, 2012 (ERDC-CERL).

\subsubsection{Character-defining features}

The character-defining features of Randolph Field are landscape features that were part of the initial design, present throughout the period of significance as established in the National Register nomination (1928-1950), and continue to be evident in the district today. The component landscapes at Randolph AFB are listed in Table 2 along with summaries of their historical significance and character-defining features. 
Table 2. Component landscape within Randolph AFB

\begin{tabular}{|c|c|c|c|c|}
\hline $\begin{array}{l}\text { Component } \\
\text { Landscapes }\end{array}$ & $\begin{array}{l}\text { Historical } \\
\text { Significance }\end{array}$ & $\begin{array}{l}\text { Character-Defining } \\
\text { Features }\end{array}$ & Significance/Integrity & $\begin{array}{l}\text { NRHP } \\
\text { Eligibility }\end{array}$ \\
\hline $\begin{array}{l}\text { Overall layout } \\
\text { and design of the } \\
\text { "Airfield Plan" }\end{array}$ & & $\begin{array}{l}\text { - Parallel flight lines } \\
\text { - Strong geometrical } \\
\text { layout with circle } \\
\text { surrounded by a } \\
\text { gridded square }\end{array}$ & $\begin{array}{l}\text { High integrity, new } \\
\text { construction } \\
\text { concentrated outside of } \\
\text { historic district to north } \\
\text { and south. Almost all } \\
\text { buildings remain. }\end{array}$ & Yes \\
\hline Road system & $\begin{array}{l}\text { The road system, } \\
\text { planned in the late } \\
1920 \text { s, provides } \\
\text { the distinct } \\
\text { organization to the } \\
\text { base. }\end{array}$ & $\begin{array}{l}\text { - Central circle } \\
\text { surrounded by a } \\
\text { gridded square. }\end{array}$ & High integrity & Yes \\
\hline $\begin{array}{l}\text { Entrance } \\
\text { Boulevard and } \\
\text { Washington } \\
\text { Circle }\end{array}$ & $\begin{array}{l}\text { The entrance drive } \\
\text { and Washington } \\
\text { Circle were part of } \\
\text { the original master } \\
\text { plan }\end{array}$ & $\begin{array}{l}\text { - Live oaks lining } \\
\text { boulevard } \\
\text { - Circular layout of } \\
\text { Washington Circle } \\
\text { - Admin building, } \\
\text { Chapel and PX } \\
\text { - Randolph field } \\
\text { signage } \\
\text { - Prominent locations } \\
\text { - Views along } \\
\text { boulevard (to and } \\
\text { away from Taj Mahal) }\end{array}$ & High integrity & Yes \\
\hline Runways & & $\begin{array}{l}\text { - Oriented to most } \\
\text { effectively } \\
\text { accommodate } \\
\text { climatic conditions } \\
\text { - Views across to } \\
\text { historic district }\end{array}$ & $\begin{array}{l}\text { Historically grass, now } \\
\text { paved. Fencing } \\
\text { separates hangers, } \\
\text { aprons, and runways }\end{array}$ & No \\
\hline $\begin{array}{l}\text { Aviation } \\
\text { Support/Hangars }\end{array}$ & $\begin{array}{l}\text { The rows of } \\
\text { hangars and } \\
\text { associated aprons } \\
\text { were part of the } \\
\text { original master } \\
\text { plan }\end{array}$ & $\begin{array}{l}\text { Double rows of } \\
\text { hangers (size, scale, } \\
\text { mass) } \\
\text { - Association to flight } \\
\text { line and aprons } \\
\text { - Lighting }\end{array}$ & $\begin{array}{l}\text { Significance - mission- } \\
\text { specific buildings that } \\
\text { line the flight line. } \\
\text { Integrity - some used for } \\
\text { admin space, windows } \\
\text { blocked in, parking } \\
\text { replaces grassy areas. } \\
\text { Rows remain as does } \\
\text { association to flight line }\end{array}$ & Yes \\
\hline
\end{tabular}




\begin{tabular}{|c|c|c|c|c|}
\hline $\begin{array}{l}\text { Component } \\
\text { Landscapes }\end{array}$ & $\begin{array}{l}\text { Historical } \\
\text { Significance }\end{array}$ & $\begin{array}{l}\text { Character-Defining } \\
\text { Features }\end{array}$ & Significance/Integrity & $\begin{array}{l}\text { NRHP } \\
\text { Eligibility }\end{array}$ \\
\hline $\begin{array}{l}\text { Officers' } \\
\text { Quarters }\end{array}$ & $\begin{array}{l}\text { Part of the original } \\
\text { master plan }\end{array}$ & $\begin{array}{l}\text { - Layout of housing } \\
\text { area } \\
\text { - Circular streets } \\
\text { - Varied styles of } \\
\text { housing } \\
\text { - Consistent } \\
\text { architecture, } \\
\text { setbacks } \\
\text { - Views along streets } \\
\text { - Relationship to } \\
\text { officers club }\end{array}$ & $\begin{array}{l}\text { Integrity - high level of } \\
\text { integrity (some windows } \\
\text { replaced but other than } \\
\text { that no external changes } \\
\text { Clubhouse is no longer } \\
\text { eligible due to } \\
\text { modifications and } \\
\text { materials. }\end{array}$ & Yes \\
\hline NCO Quarters & $\begin{array}{l}\text { Part of the original } \\
\text { master plan }\end{array}$ & $\begin{array}{l}\text { - Consistent layout, } \\
\text { setbacks, and } \\
\text { gridded road layout } \\
\text { of housing area } \\
\text { - Circular streets } \\
\text { - Varied styles of } \\
\text { housing } \\
\text { - Consistent } \\
\text { architecture, } \\
\text { setbacks }\end{array}$ & $\begin{array}{l}\text { Clubs - adaptively reused } \\
\text { Quarters - filled-in } \\
\text { porches and } \\
\text { replacement doors }\end{array}$ & Yes \\
\hline $\begin{array}{l}\text { Bachelor } \\
\text { Officers' } \\
\text { Quarters }\end{array}$ & $\begin{array}{l}\text { This area was part } \\
\text { of the original } \\
\text { master plan }\end{array}$ & $\begin{array}{l}\text { - Organization and } \\
\text { layout of buildings, } \\
\text { drives, and parking }\end{array}$ & $\begin{array}{l}\text { High level of integrity; } \\
\text { Aircraft displays across } \\
\text { the street }\end{array}$ & Yes \\
\hline $\begin{array}{l}\text { Barracks - } \\
\text { Enlisted Men's }\end{array}$ & $\begin{array}{l}\text { These areas were } \\
\text { part of the original } \\
\text { master plan }\end{array}$ & $\begin{array}{l}\text { - Long rectangular } \\
\text { barracks fronting a } \\
\text { large open area } \\
\text { - Near the flight lines } \\
\text { and in alignment } \\
\text { with the stage } \\
\text { houses }\end{array}$ & $\begin{array}{l}\text { The original pools and } \\
\text { amphitheater have been } \\
\text { removed and new } \\
\text { buildings added. } \\
\text { However, the overall } \\
\text { relationships between } \\
\text { the barracks buildings } \\
\text { have been retained. }\end{array}$ & Yes \\
\hline Cadet Complex & $\begin{array}{l}\text { The Cadet } \\
\text { Complex was an } \\
\text { integral part of the } \\
\text { base plan and was } \\
\text { significant in the } \\
\text { design because } \\
\text { the north-south } \\
\text { organizing axis } \\
\text { terminated at the } \\
\text { Cadet education } \\
\text { building. }\end{array}$ & $\begin{array}{l}\text { - Original building } \\
\text { organization and } \\
\text { layout is still } \\
\text { apparent } \\
\text { - Cadet Circle is the } \\
\text { interior courtyard }\end{array}$ & $\begin{array}{l}\text { Parking lots have been } \\
\text { added to the interior } \\
\text { spaces of the Cadet } \\
\text { Complex. Although the } \\
\text { buildings' functions have } \\
\text { changed, the spatial } \\
\text { relationships between } \\
\text { the buildings remain. }\end{array}$ & Yes \\
\hline
\end{tabular}




\begin{tabular}{|c|c|c|c|c|}
\hline $\begin{array}{l}\text { Component } \\
\text { Landscapes }\end{array}$ & $\begin{array}{l}\text { Historical } \\
\text { Significance }\end{array}$ & $\begin{array}{l}\text { Character-Defining } \\
\text { Features }\end{array}$ & Significance/Integrity & $\begin{array}{l}\text { NRHP } \\
\text { Eligibility }\end{array}$ \\
\hline $\begin{array}{l}\text { Warehouse and } \\
\text { shops area }\end{array}$ & $\begin{array}{l}\text { The area was } \\
\text { planned as the } \\
\text { warehouse and } \\
\text { shops area with } \\
\text { regularly spaced } \\
\text { buildings }\end{array}$ & $\begin{array}{l}\text { - Architecture of the } \\
\text { area is more } \\
\text { elaborate than in } \\
\text { most utilitarian } \\
\text { spaces, reflecting } \\
\text { the overall } \\
\text { architectural style of } \\
\text { the base }\end{array}$ & $\begin{array}{l}\text { Average integrity, } \\
\text { Building uses have } \\
\text { changed over time. Many } \\
\text { buildings are now used } \\
\text { for administration, and } \\
\text { some new construction } \\
\text { has taken place. }\end{array}$ & Yes \\
\hline Hospital Complex & $\begin{array}{l}\text { Significant } \\
\text { because the } \\
\text { School of Aviation } \\
\text { Medicine was a } \\
\text { unique institution } \\
\text { formed as a } \\
\text { response to the } \\
\text { growing number of } \\
\text { aviation accidents }\end{array}$ & $\begin{array}{l}\text { - Three-building } \\
\text { cluster } \\
\text { - Drive-thru entrance } \\
\text { between first two } \\
\text { buildings }\end{array}$ & $\begin{array}{l}\text { Integrity - now used for } \\
\text { administration but has } \\
\text { architectural integrity }\end{array}$ & Yes \\
\hline $\begin{array}{l}\text { Views and } \\
\text { Viewsheds }\end{array}$ & $\begin{array}{l}\text { Views around } \\
\text { Randolph Field } \\
\text { were constructed } \\
\text { and emphasized } \\
\text { through the } \\
\text { geometrical layout } \\
\text { of the base. } \\
\text { Through spatial } \\
\text { organization, } \\
\text { important features } \\
\text { of the base were } \\
\text { visually reinforced } \\
\text { by axial } \\
\text { alignments, open } \\
\text { spaces, and } \\
\text { vertically defined } \\
\text { by street trees. }\end{array}$ & $\begin{array}{l}\text { - The views at } \\
\text { Randolph AFB } \\
\text { highlight important } \\
\text { buildings and } \\
\text { functional areas } \\
\text { around the base. }\end{array}$ & $\begin{array}{l}\text { The original views } \\
\text { constructed as part of } \\
\text { Randolph Field retain a } \\
\text { high degree of integrity. }\end{array}$ & Yes \\
\hline
\end{tabular}


(This page intentionally left blank.) 


\section{Recommendations for Historic Landscape Preservation}

This chapter provides a detailed list of landscape design recommendations that will provide a guide for maintaining and preserving the historic characteristics of the Randolph AFB landscape. To determine appropriate guidance, the historic base plans, planting plans, and photographs were analyzed to determine the scope of change within the landscape. The planting designs shown in historic photographs were compared with the current landscaping conditions of these areas to determine a planting/ landscaping strategy that will reflect the historic precedent of Lt. Bone as well as meet the new Air Force Instruction (AFI) landscaping requirements for low-maintenance vegetation and water conservation. Illustrations of historically compatible landscaping for the major buildings at Randolph AFB are also included as suggestions for possible planting strategies for the component landscapes.

\subsection{Overall district management guidelines}

- The Randolph AFB road network was designed in a distinctive geometric pattern which provides the overall character to the base's landscape. This historic road network must be preserved and maintained to convey its original geometric design.

- The master plan of Randolph AFB grouped buildings that had similar functions. For example, administration buildings were located in close proximity, barracks and residential quarters were built together, and the same is true for the commercial, industrial, and aviation support buildings. While the base has undergone significant changes in its programmatic planning, when possible the spatial relationships of these historic functional areas should continue to be maintained.

- Randolph AFB is organized and laid out to convey the order and hierarchy of military culture. When planning new undertakings, consider the implications of any addition to the existing order and hierarchy that has been established in the base plan. 
- The use of open space, parks, and wide, tree-lined roads give the district a park-like feeling. The open spaces, parks, and wide boulevard system should be maintained and preserved as it was originally designed.

- Architectural continuity in the district is conveyed through the repetitions of architectural styles: Spanish Colonial Revival, Mission, and Art Moderne. Buildings with these styles should be maintained to preserve these architectural details while new buildings should be designed to stylistically blend with the original architecture.

- Preserve important views and viewsheds throughout the base. 


\subsection{Base-wide design recommendations}

- Maintain the street trees throughout the district; if one is removed, replace it with an in-kind species to preserve the spacing and placement of trees. Add trees along roads within the historic district where there are currently none. Streets on the outskirts of the district should be planted with trees.

- Where specified, all areas should be at least minimally planted and the vegetation well maintained. The quality and level of landscaping varies within the historic district from poor to quite good. The differing levels of maintenance are not a function of a designed hierarchy within the planting plan, but rather are due to pest and disease problems, lack of maintenance, or individual efforts. Make efforts to unify the planting design across the base as well as keep all vegetation maintained.

- The planting strategies from the 1930s should be the basis for the design of new vegetation in the historic areas. Accordingly, the original intent and character of the planting scheme should be reflected. However, when possible, replace species with pest- and disease-free varieties or native plants.

- For visual continuity throughout the district, establish one or two natural mulch types and a uniform garden edging type from which to choose.

- Small-scale landscape features should be similar in their design, type, and color scheme. Examples of small-scale features include street lighting, benches, and signage. Using a consistent array of these elements will give the district a unified appearance.

- New construction in the historic district should preserve the design intention of the original, late 1920s layout of the base. The open spaces of the boulevard system and parks should be retained and the street network should not be altered. 


\subsection{Component landscape design recommendations}

This section provides illustrative guidance on how the historic planting designs can be translated to meet current military landscaping requirements. While the overall management guidelines address the base as a whole, the component landscape design recommendations are specific to the functional areas of the base. Figure 205 provides a map of the component landscape design recommendations. 


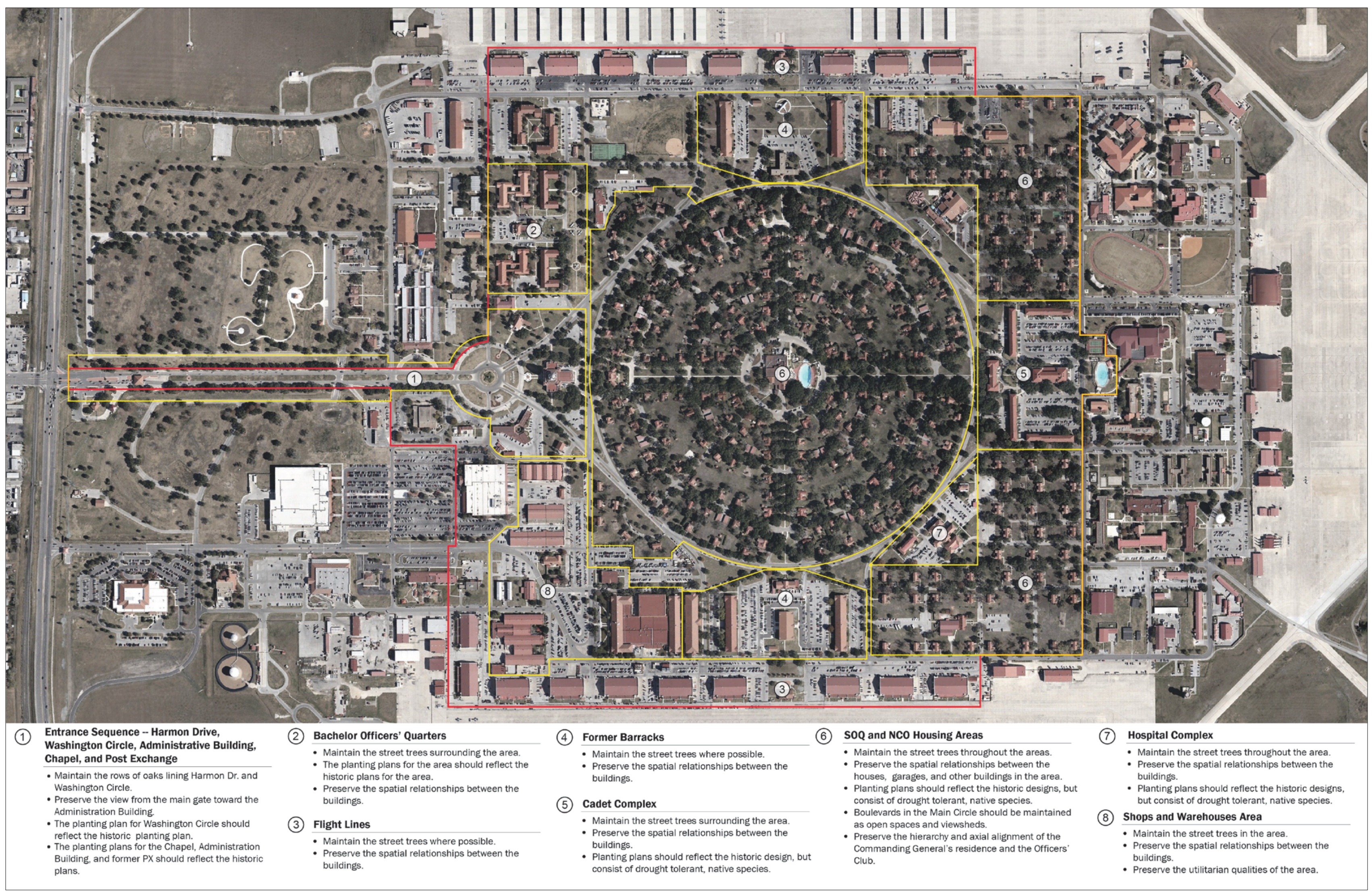

Figure 205. Overall component landscape management guidelines, 2013 (ERDC-CERL). 
ERPOC/ERR TR:1.3.14 


\subsubsection{Road system}

- The physical layout of the roads should not be altered by changing the width of the streets, blocking the through streets, or removing any streets.

- The original landscape plans specified planting trees along all major streets. In particular, these major streets are Harmon Drive (the entrance boulevard), the streets in the officers' housing areas, and the streets in the NCO housing areas.

- The boulevards are important open spaces in the Randolph AFB master plan. They should be maintained so that they provide clear lines of sight to the buildings located on the axes they create. However, the original landscape plan for Randolph Field included vegetation in these spaces. Consideration should be given to developing planting schemes for these areas that reflect the original landscape designs for these areas.

- There are many medians and remnants of space that are created by the strong geometry of the road layout. These areas should have uniform planting plans that include street trees. Designs for these areas should be based on the median designs that Lt. Bone proposed for the Park boulevards.

Because trees have been added along the medians, the planting plans developed by Lt. Bone are incompatible with the current spatial configuration. As an example, Figure 206 provides a diagram of a historically compatible planting strategy for the medians in the historic district. The plants chosen for these groups should be a mix of medium sized evergreens and smaller deciduous trees and shrubs. Figure 207 shows the overall planting patter for North Park and South Park. 


\begin{tabular}{|l} 
(1) Juniperus virginiana \\
Eastern Red-cedar \\
(2) Ilex vomitoria \\
Yaupon holly \\
(3) Ilex vomitoria 'Nana' \\
Dwarf yaupon holly \\
(4) Rhus lanceolata \\
Flameleaf sumac \\
(5) Rhaphiolepis umbellata 'Minor' \\
Dwarf Yeddo Hawthorn \\
(6) Andropogon gerardi \\
Big bluestem \\
(7) [when in shade] \\
Rivina humilis \\
Pigeonberry \\
[when in sun] \\
Achillea millefolium
\end{tabular}

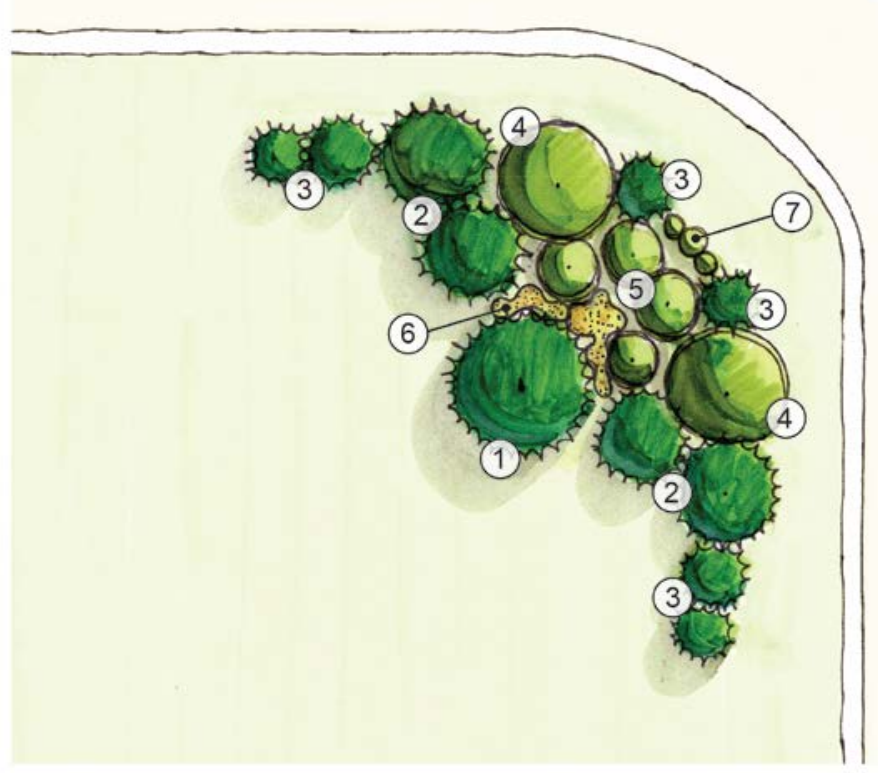

Figure 206. Diagram of a potential planting scheme for the medians, 2013 (ERDC-CERL). 


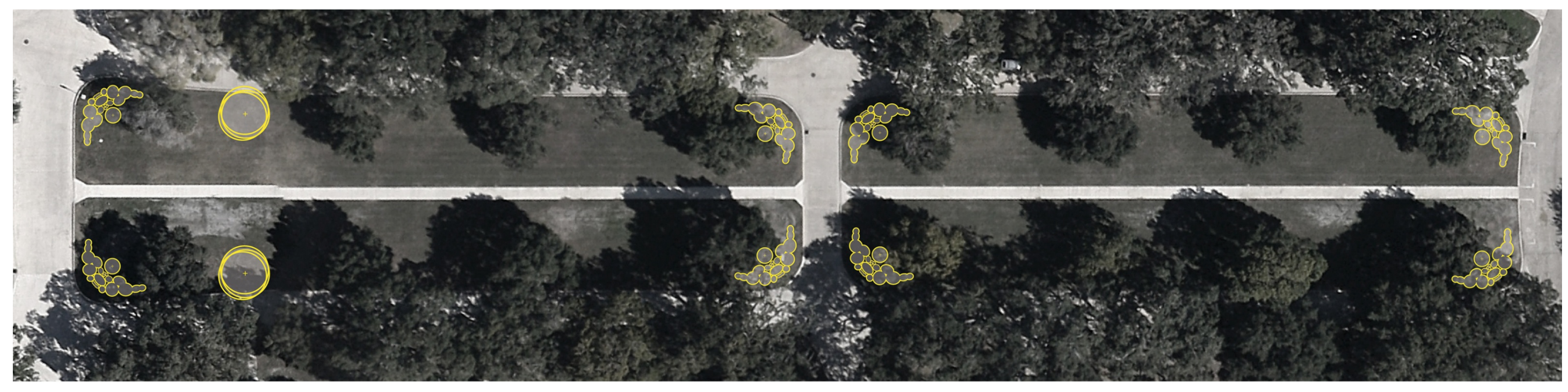

North Park median planting diagram

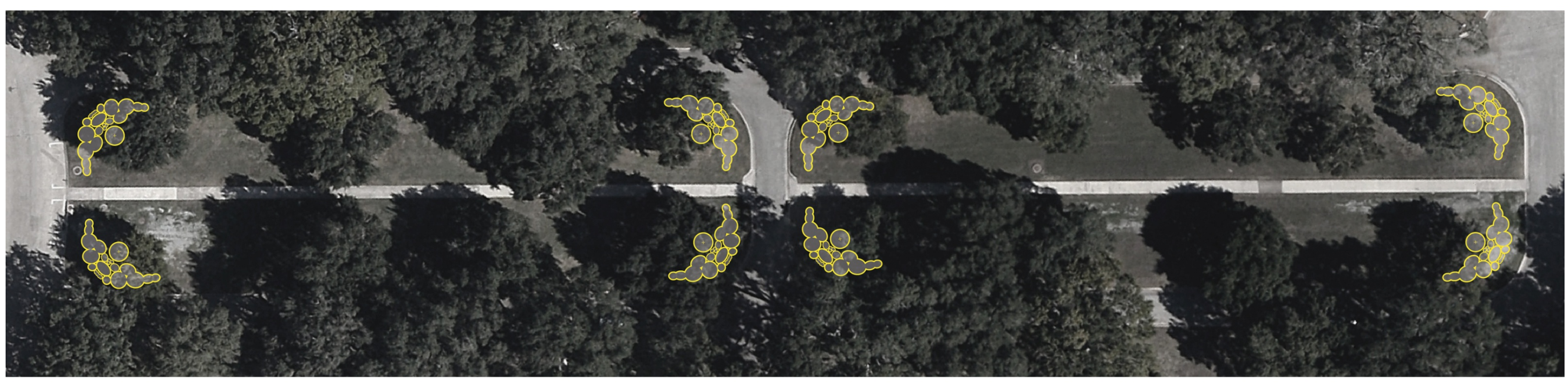

South Park median planting diagram 


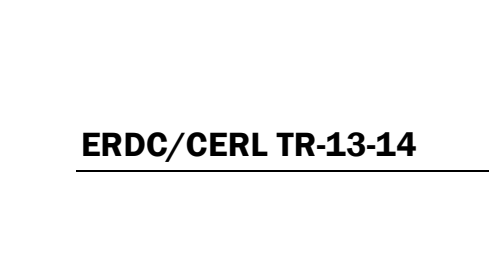




\subsubsection{Entrance Boulevard and Washington Circle}

- Street trees should be maintained on either side of Harmon Drive as well as around Washington Circle. Holes in the current tree spacing should be filled with an in-kind tree species.

- The interior of Washington Circle has several unique landscape features. The Randolph Field lettering north of the administration building should be maintained and preserved.

- The areas to the east and west of the Randolph Field lettering contain significant monuments. The areas around the monuments should be landscaped so that the spaces provide an aesthetically pleasant experience for visitors while also blending with the surrounding landscape design. Vegetation in these areas can be more ornamental, but select plants that are perennials, drought tolerant, and preferably species native to the region.

- The star made of hedges in the inner circle should be well clipped and maintained.

- The remaining open spaces created by Washington Circle should remain open and planted with grass. Select a variety of grass that can withstand drought conditions and that requires minimal maintenance.

The diagram in Figure 208 illustrates a historically-based planting strategy for the Washington Circle area. 


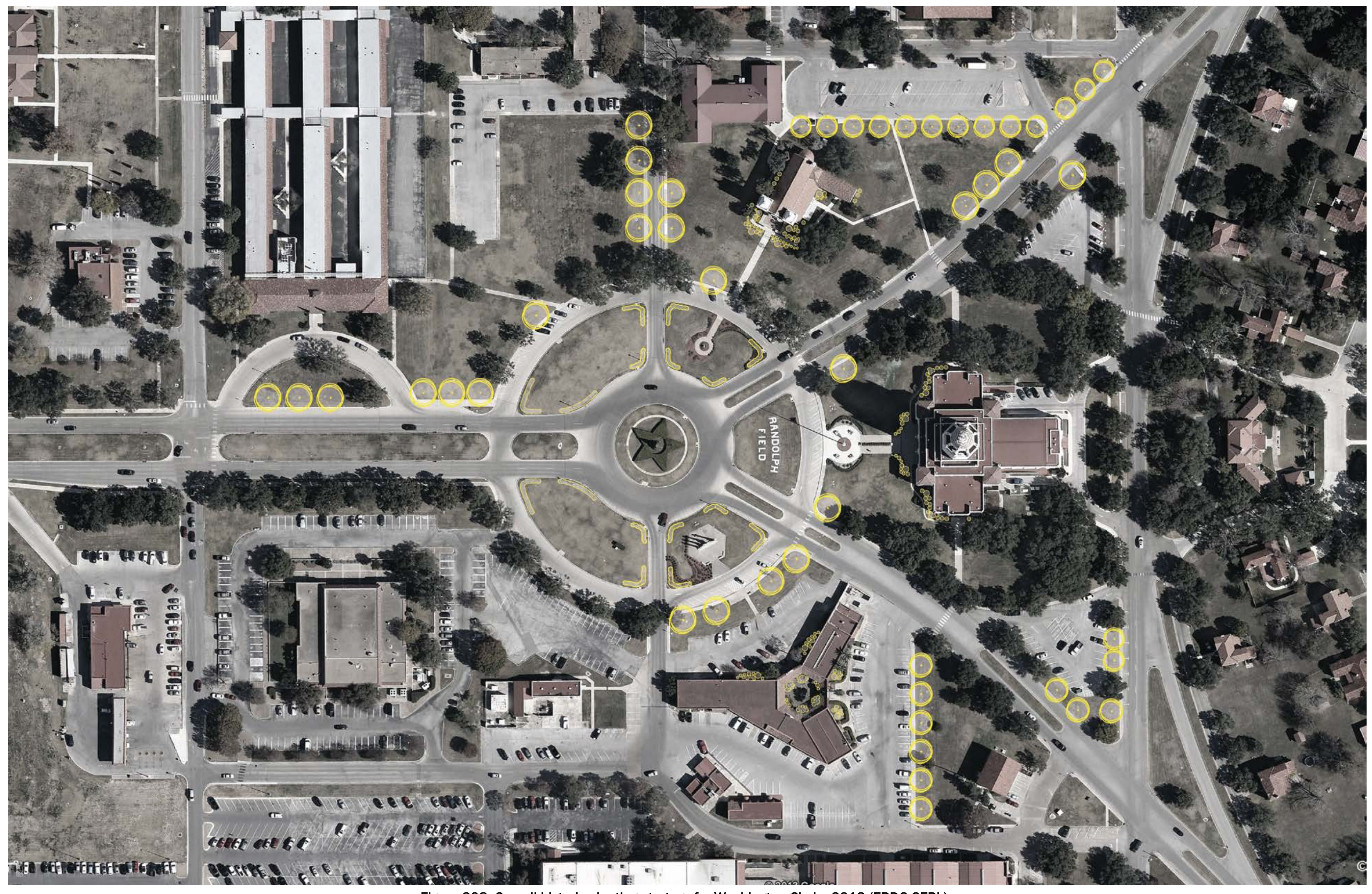




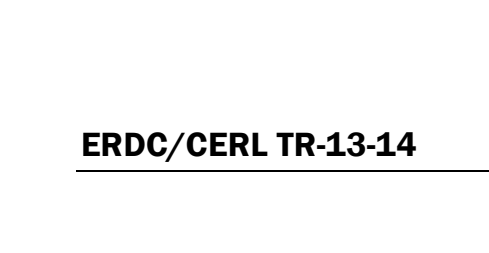




\subsubsection{Administration building}

- Street trees should line the triangular area surrounding the administration building except for the portion along Washington Circle. A clear line of sight should be maintained from the entrance gate to the Administration Building.

- The landscaping on the north side of the administration building should reflect the importance of the building's function and should be based on the planting designs of Lt. Bone. Plants selected for this design should be drought tolerant and preferably native to the region.

- The landscaping around the east, west, and south sides of the building should be less elaborate than the Washington Circle side, but should still reflect the importance of the building. On these three sides, vegetation should be used to screen transformers and other infrastructure that distracts from the building's aesthetic.

Figure 209 provides an example plan of how the administration building's landscape could be modified to more accurately represent the historic planting design for the building. Figure 210 illustrates the elevation view of the example planting plan. 
(This page intentionally left blank.) 
(1) Juniperus virginiana 'Taylor

[grouped]

Juniperus horizontal

Trailing juniper

Asclepias tuberosa
Mexican Butterfly wee

Poliomentha longifilora

(3) Ilex vomitoria 'Nana'

(4) [rows]

Ilex vomitoria 'Nana'
Dwarf yaupon holly

Sophora secundiffora

Sophora secundiflora
Texas Mountain Laure

[grouped around corner]

Nandina domestica

warf Nanidina

haphiolepis umbellata 'Mino'

Azzlea indica
Indian Azalea

Trachelospermum asiaticum

Asiatic Jasmine

[in a row]

Ilex vomitoria 'Nana'
Dwarf yaupon holly

(7) Juniperus virginiana 'Taylor'
Taylor Juniper

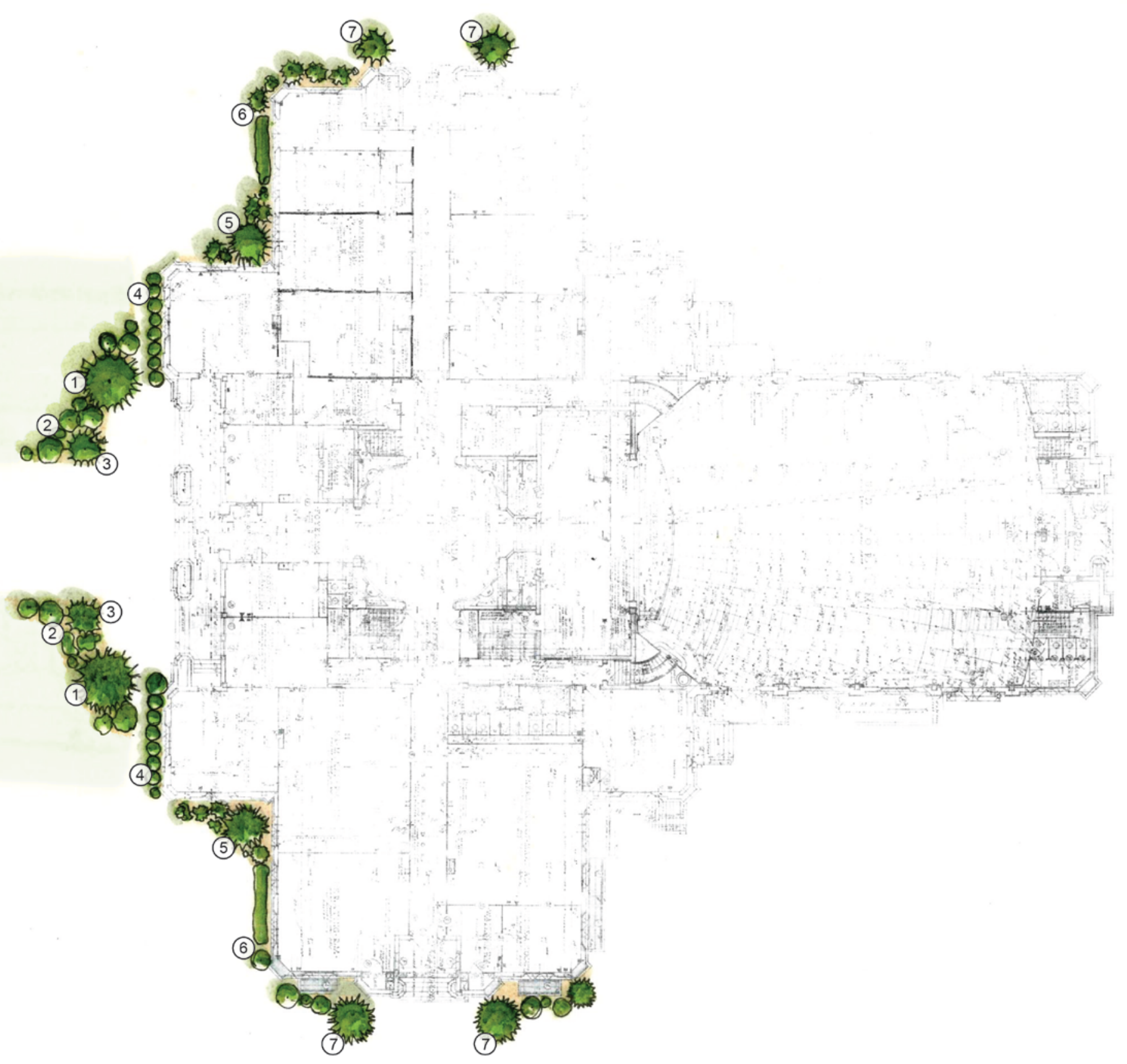


IL 


\subsubsection{Chapel}

- Street trees should line the area surrounding the Chapel building, including the portion along Washington Circle.

- The main façade of the Chapel should be planted to reflect the ornamentation of the entrance. Planting plans for the Chapel should be based on the original landscape design for the area which included evergreens accenting the building's corners. However, the vegetation should not dominate the entrance and should be planted far enough from the building so that at full size it will not damage the exterior.

- Consider screening Building 103 and the parking lot behind the Chapel from view with a row of medium-sized deciduous trees.

- Consider lining the sidewalk south of the Chapel with small shade trees such as the Blanco crabapple (Malus angustifolia)61, Possumhaw Holly (Ilex decidua) ${ }^{62}$, or the Texas Ebony (Pithecellobium flexicaule). 63

Figure 211 illustrates a possible planting design for the chapel that reflects the historic design for the building. Figure 212 is an elevation of the proposed planting plan.

\footnotetext{
$61 \mathrm{http}: / /$ texastreeplanting.tamu.edu/Display_Onetree.aspx?tid=50

$62 \mathrm{http}: / /$ texastreeplanting.tamu.edu/Display_Onetree.aspx?tid=36

$63 \mathrm{http}: / /$ texastreeplanting.tamu.edu/Display_Onetree.aspx?tid=65
} 
(This page intentionally left blank.) 
(1) Juniperus virginiana 'Taylor' Taylor Juniper

2) Rhaphiolepis umbellata 'Minor' Dwarf Yeddo Hawthorn

(3) [rows]

Ilex vomitoria 'Nana' (4) Sophora secundiflora
Texas Mountain Laurel

(5) [grouped] Mexican Oregano

Azalea indica
Indian Azalea

Trachelospermum asiaticum

Asiatic Jasmine

Juniperus horizontalis Trailing juniper

(6) Garrya ovata

(7) Ungnadia speciosa Mexican Buckeye

(8) [grouped] Azalea indica
Indian Azalea Trachelospermum asiaticum Asiatic Jasmine siaticum Santolina $\mathrm{sp}$. Santolina

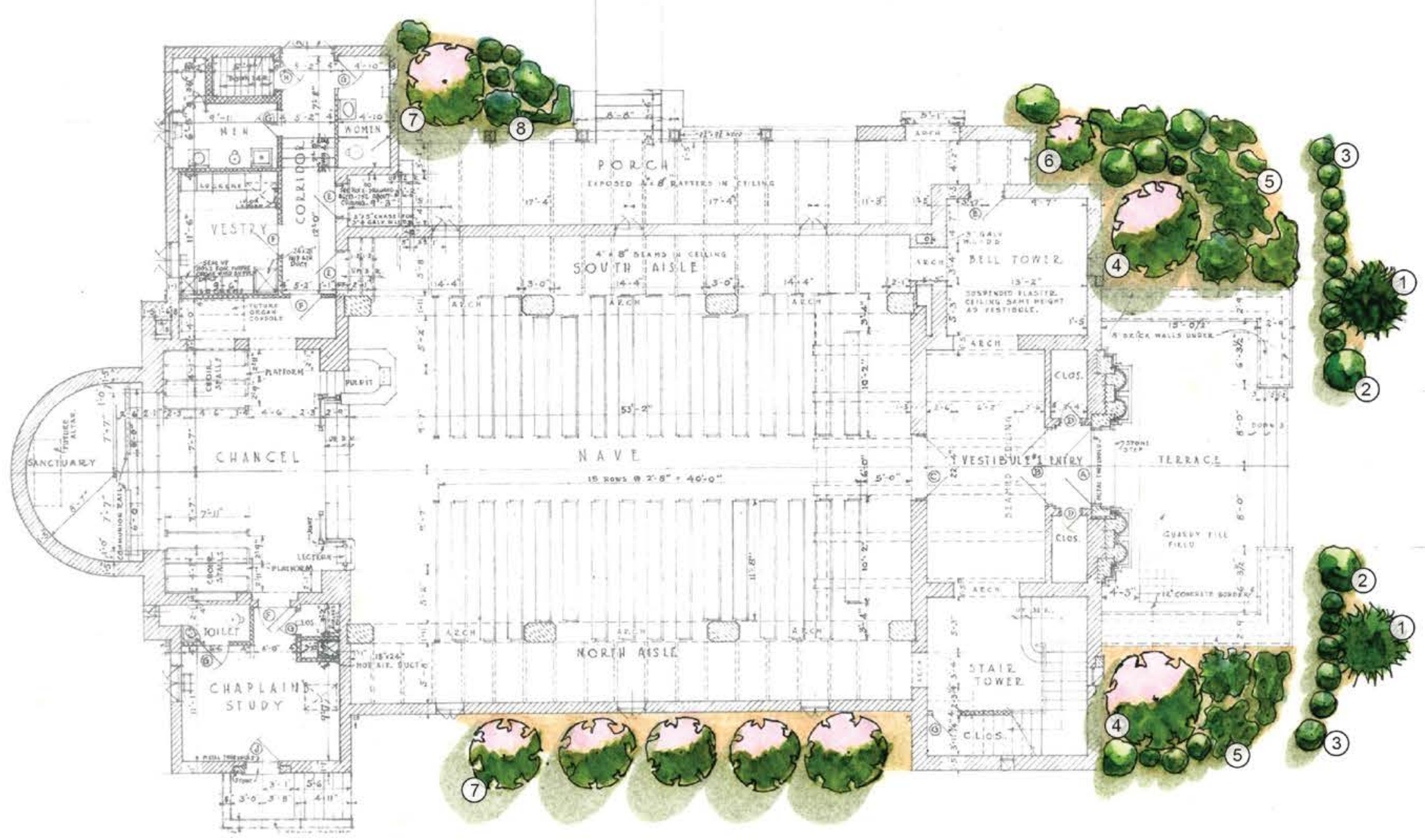

Figure 211. Proposed planting plan for the chapel, 2013 (ERDC-CERL). 
Enooceren Tre 13.19 


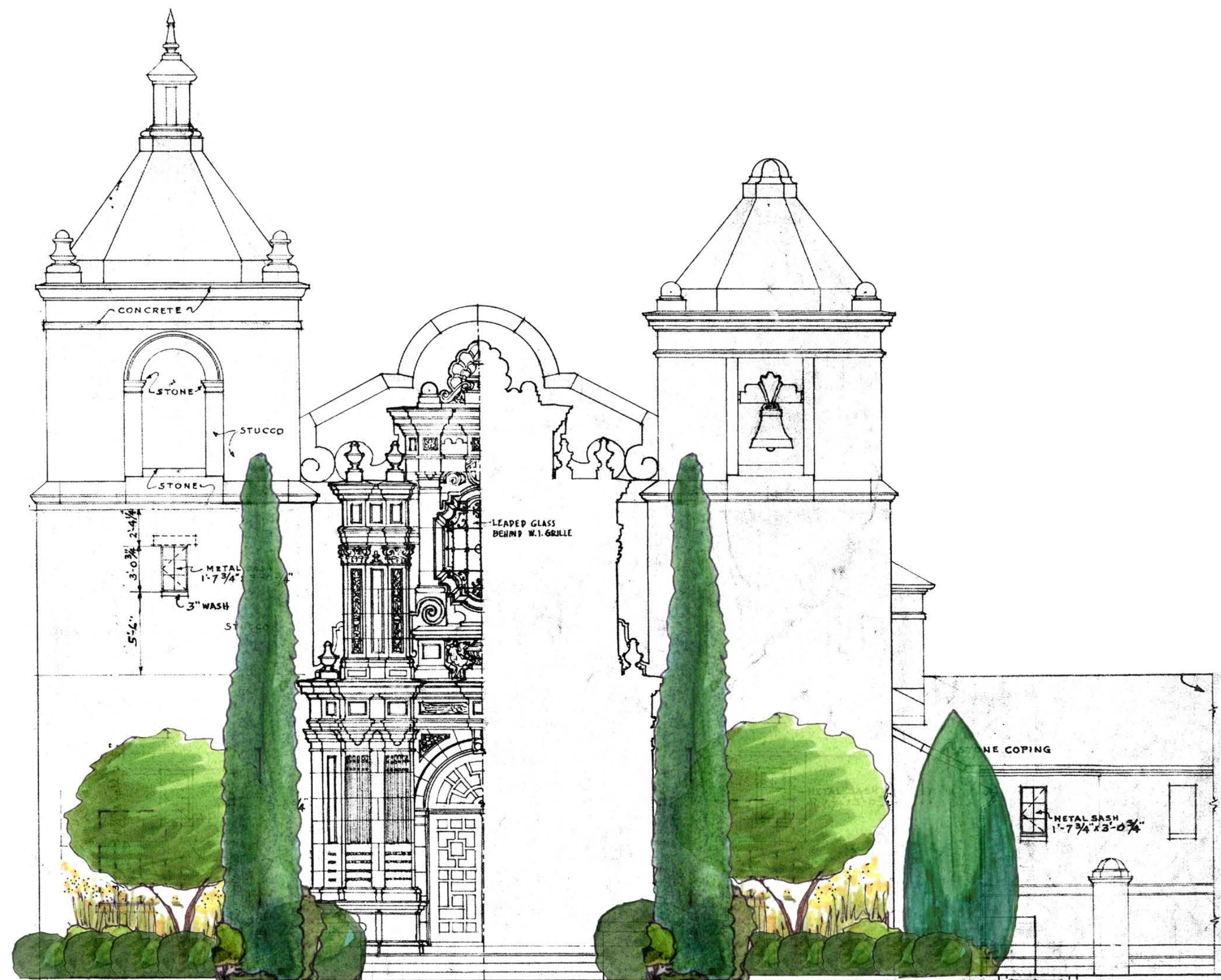

Figure 212. Proposed elevation planting for the chapel, 2013 (ERDC-CERL). 
ERPOC/ERR TR:1.3.14 


\subsubsection{Former Post Exchange}

- Street trees should line the major streets surrounding the former PX area. In this area in particular, trees should continue to line Washington Circle.

- The planting design for the former PX building should be compatible with the vegetation of the administration building and chapel. To have compatible landscaping does not mean that the PX building design has to feature as elaborate use of plants, but the vegetation used should feature a variety of species and be well maintained.

- The interior courtyard should be vegetated. According to the historic record, the courtyard featured lush plantings of palms and other ornamental plants. Develop a planting design for this area that uses low maintenance, drought tolerant, ornamental plants. 
(This page intentionally left blank.) 


\begin{tabular}{|c|c|}
\hline (1) & $\begin{array}{l}\text { Ungnadia speciosa } \\
\text { Mexican Buckeye }\end{array}$ \\
\hline \multirow[t]{4}{*}{ (2) } & [grouped] \\
\hline & $\begin{array}{l}\text { American Beautyberry } \\
\text { American ama }\end{array}$ \\
\hline & $\begin{array}{l}\text { Asclepias tuberosa } \\
\text { Mexican Butterfly Weed }\end{array}$ \\
\hline & $\begin{array}{l}\text { Poliomentha Iongiffora } \\
\text { Mexican Oregano }\end{array}$ \\
\hline \multirow{3}{*}{ (3) } & [grouped] \\
\hline & $\begin{array}{l}\text { Berberis thunbergii } \\
\text { Barberry }\end{array}$ \\
\hline & $\begin{array}{l}\text { Poliomentha Iongiflora } \\
\text { Mexican Oregano }\end{array}$ \\
\hline (4) & $\begin{array}{l}\text { Viburnum rufidulum } \\
\text { Rusty Blackhaw }\end{array}$ \\
\hline (5) & $\begin{array}{l}\text { Callicarpa americana } \\
\text { American Beautyberry }\end{array}$ \\
\hline (6) & Retain existing hedges \\
\hline (7) & [grouped] \\
\hline & $\begin{array}{l}\text { Asclepiass tuberosa } \\
\text { Mexican Butterfly Weed }\end{array}$ \\
\hline & Pavonia lasiopetala \\
\hline & Rock rose \\
\hline & $\begin{array}{l}\text { Malpighia glabra } \\
\text { Barbados Cherry }\end{array}$ \\
\hline (8) & $\begin{array}{l}\text { Garrya ovata } \\
\text { Silk-tassle }\end{array}$ \\
\hline (9) & Ilex decidua \\
\hline
\end{tabular}

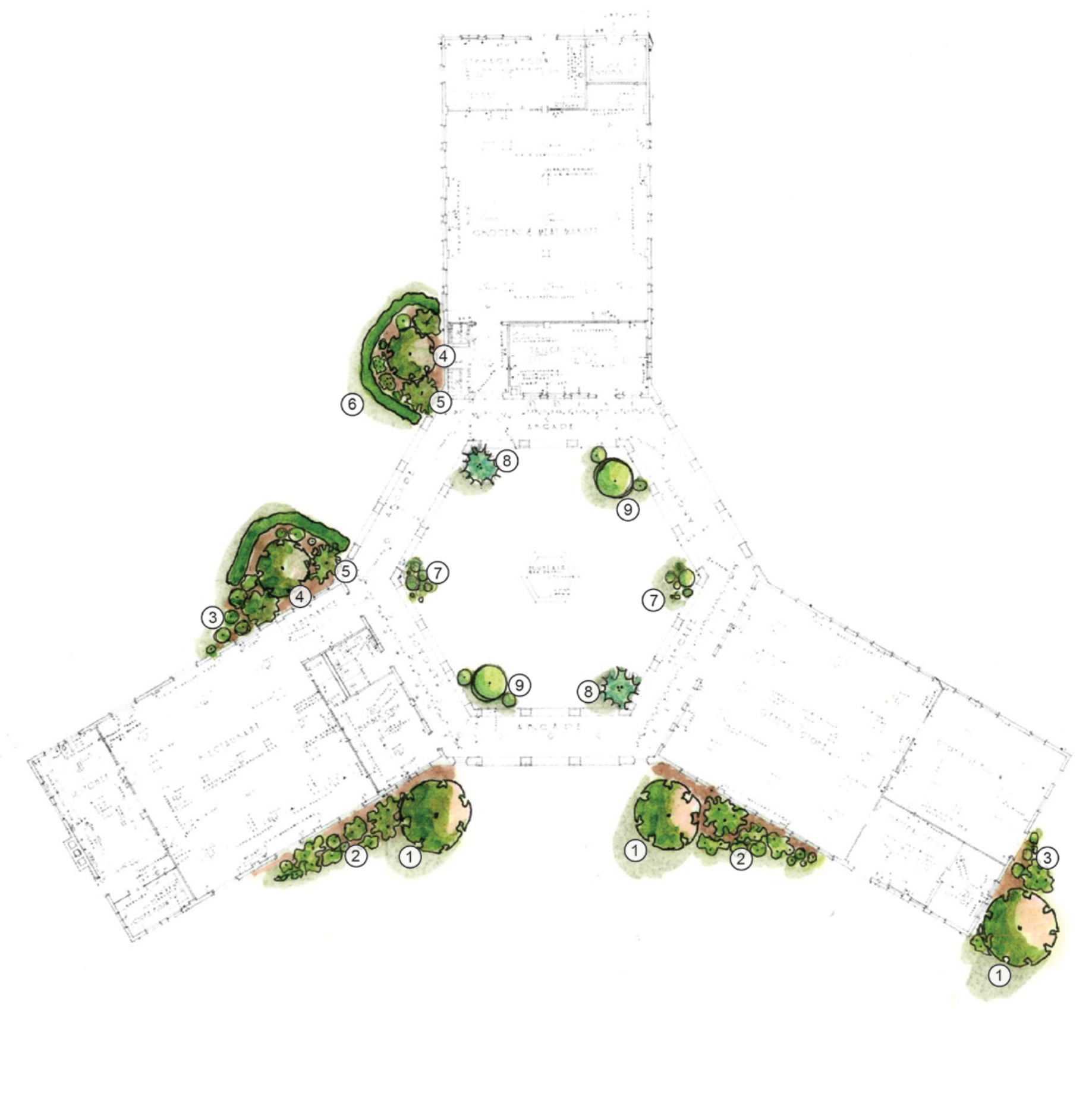

Figure 213. Proposed planting plan for the former PX, 2013 (ERDC-CERL). 
Enooceren Tre 13.19 


\subsubsection{Warehouse and shops area}

- Where possible, street trees should line the major streets in the warehouse and shops area.

- The warehouses and shop buildings were historically planted to accentuate the architectural details. To create this effect, evergreen trees were planted between doorways and at building corners. Buildings should be, at minimum, simply planted in a scheme that reflects the historic plans for the area.

- The warehouse and shops area is still a utilitarian area with several large surface parking lots. To make these parking lots more accommodating during hot weather, consider developing a landscape plan that would introduce shade trees and other vegetation to these areas.

Figure 214 proposes a street tree planting strategy for the warehouse and shops area. 
(This page intentionally left blank.) 


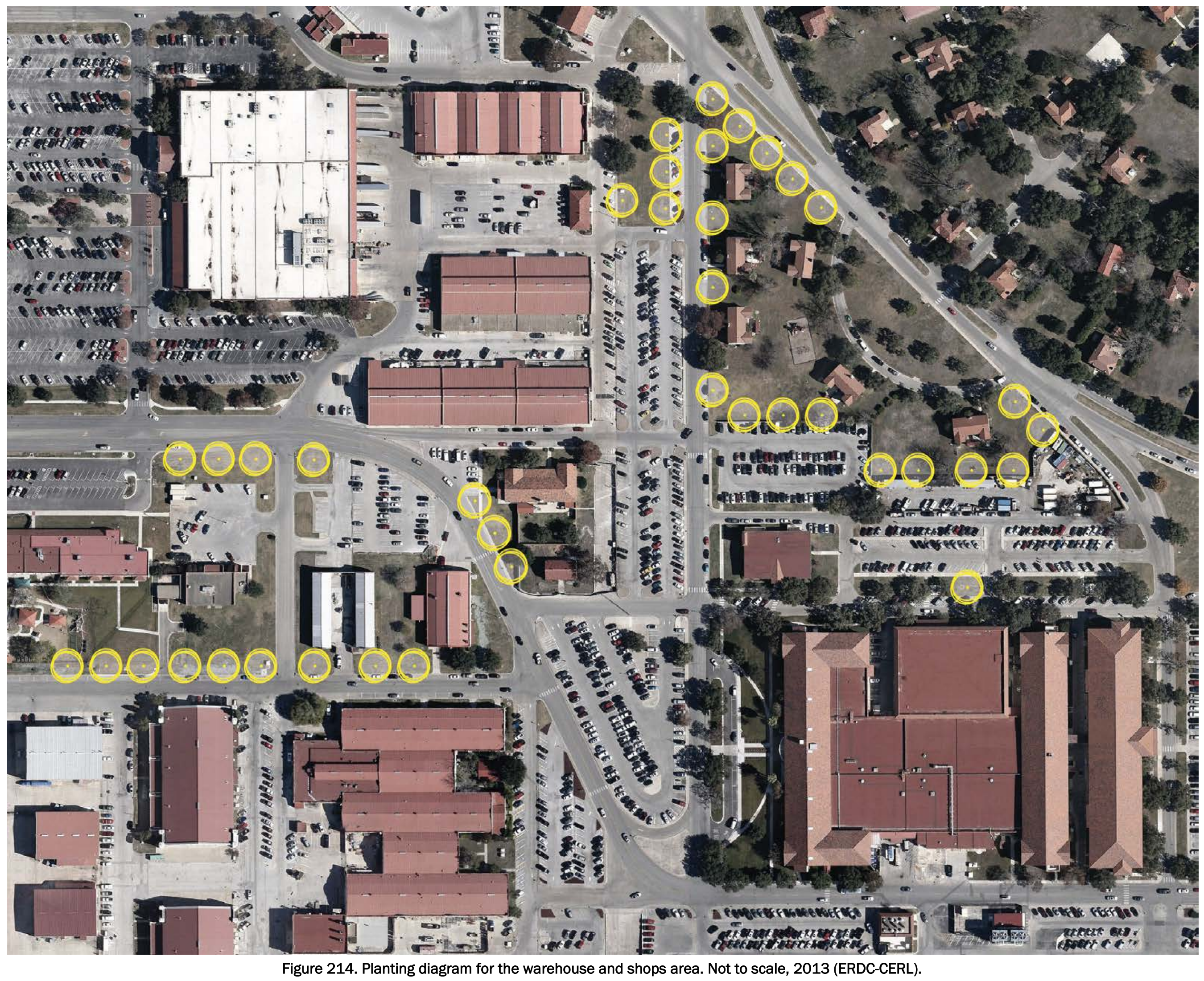




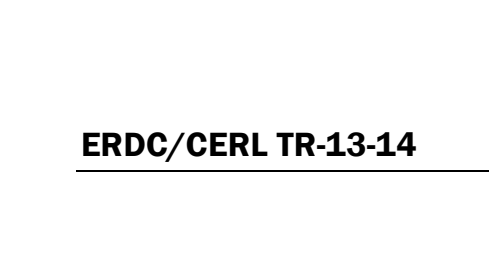




\subsubsection{Flight lines/hangars}

- Where possible, street trees should line the major streets on the cantonment sides of the flight lines.

- Historically, there was minimal vegetation around the hangars and the buildings should remain that way.

- The existing vegetation around the stage houses should remain, but the buildings should features unified foundation planting designs, and the grass in these areas should be well tended.

- Surface parking lots are located on the cantonment side of each of the hangars. Consider developing a vegetation strategy that would make parking in these areas more accommodating during hot weather.

Because historically the flight lines and hangars had minimal vegetation, this report does not include planting proposals for these areas. Although Fifth Street East and Fifth Street West did have trees planted along their cantonment sides. 


\subsubsection{Residential areas}

The residential areas provide an opportunity for more ornamental planting plans to be incorporated into the landscape of Randolph AFB. The following recommendations provide general guidance for leasing agencies and residents to develop historically compatible landscaping plans for the officers' and NCO quarters.

\subsubsection{Officers' Quarters}

- The officers' housing area layout is a distinct element of Randolph AFB. Therefore, the spatial characteristics of the area should be maintained to include the network of streets and open spaces, the architectural style of the buildings, street tree density, and vegetation patterns.

- The Randolph officers' housing is prominently located. Functional spaces such as backyards, patios, and clotheslines should be screened with vegetation.

- A consistent palette of plant material, mulch, and edgings should be used. The housing partner should make sure individual residential plantings are consistent with the overall character of the neighborhood. In general, the plantings should be of similar size, massing, ornamentation, and form.

- It is ideal to have a mix of deciduous and evergreen plants. Select plants that have different flowering times, plants that provide winter interest, and a variety of textures and habit forms.

- Vegetation should be selected that requires minimal maintenance. When possible, choose varieties native to the region. Vegetative and nonvegetated ground covers should be used to control weeds under larger plants.

- Plants should be planted far enough from the building to ensure their mature size will not damage the façade or foundation. The mature size of a plant should also be considered in regard to the scale of the house; larger houses can accept larger plants, while smaller houses are overwhelmed by out-of-scale vegetation. 
Figure 215 and Figure 216 show a plan and elevation example for landscaping the single story ranch style officers' quarters. Figure 217and Figure 218 illustrates a possible planting plan for the two story types of officers' quarters. 
(This page intentionally left blank.) 


(1) Sophora secundiffora
Texas mountain laurel
(2) Cercis canadensis var texensis
Texas redbud
(3) Ilex vomitoria 'Nana'
Dwarf yaupon holly
(4) Santolina sp.
Santolina
(5) Salvia mexicana
Mexican sage
(6) L Lantana urticoides
Texas lantana

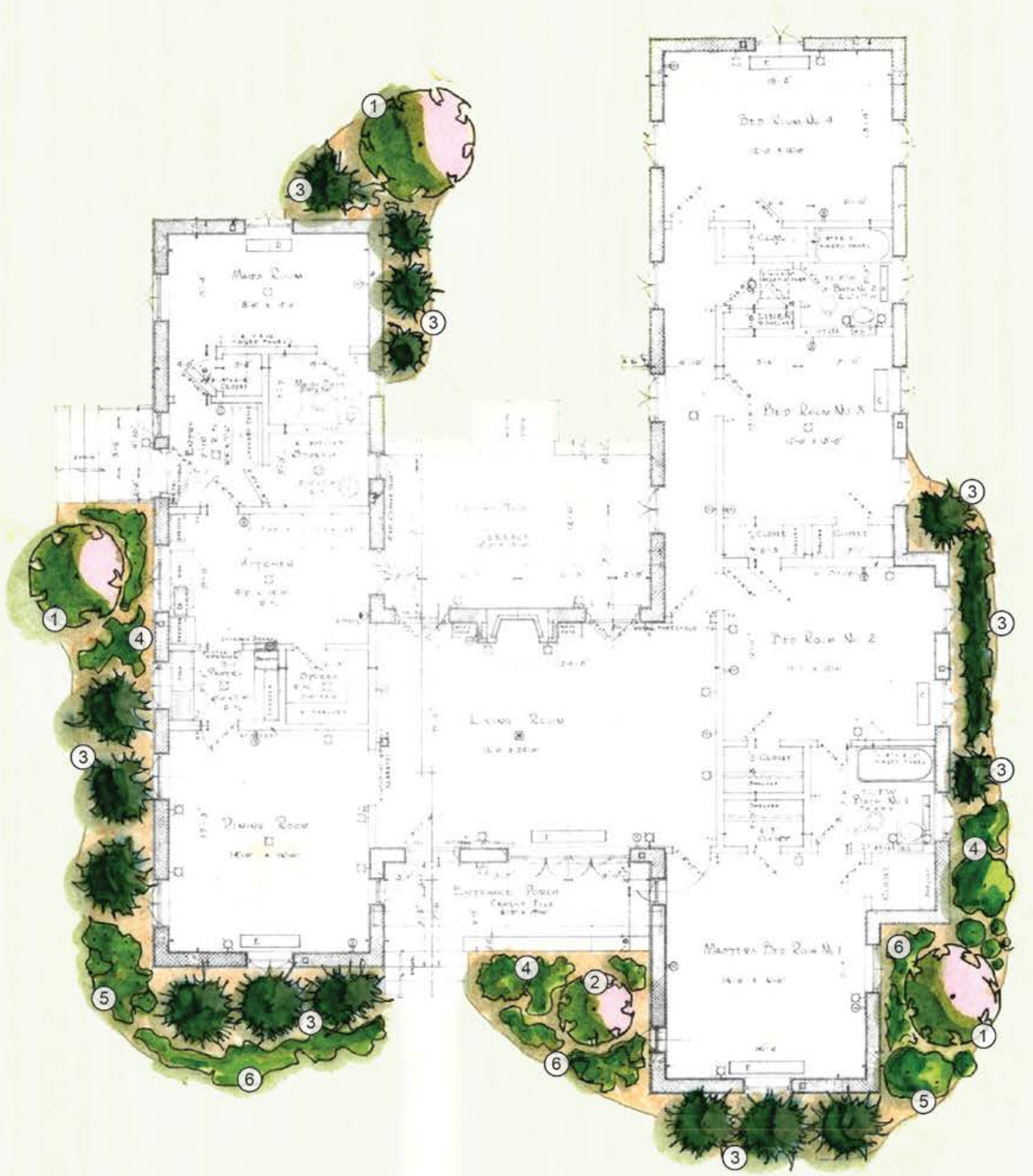

Figure 215. One-story ranch style officers' quarters, proposed planting plan, 2013 (ERDC-CERL). 
ERoc/,eren Tr.13.14 


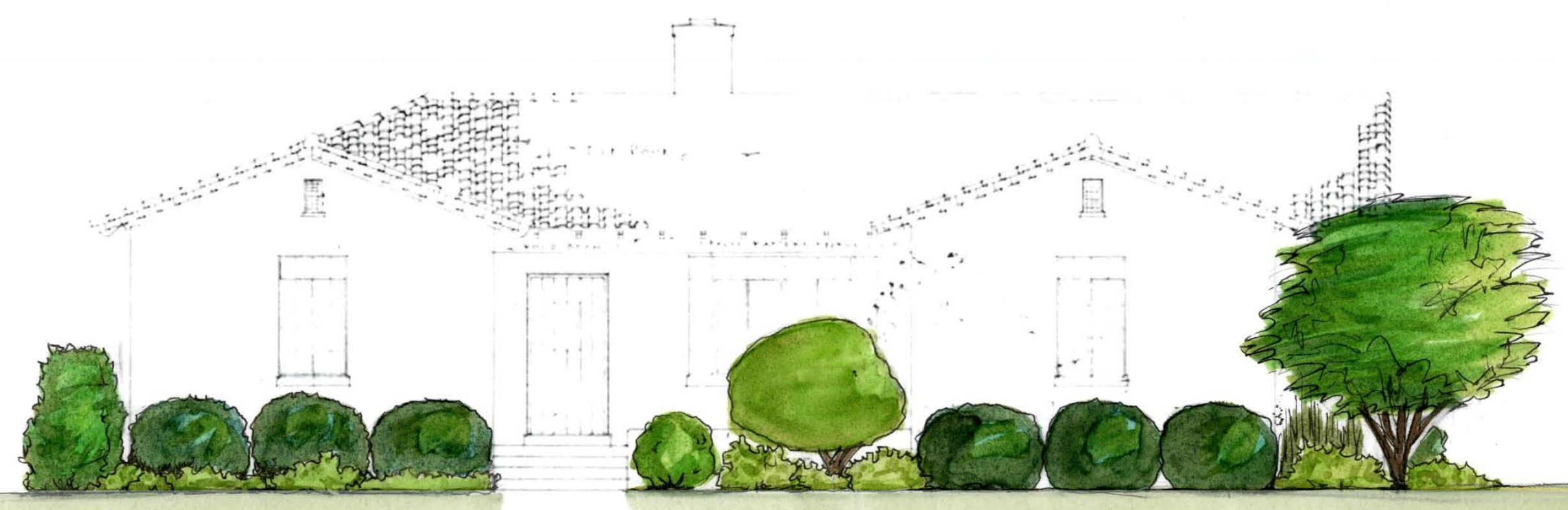

Figure 216. One-story ranch style officers' quarters, elevation planting plan, 2013 (ERDC-CERL). 
ERoc/,eren Tr.13.14 


(1) Cercis canadensis var texensis
Texas redbud
(2) Juniperus virginiana 'Taylor'
Taylor Juniper
(3) Rosmarinus officinalis
Upright rosemary
(4) Juniperus horizontalis
Trailing juniper
(5) Santolina sp.
(6) Myntolina
Dwrica pusilla Raf.
(7) Aloysia gratissima
Whitebrush
(8) Lantana urticicides
Texas lantana
(9) Ias hedges
Ilex vomitoria 'Nana'
Dwarf yaupon holly
(10) Poliomentha longiflora
Mexican Oregano

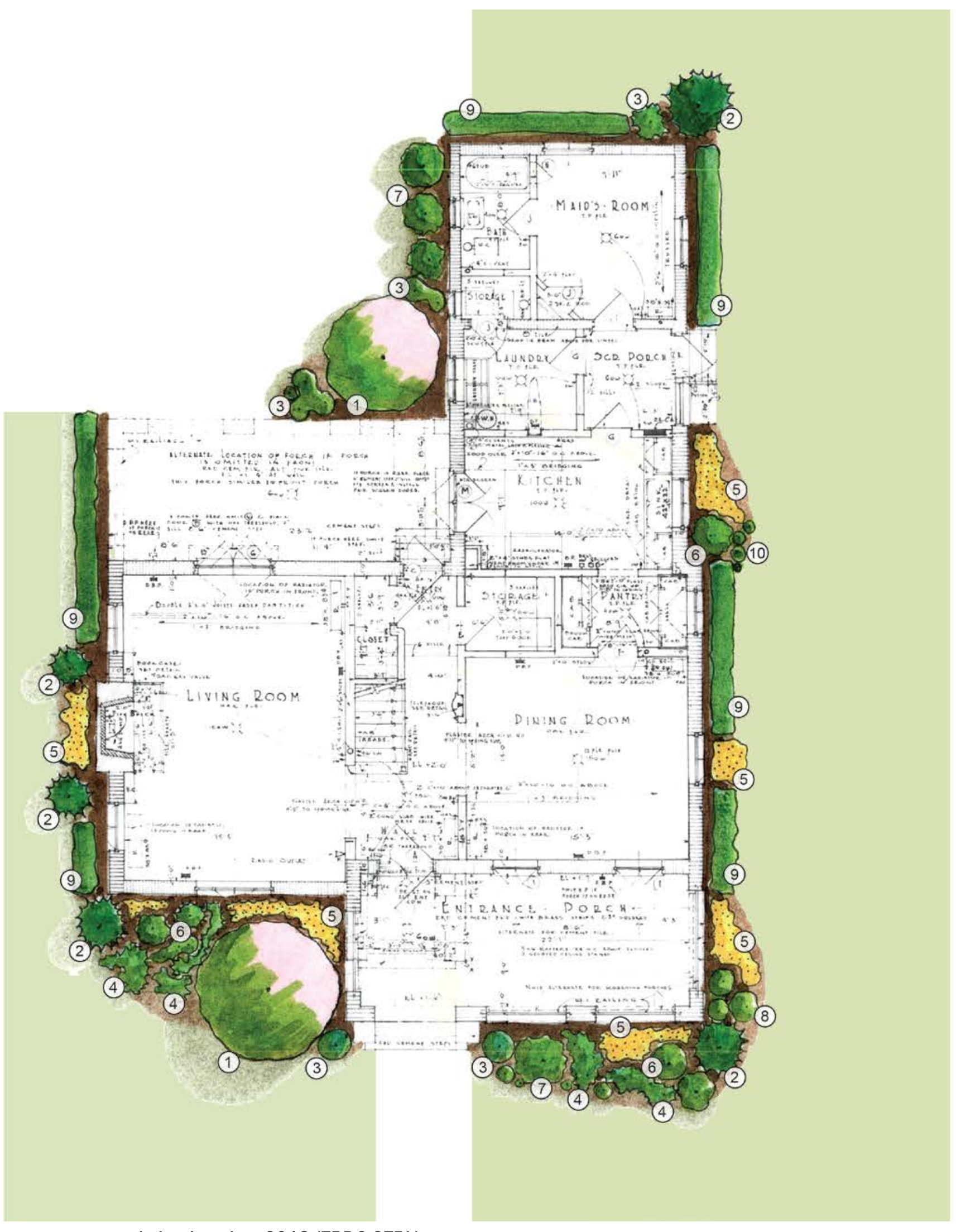

Figure 217. Two-story officers' quarters, proposed planting plan, 2013 (ERDC-CERL). 
ERoc/,eren Tr.13.14 


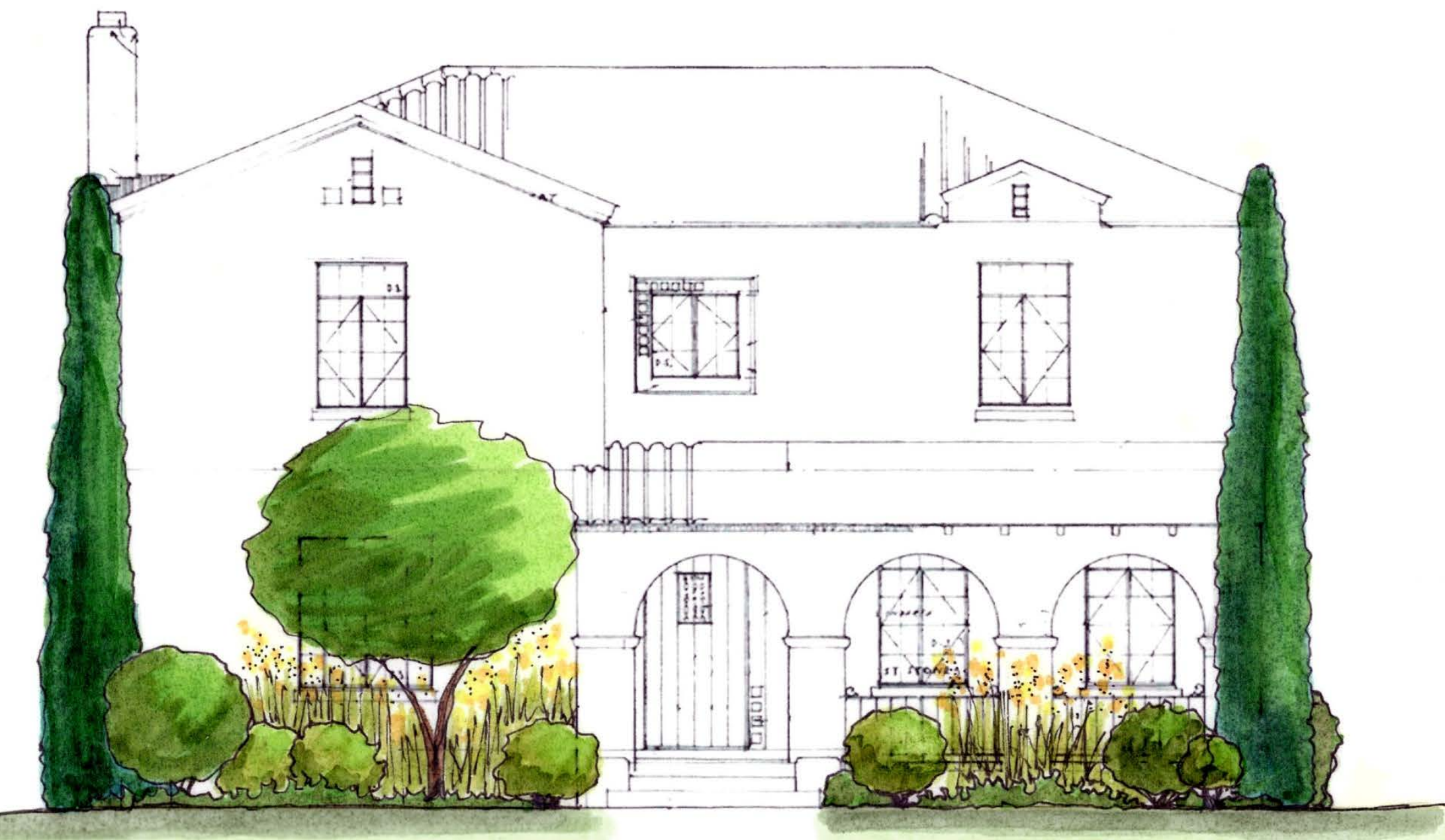

Figure 218. Two-story officers' quarters, elevation planting plan, 2013 (ERDC-CERL). 
ERPOC/ERR TR:1.3.14 


\subsubsection{NCO Quarters}

- The organization of the NCO housing areas should be maintained, including the hierarchy of streets and the housing organization.

- Plant trees along all the streets.

- Appropriate shade trees could be added around play areas.

- Functional spaces, like the alleys, parking spaces, and backyards should be screened with vegetation.

- Plants should be planted far enough from the building to ensure their mature size will not damage the façade or foundation. The mature size of a plant should also be considered in regard to the scale of the house; larger houses can accept larger plants, while smaller houses are overwhelmed by out-of-scale vegetation.

- Because the NCO quarters are duplexes, the landscaping should be consistent across both sides of the building.

- Vegetation should be selected that requires minimal maintenance. When possible, choose varieties native to the region. Vegetated and nonvegetated ground covers should be used to control weeds under larger plants.

Figure 219 and Figure 220 propose a potential planting plan for the NCO duplexes. 
(This page intentionally left blank.) 
(1) Sophora secundiffora

Texas mountain laurel

Bernardia myricifolia

Myrtle croton (Oreja de raton)

(3) Aloysia gratissima Whitebrush

Poliomentha Iongiflora

Mexican Oregano

(5) Rhus aromatica

Aquilegia spp. A. hinckleyana

Hinckley's golden columbine

(7) Rosmarinus officinalis Upright rosemary

(8) Pavonia lasiopetala

Rock rose

(9) Salvia mexican Mexican sage

(D) Rivina humilis

(11) Lantana urticoides Texas lantana

(12) Cercis canadensis var texensis Texas redbud

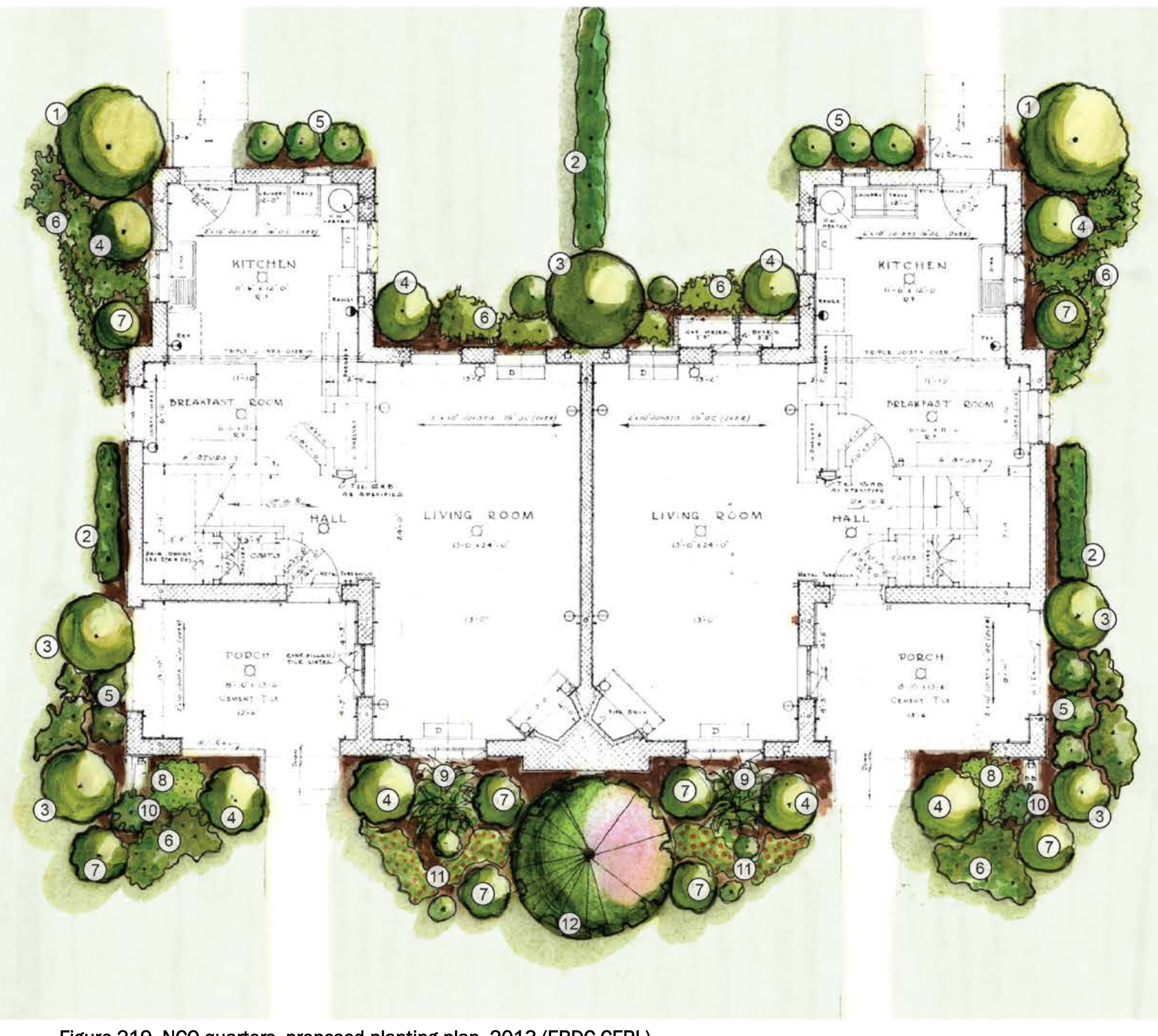

Figure 219. NCO quarters, proposed planting plan, 2013 (ERDC-CERL). 
ERoc/,eren Tr.13.14 


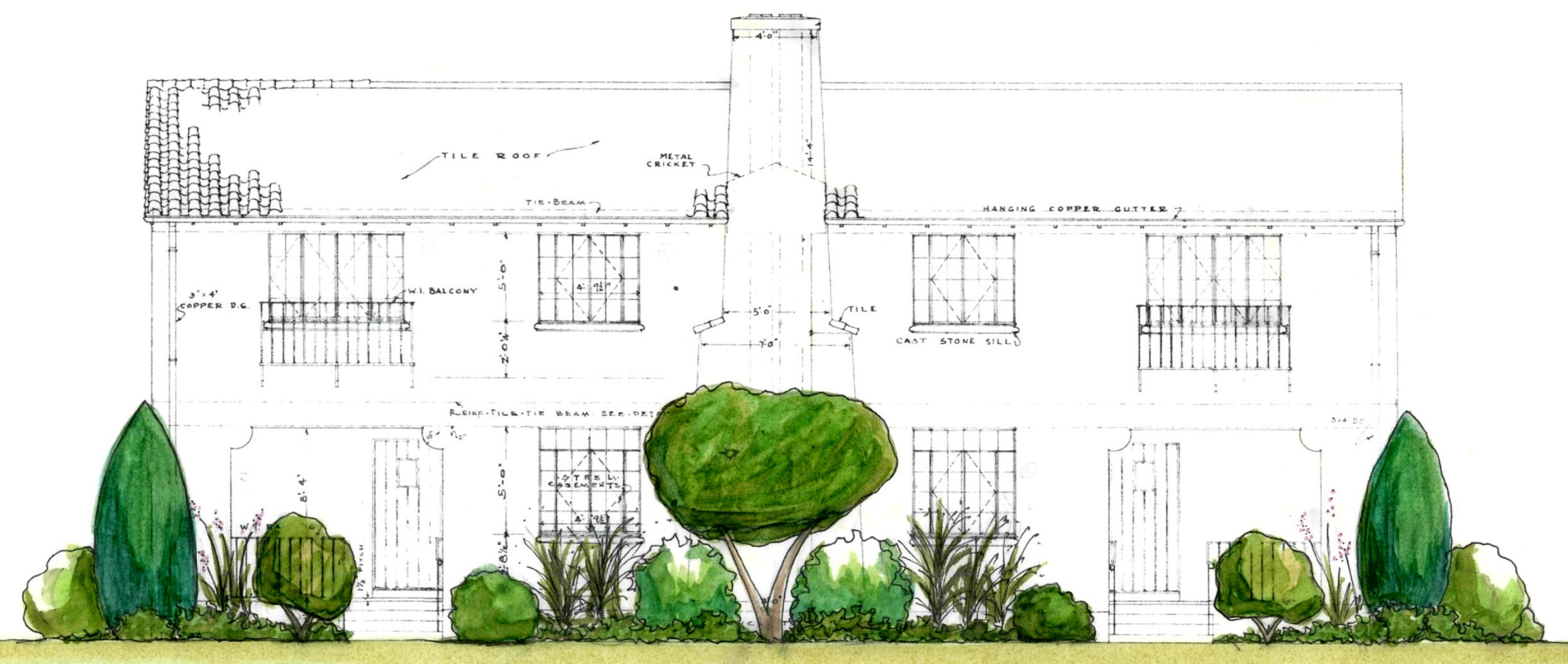

Figure 220. NCO quarters, elevation planting plan, 2013 (ERDC-CERL). 
ERPOC/ERR TR:1.3.14 


\subsubsection{Bachelor Officers' Quarters}

- Planting patterns should extend around the BOQ complex buildings and incorporate any additional entrances and views to the buildings.

- Historically, evergreens were most often used in foundation plantings at Randolph AFB. However, it is ideal to have a mix of deciduous and evergreen plants. Consider planting a mix of flowering trees (with visible branching structure) and an evergreen groundcover bed (not to exceed a height of 12 in.). In addition, highly columnar evergreens can be used to mark entrances and create form. The use of flowering plants near building entrances can give needed interest. When possible, select native plants that correspond to the form, texture, and showiness of the originallyspecified plants.

- Using mature spread as an indicator for spacing, plant trees and shrubs several feet from the building to prevent damage to the foundation and façade.

- Grouping plants is more effective at creating visual and spatial interest than a sporadically planted row. Historically, groupings of plants were used at the corners of buildings, adjacent to doorways, and to soften large areas of buildings that lacked architectural features. These historic characteristics should be retained.

- The buildings that comprise the BOQ area should spatially relate to one another. Continuity should be preserved between the buildings. 


\subsubsection{Cadet Complex}

- Planting patterns should extend around the Cadet Complex buildings and incorporate any additional entrances and views to the buildings.

- Historically, evergreens were most often used in foundation plantings at Randolph AFB. However, it is ideal to have a mix of deciduous and evergreen plants. Consider planting a mix of flowering trees (with visible branching structure) and an evergreen groundcover bed (not to exceed a height of $12 \mathrm{in}$.). In addition, highly columnar evergreens can be used to mark entrances and create form. The use of flowering plants near building entrances can give needed interest. When possible, select native plants that correspond to the form, texture, and showiness of the originally-specified plants.

- The large, circular courtyard that lies at the center of the Cadet Complex buildings is currently planted with annuals. These plants are expensive to replace and water each year. Consider using colorful perennials, such as columbine, lantana, verbena, and ornamental grasses to bring character to the area. These perennials are less costly to maintain and require less water.

- Using mature spread as an indicator for spacing, plant trees and shrubs several feet from the building to prevent damage to the foundation and façade.

- Grouping plants is more effective at creating visual and spatial interest than a sporadically planted row. Historically, groupings of plants were used at the corners of buildings, adjacent to doorways, and to soften large areas of buildings that lacked architectural features. These historic characteristics should be retained.

The buildings that comprise the Cadet Complex area should spatially relate to one another. Continuity should be preserved between the buildings. 


\subsubsection{Views and viewsheds}

- The views, viewsheds, and view corridors listed in this report should be maintained to convey their importance. Doing this means maintaining clear lines of sight between important features.

- Viewsheds should remain unobstructed. For example, the viewsheds of the Taj Mahal from multiple points around the base should not be compromised by the addition of tall buildings that would distract from the visual dominance created by the height of the Administration Building.

- Views can be emphasized through strategic tree planting strategies that will spatially define the view corridor. 
(This page intentionally left blank.) 


\section{Conclusion}

Randolph AFB is well maintained, and its historic developments are clearly seen in the physical landscape of the base. Although the historic district has undergone change, the overall quality and characteristics of the area have remained consistent as the base has grown. Randolph AFB is a good example of the military's execution of City Beautiful planning principles.

This report documents the historic landscapes of Randolph AFB and evaluates them for their military significance and historic integrity. This report identifies several landscapes that are significant to military history, the history of Randolph AFB, and the history of urban planning in the United States. The identified landscapes include the administration area; the warehouse and shop area; the base support areas such as the Chapel, hospital, former Post School, and former Post Exchange; the residential areas of the officers' housing, NCO quarters, and former barracks; the former Cadet Complex; and the flight lines. In addition, recommendations have been made to help preserve the historic characteristics of the base as well as to allow Randolph AFB to meet mission requirements and continue to grow. Planting plans are included for several of the prominent support buildings and the residential building types and styles. A plant list has been generated based on the historic planting lists created by Lt. Bone from the 1930s, and it incorporates currently acknowledged pest-free, disease-free, and sustainable plant material (See Appendix A). 
(This page intentionally left blank.) 


\section{Bibliography}

Arnold, Lt. Gen. Henry H., and Brig. Gen. I. C. Eaker. This Flying Game. New York: Funk and Wagnall, 1942.

Birnbaum, Charles A. National Park Service Preservation Brief \#36; "Protecting Cultural Landscapes Planning, Treatment and Management of Historic Landscapes.” Washington, DC: National Park Service, 1994.

Cannan, Deborah, Leo Hirrel, Katherine E. Grandine, Kathryn M. Kuranda, Bethany M. Usher, Hugh B. McAloon, and Martha R. Williams. National Historic Context for Department of Defense Installations, 1790-1940, Vol 1. Frederick, MD: R. Christopher Goodwin and Associates, prepared for U.S. Army Corps of Engineers, Baltimore District, 1995.

Clow, Victoria G., Peter E. Duane, and Lila Knight. The Architecture of Randolph Field, 1928-1931. Plano, TX: Geo-Marine, Inc., 1998.

Cook, J ody. National Historic Landmark Nomination, "Randolph Field Historic District," J ohn H. Sprinkle, ed. Atlanta, GA: National Park Service Southeast Regional Office, August 2001. Accessed online: http://pdfhost.focus.nps.gov/docs/NHLS/Text/96000753.pdf

Gallagher, Casey. Randolph Air Force Base: Preserving the "Showplace of the Air Force." University of Texas: Preservation Planning and Practice, Spring 2008 in The Architecture of Randolph Field, 19281931.

Griffith, Glenn, Sandy Bryce, J ames Omernik, and Anne Rogers. Ecoregions of Texas. Texas Commission on Environmental Quality, December 27, 2007. Accessed online: $\mathrm{ftp}$ ://ftp.epa.gov/wed/ecoregions/tx/TXeco_Jan08_v8_Cmprsd.pdf.

Keller, J . Timothy, and Genevieve P. Keller. National Register Bulletin \#18, How To Evaluate and Nominate Designed Historic Land- 
scapes, Washington, DC: U.S. Department of the Interior, National Park Service, Undated.

Suzanne Keith Loechl, Samuel A. Batzli, and Susan I. Enscore. Guidelines for Documenting and Evaluating Historic Military Landscapes: An Integrated Landscape Approach. Army Environ-mental Command (AEC) Technical Guideline. Champaign, IL: US Army Construction Engineering Research Laboratory, 2009. Accessed online: http://aec.army.mil/Portals/3/preserve/milland.pdf.

NPS (National Park Service). "Aviation: From Sand Dunes to Sonic Booms." Randolph Field Historic District. Accessed online 4 April 2012. http://www.nps.gov/nr/travel/aviation/ran.htm.

. Guide to Cultural Landscape Reports: Contents, Process, and Techniques. Credited authors: Robert R. Page, Cathy Al. Gilbert, Susan A. Dolan. Washington, DC: US Department of the Interior, 1998.

. National Register Bulletin \#15, How To Apply the National Register Criteria for Evaluation, Washington, DC: U.S. Department of the Interior, National Park Service, 1991.

. National Register Bulletin \#16A: How to Complete the National Register Registration Form. Washington, DC: US Department of the Interior, National Park Service, 1997 (rev).

. National Register Bulletin \#18: How to Evaluate and Nominate Designed Historic Landscapes. Prepared by J . Timothy Keller and Genevieve P. Keller. Washington, DC: US Department of the Interior, National Park Service, n.d..

. National Register Bulletin \#30, Guidelines for Evaluating and Documenting Rural Historic Landscapes, Washington, DC: U.S. Department of the Interior, National Park Service, 1992a. . Preservation Brief \#36: Protecting Cultural Landscapes. Prepared by Charles A. Birnbaum. Washington, DC: US Department of the Interior, National Park Service, 2000. 
The Secretary of the Interior's Standards for the Treatment of Historic Properties. Washington, DC: U.S. Department of the Interior, National Park Service. 1992.

Norfleet Giddings Bone Papers, 1917-1980, MS 141, University of Texas at San Antonio Libraries Special Collections.

Sánchez, J oseph P.; Bruce A. Erickson; J oseph E. King; \& Robert L. Spude. The Cibolo Valley, Texas, 1690-1928: Randolph Air Force Base Pre-Base History Study of the Spanish, Mexican, and Texan Periods. Washington, DC: National Park Service, 1996.

Simonds, J ohn Ormsbee. Landscape Architecture: The Shaping of Man's Natural Environment. New York: MoGraw-Hill Book Company, Inc., 1961.

Texas State Historical Association, Randolph Air Force Base, accessed online at $\mathrm{http} / /$ www.tshaonline.org/handbook/online/articles/abro1

Writers' Program of the Work Projects Administration (WPA) in the State of Texas, Randolph Field A History and Guide, sponsored by the Commanding Officer of Randolph Field, New York: Devin-Adair Co, 1942. 
(This page intentionally left blank.) 


\section{Appendix A: Plant List}

Table 3 documents the current Randolph AFB plant list. Plants native to the United States and North America should be prioritized for planting. Resources that expand the current selection of plants for Randolph with native and regionally appropriate plants can be found through the Lady Bird J ohnson Wildflower Center Native Plant Database ${ }^{64}$ and the city of San Antonio's website. ${ }^{65}$

Table 3. Current Randolph AFB plant list, 2012.

\begin{tabular}{|c|c|c|}
\hline Scientific Name & Common Name & Native Status \\
\hline \multicolumn{3}{|l|}{ TURF } \\
\hline \multirow[t]{2}{*}{ Cynodon 'TIFF 419' } & 419 Tiffway Bermuda & \\
\hline & $\begin{array}{l}\text { Hydromulch }(50 \% \text { Tiff } \\
419 \text { Bermuda/50\% Win- } \\
\text { ter Rye) }\end{array}$ & \\
\hline \multicolumn{3}{|l|}{ GROUND COVER } \\
\hline Lantana camara 'New Gold' & New Gold Lantana & naturalized \\
\hline Lantana montevidensis & Trailing Lantana & naturalized \\
\hline Aspidistra in variety & Aspidistra & \\
\hline $\begin{array}{l}\text { Scutellaria galericulata var. } \\
\text { epilobiifolia }\end{array}$ & Common Skull Cap & Native to North America \\
\hline Amaryllis belladonna & Amaryllis & \\
\hline Juniperus horizontalis & Creeping Juniper & Native to North America \\
\hline Stipa tenuissima & Stipa Grass & Native to southwestern U.S. \\
\hline Pennisetum alopecuroides & Dwarf Fountain Grass & \\
\hline \multicolumn{3}{|l|}{ SHRUBS } \\
\hline Rosmarinus officinalis 'Prostratus' & Trailing Rosemary & \\
\hline Rosmarinus officinalis 'Pyramidalis' & UpRight Rosemary & \\
\hline Cotoneaster in variety & Cotoneaster & \\
\hline Rhaphiolepis indica & Dwarf Indian Hawthorn & \\
\hline Hamelia patens & Fire Bush & Native to the American subtropics \\
\hline Ilex vomitoria 'Schillings Dwarf' & Dwarf Yaupon & Native to North America \\
\hline Viburnum acerifolium & Maple-leaf Viburnum & Native to North America \\
\hline Eriobotrya japonica 'Coppertone' & Coppertone Loquat & \\
\hline Yucca aloifolia & Aloe Yucca & Native to southern U.S. \\
\hline Yucca gloriosa & Spanish Dagger & Native to southern U.S. \\
\hline Podocarpus oleifolius & Podocarpus & \\
\hline Nerium oleander & Dwarf Oleander & \\
\hline Rosa 'Radrazz' & Knock Out Rose & \\
\hline \multicolumn{3}{|c|}{$\begin{array}{l}64 \text { Lady Bird Johnson Wildflower Center. Native Plant Database. Accessed online: } \\
\text { http://www.wildflower.org/plants/. }\end{array}$} \\
\hline $\begin{array}{l}65 \text { PDF Accessed online: } \\
\text { https://webapps1.sanantonio.gov/c }\end{array}$ & ntra & J \\
\hline
\end{tabular}




\begin{tabular}{|c|c|c|}
\hline Scientific Name & Common Name & Native Status \\
\hline Tecoma stans & Esperanza, Yellow Bells & Native to Texas \\
\hline Callistemon citrinus 'Little John' & Dwarf BottleBrush & \\
\hline Dietes iridioides & Morea Iris & \\
\hline Cortaderia selloana 'Pumila' & Dwarf Pampas Grass & \\
\hline Plumbago auriculata 'Dark Blue' & Dark Blue Plumbago & \\
\hline Photinia fraseri & Red Tip Photinia & At risk for fungal disease \\
\hline Malvaviscus drummondii & Turk's Cap & Native to Texas \\
\hline Osmanthus fragrans & Sweet Olive & \\
\hline Ligustrum sinense & Chinese Privet & Invasive in Texas \\
\hline Jasminum mesnyi & Primrose Jasmine & \\
\hline Dasylirion texanum & Texas Sotol & Native to Texas \\
\hline Opuntia in variety & Thornless Cactus & Native to the Americas \\
\hline Agave americana & Century Plant & Native to Mexico \\
\hline Lamiaceae & Salvia & $\begin{array}{l}700-900 \text { species of shrubs, herba- } \\
\text { ceous perennials, and annuals. }\end{array}$ \\
\hline Leucophyllum frutescens & Texas Purple Sage & Native to Texas. \\
\hline Hesperaloe parviflora & Red Yucca & Native to Texas. \\
\hline Cycas revolute & Sago Palm & Several types \\
\hline Dasylirion wheeleri & Razor Tooth Sotol & Native to Texas \\
\hline \multicolumn{3}{|l|}{ TREES } \\
\hline Quercus virginiana & Live Oak & $\begin{array}{l}\text { Native to southeastern United } \\
\text { States. }\end{array}$ \\
\hline Quercus macrocarpa & Burr Oak & Native to North America. \\
\hline Quercus polymorpha & Monterey Oak & Native to Mexico. \\
\hline Quercus rubric & Red Oak & Native to North America. \\
\hline Carya illinoensis & Texas Pecan & Native to North America. \\
\hline Kalmia latifolia & Mountain Laurel & $\begin{array}{l}\text { Native to the eastern United } \\
\text { States. }\end{array}$ \\
\hline Pistacia chinensis & Chinese Pistache & Native to China. Drought tolerant. \\
\hline Langerstroemia indica & $\begin{array}{l}\text { Multi Trunk Crepe Myr- } \\
\text { tle }\end{array}$ & Native to southeast Asia. \\
\hline Ilex vomitoria & Multi Trunk Yaupon & Native to North America. \\
\hline Ulmus crassifolia & Cedar Elm & Native to Texas. \\
\hline Cercis canadensis var. texensis & Texas Red Bud & Native to Texas. \\
\hline Triadica sebifera & Chinese Tallow & $\begin{array}{l}\text { One of the } 24 \text { most invasive tree } \\
\text { species in Texas. }\end{array}$ \\
\hline Eriobotrya japonica & Japanese Loquat & \\
\hline Prosopis & Mesquite & Native to Texas. Several species. \\
\hline Sabal palmetto & Sabal Palm & $\begin{array}{l}\text { Native to the southeastern United } \\
\text { States. }\end{array}$ \\
\hline Chamaerops humilis & Med Palm & $\begin{array}{l}\text { Native to the Mediterranean. Cold } \\
\text { hardy. }\end{array}$ \\
\hline Fraxinus texensis & Texas Ash & Native to Texas \\
\hline Pyrus calleryana & Bradford Pear & Native to China and Vietnam. \\
\hline Pinus thunbergii & Japanese Black Pine & $\begin{array}{l}\text { Susceptible to several diseases } \\
\text { and pests. }\end{array}$ \\
\hline Cupressus arizonica & Arizona Cyprus & $\begin{array}{l}\text { Native to southwest North Ameri- } \\
\text { ca. }\end{array}$ \\
\hline Ulmus americana & American Elm & $\begin{array}{l}\text { Native to North America. Suscep- } \\
\text { tible to Dutch elm disease. }\end{array}$ \\
\hline
\end{tabular}




\begin{tabular}{l|l|l}
\hline Scientific Name & Common Name & Native Status \\
\hline Cordia boissieri & Wild Olive & $\begin{array}{l}\text { Native to North America and Mex- } \\
\text { ico. }\end{array}$ \\
Quercus marilandica & Blackjack Oak & $\begin{array}{l}\text { Native to the southern and central } \\
\text { United States. }\end{array}$ \\
\hline
\end{tabular}


(This page intentionally left blank.) 


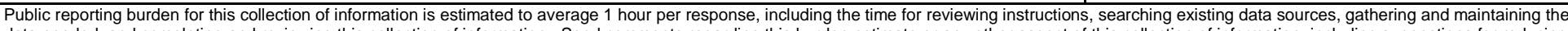

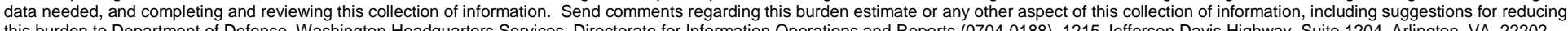

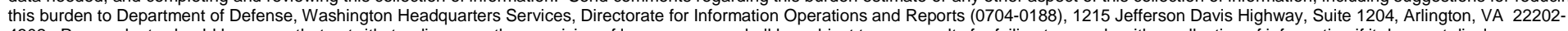

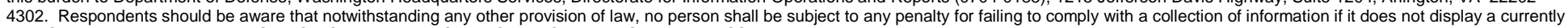
valid OMB control number. PLEASE DO NOT RETURN YOUR FORM TO THE ABOVE ADDRESS.

\section{REPORT DATE (DD-MM-YYYY) September 2013 \\ 4. TITLE AND SUBTITLE \\ Final Technical Report}

Historic Landscape Survey, Randolph AFB, Texas

\section{DATES COVERED (From - To)}

5a. CONTRACT NUMBER

5b. GRANT NUMBER

5c. PROGRAM ELEMENT NUMBER

5d. PROJECT NUMBER

370647

5e. TASK NUMBER

MIPR \#F3PF171257G0001

5f. WORK UNIT NUMBER

8. PERFORMING ORGANIZATION REPORT NUMBER

ERDC/CERL TR-13-14

U.S. Army Engineer Research and Development Center (ERDC)

Construction Engineering Research Laboratory (CERL)

PO Box 9005

Champaign, IL 61826-9005

\section{SPONSORING I MONITORING AGENCY NAME(S) AND ADDRESS(ES)}

Headquarters Air Education and Training

Command/A7CAN

266 F Street West

Bldg 901

Randolph AFB, TX 78150

\section{SPONSOR/MONITOR'S ACRONYM(S)} AETC

11. SPONSOR/MONITOR'S REPORT NUMBER(S)

\section{DISTRIBUTION I AVAILABILITY STATEMENT}

Approved for public release. Distribution is unlimited.

\section{SUPPLEMENTARY NOTES}

Copies are available from the National Technical Information Service, 5285 Port Royal Road, Springfield, VA 22161.

\section{ABSTRACT}

As an inventory and evaluation of the historic landscape and landscape features of Randolph Air Force Base (AFB), Texas, this document meets the requirement for federal agencies to address their cultural resources, defined as any prehistoric or historic district, site, building, structure, or object.

Randolph AFB's historic landscape is unique in its design and implementation. The base was planned and designed as an ideal "Air City” to meet flying training requirements while providing a pleasant place for airmen and their families to live. The landscape reflects early twentieth-century planning ideas that grouped functional uses together in geometrically distinct patterns. Implementing these design principles at Randolph Field resulted in a main circle surrounded by a grid of streets, with two flight lines on the east and west sides.

This report identifies several historic component landscapes within Randolph AFB and makes recommendations on their maintenance and preservation. The component landscapes are the administration area; the warehouse and shop area; the base support areas such as the Chapel, hospital, former Post School, and former Post Exchange; the residential areas of the officers' housing, NCO quarters, and former barracks; the former Cadet Complex; and the flight lines.

\section{SUBJECT TERMS}

National Register of Historic Places (NRHP), cultural resources management, Randolph AFB, historic landscape, historic preservation, master planning

\begin{tabular}{|c|c|c|c|c|c|}
\hline 16. SECURITY CL & IFICATION OF: & & 17. LIMITATION & 18. NUMBER & 19a. NAME OF RESPONSIBLE PERSON \\
\hline $\begin{array}{l}\text { a. REPORT } \\
\text { Unclassified }\end{array}$ & $\begin{array}{l}\text { b. ABSTRACT } \\
\text { Unclassified }\end{array}$ & $\begin{array}{l}\text { c. THIS PAGE } \\
\text { Unclassified }\end{array}$ & UU & 273 & $\begin{array}{l}\text { 19b. TELEPHONE NUMBER (in- } \\
\text { clude area code) }\end{array}$ \\
\hline
\end{tabular}

